Benoît Francis Patrice Loeuille

\title{
Towards a phylogenetic classification of Lychnophorinae (Asteraceae: Vernonieae)
}

São Paulo, 2011 

Benoît Francis Patrice Loeuille

\section{Towards a phylogenetic classification of Lychnophorinae (Asteraceae: Vernonieae)}

Tese apresentada ao Instituto de Biociências da Universidade de São Paulo, para a obtenção de Título de Doutor em Ciências, na Área de Botânica.

Orientador: José Rubens Pirani 



\begin{tabular}{|l|}
\hline Loeuille, Benoît \\
Towards a phylogenetic classification of \\
Lychnophorinae (Asteraceae: Vernonieae) \\
Número de paginas: 432 \\
Tese (Doutorado) - Instituto de Biociências \\
da Universidade de São Paulo. \\
Departamento de Botânica. \\
1. Compositae 2. Sistemática 3. Filogenia \\
I. Universidade de São Paulo. Instituto de \\
Biociências. Departamento de Botânica. \\
\end{tabular}

\section{Comissão Julgadora:}

Prof(a). Dr(a).

Prof(a). Dr(a).
Prof(a). Dr(a).

Prof(a). $\operatorname{Dr}(a)$.

Prof. Dr. José Rubens Pirani

Orientador 

To my grandfather,

who made me discover

the joy of the vegetal world. 



\section{Chacun sa chimère}

Sous un grand ciel gris, dans une grande plaine poudreuse, sans chemins, sans gazon, sans un chardon, sans une ortie, je rencontrai plusieurs hommes qui marchaient courbés.

Chacun d'eux portait sur son dos une énorme Chimère, aussi lourde qu'un sac de farine ou de charbon, ou le fourniment d'un fantassin romain.

Mais la monstrueuse bête n'était pas un poids inerte; au contraire, elle enveloppait et opprimait l'homme de ses muscles élastiques et puissants; elle s'agrafait avec ses deux vastes griffes à la poitrine de sa monture et sa tête fabuleuse surmontait le front de l'homme, comme un de ces casques horribles par lesquels les anciens guerriers espéraient ajouter à la terreur de l'ennemi.

Je questionnai l'un de ces hommes, et je lui demandai où ils allaient ainsi. Il me répondit qu'il n'en savait rien, ni lui, ni les autres; mais qu'évidemment ils allaient quelque part, puisqu'ils étaient poussés par un invincible besoin de marcher.

Chose curieuse à noter : aucun de ces voyageurs n'avait l'air irrité contre la bête féroce suspendue à son cou et collée à son dos; on eût dit qu'il la considérait comme faisant partie de lui-même. Tous ces visages fatigués et sérieux ne témoignaient d'aucun désespoir; sous la coupole spleenétique du ciel, les pieds plongés dans la poussière d'un sol aussi désolé que ce ciel, ils cheminaient avec la physionomie résignée de ceux qui sont condamnés à espérer toujours.

Et le cortège passa à côté de moi et s'enfonça dans l'atmosphère de l'horizon, à l'endroit où la surface arrondie de la planète se dérobe à la curiosité du regard humain.

Et pendant quelques instants je m'obstinai à vouloir comprendre ce mystère; mais bientôt l'irrésistible Indifférence s'abattit sur moi, et j'en fus plus lourdement accablé qu'ils ne l'étaient eux-mêmes par leurs écrasantes Chimères.

Charles Baudelaire, Petits poèmes en prose ou Le Spleen de Paris 



\section{ACKNOWLEDGEMENTS}

First, I would like to thank the Instituto de Biociências, Universidade de São Paulo and in particular the Laboratório de Sistemática Vegetal, which offered me the conditions and facilities to turn this study possible. Thanks to Conselho Nacional de Pesquisas (CNPq), which supported me through a scholarship during 2006 - 2011. Funding for my research was also provided by Fundação de Amparo à Pesquisa do Estado de São Paulo (FAPESP) and the Cuatrecasas Fellowship Award of the Smithsonian Institution. Thanks to Instituto Brasileiro do Meio Ambiente e dos Recursos Naturais Renóvaveis (IBAMA) and Instituto Estadual de Florestas do Minas Gerais (IEF-MG) for collection permits.

Thanks to José Rubens Pirani for the trust given me, his advices and insights, for being so supportive throughout these last six years.

I would like to thank João Semir for his enthusiasm, suggestions and sharing with me his deep knowledge of the Vernonieae.

Thanks to Lúcia Garcez Lohmann for her advices and support in the molecular part of this study, in particular for having opened the doors of her molecular lab to me.

Thanks also to Sterling Keeley for sharing with me her knowledge of the tribes and for all her advices on the molecular part of this study.

I am grateful to Nicholas Hind, Harold Robinson and Vicki Funk for their interests in my work and providing helpful suggestions and ideas.

I am grateful to the Brazilian synantherologists for their help, enthusiasm and discussions: Mara Magenta, Jimi Nakajima, Gustavo Heiden, Nádia Roque, Rosangela Bianchini, Mariana Saavedra, Fátima Otavina de Souza Buturi, Marcelo Monge, Rafael Borges, Silvana Ferreira, Roberto and Vânia Esteves, Leonardo Deble and Aristônio Teles.

Thanks to Denise Maria Trombert Oliveira for her help on cypsela anatomy; to Leonardo Gobbo-Neto and Fernando Batista da Costa for their help and patience to explain to me the structure of the sesquiterpene lactones.

I am grateful to all the Brazilian botanists who collected plant material and took pictures for me, in particular to Renato Mello-Silva, Jimi Nakajima, Anselmo, Paulo, Carol, Alex Popovkin and Nádia Roque.

I would like to thank Renato Mello-Silva and Jefferson Prado for helping me with some nomenclatural problems.

Thanks to Livia Echternacht, René Zaragüeta-Bagils and Carlos Antônio Marques for their discussion about three-item analysis.

I am grateful to Carol, Alice, He-Man, Luiz, Fê, Ana and Vânia for their help in the molecular lab.

Thanks are due to all the people who helped me to collect my plants: Jimi Nakajima, Marcelo, Maura, Maurício, Silvana Ferreira, Vera Klein, Anselmo, Fabiane Nepomuceno Costa, 
Mariana Saavedra, Caqui, Matheus (Bozo), Fê and Euder.

Thanks to Abel for mounting my plants and preparing the liters of coffee I drunk.

During these last years I spent most of my time in the Laboratório de Sistemática Vegetal, I would like to thank all the students who have frequented this place and made it cheerful and friendly. I prefer not to cite everybody fearing to forget someone !

Thanks to Caqui and Bozo for our conversation about botany, biology and life.

Alê, Paty, Maurício, Suzana, Gustavo, Anselmo, Jenifer, Ju Lovo, Armando and Soffi: thanks for your friendships, for being there when the sky was grey and to help me forget the thesis or to remind me of it !

I would not be here finishing to write this thesis without my parents and my brother who gave me a constant support all along these years.

Mariana, you gave me support, love and always believed in me. You read the manuscript of the whole thesis, cut the leaves, prepared, and analyzed all the trichomes slides. You made this long journey easier for me. You were always present to listen to my ideas or calm my anxieties. Thank you for being there. 


\section{CONTENTS}

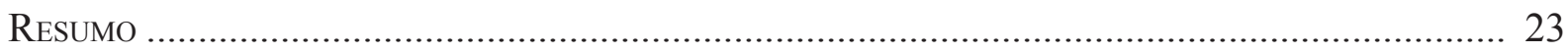

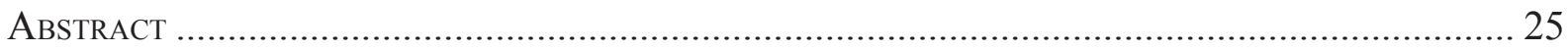

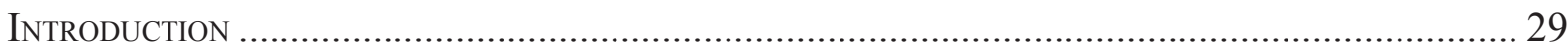

CHAPTER 1 Systematics and evolution of syncephaly in American Vernonieae (Asteraceae) based on molecular and morphological data ............................................ 43

CHAPTER 2 A Phylogenetic analysis of Lychnophorinae (Asteraceae: Vernonieae) based on molecular and morphological data ..................................................... 99

CHAPTER 3 Cladistic analysis of American Vernonieae and Lychnophorinae (Asteraceae): contributions from a hierarchical homology approach ............................ 153

CHAPTER 4 Taxonomic studies in Lychnophorinae (Asteraceae: Vernonieae) ............. 229

PART 1 Taxonomic novelties in Eremanthus (Compositae: Vernonieae) from Brazil ... 233

Part 2 Two New Species of Heterocoma (Asteraceae: Vernonieae) and a broadened concept of the genus ........................................................................... 253

PART 3 Minasia ramosa (Asteraceae: Vernonieae), a new species from the Serra do Cabral, Minas Gerais, Brazil .................................................................. 277

PART 4 A new species of Paralychnophora (Asteraceae: Vernonieae) and comments on the identity of P. bicolor .................................................................... 291

PART 5 Three new species of Piptolepis (Compositae: Vernonieae) from Minas Gerais, Brazil .............................................................................. 305

CHAPTER 5 A synopsis of the subtribe Lychnophorinae (Asteraceae: Vernonieae) ....... 323

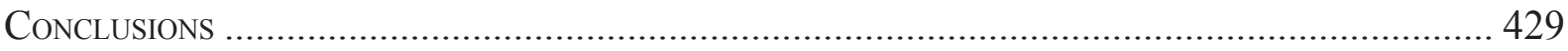





\section{LIST OF TABLES, FIGURES AND APPENDICES}

\section{INTRODUCTION}

Fig. 1. Bayesian inference phylogram based on the combined analysis of DNA sequences of ITS, ndhF, trnL-F for90taxa ofVernonieae.(Modified fromKeeley andRobinson, 2009)......39

\section{Chapter 1}

Table 1. Present-day classification of American Vernonieae. Genera and species numbers are from Keeley \& Robinson (2009). Main features obtained from Keeley \& Robinson (2009) and Robinson (1999, 2007).

Table 2. Comparison of results obtained from the ITS, $n d h \mathrm{~F}, r p l 32-t r n \mathrm{~L}, n d h \mathrm{~F}+r p l 32-$ $\operatorname{trn} \mathrm{L}, \mathrm{ITS}+n d h \mathrm{~F}+r p l 32-\operatorname{tr} n \mathrm{~L}$ and total evidence (molecular and morphology) datasets. The consistency and retention indexes are calculated excluding uninformative characters ... 65

Fig. 1. Morphological diversity and syncephalia in American Vernonieae: A, Lychnophora salicifolia; B, Blanchetia heterotricha; C, Xerxes ekmanianum; D, Eremanthus incanus; E, Chresta sphaerocephala; F, Rolandra fruticosa; G, Elephantopus mollis; H, Lychnophora humillima; I, Eremanthus erythropappus. Photographs: A, B, D, E, G, I, B. Loeuille; C, G. Shimizu; F, R. Graveson; H, D. Zappi.

Fig. 2. Strict consensus tree of 96 equally most parsimonious trees based on the combined analysis (all molecular data). Tree length $=2580$ steps, $\mathrm{CI}=0.44, \mathrm{RI}=0.78$. Jackknife values $(\geq 50 \%)$ and Bayesian posterior probabilities $(\geq 0.9)$ are shown above and below the nodes. Vernonieae subtribes are indicated with three-letter abbreviations (see Table 1), OUT = outgroup, UNP = unplaced (taxa not placed in a subtribe). Taxa in bold display syncephaly.

Fig. 3. Strict consensus tree of 108 equally most parsimonious trees based on the combined analysis with morphology and all molecular data. Tree length $=3097$ steps, CI $=0.39$, $\mathrm{RI}=0.75$. Jackknife values $(\geq 50 \%)$ and Bayesian posterior probabilities $(\geq 0.9)$ are shown above and below the nodes. Vernonieae subtribes are indicated with three-letter abbreviations (see Table 1), OUT = outgroup, UNP = unplaced (taxa not placed in a subtribe). Taxa in bold display syncephaly.

Fig. 4. Comparison of parsimony strict consensus tree (on left) and Bayesian inference phylogram (on right). White triangles are collapsed clades; a full listing of taxa in these clades is given in Fig. 3. Jackknife values $(\geq 50 \%)$ are shown above the nodes of the parsimony tree and Bayesian posterior probabilities $(\geq 0.9)$ are shown above the nodes of the Bayesian inference phylogram. 1 =Leiboldiinae; 2 =Asian taxa; 3 =Critoniopsis; 4 =Piptocarpha $; 5=$ Cyrtocymura $; 6=$ Strophopappus $; 7=$ Rolandra $; 8=$ Stenocephalum.. .73 Fig. 5. Syncephalia diversity in American Vernonieae. Chresta angustifolia: A, syncephalium; B, capitulum; C, floret. Rolandra fruticosa: D, syncephalium; E, capitulum; F, floret. Elephantopus mollis: G, syncephalium; H, capitulum; I, floret. Eremanthus erythropappus: $\mathbf{J}$, syncephalium; $\mathbf{K}$, syncephalium in long section; $\mathbf{L}$, floret 
Appendix 1. Species included in the molecular analysis, voucher information and GenBank accession numbers (ITS, $n d h \mathrm{~F}$ and $r p l 32-t r n \mathrm{~L}$ ). An en-dash indicates that a region was not sequenced for this taxon. An asterisk indicates a sequence previously published by Keeley \& al. (2007) or taken from Keeley \& al. (unpub.).

Appendix 2. Morphological characters and character states used for the combined phylogenetic analysis.

Appendix 3. The data matrix used in the morphological part of the phylogenetic analysis. Multiple states of characters are coded with the next letters: $a=(01), b=(12),-=$ inapplicable data, ? = missing data.

\section{Electronic Supplement}

Fig. S1. Strict consensus tree of 354 equally most parsimonious trees based on the ITS analysis. Tree length $=2030$ steps, $C I=0.41, \mathrm{RI}=0.77$. Jackknife values $(\geq 50 \%)$ are shown above the nodes.

Fig. S2. Strict consensus tree of 785 equally most parsimonious trees based on the chloroplast ( $n d h \mathrm{~F}$ and $r p l 32-t r n \mathrm{~L}$ ) analysis. Tree length $=490$ steps, $\mathrm{CI}=0.60, \mathrm{RI}=0.85$. Jackknife values ( $\geq 50 \%$ ) are shown above the nodes.

Fig. S3. Bayesian inference phylogram based on the combined analysis (all molecular data). Bayesian posterior probabilities $(\geq 0.9)$ are shown above the nodes.

Fig. S4. Bayesian inference phylogram based on the combined analysis with morphology and all molecular data. Bayesian posterior probabilities $(\geq 0.9)$ are shown above the nodes. 95

\section{Chapter 2}

Table 1. Comparison of results obtained from the ITS, ETS, nuclear, $n d h \mathrm{~F}+r p l 32-t r n \mathrm{~L}$, molecular and total evidence (molecular and morphology) datasets. The consistency and retention indexes are calculated excluding uninformative characters.

Fig. 1. Representatives of Lychnophorinae. A. Prestelia eriopus. B. Lychnophora sellowii. C. Heterocoma albida. D. Paralychnophora harleyi. E. Minasia alpestris. F. Lychnophora santosii. G. Piptolepis oleaster. H. Lychnophora ericoides. I. Eremanthus glomerulatus. Photo A courtesy of P. Gonella; B of G. Shimizu; C of C. Oliveira and F of S. Ferreira ......

Fig. 2. Strict consensus tree of 168 equally most parsimonious trees based on the nuclear (ITS and ETS) analysis. Tree length $=1790$ steps, $\mathrm{CI}=0.53$, RI $=0.75$. Jackknife values $(\geq 50 \%)$ are shown above the nodes. Taxa in bold display an incongruent position in the chloroplast phylogeny (Fig. S1), the latter is indicated by the number in a black circle: Eremanthus sp. $\times$ Paralychnophora reflexoauriculata branched at 1 ; Lychnophora mellobarreto $i$ and Minasia alpestris at 2; Piptolepis ericoides $\times$ Eremanthus erythropappus branched at 3 .

Fig. 3. Strict consensus tree of 12 equally most parsimonious trees based on the combined 
analysis (all molecular data). Tree length $=1968$ steps, $\mathrm{CI}=0.52, \mathrm{RI}=0.73$. Jackknife values $(\geq 50 \%)$ and Bayesian posterior probabilities $(\geq 0.9)$ are shown above and below the nodes.

Fig. 4. Strict consensus tree of 44 equally most parsimonious trees based on the combined analysis with morphology and all molecular data. Tree length $=2624$ steps, CI $=0.42$, RI $=0.68$. Jackknife values $(\geq 50 \%)$ and Bayesian posterior probabilities $(\geq 0.9)$ are shown above and below the nodes.

Fig. 5. Putative intergeneric hybrids. A. Piptolepis ericoides. B. Piptolepis ericoides $\times$ Eremanthus erythropappus. C. Eremanthus erythropappus. Note the pad-like leaf sheath (white arrows) and the capitula with imbricate phyllaries (black arrows). D. Paralychnophora reflexoauriculata. E. Eremanthus sp. $\times$ Paralychnophora reflexoauriculata. F. Eremanthus capitatus. 132

Appendix 1. Species included in the molecular analyses, voucher information and GenBank accession numbers (ETS, ITS, $n d h \mathrm{~F}$ and $r p l 32-t r n \mathrm{~L}$ ). An en-dash indicates that a region was not sequenced for this taxon. An asterisk indicates a sequence previously published by Keeley \& al. (2007) or taken from Chapter 1 and Keeley et al. (unpub.)...133 Appendix 2. Morphological characters and character states used for the combined phylogenetic analysis (see Supplemental Appendix 1)

\section{Eletronic Supplement}

Appendix S1. The data matrix used in the morphological part of the phylogenetic analysis. Multiple states of characters are coded with the next letters: $a=(01), b=(12), c=(23), d$ $=(02), \mathrm{e}=(03),-=$ inapplicable data, $?=$ missing data .

Fig. S1. Strict consensus tree of 10,000 equally most parsimonious trees based on the chloroplast $(n d h \mathrm{~F}$ and $r p l 32-t r n \mathrm{~L}$ ) analysis. Tree length $=132$ steps, $\mathrm{CI}=0.66, \mathrm{RI}=0.83$. Jackknife values $(\geq 50 \%)$ are shown above the nodes.

Fig. S2. Bayesian inference phylogram based on the combined analysis (all molecular data). Bayesian posterior probabilities $(\geq 0.9)$ are shown above the nodes.

Fig. S3. Bayesian inference phylogram based on the combined analysis with morphology and all molecular data. Bayesian posterior probabilities $(\geq 0.9)$ are shown above the nodes.

\section{Chapter 3}

Table 1 Morphological characters and character states of the Matrix 1 (American Vernonieae taxa) with their associated hypothese of homology for the $3 i a$. 175

Table 2 Morphological characters and characters states of the Matrix 2 (Lychnophorinae taxa) 178

Fig. 1 Strict consensus tree of 240 most parsimonious trees based on the standard analysis of Matrix 1 (American Vernonieae taxa). Tree length $=431$ steps. Black symbols indicates synapomorphies. Vernonieae subtribes are indicated with three-letter abbreviations, CEN 
$=$ Centratherinae, $\mathrm{CHR}=$ Chrestinae, $\mathrm{ELE}=$ Elephantopinae, $\mathrm{LEI}=$ Leiboldiinae, $\mathrm{LYC}$ $=$ Lychnophorinae, $\mathrm{PIP}=$ Piptocarphinae, $\mathrm{SIP}=$ Sipolisiinae, $\mathrm{STO}=$ Stokesiinae, $\mathrm{VER}=$ Vernoniinae and $\mathrm{UNP}=$ unplaced (taxa not placed in a subtribe)

Fig. 2 Intersection tree of 3 optimal trees based on the 3ia of Matrix 1 (American Vernonieae taxa). Black symbols indicate hypothese of homology accepted. Blue symbols indicate a homologous state accepted. Characters placed at the root (grey symbols) indicate that there is no reason to reject the homology hypothesis but also no reason to accept the character as a synapormophy given the sampling. Red symbols indicate that there is no reason to reject or to accept the state as homologous given the sampling. Vernonieae subtribes are indicated with three-letter abbreviations (see legend of Fig. 1).... 185

Fig. 3 Strict consensus tree of 110 most parsimonious trees based on the standard analysis of Matrix 2 (Lychnophorinae taxa). Tree length $=535$ steps. Black symbols indicate synapomorphies. Grey symbols indicate absence of a character treated as synapomorphy.

Fig. 4 Optimal tree based on the 3ia of Matrix 2. (Lychnophorinae taxa) Black symbols indicate hypothese of homology accepted. Blue symbols indicate a homologous state accepted. Characters placed at the root (red symbols) indicate that there is no reason to reject or to accept the state as homologous given the sampling.

Appendix 1 Characters used in the cladistic analysis of the matrix 1 (American Vernonieae taxa). The numbers correspond to those in the data matrix (Electronic Supplementary Appendix 1). 191

Appendix 2 Characters used in the cladistic analysis of the matrix 2 (Lychnophorinae taxa). The numbers correspond to those in the data matrix (Electronic Supplementary Appendix 2). 198

Electronic Supplementary Appendix 1 The data matrix 1. Multiple states of characters are coded with the next letters: $\mathrm{a}=(01), \mathrm{b}=(12),-=$ inapplicable data, ? = missing data..

Electronic Supplementary Appendix 2 The data matrix 2. Multiple states of characters are coded with the next letters: $\mathrm{a}=(01), \mathrm{b}=(12), \mathrm{c}=(23), \mathrm{d}=(02), \mathrm{e}=(03),-=$ inapplicable data, ? = missing data.

Electronic Supplementary Appendix 3 The 3ia data matrix 1. The second line indicates the hypotheses of homology.

Electronic Supplementary Appendix 4 The 3ia data matrix 2. The second line indicates the hypotheses of homology.

Electronic Supplementary Appendix 5 List of specimens examined. The following abbreviations designate the states of Brazil: BA Bahia, CE Ceará, DF Distrito Federal, GO Goiás, MT Mato Grosso, MG Minas Gerais, PR Paraná, RS Rio Grande do Sul, SC Santa Catarina, SP São Paulo. 223 


\section{Chapter 4}

PART 1

Table 1. Morphological characters used to separate the putative species: Eremanthus capitatus, E. graciellae and E. pohlii. 246

Map 1. Geographical distribution of Eremanthus capitatus, depicting variation of glomerules and involucres (A - Mendonça et al. 2329; B - Loeuille et al. 345; C Coradin et al. 8694; D - Vandely 106; E - Ganev 2009; F - Macleish \& Soares Nunes 758; G - Schumacher 1080; H \& I - Hatschbach et al. 67936; J - Loeuille et al. 287; K Schumacher 1032; L-Aparecida da Silva 1527).

Map 2. Geographical distribution of Eremanthus brevifolius and E. elaeagnus.

Fig. 1. Eremanthus brevifolius. A habit; B leaf, abaxial surface; $\mathrm{C}$ magnified abaxial surface of leaf; D glomerule; E corolla; F anther; G style; H cypsela and pappus.

PART 2

Fig. 1. Leaf cross section of Heterocoma erecta (King \& Bishop 8729, UB; scale $=100$ $\mu \mathrm{m}) . \mathrm{E}=$ epiderm; $\mathrm{P}=$ palissadic parenchyme; $\mathrm{Ph}=$ phloem; $\mathrm{VB}=$ vascular bundle; $\mathrm{X}=$ xylem.

Fig. 2. Cypselae of Heterocoma species, showing phytomelanin (A-E, G-I, K, cross sections; F, J, L, longitudinal sections). A-C, Heterocoma albida; A, General view; B, Lateral view, detaching a rib; in detail, note the phytomelanin in a non-stained preparation; C, Detail of fibers and phytomelanin deposits; D, Heterocoma ekmaniana, next to the carpopodium; E-F, Heterocoma erecta; E, next to the carpopodium; F, lateral view, with phytomelanin inner and between fibers; G-H, Heterocoma gracilis; G, lateral view; $\mathrm{H}$, next to the floral disk; I-J, Heterocoma lanuginosa; I, lateral view; in detail, note the phytomelanin in a non-stained preparation; J, lateral view, with phytomelanin inner and between fibers; K-L, Heterocoma robinsoniana; K, lateral view; L, tangential view. Arrowheads: phytomelanin. Scale bars: A, K = $200 \mu \mathrm{m}$; B, D-E, G-I, L $=100 \mu \mathrm{m}$; C, F, J $=20 \mu \mathrm{m}$.

Fig. 3. Heterocoma gracilis. A. Habit. (From a photograph). B. Flowering branch. C. Leaf, abaxial surface. D. Detail of leaf abaxial surface. E. Detail of leaf adaxial surface. F. Capitulum. G. Palea. H. Corolla. I. Anther. J. Style. K. Cypsela and pappus. L. Inner pappus seta. (From the holotype).

Fig. 4. Heterocoma robinsoniana. A. Habit (From a photograph). B. Flowering branch. C. Leaf, abaxial surface. D. Detail of leaf abaxial surface. E. Detail of leaf adaxial surface. F. Capitulum. G. Corolla. H. Anther. I. Style. J. Cypsela and pappus. K. Inner pappus seta. (From the holotype).

Part 3

Fig. 1. Minasia ramosa Loeuille, H. Rob. \& Semir. A. Habit. B. Leaf. C. Capitulum. D. Corolla. E. Stamen. F. Style. G. Cypsela with pappus; A-G. Hatschbach et al. 64718 (ESA). 


\section{PART 4}

Fig.1.Paralychnophoraglaziouana.A.Habit.B.Leaf,abaxialsurface.C.Detailofleafadaxial surface.D.Syncephalium.E.Corolla.F.Anther.G.Style.H.Cypselaandpappus.(Drawn from the holotype). 301

Fig. 2. Paralychnophora glaziouana. A. Habit. (Drawn from a photograph). B. Leaf, abaxial surface. (Drawn from the holotype). Paralychnophora bicolor. C. Habit. (Drawn from a photograph). D. Leaf, abaxial surface. (Drawn from Bondar 2601, SP).......302

\section{PART 5}

Fig. 1. Piptolepis campestris. A habit; B leaf, adaxial surface; C leaf, abaxial surface; D pseudoglomerule; E corolla; F style; G anther; H cypsela and pappus; I pappus seta. All from the holotype (SPF)

Fig. 2. Piptolepis schultziana. A habit; B leaf, abaxial surface; C leaf, adaxial surface; D capitulum; E corolla; F anther; G style; H cypsela and pappus; I pappus seta. All from the holotype (SPF). 318

Fig. 3. Piptolepis monticola. A habit; B leaf, adaxial surface; C leaf, abaxial surface; D pseudoglomerule; E corolla; F style; G anther; H cypsela and pappus; I pappus seta. All from the holotype (SPF).

\section{Chapter 5}

Tab. 1. Taxonomic history of the subtribe Lychnophorinae (Asteraceae: Vernonieae)....416

Tab. 2. Chromosome numbers in Lychnophorinae

Fig. 1. Morphological diversity in Lychnophorinae. A, Albertinia brasiliensis Spreng.; B, Hololepis pedunculata (DC. ex Pers.) DC.; C, Lychnocephalus mellobarretoi (G.M. Barroso) Loeuille, Semir \& Pirani; D, Anteremanthus hatschbachii H. Rob.; E, Chronopappus bifrons (DC. ex Pers.) DC.; F, Heterocoma albida (DC. ex Pers.) DC.; G, Lychnophorella regis (H. Rob.) Loeuille, Semir \& Pirani; H, Lychnophora ericoides Mart.; I, Eremanthus elaeagnus (Mart. ex DC.) Sch. Bip. Photographs: A, A. Popovkin; B, C, D, E, H, I, B. Loeuille; F, C. Siniscalchi; G, S. C. Ferreira.

Fig. 2. Diversity of life-forms in Lychnophorinae I. A, Herb, Centratherum punctatum Cass.; B, Heterocomoid habit (sensu Semir (1991)), Heterocoma robinsoniana Loeuille, J. N. Nakaj. \& Semir; C-E, Caulirosulas, C, Proteopsis argentea Mart. \& Zucc. ex Sch. Bip., D, Minasia ramosa Loeuille, Robinson \& Semir, E, Prestelia eriopus Sch. Bip..420 Fig. 3. Diversity of life-forms in Lychnophorinae II. A-B, Shrubs, A, Lychnophorella triflora (Mattf.) Loeuille, Semir \& Pirani, B, Piptolepis monticola Loeuille; C-F, Treelets to trees, C, Paralychnophora bicolor (DC.) MacLeish, D, Lychnophora salicifolia Mart., E, Eremanthus erythropappus (DC.) MacLeish, F, Lychnocephalus mellobarretoi (G. M. Barroso) Loeuille, Semir \& Pirani. 421

Fig. 4. Types of leaf sheath in Lychnophorinae. A, pad-like, Lychnophorella regis $(\mathrm{H}$. Rob.) Loeuille, Semir \& Pirani, B, semi-amplexicaul, Paralychnophora bicolor (DC.) 
MacLeish, C, amplexicaul, Proteopsis hermogenesii sp. ined.

Fig. 5. Trichomes in Lychnophorinae. A-E, Unbranched, A, regular, Chronopappus bifrons (DC. ex Pers.) DC., B, auriculate, Piptolepis oleaster (Mart. ex DC.) Sch. Bip., C, geminate, Chronopappus bifrons (DC. ex Pers.) DC., D, side-armed, Lychnocephalus jolianus sp. ined., E, curly, Lychnophora markgravii G. M. Barroso; F-I, 2-armed, F, long arms T-shaped, Albertinia brasiliensis Spreng., G, asymmetric T-shaped, Lychnophora markgravii G. M. Barroso, H, swollen T-shaped, Minasia alpestris (Gardner) H. Rob., I, swollen with asymmetric T-shaped, Vinicia tomentosa Dematt., J, inverted Y-shaped, Lychnocephalus humillimus (Sch. Bip.) Loeuille, Semir \& Pirani; K-Q, 3- to 5-armed trichomes, K, regular, Heterocoma lanuginosa (Glaz. ex Oliv.) Loeuille, J. N. Nakaj. \& Semir, L, swollen, Eremanthus elaeagnus (Mart. ex. DC.) Sch. Bip., M, curly, Lychnophora pinaster Mart., N, porrect, Heterocoma gracilis Loeuille, J. N. Nakaj. \& Semir, O, geminate, Heterocoma lanuginosa (Glaz. ex Oliv.) Loeuille, J. N. Nakaj. \& Semir, $\mathbf{P}$, long multicellular stalked, Gorceixia decurrens Baker, $\mathbf{Q}$, long multicellular stalked with side-arm, Gorceixia decurrens Baker; R-W, stellate, R, regular, Heterocoma ekmaniana (Philipson) Loeuille, J. N. Nakaj. \& Semir, S, swollen, Piptolepis oleaster (Mart. ex DC.) Sch. Bip., T, porrect, Heterocoma gracilis Loeuille, J. N. Nakaj. \& Semir, U, geminate, Heterocoma ekmaniana (Philipson) Loeuille, J. N. Nakaj. \& Semir, V, long stalked, Eremanthus crotonoides (DC.) Sch. Bip., W, with forked arms, Blanchetia heterotricha DC.

Fig. 6. Capitulescences in Lychnophorinae. A, Glomerule; B, Pseudoglomerule; C, Pseudoglomerule with subinvolucral bracts; D, Syncephalium of second-order; E, Syncephalium of third-order; F, Panicle of capitula; G, Cyme of syncephalia (secondorder). D, E, modified from Harris (1999).

Fig. 7. Receptacle surface in Lychnophorinae. A, Areolate; B, Fimbrillate; C, Alveolate. Modified from Small (1919). 425

Fig. 8. Geographic distribution of the subtribe Lychnophorinae ( black isoline) and of the subtribe minus Centratherum punctatum (dark grey shaded area), a species native to the Americas which became subspontaneous in Australia, Hawaii, Philippines and Taiwan. ... 426

Fig. 9. Hypothesized phylogenetic relationships within the Lychnophorinae based on molecular and morphological data. Arrow indicates nodes with support $<50 \%$ in the parsimony analyses. (Adapted from Loeuille et al. in press; see Chapters 1 and 2)...... 429 



\section{RESUMO}

\section{Rumo a uma classificação filogenética de Lychnophorinae (Asteraceae: Vernonieae)}

Uma hipótese filogenética das Vernonieae Americanas, baseada em uma matriz morfológica e em três regiões moleculares (ITS, $n d h \mathrm{~F}, r p l 32-t r n \mathrm{~L}$ ), revela a existência de quatro linhagens principais neste grupo. Três desses linhagens correspondem, com alguns ajustes, às subtribos Chrestinae, Lychnophorinae e Vernoniinae. A última linhagem é principalmente composta de Lepidaploinae e Elephantopinae. Para uma circunscrição de Lychnophorinae monofilética, devem ser aqui incluídos duas pequenas subtribos (Centratherinae, Sipolisiinae) e três gêneros monotípicos (Albertinia, Blanchetia e Gorceixia), tendo como sinapomorfia a presença de heliangolidos nas partes aéreas. Nossos resultados mostram que a sincefalia provavelmente surgiu três ou quatro vezes ao longo da evolução das Vernonieae Americanas. As características especiais desses agregações de capítulos em cada linhagem sugerem que a formação da sincefalia deve estar relacionada a diferente funções biológicas: atração nas Chrestinae, dispersão nas Rolandrinae ou proteção nas Lychnophorinae.

A análise filogenética das Lychnophorinae foi realizada baseada numa matriz morfológica e quatro regiões moleculares (ETS, ITS, $n d h \mathrm{~F}, r p l 32-t r n \mathrm{~L}$ ), a fim de delimitar gêneros monofiléticos na subtribo, e alcançar uma melhor compreensão das relações entre seus gêneros. O gênero mais rico da subtribo, Lychnophora, com 32 espécies descritas, emergiu como polifilético, envolvendo três principais linhagens não estreitamente relacionadas. A maioria dos clados obtidos estão associados a conceitos de gêneros já existentes e podem ser definidos por uma combinação simples de caracteres morfológicos. Albertinia, Blanchetia e Gorceixia são as linhagens mais basais, enquanto Eremanthus e Lychnophora stricto sensu emergiram como o clado mais derivado, que contém metade das espécies da subtribo. Porém, as relações entre os demais clados persistem apenas parcialmente resolvidas.

Com o objetivo de comparar a influência de uma representação hierárquica de hipóteses de homologia em inferência filogenética, uma matriz morfológica das Vernonieae Americanas e uma das Lychnophorinae (Asteraceae) foram ambas analisadas usando a parcimônia e análise de três itens. Os resultados divergiram muito não só em termos de topologia, mas também no número de homologias recuperadas. A análise de três itens parece recuperar um maior conteúdo de informação das matrizes originais. O nível elevado de homoplasia já reconhecido em dados morfológicos de Vernonieae foi aqui confirmado e a maioria dos clados não são sustendados por sinapomorfias.

Baseada nos resultados das análises filogenéticas realizadas, propõe-se aqui uma nova classificação da subtribo Lychnophorinae, e uma sinopse é apresentada. As subtribos 
Centratherinae e Sipolisiinae são reduzidas a sinonímia de Lychnophorinae e três gêneros (Albertinia, Blanchetia, Gorceixia) são transferidos para a subtribo. Como agora circunscrita, Lychnophorinae compreende 18 gêneros e 104 espécies distribuídas principalmente no domínio do cerrado do Planalto Central Brasileiro. Propõe-se a sinonimização de Oiospermum sob Centratherum, e de Irwinia sob Blanchetia. Devido ao fato de Lychnophora, como atualmente circunscrito ter-se mostrado polifilético, suas espécies tiveram que ser rearranjadas em três gêneros monofiléticos: Lychnophora s.s., Lychnocephalus e um novo gênero agora descrito, Lychnophorella. 17 novas combinações são propostas bem como 10 novas sinonímias. As descrições de oito novas espécies de Lychnophorinae são apresentadas: Eremanthus brevifolius, Heterocoma gracilis, H. robinsoniana, Minasia ramosa, Paralychnophora glaziouana, Piptolepis campestris, P. monticola e P. schultziana. A sinopse inclui os dados fundamentais de todas as espécies de Lychnophorinae: status taxonômico, dados sobre os tipos nomeclaturais, distribuição geográfica e habitat, além de notas taxonômicas. 


\begin{abstract}
Towards a phylogenetic classification of Lychnophorinae (Asteraceae: Vernonieae)

A phylogenetic hypothesis of American Vernonieae based on three molecular regions (ITS, $n d h \mathrm{~F}, r p l 32-t r n \mathrm{~L})$ and on a morphological dataset reveals the existence of four main lineages in the group. Three of these lineages correspond, with a few adjustments, to subtribes Chrestinae, Lychnophorinae and Vernoniinae. The last lineage is mainly composed of Lepidaploinae and Elephantopinae. In order to keep the Lychnophorinae monophyletic, two small subtribes (Centratherinae, Sipolisiinae) and three monotypic genera (Albertinia, Blanchetia and Gorceixia) must be to transferred to Lychnophorinae, which has the presence of heliangolide in aerial parts as a synapomorphy. Our results show that syncephaly probably appeared independently three or four times in the course of evolution of American Vernonieae. Special features of these aggregation of heads in each lineage suggest that the formation of syncephalia is related to different biological functions: attractive in Chrestinae, disseminative in Rolandrinae or protective in Lychnophorinae.
\end{abstract}

A phylogenetic analysis of Lychnophorinae was further performed based on a morphological dataset and on four molecular regions (ETS, ITS, $n d h \mathrm{~F}, r p l 32-\operatorname{trn} \mathrm{L}$ ), in order to delimit monophyletic genera in Lychnophorinae, and to achieve a better understanding of the relationships between the genera of the subtribe. The richest genus of the subtribe, Lychnophora, with 32 described species, emerged as polyphyletic, involving three main lineages not closely related. Most clades obtained are associated with some existing generic concept and can be defined by a simple combination of morphological characters. Albertinia, Blanchetia and Gorceixia are the most basal lineages, whereas Eremanthus and Lychnophora stricto sensu emerged as the most derived clade, which contains half of the species of the subtribe. However, relationships between the remaining clades persist partially unresolved.

Aiming to compare the influence of a hierarchical representation of homology hypotheses on phylogenetic inference, two morphological datasets of American Vernonieae and Lychnophorinae (Asteraceae) have been analyzed using parsimony and three-item analysis. The results widely diverged not only in terms of topology but also in the number of homologies recovered. The three-item analysis appears to retrieve a higher information content from the original datasets. The already acknowledged high level of homoplasy in Vernonieae morphological data is here confirmed and most of the clades are not supported by synapomorphies.

Based on the results of the phylogenetic analyses performed, a new classification of the subtribe Lychnophorinae is here proposed. The subtribes Centratherinae and Sipolisiinae are reduced to synonymy of Lychnophorinae and three genera (Albertinia, Blanchetia, Gorceixia) 
are transferred to the subtribe. As now circumscribed, Lychnophorinae comprises 18 genera and 104 species distributed mostly in the cerrado domain of the Brazilian Central Plateau. Oiospermum is synonymized under Centratherum, and Irwinia under Blanchetia. Because Lychnophora as currently circumscribed was shown to be polyphyletic, it is here dismantled into three monophyletic genera: Lychnophora s.s., Lychnocephalus and a new genus described herein, Lychnophorella. 17 new combinations are proposed as well as 10 new synonymies. The descriptions of eight new species of Lychnophorinae are presented: Eremanthus brevifolius, Heterocoma gracilis, H. robinsoniana, Minasia ramosa, Paralychnophora glaziouana, Piptolepis campestris, P. monticola and P. schultziana. The synopsis provides the taxonomic status, data on nomeclatural types, geographical distribution, and taxonomic notes for each species. 
INTRODUCTION 



\section{The study group}

Asteraceae (or Compositae) is one of the largest flowering plants families (about 10\%) with ca. 24,000-30,000 species in 1,600-2,000 genera, distributed in all continents but Antarctica and nearly all habitats with its higher diversity found open formations, mostly in temperate and arid regions as well as tropical and subtropical mountains. The family is easily recognized by its florets arranged on a receptacle in centripetal heads (capitula) and surrounded by bracts (phyllaries), by anthers fused in a ring with a mechanism of secondary pollen presentation, and by the presence of cypselae often with a pappus (Bremer, 1994; Wagstaff and Breitwieser, 2002; Funk et al., 2005, 2009; Jeffrey, 2007). Asteraceae is monophyletic based on morphological and molecular phylogenetic analyses (Bremer, 1987; Jansen and Palmer, 1987; Kim et al., 1992; Panero and Funk, 2002).

Currently 12 subfamilies are recognized, with 43 tribes (Funk et al., 2009). Vernonieae is one of the major tribes of Asteraceae (subfamily Cichorioideae) with ca. 1100 species placed into 129 genera (Keeley et al., 2007; Keeley and Robinson, 2009). They are distributed into two main biodiversity centers (Brazil and Africa). The Vernonieae are very variable in habit (from small herbs to large trees), bearing leaves generally alternate and discoid capitula with white, blue or purple florets (rarely red or yellow). The most distinctive feature of the Vernonieae is given by the styles, which are slender with filiform, pilose style branches and a pilose upper shaft, but this type of styles also occur in the tribe Lactuceae of the same subfamily Cichorioideae. The pollen is highly ornamented, lophate, sublophate, echinate or psilate (Keeley and Jones, 1979; Bremer, 1994; Robinson, 1977, 2007; Keeley and Robinson, 2009).

If the delimitation of the tribe has posed few problems (but see Funk and Chan, 2009 for the position of Distephanus), much more problematical are subtribal classification and delimitation of genera (Bremer, 1994). Historically, the tribe has been organized around the large genus Vernonia (ca. 1,000 spp.), which was traditionally defined by the lack of features present in other Vernonieae genera. Phytochemical, cytological and palynological studies have indicated a putative paraphyly or polyphyly of Vernonia, which was confirmed by phylogenetic analyses based on morphological (Keeley and Turner, 1990) or molecular data (Keeley and Jansen, 1994; Keeley et al., 2007), and a subtribal classification was proposed by Robinson et al. (1980) and further modified (Robinson, 1999a, b; Keeley and Robinson, 2009). Subsequently the generic concept of Vernonia has been restricted to a small group of 22 taxa mostly from North America and other species placed in new (or re-established) genera (summarized in Robinson 1999a, b, 2007). Another characteristic of the tribe is its high number of monotypic or two species genera (about 60\%) which clearly reflects how poorly understood are the relationships between the genera and subtribes of Vernonieae (Keeley et al., 2007; Keeley and Robinson, 2009). 
The monophyly of the tribe is supported by molecular (Kim and Jansen, 1995; Kim et al., 1998; Panero and Funk, 2002; Goerzten et al., 2003; Funk et al., 2005) and morphological data (Bremer, 1987). Keeley et al. (2007) published the first phylogeny of the tribe based on DNA sequence data (ITS, $n d h \mathrm{~F}$ and $t r n \mathrm{~L}-\mathrm{F}$ ) including 90 species (35 genera) (Fig. 1). It revealed a complex biogeographic history: Vernonieae is a Gondwanan group but there is not a clear separation between New and Old World lineages; nonetheless, the limited taxonomic sampling used in that analysis prevents solid conclusions about the subtribes and genera relationships.

Among the 21 subtribes currently recognized in Vernonieae, the subtribe Lychnophorinae is nearly endemic to Brazil (only one species occurs outside) and contains 11 genera and ca. 100 species (Dematteis 2007; Robinson 2007; Keeley and Robinson, 2009). Most species are restricted to campo rupestre areas in the highlands of southeastern and northeastern Brazil and to cerrado (Brazilian savanna), a region that represents also one of the centers of diversity of the tribe Vernonieae. Established by Bentham (1873), the subtribe initially contained taxa with one- to few-flowered capitula with the capitula densely aggregated into glomerules or syncephalia and possessing simple biseriate, paleaceous, rarely setose, pappus setae (Hind, 2000). But this traditional definition has been completely abandoned by Robinson in his review of American Vernonieae, through the inclusion of genera with separate heads (Anteremanthus, Minasia, Piptolepis, Proteopsis) in Lychnophorinae (Robinson 1992, 1999, 2007; Keeley and Robinson, 2009) and proposal of a set of alternative characteristics (not necessarily restricted to Lychnophorinae, but rather consistent within the group) to define the subtribe: lack of enlarged nodes or sclerified cells at the bases of the styles, usual extensive presence of a pubescence of T-shaped hairs, presence of sclerified cells and lack of glands in the anther appendages and presence of type A pollen (Robinson, 1992). The only available molecular phylogeny (Keeley et al., 2007) does not bring any clue for the Lychnophorinae problem, due to the poor sampling of Brazilian taxa.

The genera currently recognized in the subtribe Lychnophorinae are: Anteremanthus, Chronopappus, Eremanthus (including Vanillosmopsis), Lychnophora (including Haplostephium), Lychnophoriopsis, Minasia, Paralychnophora, Piptolepis, Prestelia, Proteopsis and Vinicia. Generic limits between Eremanthus, Lychnophora, Lychnophoriopsis, and Paralychnophora are the most problematic (see Hind 2000 for a recent review).

General aspects of plants and capitula of Vernonieae-Lychnophorinae species treated in this thesis may be appreciated at figure 1 from Chapter 1 (page 67), figures 1 and 5 from Chapter 2 (pages 125 and 127), and figures 2-4 from Chapter 5 (pages 420-422). 


\section{Goals}

The objectives of the present thesis are:

- to evaluate the phylogenetic relationships within the American Vernonieae and test the monophyly of the subtribe Lychnophorinae, composed in great part by syncephalous taxa, as well as providing preliminar hypotheses about the evolution of syncephaly based on the phylogeny;

- to delimit monophyletic genera in Lychnophorinae, to confirm or refute the generic assignment of several Lychnophorinae species, and to achieve a better understanding of the relationships between the genera of this subtribe;

- to present a synopsis of Lychnophorinae, providing the taxonomic status, synonyms, data on nomenclatural types, geographical distribution, habitats, and taxonomic notes for each species.

\section{Significance}

The Cerrado Domain, one of the biodiversity hotspots recognized by Myers et al. (2000), is a savanna covering ca. 2 million $\mathrm{km}^{2}$ of the Central Brazilian Plateau, extending west into Bolivia, south to Paraguay, and east to the Caatinga Domain (Prance, 1996; Daly and Mitchell, 2000; Fiaschi and Pirani, 2009). The highest levels of endemism and diversity in the Cerrado are found in the campos rupestres (Joly, 1970; Giulietti and Pirani, 1988; Harley, 1995; Rapini et al., 2002). These formations occur on areas above 900-1000 $\mathrm{m}$ along the mountains of the Espinhaço Range (Minas Gerais and Bahia states) and the Chapada dos Veadeiros (Goiás state), covered by a low, mostly herbaceous or shrubby vegetation on sandy or rocky soils (Giulietti and Pirani, 1988; Prance, 1994; Harley, 1995; Simon and Proença, 2000; Silva and Bates, 2002; Fiaschi and Pirani, 2009). In the campos rupestres it is noteworthy a conspicuous convergent evolution of the habit, leaf shape, and pubescence between sclerophyllous evergreen small trees, shrubs and subshrubs from several families (Asteraceae, Ericaceae, Lamiaceae, Melastomataceae, Velloziaceae etc.) (Coile and Jones, 1981; Hind, 1993).

Asteraceae is one of the most important flowering plant families of the Central Brazilian Plateau displaying an amazing diversity (Hind, 1995; Munhoz and Proença, 1998). In this region, the tribe Vernonieae is one of the most species-rich (Hind, 1993). A large majority of Lychnophorinae occurs in the cerrado and campo rupestre and frequently exhibits many features which are likely to be protective against fire or against herbivory.

Cerrado and campo rupestre ecosystems suffer from several threats, in particular cattle-raising, charcoal production and indiscriminate collection of whole plants for horticultural use (Giulietti et al., 1997; Ratter et al., 1997; Silva and Bates, 2002) and their conservation requires detailed 
studies to achieve a better understanding of biodiversity origins and, especially, the evolutionary history of these taxa. The subtribe Lychnophorinae provides, with its geographic distribution nearly restricted to the Central Brazilian Plateau and its high morphological diversity, a unique biological model to study diversification and speciation.

\section{Conceptual framework}

The principal objective of systematics is to produce a predictive classification of life diversity reflecting the relationships between its elements, and includes the survey, discovery, inventory and description of species diversity (Knapp and Press, 2010). The genealogical history of species, or group of species, forms a pattern of ancestry and descent, which may be represented by a cladogram (Nelson, 1973). The aim of cladistics is to establish sister-group relationships that are hypothesized through the analysis of characters (Kitching et al., 1998). The use of cladistics analyses aiming to achieve better systems of classification of living organisms at any level of taxonomic hierarchy has been since paradigmatic in Biological Science, and a great wealth of methods have been developed in order to produce stronger supported phylogenies.

Simultaneous phylogenetic analysis (also called 'total evidence' but see Lecointre and Deleporte, 2004; Rieppel, 2005) produces best-supported hypotheses, and so maximizes congruence among different sources of data (Nixon and Carpenter, 1996). In order to establish a phylogenetic classification based on monophyletic groups supported by morphological synapomorphies (= secondary homologies) it is indispensable to test the primary homology hypotheses through the congruence test (Patterson, 1982; de Pinna, 1991). Standard cladistic analysis operates on the basis of character congruence, in which the congruence of all characters is assessed simultaneously. Only this approach guarantees finding the cladogram containing the maximal explanatory power (Nixon and Carpenter, 1996; Jenner, 2004).

The phylogenetic species concept (or cladistic species concept) followed in the present thesis, defines the species as 'the smallest aggregation of (sexual) populations or (asexual) lineages diagnosable by a unique combination of character states' (Nixon and Wheeler, 1990; Wheeler and Platnick, 2000). In practice, the use of this species definition is relatively similar to the L.I.T.U. (Least-inclusive Taxonomic Unit) of Pleijel and Rouse (2000). Concept of monophyly should not be applied to species since no hierarchical structure is observed at the tokogenetic level or it reduces unwarrantedly the meaning of monophyly to a unique evolutionary origin (for a review of species monophyly, see Rieppel 2010). Species are here understood as the basic unit for phylogenetic reconstruction; otherwise in the absence of hierarchy, on what basis are we to assume that a resulting cladogram may be interpreted as showing phylogenetic relations (Nelson and Platnick, 1981; Wheeler and Platnick, 2000)? 


\section{Structure of the thesis}

Besides the present Introduction and a Conclusion, the thesis is composed of five chapters:

- Chapter 1 presents the phylogenetic analyses of American Vernonieae focusing on syncephaly evolution. The manuscript follows the format instructions of the international periodical Taxon, to which it will be submitted conjointly with Sterling C. Keeley, Lúcia G. Lohmann and José R. Pirani.

- Chapter 2 comprises the phylogenetic analyses of the subtribe Lychnophorinae with a discussion of systematic implications. The manuscript follows the format instructions of the international journal Systematic Botany, to which it will be submitted conjointly with João Semir, Lúcia G. Lohmann and José R. Pirani.

- Chapter 3 explores the contributions of a hierarchical homology representation in phylogenetic inference based on analyses of two morphological datasets of American Vernonieae and Lychnophorinae. The manuscript follows the format instructions of the international journal Plant Systematics and Evolution, to which it will be submitted conjointly with René Zaragüeta-Bagils and José R. Pirani.

- Chapter 4 is composed of five taxonomic studies in Lychnophorinae. First part comprises the description of a new species of Eremanthus and several new synonymization (paper accepted for publication in Kew Bulletin conjointly written with Jenifer C. Lopes and José R. Pirani). An amplified concept of the genus Heterocoma is the subject of the second part as well as the descriptions of two new species of that genus (paper to be submitted to Systematic Botany conjointly with Jimi N. Nakajima, Denise M. Trombert Oliveira, João Semir and José R. Pirani). The third part comprises the description of a new species of Minasia (paper accepted for publication in Phytotaxa conjointly written with Harold Robinson and João Semir). The fourth part deals with the description of a new species of Paralychnophora with some comments on the identity of P. bicolor (paper to be submitted to Brittonia conjointly written with João Semir and José R. Pirani). The description of three new species of Piptolepis is the subject of the fifth part (paper accepted for publication in Kew Bulletin conjointly written with João Semir, David J. N. Hind and José R. Pirani).

- Chapter 5 presents the synopsis of the Lychnophorinae, corresponding to classification of the subtribe that incorporates the phylogenetic analyses results presented in Chapter 2. It will be submitted to the international periodical Havard Papers in Botany_conjointly with João Semir and José R. Pirani, after a further visit to European herbaria aiming to complement and fill some pending blanks in the manuscript, mostly to check type specimens and to select lectotypes where necessary. 
I hereby declare that all the new names and new combinations will be published in periodicals and, consequently, the present thesis should not be considered as the effective publication of these names.

\section{References}

Bentham, G. 1873. Compositae. In: G. Bentham and J. D. Hooker (eds), Genera plantarum, 2(1), Reeve \& Co., London and Williams and Norgate, London, pp. 163-533.

Bremer, K. 1987. Tribal interrelationships of the Asteraceae. Cladistics 3: 210-253.

Bremer, K. 1994. Asteraceae: cladistics and classification. Timber Press, Oregon.

Coile, N. C. And S. B. Jones JR. 1981. Lychnophora (Compositae: Vernonieae), a genus endemic to the Brazilian Planalto. Brittonia 33: 528-542.

Daly, D. C. And J. Mitchell. 2000. Lowland vegetation of tropical South America. In: D. LENTZ (ed.) Imperfect balance: landscape transformations in the pre-Columbian Americas. Columbia University Press, New York, pp. 393-453.

Dematteis, M. 2007. Vinicia tomentosa, nuevo género y especie de Lychnophorinae (Vernonieae, Asteraceae) de Minas Gerais, Brasil. Bonplandia 16: 259-264.

Fiaschi, P. AND J. R. Pirani. 2009. Review of plant biogeographic studies in Brazil. J. Syst. Evol. 47: 477-496.

Funk, V. A. And R. Chan. 2009. Introduction to Cichorioideae. In: V. A. Funk; A. Susana; And T. F. Stuessy and R. J. BAyer (eds.), Systematics, Evolution, and Biogeography of Compositae. Vienna, Austria: International Association for Plant Taxonomy (IAPT), pp. 335-342.

Funk, V. A.; Susanna, A.; Stuessy, T. F. And R. J. BAyer. 2009. Systematics, evolution and biogeography of Compositae. Vienna, Austria: International Association for Plant Taxonomy (IAPT).

Funk, V. A.; Bayer, R. J.; Keeley, S.; Chan, R.; Watson, L.; Gemeinholzer, B.; Schilling, E.; Panero, J. L.; Baldwin, B. G.; Garcia-Jacas, N. T.; Susanna, A. and R. K. Jansen. 2005. Everywhere but Antarctica: Using a supertree to understand the diversity and distribution of the Compositae. In: I. FriIS AND H. BALSLEv (eds.) Plant diversity and complexity patterns - local, regional and global dimensions. Proceedings of an International Symposium. Biol. Skr. 55: 343-373.

Giulietti, A. M. And J. R. Pirani. 1988. Patterns of geographic distribution of some plant species from the Espinhaço Range, Minas Gerais and Bahia, Brazil. In: P. E. VAnzolini And W. R. Heyer (eds) Proceedings of a workshop on neotropical distribution patterns. Academia Brasileira de Ciências, Rio de Janeiro, pp. 39-69.

Giulietti, A. M.; Pirani, J. R. And R. M. Harley 1997. Espinhaço range region. Eastern Brazil. In: S. D. Davis, V. H. Heywood, O. Herrera-MacBryde, J. Villa-Lobos and A. C. Hamilton (eds) Centres of plant diversity. A guide and strategy for their conservation. Volume 3 The Americas. WWF and IUCN, pp. 397-404. 
Goertzen, L. R.; Cannone, J. J.; Gutell, R. R. and R. K. Jansen. 2003. ITS secondary structure derived from comparative analysis : implications for sequence alignment and phylogeny of the Asteraceae. Mol. Phyl. Evol. 29: 216-234.

Harley, R. M. 1995. Introdução. In: B. L. Stannard (ed) Flora of the Pico das Almas-Chapada Diamantina, Bahia, Brazil. Kew: Royal Botanic Gardens, pp. 43-78.

Hind, D. J. N. 1993. Notes on the Compositae of Bahia, Brazil: I. Kew Bull. 48: 245-277.

Hind, D. J. N. 1995. Compositae. In: B. L. Stannard (ed) Flora of the Pico das Almas-Chapada Diamantina, Bahia, Brazil. Kew: Royal Botanic Gardens, pp. 245-277.

Hind, D. J. N. 2000. Two new species of Paralychnophora (Compositae: Vernonieae) from Bahia. Kew Bull. 55: 367-379.

JANSEN, R. K. AND J. D. PALMER. 1987. A chloroplast DNA inversion marks an ancient evolutionary split in the sunflower family (Asteraceae). Proc. Natl. Acad. USA 84: 5818-5822.

Jefrerey, C. 2007. Introduction with key to tribes. In: J. W. Kadereit and C. JefFrey (eds.) The families and genera of vascular plants, vol 8. Flowering plants-eudicot, Asterales. Springer, Berlin, pp 61-87.

JenNeR, R. A. 2004. Accepting partnership by submission ? Morphological phylogenetics in a molecular millennium. Syst. Biol. 53: 333-342.

Joly, A. B. 1970. Conheça a vegetação brasileira. EDUSP e Polígono. São Paulo.

Keeley, S. C. and R. K. Jansen. 1994. Chloroplast DNA restriction site variation in the Vernonieae (Asteraceae), an initial appraisal of the relationship of New and Old World taxa and the monophyly of Vernonia. Pl. Syst. Evol. 193: 249-265.

Keeley, S. C. and S. B. Jones. 1979. Distribution of pollen types in Vernonia (Vernonieae: Compositae). Syst. Bot. 4: 195-202.

Keeley, S. C. and H. Robinson. 2009. Vernonieae. In: V. A. Funk; A. Susana; and T. F. Stuessy AND R. J. BAYER (eds.), Systematics, Evolution, and Biogeography of Compositae. Vienna, Austria: International Association for Plant Taxonomy (IAPT), pp. 439-469.

Keeley, S. C. And B. L. Turner. 1990. A preliminary cladistic analysis of the genus Vernonia (Vernonieae: Asteraceae). Pl. Syst. Evol., Suppl. 4: 45-66.

Keeley, S. C.; Forsman, H. Z. and R. Chan. 2007. A phylogeny of the 'evil tribe' (Vernonieae : Compositae) reveals Old/New World long distance dispersal: support from separate and combined congruent datasets (trnL-F, ndhF, ITS). Mol. Phyl. Evol 44: 89-103.

Kim, H. G.; Keeley, S. C.; VRoom, P. S. and R. K. Jansen. 1998. Molecular evidence for an African origin of the Hawaiian endemic Hesperomannia (Asteraceae). Proc. Natl. Acad. USA 95: 15440-15445.

Kim, K. -J. And R. K. JAnSEn. 1995. NdhF sequence evolution and the major clades in the sunflower family. Proc. Natl. Acad. USA 92: 10379-10383.

Kim, K. -J.; Jansen, R. K.; Wallace, R. S.; Michaels, H. J. and J. D. Palmer. 1992. Phylogenetic implications of $r b c \mathrm{~L}$ sequence variation in the Asteraceae. Ann. Missouri Bot. Gard. 79: $428-445$. 
Kitching, I. J.; Forey, P. L.; Humphries, C. J. And D. W. Williams. 1998. Cladistics: the theory and practice of parsimony analysis, second edition. Oxford University Press, Oxford, UK.

Knapp, S. and J. R. Press. 2010. Floras to phylogenies: why descriptive taxonomy matters. In: S. Knapp And D. M. Williams (eds) Beyond Cladistics: the branching of a paradigm. University of California Press, Berkeley, Los Angeles, London, pp. 77-90.

LeCointre, G. AND P. Deleporte. 2005. Total evidence requires exclusion of phylogeneticallt misleading data. Zool. Scripta 34: 101-117.

Munhoz, C. B. R. and C. E. B. ProençA. 1998. Composição florística de Alto Paraíso de Goiás na Chapada dos Veadeiros. Bol. Herbário Ezechias Paulo Heringer 3 : 102-150.

Myers, N.; Mittermeier, R. A.; Mittermeier, C. G.; da Fonseca, G. A. B. and J. Kent. 2000. Biodiversity hotspots for conservation priorities. Nature 403: 853-858.

Nelson, G. 1973. Classification as an expression of phylogenetic relationships. Syst. Zool. 22: 344-359.

Nelson, G. and N. I. Platnick. 1981. Systematics and Biogeography: Cladistics and Vicariance. New York: Columbia University Press.

Nixon, K. C. And Q. D. Wheeler. 1990. An amplification of the phylogenetic species concept. Cladistics 6: 211-223.

Nixon, K. C. And J. M. Carpenter. 1996. On simultaneous analysis. Cladistics 12: 221-241.

Panero, J. L. and V. A. Funk. 2002. Toward a phylogenetic subfamilial classification for the Compositae (Asteraceae). Proc. biol. soc. Washington 115: 909-922.

PAtTERSOn, C. 1982. Morphological characters and homology. In: K. A. Joysey AND A. E. FridAy (Eds) Problems of phylogenetic reconstruction. London: Academic Press, pp. 21-74.

DE Pinna M. C. C. 1991. Concepts and tests of homology in the cladistic paradigm. Cladistics 7: 367-394.

Pleijel, F. and G. W. Rouse. 2000. Least-inclusive taxonomic unit: a new taxonomic concept for biology. Proc. R. Soc. Lond. B. 267: 627-630.

Prance, G. T. 1994. A comparison of the efficacy of higher taxa and species numbers in the assessment of biodiversity in the Neotropics. Philos. Trans. R. Soc. Lond. B 345: 89-99.

Prance, G. T. 1996. Islands in Amazonia. Philos. Trans. R. Soc. Lond. B 351: 823-833.

Rapini, A.; Mello-Silva, R. and M. L. Kawasaki. 2002. Richness and endemism in Asclepiadoideae (Apocynaceae) from the Espinhaço Range of Minas Gerais, Brazil - a conservationist view. Biodivers. Conserv. 11: 1733-1746.

Ratter, J. A.; Ribeiro, J. F. and S. Bridgewater. 1997. The Brazilian cerrado vegetation and threats to its biodiversity. Ann. Bot. 80: 223-230.

RIEPPEL, O. 2005. The philosophy of total evidence and its relevance for phylogenetic inference. Pap. Avuls. Zool. 45: 77-89.

Rieppel, O. 2010. Species monophyly. J. Zool. Syst. Evol. Res. 48: 1-8.

RoBinson, H. 1977. An analysis of the characters and relationships of the tribes Eupatorieae and Vernonieae (Asteraceae). Syst. Bot. 2: 199-208. 
Robinson, H. 1992. Notes on Lychnophorinae from Minas Gerais, Brazil, a synopsis of Lychnophoriopsis Schultz-Bip., and the new genera Anteremanthus and Minasia (Vernonieae: Asteraceae). Proc. Biol. Soc. Washington 105: 640-652.

Robinson, H. 1999a. Generic and subtribal classification of American Vernonieae. Smithsonian Contr. Bot. 89.

Robinson, H. 1999b. Revisions in paleotropical Vernonieae (Asteraceae). Proc. Biol. Soc. Washington 112: 220-247.

Robinson, H. 2007 [2006]. VI. Tribe Vernonieae Cass. In: J. W. Kadereit and C. Jefrrey (eds.) The families and genera of vascular plants, vol 8. Flowering plants-eudicot, Asterales. Springer, Berlin, pp. 149-174.

Robinson, H.; Bohlmann, F. And R. M. King. 1980. Chemosystematics notes of the Asteraceae, III : natural subdivisions of the Vernonieae. Phytologia 46: 421-436.

Silva, J. M. C. DA AND J. M. Bates. 2002. Biogeographic patterns and conservation in the South American Cerrado: a tropical savanna hotspot. BioScience 52: 225-233.

Simon, M. F. And C. Proença. 2000. Phytogeographic patterns of Mimosa (Mimosoideae, Leguminosae) in the Cerrado biome of Brazil: an indicator genus of high-altitude centers of endemism ? Biol. Conserv. 96: 279-296.

Wagstaff, S. J. and I. Breitwieser. 2002. Phylogenetic relationships of New Zealand Asteraceae inferred from ITS sequences. Pl. Syst. Evol. 231: 203-224.

Wheeler, Q. D. And N. I. Platnick. 2000. The phylogenetic species concept (sensu Wheeler and Platnick). In: Q. D. Wheeler And R. MeIER (eds) Species concepts and phylogenetic theory: a debate. New York: Columbia University Press, pp. 55-69. 



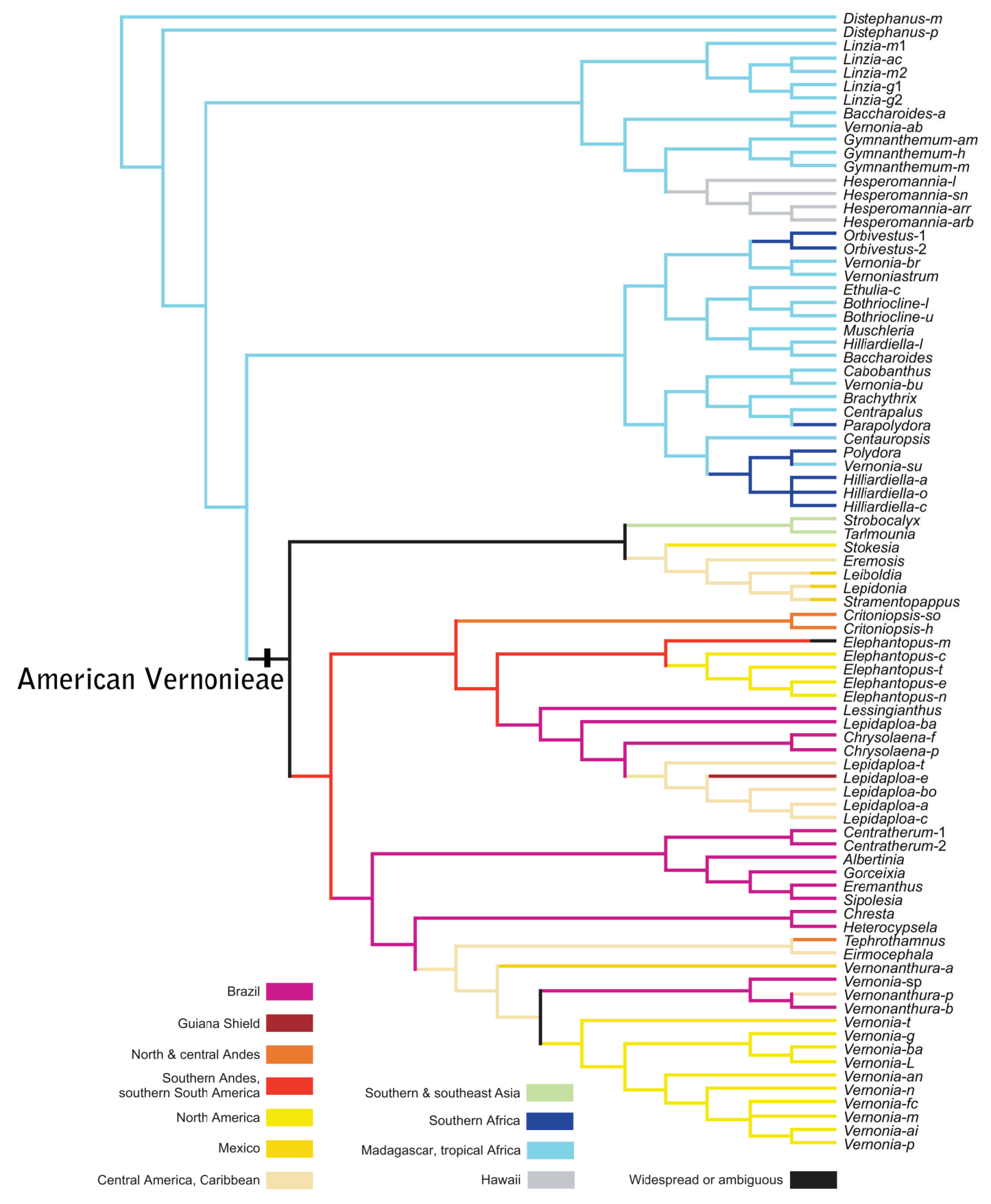

Fig. 1 Bayesian inference phylogram based on the combined analysis of DNA sequences of ITS, $n d h \mathrm{~F}$, trnL-F for 90 taxa of Vernonieae. (Modified from Keeley and Robinson, 2009). 



\section{CHAPTER 1}

Systematics and evolution of syncephaly in American Vernonieae (Asteraceae) based on molecular and morphological data 

Systematics and evolution of syncephaly in American Vernonieae (Asteraceae) based on molecular and morphological data

\author{
Benoît Loeuille ${ }^{1}$, Sterling C. Keeley ${ }^{2}$, Lúcia G. Lohmann르, and José R. Pirani1 ${ }^{1}$ \\ ${ }^{1}$ Laboratório de Sistemática Vegetal, Departamento de Botânica, Instituto de Biociências \\ da Universidade de São Paulo, Rua do Matão, 277, CEP: 05508-090, São Paulo, SP, Brasil. \\ benoit_loeuille@yahoo.fr (authorfor correspondence) \\ ${ }^{2}$ Department of Botany, University of Hawaii at Manoa, 3190 Maile Way, Honolulu, HI \\ 96822, USA
}

Paper to be submitted to TAXON 



\begin{abstract}
A phylogenetic hypothesis of American Vernonieae based on three molecular regions (ITS, $n d h \mathrm{~F}, r p l 32-t r n \mathrm{~L})$ and on a morphological dataset reveals the existence of four main lineages. Three of these lineages correspond, with a few adjustments, to subtribes Chrestinae, Lychnophorinae and Vernoniinae. The last lineage, which has never been recognized at a taxonomic rank due to the lack of morphological characterization, is mainly composed of Lepidaploinae and Elephantopinae as well as a number of genera traditionally placed in others subtribes (Chrestinae, Piptocarphinae, Vernoniinae). The relationships between these lineages are still not satisfactorily resolved. In order to keep the Lychnophorinae monophyletic, two small subtribes (Centratherinae, Sipolisiinae) and three monotypic genera (Albertinia, Blanchetia and Gorceixia) have to be to transferred to Lychnophorinae, which has the presence of heliangolide in aerial parts as a synapomorphy. Even though syncephaly has been historically used to delimitate the subtribe Lychnophorinae, our results show that this character probably appeared independently three or four times in American Vernonieae. The formation of syncephalium, in each case, seems to be related to different biological functions: attractive (Chrestinae), disseminative (Rolandrinae) or protective (Lychnophorinae).
\end{abstract}

Keywords Compositae, ITS, $n d h \mathrm{~F}, r p l 32-t r n \mathrm{~L}$, syncephaly evolution, classification. 



\section{INTRODUCTION}

The syncephalia (secondary heads, rarely termed syncalathia or pseudocephalia), aggregations of several capitula into higher order inflorescences have caught the attention from either morphological (Troll, 1928; Kunze, 1969; Weberling, 1992; Harris, 1995, 1999; ClaßenBockhoff, 1996) and evolutionary points of view (Good, 1956; Leppik, 1960; Burtt, 1961; Stebbins, 1967). The aggregation of capitula (condensation), sometimes accompanied by some degree of reduction, into a syncephalium occurs in ca. 70 genera of Asteraceae (Harris, 1999; Katinas \& al., 2008). Documentation of syncephalium has relied on characteristics of mature inflorescences: sequence of flowering, unusual arrangements of florets and their associated bracts, and relative size of palea and phyllaries (Kunze, 1969; Harris, 1994). At maturity, the determination of the origin and precise nature of these structures are often problematic, given differential growth and expansion (Harris, 1994). Hence, homologies of syncephalia are extremely difficult to establish (Stuessy \& Spooner, 1988; Susanna \& Garcia-Jacas, 2009).

The tribe Vernonieae comprises 14 syncephalous genera, nearly all of them from the New World (only Hystrichophora occurs in Tanzania). The American Vernonieae (73 genera, ca. 700 spp.) mostly show a neotropical distribution with a great concentration in Brazil and only a few genera in North America and other southern South American countries. The current subtribal classification (15 subtribes) is largely based on floral microcharacters, chromosome number, palynological and phytochemical data (Table 1) (Robinson, 1999; Robinson, 2007; Keeley \& Robinson, 2009). The presence of syncephalium has been used to define the subtribe Lychnophorinae (Baker, 1873; Bentham, 1873; Hoffmann, 1890), a group that also included all genera presently ascribed to the subtribes Elephantopinae and Rolandrinae. Cabrera (1944) and Cabrera \& Vittet (1961) recognized the Elephantopinae at the subtribal level and Rolandrinae was re-established as a subtribe by Robinson \& al. (1980). Later, syncephalous herbaceous taxa with lophate pollen and glaucolides (Chresta and Soaresia) were excluded from the Lychnophorinae (Robinson, 1992) and acknowledged as the subtribe Chrestinae (Robinson, 1999). Since Robinson \& al. (1980), with the inclusion of genera with separate capitula such as Proteopsis and Minasia, the definition of Lychnophorinae based strictly on the presence of syncephalium has been abandoned.

Phylogenetic studies have been primarily concerned with the delimitation of Vernonia (Keeley \& Turner, 1990; Keeley \& Jansen, 1994). The first phylogeny of the tribe (Keeley $\&$ al., 2007) showed Old World taxa to be basal and the New World to form a clade (here called American Vernonieae) with some exceptions (some Asian taxa appeared to be related to the Central American Leiboldiinae). Two main lineages were evidenced: (1) one composed of Albertinia, Centratherum, Eremanthus, Gorceixia (the latter two genera being syncephalous), Vernonia, and Vernonanthura; (2) the other composed of Critoniopsis, Elephantopinae, and taxa from the Lepidaploa complex (Keeley \& al., 2007; Keeley \& Robinson, 2009).

By largely increasing the sampling density, the present study investigated into greater details 
the phylogeny of the American Vernonieae using two plastid regions ( $n d h \mathrm{~F}, r p l 32-\operatorname{trn} \mathrm{L}$ ), a nuclear region (ITS) and a morphological dataset which includes most of the characters used in the current subtribal classification. We aim to (1) evaluate the phylogenetic relationships within the American Vernonieae; (2) test the monophyly of the subtribe Lychnophorinae, composed in great part by syncephalous taxa; and (3) provide preliminar hypotheses about the evolution of syncephaly based on the phylogeny.

\section{MATERIALS AND METHODS}

Outgroup choice and taxon sampling. - Moquinia racemosa (Spreng.) DC. (tribe Moquinieae) and Gymnanthemum amygdalinum (Delile) Sch. Bip. ex Walp. were used as outgroups based on previous phylogenetic studies (Keeley \& al., 2007; Funk \& Chan, 2009). Two Asian taxa were also included as they are related to the American subtribe Leiboldiinae (Keeley \& al., 2007). Seventy species from 39 genera were sampled out of the 73 genera (ca. 700 spp.) of Vernonieae occuring in Americas were sampled, representing 10 of the 15 American subtribes. Most syncephalous genera of the tribe were included (except the three monotypic genera: Hystrichophora, Spiracantha and Telmatophila) as well as all Lychnophorinae genera (Tab. 1). The sampling for morphological data comprised one more species than the molecular dataset: Vinicia tomentosa Dematt. a monotypic genus only known from the type collection (efforts to extract DNA from this material were unsuccessful).

Morphological data. - Examination of herbarium specimens and field observations provided 57 qualitative characters and one quantitative character (florets number per capitulum), which are listed in Appendix 2, and compiled on a morphological matrix (Appendix 3). The quantitative character has been coded using the gap weighting method of Thiele (1993) in ten states. Garcia-Cruz \& Sosa (2006) have shown that this method performs better in recovering phylogenetic signal than others proposed methods for coding quantitative character. Detailed explanations of the character sampling and coding is provided in Loeuille \& Pirani (in prep.) (see Chapter 3).

DNA extraction, amplification and sequencing. - Total genomic DNA was extracted from silica-gel-dried leaves collected in the field using the commercial kit Invisorb ${ }^{\circledR}$ Spin Plant Mini Kit (Invitek, Berlin Germany), following the manufacturer's instructions. DNA were extracted from herbarium material for two species, using the QIAamp ${ }^{\circledR}$ DNA stool Mini Kit (Qiagen Inc., Hilden, Germany) with a modified protocol.

Primers ITS4 (White \& al., 1990) and ITS5A (Downie \& Katz-Downie, 1996) based on White \& al.'s (1990) fungal primer ITS5 and corrected at two positions for angiosperms were used to amplify and sequence the ITS region. Primers 1603 and +607 used to amplify and sequence the 3 ' end of the $n d h \mathrm{~F}$ region were designed by Jansen (1992) and those used for rpl32-trnL (trnLretF and rpl32retR) by Timme \& al. (2007).

PCR amplifications were carried out in $25-\mu \mathrm{L}$ reactions with $2.5 \mu \mathrm{L} 10 \times$ PCR reaction Buffer A (Promega, Madison, WI, U.S.A.), $0.5 \mu \mathrm{L}$ of $10 \mu \mathrm{M}$ dNTPs (Promega) in an equimolar ratio, 
$2.5 \mu \mathrm{L}$ of $25-\mathrm{mM}$ magnesium chloride, $0.5 \mu \mathrm{L}$ of $10 \mathrm{mg} / \mathrm{ml}$ Bovine Serum Albumine (New England BioLabs Inc., Beverly, M.A., U.S.A.), $1 \mu \mathrm{L}$ of D.M.S.O. (Sigma, St. Louis, M.O., U.S.A.) (only for ITS), $1 \mu \mathrm{L}$ of a $10 \mu \mathrm{M}$ concentration of the forward primer, $1 \mu \mathrm{L}$ of a $10 \mu \mathrm{M}$ concentration of the reverse primer, $0.1 \mu \mathrm{L}$ of Taq DNA polymerase enzyme $(5 \mathrm{U} / \mu \mathrm{L}$ from Promega), $14.9 \mu \mathrm{L}$ of sterile water and $1 \mu \mathrm{L}$ of template DNA. The PCR program for ITS region consisted of $2 \mathrm{~min}$ initial denaturation at $95^{\circ} \mathrm{C}$, and 29 cycles of $1 \mathrm{~min}$ denaturation at $95^{\circ} \mathrm{C}, 1$ min annealing at $54^{\circ} \mathrm{C}, 2$ min extension at $72^{\circ} \mathrm{C}$, followed by a final extension of $7 \mathrm{~min}$ at $72^{\circ} \mathrm{C}$. The PCR program for $3^{\prime}$ end $n d h \mathrm{~F}$ was $3 \mathrm{~min}$ at $93^{\circ} \mathrm{C}, 1 \mathrm{~min}$ at $46^{\circ} \mathrm{C}, 1 \mathrm{~min} 20 \mathrm{~s}$ at $72^{\circ} \mathrm{C}$ and 29 cycles of $1 \mathrm{~min} 95^{\circ} \mathrm{C}, 1 \mathrm{~min} 50^{\circ} \mathrm{C}, 1 \mathrm{~min} 20 \mathrm{sec}\left(+3 \mathrm{sec} /\right.$ cycle) $72^{\circ} \mathrm{C}$, followed by $7 \mathrm{~min}$ at $72^{\circ} \mathrm{C}$. And the PCR program for rpl32-trn L consisted of $5 \mathrm{~min}$ at $80^{\circ} \mathrm{C}$ and 29 cycles of $1 \mathrm{~min}$ at $95^{\circ} \mathrm{C}, 1 \mathrm{~min}$ at $56^{\circ} \mathrm{C}, 4 \mathrm{~min}$ at $65^{\circ} \mathrm{C}$, followed by $10 \mathrm{~min}$ at $65^{\circ} \mathrm{C}$. The PCRs were performed on thermal cycler (DNA Engine ${ }^{\circledR}$; Bio-Rad, Hercules, CA, U.S.A.).

In a few cases, to obtain readable ITS sequences, the PCR products were cloned using the Promega pGEM-T Easy Vector System II cloning kit, following the manufacturers instructions and using half reactions. When possible, eight positive colonies were screened via PCR using M13 universal primers under the following conditions: 5 min at $94^{\circ} \mathrm{C}$ followed by 29 cycles of $94^{\circ} \mathrm{C}$ for $45 \mathrm{~s}, 53^{\circ} \mathrm{C}$ for $1 \mathrm{~min}$ and $72^{\circ} \mathrm{C}$ for $1 \mathrm{~min} 30 \mathrm{~s}$, ending with $72^{\circ} \mathrm{C}$ for $7 \mathrm{~min}$. Five to eight PCR products were selected for sequecing in both directions using the same primers. After checking that all cloned sequences formed a clade, one of the sequences was chosen for the phylogenetic analyses.

The PCR products were purified using the QIAquick PCR Purification Kit (Qiagen Inc.). Direct sequencing of the amplified DNA segments was performed as a service of Macrogen, Inc. (Seoul, South Korea) with the same primers used for PCR amplification. Sequences from both strands of each PCR product were examined, compared, and corrected using Sequencher v. 4.1.4. (Gene Codes Corp., Ann Arbor, Michigan). Sequences are available in GenBank (accessions numbers provided in the Appendix 1).

The analyses used 159 new sequences (53 ITS, $48 n d h \mathrm{~F}, 58 \mathrm{rpl32}-\operatorname{trn} \mathrm{L}$ ) together with 40 sequences from published EMBL/GenBank accessions as documented in Keeley \& al. (2007) and Keeley \& al. (unpub.).

Alignments. - Alignments of the sequences were made in MAFFT v. 6.611b (Katoh \& Toh, 2008) using the default setting and Fast Fourier Transform algorithm, followed by manual gap adjustments in BioEdit v. 5.0.6 (Hall, 1999). Indels were coded as binary characters using simple indel coding (SIC; Simmons \& Ochoterena, 2000) as implemented in the program SeqState (Müller, 2005, 2006).

Parsimony analyses. - Parsimony uninformative characters were excluded from the analyses. Heuristic searches were conducted using NONA (Goloboff, 1999) spawned by Winclada (Nixon, 1999-2002). Tree-bisection-reconnection (TBR) swapping on Wagner trees were conducted from 10,000 random addition sequences with 20 trees held in each replicate initiations expanding the memory to $1,000,000$ to do further TBR. A strict consensus tree was 
constructed. To increase the likelihood of exploring all possible tree-islands, an additional search strategy was applied: the parsimony ratchet procedure (Nixon, 1999). Ten independent ratchet searches with 400 iterations each were performed, the results were combined and a strict consensus tree constructed after applying the commands "hard collapse unsupported nodes in all trees" and "keep best only". The two strict consensus trees obtained were then compared. Datasets were analyzed separately and combined using simultaneous analysis approach (Nixon \& Carpenter, 1996). The morphological dataset has been analized by Loeuille \& Pirani (in prep., see Chapter 3) and its analysis was not repeated here. Branch support was assessed by Jackknife support (JK) (Farris \& al., 1996), which is preferable to bootstrap because of its closer relationship to original data (Freudenstein \& Davis, 2010) and clearer, less ambiguous meaning (Siddall, 2002). It was calculated with NONA spawned by Winclada with 1000 replications with 100 search replications and 10 trees held in memory. Jackknife values are described as high (95-100\%), moderate (85-94\%) and low ( $\leq 84 \%)$.

Bayesian analysis. - Bayesian inference of phylogeny with posterior probabilities (PP) was conducted with MrBayes v. 3.1.2 (Huelsenbeck \& Ronquist, 2001; Ronquist \& Huelsenbeck, 2003) for the two combined analysis (all molecular data and morphology + all molecular data). The models of molecular evolution were selected using the Akaike Information Criterion (AIC) as implemented in jModelTest v. 0.1.1 (Guindon \& Gascuel, 2003; Posada, 2008). The chosen models were GTR $+\mathrm{I}+\mathrm{G}$ for ITS and GTR $+\mathrm{G}$ for $n d h \mathrm{~F}$ and $r p l 32-t r n \mathrm{~L}$. The standard discrete model was used for the coded gaps and morphological data. Searches used default settings for all parameters. Four simultaneous independent runs initiated from random start trees were run for 10 million generations, sampling from the posterior distribution of trees every 1000 generations (for a total of 10,000 samples). Several strategies were employed to confirm that chains have achieved stationarity and the appropriate burn-in for each analysis was determined: (1) we plotted overall - $\operatorname{lnL}$, (2) we examined the standard deviation of split frequencies, (3) we examined the potential scale reduction factor (PSRF), and (4) we checked graphically the convergence of the MCMC by monitoring the cumulative posterior split probabilities and among-run variability of split frequencies using the online tool AWTY (Wilgenbusch \& al., 2004). A total of $25 \%$ of the samples were discarded as burn-in. Posterior probability support (PP) was estimated to be significant for nodes with $\mathrm{PP} \geq 0.90$.

Congruence of datasets. - Congruence among datasets was tested with the Incongruence Length Difference (ILD) test (Farris \& al., 1995). However a high false positive rate has been reported (Cunningham, 1997; Darlu \& Lecointre, 2002; Hipp \& al., 2004). As pointed out by Pelser \& al. (2010), alternative methods for testing incongruence may suffer from errors as well (Cunningham, 1997; Hipp \& al., 2004). Therefore, in addition to the ILD test, incongruent patterns supported were assessed by high JK or PP values. The incongruence test value was calculated by performing with NONA using Winclada. One thousand replications were executed with 10 searches per replication holding 10 trees for each search and holding a total of 100 trees. Uninformative characters were removed from the analyses before running the ILD test 
(Cunningham, 1997; Lee, 2001). Following Nixon \& Carpenter (1996), we did not conduct the tests to decide whether datasets should be combined or not, but to detect sources of conflict between the datasets.

\section{RESULTS}

DNA sequences and alignments. - Table 2 lists the characteristics of each data matrix used in the phylogenetic analysis.

Phylogenetic analyses. - The results of the ITS parsimony analysis are given in Table 2 and Fig. S1 (Electronic Supplement). Several well-supported lineages were found but the high-level relationships remained ambiguous. All the Lychnophorinae genera are found in a clade with high support $(\mathrm{JK}=99 \%)$ but the Sipolisiinae and two other genera (Blanchetia and Gorceixia) are nested inside this clade. The (Centratherum/Albertinia/Lychnophorinae) clade is well-supported ( $\mathrm{JK}=99 \%$ ) but the relationships between these three taxa is unclear, (Centratherum/Albertinia) having a low support $(\mathrm{JK}=50 \%)$. A large clade with moderate support ( $\mathrm{JK}=89 \%$ ) was found containing taxa from Lepidaploinae, Elephantopinae and several genera from other subtribes (Chrestinae, Piptocarphinae, Vernoniinae). All Lepidaploinae taxa are in the same clade $(\mathrm{JK}=100 \%)$ with the exception of Stenocephalum which is sister-group of Rolandra fruticosa $(\mathrm{JK}=100 \%)$. Soaresia velutina (Chrestinae) and Elephantopinae genera formed a monophyletic group ( $\mathrm{JK}=100 \%)$. Relationships between these different clades and other genera (Critoniopsis, Cyrtocymura, Piptocarpha and Strophopappus) have low support. The Chrestinae (except Soaresia) are grouped in a high-supported clade ( $\mathrm{JK}=100 \%$ ) which is sister to Stokesia laevis $(\mathrm{JK}=80 \%)$. The Chrestinae clade is divided in two subclades: Chresta $(\mathrm{JK}=100 \%)$ and Pithecoseris/Argyrovernonia $(\mathrm{JK}=96 \%)$. Vernonanthura/Vernonia clade (JK $=100 \%)$ is sister to Stokesia/Chrestinae but the support is low $(\mathrm{JK}=63 \%)$.

The results of the chloroplast $(n d h \mathrm{~F}+\operatorname{rpl32}-\operatorname{trn} \mathrm{L})$ parsimony analysis are given in Table 2 and Fig. S2. The individual chloroplast analysis gave poorly resolved strict consensus trees (data not shown). The result of the ILD test indicates that the two chloroplast datasets are statistically incongruent ( $p=0.02$ ), but no incongruent patterns with high support (JK) were found. The chloroplast strict consensus tree is less resolved than the ITS tree and only some of the higher clades were found: Elephantopinae/Soaresia $(\mathrm{JK}=97 \%)$, Chrestinae $(\mathrm{JK}=99 \%)$ and Lychnophorinae/Albertinia $(\mathrm{JK}=72 \%$ ) and Lepidaploinae (without Stenocephalum but with Strophopappus, JK = 51\%; without both genera: JK = 99\%).

The nuclear and chloroplast datasets are statistically incongruent $(p=0.01)$ according to the ILD test. However no incongruent patterns with high support were found between the nuclear (ITS) and chloroplast trees. The molecular combined parsimony analysis (Fig. 1; Table 2) and Bayesian analysis (Fig. S3) resulted on similar topologies. The main difference is the position of Stokesia laevis: placed as sister to clade B (Chrestinae) in the parsimony tree (but without support) and as sister to Leiboldiinae in the Bayesian tree $(\mathrm{PP}=0.99)$. The Stokesia laevis branch is exceptionally long (Fig. S3) and a possible explanation for this topological incongruence is 
long-branch attraction (Felsenstein, 1978). Parsimony has a stronger bias towards grouping longer branches together (Bergsten, 2005) and the branch of clade B (Chrestinae) clade is also very long. The Bayesian tree is more resolved than the strict consensus tree of the parsimony and displays significant supports for basal nodes. The clade (Leiboldiinae/Asian taxa) emerges as sister-group of the rest of American Vernonieae $(\mathrm{PP}=1)$, a relationship which does not receive support in the parsimony analysis. The same discrepancies were found by Keeley \& al. (2007) for the position of the (Leiboldiinae/Asian taxa) clade between the parsimony and Bayesian analysis but not for the position of Stokesia. The main clades found in the ITS tree were also present in the molecular combined analysis but the clade C (Vernonia/Vernonanthura) is sister to clade D and not clade B (Chrestinae). Nonetheless the support for this relationship is low in parsimony $(\mathrm{JK}=64)$ but significant in Bayesian analysis $(\mathrm{PP}=1)$.

Results of the ILD test indicate that the molecular and morphological datasets are statistically incongruent ( $p=0.01$ ) (even after exclusion of Stokesia), but no incongruent patterns with high support (JK) were found (see Chap 1). The simultaneous analysis (molecular and morphological datasets) (Fig. 2; Fig. S4) resulted in similar results to the molecular combined analysis. The Bayesian analysis, especially, produced the same topology in both analyses. The parsimony strict consensus tree is less resolved (but these nodes have low support in the molecular combined analysis) and most of the Jackknife values are lowered. Three morphological synapomorphies and two phytochemical synapomorphies have been found: the lobed leaf blade for the clade (Argyrovernonia, Pithecoseris), the receptacle with a short thick column for the Piptocarpha clade, the paleae on the receptacle for the clade (Bishopalea, Heterocoma), the presence of heliangolide for the clade D and the presence of phytomelanin in the cypsela wall for the clade formed by Bishopalea, Heterocoma, Sipolisia and Xerxes. The differences at high-level relationships between parsimony and Bayesian analysis are shown on Fig. 3.

\section{DISCUSSION}

Subtribal classification and morphological characterization. - Our results are highly similar to those of Keeley \& al. (2007). Notably the sister-group relationship between Leiboldiinae/Asian taxa and the rest of American Vernonieae is only found in Bayesian analysis. The addition of the morphology (including palynological and phytochemical data) did not change the molecular pattern and confirmed the high level of homoplasy in morphological data of Vernonieae. The following discussion will concern only clades and relationships found with high support in both methods (parsimony and Bayesian analysis).

Of the 15 subtribes in the present-day classification of American Vernonieae (Keeley \& Robinson, 2009) only seven have more than ten species (Table 1). Our taxonomic sampling focused mainly on subtribes Chrestinae and Lychnophorinae, because we were mostly concerned to syncephalous taxa, but even such a limited sampling showed nearly all of these subtribes as paraphyletic (Leiboldiinae is monophyletic in our study but only two taxa were included).

The Elephantopinae is monophyletic and well defined morphologically (Fig. 1G, Table 1), 
noteworthy is the derived position of Orthopappus angustifolius in Elephantopus. Based on its unusual pollen Robinson $(1999,2007)$ kept Orthopappus separate from Elephantopus. In light of the present analysis, we considered both as synonyms. The monotypic genus Soaresia velutina, previously placed in Chrestinae based on its syncephaly (Robinson, 1999, 2007), is here related to Elephantopinae (clade A1). Its bristle-like awns pappus and unbranched trichomes (not T-shaped) are common features of subtribe Elephantopinae and, consequently, we regard Soaresia as a member within it.

The Chrestinae is here defined as monophyletic (clade B) (Fig. 1E, 5ABC, Table 1), all of its members are rosulate herbs (plants of Pithecoseris have cauline and rosulate leaves) with syncephaly, and most of them have T-shaped trichomes (only Chresta speciosa have only unbranched trichomes). Argyrovernonia has been recently treated as a synonym of Chresta (Robinson, 1999, 2007), however our results indicate a closer relationship to Pithecoseris. Both genera have lobed leaves and indeterminate syncephalium, features that are unique among American Vernonieae (MacLeish, 1984). Also, Argyrovernonia and Pithecoseris occur in the caatinga region of northeastern Brazil, whereas Chresta is restricted of the cerrado and campo rupestre of Brazilian Central Plateau (MacLeish, 1985a). Finally, the highly distinctive Chresta speciosa with its red and yellow corollas (unique in American Vernonieae), unbranched trichomes and subechinolophate pollen (all others species of Chresta have lophate pollen) has been considered as a distinct genus (Glaziovianthus, MacLeish, 1985b), but is here nested in the Chresta clade.

The Lepidaploinae is paraphyletic in our study, the genera Chrysolaena, Echinocoryne, Lessingianthus and Lepidaploa form a well-supported clade (clade A2) but Strophopappus and Stenocephalum appear not to have a close relation to this clade. The members of the clade A2 have biseriate pappus with setose inner series and inflorescence with cymose branching pattern, while Strophopappus has multiseriate paleaceous pappus and inflorescence with paniculate branching pattern, and Stenocephalum has a racemose inflorescence (sensu Endress (2010)). The latter genus displays a close relationship with the monotypic syncephalous Rolandra. This relationship suggests that the reduced number of phyllaries and florets in Stenocephalum may be interpreted as preliminary steps towards the one-flowered capitulum with two bracts of Rolandra (Fig. 1F, 5DEF). Furthermore, it seems likely that the axillary and sessile syncephaly of Rolandra is derived from the racemose inflorescence of closely spaced sessile capitula at the nodes of Stenocephalum. However, a wider taxonomic sampling is necessary to achieve a better understanding of the relationships between Rolandra, Stenocephalum and the syncephalous Elephantopinae, especially including Spiracantha.

The subtripe Piptocarphinae is poorly represented in the present study but appears paraphyletic. Blanchetia is related to the Lychnophorinae (see below) (Fig. 1B); Critoniopsis and Piptocarpha are lineages at the base of the clade A, which includes the Lepidaploinae and Elephantopinae. Critoniopsis and Piptocarpha form a clade in the parsimony analysis but without any branch support, and such clade is not recovered in the Bayesian analysis. Even so, 
both genera have ca. 45 species and a higher sampling might modify this topology. They have stellate trichomes, deciduous phyllaries, tailed anthers and carpopodium with thick cell walls nearly occluding the lumina.

The Vernoniinae is represented by three genera in this study. Vernonia and Vernonanthura emerged as closely related taxa (clade D), both having a style with a basal node, prominent carpopodium with thick cell walls nearly occluding the lumina, and in which druses are common, chromosome number $n=17$ and sublophate pollen. Cyrtocymura does not appear closely related to this group, but to the clade A as an independent lineage.

The position of the Stokesiinae (containing the monotypic genus Stokesia laevis) is probably better inferred from the Bayesian topology than parsimony, due to a possible long-branch attraction effect in the parsimony analysis. Its relationship with the Leiboldiinae was also found by Keeley \& al. (2007), but morphologically Stokesia shares few or no characters with this subtribe. The genus accumulates a number of features (such as liguliform corolla, style with glands, chromosome number $n=7$ ) which makes it unique in the tribe.

An amplified definition of the subtribe Lychnophorinae. - As presently defined, Lychnophorinae is paraphyletic due to the nested position of Sipolisiinae, Blanchetia and Gorceixia. Four genera of the Sipolisiinae (Bishopalea, Heterocoma, Sipolisia and Xerxes) (Fig. 1C) forms a well-defined clade with a morphological synapormophy: presence of phytomelanin in the cypsela wall (see Chapter 4). The other genus of this subtribe, Hololepis, is not closely related to this group but to a Lychnophorinae genus, Prestelia. The axillary position of the inflorescence, presence of leaf sheath, lanose indument, 3- to 5-armed, stellate or T-shaped trichomes are common characters among Lychnophorinae. In addition, all these genera occur in cerrado and campo rupestre of Central Brazil, like most Lychnophorinae. Historically, Blanchetia has been placed adjacent to Vanillosmopsis (= Eremanthus) in keys to Ethulieae (series sensu Bentham (1873) and tribe sensu Baker (1873)). Blanchetia was placed in the Vernoniinae (Robinson, 1999) and then in Piptocarphinae (Robinson, 2007) probably due to the presence of stellate trichomes. But stellate trichomes occur in two different lineages: Critoniopsis/Piptocarpha group and Lychnophorinae (for example, in Chronopappus). Hoffmann (1890) placed the aforementioned Gorceixia decurrens in the Lychnophorinae based on the presence of a syncephalium, while Robinson $(1999,2007)$ left the genus unassigned to a subtribe. A position of Gorceixia within Piptocarphinae has been suggested (Pruski, 1992; Hind $\&$ al., 2006) due mostly to the coroniform pappus. Gorceixia displays syncephaly and 3- to 5-armed trichomes, a combination of characters common in Lychnophorinae. Consequently, we consider the subtribe Sipolisiinae as a synonym of Lychnophorinae, Blanchetia and Gorceixia as members of the subtribe Lychnophorinae.

A well-supported clade D, composed by Centratherum, Albertinia and the Lychnophorinae, is supported by a chemical synapomorphy: the presence of heliangolide in the leaves. Heliangolide has been reported only twice outside of this clade: in Chresta sphaerocephala, where it has been isolated from the roots and not from the aerial parts (Bohlmann \& al., 1981; 
Bohlmann \& al., 1982), and in Piptocoma discolor (Castro \& al., 1989), which is presently placed in the Piptocarphinae but not included in any phylogenetic analysis so far. Even though Albertinia is unquestionably the sister-group of Lychnophorinae in the Bayesian analysis, the parsimony analysis gave a low support for this relationship, and the ITS gene tree depicts the topology ((Centratherum, Albertinia), Lychnophorinae) with a low support as well. Like Blanchetia, Centratherum has been placed adjacent to Vanillosmopsis (=Eremanthus) in keys to Ethulieae (series sensu Bentham (1873) and tribe sensu Baker (1873)) based on their deciduous setose pappus. Furthermore, the foliose subinvolucral bracts and multiflowered capitula of Centratherum are also found in several genera of Sipolisiinae, now placed in Lychnophorinae (see above). The latter feature precluded Robinson \& al. (1980) in inferring a close relationship between these taxa by a different feature other than chemistry. Albertinia is a scandent shrub or vine, with an alveolate receptacle, mostly restricted to the coastal Atlantic Forest region, though sometimes collected in the Chapada Diamantina area, inland the state of Bahia. Candolle (1836) assumed that A . brasiliensis had one floret per capitulum and fused capitula like in Eremanthus (Fig. 1D) and Lychnophora (Fig. 1A). However, since Schultz-Bipontinus (1861, 1863) Albertinia is considered as having multiflowered capitula and the receptacle surface with deep holes (alveolae) that enclose the full length of the cypselae (Robinson, 1999). Robinson \& al. (1980) placed Albertinia within Lychnophorinae, but later excluded it from the subtribe based on the presence of a small sclerified node at the base of the style (Robinson, 1992). The receptacle of Blanchetia has thin partitions enclosing the bases of the cypselae (Robinson, 1999), which may be related to the structures observed in the receptacle of Albertinia or to the highly fimbrillate receptacles of some members of the Sipolisiinae. We believe that it is more interesting to clearly express in the classification the close relationship of Centratherum and Albertinia by including them in the subtribe Lychnophorinae, instead of keeping the subtribe Centratherinae (two genera, four species) and creating a monotypic subtribe for Albertinia.

As here defined, the subtribe Lychnophorinae is monophyletic. Even though no morphological synapomorphy has been found for it, most members are woody plants and have apical anthers appendages with conspicuous wall thickenings (except Centratherum), style without basal node (except Albertinia) and sublophate pollen. This combination of characters is highly similar to the one proposed by Robinson (1992). Additionally, the following characters are commonly found in the group and rarely outside of it: 3- to 5-armed trichomes, leaf sheath, syncephaly, paleaceous and deciduous to caducous pappus.

Evolution of syncephaly. - Our results confirm the artificiality of using the syncephalium to define subtribes in the American Vernonieae. Syncephalia probably appeared three to four times in the evolution of the tribe (Fig. 3): in the Chrestinae, Lychnophorinae (with several reversions), and in Elephantopinae/Rolandrinae. In the latter case, our analysis is inconclusive whether the syncephalium has been acquired independently or not. Consequently the syncephalia in each group are not homologous.

Functional hypotheses for the emergence of these complex structures include mainly 
a transfer of the attractive function from the capitulum to the syncephalium (e.g., Dyssodia decipiens, Lagascea spp., Oedera capensis) (Harris 1994, 1995, 1999; Claßen-Bockhoff, 1996), but also a disseminative function from the cypsela to the capitulum usually associated with a reduction of the latter (e.g., Didelta carnosa, Gundelia tournefortii) (Claßen-Bockhoff, 1996). The phenomenon is often accompanied by a reduction of the number of florets per capitulum (Harris, 1995). Schultz-Bipontinus $(1861,1863)$ listed over 150 species which exhibit singleflowered capitula condensed into higher order syncephalia. Burtt (1961) and Stebbins (1967) pointed out that a small number of florets per capitulum gives a greater protection against insect attack. But the nutritional advantage of a capitulum, by shortening the supply route, might be largely lost in the extreme case of one-flowered capitula. Therefore, the condensation into a secondary head would also be partly a reflection of this nutritional adaptive scheme. Finally, in some cases the syncephalium might offer an even more efficient protection than few flowered capitula against feeding insects by transfering the protective function of the phyllaries to the secondary bracts and the secondary receptacle by immersing the ovules into it (accompanied by a loss of individuality by each capitulum).

In the case of the Chrestinae syncephalium, the overall aspect of a single capitulum unit is striking (Fig. 1, 5ABC) and probably acts efficiently as an attractive unit. The corolla, usually purple, is sometimes associated with coloured bracts (e.g., Chresta angustifolia) or displays a narrow yellow band at the base of lobes contrasting with the red of the rest of the corolla in C. curumbensis and C. speciosa. The long tube of the corolla also strengthens the impression of a single attractive structure. In this case it is likely the most important (if not the unique) adaptative value of the syncephalium. Each capitulum is well-individualized and no apparent additional protection against feeding insects is offered by the secondary head, neither any trends towards a reduction of the florets or bracts are noticed (Fig. 5ABC).

The syncephalium of Rolandra fruticosa (Fig. 1, 5DEF) comes along with a strong reduction of the size of the floret and the involucre is reduced to two (rarely three) somewhat keeled phyllaries, which enclose the unique floret, the outermost phyllary being sharply acuminate. In addition the pappus is reduced to a crown of slightly lacerate scales (Fig. 5F). Regarding this morphology, the disseminule is likely to be the capitulum itself, and not the cypsela, a probable adaptation to zoochory. This disseminative function of the Rolandra syncephalium may be related to the wide distribution of that species (from Honduras to Brazil, including the Lesser Antilles). The clade containing Rolandra and the Elephantopinae did not receive any branch support and it remains open to discussion whether the two kinds of syncephalia are homologous or not. The involucre of the Elephantopinae is reduced to eight or less phyllaries and the florets are also small (Fig. 5GHI), but here the disseminule is the cypsela and not the capitulum. In Rolandra and Elephantopus the attractive function of the syncephalium appears to be limited, especially in Rolandra which have inconspicuous florets.

The syncephalium of the Lychnophorinae seems to associate the attractive and protective function. The overall aspect of a single capitulum is variable (e.g., nearly perfect in Lychnophora 
humillima (Fig. 1H) but far to be reached in Eremanthus polycephalus). Reduction to a single floret per capitulum is very common in Lychnophorinae (mostly in Eremanthus and Lychnophora). Capitula fusion occurs in Eremanthus (Fig. 1I) and Paralychnophora via interwoven pubescence of phyllaries or concrescence of receptacle and phyllaries tissues (MacLeish, 1987) (Fig. 5JKL). Thereby, each ovule is protected by the phyllaries, an additional tissue (from the receptacle and/or phyllaries) and in some cases by secondary bracts (e.g., $E$. cinctus). This structure probably limits the action of feeding insects. The disseminule is the cypsela and no trends towards reduction of the floret are encountered in the subtribe.

\section{CONCLUDING REMARKS}

This study encourages further investigation in American Vernonieae. A more complete taxonomic sampling is needed to recognize monophyletic subtribes, especially regarding the Piptocarphinae and the Vernoniinae. Our results show the monophyly of Chrestinae, Elephantopinae and Lychnophorinae, with minor adjustments. Only for the latter a phytochemical synapomorphy was found, while the two others are diagnosable by a simple combination of morphological characters (including microcharacters). The formation of a syncephalium is a multifactorial complex, and field studies are necessary to test the functional hypotheses we propose in the present study.

\section{ACKNOWLEDGEMENTS}

This project represents part of the Ph.D. thesis of B.L. Authors thank CNPq, FAPESP and the Cuatrecasas Fellowship Award of the Smithsonian Institution for financial support; IBAMA and IF-MG for collection permits; Silvana Ferreira, Vera Klein, Renato Mello-Silva, Jimi Nakajima, Alex Popovkin, Nádia Roque and Paulo Sano for assistance during field work and/or providing silica-dried material; L.M. Borges for the drawings, and the directors or curators of the following herbaria for the loan of (or access to) their collections: ALCB, BHCB, ESA, GA, GH, HRB, HUEFS, HUFU, IBGE, MBM, MO, NY, RB, SP, SPF, TEX, UB, UFG, UEC, US.

\section{LITERATURE CITED}

Baker, J.G. 1873. Compositae I. Vernoniaceae. Pp. 5--180 in: von Martius, C.F.P.† \& Eichler, A.W. (eds), Flora Brasiliensis, 6(2). Fried. Fleischer, Münich, Vienna, Leipzig.

Bentham, G. 1873. Compositae. Pp. 163--533 in: Bentham, G. \& Hooker, J.D. (eds), Genera Plantarum, 2(1). Reeve \& Co., London and Williams \& Norgate, London.

Bergsten, J. 2005. A review of long-branch attraction. Cladistics 21: 163--193.

Bohlmann, F., Zdero, C., King, R.M. \& Robinson, H. 1981. Two hirsutinolides and a germacranolide from Chresta sphaerocephala. Phytochem. 20: 518--519.

Bohlmann, F., Singh, P., Zdero, C., Ruhe, A., King, R.M. \& Robinson, H. 1982. Furanoheliangolides from two Eremanthus species and from Chresta sphaerocephala. Phytochem. 21: 1669--1673. 
Burtt, B.L. 1961. Compositae and the study of functional evolution. Trans. \& Proc. Bot. Soc. Edinburgh. 39: 216--232.

Cabrera, A.L. 1944. Vernonieas Argentinas (Compositae). Darwiniana 6: 265--379.

Cabrera, A.L. \& Vittet, N. 1961. Compositae Catharinensis. I Vernonieae. Sellowia 13: 143$-193$.

Candolle, A.P. de. 1836. Vernoniaceae. Pp. 9--103 in: Prodromus Systematis Naturalis Regni Vegetabilis, ... v. 5. Treutel et Würtz, Paris.

Claßen-Bockhoff, R. 1996. Functional units beyond the level of the capitulum and cypsela in Compositae. Pp. 129--160 in D.J.N. Hind (ed.), Compositae: Biology and utilization, Proceedings of the International Compositae Conference. Royal Botanic Gardens, Kew, UK.

Castro, V. 1989. Centratherin and related sesquiterpene lactones from Oliganthes discolor. Rev. Latinoamer. Quim. 20: 85--86.

Cunningham, C.W. 1997 . Can three incongruence tests predict when data should be combined ? Molec. Biol. Evol. 14: 733--740.

Darlu, P. \& Lecointre, G. 2002. When does the incongruence length difference test fail ? Molec. Biol. Evol. 19: 432--437.

Downie, S.R. \& Katz-Downie, D.S. 1996. A molecular phylogeny of Apiaceae subfamily Apioideae: evidence from nuclear ribosomal DNA internal transcribed spacer sequences. Amer. J. Bot. 83: 234--251.

Endress, P.K. 2010. Disentangling confusions in inflorescence morphology: patterns and diversity of reproductive shoot ramification in angiosperms. J. Syst. Evol. 48: 225--239.

Farris, J.S., Källersjö, M., Kluge, A.G. \& Bult, C. 1995. Testing significance of incongruence. Cladistics 10: 315--319.

Farris, J.S., Albert, V.A., Källersjö, M., Lipscomb, D. \& Kluge, A.G. 1996. Parsimony jackknifing outperforms neighbor-joining. Cladistics 12: 99--124.

Felsenstein, J. 1978. Cases in which parsimony or compatibility methods will be positively misleading. Syst. Zool. 27: 401--410.

Freudenstein, J.V. \& Davis, J.I. 2010. Branch support via resampling: an empirical study. Cladistics 26: 643--656.

Funk, V.A. \& Chan, R. 2009. Introduction to Cichorioideae. Pp. 335--342 in: Funk, V.A., Susana, A., Stuessy, T.F. \& Bayer, R.J. (eds.), Systematics, Evolution, and Biogeography of Compositae. Vienna, Austria: International Association for Plant Taxonomy (IAPT).

Garcia-Cruz, J. \& Sosa, V. 2006. Coding quantitative character data for phylogenetic analysis: a comparison of five methods. Syst. Bot. 31: 302--309.

Goloboff, P. 1999. NONA, version 2. Tucumán, Argentina: published by the author, http:// www.cladistics.com/aboutNona.htm.

Good, R. 1956. Features of evolution in the flowering plants. Longmans, Green and Co., London, UK.

Guindon, S. \& Gascuel, O. 2003. A simple, fast, and accurate algorithm to estimate large 
phylogenies by maximum likelihood. Syst. Biol. 52: 696--704.

Harris, E.M. 1994. Developmental evidence for the derivation of syncephalia in Lagascea (Heliantheae; Asteraceae). Amer. J. Bot. 81: 1139--1148.

Harris, E.M. 1995. Inflorescence and floral ontogeny in Asteraceae: a synthesis of historical and current concepts. Bot. Rev. 61: 93--278.

Harris, E.M. 1999. Capitula in the Asteridae: a widespread and varied phenomenon. Bot. Rev. 65: 348--369.

Hall, T.A. 1999. BioEdit: a user-friendly biological sequence alignment editor and analysis program for Windows 95/98/NT. Nucl. Acids Symp. Ser. 41: 95--98.

Hind, D.J., Giulietti, A.M. \& Harley, R.M. 2006. Gorceixia decurrens (Compositae: Vernonieae): new for Bahia State, Brazil. Sitientibus Ser. Cienc. Biol. 6: 129--132.

Hipp, A.L., Hall, J.C. \& Sytsma, K.J. 2004. Congruence versus phylogenetic accuracy: revisiting the incongruence length difference test. Syst. Biol. 53: 81--89.

Hoffmann, O. 1890. Compositae, Tubuliflorae-Vernonieae. Pp. 120--131 in: Engler, A. \& Prantl, K. (eds.), Die natürlichen Pflanzenfamilien, 4(5). Wilhelm Engelmann, Leipzig.

Huelsenbeck, J.P. \& Ronquist, F. 2001. MRBAYES: Bayesian inference of phylogenetic trees. Bioinformatics 17: 754--755.

Jansen, R.K. 1992. Current research. Pl. Molec. Evol. Newsl. 2: 13--14.

Katinas, L., Crisci, J.V., Jabaily, R.S., Williams, C., Walker, J., Drew, B., Bonifacino, J.M. \& Sytsma, K.J. 2008. Evolution of secondary heads in Nassauviinae (Asteraceae, Mutisieae). Amer. J. Bot. 95: 229--240.

Katoh, K. \& Toh, H. 2008. Recent developments in the MAFFT multiple sequence alignment program. Brief. Bioinformatics 9: 286--298.

Keeley, S.C. \& Turner, B.L. 1990. A preliminary cladistic analysis of the genus Vernonia (Vernonieae: Asteraceae). Pl. Syst. Evol., Suppl. 4: 45--66.

Keeley, S.C. \& Jansen, R.K. 1994. Chloroplast DNA restriction site variation in the Vernonieae (Asteraceae), an initial appraisal of the relationship of New and Old World taxa and the monophyly of Vernonia. Pl. Syst. Evol. 193: 249--265.

Keeley, S.C. \& Robinson, H. 2009. Vernonieae. Pp. 439--469 in: Funk, V.A., Susana, A., Stuessy, T.F. \& Bayer, R.J. (eds.), Systematics, Evolution, and Biogeography of Compositae. Vienna, Austria: International Association for Plant Taxonomy (IAPT).

Keeley, S.C., Forsman, Z.H. \& Chan, R. 2007. A phylogeny of the "evil tribe" (Vernonieae: Compositae) reveals Old/New World long distance dispersal: support from separate and combined congruent datasets (trnL-F, ndhF, ITS). Molec. Phylog. Evol. 44: 89--103.

Kunze, V.H. 1969. Vergleichend-morphologische untersuchungen an komplexen Compositen blütenstanden. Beitr. Biol. Pflanz. 46: 97--154.

Lee, M.S.Y. 2001. Uninformative characters and apparent conflict between molecules and morphology. Molec. Biol. Evol. 18: 676--680.

Leppik, E.E. 1960. Evolutionary differentiation of the flower head of the Compositae. Arch. 
Soc. Zool. Bot. Fenn. Vanamo. 14: 466--481.

MacLeish, N.F.F. 1984. Revision of Eremanthus Less. (Compositae: Vernonieae). PhD thesis, unpublished. University of Georgia.

MacLeish, N.F.F. 1985a. Revision of Chresta and Pycnocephalum (Compositae: Vernonieae). Syst. Bot. 10: 459--470.

MacLeish, N.F.F. 1985b. Revision of Glaziovianthus (Compositae: Vernonieae). Syst. Bot. 10: 347--352.

MacLeish, N.F.F. 1987. Revision of Eremanthus (Compositae: Vernonieae). Ann. Missouri Bot. Gard. 74: 265--290.

Müller, K. 2005. SeqState: primer design and sequence statistics for phylogenetic DNA datasets. Applied Bioinformatics 4: 65--69.

Müller, K. 2006. Incorporating information from length-mutational events into phylogenetic analysis. Molec. Phylog. Evol. 38: 667--676.

Nixon, K.C. 1999. The parsimony ratchet, a new method for rapid parsimony analysis. Cladistics 15: 407--414.

Nixon, K.C. 1999--2002. WinClada, version 1.00.08. Ithaca, New York: published by the author. http://www.cladistics.com/aboutWinc.htm.

Nixon, K.C. \& Carpenter, J.M. 1996. On simultaneous analysis. Cladistics 12: 221--241.

Pelser, P.B., Kennedy, A.H., Tepe, E.J., Shidler, J.B., Nordenstam, B., Kadereit, J.W. \& Watson, L.E. 2010. Patterns and causes of incongruence between plastid and nuclear Senecioneae (Asteraceae) phylogenies. Amer. J. Bot. 97: 856--873.

Posada, D. 2008. jModelTest: Phylogenetic Model Averaging. Molec. Biol. Evol. 25: 1253-1256.

Pruski, J.F. 1992. Compositae of Guayana Highlands: VI. Huberopappus maigualidae (Vernonieae), a new genus and species from Venezuela. Novon 2: 19--25.

Robinson, H. 1992. Notes on Lychnophorinae from Minas Gerais, Brazil, a synopsis of Lychnophoriopsis Schultz-Bip., and the new genera Anteremanthus and Minasia (Vernonieae: Asteraceae). Proc. Biol. Soc. Washington 105: 640--652.

Robinson, H. 1999. Generic and subtribal classification of American Vernonieae. Smithsonian Contr. Bot. 89: 1--116.

Robinson, H. (2007) [2006]. Vernonieae. Pp. 149--174 in: Kadereit, J. \& Jeffrey, C. (vol. eds), Vol. 8: Asterales. The families and genera of vascular plants, (Kubitzki, K., series ed.). Berlin, Heidelberg, New York: Springer.

Robinson, H., Bohlmann, F. \& King, R.M. 1980. Chemosystematic notes on the Asteraceae. III. Natural subdivisions of the Vernonieae. Phytologia 46: 421--436.

Ronquist, F. \& Huelsenbeck, J.P. 2003. MRBAYES 3: Bayesian phylogenetic inference under mixed models. Bioinformatics 19: 1572--1574.

Schultz-Bipontinus, C.H. 1861. Cassiniaceae uniflorae, oder Verzeichniss der Cassiniaceen mit 1-blüthigen Köpfchen. Jahresber. Pollichia 18/19: 157--190. 
Schultz-Bipontinus, C.H. 1863 [1864]. Lychnophora Martius! und einige benachbarte Gattungen. Jahresber. Pollichia 20/21: 321--439.

Siddall, M.E. 2002. Measures of support. Pp. 80--101 in: Desalle, R., Giribet, G. \& Wheeler, W. (eds), Techniques in molecular systematics and evolution. Basel: Birkhäuser Verlag.

Simmons, M.P. \& Ochoterena, H. 2000. Gaps as characters in sequence-based phylogenetic analysis. Syst. Biol. 49: 369--381.

Stebbins, G.L. 1967. Adaptive radiation and trends of evolution in higher plants. Pp. 101-142 in: Dobzhansky, T., Hecht, M.K. \& Steere, W.C. (eds), Evolutionary Biology, vol. 1. Appleton-Century-Crofts, New York, New York, USA.

Stuessy, T.F. \& Spooner, D.M. 1988. The adaptative and phylogenetic significance of receptacular bracts in the Compositae. Taxon 37: 114--126.

Susanna, A. \& Garcia-Jacas, N. 2009. Cardueae (Carduoideae). Pp. 293--313 in: Funk, V.A., Susana, A., Stuessy, T.F. \& Bayer, R.J. (eds.), Systematics, Evolution, and Biogeography of Compositae. Vienna, Austria: International Association for Plant Taxonomy (IAPT).

Thiele, K. 1993. The Holy Grail of the perfect character: the cladistic treatment of morphometric data. Cladistics 9: 275--304.

Timme, R.E., Kuehl, J.V., Boore, J.L. \& Jansen, R.K. 2007. A comparative analysis of the Lactuca and Helianthus (Asteraceae) plastid genomes: identification of divergent regions and categorization of shared repeats. Amer. J. Bot. 94: 302--312.

Troll, W. 1928. Organisation und Gestalt in Bereich der Blüte. Springer, Berlin, Germany.

Weberling, F. 1992. Morphology of flowers and inflorescences. Cambridge University Press, Cambridge, UK.

White, T.J., Bruns, T., Lee, S. \& Taylor, J. 1990. Amplification and direct sequencing of fungal ribosomal RNA genes for phylogenetics. Pp. 315--322 in: Innics, M., Glfand, D., Sninsky, J. \& T.J. White (eds), PCR protocols: a guide to methods and applications. San Diego: Academic Press.

Wilgenbusch, J.C., Warren, D.L. \& Swofford, D.L. 2004. AWTY: A system for graphical exploration of MCMC convergence in Bayesian phylogenetic inference. http://ceb.csit.fsu. edu/awty. 


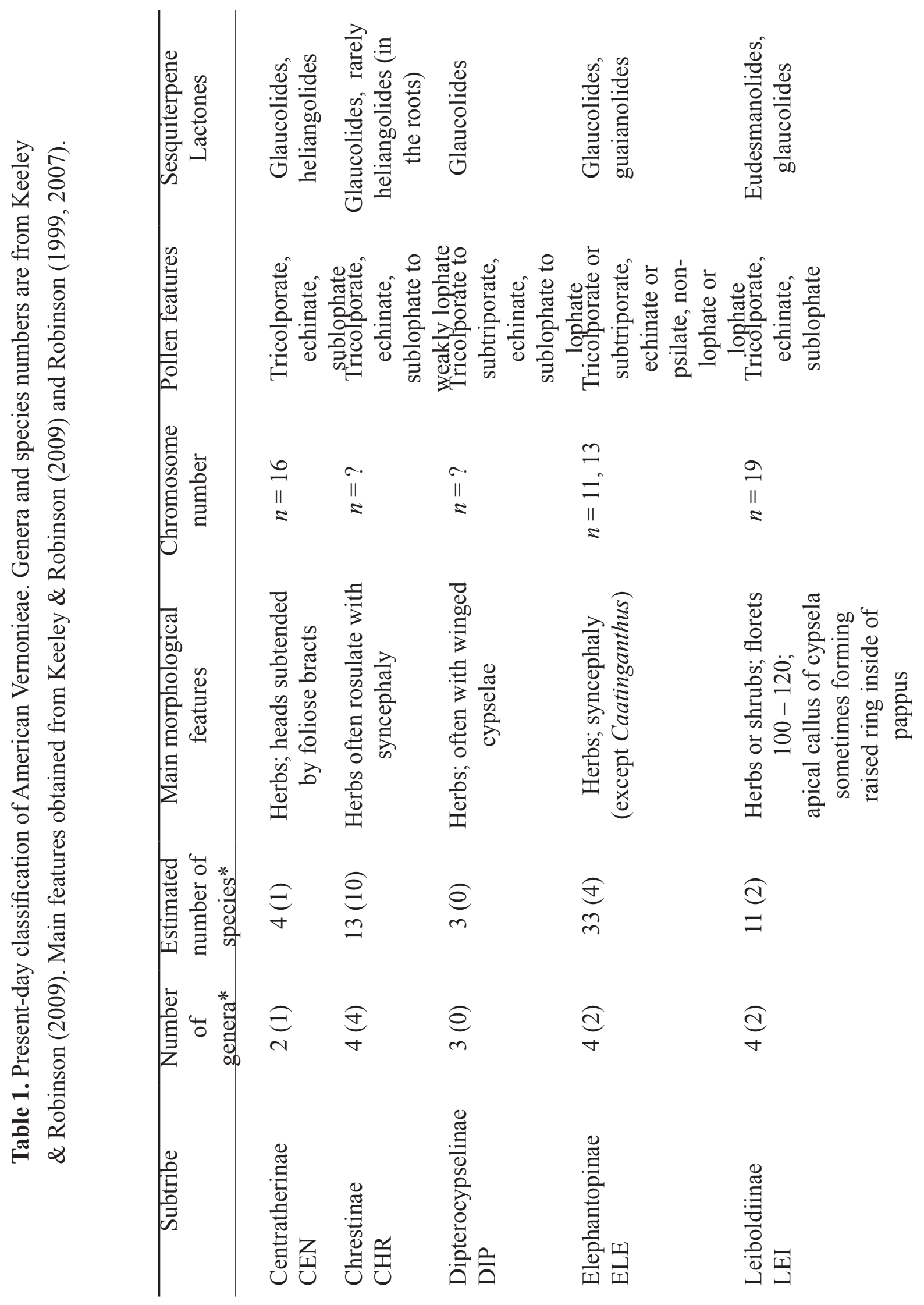




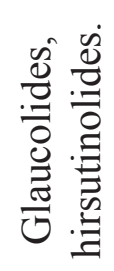

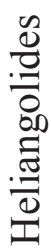

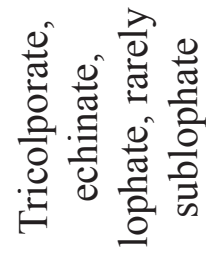

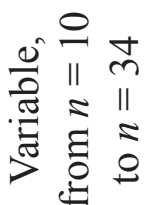

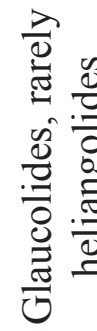

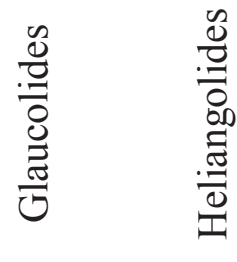

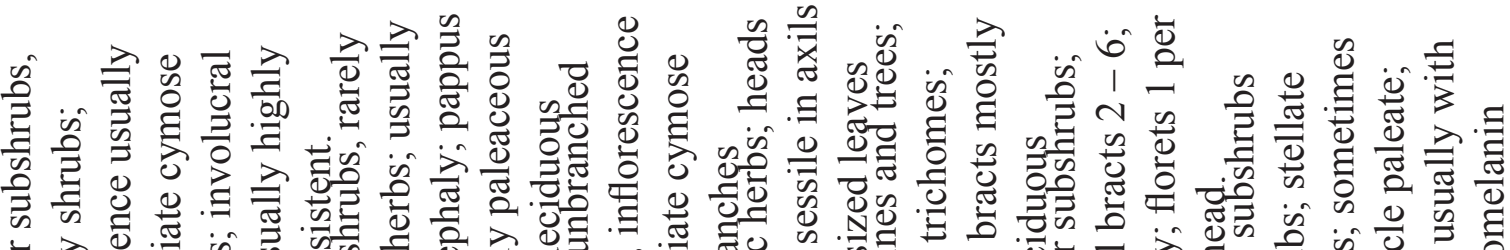

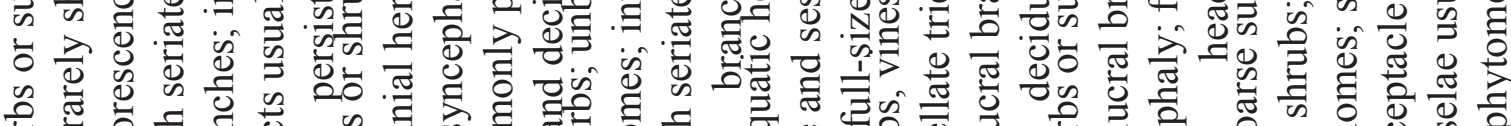

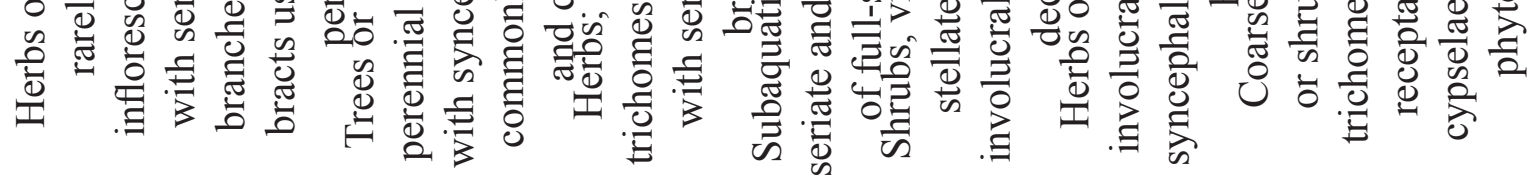

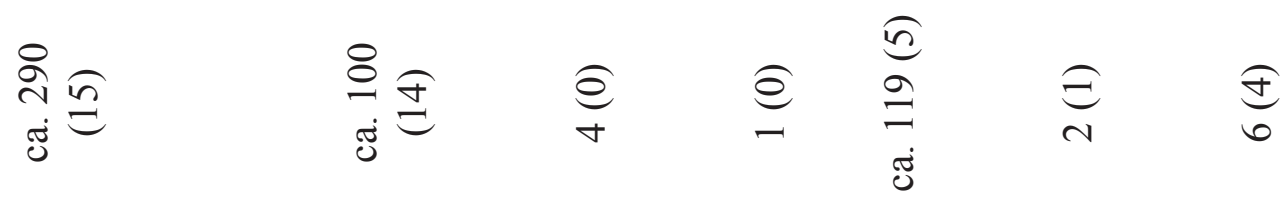

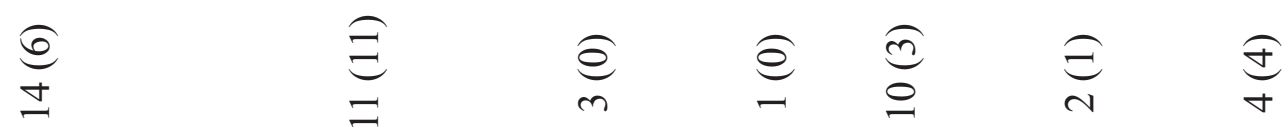

高高

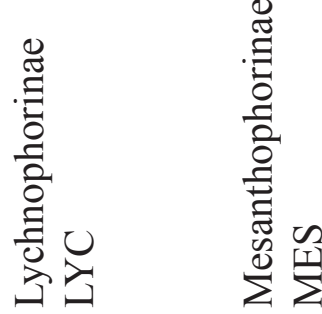

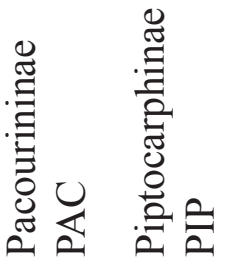

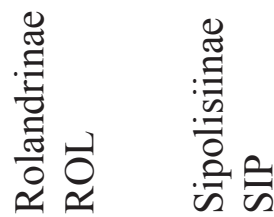



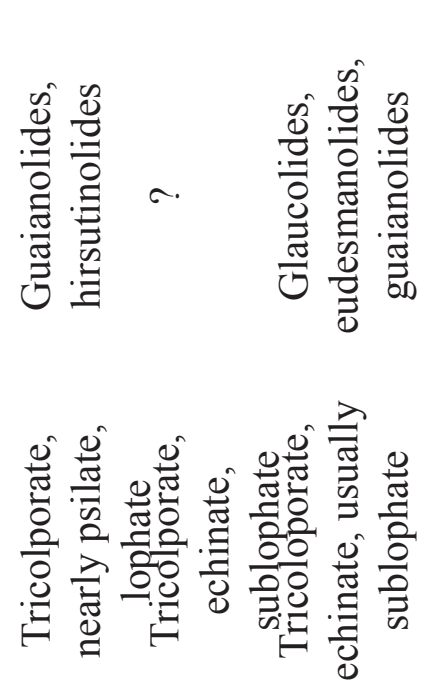

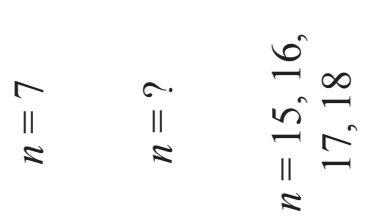

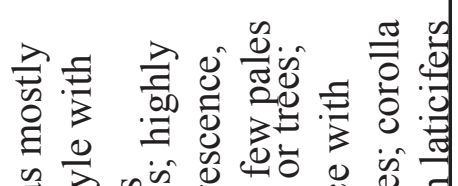

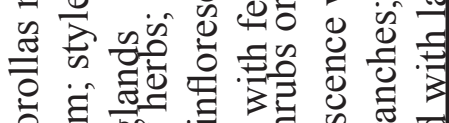

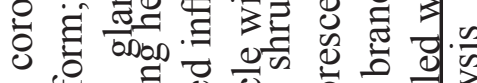

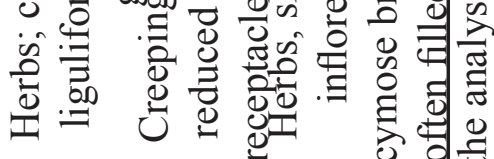

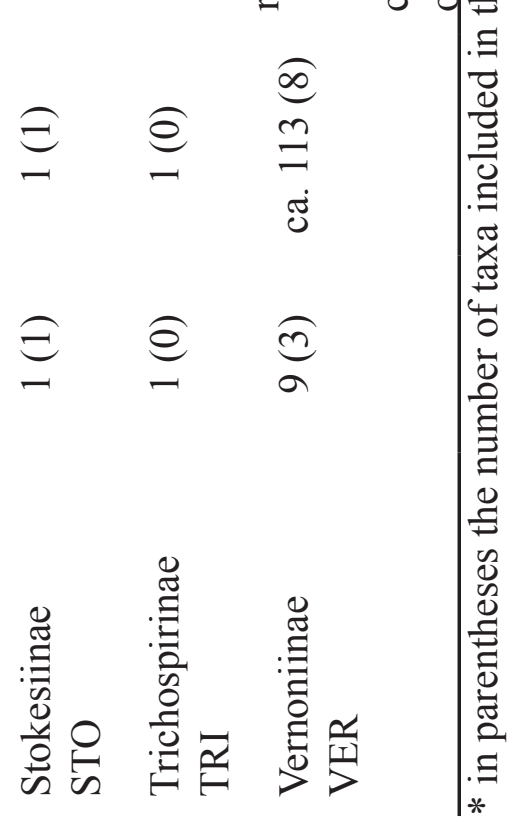




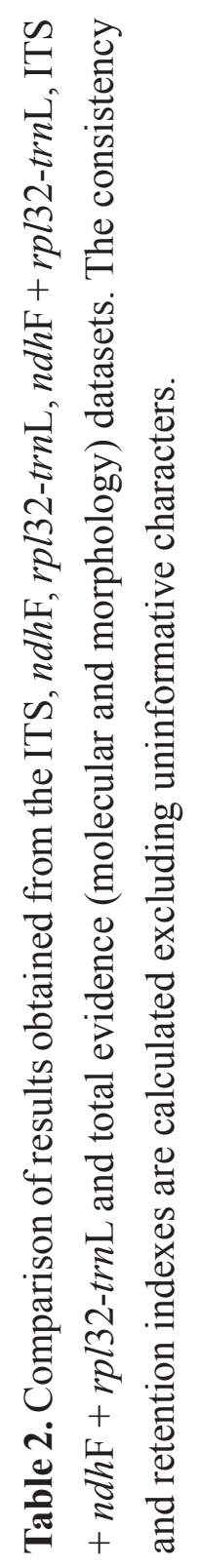

\begin{tabular}{|c|c|c|c|c|c|c|c|c|}
\hline 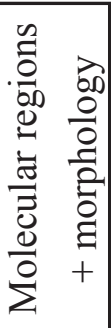 & t & 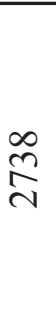 & $\begin{array}{l}\infty \\
\end{array}$ & 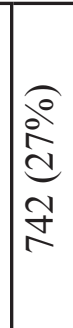 & $\stackrel{\infty}{\varrho}$ & 命 & के & $\frac{n}{o}$ \\
\hline 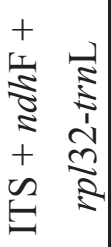 & $\cong$ & 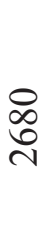 & $\stackrel{\infty}{n}$ & 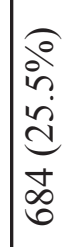 & ฉ & $\begin{array}{l}\infty \\
\infty \\
i \\
\end{array}$ & $\underset{0}{\stackrel{f}{0}}$ & 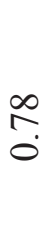 \\
\hline 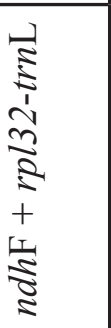 & $R$ & $\stackrel{\vec{\circ}}{\stackrel{\Omega}{\sigma}}$ & $\cong$ & 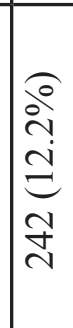 & $\begin{array}{l}n \\
\infty \\
\infty\end{array}$ & ஓ্ & : & $\begin{array}{l}n \\
\infty \\
0 \\
0\end{array}$ \\
\hline 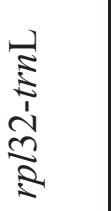 & 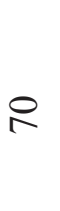 & $\stackrel{\infty}{\stackrel{+}{I}}$ & $\infty$ & 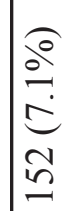 & $\frac{⿱}{\forall}$ & $\stackrel{2}{\circ}$ & $\stackrel{\square}{0}$ & $\begin{array}{l}\infty \\
\infty \\
\infty \\
0\end{array}$ \\
\hline 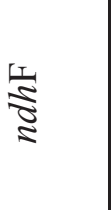 & $\ddot{0}$ & $\stackrel{\Re}{\Re}$ & $\hat{\lambda}$ & 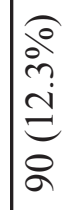 & 守 & 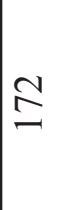 & | & $\begin{array}{c}\infty \\
0 \\
0\end{array}$ \\
\hline$\underline{E}$ & $\cong$ & ठેे & I & 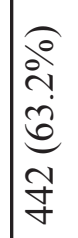 & 芯 & ֶి & $\begin{array}{l}\vec{f} \\
0\end{array}$ & 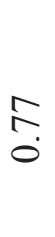 \\
\hline & 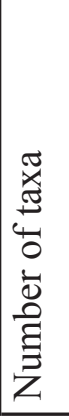 & 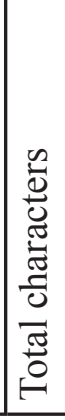 & 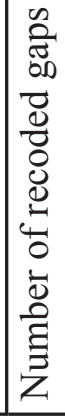 & 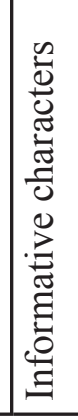 & 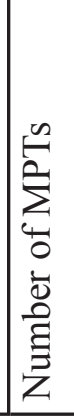 & 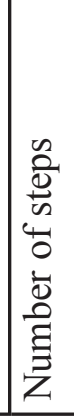 & 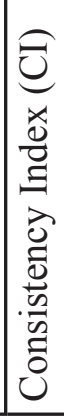 & 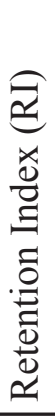 \\
\hline
\end{tabular}


Fig. 1. Morphological diversity and syncephalia in American Vernonieae: A, Lychnophora salicifolia; B, Blanchetia heterotricha; C, Xerxes ekmanianum; D, Eremanthus incanus; E, Chresta sphaerocephala; F, Rolandra fruticosa; G, Elephantopus mollis; H, Lychnophora humillima; I, Eremanthus erythropappus. Photographs: A, B, D, E, G, I, B. Loeuille; C, G. Shimizu; F, R. Graveson; H, D. Zappi. 

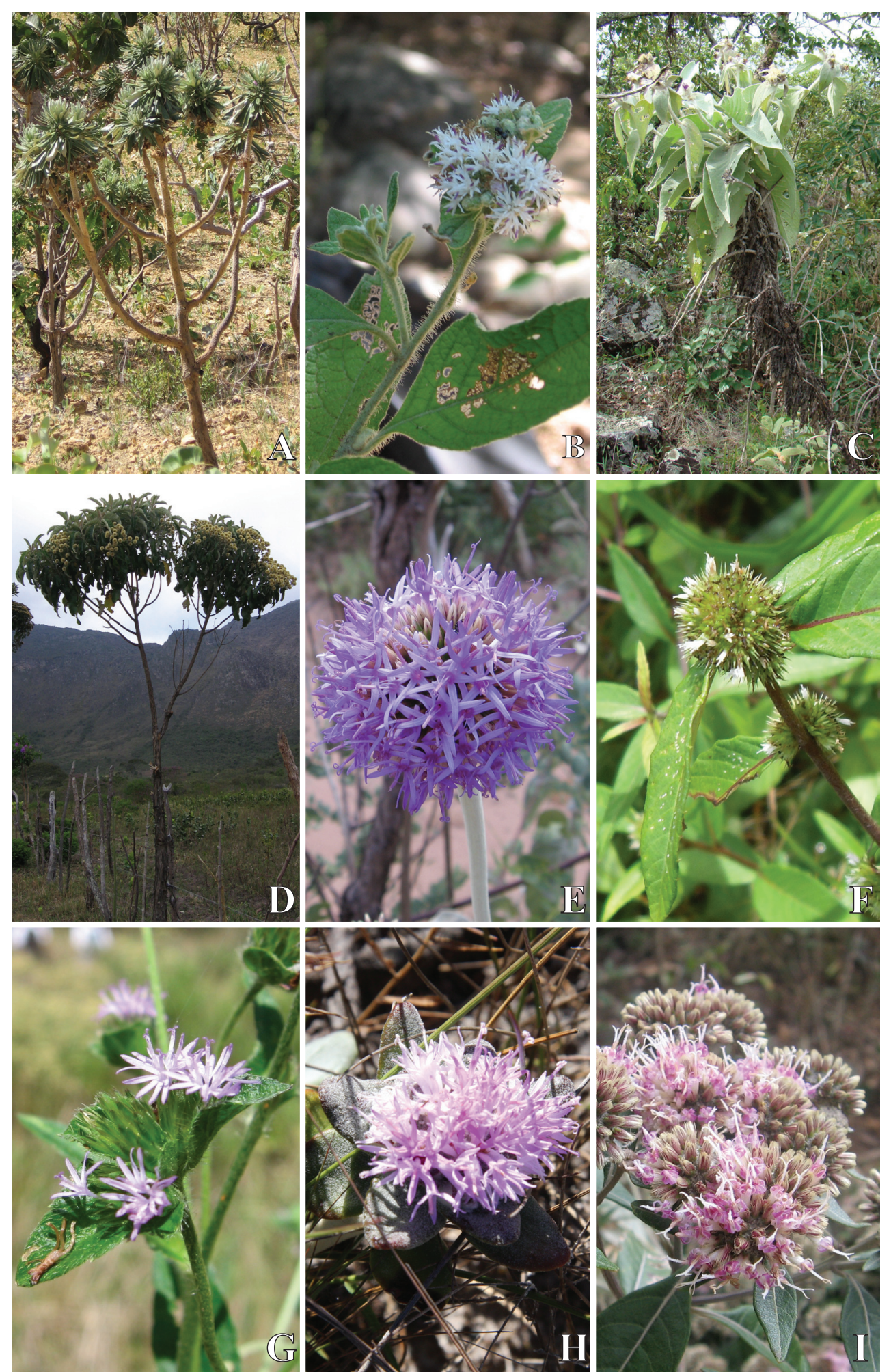
Fig. 2. Strict consensus tree of 96 equally most parsimonious trees based on the combined analysis (all molecular data). Tree length $=2580$ steps, $\mathrm{CI}=0.44, \mathrm{RI}=0.78$. Jackknife values $(\geq 50 \%)$ and Bayesian posterior probabilities $(\geq 0.9)$ are shown above and below the nodes. Vernonieae subtribes are indicated with three-letter abbreviations (see Table 1), OUT = outgroup, $\mathrm{UNP}=$ unplaced (taxa not placed in a subtribe). Taxa in bold display syncephaly. 


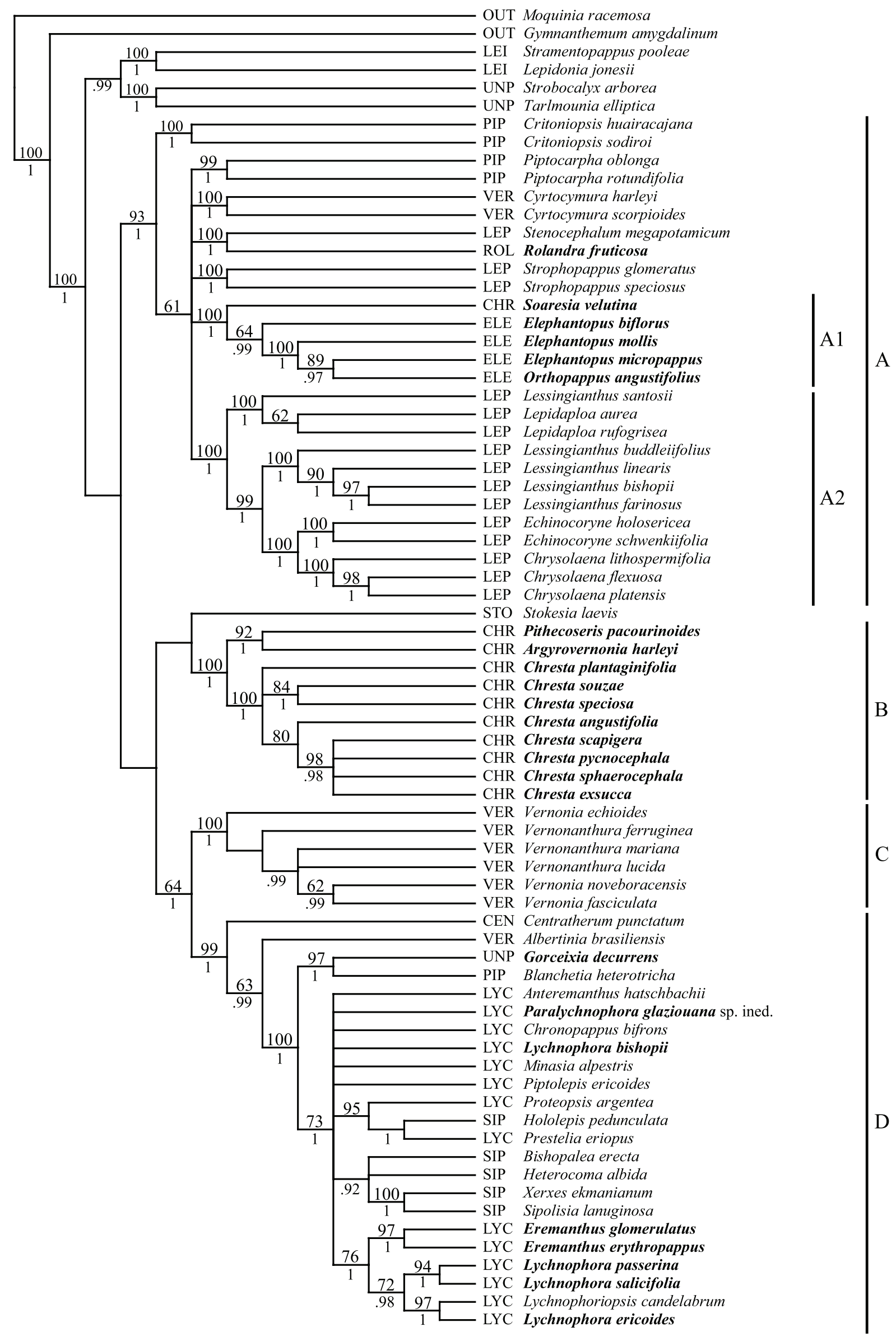


Fig. 3. Strict consensus tree of 108 equally most parsimonious trees based on the combined analysis with morphology and all molecular data. Tree length $=3097$ steps, CI $=0.39, \mathrm{RI}=$ 0.75. Jackknife values $(\geq 50 \%)$ and Bayesian posterior probabilities $(\geq 0.9)$ are shown above and below the nodes. Vernonieae subtribes are indicated with three-letter abbreviations (see Table 1), OUT = outgroup, UNP = unplaced (taxa not placed in a subtribe). Taxa in bold display syncephaly. 


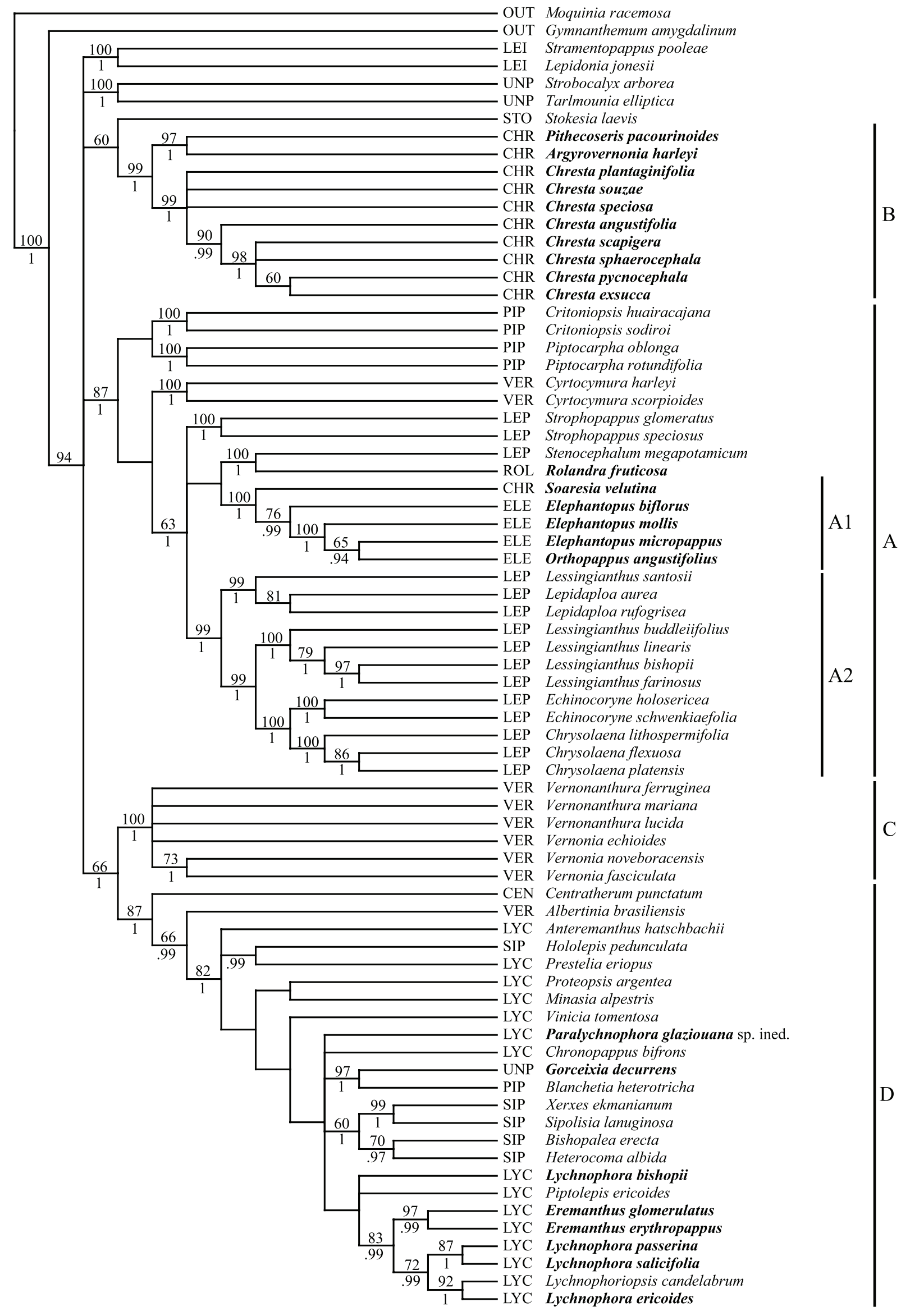


Fig. 4. Comparison of parsimony strict consensus tree (on left) and Bayesian inference phylogram (on right). White triangles are collapsed clades; a full listing of taxa in these clades is given in Fig. 3. Jackknife values $(\geq 50 \%)$ are shown above the nodes of the parsimony tree and Bayesian posterior probabilities $(\geq 0.9)$ are shown above the nodes of the Bayesian inference phylogram. 1 = Leiboldiinae; 2 = Asian taxa; $3=$ Critoniopsis; $4=$ Piptocarpha $; 5=$ Cyrtocymura $; 6=$ Strophopappus $; 7=$ Rolandra $; 8=$ Stenocephalum. 


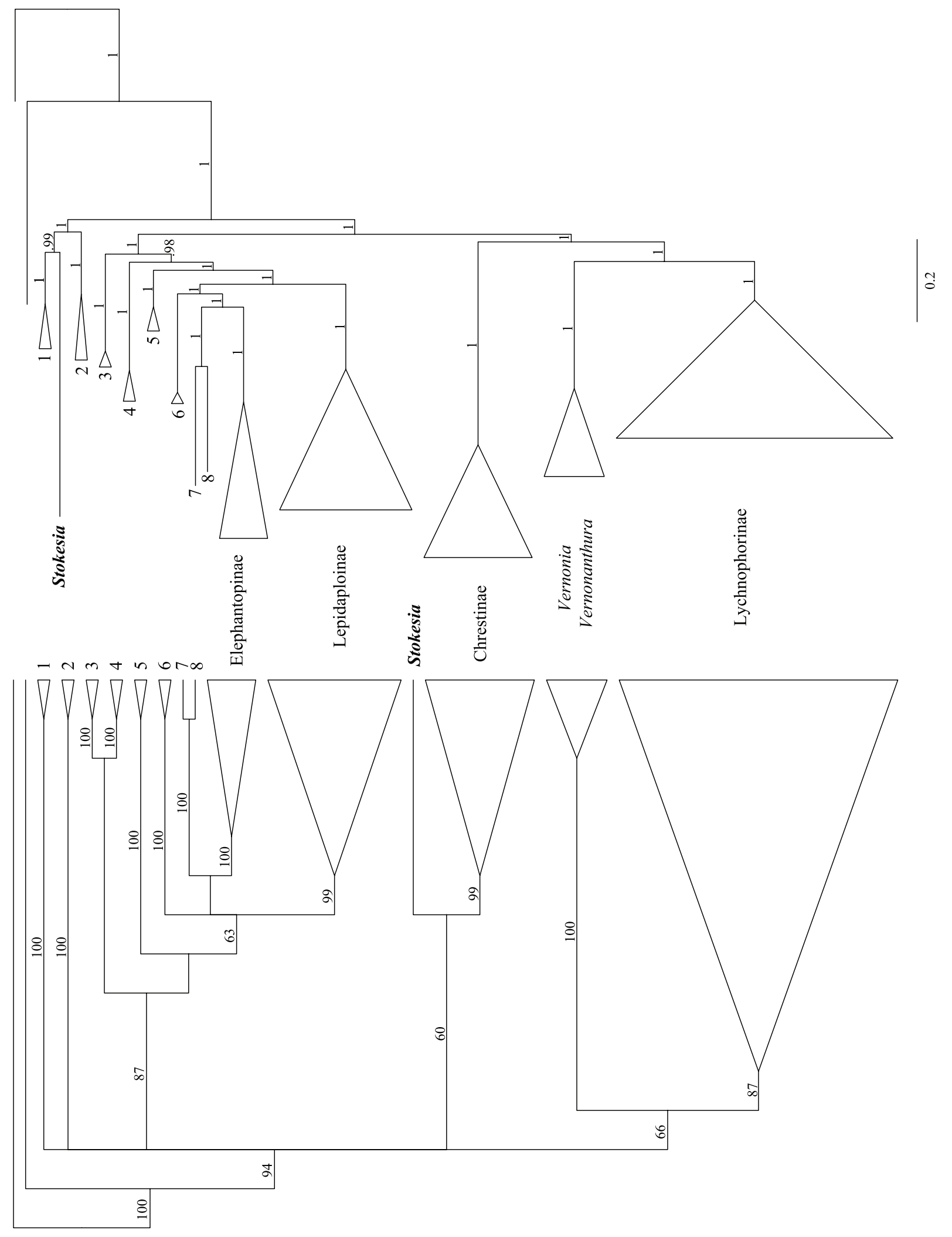




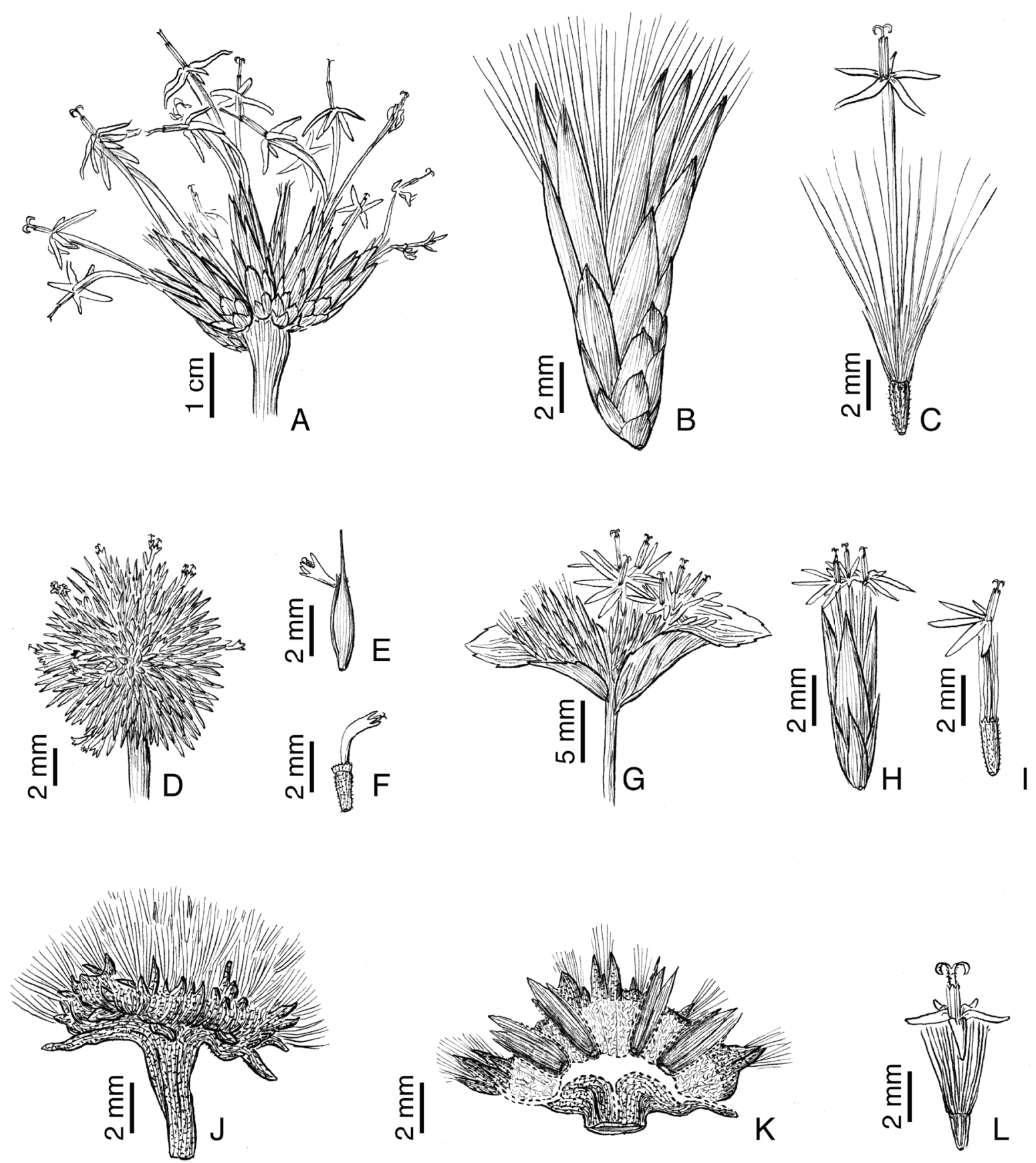

Fig. 5. Syncephalia diversity in American Vernonieae. Chresta angustifolia: A, syncephalium; B, capitulum; C, floret. Rolandra fruticosa: D, syncephalium; E, capitulum; F, floret. Elephantopus mollis: G, syncephalium; H, capitulum; I, floret. Eremanthus erythropappus: J, syncephalium; $\mathbf{K}$, syncephalium in long section; $\mathbf{L}$, floret. 

Appendix 1. Species included in the molecular analysis, voucher information and GenBank accession numbers (ITS, $n d h \mathrm{~F}$ and $r p l 32-t r n \mathrm{~L}$ ). An en-dash indicates that a region was not sequenced for this taxon. An asterisk indicates a sequence previously published by Keeley \& al. (2007) or taken from Keeley \& al. (unpub.).

Albertinia brasiliensis Spreng., EF155744*; EF155656*; Brazil: Bahia State, Entre Rios, Popovkin 476 (HUEFS), XXXXX. Anteremanthus hatschbachii H. Rob., Brazil: Minas Gerais, Grão Mogol, 6-VI-2008, Loeuille \& al. 441 (SPF), XXXXX; XXXXX; XXXXX. Argyrovernonia harleyi (H. Rob.) MacLeish, Brazil: Bahia, Oliveira dos Brejinhos, 2-II-2008, Loeuille \& al. 377 (SPF), XXXXX; XXXXX; XXXXX. Bishopalea erecta H. Rob., Brazil: Bahia, Mucugê, 23-V-2009, Roque 2047 (ALCB), XXXXX; XXXXX; XXXXX. Blanchetia heterotricha DC. Brazil: Bahia, Morro do Chapéu, 4-II-2008, Loeuille \& al. 394 (SPF), XXXXX; XXXXX; XXXXX. Centratherum punctatum Cass., EF155753*; EF155665*; Brazil: Bahia, Feira de Santana, 21-IX-2007, Loeuille \& Moraes 348 (SPF), XXXXX. Chresta angustifolia Gardner, 20-VII-2007, Loeuille \& al. 291 (SPF), XXXXX; XXXXX; XXXXX. Chresta exsucca DC., XXXXX*;-;-. Chresta plantaginifolia (Less.) Gardner, Brazil: Minas Gerais: Capitólio, 25-X-2006, Nakajima \& al. 4240 (SPF), XXXXX; XXXXX; XXXXX. Chresta pycnocephala DC., Brazil: Goiás, Planaltina de Goiás, 18-VII-2007, Loeuille \& al. 272 (SPF), XXXXX; XXXXX; XXXXX. Chresta scapigera (Less.) Gardner, Brazil: Minas Gerais, São Roque de Minas, 14-V-2007, Loeuille \& al. 255 (SPF), XXXXX; XXXXX; XXXXX. Chresta souzae H. Rob., Brazil: Goiás, Chapada dos Veadeiros, 4-XII-2007, Sano \& al. 3875 (SPF), XXXXX; XXXXX; XXXXX. Chresta speciosa Gardner, Brazil: Goiás, Alto Paraíso, 20-VII-2007, Loeuille \& al. 294 (SPF), XXXXX; XXXXX; XXXXX. Chresta sphaerocephala DC., EF155755*; EF155667*; Brazil: Minas Gerais, Diamantina, 22-I-2007, Loeuille \& al. 86 (SPF), XXXXX. Chronopappus bifrons (DC. ex Pers.) DC., Brazil: Minas Gerais, Catas Altas, 18-XI-2008, Loeuille \& Albergaria Pena 460 (SPF), XXXXX; XXXXX; XXXXX. Chrysolaena flexuosa (Sims) H. Rob., EF155756*; EF155668*; XXXXX*. Chrysolaena lithospermifolia (Hieron.) H. Rob., Brazil: Santa Catarina, Lages, 7-I-2008, Loeuille \& Wagner Loeuille 359 (SPF), XXXXX; XXXXX; XXXXX. Chrysolaena platensis 
(Spreng.) H. Rob., EF155757*, EF155669*, XXXXX*. Critoniopsis huairacajana (Hieron.) H. Rob., EF155821*; EF155733*; XXXXX*. Critoniopsis sodiroi (Hieron.) H. Rob., EF155760*; EF155672*; XXXXX*. Cyrtocymura harleyi (H. Rob.) H. Rob., Brazil: Bahia, Morro do Chapéu, 3-II-2008, Loeuille \& al 383 (SPF), XXXXX; XXXXX; XXXXX. Cyrtocymura scorpioides (Lam.) H. Rob., Brazil: Minas Gerais, Santana do Riacho, 16-I-2007, Loeuille \& al. 62 (SPF), XXXXX; XXXXX; XXXXX. Echinocoryne holosericea (Mart.) H. Rob., Brazil: Goiás, Alto Paraíso, 19-VII-2007, Loeuille \& al. 282 (SPF), XXXXX; -; XXXXX. Echinocoryne schwenkiaefolia (Mart. ex DC.) H. Rob., Brazil: Minas Gerais, Uberlândia, 7-VIII-2007, Loeuille \& al. 307 (SPF), XXXXX; XXXXX; XXXXX. Elephantopus biflorus (Less.) Sch. Bip., XXXXX*; -; XXXXX*. Elephantopus micropappus Less., XXXXX*; -; XXXXX*. Elephantopus mollis Kunth, EF155766*; EF155678*; Brazil: Santa Catarina, Urupema, 3-IV-2007, Loeuille \& al. 140 (SPF), XXXXX. Eremanthus erythropappus (DC.) MacLeish, Brazil: Minas Gerais, Capítolio, 26-X-2006, Loeuille \& al. 51 (SPF), XXXXX; XXXXX; XXXXX. Eremanthus glomerulatus Less., Brazil: Minas Gerais, Francisco Sá, 5-VI-2008, Loeuille \& al. 438 (SPF), XXXXX; XXXXX; XXXXX. Gorceixia decurrens Baker, EF155773*; EF155685*; XXXXX*. Gymnanthemum amygdalinum (Delile) Sch. Bip. ex Walp., AY504695*; AY504737*; XXXXX*. Heterocoma albida (DC. ex Pers.) DC., Brazil: Minas Gerais, Serro, 9-VI-2008, Loeuille \& al. 450 (SPF), XXXXX; XXXXX; XXXXX. Hololepis pedunculata (DC. ex Pers.) DC., Brazil: Minas Gerais, São Roque de Minas, 15-V2007, Loeuille \& al. 259 (SPF), XXXXX; XXXXX; XXXXX. Lepidaploa aurea (Mart. ex DC.) H. Rob., Brazil: Goiás, Alto Paraíso, 19-VII-2007, Loeuille \& al. 283 (SPF), XXXXX; XXXXX; XXXXX. Lepidaploa rufogrisea (A. St. -Hil.) H. Rob., Brazil: Minas Gerais, Santana do Riacho, 14-II-2007, Loenille \& al. 110 (SPF), XXXXX; XXXXX; XXXXX. Lepidonia jonesii (B.L. Turner) H. Rob. \& V.A. Funk, EF155788*; EF155700*; XXXXX*. Lessingianthus bishopii (H. Rob.) H. Rob., Brazil: Goiás, Pirenópolis, 22-VII-2007, Loeuille et al. 302 (SPF), XXXXX; XXXXX; XXXXX. Lessingianthus buddleiifolius (Mart. ex DC.) H. Rob., Brazil: Minas Gerais, São Roque de Minas, 15-V-2007, Loeuille \& al. 264 (SPF), XXXXX; XXXXX; XXXXX. Lessingianthus farinosus (Baker) H. Rob., Brazil: Bahia, Abaíra, 17-IX-2007, Loeuille \& al. 319 (SPF), XXXXX; XXXXX; XXXXX. Lessingianthus linearis (Spreng.) H. 
Rob., Brazil: Minas Gerais, São Roque de Minas, 15-V-2007, Loeuille \& al. 260 (SPF), XXXXX; XXXXX; XXXXX. Lessingianthus santosii (H. Rob.) H. Rob., Brazil: Bahia, Abaíra, 18-IX-2007, Loeuille \& al. 338 (SPF), XXXXX; XXXXX; XXXXX. Lychnophora bishopii H. Rob., Brazil: Bahia, Mucugê, 16-II-2002, Oliveira 43 (SPF), XXXXX; XXXXX; XXXXX. Lychnophora ericoides Mart., Brazil: Minas Gerais, Diamantina, 22-I-2007, Loeuille \& al. 89 (SPF), XXXXX; XXXXX; XXXXX. Lychnophora passerina (Mart. ex DC.) Gardner, Brazil: Bahia, Abaíra, 18-IX-2007, Loeuille \& al. 337 (SPF), XXXXX; XXXXX; XXXXX. Lychnophora salicifolia Mart., Brazil: Minas Gerais, Botumirim, 17-XI-2007, Mello-Silva \& al. 3000 (SPF), XXXXX; XXXXX; XXXXX. Lychnophoriopsis candelabrum (Sch. Bip.) H. Rob., Brazil: Minas Gerais, Buenópolis, 3-VI-2008, Loeuille \& al. 435 (SPF), XXXXX; XXXXX; XXXXX. Minasia alpestris (Gardner) H. Rob., Brazil: Minas Gerais, Diamantina, Nakajima \& al. 4624 (SPF), XXXXX; XXXXX; XXXXX. Moquinia racemosa (Spreng.) DC., Brazil: Bahia, Piatã, 16-IX-2007, Loeuille \& al. 311 (SPF), XXXXX; XXXXX; XXXXX. Orthopappus angustifolius (Sw.) Gleason, Brazil: São Paulo, São Paulo, 24-IV-2010, Loeuille 523 (SPF), XXXXX; XXXXX; XXXXX. Paralychnophora glaziouana Loeuille sp. ined., Brazil: Minas Gerais, Serro, 9-VI-2008, Loeuille \& al. 451 (SPF), XXXXX; XXXXX; XXXXX. Piptocarpha oblonga (Gardner) Baker, Brazil: Minas Gerais, Capitólio, 26-X-2006, Loeuille \& al. 57 (SPF), XXXXX; XXXXX; XXXXX. Piptocarpha rotundifolia (Less.) Baker, Brazil: Minas Gerais, Capitólio, 25-X-2006, Loeuille \& al. 46 (SPF), XXXXX; XXXXX; XXXXX. Piptolepis ericoides Sch. Bip., Brazil: Minas Gerais, Santana do Riacho, 21-IV-2006, Loeuille \& al. 17 (SPF), XXXXX; XXXXX; XXXXX. Pithecoseris pacourinoides Mart. ex DC., Brazil: Bahia, Feira de Santana, 22-IX-2007, Loeuille \& França 350 (SPF), XXXXX; XXXXX; XXXXX. Prestelia eriopus Sch. Bip., Brazil: Minas Gerais, Santana do Riacho, 14-II-2007, Loeuille \& al. 113 (SPF), XXXXX; XXXXX; XXXXX. Proteopsis argentea Mart. \& Zucc. ex DC., Brazil: Minas Gerais, Grão Mogol, 7-VI-2008, Loeuille \& al. 444 (SPF), XXXXX; XXXXX; XXXXX. Rolandra fruticosa (L.) Kuntze, Brazil: Bahia, Mascote, 25-X-2008, Mello-Silva \& al. 3128 (SPF), XXXXX; XXXXX; XXXXX. Sipolisia lanuginosa Glaz. ex Oliv., EF155798*; EF155710*; XXXXX*. Soaresia velutina Sch. Bip., Brazil: Distrito Federal, Brasília, 7-V-2003, Fonseca \& Alvarenga 4710 (IBGE), XXXXX; XXXXX; XXXXX. 
Stenocephalum megapotamicum (Spreng.) Sch. Bip., Brazil: Santa Catarina, Lages, 7-I-2008, Loeuille \& Wagner Loeuille 367 (SPF), XXXXX; XXXXX; XXXXX. Stokesia laevis (Hill) Greene, EF155799*; EF155711*; XXXXX*. Stramentopappus poolae (B.L. Turner) H. Rob. \& V.A. Funk, EF155801*; EF155713*; XXXXX*. Strobocalyx arborea (Buch. -Ham.) Sch. Bip., EF155774*; EF155686*; XXXXX*. Strophopappus glomeratus (Gardner) R. Esteves, Brazil: Goiás, Alto Paraíso, 19-VII-2007, Loeuille \& al. 278 (SPF), XXXXX; XXXXX; XXXXX. Strophopappus speciosus (Less.) R. Esteves, Brazil: Minas Gerais, Capitólio, 25-X2006, Loeuille \& al. 44 (SPF), XXXXX; XXXXX; XXXXX. Tarlmounia elliptica (DC.) H. Rob., S.C. Keeley, Skvarla \& R. Chan, EF155813*; EF155725*; XXXXX*. Vernonanthura ferruginea (Less.) H. Rob., Brazil: Goiás, Pirenópolis, 22-VII-2007, Loeuille \& al. 297 (SPF), XXXXX; XXXXX; XXXXX. Vernonanthura lucida (Less.) H. Rob., Brazil: Minas Gerais, Santana do Riacho, 16-II-2007, Loeuille \& al. 135 (SPF), XXXXX; XXXXX; XXXXX. Vernonanthura mariana (Mart. ex Baker) H. Rob., Brazil: Minas Gerais, Diamantina, 22-I2007, Loeuille \& al. 95 (SPF), XXXXX; XXXXX; XXXXX. Vernonia echioides Less., Brazil: Santa Catarina, Urupema, 10-I-2008, Loeuille \& al. 371 (SPF), XXXXX; -; XXXXX. Vernonia fasciculata Michx., EF155815*; EF155727*; XXXXX*. Vernonia noveboracensis (L.) Willd., EF155825*; EF155737*; XXXXX*. Xerxes ekmanianum (Philipson) J.R. Grant, Brazil: Goiás, Cavalcante, 4.II.2007, Trovó et al. 440 (SPF), XXXXX; XXXXX; XXXXX. 
Appendix 2. Morphological characters and character states used for the combined phylogenetic analysis.

Characters 7 to 16 refer to leaf trichomes (adaxial and abaxial surfaces). For explanations on coding see Loeuille \& Pirani (in prep.) (see Chapter 1).

1. Life form: (0) shrub or tree; (1) herb. 2. Leaf position: (0) cauline; (1) rosulate or grouped near the base of stems. 3. Leaf venation: (0) pinnate; (1) parallel; (2) hyphodromous. 4. Leaf margin: (0) entire; (1) serrate to dentate. 5. Leaf blade: (0) not lobed; (1) lobed. 6. Leaf sheath: (0) absent; (1) semi-amplexicaul to amplexicaul; (2) pad-like. 7. Unbranched trichomes: (0) absent; (1) present. 8. T-shaped trichomes: (0) absent; (1) present. 9. L-shaped trichomes: (0) absent; (1) present. 10. 3- to 5-armed trichomes: (0) absent; (1) present. 11. Stellate trichomes: (0) absent; (1) present. 12. Curly trichomes: (0) absent; (1) present. 13. Geminate trichomes: (0) absent; (1) present. 14. Spurred trichomes: (0) absent; (1) present. 15. Porrect trichomes: (0) absent; (1) present. 16. Swollen trichomes: (0) absent; (1) present. 17. Capitulescence position: (0) terminal; (1) axillary. 18. Capitulescence of first-order type: (0) 1-few terminal capitula; (1) racemose branching pattern; (2) cymose branching pattern; (3) paniculate pattern. 19. Capitulescence of first-order showing internode reduction: (0) no; (1) yes but not syncephalia; (2) syncephalia. 20. Number of florets per capitulum (quantitative character). 21. Capitulum bracteole: (0) absent; (1) present. 22. Capitulum peduncle: (0) absent; (1) present. 23. Phyllary series: (0) many; (1) 5-8; (2) 4 or fewer. 24. Phyllary imbrication: (0) strong; (1) weak or none. 25. Phyllary duration (any series): (0) persistent; (1) deciduous or caducous. 26. Capitulum receptacle shape: (0) concave; (1) flat; (2) convex to conical; (3) short thick column. 27. Capitulum receptacle pitting: (0) smooth; (1) areolate or foveolate; (2) fimbrillate; (3) alveolate. 28. Palea: (0) absent; (1) present. 29. Corolla color (before anthesis): (0) white or cream; (1) purple (lavender to lilac) or blue; (2) red. 30. Tube/limb ratio: (0) tube $>$ limb; (1) tube $=$ limb; (2) tube $<$ limb. 31. Corolla laticifer: (0) absent; (1) present. 32. Corolla of peripheral florets symmetry: (0) regular 5-lobed; (1) irregular 5-lobed. 33. Anther base: (0) ecalcarate; (1) calcarate. 34. Anther tail: (0) absent; (1) present. 35. Apical anther appendage cells: (0) lacking conspicuous wall thickenings; (1) with conspicuous wall thickenings. 36. Apical anther appendage gland: (0) absent; (1) present. 37. Apical anther appendage length: (0) at least 3 times as long as wide; (1) at least twice as long as wide; (2) up to twice as long as wide. 38. Pollen aperture type: (0) colporate; (1) porate (with the ectoaperture as a pore rather than a colpus). 39. Pollen macro-ornamentation: (0) non-lophate, (1) sublophate (having spines arranged in a pattern as if lophate); (2) lophate. $\mathbf{4 0 .}$ Pollen tectum extension: (0) covering less than $50 \%$ of pollen grain surface (semi-tectate); (1) covering more more than 50\% but discontinuous; (2) continuous. 41. Pollen tectum: (0) not perforate; (1) perforate. 42. Pollen polar aerole: (0) absent; (1) present. 43. Style base: (0) not expanded; (1) expanded. 44. Sweeping hairs shape: (0) scabrid; (1) subulate to acicular; (2) clavate to lageniform. 45. Phytomelanin on cypsela wall: (0) absent; (1) present. 46. Cypsela 
wall: (0) glabrous; (1) pubescent. 47. Cypsela rib: (0) more than 10-ribbed; (1) 8 to 10-ribbed; (2) c. 5-ribbed. 48. Carpopodium: (0) absent or inconspicuous; (1) prominent. 49. Carpopodium cells druze: (0) absent; (1) present. 50. Carpopodium cells wall: (0) thin-walled; (1) thickwalled; (2) thick-walled nearly occluding lumina. 51. Number of pappus series: (0) one; (1) two; (2) more than two. 52. Pappus duration (any part): (0) persistent; (1) deciduous or caducous. 53. Pappus fusion (any part): (0) free; (1) fused. 54. Outer pappus type: (0) setose; (1) paleaceous. 55. Inner pappus type: (0) setose; (1) paleaceous. 56. Guaianolide: (0) absent; (1) present. 57. Germacranolide: (0) absent; (1) present. 58. Germacranolide derivatives: (0) germacrolide derivatives; (1) heliangolide derivatives.

Appendix 3. The data matrix used in the morphological part of the phylogenetic analysis. Multiple states of characters are coded with the next letters: $a=(01), b=(12),-=$ inapplicable data, $?=$ missing data. 
Character numbers as listed in the Appendix 2

$\begin{array}{lllllllllllllllllllllllllllll}1 & 2 & 3 & 4 & 5 & 6 & 7 & 8 & 9 & 1 & 1 & 1 & 1 & 1 & 1 & 1 & 1 & 1 & 1 & 2 & 2 & 2 & 2 & 2 & 2 & 2 & 2 & 2 & 2\end{array}$ \begin{tabular}{llllllllllllllllllll}
0 & 1 & 2 & 3 & 4 & 5 & 6 & 7 & 8 & 9 & 0 & 1 & 2 & 3 & 4 & 5 & 6 & 7 & 8 & 9 \\
\hline 3 & 4 & 4 & 4 & 4 & 4 & 4 & 4 & 4 & 4 & 4 & 5 & 5 & 5 & 5 & 5 & 5 & 5 & 5 & 5
\end{tabular}

$\begin{array}{llllllllllllllllllllllllllllllll}3 & 3 & 3 & 3 & 3 & 3 & 3 & 3 & 3 & 3 & 4 & 4 & 4 & 4 & 4 & 4 & 4 & 4 & 4 & 4 & 5 & 5 & 5 & 5 & 5 & 5 & 5 & 5 & 5 \\ 0 & 1 & 2 & 3 & 4 & 5 & 6 & 7 & 8 & 9 & 0 & 1 & 2 & 3 & 4 & 5 & 6 & 7 & 8 & 9 & 0 & 1 & 2 & 3 & 4 & 5 & 6 & 7 & 8\end{array}$

Chrysolaena flexuosa

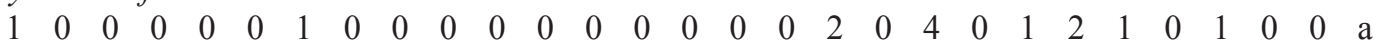

$\begin{array}{lllllllllllllllllllllllllllll}0 & 0 & 0 & 1 & 0 & 1 & 1 & 0 & 0 & 2 & 1 & 1 & 1 & 0 & 1 & 0 & 1 & 2 & 1 & 0 & 2 & 1 & 0 & 0 & 0 & 0 & 1 & 0 & \square\end{array}$

Chrysolaena lithospermifolia

$\begin{array}{lllllllllllllllllllllllllllll}1 & 0 & 0 & 0 & 0 & 0 & 1 & 0 & 0 & 0 & 0 & 0 & 0 & 0 & 0 & 0 & 0 & 2 & 0 & 3 & 0 & 1 & 2 & 1 & 0 & 1 & 1 & 0 & 1\end{array}$

$\begin{array}{llllllllllllllllllllllllllllll}0 & 0 & 0 & 1 & 0 & 1 & 1 & 1 & 0 & 2 & 1 & 1 & 1 & 0 & 1 & 0 & 1 & 2 & 1 & 1 & 2 & 1 & 0 & 0 & 0 & 0 & \text { ? } & \text { ? }\end{array}$

Chrysolaena platensis

$\begin{array}{llllllllllllllllllllllllllllll}0 & 0 & 0 & 0 & 0 & 0 & 1 & 0 & 0 & 0 & 0 & 0 & 0 & 0 & 0 & 0 & 0 & 2 & 1 & 2 & 1 & 1 & 2 & 1 & 0 & 1 & 1 & 0 & 1\end{array}$

$\begin{array}{lllllllllllllllllllllllllllllll}0 & 0 & 0 & 1 & 0 & 1 & 1 & 1 & 0 & 2 & 1 & 1 & 1 & 0 & 1 & 0 & 1 & 2 & 1 & 1 & 2 & 1 & 0 & 0 & 0 & 0 & 0 & 1 & 0\end{array}$

Critoniopsis huairacajana

$\begin{array}{lllllllllllllllllllllllllllll}0 & 0 & 0 & 0 & 0 & 0 & 0 & 0 & 0 & 1 & 1 & 0 & 0 & 0 & 0 & 1 & 0 & 3 & 0 & 1 & 0 & 0 & 1 & 1 & 1 & 1 & 0 & 0 & 1\end{array}$

$\begin{array}{lllllllllllllllllllllllllllll}2 & 0 & 0 & 1 & 1 & 1 & 0 & 1 & 0 & 1 & 2 & 1 & \square & 1 & 1 & 0 & 0 & 1 & 1 & 0 & 2 & 1 & 0 & 0 & 0 & 0 & 0 & 1 & 0\end{array}$

Critoniopsis sodiroi

$\begin{array}{llllllllllllllllllllllllllllll}0 & 0 & 0 & 0 & 0 & 0 & 0 & 0 & 0 & 1 & 1 & 0 & 0 & 0 & 0 & 1 & 0 & 3 & 0 & 0 & 1 & \text { a } & 1 & 1 & 1 & 1 & 0 & 0 & 0\end{array}$

$\begin{array}{lllllllllllllllllllllllllllll}2 & 0 & 0 & 1 & 1 & 1 & 0 & 1 & 0 & 1 & 2 & 1 & \square & 1 & 1 & 0 & 1 & 1 & 1 & 0 & 2 & 1 & 0 & 0 & 0 & 0 & \text { ? } & \text { ? }\end{array}$

Cyrtocymura harleyi

$\begin{array}{lllllllllllllllllllllllllllll}1 & 0 & 0 & 1 & 0 & 0 & 1 & 0 & 0 & 0 & 0 & 1 & 0 & 0 & 0 & 0 & 0 & 2 & 1 & 2 & 1 & 1 & 2 & 0 & 0 & 2 & 1 & 0 & 1\end{array}$

$\begin{array}{llllllllllllllllllllllllllllll}0 & 0 & 0 & 1 & 0 & 0 & 0 & 1 & 0 & 1 & 2 & 1 & \square & 0 & 1 & 0 & 1 & 1 & 1 & 0 & 1 & 1 & 0 & 0 & 0 & 0 & ? & \text { ? }\end{array}$

Cyrtocymura scorpioides

$\begin{array}{llllllllllllllllllllllllllllll}0 & 0 & 0 & 1 & 0 & 0 & 1 & 0 & 0 & 0 & 0 & 0 & 0 & 0 & 0 & 0 & 0 & 2 & 1 & 1 & 0 & 1 & 2 & 0 & 0 & 2 & 2 & 0 & 1\end{array}$

$\begin{array}{lllllllllllllllllllllllllllll}0 & 0 & 0 & 1 & 0 & 1 & 0 & 0 & 0 & 1 & 2 & 1 & \square & 0 & 1 & 0 & 1 & 1 & 1 & 0 & 1 & 1 & 0 & 0 & 0 & 0 & 0 & 1 & 0\end{array}$

Echinocoryne holosericea

$\begin{array}{llllllllllllllllllllllllllllll}1 & 0 & 0 & 0 & 0 & 0 & 1 & 0 & 0 & 0 & 0 & 0 & 0 & 0 & 0 & 0 & 0 & 2 & 0 & 4 & 1 & 0 & 0 & 1 & 0 & 1 & 1 & 0 & 1\end{array}$

$\begin{array}{llllllllllllllllllllllllllllll}0 & 0 & 0 & 1 & 0 & 0 & 0 & 2 & 0 & 2 & 1 & 1 & 1 & 1 & 1 & 0 & 1 & 2 & 1 & 0 & 2 & 1 & 0 & 0 & 1 & 0 & \text { ? } & \text { ? }\end{array}$

Echinocoryne schwenkiaefolia

$\begin{array}{lllllllllllllllllllllllllllll}1 & 0 & 0 & 0 & 0 & 0 & 1 & 0 & 0 & 0 & 0 & 0 & 0 & 0 & 0 & 0 & 0 & 2 & 0 & 3 & 1 & 0 & 0 & 1 & 0 & 1 & 1 & 0 & 1\end{array}$

$\begin{array}{lllllllllllllllllllllllllllll}0 & 0 & 0 & 1 & 0 & 0 & 0 & 1 & 0 & 2 & 1 & 1 & 1 & 1 & 1 & 0 & 1 & 2 & 1 & 0 & 2 & 1 & 1 & 0 & 1 & 0 & \text { ? } & \text { ? }\end{array}$

Elephantopus biflorus

$\begin{array}{lllllllllllllllllllllllllllllll}1 & 0 & 0 & 1 & 0 & 1 & 1 & 0 & 0 & 0 & 0 & 0 & 0 & 0 & 0 & 0 & 1 & \square & 2 & 0 & 1 & 1 & 2 & 1 & 0 & 1 & 0 & 0 & a\end{array}$ $\begin{array}{lllllllllllllllllllllllllllllll}0 & 0 & 1 & 0 & 0 & 0 & 0 & 2 & \text { ? } & \text { ? } & \text { ? } & \text { ? } & \text { ? } & 0 & 1 & 0 & 1 & 1 & 1 & 0 & 1 & 1 & 1 & 0 & 1 & 1 & \text { ? } & \text { ? } & \text { ? }\end{array}$

Elephantopus micropappus

$\begin{array}{llllllllllllllllllllllllllllll}1 & 0 & 0 & 1 & 0 & 1 & 1 & 0 & 0 & 0 & 0 & 0 & 0 & 0 & 0 & 0 & 0 & \square & 2 & 0 & 1 & 1 & 2 & 1 & 0 & 1 & 0 & 0 & \text { a }\end{array}$ $\begin{array}{llllllllllllllllllllllllllllll}0 & 0 & 1 & 0 & 0 & 0 & 0 & 2 & ? & ? & ? & ? & ? & 0 & 1 & 0 & 1 & 1 & 1 & 0 & 1 & 0 & 0 & 0 & \text { ? } & 1 & \text { ? } & \text { ? } & \text { ? }\end{array}$

Elephantopus mollis

$\begin{array}{lllllllllllllllllllllllllllllll}1 & 1 & 0 & 1 & 0 & 0 & 1 & 0 & 0 & 0 & 0 & 0 & 0 & 0 & 0 & 0 & 1 & \square & 2 & 0 & 1 & 1 & 2 & 1 & 0 & 1 & 0 & 0 & 1\end{array}$

$\begin{array}{lllllllllllllllllllllllllllll}0 & 0 & 1 & 0 & 0 & 0 & 0 & 2 & 1 & 2 & 0 & 1 & 1 & 0 & 1 & 0 & 1 & 1 & 1 & 0 & 1 & 0 & 0 & 0 & ? & 0 & 1 & 1 & 0\end{array}$

Eremanthus erythropappus

$\begin{array}{lllllllllllllllllllllllllllll}0 & 0 & 0 & 0 & 0 & 0 & 0 & 0 & 0 & 1 & 0 & 0 & 0 & 0 & 0 & 1 & 0 & \square & 2 & 0 & 0 & 1 & 1 & 0 & 0 & 1 & 2 & 0 & 1\end{array}$ $\begin{array}{lllllllllllllllllllllllllllll}0 & 0 & 0 & 1 & 0 & 1 & 0 & 1 & 0 & 1 & 2 & 1 & \square & 0 & 1 & 0 & 0 & 1 & 0 & \square & \square & 2 & 1 & 0 & 0 & 0 & 1 & 1 & 1\end{array}$

Eremanthus glomerulatus

$\begin{array}{lllllllllllllllllllllllllllll}0 & 0 & 0 & 0 & 0 & 0 & 0 & 0 & 0 & 1 & 0 & 0 & 0 & 0 & 0 & 1 & 0 & \square & 2 & 0 & 0 & 1 & 1 & 0 & 0 & 1 & 0 & 0 & a\end{array}$ $\begin{array}{lllllllllllllllllllllllllllll}1 & 0 & 0 & 1 & 0 & 1 & 0 & 1 & 0 & 1 & 2 & 1 & \square & 0 & 1 & 0 & 1 & 1 & 0 & \square & \square & 2 & 0 & 0 & 1 & 1 & 1 & 1 & 1\end{array}$

Gorceixia decurrens

$\begin{array}{lllllllllllllllllllllllllllllll}0 & 0 & 0 & 1 & 0 & 0 & 0 & 0 & 0 & 1 & 0 & 0 & 0 & 1 & 0 & 0 & 0 & \square & 2 & 0 & 0 & 1 & 2 & 1 & 0 & 1 & 0 & 0 & 0\end{array}$ $\begin{array}{lllllllllllllllllllllllllllllllllll}0 & 0 & 0 & 1 & 0 & 1 & 0 & 1 & 0 & 1 & 1 & 1 & \square & 0 & 1 & 0 & 0 & 1 & 0 & \square & \square & 0 & 0 & 1 & 1 & \text { ? } & \text { ? }\end{array}$ ?

Heterocoma albida $\begin{array}{llllllllllllllllllllllllllllll}0 & 0 & 0 & 0 & 0 & 1 & 0 & 0 & 0 & 1 & 1 & 0 & 0 & 0 & 0 & 0 & 1 & 0 & 0 & 4 & 1 & 1 & 2 & 1 & 0 & 1 & 2 & 1 & 1\end{array}$ $\begin{array}{lllllllllllllllllllllllllllll}2 & 1 & 0 & \text { ? } & \text { ? } & \text { ? } & \text { ? } & \text { ? } & 0 & 1 & 1 & 1 & \square & 0 & 1 & 1 & 0 & 1 & 0 & \square & \square & 1 & 1 & 0 & 1 & 1 & 1 & 0 & \square\end{array}$

Hololepis pedunculata

$\begin{array}{lllllllllllllllllllllllllllll}0 & 0 & 0 & \mathrm{a} & 0 & 0 & 0 & 1 & 0 & 0 & 0 & 0 & 0 & 0 & 0 & 0 & 1 & 0 & 0 & 3 & 1 & 0 & 1 & 1 & 0 & 1 & 2 & 0 & 1\end{array}$ $\begin{array}{lllllllllllllllllllllllllllll}1 & 1 & 0 & 1 & 1 & 1 & 0 & 0 & 0 & 1 & 1 & 1 & \square & 0 & 1 & 0 & 1 & 1 & 1 & 0 & 1 & 1 & 0 & 0 & 1 & 1 & 0 & 1 & 1\end{array}$

Lepidaploa aurea

$\begin{array}{lllllllllllllllllllllllllllll}1 & 0 & 0 & 0 & 0 & 0 & 1 & 0 & 0 & 0 & 0 & 1 & 0 & 0 & 0 & 0 & 0 & 2 & 1 & 3 & 1 & 1 & 1 & 0 & 0 & 1 & 0 & 0 & 1\end{array}$

$\begin{array}{lllllllllllllllllllllllllllll}2 & 0 & 0 & 1 & 0 & 1 & 0 & 1 & 0 & 2 & 1 & 1 & 0 & 1 & 1 & 0 & 1 & 1 & 1 & 0 & 1 & 1 & 0 & 0 & 1 & 0 & 0 & 1 & 0\end{array}$ 
Character numbers as listed in the Appendix 2

$\begin{array}{lllllllllllllllllllllllllllll}1 & 2 & 3 & 4 & 5 & 6 & 7 & 8 & 9 & 1 & 1 & 1 & 1 & 1 & 1 & 1 & 1 & 1 & 1 & 2 & 2 & 2 & 2 & 2 & 2 & 2 & 2 & 2 & 2\end{array}$ $\begin{array}{llllllllllllllllllll}0 & 1 & 2 & 3 & 4 & 5 & 6 & 7 & 8 & 9 & 0 & 1 & 2 & 3 & 4 & 5 & 6 & 7 & 8 & 9\end{array}$

$\begin{array}{llllllllllllllllllllllllllllll}3 & 3 & 3 & 3 & 3 & 3 & 3 & 3 & 3 & 3 & 4 & 4 & 4 & 4 & 4 & 4 & 4 & 4 & 4 & 4 & 5 & 5 & 5 & 5 & 5 & 5 & 5 & 5 & 5\end{array}$

$\begin{array}{lllllllllllllllllllllllllllll}0 & 1 & 2 & 3 & 4 & 5 & 6 & 7 & 8 & 9 & 0 & 1 & 2 & 3 & 4 & 5 & 6 & 7 & 8 & 9 & 0 & 1 & 2 & 3 & 4 & 5 & 6 & 7 & 8\end{array}$

a flexuosa

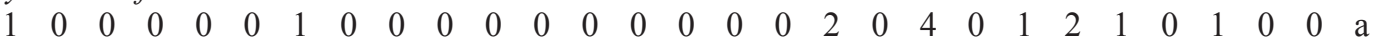

$\begin{array}{llllllllllllllllllllllllllllll}0 & 0 & 0 & 1 & 0 & 1 & 1 & 0 & 0 & 2 & 1 & 1 & 1 & 0 & 1 & 0 & 1 & 2 & 1 & 0 & 2 & 1 & 0 & 0 & 0 & 0 & 1 & 0 & \square\end{array}$

Chrysolaena lithospermifolia

$\begin{array}{llllllllllllllllllllllllllllll}1 & 0 & 0 & 0 & 0 & 0 & 1 & 0 & 0 & 0 & 0 & 0 & 0 & 0 & 0 & 0 & 0 & 2 & 0 & 3 & 0 & 1 & 2 & 1 & 0 & 1 & 1 & 0 & 1\end{array}$

$\begin{array}{llllllllllllllllllllllllllllll}0 & 0 & 0 & 1 & 0 & 1 & 1 & 1 & 0 & 2 & 1 & 1 & 1 & 0 & 1 & 0 & 1 & 2 & 1 & 1 & 2 & 1 & 0 & 0 & 0 & 0 & \text { ? } & \text { ? }\end{array}$

Chrysolaena platensis

$\begin{array}{llllllllllllllllllllllllllllll}0 & 0 & 0 & 0 & 0 & 0 & 1 & 0 & 0 & 0 & 0 & 0 & 0 & 0 & 0 & 0 & 0 & 2 & 1 & 2 & 1 & 1 & 2 & 1 & 0 & 1 & 1 & 0 & 1\end{array}$

$\begin{array}{lllllllllllllllllllllllllllll}0 & 0 & 0 & 1 & 0 & 1 & 1 & 1 & 0 & 2 & 1 & 1 & 1 & 0 & 1 & 0 & 1 & 2 & 1 & 1 & 2 & 1 & 0 & 0 & 0 & 0 & 0 & 1 & 0\end{array}$

Critoniopsis huairacajana

$\begin{array}{lllllllllllllllllllllllllllll}0 & 0 & 0 & 0 & 0 & 0 & 0 & 0 & 0 & 1 & 1 & 0 & 0 & 0 & 0 & 1 & 0 & 3 & 0 & 1 & 0 & 0 & 1 & 1 & 1 & 1 & 0 & 0 & 1\end{array}$

$2 \begin{array}{lllllllllllllllllllllllllllll}2 & 0 & 0 & 1 & 1 & 1 & 0 & 1 & 0 & 1 & 2 & 1 & \square & 1 & 1 & 0 & 0 & 1 & 1 & 0 & 2 & 1 & 0 & 0 & 0 & 0 & 0 & 1 & 0\end{array}$

Critoniopsis sodiroi

$\begin{array}{llllllllllllllllllllllllllllll}0 & 0 & 0 & 0 & 0 & 0 & 0 & 0 & 0 & 1 & 1 & 0 & 0 & 0 & 0 & 1 & 0 & 3 & 0 & 0 & 1 & \text { a } & 1 & 1 & 1 & 1 & 0 & 0 & 0\end{array}$

$\begin{array}{llllllllllllllllllllllllllllll}2 & 0 & 0 & 1 & 1 & 1 & 0 & 1 & 0 & 1 & 2 & 1 & \square & 1 & 1 & 0 & 1 & 1 & 1 & 0 & 2 & 1 & 0 & 0 & 0 & 0 & \text { ? } & \text { ? }\end{array}$

Cyrtocymura harleyi

$\begin{array}{llllllllllllllllllllllllllllll}1 & 0 & 0 & 1 & 0 & 0 & 1 & 0 & 0 & 0 & 0 & 1 & 0 & 0 & 0 & 0 & 0 & 2 & 1 & 2 & 1 & 1 & 2 & 0 & 0 & 2 & 1 & 0 & 1\end{array}$

$\begin{array}{lllllllllllllllllllllllllllll}0 & 0 & 0 & 1 & 0 & 0 & 0 & 1 & 0 & 1 & 2 & 1 & \square & 0 & 1 & 0 & 1 & 1 & 1 & 0 & 1 & 1 & 0 & 0 & 0 & 0 & \text { ? } & \text { ? }\end{array}$

Cyrtocymura scorpioides

$\begin{array}{llllllllllllllllllllllllllllll}0 & 0 & 0 & 1 & 0 & 0 & 1 & 0 & 0 & 0 & 0 & 0 & 0 & 0 & 0 & 0 & 0 & 2 & 1 & 1 & 0 & 1 & 2 & 0 & 0 & 2 & 2 & 0 & 1\end{array}$

$\begin{array}{lllllllllllllllllllllllllllll}0 & 0 & 0 & 1 & 0 & 1 & 0 & 0 & 0 & 1 & 2 & 1 & \square & 0 & 1 & 0 & 1 & 1 & 1 & 0 & 1 & 1 & 0 & 0 & 0 & 0 & 0 & 1 & 0\end{array}$

Echinocoryne holosericea

$\begin{array}{lllllllllllllllllllllllllllll}1 & 0 & 0 & 0 & 0 & 0 & 1 & 0 & 0 & 0 & 0 & 0 & 0 & 0 & 0 & 0 & 0 & 2 & 0 & 4 & 1 & 0 & 0 & 1 & 0 & 1 & 1 & 0 & 1\end{array}$

$\begin{array}{lllllllllllllllllllllllllllll}0 & 0 & 0 & 1 & 0 & 0 & 0 & 2 & 0 & 2 & 1 & 1 & 1 & 1 & 1 & 0 & 1 & 2 & 1 & 0 & 2 & 1 & 0 & 0 & 1 & 0 & \text { ? } & \text { ? }\end{array}$

Echinocoryne schwenkiaefolia

$\begin{array}{lllllllllllllllllllllllllllll}1 & 0 & 0 & 0 & 0 & 0 & 1 & 0 & 0 & 0 & 0 & 0 & 0 & 0 & 0 & 0 & 0 & 2 & 0 & 3 & 1 & 0 & 0 & 1 & 0 & 1 & 1 & 0 & 1\end{array}$

$\begin{array}{llllllllllllllllllllllllllllllll}0 & 0 & 0 & 1 & 0 & 0 & 0 & 1 & 0 & 2 & 1 & 1 & 1 & 1 & 1 & 0 & 1 & 2 & 1 & 0 & 2 & 1 & 1 & 0 & 1 & 0 & \text { ? } & \text { ? }\end{array}$

Elephantopus biflorus

$\begin{array}{lllllllllllllllllllllllllllllll}1 & 0 & 0 & 1 & 0 & 1 & 1 & 0 & 0 & 0 & 0 & 0 & 0 & 0 & 0 & 0 & 1 & \square & 2 & 0 & 1 & 1 & 2 & 1 & 0 & 1 & 0 & 0 & a\end{array}$

$\begin{array}{llllllllllllllllllllllllllllll}0 & 0 & 1 & 0 & 0 & 0 & 0 & 2 & \text { ? } & \text { ? } & \text { ? } & \text { ? } & \text { ? } & 0 & 1 & 0 & 1 & 1 & 1 & 0 & 1 & 1 & 1 & 0 & 1 & 1 & \text { ? } & \text { ? } & \text { ? }\end{array}$

Elephantopus micropappus

$\begin{array}{lllllllllllllllllllllllllllllll}1 & 0 & 0 & 1 & 0 & 1 & 1 & 0 & 0 & 0 & 0 & 0 & 0 & 0 & 0 & 0 & 0 & \square & 2 & 0 & 1 & 1 & 2 & 1 & 0 & 1 & 0 & 0 & a\end{array}$

$\begin{array}{lllllllllllllllllllllllllllll}0 & 0 & 1 & 0 & 0 & 0 & 0 & 2 & \text { ? } & \text { ? } & \text { ? } & \text { ? } & \text { ? } & 0 & 1 & 0 & 1 & 1 & 1 & 0 & 1 & 0 & 0 & 0 & \text { ? } & 1 & \text { ? } & \text { ? }\end{array}$ ?

Elephantopus mollis

$\begin{array}{lllllllllllllllllllllllllllll}1 & 1 & 0 & 1 & 0 & 0 & 1 & 0 & 0 & 0 & 0 & 0 & 0 & 0 & 0 & 0 & 1 & \square & 2 & 0 & 1 & 1 & 2 & 1 & 0 & 1 & 0 & 0 & 1\end{array}$

$\begin{array}{lllllllllllllllllllllllllllll}0 & 0 & 1 & 0 & 0 & 0 & 0 & 2 & 1 & 2 & 0 & 1 & 1 & 0 & 1 & 0 & 1 & 1 & 1 & 0 & 1 & 0 & 0 & 0 & ? & 0 & 1 & 1 & 0\end{array}$

Eremanthus erythropappus

$\begin{array}{lllllllllllllllllllllllllllll}0 & 0 & 0 & 0 & 0 & 0 & 0 & 0 & 0 & 1 & 0 & 0 & 0 & 0 & 0 & 1 & 0 & \square & 2 & 0 & 0 & 1 & 1 & 0 & 0 & 1 & 2 & 0 & 1\end{array}$

$\begin{array}{lllllllllllllllllllllllllllll}0 & 0 & 0 & 1 & 0 & 1 & 0 & 1 & 0 & 1 & 2 & 1 & \square & 0 & 1 & 0 & 0 & 1 & 0 & \square & \square & 2 & 1 & 0 & 0 & 0 & 1 & 1 & 1\end{array}$

Eremanthus glomerulatus

$\begin{array}{lllllllllllllllllllllllllllll}0 & 0 & 0 & 0 & 0 & 0 & 0 & 0 & 0 & 1 & 0 & 0 & 0 & 0 & 0 & 1 & 0 & \square & 2 & 0 & 0 & 1 & 1 & 0 & 0 & 1 & 0 & 0 & \text { a }\end{array}$

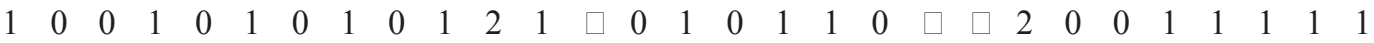

Gorceixia decurrens

$\begin{array}{lllllllllllllllllllllllllllllll}0 & 0 & 0 & 1 & 0 & 0 & 0 & 0 & 0 & 1 & 0 & 0 & 0 & 1 & 0 & 0 & 0 & \square & 2 & 0 & 0 & 1 & 2 & 1 & 0 & 1 & 0 & 0 & 0\end{array}$

$\begin{array}{llllllllllllllllllllllllllllllllll}0 & 0 & 0 & 1 & 0 & 1 & 0 & 1 & 0 & 1 & 1 & 1 & \square & 0 & 1 & 0 & 0 & 1 & 0 & \square & \square & 0 & 0 & 1 & 1 & \text { ? } & \text { ? } & \text { ? }\end{array}$

Heterocoma albida

$\begin{array}{lllllllllllllllllllllllllllll}0 & 0 & 0 & 0 & 0 & 1 & 0 & 0 & 0 & 1 & 1 & 0 & 0 & 0 & 0 & 0 & 1 & 0 & 0 & 4 & 1 & 1 & 2 & 1 & 0 & 1 & 2 & 1 & 1\end{array}$

$\begin{array}{lllllllllllllllllllllllllllll}2 & 1 & 0 & \text { ? } & \text { ? } & \text { ? } & \text { ? } & \text { ? } & 0 & 1 & 1 & 1 & \square & 0 & 1 & 1 & 0 & 1 & 0 & \square & \square & 1 & 1 & 0 & 1 & 1 & 1 & 0 & \square\end{array}$

Hololepis pedunculata

$\begin{array}{lllllllllllllllllllllllllllll}0 & 0 & 0 & \mathrm{a} & 0 & 0 & 0 & 1 & 0 & 0 & 0 & 0 & 0 & 0 & 0 & 0 & 1 & 0 & 0 & 3 & 1 & 0 & 1 & 1 & 0 & 1 & 2 & 0 & 1\end{array}$

$\begin{array}{lllllllllllllllllllllllllllll}1 & 1 & 0 & 1 & 1 & 1 & 0 & 0 & 0 & 1 & 1 & 1 & \square & 0 & 1 & 0 & 1 & 1 & 1 & 0 & 1 & 1 & 0 & 0 & 1 & 1 & 0 & 1 & 1\end{array}$

Lepidaploa aurea

$1 \quad 0 \begin{array}{llllllllllllllllllllllllllll} & 0 & 0 & 0 & 0 & 1 & 0 & 0 & 0 & 0 & 1 & 0 & 0 & 0 & 0 & 0 & 2 & 1 & 3 & 1 & 1 & 1 & 0 & 0 & 1 & 0 & 0 & 1\end{array}$

$\begin{array}{lllllllllllllllllllllllllllll}2 & 0 & 0 & 1 & 0 & 1 & 0 & 1 & 0 & 2 & 1 & 1 & 0 & 1 & 1 & 0 & 1 & 1 & 1 & 0 & 1 & 1 & 0 & 0 & 1 & 0 & 0 & 1 & 0\end{array}$ 
Character numbers as listed in the Appendix 2

$\begin{array}{lllllllllllllllllllllllllllll}1 & 2 & 3 & 4 & 5 & 6 & 7 & 8 & 9 & 1 & 1 & 1 & 1 & 1 & 1 & 1 & 1 & 1 & 1 & 2 & 2 & 2 & 2 & 2 & 2 & 2 & 2 & 2 & 2\end{array}$ $\begin{array}{llllllllllllllllllll}0 & 1 & 2 & 3 & 4 & 5 & 6 & 7 & 8 & 9 & 0 & 1 & 2 & 3 & 4 & 5 & 6 & 7 & 8 & 9\end{array}$

$\begin{array}{lllllllllllllllllllllllllllll}3 & 3 & 3 & 3 & 3 & 3 & 3 & 3 & 3 & 3 & 4 & 4 & 4 & 4 & 4 & 4 & 4 & 4 & 4 & 4 & 5 & 5 & 5 & 5 & 5 & 5 & 5 & 5 & 5\end{array}$ $\begin{array}{lllllllllllllllllllllllllllll}0 & 1 & 2 & 3 & 4 & 5 & 6 & 7 & 8 & 9 & 0 & 1 & 2 & 3 & 4 & 5 & 6 & 7 & 8 & 9 & 0 & 1 & 2 & 3 & 4 & 5 & 6 & 7 & 8\end{array}$

Lepidaploa rufogrisea

$\begin{array}{lllllllllllllllllllllllllllll}0 & 0 & 0 & 1 & 0 & 0 & 0 & 1 & 0 & 0 & 0 & 0 & 0 & 0 & 0 & 0 & 0 & 2 & 1 & 1 & 1 & 1 & 1 & 0 & 0 & 1 & 0 & 0 & 1\end{array}$

$\begin{array}{llllllllllllllllllllllllllllll}0 & 0 & 0 & 1 & 0 & 0 & 0 & 0 & 0 & 2 & 1 & 1 & 0 & 1 & 1 & 0 & 1 & 1 & 1 & 0 & 2 & 1 & 0 & 0 & 1 & 0 & \text { ? } & \text { ? }\end{array}$

Lepidonia jonesii

$\begin{array}{llllllllllllllllllllllllllllll}0 & 0 & 0 & 1 & 0 & 0 & 1 & 0 & 0 & 0 & 0 & 0 & 0 & 0 & 0 & 0 & 1 & 0 & 0 & 8 & 1 & 0 & 1 & 1 & 0 & 2 & 1 & 0 & 1\end{array}$

$\begin{array}{lllllllllllllllllllllllllllll}0 & 0 & 0 & 1 & 0 & 1 & 0 & 2 & 0 & 1 & 1 & 1 & \square & 0 & 1 & 0 & 0 & 2 & 1 & 1 & 1 & 2 & 1 & 0 & 0 & 0 & 0 & 1 & 0\end{array}$

Lessingianthus bishopii

$\begin{array}{llllllllllllllllllllllllllllll}0 & 0 & 0 & 1 & 0 & 0 & 1 & 0 & 0 & 0 & 0 & 1 & 0 & 0 & 0 & 0 & 0 & 2 & 0 & 8 & 0 & 0 & 1 & 0 & 0 & 1 & 2 & 0 & 0\end{array}$

$\begin{array}{llllllllllllllllllllllllllllllllll}0 & 0 & 0 & 1 & 0 & 1 & 0 & 1 & 0 & 2 & 1 & 1 & 0 & 0 & 1 & 0 & 1 & 1 & 1 & 0 & 0 & 1 & 0 & 0 & 1 & 0 & \text { ? } & \text { ? }\end{array}$

Lessingianthus buddleiifolius

$\begin{array}{lllllllllllllllllllllllllllll}0 & 0 & 0 & 1 & 0 & 0 & 1 & 0 & 0 & 0 & 0 & 1 & 0 & 0 & 0 & 0 & 0 & 2 & 0 & 6 & 1 & 1 & 1 & 0 & 0 & 1 & 1 & 0 & 1\end{array}$

$\begin{array}{lllllllllllllllllllllllllllll}0 & 0 & 0 & 1 & 0 & 0 & 0 & 1 & 0 & 2 & 1 & 1 & 0 & 0 & 1 & 0 & 1 & 1 & 1 & 0 & 1 & 1 & 1 & 0 & 1 & 0 & \text { ? } & \text { ? }\end{array}$

Lessingianthus farinosus

$\begin{array}{lllllllllllllllllllllllllllll}0 & 0 & 0 & 1 & 0 & 0 & 1 & 0 & 0 & 0 & 0 & 1 & 0 & 0 & 0 & 0 & 0 & 2 & 0 & 2 & 1 & 1 & 1 & 0 & 0 & 1 & 1 & 0 & 1\end{array}$

$\begin{array}{lllllllllllllllllllllllllllll}0 & 0 & 0 & 1 & 0 & 1 & 0 & 1 & 0 & 2 & 1 & 1 & 0 & 0 & 1 & 0 & 1 & 2 & 1 & 0 & 2 & 1 & 0 & 0 & 1 & 0 & \text { ? } & \text { ? }\end{array}$

Lessingianthus linearis

$\begin{array}{llllllllllllllllllllllllllllll}0 & 0 & 2 & 0 & 0 & 0 & 1 & 0 & 0 & 0 & 0 & 1 & 0 & 0 & 0 & 0 & 0 & 2 & 0 & 2 & 1 & \text { a } & 1 & 0 & 0 & 1 & 1 & 0 & 1\end{array}$

$1 \quad 0 \begin{array}{lllllllllllllllllllllllllll} & 0 & 1 & 0 & 1 & 0 & 1 & 0 & 2 & 1 & 1 & 0 & 0 & 1 & 0 & 1 & 1 & 1 & 0 & 2 & 1 & 0 & 0 & 1 & 0 & \text { ? } & \text { ? }\end{array}$

Lessingianthus santosii

$\begin{array}{llllllllllllllllllllllllllllll}1 & 1 & 0 & 0 & 0 & 0 & 1 & 0 & 0 & 0 & 0 & 0 & 0 & 0 & 0 & 0 & 0 & 0 & 0 & 4 & 1 & 0 & \mathrm{~b} & 0 & 0 & 1 & 1 & 0 & 1\end{array}$

$\begin{array}{lllllllllllllllllllllllllllll}0 & 0 & 0 & 1 & 0 & 1 & 0 & 1 & 1 & 2 & 1 & 1 & 1 & 0 & 1 & 0 & 1 & 1 & 1 & 0 & 1 & 1 & 0 & 0 & 1 & 0 & \text { ? } & \text { ? }\end{array}$

Lychnophora bishopii

$\begin{array}{lllllllllllllllllllllllllllll}0 & 0 & 2 & 0 & 0 & 2 & 0 & 0 & 0 & 1 & 0 & 0 & 0 & 0 & 0 & 1 & 0 & \square & 2 & 0 & 1 & 1 & 1 & 0 & 0 & 1 & 1 & 0 & 1\end{array}$

$\begin{array}{llllllllllllllllllllllllllllllllllll}0 & 0 & 0 & 1 & 0 & 1 & 0 & 0 & 0 & 1 & 2 & 1 & \square & 0 & 1 & 0 & 1 & 1 & 0 & \square & \square & 1 & 1 & 0 & 1 & 1 & \text { ? } & \text { ? }\end{array}$

Lychnophora ericoides

$\begin{array}{llllllllllllllllllllllllllllll}0 & 0 & 0 & 0 & 0 & 0 & 0 & 0 & 0 & 1 & 0 & 0 & 0 & 0 & 0 & 0 & 0 & \square & 2 & 0 & 1 & 1 & 1 & 0 & 0 & 1 & 0 & 0 & 1\end{array}$

$\begin{array}{llllllllllllllllllllllllllllll}0 & 0 & 0 & 1 & 0 & 1 & 0 & 0 & 0 & 1 & 2 & 1 & \square & 0 & 1 & 0 & 0 & 1 & 0 & \square & \square & 1 & 1 & 0 & 1 & 1 & 1 & 1 & 1\end{array}$

Lychnophora passerina

$\begin{array}{llllllllllllllllllllllllllllll}0 & 0 & 2 & 0 & 0 & 0 & 0 & 0 & 0 & 1 & 0 & 0 & 0 & 0 & 0 & 0 & 0 & \square & 2 & 0 & 1 & 1 & 2 & 1 & 0 & 1 & 0 & 0 & 1\end{array}$ $\begin{array}{lllllllllllllllllllllllllllll}1 & 0 & 0 & 1 & 0 & 1 & 0 & 1 & 0 & 1 & 2 & 1 & \square & 0 & 1 & 0 & 0 & 1 & 0 & \square & \square & 1 & 1 & 1 & 1 & 1 & 1 & 1 & 1\end{array}$

Lychnophora salicifolia

$\begin{array}{llllllllllllllllllllllllllllll}0 & 0 & 0 & 0 & 0 & 0 & 0 & 0 & 0 & 1 & 0 & 0 & 0 & 0 & 0 & 0 & 0 & \square & 2 & 0 & 1 & 1 & 1 & 0 & 0 & 1 & 0 & 0 & 1\end{array}$

$\begin{array}{llllllllllllllllllllllllllllll}0 & 0 & 0 & 1 & 0 & 1 & 0 & 1 & 0 & 1 & 2 & 1 & \square & 0 & 1 & 0 & \mathrm{a} & 1 & 0 & \square & \square & 1 & 1 & 1 & 1 & 1 & 1 & 1 & 1\end{array}$

Lychnophoriopsis candelabrum

$\begin{array}{lllllllllllllllllllllllllllll}0 & 0 & 0 & 0 & 0 & 0 & 1 & 0 & 0 & 1 & 0 & 1 & 0 & 0 & 0 & 0 & 0 & \square & 1 & 1 & 1 & 1 & 1 & 0 & 0 & 0 & 1 & 0 & 1\end{array}$

$\begin{array}{lllllllllllllllllllllllllllll}2 & 0 & 0 & 1 & 0 & 1 & 0 & 0 & 0 & 1 & 2 & 1 & \square & 0 & 1 & 0 & 0 & 1 & 0 & \square & \square & 1 & 1 & 1 & 1 & 1 & 1 & 1 & 1\end{array}$

Minasia alpestris

$\begin{array}{lllllllllllllllllllllllllllll}1 & 1 & 0 & 0 & 0 & 1 & 0 & 1 & 0 & 0 & 0 & 0 & 0 & 0 & 0 & 0 & 1 & 1 & 1 & 1 & 1 & 1 & 1 & 0 & 0 & 0 & 2 & 0 & 1\end{array}$

$\begin{array}{lllllllllllllllllllllllllllll}0 & 0 & 0 & 1 & 1 & 1 & 0 & 0 & 0 & 1 & 2 & 1 & \square & 0 & 1 & 0 & 1 & 1 & 1 & 0 & 1 & 1 & 0 & 0 & 0 & 0 & 1 & 1 & 1\end{array}$

Orthopappus angustifolius

$\begin{array}{llllllllllllllllllllllllllllll}1 & 1 & 0 & 1 & 0 & 0 & 1 & 0 & 0 & 0 & 0 & 0 & 0 & 0 & 0 & 0 & 0 & \square & 2 & 0 & 1 & 1 & 2 & 1 & 0 & 1 & 0 & 0 & 1\end{array}$

$\begin{array}{lllllllllllllllllllllllllllll}0 & 0 & 0 & 1 & 0 & 0 & 0 & 1 & 0 & 1 & 1 & 1 & \square & 1 & 1 & 0 & 1 & 1 & 1 & 0 & 1 & \mathrm{~b} & 0 & 0 & 0 & 0 & 0 & 1 & 0\end{array}$

Paralychnophora glaziouana sp. ined.

$\begin{array}{llllllllllllllllllllllllllllll}0 & 0 & 0 & 0 & 0 & 1 & 0 & 0 & 0 & 1 & 0 & 0 & 0 & 0 & 0 & 1 & 1 & \square & 2 & 0 & 0 & 1 & 2 & 0 & 1 & 1 & 2 & 0 & 1\end{array}$

$\begin{array}{lllllllllllllllllllllllllllllllll}0 & 0 & 0 & 1 & 0 & 1 & 0 & 1 & 0 & 1 & 2 & 1 & \square & 0 & 1 & 0 & 0 & 1 & 1 & 0 & 1 & 1 & 1 & 0 & 1 & 0 & \text { ? } & \text { ? }\end{array}$

Piptocarpha oblonga

$\begin{array}{llllllllllllllllllllllllllllll}0 & 0 & 0 & 0 & 0 & 0 & 0 & 0 & 0 & 0 & 1 & 0 & 0 & 0 & 0 & 0 & 1 & 1 & 1 & 0 & 0 & 1 & 1 & 1 & 1 & 3 & 0 & 0 & 0\end{array}$ $\begin{array}{lllllllllllllllllllllllllllll}1 & 0 & 0 & 1 & 1 & 1 & 0 & 2 & 0 & 1 & 2 & 1 & \square & 1 & 1 & 0 & 0 & 1 & 1 & 0 & 2 & 1 & 0 & 0 & 0 & 0 & 0 & 0 & \square\end{array}$

Piptocarpha rotundifolia

$\begin{array}{llllllllllllllllllllllllllllll}0 & 0 & 0 & 0 & 0 & 0 & 0 & 0 & 0 & 0 & 1 & 0 & 0 & 0 & 0 & 0 & 1 & 1 & 1 & 0 & 0 & 1 & \text { a } & 0 & 1 & 3 & 0 & 0 & 0\end{array}$

$\begin{array}{lllllllllllllllllllllllllllllllll}2 & 0 & 0 & 1 & 1 & 1 & 0 & 2 & 0 & 1 & 2 & 1 & \square & 1 & 1 & 0 & 0 & 1 & 1 & 0 & 2 & 1 & 0 & 0 & 0 & 0 & \text { ? } & \text { ? }\end{array}$

Piptolepis ericoides

$\begin{array}{lllllllllllllllllllllllllllllll}0 & 0 & 2 & 0 & 0 & 2 & 0 & 0 & 0 & 1 & 0 & 0 & 0 & 0 & 0 & 1 & 0 & 0 & 0 & 1 & 1 & 1 & 2 & 1 & 1 & 1 & 2 & 0 & 1\end{array}$ $\begin{array}{llllllllllllllllllllllllllllllll}0 & 0 & 0 & 1 & 0 & 1 & 0 & 1 & 0 & 1 & 2 & 1 & \square & 0 & 1 & 0 & 0 & 1 & 0 & \square & \square & 1 & 1 & 0 & 0 & 0 & 0 & 1 & 1\end{array}$ 
Character numbers as listed in the Appendix 2

$\begin{array}{lllllllllllllllllllllllllllll}1 & 2 & 3 & 4 & 5 & 6 & 7 & 8 & 9 & 1 & 1 & 1 & 1 & 1 & 1 & 1 & 1 & 1 & 1 & 2 & 2 & 2 & 2 & 2 & 2 & 2 & 2 & 2 & 2\end{array}$

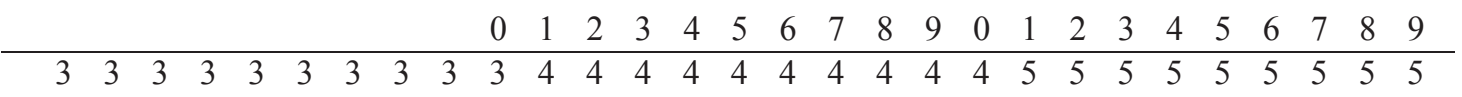

$\begin{array}{lllllllllllllllllllllllllllll}0 & 1 & 2 & 3 & 4 & 5 & 6 & 7 & 8 & 9 & 0 & 1 & 2 & 3 & 4 & 5 & 6 & 7 & 8 & 9 & 0 & 1 & 2 & 3 & 4 & 5 & 6 & 7 & 8\end{array}$

Pithecoseris pacourinoides

$\begin{array}{lllllllllllllllllllllllllllll}1 & \mathrm{a} & 0 & 1 & 1 & 0 & 0 & 1 & 0 & 0 & 0 & 0 & 0 & 0 & 0 & 0 & 0 & \square & 2 & 0 & 0 & 1 & \mathrm{~b} & 0 & 0 & 1 & 0 & 0 & \mathrm{a}\end{array}$

$\begin{array}{lllllllllllllllllllllllllllllll}0 & 0 & 0 & 1 & 0 & 0 & 0 & 2 & 0 & 2 & 1 & 1 & 1 & 0 & 2 & 0 & \text { a } & 1 & 1 & 0 & 1 & 1 & 1 & 0 & \text { ? } & 0 & \text { ? } & \text { ? }\end{array}$ ?

Prestelia eriopus

$\begin{array}{lllllllllllllllllllllllllllll}1 & 1 & 0 & 0 & 0 & 1 & 1 & 0 & 0 & 1 & 0 & 0 & 0 & 1 & 1 & 0 & 1 & 0 & 2 & 0 & 1 & 1 & 2 & 1 & 0 & 1 & 1 & 0 & 1\end{array}$

$\begin{array}{lllllllllllllllllllllllllllll}0 & 0 & 0 & 1 & 0 & 1 & 0 & 1 & 0 & 1 & 2 & 1 & \square & 0 & 1 & 0 & 1 & 1 & 0 & \square & \square & 2 & 0 & 0 & 0 & 0 & 0 & 1 & 1\end{array}$

Proteopsis argentea

$\begin{array}{llllllllllllllllllllllllllllll}1 & 1 & 0 & 0 & 0 & 1 & 1 & 0 & 0 & 0 & 0 & 0 & 0 & 0 & 0 & 0 & 1 & 1 & 1 & 7 & 1 & 0 & 1 & 0 & 0 & 0 & 2 & 0 & 1\end{array}$

$\begin{array}{lllllllllllllllllllllllllllllll}0 & 0 & 0 & 1 & 0 & 1 & 0 & 1 & 0 & 1 & 2 & 1 & \square & 0 & 1 & 0 & \text { a } & 1 & 1 & 0 & 0 & 0 & 1 & 0 & ? & 1 & 0 & 1 & 1\end{array}$

Rolandra fruticosa

$\begin{array}{lllllllllllllllllllllllllllll}0 & 0 & 0 & \mathrm{a} & 0 & 0 & 1 & 0 & 0 & 0 & 0 & 1 & 0 & 0 & 0 & 0 & 1 & \square & 2 & 0 & 1 & 1 & 2 & 0 & 0 & 1 & 0 & 0 & 0\end{array}$

$\begin{array}{lllllllllllllllllllllllllllll}0 & 0 & 1 & 1 & 0 & 1 & 0 & 1 & 1 & 2 & 0 & 0 & 1 & 0 & 1 & 0 & 0 & 2 & 0 & \square & \square & 0 & 0 & 1 & 1 & ? & 0 & 1 & 0\end{array}$

Sipolisia lanuginosa

$\begin{array}{lllllllllllllllllllllllllllll}0 & 0 & 0 & 1 & 0 & 1 & 0 & 0 & 0 & 1 & 1 & 0 & 1 & 0 & 0 & 0 & 1 & 0 & 1 & 3 & 1 & 1 & 1 & 1 & 0 & 1 & 2 & 0 & 1\end{array}$

$\begin{array}{llllllllllllllllllllllllllllllllllll}0 & 1 & 0 & \text { ? } & \text { ? } & \text { ? } & \text { ? } & \text { ? } & 0 & 1 & 2 & 1 & \square & 0 & 1 & 1 & 0 & 1 & 0 & \square & \square & 1 & 1 & 0 & 1 & 1 & \text { ? } & \text { ? } & \text { ? }\end{array}$

Soaresia velutina

$\begin{array}{lllllllllllllllllllllllllllll}1 & 0 & 1 & 1 & 0 & 0 & 1 & 0 & 0 & 0 & 0 & 0 & 0 & 0 & 0 & 0 & 0 & \square & 2 & 0 & 1 & 1 & 2 & 0 & 0 & 1 & 0 & 0 & \mathrm{a}\end{array}$

$\begin{array}{lllllllllllllllllllllllllllllllll}0 & 0 & 0 & 1 & 0 & 0 & 0 & 2 & 0 & 2 & 1 & 1 & 1 & 0 & 1 & 0 & 1 & 2 & 0 & \square & \square & 0 & 0 & 0 & 1 & \text { ? } & \text { ? }\end{array}$

Stenocephalum megapotamicum

$\begin{array}{lllllllllllllllllllllllllllll}1 & 0 & 0 & 0 & 0 & 0 & 1 & 0 & 0 & 0 & 0 & 1 & 0 & 0 & 0 & 0 & 0 & 1 & 0 & 0 & 1 & 1 & 1 & 0 & 0 & 1 & 0 & 0 & 1\end{array}$

$\begin{array}{llllllllllllllllllllllllllllll}0 & 0 & 0 & 1 & 0 & 0 & 0 & 0 & 0 & 2 & 1 & 1 & 1 & 1 & 1 & 0 & 1 & 1 & 1 & 1 & 1 & 1 & 0 & 0 & 0 & 0 & \text { ? } & \text { ? }\end{array}$ ?

Stokesia laevis

$\begin{array}{lllllllllllllllllllllllllllll}1 & 1 & 0 & \mathrm{a} & 0 & 1 & 1 & 0 & 0 & 0 & 0 & 0 & 0 & 0 & 0 & 0 & 0 & 0 & 0 & 5 & 1 & 0 & 2 & 1 & 0 & ? & ? & 0 & \mathrm{a}\end{array}$

$\begin{array}{lllllllllllllllllllllllllllll}0 & 0 & 1 & 1 & 0 & 0 & 0 & 0 & 0 & 2 & 1 & 1 & 0 & 0 & 1 & 0 & 0 & 2 & 0 & \square & \square & 0 & 1 & 0 & 1 & ? & 1 & 1 & 0\end{array}$

Stramentopappus poolae

$\begin{array}{lllllllllllllllllllllllllllll}0 & 0 & 0 & 1 & 0 & 0 & 1 & 0 & 0 & 0 & 0 & 0 & 0 & 0 & 0 & 0 & 0 & 0 & 0 & 9 & 1 & 0 & 0 & 1 & 0 & 2 & 1 & 0 & 1\end{array}$

$\begin{array}{lllllllllllllllllllllllllllll}0 & 0 & 0 & 1 & 0 & 1 & 0 & 1 & 0 & 1 & 2 & 1 & \square & 0 & 1 & 0 & 0 & 2 & 1 & 0 & 0 & 2 & 1 & 0 & 0 & 0 & 0 & 1 & 0\end{array}$

Strobocalyx arborea

$\begin{array}{lllllllllllllllllllllllllllllll}0 & 0 & 0 & 0 & 0 & 0 & 1 & 0 & 0 & 0 & 0 & 0 & 0 & 0 & 0 & 0 & 0 & 3 & 0 & 0 & 0 & 0 & 2 & 1 & 1 & 1 & 0 & 0 & 0\end{array}$

$\begin{array}{llllllllllllllllllllllllllllll}0 & 0 & 0 & 1 & 0 & 1 & 0 & 0 & 0 & 1 & 2 & 1 & \square & 1 & 1 & 0 & 1 & 2 & 1 & 0 & 1 & 1 & 0 & 0 & 0 & 0 & 1 & 0 & \square\end{array}$

Strophopappus glomeratus

$\begin{array}{lllllllllllllllllllllllllllll}0 & 0 & 0 & 0 & 0 & 0 & 1 & 0 & 0 & 0 & 0 & 1 & 0 & 0 & 0 & 0 & 0 & 3 & 1 & 1 & 1 & 1 & 2 & 1 & 0 & 1 & 2 & 0 & 1\end{array}$

$\begin{array}{llllllllllllllllllllllllllllllll}2 & 0 & 0 & 1 & 0 & 1 & 0 & 0 & 0 & 2 & 1 & 1 & 1 & 1 & 1 & 0 & 1 & 1 & 0 & \square & \square & 2 & 0 & 1 & 1 & 1 & 0 & 1 & 0\end{array}$

Strophopappus speciosus

$\begin{array}{lllllllllllllllllllllllllllll}0 & 0 & 0 & 0 & 0 & 0 & 1 & 0 & 0 & 0 & 0 & 1 & 0 & 0 & 0 & 0 & 0 & 3 & 1 & 0 & 0 & 1 & 2 & 1 & 0 & 1 & 2 & 0 & 1\end{array}$ $\begin{array}{llllllllllllllllllllllllllllllllll}2 & 0 & 0 & 1 & 0 & 1 & 0 & 0 & 0 & 2 & 1 & 1 & 0 & 1 & 1 & 0 & 1 & 1 & 0 & \square & \square & 2 & 0 & 0 & 1 & 1 & \text { ? ? }\end{array}$

Tarlmounia elliptica $\begin{array}{lllllllllllllllllllllllllllll}0 & 0 & 0 & 0 & 0 & 0 & 0 & 1 & 0 & 0 & 0 & 0 & 0 & 0 & 0 & 0 & 0 & 3 & 0 & 0 & 0 & 0 & 1 & 0 & 1 & 2 & 1 & 0 & \mathrm{a}\end{array}$ $\begin{array}{lllllllllllllllllllllllllllllllllll}0 & 0 & 0 & 1 & 0 & 1 & 0 & 1 & 0 & 1 & 2 & 1 & \square & 1 & 1 & 0 & 1 & 2 & 1 & 0 & 1 & 0 & 0 & 0 & ? & 0 & \text { ? } & \text { ? }\end{array}$

Vernonia echioides

$\begin{array}{lllllllllllllllllllllllllllll}1 & 1 & 0 & 1 & 0 & 0 & 1 & 0 & 0 & 0 & 0 & 0 & 0 & 0 & 0 & 0 & 0 & 2 & 0 & 3 & 1 & 0 & 2 & 1 & 0 & 1 & 1 & 0 & 1\end{array}$ $\begin{array}{lllllllllllllllllllllllllllll}0 & 0 & 0 & 1 & 0 & 1 & 1 & 1 & \text { ? } & \text { ? } & \text { ? } & \text { ? } & \text { ? } & 1 & 1 & 0 & 1 & 1 & 1 & 1 & 2 & 1 & 0 & 0 & 0 & 0 & \text { ? } & \text { ? }\end{array}$

Vernonia fasciculata $\begin{array}{lllllllllllllllllllllllllllll}1 & 0 & 0 & 1 & 0 & 0 & 1 & 0 & 0 & 0 & 0 & 0 & 0 & 0 & 0 & 0 & 0 & 2 & 0 & 1 & 1 & 0 & 1 & 0 & 0 & 1 & 1 & 0 & 1\end{array}$ $\begin{array}{lllllllllllllllllllllllllllll}0 & 0 & 0 & 1 & 0 & 1 & 1 & 0 & 0 & 1 & 2 & 1 & \square & 1 & 1 & 0 & 1 & 1 & 1 & 1 & 2 & 1 & 0 & 0 & 0 & 0 & 0 & 1 & 0\end{array}$

Vernonia noveboracensis

$\begin{array}{lllllllllllllllllllllllllllll}1 & 0 & 0 & 1 & 0 & 0 & 1 & 0 & 1 & 0 & 0 & 0 & 0 & 0 & 0 & 0 & 0 & 2 & 0 & 4 & 0 & 0 & 1 & 0 & 0 & 1 & 1 & 0 & 1\end{array}$ $\begin{array}{lllllllllllllllllllllllllllll}0 & 0 & 0 & 1 & 0 & 1 & 1 & 0 & 0 & 1 & 2 & 1 & \square & 1 & 1 & 0 & 1 & 1 & 1 & 1 & 2 & 1 & 0 & 0 & 0 & 0 & 0 & 1 & 0\end{array}$

Vernonanthura ferruginea $\begin{array}{lllllllllllllllllllllllllllll}0 & 0 & 0 & 1 & 0 & 0 & 1 & 0 & 1 & 0 & 0 & 0 & 0 & 0 & 0 & 0 & 0 & 2 & 0 & 2 & 1 & 1 & 1 & 1 & 0 & 1 & 1 & 0 & \mathrm{a}\end{array}$ $\begin{array}{lllllllllllllllllllllllllllll}0 & 1 & 1 & 1 & 0 & 1 & 0 & 0 & 0 & 1 & 2 & 1 & \square & 1 & 1 & 0 & 1 & 1 & 1 & 1 & 2 & 1 & 0 & 0 & 0 & 0 & \text { ? } & \text { ? }\end{array}$

Vernonanthura lucida $\begin{array}{lllllllllllllllllllllllllllllll}0 & 0 & 0 & 1 & 0 & 0 & 0 & 0 & 1 & 0 & 0 & 0 & 0 & 0 & 0 & 0 & 0 & 2 & 0 & 1 & 1 & 0 & 2 & 1 & 0 & 1 & 1 & 0 & 1\end{array}$ $\begin{array}{llllllllllllllllllllllllllllll}0 & 0 & 1 & 1 & 0 & 1 & 0 & 0 & 0 & 1 & 2 & 1 & \square & 1 & 1 & 0 & 1 & 1 & 1 & 1 & 2 & 1 & 1 & 0 & 0 & 0 & \text { ? } & \text { ? }\end{array}$ 
Character numbers as listed in the Appendix 2

$\begin{array}{lllllllllllllllllllllllllllll}1 & 2 & 3 & 4 & 5 & 6 & 7 & 8 & 9 & 1 & 1 & 1 & 1 & 1 & 1 & 1 & 1 & 1 & 1 & 2 & 2 & 2 & 2 & 2 & 2 & 2 & 2 & 2 & 2\end{array}$

\begin{tabular}{lllllllllllllllllllllllllllll} 
& & & & & & & & 0 & 1 & 2 & 3 & 4 & 5 & 6 & 7 & 8 & 9 & 0 & 1 & 2 & 3 & 4 & 5 & 6 & 7 & 8 & 9 \\
\hline 3 & 3 & 3 & 3 & 3 & 3 & 3 & 3 & 3 & 3 & 4 & 4 & 4 & 4 & 4 & 4 & 4 & 4 & 4 & 4 & 5 & 5 & 5 & 5 & 5 & 5 & 5 & 5 & 5
\end{tabular}

\begin{tabular}{lllllllllllllllllllllllllllllll}
0 & 1 & 2 & 3 & 4 & 5 & 6 & 7 & 8 & 9 & 0 & 1 & 2 & 3 & 4 & 5 & 6 & 7 & 8 & 9 & 0 & 1 & 2 & 3 & 4 & 5 & 6 & 7 & 8 \\
\hline
\end{tabular}

Vernonanthura mariana

$\begin{array}{lllllllllllllllllllllllllllll}0 & 0 & 0 & 0 & 0 & 0 & 1 & 0 & 1 & 0 & 0 & 0 & 0 & 0 & 0 & 0 & 0 & 2 & 0 & 1 & 1 & 1 & 2 & 1 & 0 & 1 & 1 & 0 & \mathrm{a}\end{array}$

$\begin{array}{lllllllllllllllllllllllllllll}0 & 0 & 1 & 1 & 0 & 1 & 0 & 0 & 0 & 1 & 2 & 1 & \square & 1 & 1 & 0 & 1 & 1 & 1 & 1 & 2 & 1 & 1 & 0 & 0 & 0 & 1 & 1 & 0\end{array}$

Xerxes ekmaniana

$\begin{array}{lllllllllllllllllllllllllllll}0 & 0 & 0 & 1 & 0 & 1 & 1 & 0 & 0 & 0 & 1 & 0 & 1 & 0 & 0 & 0 & 1 & 0 & a & 6 & 1 & 1 & 1 & 1 & 0 & 1 & 2 & 0 & 1\end{array}$

$\begin{array}{lllllllllllllllllllllllllllll}0 & 1 & 0 & 1 & 0 & 1 & 0 & 0 & 0 & 1 & 2 & 1 & \square & 0 & 1 & 1 & 0 & 1 & 0 & \square & \square & 1 & 1 & 0 & 1 & 1 & 0 & 1 & 1\end{array}$

Vinicia tomentosa

$\begin{array}{llllllllllllllllllllllllllllll}0 & 0 & 0 & 0 & 0 & 1 & 0 & 1 & 0 & 1 & 0 & 0 & 0 & 0 & 0 & 1 & 0 & 3 & 1 & 1 & 1 & 1 & 1 & 0 & 0 & 1 & 1 & 0 & 1\end{array}$

$\begin{array}{lllllllllllllllllllllllllllll}0 & 0 & 0 & 1 & 0 & 1 & 0 & 0 & 0 & 1 & 2 & 1 & \square & 0 & 1 & 0 & 1 & 1 & 0 & \square & \square & 1 & 1 & 0 & 1 & 0 & \text { ? } & \text { ? }\end{array}$ 
Fig. S1. Strict consensus tree of 354 equally most parsimonious trees based on the ITS analysis. Tree length $=2030$ steps, $C I=0.41, \mathrm{RI}=0.77$. Jackknife values $(\geq 50 \%)$ are shown above the nodes. 


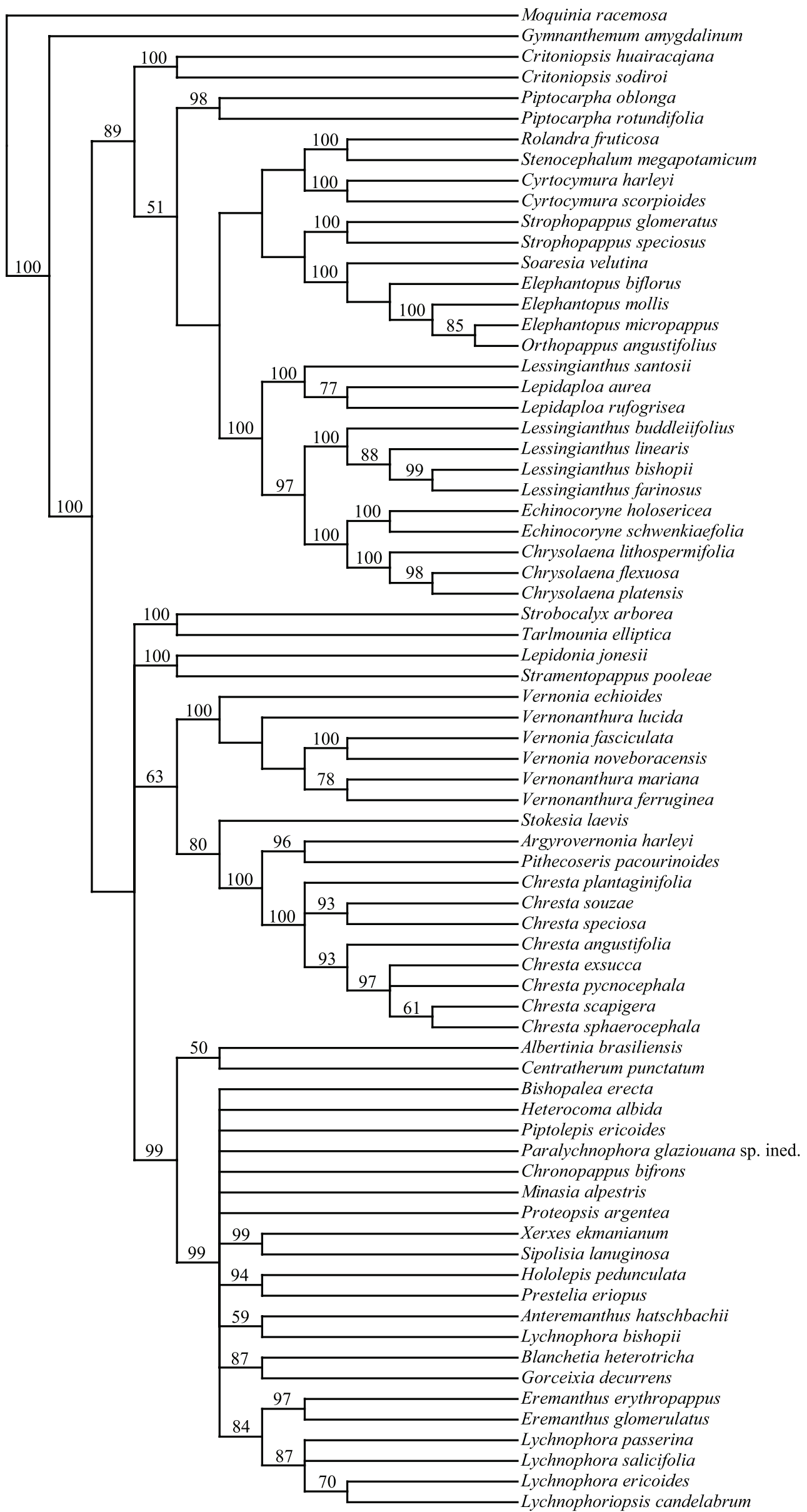


Fig. S2. Strict consensus tree of 785 equally most parsimonious trees based on the chloroplast ( $n d h \mathrm{~F}$ and $r p l 32-t r n \mathrm{~L}$ ) analysis. Tree length $=490$ steps, $\mathrm{CI}=0.60, \mathrm{RI}=0.85$. Jackknife values $(\geq 50 \%)$ are shown above the nodes. 


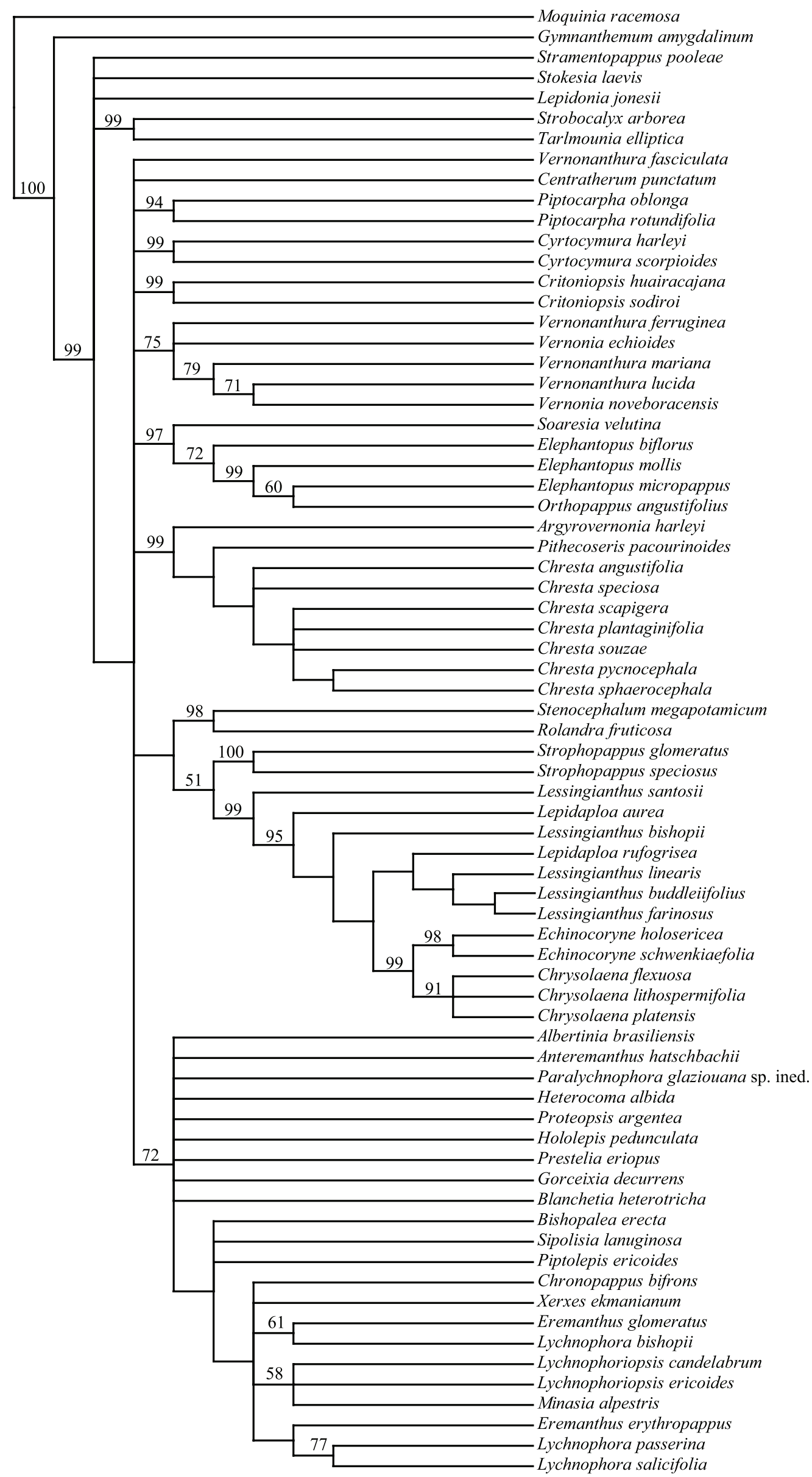


Fig. S3. Bayesian inference phylogram based on the combined analysis (all molecular data). Bayesian posterior probabilities $(\geq 0.9)$ are shown above the nodes. 


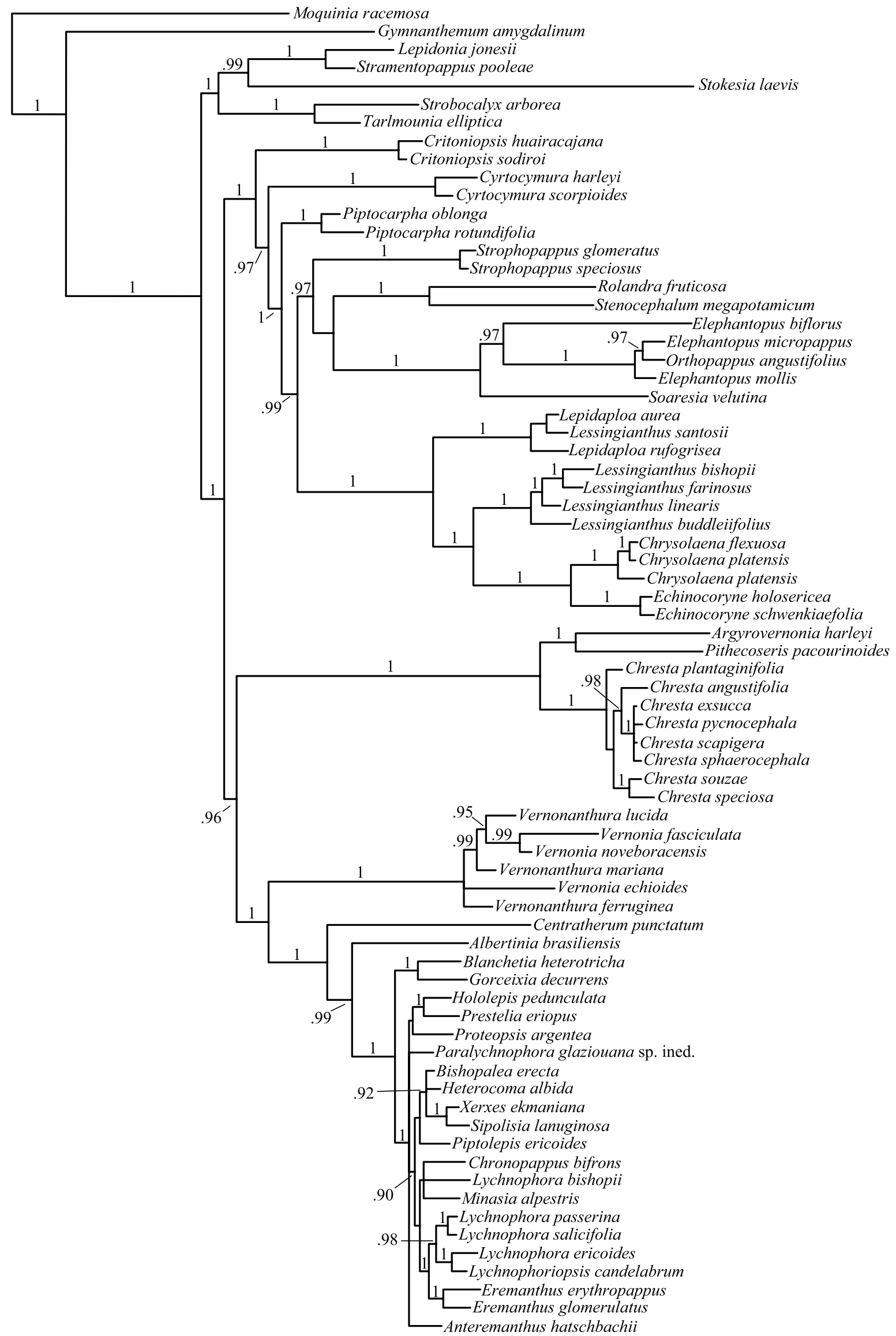


Fig. S4. Bayesian inference phylogram based on the combined analysis with morphology and all molecular data. Bayesian posterior probabilities $(\geq 0.9)$ are shown above the nodes. 


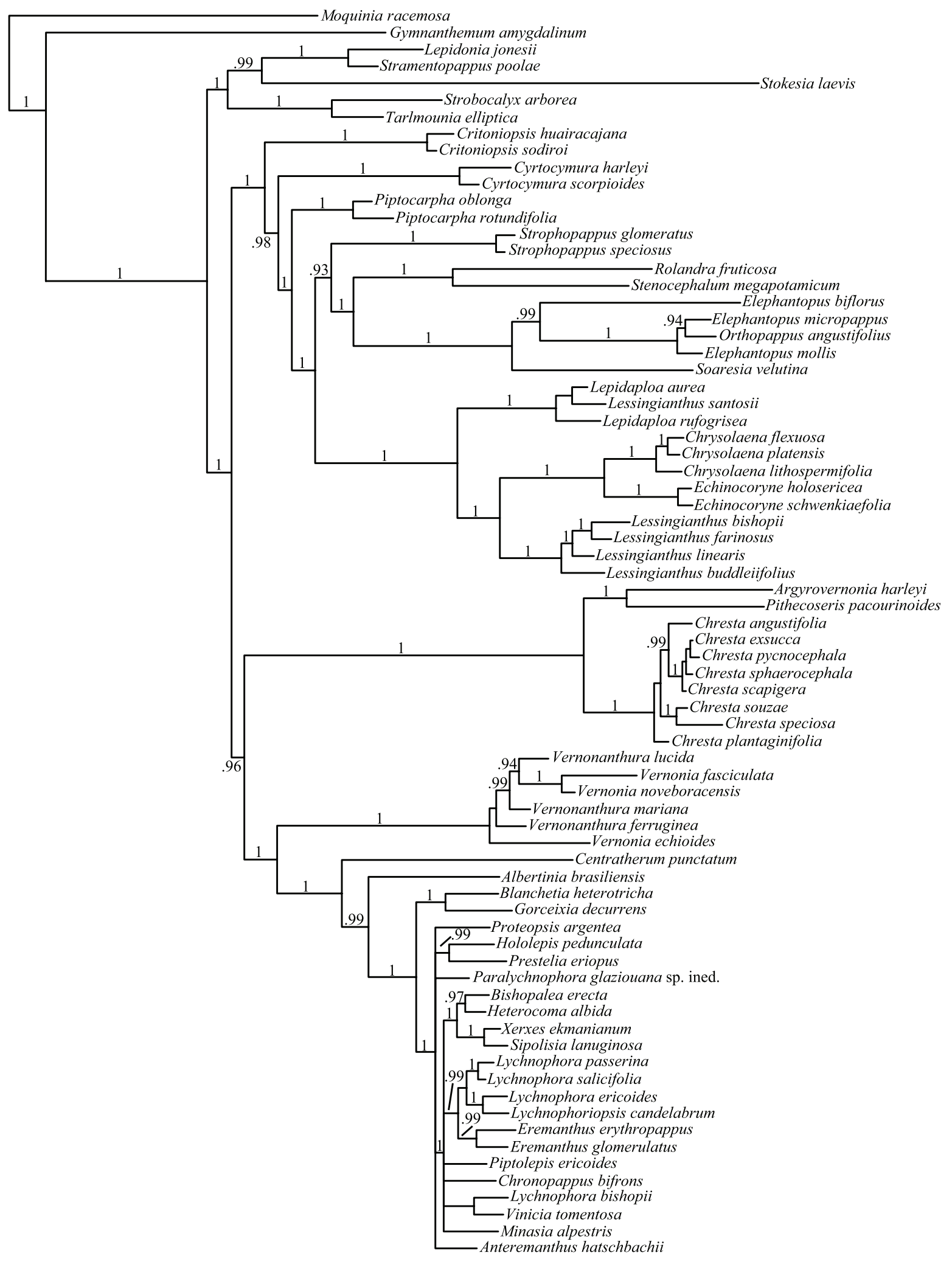





\section{CHAPTER 2}

A Phylogenetic Analysis of Lychnophorinae (Asteraceae: Vernonieae) based on molecular and morphological data 

A Phylogenetic analysis of Lychnophorinae (Asteraceae: Vernonieae) based on molecular and morphological data

Benoît Loeuille ${ }^{1,3}$, João Semir², Lúcia G. Lohmann", and José R. Pirani ${ }^{1}$

${ }^{1}$ Laboratório de Sistemática Vegetal, Departamento de Botânica, Instituto de Biociências da Universidade de São Paulo, Rua do Matão, 277, CEP: 05508-090, São Paulo, SP, Brazil.

${ }^{2}$ Departamento de Botânica, Universidade Estadual de Campinas, C.P. 6109, 13083-970, Campinas, São Paulo, Brazil.

${ }^{3}$ Author for correspondence (benoit_loeuille@yahoo.fr) 

Abstract - The subtribe Lychnophorinae (Asteraceae: Vernonieae) comprises approximately 100 species in 18 genera distributed mostly in the cerrado domain of the Brazilian Central Plateau. A phylogenetic analysis based on four molecular regions (ETS, ITS, $n d h \mathrm{~F}, r p l 32-$ $\operatorname{trn} \mathrm{L}$ ) and a morphological dataset was performed in order to delimit monophyletic genera in Lychnophorinae, to confirm or refute the generic assignment of several Lychnophorinae species, and to achieve a better understanding of the relationships between the genera of the subtribe. The richest genus of the subtribe, Lychnophora, with 32 described species, emerged as polyphyletic, involving three main lineages not closely related. Most clades obtained are associated with some existing generic concept and can be defined by a simple combination of morphological characters. Albertinia, Blanchetia and Gorceixia are the most basal lineages whereas Eremanthus and Lychnophora stricto sensu emerged as the most derived clade, which contains half of the species of the subtribe. However, relationships between the remaining clades persist partially unresolved. Some incongruence between the nuclear and chloroplast phylogenies provided additional evidence for the occurrence of two putative intergeneric hybrids in the wild, involving species from Eremanthus, Paralychnophora and Piptolepis.

Keywords-Compositae, ETS, ITS, classification, intergeneric hybrid, $n d h \mathrm{~F}, r p l 32-t r n \mathrm{~L}$. 

The Cerrado Domain, one of the biodiversity hotspots recognized by Myers et al. (2000), is a savanna covering ca. 2 million $\mathrm{km}^{2}$ of the Central Brazilian Plateau, extending west into Bolivia, south to Paraguay, and east to the Caatinga Domain (Daly and Mitchell 2000, Prance 1996, Fiaschi and Pirani 2009). The highest levels of endemism and diversity in the Cerrado are found in the campos rupestres (Joly 1970, Giulietti and Pirani 1988, Harley 1995, Rapini et al. 2002). These formations occur on areas above 900-1000 $\mathrm{m}$ along the mountains of the Espinhaço Range (Minas Gerais and Bahia states) and the Chapada dos Veadeiros (Goiás state), covered by a low, mostly herbaceous or shrubby vegetation on sandy or rocky soils (Giulietti and Pirani 1988, Prance 1994, Harley 1995, Simon and Proença 2000, Silva and Bates 2002, Fiaschi and Pirani 2009). In the campos rupestres there is conspicuous convergent evolution of the habit, leaf shape, and pubescence between sclerophyllous evergreen small trees, shrubs and subshrubs from several families (Asteraceae, Ericaceae, Lamiaceae, Melastomataceae, Velloziaceae etc.) (Coile and Jones 1981, Hind 1993).

These adaptations to a seasonally dry environment subject to periodic fires have given to the cerrado endemic genus Lychnophora (Asteraceae, Vernonieae) a remarkable appearance (Coile and Jones 1981) (Fig. 1H). This was the first genus published by Martius (1822) upon his return from Brazil (Coile and Jones 1981). Genera related to Lychnophora also occurring in the Brazilian cerrado were later described: Eremanthus (Lessing 1829), Chronopappus, Haplostephium (Candolle 1836), Lychnophoriopsis, Piptolepis, Prestelia and Vanillosmopsis (Schultz-Bipontinus 1861, 1863, 1864). Bentham (1873) placed most of them in the subtribe Lychnophorinae, defined principally by the aggregation of capitula (syncephalia). This definition was mostly ignored after the work of Hoffmann (1890), with the inclusion of genera with separate capitula by Robinson et al. (1980) in the subtribe and the exclusion of unrelated syncephalous genera (Elephantopus, Rolandra, Spiracantha and Telmatophila). Robinson $(1992,1999,2007)$ refined further the concept of the subtribe excluding the herbaceous members into a new subtribe Chrestinae and describing new genera (Anteremanthus and Minasia).

Recent phylogenetic analyses based on molecular and morphological data (Loeuille et al. in prep., see Chapter 1) provided an amplified concept of the subtribe Lychnophorinae, with the transfer of several genera (Albertinia, Blanchetia, Centratherum and Gorceixia) and the subtribe Sipolisiinae to an expanded Lychnophorinae. The Lychnophorinae as defined by Loeuille et al. (in prep.) is monophyletic and supported by the presence of heliangolide in the aerial parts as a synapomorphy. Additionally, most members of Lychnophorinae are woody plants and have apical anthers appendages with conspicuous wall thickenings (except Centratherum), style without basal node (except Albertinia) and sublophate pollen. This combination of characters defining Lychnophorinae is highly similar to the one proposed by Robinson (1992). Also, the following characters are commonly found in the group and rarely outside of it: 3- to 5-armed trichomes, leaf sheath, syncephaly, paleaceous and deciduous to caducous pappus.

In this new circumscription, the subtribe Lychnophorinae comprises 18 genera (ca. $100 \mathrm{spp}$.) 
nearly restricted to the Cerrado Domain and especially to the campos rupestres. The elevated proportion of monotypic genera (42\%) in the subtribe reflects how poorly understood are the relationships between the members of the group. In addition, the generic limits of Eremanthus and Lychnophora are controversial: Haplostephium (Coile and Jones 1983, Semir 1991), Lychnophoriopsis (Robinson 1992, Semir 1991) and Paralychnophora (MacLeish 1984a, Semir 1991, Robinson 1997, Hind 2000a) have been variously recognized at the generic level. Several species of Lychnophorinae have also an uncertain generic position (in Eremanthus, Lychnophora or Piptolepis) (Coile and Jones 1981, Hind 1993). Some authors have placed several Lychnophorinae in Vernonia s.1. (MacLeish 1984b, Hind 1995, Hind 2003), whereas Robinson (1999) considered most of them as good members of the subtribe. As a consequence, Coile and Jones (1981) recognized 11 species of Lychnophora whereas Semir (1991) acknowledged 41 species (not including in these 41 the 27 unpublished new species). Hind (2000) noted that "intensive field work and cpDNA analysis would possibly resolve the generic limits to everyone's satisfaction".

Fiaschi and Pirani (2009) cited the genera Eremanthus and Lychnophora (among others) as good candidates for phylogenetic studies evaluating whether or not most of the endemic flora of the Cerrado is the result of recent radiations. Nonetheless, it is elementary to answer first: what is Lychnophora? What is Eremanthus ? By conducting phylogenetic analyses based on molecular (ETS, ITS, rpl32-trnL and $n d h \mathrm{~F}$ ) and morphological data, we endeavoured to answer these questions with three main objectives: (1) to delimit monophyletic genera in Lychnophorinae, (2) to confirm or refute the generic assignment of several Lychnophorinae species, and (3) to achieve a better understanding of the relationships between the genera of the subtribe.

\section{Materials AND Methods}

Outgroup choice and taxon sampling-Piptocarpha oblonga (Gardner) Baker (subtribe Piptocarphinae) and Pithecoseris pacourinoides Mart. ex DC. were used as outgroups based on a previous phylogenetic study of American Vernonieae (Chapter 1).

Seventy-nine species from 17 genera out of the 18 genera (ca. 100 spp.) of Lychnophorinae (as defined in Chapter 1) were sampled. The sampling for morphological data comprised one more species than the molecular dataset: Vinicia tomentosa Dematt. a monotypic genus only known from the type collection (efforts to extract DNA from this material were unsuccessful).

Morphological data-Examination of herbarium specimens and field observations provided 61 qualitative characters and one quantitative character (florets number per capitulum), which are listed in Appendix 2, and compiled on a morphological matrix (Supplemental Appendix 1). The quantitative character has been coded using the gap weighting method of Thiele (1993) in ten states. Garcia-Cruz and Sosa (2006) have shown that this method performs better in recovering phylogenetic signal than others proposed methods for coding quantitative character. Detailed explanations of the character sampling and coding is provided in Loeuille and Pirani (in prep.) (see Chapter 3). 
DNA extraction, amplification and sequencing - Total genomic DNA was extracted from silica-gel-dried leaves collected in the field using the commercial kit Invisorb ${ }^{\circledR}$ Spin Plant Mini Kit (Invitek, Berlin Germany), following the manufacturer's instructions. DNA were extracted from herbarium material for two species, using the QIAamp ${ }^{\circledR}$ DNA stool Mini Kit (Qiagen Inc., Hilden, Germany) with a modified protocol.

Primers ITS4 (White et al. 1990) and ITS5A (Downie and Katz-Downie 1996) based on White et al.'s (1990) fungal primer ITS5 and corrected at two positions for angiosperms were used to amplify and sequence the ITS region. Primers ETS1f and 18S-2L (Linder et al. 2000) were used to amplify the ETS region. Primers 1603 and +607 used to amplify and sequence the 3 ' end of the $n d h \mathrm{~F}$ region were designed by Jansen (1992) and those used for rpl32-trn L (trnLretF and rpl32retR) by Timme et al. (2007).

PCR amplifications were carried out in $25-\mu$ L reactions with $2.5 \mu \mathrm{L} 10 \times$ PCR reaction Buffer A (Promega, Madison, WI, U.S.A.), $0.5 \mu \mathrm{L}$ of $10 \mu \mathrm{M}$ dNTPs (Promega) in an equimolar ratio, $2.5 \mu \mathrm{L}$ of $25-\mathrm{mM}$ magnesium chloride, $0.5 \mu \mathrm{L}$ of $10 \mathrm{mg} / \mathrm{ml}$ Bovine Serum Albumine (New England BioLabs Inc., Beverly, M.A., U.S.A.), $1 \mu$ L of D.M.S.O. (Sigma, St. Louis, M.O., U.S.A.) (only for ITS), $1 \mu \mathrm{L}$ of a $10 \mu \mathrm{M}$ concentration of the forward primer, $1 \mu \mathrm{L}$ of a $10 \mu \mathrm{M}$ concentration of the reverse primer, $0.1 \mu \mathrm{L}$ of Taq DNA polymerase enzyme $(5 \mathrm{U} / \mu \mathrm{L}$ from Promega), $14.9 \mu \mathrm{L}$ of sterile water and $1 \mu \mathrm{L}$ of template DNA. The PCR program for ITS region consisted of $2 \mathrm{~min}$ initial denaturation at $95^{\circ} \mathrm{C}$, and 29 cycles of 1 min denaturation at $95^{\circ} \mathrm{C}$, $1 \mathrm{~min}$ annealing at $54^{\circ} \mathrm{C}, 2 \mathrm{~min}$ extension at $72^{\circ} \mathrm{C}$, followed by a final extension of $7 \mathrm{~min}$ at $72^{\circ} \mathrm{C}$. The PCR program for ETS was $5 \mathrm{~min}$ at $95^{\circ} \mathrm{C}$ and 34 cycles of $45 \mathrm{sec}$ at $94^{\circ} \mathrm{C}, 45 \mathrm{sec}$ at $50^{\circ} \mathrm{C}, 40 \mathrm{sec}$ at $72^{\circ} \mathrm{C}$ followed by $10 \mathrm{~min}$ at $72^{\circ} \mathrm{C}$. The PCR program for $3^{\prime}$ end $n d h \mathrm{~F}$ was $3 \mathrm{~min}$ at $93^{\circ} \mathrm{C}, 1 \mathrm{~min}$ at $46^{\circ} \mathrm{C}, 1 \mathrm{~min} 20 \mathrm{~s}$ at $72^{\circ} \mathrm{C}$ and 29 cycles of $1 \min 95^{\circ} \mathrm{C}, 1 \min 50^{\circ} \mathrm{C}, 1$ $\min 20 \mathrm{sec}(+3 \mathrm{sec} / \mathrm{cycle}) 72^{\circ} \mathrm{C}$, followed by $7 \mathrm{~min}$ at $72^{\circ} \mathrm{C}$. And the PCR program for $\mathrm{rpl} / 32-$ $\operatorname{trn} \mathrm{L}$ consisted of $5 \mathrm{~min}$ at $80^{\circ} \mathrm{C}$ and 29 cycles of $1 \mathrm{~min}$ at $95^{\circ} \mathrm{C}, 1 \mathrm{~min}$ at $56^{\circ} \mathrm{C}, 4 \mathrm{~min}$ at $65^{\circ} \mathrm{C}$, followed by $10 \mathrm{~min}$ at $65^{\circ} \mathrm{C}$. The PCRs were performed on thermal cycler (DNA Engine ${ }^{\circledR}$; BioRad, Hercules, CA, U.S.A.).

In some cases, to obtain readable ITS and ETS sequences, the PCR products were cloned using the Promega pGEM-T Easy Vector System II cloning kit, following the manufacturer's instructions and using half reactions. When possible, eight positive colonies were screened via PCR using M13 universal primers under the following conditions: $5 \mathrm{~min}$ at $94^{\circ} \mathrm{C}$ followed by 29 cycles of $94^{\circ} \mathrm{C}$ for $45 \mathrm{~s}, 53^{\circ} \mathrm{C}$ for $1 \mathrm{~min}$ and $72^{\circ} \mathrm{C}$ for $1 \mathrm{~min} 30 \mathrm{~s}$, ending with $72^{\circ} \mathrm{C}$ for 7 min. Five to eight PCR products were selected for sequencing in both directions using the same primers. After checking that all cloned sequences formed a clade, one of the sequences was chosen for the phylogenetic analyses.

The PCR products were purified using the QIAquick PCR Purification Kit (Qiagen Inc.). Direct sequencing of the amplified DNA segments was performed as a service of Macrogen, Inc. (Seoul, South Korea) with the same primers used for PCR amplification. Sequences from both strands of each PCR product were examined, compared, and corrected using Sequencher 
v. 4.1.4. (Gene Codes Corp., Ann Arbor, Michigan). Sequences are available in GenBank (accessions numbers provided in the Appendix 1).

The analyses used 259 new sequences (59 ITS, $82 \mathrm{ETS}, 59 n d h \mathrm{~F}, 59 \operatorname{rpl32}$-trnL) together with 69 sequences from published EMBL/GenBank accessions as documented in Keeley et al. (2007) and in Chapter 1.

Alignments - Alignments of the sequences were made in MAFFT v. 6.611b (Katoh and Toh 2008) using the default setting and Fast Fourier Transform algorithm, followed by manual gap adjustments in BioEdit v. 5.0.6 (Hall 1999). Indels were coded as binary characters using simple indel coding (SIC; Simmons and Ochoterena 2000) as implemented in the program SeqState (Müller 2005, 2006).

Parsimony analyses - Parsimony uninformative characters were excluded from the analyses. Heuristic searches were conducted using NONA (Goloboff 1999) spawned by Winclada (Nixon 1999-2002). Tree-bisection-reconnection (TBR) swapping on Wagner trees were conducted from 10,000 random addition sequences with 20 trees held in each replicate initiations expanding the memory to $1,000,000$ to do further TBR. A strict consensus tree was constructed. To increase the likelihood of exploring all possible tree-islands, an additional search strategy was applied: the parsimony ratchet procedure (Nixon 1999). Ten independent ratchet searches with 400 iterations each were performed, the results were combined and a strict consensus tree constructed after applying the commands "hard collapse unsupported nodes in all trees" and "keep best only". The two strict consensus trees obtained were then compared. Datasets were analyzed separately and combined using simultaneous analysis approach (Nixon and Carpenter 1996). The morphological dataset has been analized by Loeuille and Pirani (in prep., see Chapter 3 ) and its analysis was not repeated here. Branch support was assessed by Jackknife support (JK) (Farris et al. 1996), which is preferable to bootstrap because of its closer relationship to original data (Freudenstein and Davis 2010) and clearer, less ambiguous meaning (Siddall 2002). It was calculated with NONA spawned by Winclada with 1000 replications with 100 search replications and 10 trees held in memory. Jackknife values are described as high (95$100 \%)$, moderate $(85-94 \%)$ and low $(\leq 84 \%)$.

Bayesian analysis-Bayesian inference of phylogeny with posterior probabilities (PP) was conducted with MrBayes v. 3.1.2 (Huelsenbeck and Ronquist 2001; Ronquist and Huelsenbeck 2003) for the two combined analyses (all molecular data and morphology + all molecular data). The models of molecular evolution were selected using the Akaike Information Criterion (AIC) as implemented in jModelTest v. 0.1.1 (Guindon and Gascuel 2003, Posada 2008). The chosen models were HKY + G for ITS, $r p l 32-t r n \mathrm{~L}$ and GTR $+\mathrm{G}$ for ETS, $n d h \mathrm{~F}$. The standard discrete model was used for the coded gaps and morphological data. Searches used default settings for all parameters. Four simultaneous independent runs initiated from random start trees were run for 10 million generations, sampling from the posterior distribution of trees every 1000 generations (for a total of 10,000 samples). Several strategies were employed to confirm that chains have achieved stationarity and the appropriate burn-in for each analysis was determined: 
(1) we plotted overall - $\ln L$, (2) we examined the standard deviation of split frequencies, (3) we examined the potential scale reduction factor (PSRF), and (4) we checked graphically the convergence of the MCMC by monitoring the cumulative posterior split probabilities and among-run variability of split frequencies using the online tool AWTY (Wilgenbusch et al. 2004). A total of $25 \%$ of the samples were discarded as burn-in. Posterior probability support (PP) was estimated to be significant for nodes with $\mathrm{PP} \geq 0.90$.

Congruence of datasets-Congruence among datasets was tested with the Incongruence Length Difference (ILD) test (Farris et al. 1995). However a high false positive rate has been reported (Cunningham 1997, Darlu and Lecointre 2002, Hipp et al. 2004). As pointed out by Pelser et al. (2010), alternative methods for testing incongruence may suffer from errors as well (Cunningham 1997, Hipp et al. 2004). Therefore, in addition to the ILD test, incongruent patterns supported were assessed by high JK or PP values. The incongruence test value was calculated by performing with NONA using Winclada. One thousand replications were executed with 10 searches per replication holding 10 trees for each search and holding a total of 100 trees. Uninformative characters were removed from the analyses before running the ILD test (Cunningham 1997, Lee 2001). Following Nixon and Carpenter (1996), we did not conduct the tests to decide whether datasets should be combined or not, but to detect sources of conflict between the datasets.

\section{Results}

DNA sequences and alignments-Table 1 lists the characteristics of each data matrix used in the phylogenetic analysis.

Phylogenetic analyses - The results of the nuclear (ETS + ITS) parsimony analysis are given in Table 1 and in Fig. 2. The individual analyses of ETS and ITS gave similar strict consensus trees (data not shown). The result of the ILD test indicates that the two nuclear datasets are statistically incongruent ( $p=0.0099$ ), but no incongruent patterns with high support (JK) were found. Albertinia as sister to the rest of Lychnophorinae was found with high support (JK = $100 \%$ ). At the next level, a first split was retrieved between a clade (without support) composed of Eremanthus crotonoides, Hololepis, Lychnophoriopsis damazioi, Prestelia and a subclade of species of Lychnophora, the latter three forming a highly supported group (JK $=100 \%)$. The remainder of Lychnophorinae emerged as a clade $(\mathrm{JK}=100 \%)$, but the relationships within it are unresolved. The genera Minasia and Proteopsis are monophyletic with a high support (JK $=100 \%)$, another clade with high support $(\mathrm{JK}=100 \%)$ comprised Bishopalea, Heterocoma, Sipolisia and Xerxes. Paralychnophora did not appear as monophyletic due to the position of P. glaziouana in a polytomy. Better resolved are the relationships between a first clade of Lychnophora species sister to (Piptolepis ((Lychnophora), (Eremanthus))), the latter clade has a moderate support $(\mathrm{JK}=87 \%)$ and a high support for the ((Eremanthus) (Lychnophora) $)$ subclade. Eremanthus is not monophyletic due to the positions of three species, which appeared not to be closely related to the bulk of the genus. Lychnophora is polyphyletic, with its species 
distributed on three main lineages not closely related, plus a number of isolated species.

The results of the chloroplast parsimony analysis are shown in Table 1 and in the Supplemental Figure 1. Due to the low number of variable characters, the regions were not analyzed separately. The topology of the strict consensus tree is highly unresolved and only Albertinia as sister of the remainder of Lychnophorinae was found with high support $(\mathrm{JK}=100 \%)$. Nonetheless, most of the clades are compatible with the nuclear topology. The incongruent clades concern the two suspected intergeneric hybrids included in the analysis (Fig. 2): Eremanthus sp. $\times$ Paralychnophora reflexoauriculata and Piptolepis ericoides $\times$ Eremanthus erythropappus. These two taxa were removed from the further combined analysis. Two other taxa had an incongruent position: Minasia alpestris and Lychnophora mellobarretoi, which emerged in a clade with other derived Lychnophora species $(\mathrm{JK}=82 \%)$. In the nuclear strict consensus tree, L. mellobarretoi is related to an early divergent group of Lychnophora species and M. alpestris to the other Minasia species. In the absence of other data suggesting a possible relationship with the derived Lychnophora clade, these two taxa were maintained in the further analyses; especially since the ILD test performed between the nuclear and chloroplast datasets gave the same result (incongruent at $p=0.002$ ) with or without L. mellobarretoi and M. alpestris.

The combined analysis of molecular data (ETS, ITS, $n d h \mathrm{~F}$ and $r p l 32-t r n \mathrm{~L}$ ) (Table 1, Fig. 3) provided a more resolved topology than the nuclear and chloroplast individual analyses. The topologies of the parsimony (Fig. 3) and of the Bayesian (Supplemental Figure 2) analyses are highly similar, the few differences concerning clades which received neither JK nor PP support. All the clades found in the nuclear analysis were found again and for some of them with higher support. At the base of the tree, the topology (Albertinia ((Blanchetia, Gorceixia) (rest of Lychnophorinae)) ) received high support for each node $(\mathrm{JK}=100$ or 99\%; PP = 1). In most cases a high JK support value was associated to a high PP support value. An exception is the clade (Eremanthus crotonoides ((Hololepis) (clade A))), which had a high support in the Bayesian analysis $(\mathrm{PP}=1)$ and hardly any $\mathrm{JK}$ support $(\mathrm{JK} \leq 50 \%)$.

Results of the ILD test indicate that the molecular and morphological datasets are statistically incongruent ( $p=0.002$ ), but no incongruent patterns with high support (JK) were found (see Chap 3). The simultaneous parsimony analysis resulted in a higher number of equally most parsimonious trees (Table 1) but the topology of the strict consensus tree is nearly identical. The genus Paralychnophora is monophyletic $(\mathrm{JK}=81 \%$; $\mathrm{PP}=0.98)$ in the simultaneous analysis. Four morphological and one phytochemical synapomorphies were found: the syncephalium of tertiary order for the Lychnophora subclade of the clade A, the tailed anther base for the Minasia clade, swollen T-shaped trichomes for the clade (Vinicia + Minasia), paleae on the receptacle for the clade (Bishopalea erecta + Heterocoma albida $+H$. gracilis sp. ined.) and the presence of phytomelanin in the cypsela wall for the Heterocoma clade. The Bayesian topology (Supplemental Figure 3) differs in some minor points such as the position of Eremanthus crotonoides as sister to the clade A ( $\mathrm{PP}=0.98)$ whereas the parsimony analysis depicts it as sister to the remainder of Lychnophorinae (minus Albertinia, Blanchetia and Gorceixia) 
(although not supported by JK).

\section{DisCUSSION}

Our analyses recovered a number of well-supported clades, which correspond mostly to existing generic concepts. The relationships between the basal lineages remain in great part unresolved, whereas the relationships among the most derived lineages are now better understood. The supposed polyphyly of Lychnophora (Hind 2000a) is here confirmed because its species currently recognized in the genus emerged in three main lineages not closely related each other. Formal nomenclatural changes regarding these findings will be proposed elsewhere (Loeuille et al. in prep.; Chapters 4 and 5). The following discussion refers to clades on Fig. 4.

Clade $\boldsymbol{A}$-In a basal position, this clade comprises one of the three Lychnophora lineages associated with Lychnophoriopsis damazioi and Prestelia. More distantly related are Hololepis and Eremanthus crotonoides (Fig. 4). That lineage of Lychnophora species was recognized as a separate genus (Lychnocephalus) by Candolle (1836) (based on Martius herbarium annotations) or as an infrageneric category (Lychnocephaliopsis) of Lychnophora: either a subgenus by Schultz-Bipontinus (1863) or as a section by Baker (1873). A synapomorphy of this clade is the presence of a syncephalium of tertiary order. The species of this clade share numerous characters: amplexicaul leaf sheath, unbranched trichome, unswollen 3- to 5-armed trichome, spurred trichome (except L. humillima), secondary involucre, obtuse phyllary apex (except L. joliana) and a paleaceous caducous twisted pappus (Fig. 1B). They are also these species restricted to the campos rupestres of the Espinhaço Range of mountains in Minas Gerais. This subclade has for sister-group Prestelia and Lychnophoriopsis damazioi.

Prestelia is a caulirosulate genus (sensu Cuatrecasas and Robinson in press.) with pedunculate syncephalium (Fig. 1A) and Lychnophoriopsis damazioi a poorly branched treelet with pad-like leaf sheath and pedunculate capitula on a terminal inflorescence. The latter species had been originally described in Lychnophora (Beauverd 1913), then transferred to Vernonia (Leitão Filho and Semir 1979) and was finally placed in Lychnophoriopsis by Robinson (1992) (see below). Prestelia and L. damazioi share the following combination of characters: revolute leaves and a persistent pappus. In addition, both genera are mostly restricted to the Serra do Cipó (in the southern portion of the Espinhaço Range of mountains of Minas Gerais). However, numerous characters set apart Prestelia and L. damazioi such as the habit and the inflorescence type. The small genus Hololepis (2 spp.) emerged in a basal position of the clade A. In sharp contrast to the previous genera it does not have leaf sheath nor 3- to 5-armed trichomes, and displays a solitary capitulum with secondary involucre composed of trinervate bracts (a character unique in the subtribe).

Paralychnophora-This genus has been variously treated as a synonym of Eremanthus (Robinson 1997, 1999, 2007) or Lychnophora (Semir 1991), but also as a separate genus (MacLeish 1984a, Hind 2000a). Robinson(1997) and Hind(2000a)noticed that Paralychnophora could be distinguished from Eremanthus and Lychnophora by the presence of often large 
axillary syncephalium on peduncle. Our results indicate that the genus is monophyletic and distantly related to both Eremanthus and Lychnophora. It can be characterized by the following combination of characters: semi-amplexicaul leaf sheath, 3- to 5-armed trichomes, axillary pedunculate syncephalium, prismatic glabrous cypselae (except Paralychnophora atkinsiae) with a biseriate pappus ( $P$. atkinsiae rarely displays pappus with three series) (Figures 1D and 5D). Lychnophora markgravii is the sister-group of Paralychnophora but there is no JK or PP support for this relationship. This species shares with the latter the presence of semi-amplexicaul leaf sheath, 3- to 5-armed trichomes, axillary inflorescence and a biseriate pappus. However, $L$. markgravii does not show syncephalia and displays crenate leaves with T-shaped trichomes and a paleaceous pappus, characters not found in Paralychnophora.

Minasia-This is a monophyletic genus having tailed anther base for synapomorphy. The seven species of Minasia occur in the campos rupestres of the Espinhaço Range of mountains (Minas Gerais State), they are caulirosula plants, with T-shaped swollen trichomes, axillary scapose inflorescences, prismatic cypselae, developed carpopodium, biseriate setose pappus with inner setae having enlarged apices (Fig. 1E).

Clade B-This group is sister to the clade (Piptolepis, (Lychnophora, Eremanthus)). It comprises a number of Lychnophora species and Eremanthus leucodendron characterized by the presence of pad-like leaf sheath, syncephalia (except E. leucodendron), glabrous corolla lobes and anther appendage constricted at the base (Fig. 1F). The species of this clade are all restricted to the campos rupestres of the Chapada Diamantina, the northern sector of the Espinhaço range of mountains, in the Bahia State. A similar group has been identified by Hind (2000b) defining it as small dome-headed 'ericoid' profusely branched trees; the delimitation of the group is here slightly different by including Eremanthus leucodendron and excluding Lychnophora granmogolensis (placed in our analyses in Lychnophora s.s). The clade B has a lower support in the simultaneous (Fig. 4) than in the combined molecular analysis (Fig. 3), a fact that may be due to the quite distinctive morphology of E. leucodendron, which also shares several characteristics of Piptolepis except for the caducous phyllaries weakly imbricate. Nonetheless, we believe that this clade would deserve a generic status.

Piptolepis-The genus is monophyletic and appeared closely related to Eremanthus pabstii. The latter shares with Piptolepis a combination of characters: pad-like leaf sheath (rarely a semi-amplexicaul leaf sheath), 3- to 5-armed swollen trichomes, caducous phyllaries weakly imbricate, anther appendage not constricted at the base and outer pappus seta with a enlarged base (Figures 1G and 5A). Eremanthus pabstii differs in particular from Piptolepis for bearing syncephalia and for being endemic to Serra dos Cristais (Goiás State), whereas species recognized as Piptolepis lack syncephalia and are restricted to the Espinhaço Range of mountains (Minas Gerais State). Despite these contrasts, we consider E. pabstii as a member of Piptolepis, since the development of syncephalia seems to have occurred several times in the history of Vernonieae lineages, and because many other genera are known with a disjunct distribution on serras of Goiás and Minas Gerais (see Giulietti and Pirani 1988). 
Core Lychnophorinae and Lychnophora-Lychnophora and Eremanthus comprise nearly half of the species of the subtribe Lychnophorinae. They form a well-supported clade, named here Core Lychnophorinae. Plants included in this clade are characteristically treelets, trees or rarely shrubs, whose leaves lack a sheath, terminal inflorescence which usually is a second order syncephalium, and cypselae with inconspicuous carpopodia. Most of the generic delimitation controversies concerned Lychnophora, despite two taxonomic revisions in the last decades (Coile and Jones 1981, Semir 1991). As pointed out before, our results show that Lychnophora, as hitherto circumscribed, is polyphyletic: most species are found in three distantly related main lineages (Fig. 4) while other emerged as isolated branches (L. markgravii, L. mellosilvae and L. syncephala).

Haplostephium (represented here by L. granmogolensis, L. passerina and L. ramosissima) has been considered as a separate genus by Candolle (1836), Schultz-Bipontinus (1863), Baker (1873), Duarte (1974) and Coile and Jones (1983) based on the residual outer pappus. Nevertheless, this character also occurs in L. pinaster, and several authors (Hind 2000a, b, Robinson 1999, 2007, Semir 1991) considered Haplostephium as a synonym of Lychnophora. Such a proposition is supported by our analyses, where species formerly placed in Haplostephium do not appear closely related but scattered in this clade, amongst the other Lychnophora species and in the Clade B.

Lychnophoriopsis has been established by Schultz-Bipontinus (1863) for a Lychnophoralike specimen that he described as having dimorphic cypselae. Semir (1991) and Robinson (1992) pointed out that this characteristic has never been confirmed in any other specimen. However the two authors took different decisions: Semir (1991) considered Lychnophoriopsis as a synonym of Lychnophora, whereas Robinson (1992) set apart Lychnophoriopsis from Lychnophora by its larger and more discrete capitula bearing more florets, born on longer inflorescences not forming a syncephalium. This new concept made him transfer L. damazioi to Lychnophoriopsis. Our phylogenetic analyses show that this latter species is closely related to Prestelia (on Clade A) and that the two other species of Lychnophoriopsis are nested within the Lychnophora clade (Fig. 4).

As circumscribed here, Lychnophora becomes monophyletic with a strong support. These are treelets or more rarely shrubs, with revolute leaves and no leaf sheath, 3- to 5-armed trichomes, terminal syncephalium (except for L. candelabrum and L. hatschbachii) and with glabrous prismatic cypselae, biseriate pappus with a paleaceous twisted caducous inner serie (Fig. 1H).

Eremanthus - Generic delimitation of Eremanthus has been controversial as well. Revisionary studies by MacLeish (1984a, 1984b, 1987) clarified the limits of Eremanthus. She transferred to Vernonia eight species previously described in Eremanthus or Vanillosmopsis. Five of these species were included in our analyses (the remainder species are from Peru and Africa and are unlikely related to Lychnophorinae). Eremanthus pabstii and E. leucodendron have been discussed above (see the Clade B and the Piptolepis topic). Even though they were treated as Vernonia by MacLeish (1984b), Eremanthus mollis and E. veadeiroensis here appeared nested 
within the Eremanthus clade. Exclusion of the first species from Eremanthus was based on a supposed herbaceous habit, presence of cauline leaves with stellate trichomes. However, the species is clearly woody and bears the same 3- to 5-armed swollen trichomes as most species of Eremanthus do. Eremanthus veadeiroensis was excluded from Eremanthus due to its pubescent stems, larger number of florets (8-11) and loose inflorescence. Only the number of florets per capitulum is not found in the other species of this clade but E. brevifolius has up to seven florets per capitulum. Finally, Vanillosmopsis syncephala was excluded and synonymized with Vernonia crispa (MacLeish 1984b). Semir (1991) placed both taxa in Lychnophora, the first species as a synonym of $L$. reticulata, the second as a distinct species. Additional taxonomic studies on this species complex are necessary but preliminary results (see Chapter 5) suggest the existence of three species: L. crispa, L. syncephala and L. reticulata. The latter species was not included in our analysis. Lychnophora crispa emerged in the Lychnophora clade; this taxon shares with Lychnophora the revolute leaves, glabrous prismatic cypselae and twisted pappus. L. syncephala appeared nested within Eremanthus, sharing with other species in the clade a cymose pedunculate inflorescence composed of syncephalia lacking reduced leaves between the capitula (in contrast to most Lychnophora species), as well as a glabrous turbinate cypsela which is common in Eremanthus.

Formerly, Vanillosmopsis included species with glabrous cypselae and caducous setose pappus while species syncephalia, pubescent cypselae and persistent paleaceous pappus were placed in Eremanthus (Schultz-Bipontinus 1861, 1863, Bentham 1873, Baker 1873). MacLeish (1987) synonymized Vanillosmopsis with Eremanthus based on the presence of syncephalia in some species of Vanillosmopsis ( $V$. erythropappa and $V$. polycephala) as well as a number of species exhibiting characteristics intermediate to both genera (E. elaeagnus and E. incanus). In our analyses Vanillosmopsis emerged as a subclade in the Eremanthus clade, but recognizing it at the generic level would make Eremanthus s.s. paraphyletic. Therefore, there are strong reasons to follow MacLeish's (1987) proposal, and here we adopt Eremanthus including Vanillosmopsis.

The monophyly of Eremanthus is strongly supported and the genus is characterized by the following combination of characters: trees or treelets (rarely shrubs) bearing sheathless leaves with flat margins, 3- to 5-armed swollen trichomes (very rarely absent), terminal cymose pedunculate inflorescence, turbinate (rarely cylindrical) cypselae with multiseriate usually straight pappus (rarely two series) (Figures 1I and 5AF).

Monotypic genera - Of the 21 genera recognized in the subtribe (based on phylogenetic analyses (Loeuille et al. in prep.; Chapter 1)), 11 are monotypic. Recent intensive fieldwork provided new species for the previously monotypic genera Prestelia and Proteopsis. Our results partially helped to achieve a better understanding of the relationships among these genera and the rest of the Lychnophorinae. Blanchetia and Gorceixia are closely related (Fig. 4) and formed a clade sister to the remainder of Lychnophorinae (minus Albertinia). Both genera have serrate to dentate leaves, stellate trichomes with squared cell stalk and uniseriate pappus (reduced to 
a crown in Gorceixia), but Gorceixia is a small tree with syncephalia (Hind et al. 2006) and Blanchetia a small shrub with a condensed panicle of capitula.

The Heterocoma clade (Fig. 4) comprises four monotypic genera (Bishopalea, Heterocoma, Sipolisia and Xerxes), all sharing as morphological synapomorphy the presence of phytomelanin in the cypsela wall. A detailed morphological analysis (Loeuille et al. in prep; Chapter 4) has shown that there are no relevant morphological characters reliable to clearly support Heterocoma, Bishopalea, Sipolisia and Xerxes at the generic level, and thus, the three latter shall be treated as synonyms of Heterocoma (Fig. 1C).

Three other monotypic genera were included in the present analysis (Anteremanthus, Chronopappus and Vinicia). In the simultaneous analysis, Anteremanthus formed a clade with Lychnophora mellosilvae but without support and few or any morphological characters are shared by both taxa. Noteworthy is the fact that both taxa are restricted to the campos rupestres in northern Minas Gerais State. Robinson (1992) noted some similarities between Anteremanthus and Paralychnophora glaziouana (cited as Eremanthus bicolor): the discolorous petiolate leaves and the inflorescence bracts, but our analyses did not suggest any close relationship between Anteremanthus and Paralychnophora. Chronopappus emerged as an isolated lineage in a part of the tree where the nodes received low or any support. The strongly muricate leaves of Chronopappus are unique in the subtribe. Semir (1991) proposed a close relationship with Lychnophora markgravii based particularly on the axillary inflorescence and pilose corolla lobes. This relationship was not found in any of our analyses. When Dematteis (2007) described Vinicia, he implied a close similarity of the new genus with Chronopappus and Lychnophora based on pappus characteristics (biseriate pappus with outer series paleaceous). Vinicia does not seem to be closely related to these genera, instead it emerged as the sister-group of Minasia (but without support). This clade has for synapomorphy the presence of swollen T-shaped trichomes. Minasia is one of the caulirosulate genera of the subtribe and Vinicia has been described as a subshrub (based on the only existing collection). The position of the inflorescence also separates Minasia (axillary) from Vinicia (terminal). Nonetheless, the lack of resolution with good support prevents us to propose a clearer picture of the relationships between these three genera and the rest of the Lychnophorinae, especially with Heterocoma, Minasia, Paralychnophora, Proteopsis, and two taxa previously placed in Lychnophora: L. markgravii and L. mellosilvae.

Putative intergeneric hybrids-Interspecific hybridization have been suspected in Lychnophora (Coile and Jones 1981, Hind 1995) and Eremanthus (MacLeish 1987) mainly based on field observations. The use of multiple markers with different modes of inheritance (i.e., nuclear and organelle) may detect cytonuclear discordance as evidence of hybridization (Seehausen 2004). Therefore, the two putative intergeneric hybrids Piptolepis ericoides $\times$ Eremanthus erythropappus and Eremanthus sp. $\times$ Paralychnophora reflexoauriculata were included in our phylogenetic analyses (Fig. 2) in order to provide additional evidence of their hybrid status.

Piptolepis ericoides $\times$ Eremanthus erythropappus occurs at the same locality than the two 
suspected parentals (in Serra do Cipó, Minas Gerais State). The plant displays the pad-like leaf sheath also found in Piptolepis and absent in Eremanthus, whereas the capitula are not solitary like in $P$. ericoides and do not form a syncephalium like in E. erythropappus. The involucre is obconic and the phyllaries are imbricate and persistent like in the latter cited species (not the typical campanulate with subimbricate caducous phyllaries of Piptolepis) (Fig. 5A, B and C). In the phylogenetic analysis based on nuclear regions this hybrid emerged at the base of the Piptolepis clade (Fig. 2); on the other hand, in the plastidial analysis, it is placed within a clade with E. erythropappus (Fig. 2 and Supplemental Figure 1). Consequently our analyses confirmed the intergeneric hybrid status of that plant. Very few individuals of this hybrid are known in the Serra do Cipó and in each case a few individuals were found with any evidence of fertility of the F1 or introgression. Only the chromosome number of Eremanthus erythropappus is known $(x=17$; Salles de Melo et al. 2010), so we cannot be certain whether this is a homoploid or an allopolyploid hybrid.

The putative hybrid Eremanthus sp. $\times$ Paralychnophora reflexoauriculata was found growing close to P. reflexoauriculata but no individuals of Eremanthus were encountered at the same area (Fig. 5D, E and F). Nonetheless there are several reports of Eremanthus capitatus in the same region (Jacobina, Bahia State). The hybrid shares more characteristics with Eremanthus (absence of leaf sheath, cymose inflorescence and multiseriate pappus) than with Paralychnophora, but displays the typical prismatic glabrous cypselae of the latter. A peculiar feature of this plant is the syncephalium with various degrees of fusion of capitula, ranging from complete fusion to slightly connate at the base (Fig. 5E), uncommon in the whole subtribe where the degree of fusion is relatively fixed within a species. Typical Paralychnophora reflexo-auriculata bears syncephalia with capitula fused at its entire length, while the capitula of Eremanthus capitatus do not form a syncephalium and are only slightly connate at the base. The hybrid is placed close to $P$. reflexoauriculata in the plastidial tree (Fig. 2 and Supplemental Figure 1) and formed a clade with E. capitatus and E. arboreus in the nuclear tree (the latter species is endemic of Ceará State). Hence the molecular results seem to confirm the hybrid status of that plant and indicate as a possible parental species the only species of Eremanthus occuring in the region of Jacobina. Chromosome number is known for only one putative parental species: $x=19$ for P. reflexoauriculata (Salles de Melo et al. 2010) (a previous count by Jones (1982) indicated $x$ $=18$ ). The two chromosome numbers so far reported to Eremanthus are $x=15$ and $x=17$.

It is clear that the dearth of cytological studies (chromosome counts being available for only 29 of 103 Lychnophorinae species (28.2\%)) precludes us to draw conclusions on the importance of these intergeneric hybrids regarding the evolutive history of the Lychnophorinae. However intergeneric hybrid in the wild is considered as a rare phenomenon (Stace 1975, 1986, McKenzie et al. 2004) and only a few cases of intergeneric hybridization naturally occurring in Asteraceae have been documented (McKenzie et al. 2004, Saito et al. 2006, Shilling et al. 2008). Furthermore, the fact that in the chloroplast analysis Minasia alpestris and Lychnophora mellobarretoi emerged in a clade of derived Lychnophora species (Fig. 2 and Supplemental 
Figure 1) constitutes two other incongruences with the nuclear analysis that might suggest some past hybridization in Lychnophorinae. But incongruent phylogenetic patterns can have causes other than the hybrid origin of the species involved, such as incomplete lineage sorting, homoplasy and taxonomic error (Wendel and Doyle 1998, Avise 2000, Andreasen and Baldwin 2003). Further studies are necessary to provide evidence in favor of one of these causes.

Concluding remarks - Our study of the phylogeny of Lychnophorinae provides the foundation for a new generic classification in the subtribe based on monophyletic genera. Nonetheless, the relationships between these genera, a number of monotypic genera and some taxa previously placed in Eremanthus or Lychnophora remained unresolved due to a lack of resolution. The putative intergeneric hybrids and some other incrongruences between nuclear and chloroplast phylogenies may indicate that past hybridization occurred during the evolutionary history of the Lychnophorinae. McDade (1995) defined "primary hybrids" ("with simple histories and little change since origination") as opposed to "derived hybrids" ("with considerable evolutionary change since origination") and pointed out that we can only expect to understand the behavior of primary hybrid characters. It is known that including hybrids in phylogenetic analyses may possibly cause long-branch attraction (McDade 1995), influence tree topology (loss of resolution), tree length (Kornet and Turner 1999), and support analysis (Simmons 2001). McDade (1990) and Soltis et al. (2008) concluded that the inclusion of hybrid species in a phylogenetic analysis must be employed with caution. In fact, hybridization results in a phylogenetic net, rather than a classic bifurcating tree (Soltis and Soltis 2009); consequently, network reconstruction methods combining as many independent gene trees as possible into a species tree permit to better infer hybrid relationships (Vriesendorp and Bakker 2005). Further studies are necessary to elucidate if the unresolved part of the Lychnophorinae phylogeny is linked or not with the inclusion of derived hybrids, i.e. whether some of the "problematic" monotypic genera and taxa have a hybrid origin. On the whole, we might not be able to depict the evolutionary history of the Lychnophorinae completely as a classic bifurcating tree.

\section{ACKNOWLEDGMENTS}

This work represents part of the Ph.D. thesis of B.L. Authors thank CNPq, FAPESP and the Cuatrecasas Fellowship Award of the Smithsonian Institution for financial support; IBAMA and IF-MG for collection permits; Silvana Ferreira, Vera Lucia Gomes Klein, Renato de MelloSilva, Jimi N. Nakajima, Alex Popovkin and Nádia Roque for assistance during field work and/ or providing silica-dried material and the directors or curators of the following herbaria for the loan of (or access to) their collections: ALCB, BHCB, ESA, GA, GH, HRB, HUEFS, HUFU, IBGE, MBM, MO, NY, RB, SP, SPF, TEX, UB, UFG, UEC, US. 


\section{Literature Cited}

Andreasen, K. and B. G. Baldwin. 2003. Nuclear ribosomal DNA sequence polymorphism and hybridization in checker mallows (Sidalcea, Malvaceae). Molecular Phylogenetics and Evolution 29: 563-581.

Avise, J. C. 2000. Phylogeography: the history and formation of the species. Harvard University Press. Cambridge, Massachusetts.

Baker, J. G. 1873. Compositae I. Vernoniaceae. Pp. 5-180 in Flora brasiliensis, 6(2), eds C. F. P. von Martius $\dagger$ and A. W. Eichler, Fried. Fleischer, Münich, Vienna, Leipzig.

Beauverd, G. 1913. Contribution à l'étude des Composées (suite VIII). Bulletin de la Société Botanique de Genève, séries II, 5: 239-244.

Bentham, G. 1873. Compositae. Pp. 163-533 in Genera plantarum, 2(1), eds G. Bentham and J. D. Hooker, Reeve \& Co., London and Williams and Norgate, London.

Candolle, A. P. de. 1836. Vernoniaceae. Pp. 9-103 in Prodromus Systematis Naturalis Regni Vegetabilis, ... v. 5, Ed. A. P. de Candolle, Treutel et Würtz, Paris. Masson, Paris.

Coile, N. C., and S. B. Jones Jr. 1981. Lychnophora (Compositae: Vernonieae), a genus endemic to the Brazilian Planalto. Brittonia 33: 528-542.

Coile, N. C., and S. B. Jones Jr. 1983. Haplostephium (Compositae: Vernonieae). Castanea 48: $232-236$.

Cunningham, C.W. 1997. Can three incongruence tests predict when data should be combined ? Molecular Biology and Evolution 14: 733-740.

Daly, D. C., and J. Mitchell. 2000. Lowland vegetation of tropical South America. Pp. 393-453 in: Imperfect balance: landscape transformations in the pre-Columbian Americas, Ed. D. Lentz. Columbia University Press. New York

Darlu, P. and G. Lecointre. 2002. When does the incongruence length difference test fail ? Molecular Biology and Evolution 19: 432-437.

Dematteis, M. 2007. Vinicia tomentosa, nuevo género y especie de Lychnophorinae (Vernonieae, Asteraceae) de Minas Gerais, Brasil. Bonplandia 16: 259-264.

Downie, S.R., and D. S. Katz-Downie. 1996. A molecular phylogeny of Apiaceae subfamily Apioideae: evidence from nuclear ribosomal DNA internal transcribed spacer sequences. American Journal of Botany 83: 234-251.

Duarte, A. P. 1974. Contribuição para o conhecimento de duas espécies do gênero Haplostephium. Revista Brasileira de Biologia 34: 653-663.

Farris, J. S., M. Källersjö, A. G. Kluge, and C. Bult. 1995. Testing significance of incongruence. Cladistics 10: 315-319.

Farris, J. S., V. A. Albert, M. Källersjö, D. Lipscomb \& A. G. Kluge. 1996. Parsimony jackknifing outperforms neighbor-joining. Cladistics 12: 99-124.

Fiaschi, P., and J. R. Pirani. 2009. Review of plant biogeographic studies in Brazil. Journal of Systematics and Evolution 47: 477-496.

Freudenstein, J. V. and J. I. Davis. 2010. Branch support via resampling: an empirical study. 
Cladistics 26: 643-656.

Garcia-Cruz, J., and V. Sosa. 2006. Coding quantitative character data for phylogenetic analysis: a comparison of five methods. Systematic Botany 31: 302-309.

Giulietti, A. M., and J. R. Pirani. 1988. Patterns of geographic distribution of some plant species from the Espinhaço Range, Minas Gerais and Bahia, Brazil. Pp. 39-69 in Proceedings of a workshop on neotropical distribution patterns, eds P. E. Vanzolini and W. R. Heyer. Academia Brasileira de Ciências. Rio de Janeiro.

Goloboff, P. 1999. NONA, version 2. Tucumán, Argentina: published by the author, http:// www.cladistics.com/aboutNona.htm.

Guindon, S. and O. Gascuel. 2003. A simple, fast, and accurate algorithm to estimate large phylogenies by maximum likelihood. Systematic Biology 52: 696-704.

Hall, T. A. 1999. BioEdit: a user-friendly biological sequence alignment editor and analysis program for Windows 95/98/NT. Nucleic Acids Symposium Series 41: 95-98.

Harley, R. M. 1995. Introdução. Pp. 43-78 in Flora of the Pico das Almas-Chapada Diamantina, Bahia, Brazil, ed. B. L. Stannard. Kew: Royal Botanic Gardens.

Hind, D. J. N. 1993. Notes on the Compositae of Bahia, Brazil: I. Kew Bulletin 48: 245-277.

Hind, D. J. N. 1995. Compositae. Pp. 175-278 in Flora of the Pico das Almas-Chapada Diamantina, Bahia, Brazil, ed. B. L. Stannard. Kew: Royal Botanic Gardens.

Hind, D. J. N. 2000a. Two new species of Paralychnophora (Compositae: Vernonieae) from Bahia. Kew Bulletin 55: 367-379.

Hind, D. J. N. 2000b. Anew species of Lychnophora (Compositae: Vernonieae: Lychnophorinae) from Bahia, Brazil. Kew Bulletin 55: 393-397.

Hind, D. J. N. 2003. Flora of Grão-Mogol, Minas Gerais: Compositae (Asteraceae). Boletim de Botânica da Universidade de São Paulo 21: 179-234.

Hind, D. J., A. M. Giulietti, and R. M. Harley. 2006. Gorceixia decurrens (Compositae: Vernonieae): new for Bahia State, Brazil. Sitientibus Série Ciências Biológicas 6: 129132.

Hipp, A. L., J. C. Hall, and K. J. Sytsma. 2004. Congruence versus phylogenetic accuracy: revisiting the incongruence length difference test. Systematic Biology 53: 81-89.

Hoffmann, O. 1890. Compositae, Tubuliflorae-Vernonieae. Pp. 120-131 in Die natürlichen Pflanzenfamilien, 4(5), eds A. Engler and K. Prantl, Wilhelm Engelmann, Leipzig.

Huelsenbeck, J. P. and F. Ronquist. 2001. MRBAYES: Bayesian inference of phylogenetic trees. Bioinformatics 17: 754-755.

Jansen, R. K. 1992. Current research. Plant Molecular Evolution Newsletter 2: 13-14.

Joly, A. B. 1970. Conheça a vegetação brasileira. EDUSP e Polígono. São Paulo.

Jones, S. B. 1982. IOPB chromosome number reports LXIV. Taxon 31: 126-127.

Katoh, K. and H. Toh. 2008. Recent developments in the MAFFT multiple sequence alignment program. Briefings in Bioinformatics 9: 286-298.

Kornet, D. J. and H. Turner. 1999. Coding polymorphism for phylogeny reconstruction. 
Systematic Biology 48: 365-379.

Lee, M. S. Y. 2001. Uninformative characters and apparent conflict between molecules and morphology. Molecular Biology and Evolution 18: 676-680.

Leitão Filho, H. de F. and J. Semir. 1979. Uma nova combinação para o gênero Vernonia Schreb. (Compositae): Vernonia damazioi (Beauverd) Leitão Filho \& Semir. Revista Brasileira de Botânica 2: 113-116.

Lessing, C. F. 1829. De synanthereis herbarii regii berolinensis dissertatio prima. Linnaea 4: 240-356.

Linder, C. R., L. R. Goertzen, B. Vanden Heuvel, J. Francisco-Ortega, and R. K. Jansen. 2000. The complete external transcribed spacer of 18S-26S rDNA: amplification and phylogenetic utility at low taxonomic levels in Asteraceae and closely allied families. Molecular Phylogenetics and Evolution 14: 285-303.

MacLeish, N. F. F. 1984a. Argyrovernonia and Paralychnophora: new names in the tribe Vernonieae (Asteraceae/Compositae). Taxon 33: 105-106.

MacLeish, N. F. F. 1984b. Eight new combinations in Vernonia (Compositae: Vernonieae). Systematic Botany 9: 133-136.

MacLeish, N. F. F. 1987. Revision of Eremanthus (Compositae: Vernonieae). Annals of the Missouri Botanical Garden 74: 265-290.

Martius, C. F. P. von. 1822. Novum plantarum genus Lychnophora. Denkschriften der KoniglichBaierischen Botanischen Gesellschaft in Regensburg. 2: 148-159, tab. 4-10.

McDade, L. A. 1990. Hybrids and phylogenetic systematics I. Patterns of character expression in hybrids and their implications for cladistic analysis. Evolution 44: 1685-1700.

McDade, L. A. 1995. Hybridization and phylogenetics. Pp. 305-331 in Experimental and Molecular Approaches to Plant Biosystematics, eds P. C. Hoch and A. G. Stephenson. Missouri Botanical Garden. St Louis.

McKenzie, R. J., J. M. Ward, J. D. Lovis, and I. Breitwieser. 2004. Morphological evidence for natural intergeneric hybridization in the New Zealand Gnaphalieae (Compositae): Anaphalioides bellidioides $\times$ Ewartia sinclairii. Botanical Journal of the Linnean Society 145: 59-75.

Müller, K. 2005. SeqState: primer design and sequence statistics for phylogenetic DNA datasets. Applied Bioinformatics 4: 65-69.

Müller, K. 2006. Incorporating information from length-mutational events into phylogenetic analysis. Molecular Phylogenetics and Evolution 38: 667-676.

Myers, N., R. A. Mittermeier, C. G. Mittermeier, G. A. B. da Fonseca, and J. Kent. 2000. Biodiversity hotspots for conservation priorities. Nature 403: 853-858.

Nixon, K. C. 1999. The parsimony ratchet, a new method for rapid parsimony analysis. Cladistics 15: 407-414.

Nixon, K. C. 1999-2002. WinClada, version 1.00.08. Ithaca, New York: published by the author. http://www.cladistics.com/aboutWinc.htm. 
Nixon, K. C. and J. M. Carpenter. 1996. On simultaneous analysis. Cladistics 12: 221-241.

Pelser, P. B., A. H. Kennedy, E. J.Tepe, J. B. Shidler, B. Nordenstam, J. W. Kadereit, and L. E. Watson. 2010. Patterns and causes of incongruence between plastid and nuclear Senecioneae (Asteraceae) phylogenies. American Journal of Botany 97: 856-873.

Posada, D. 2008. jModelTest: Phylogenetic Model Averaging. Molecular Biology and Evolution 25: $1253-1256$.

Prance, G. T. 1994. A comparison of the efficacy of higher taxa and species numbers in the assessment of biodiversity in the Neotropics. Philosophical Transactions of the Royal Society London, Series B: Biological Sciences 345: 89-99.

Prance, G.T. 1996. Islands in Amazonia. Philosophical Transactions of the Royal Society London, Series B: Biological Sciences 351: 823-833.

Rapini,A., R. Mello-Silva, and M.L. Kawasaki. 2002. Richness and endemism in Asclepiadoideae (Apocynaceae) from the Espinhaço Range of Minas Gerais, Brazil - a conservationist view. Biodiversity and Conservation 11: 1733-1746.

Robinson, H. 1992. Notes on Lychnophorinae from Minas Gerais, Brazil, a synopsis of Lychnophoriopsis Schultz-Bip., and the new genera Anteremanthus and Minasia (Vernonieae: Asteraceae). Proceedings of the Biological Society of Washington 105: 640652.

Robinson, H. 1999. Generic and subtribal classification of American Vernonieae. Smithsonian Contributions to Botany 89: 1-116.

Robinson, H. 2007 [2006]. Vernonieae. Pp. 149-174 in Vol. 8: Asterales, vol. eds. J. Kadereit and C. Jeffrey,. The families and genera of vascular plants, series ed. K. Kubitzki, Springer. Berlin, Heidelberg, New York.

Robinson, H., F. Bohlmann, and R. M. King. 1980. Chemosystematic notes on the Asteraceae. III. Natural subdivisions of the Vernonieae. Phytologia 46: 421-436.

Ronquist, F. and J. P. Huelsenbeck. 2003. MRBAYES 3: Bayesian phylogenetic inference under mixed models. Bioinformatics 19: 1572-1574.

Saito, Y., M. Möller, G. Kokubugata, T. Katsuyama, W. Marubashi,and T. Iwashina. 2006. molecular evidence for repeated hybridization events involved in the origin of the genus $\times$ Crepidiastrixeris (Asteraceae) using RAPDs and ITS data. Botanical Journal of the Linnean Society 151: 333-343.

Salles-de-Melo M. R. C. , R. M. de Lucena, J. Semir, R. de Carvalho, R. de C. Araújo Pereira, and A. M. Benko-Iseppon. 2010. Karyological features and cytotaxonomy of the tribe Vernonieae. Plant Systematic and Evolution 285: 189-199

Schultz-Bipontinus, C. H. 1861. Cassiniaceae uniflorae, oder Verzeichniss der Cassiniaceen mit 1-blüthigen Köpfchen. Jahresbericht der Pollichia 18/19: 157-190.

Schultz-Bipontinus, C. H. 1863 [1864]. Lychnophora Martius! und einige benachbarte Gattungen. Jahresbericht der Pollichia 20/21: 321-439.

Schultz-Bipontinus, C. H. 1864. Prestelia C. H. Schultz-Bipontinus. Hor. Vernoniacearum 
genus. Festschrift zum 50.-jährigen Jubiläum der Naturforschenden Gesellschaft zu Emden von 181473.

Seehausen, O. 2004. Hybridization and adaptative radiation. Trends in Ecology and Evolution 19: 198-207.

Semir, J. 1991. Revisão taxonômica de Lychnophora Mart. (Vernonieae: Compositae). PhD thesis, unpublished. Universidade Estadual de Campinas, São Paulo.

Shilling, E. E., J. B. Beck, P. J. Calie, and R. L. Small. 2008. Molecular analysis of Solidaster cv. Lemore, a hybrid goldenrod (Asteraceae). Journal of the Botanical Research Institute of Texas 2: 7-18.

Siddall, M. E. 2002. Measures of support. Pp. 80-101 in Techniques in molecular systematics and evolution, eds R. Desalle, G. Giribet, and W. Wheeler. Birkhäuser Verlag. Basel.

Silva, J. M. C. da, and J. M. Bates. 2002. Biogeographic patterns and conservation in the South American Cerrado: a tropical savanna hotspot. BioScience 52: 225-233.

Simmons, M. P. and H Ochoterena. 2000. Gaps as characters in sequence-based phylogenetic analysis. Systematic Biology 49: 369-381.

Simmons, N. B. 2001. Misleading results from the use of ambiguity coding to score polymorphisms in higher-level taxa. Systematic Biology 50: 613-620.

Simon, M. F., and C. Proença. 2000. Phytogeographic patterns of Mimosa (Mimosoideae, Leguminosae) in the Cerrado biome of Brazil: an indicator genus of high-altitude centers of endemism ? Biological Conservation 96: 279-296.

Soltis, D. E., E. V. Mavrodiev, J. J. Doyle, J. Rauscher, and P. S. Soltis. 2008. ITS and ETS sequence data and phylogeny reconstruction in allopolyploids and hybrids. Systematic Botany 33: 7-20.

Soltis, P. S. and D. E. Soltis. 2009. The role of hybridization in plant speciation. Annual Review of Plant Biology 60: 561-588.

Stace, C. A., ed. 1975. Hybridization and the flora of the British Isles. Academic Press. London.

Stace, C. A. 1986. Hybridization and plant taxonomy. Symbolae Botanicae Upsalienses 27: 9-18.

Thiele, K. 1993. The Holy Grail of the perfect character: the cladistic treatment of morphometric data. Cladistics 9: 275-304.

Timme, R. E., J. V. Kuehl, J. L. Boore, and R. K. Jansen. 2007. A comparative analysis of the Lactuca and Helianthus (Asteraceae) plastid genomes: identification of divergent regions and categorization of shared repeats. American Journal of Botany 94: 302-312.

Vriesendorp, B. and F. T. Bakker. 2005. Reconstructing patterns of reticulate evolution in Angiosperms: what can we do ? Taxon 54: 593-604.

Wendel, J. F. and J. J. Doyle. 1998. Phylogenetic incongruence: window into genome history and molecular evolution. Pp. 265-296 in Molecular Systematics of Plants II, eds D. E. Soltis, P. S. Soltis and J. J. Doyle. Kluwer. Boston.

White, T.J., T. Bruns, S. Lee, and J. Taylor. 1990. Amplification and direct sequencing of fungal 
ribosomal RNA genes for phylogenetics. Pp. 315-322 in PCR protocols: a guide to methods and applications, eds M. Innics, D. Glfand, J. Sninsky, and T. J. White. Academic Press. San Diego.

Wilgenbusch, J. C., D. L. Warren, and D. L. Swofford. 2004. AWTY: A system for graphical exploration of MCMC convergence in Bayesian phylogenetic inference. http://ceb.csit. fsu.edu/awty. 



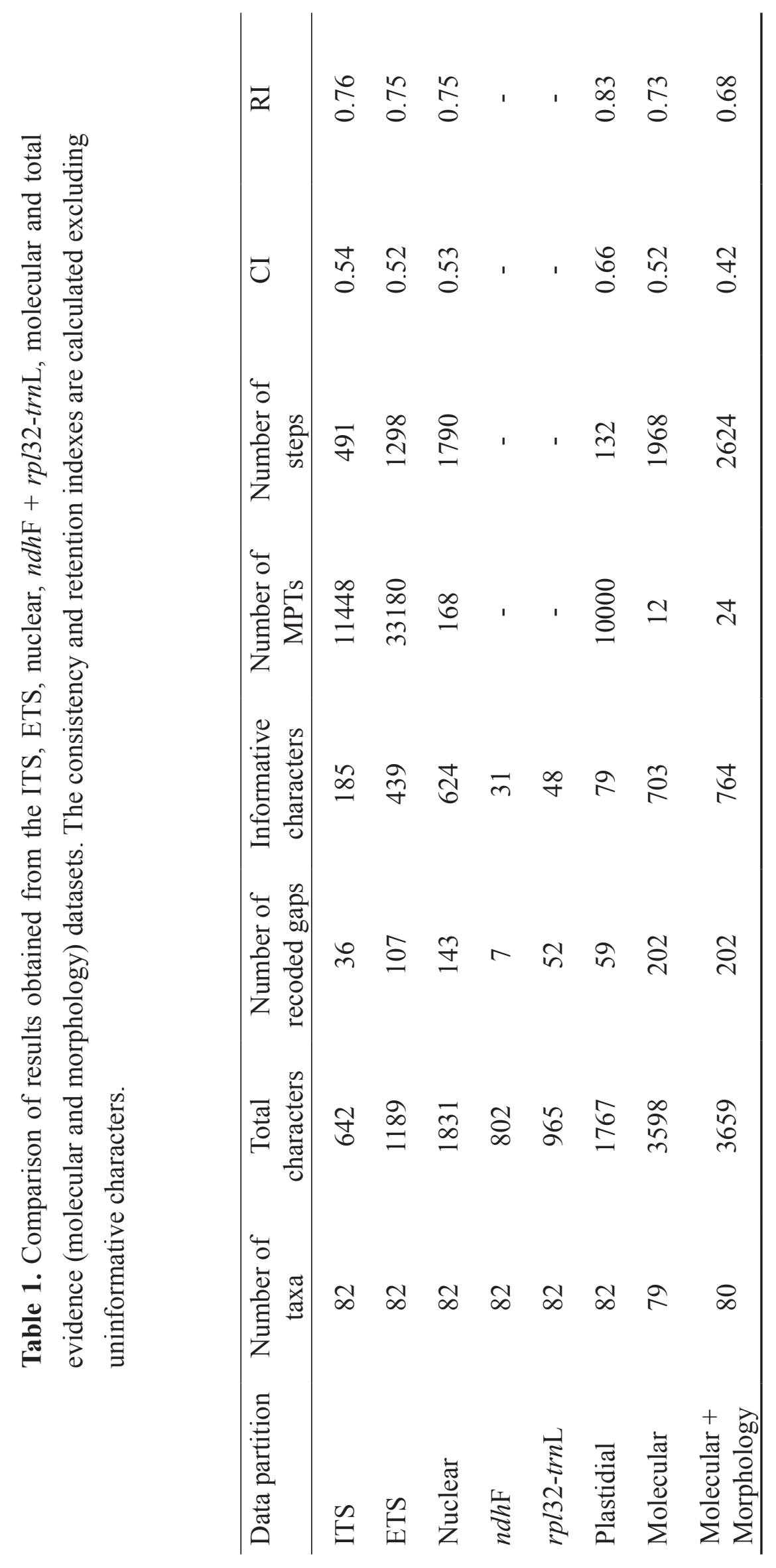


Fig. 1. Representatives of Lychnophorinae. A. Prestelia eriopus. B. Lychnophora sellowii. C. Heterocoma albida. D. Paralychnophora harleyi. E. Minasia alpestris. F. Lychnophora santosii. G. Piptolepis oleaster. H. Lychnophora ericoides. I. Eremanthus glomerulatus. Photo A courtesy of P. Gonella; B of G. Shimizu; C of C. Oliveira and F of S. Ferreira. 

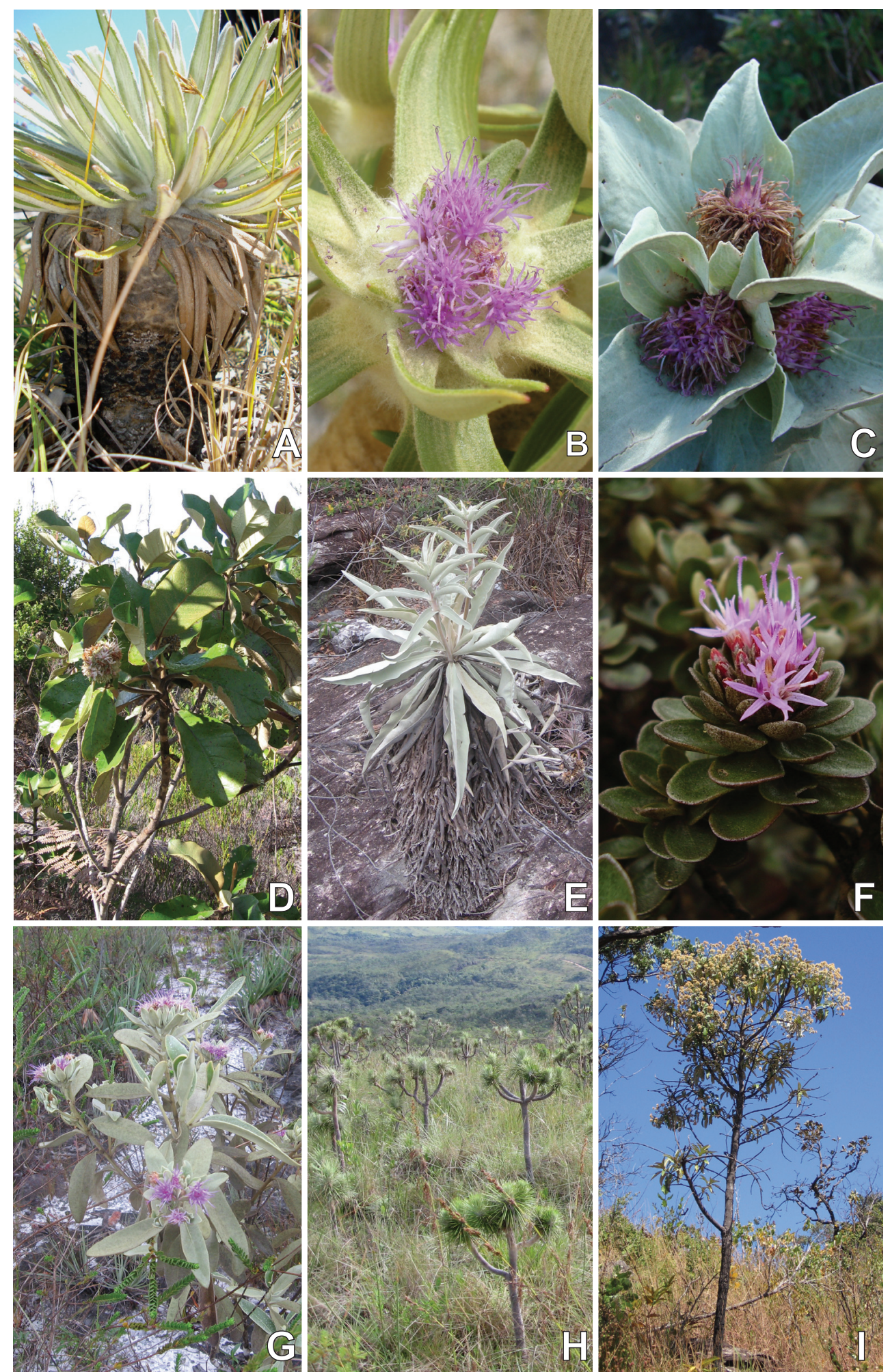
Fig. 2. Strict consensus tree of 168 equally most parsimonious trees based on the nuclear (ITS and ETS) analysis. Tree length $=1790$ steps, $C I=0.53, \mathrm{RI}=0.75$. Jackknife values $(\geq 50 \%)$ are shown above the nodes. Taxa in bold display an incongruent position in the chloroplast phylogeny (Fig. S1), the latter is indicated by the number in a black circle: Eremanthus sp. $\times$ Paralychnophora reflexoauriculata branched at 1 ; Lychnophora mellobarretoi and Minasia alpestris at 2; Piptolepis ericoides $\times$ Eremanthus erythropappus branched at 3 . 


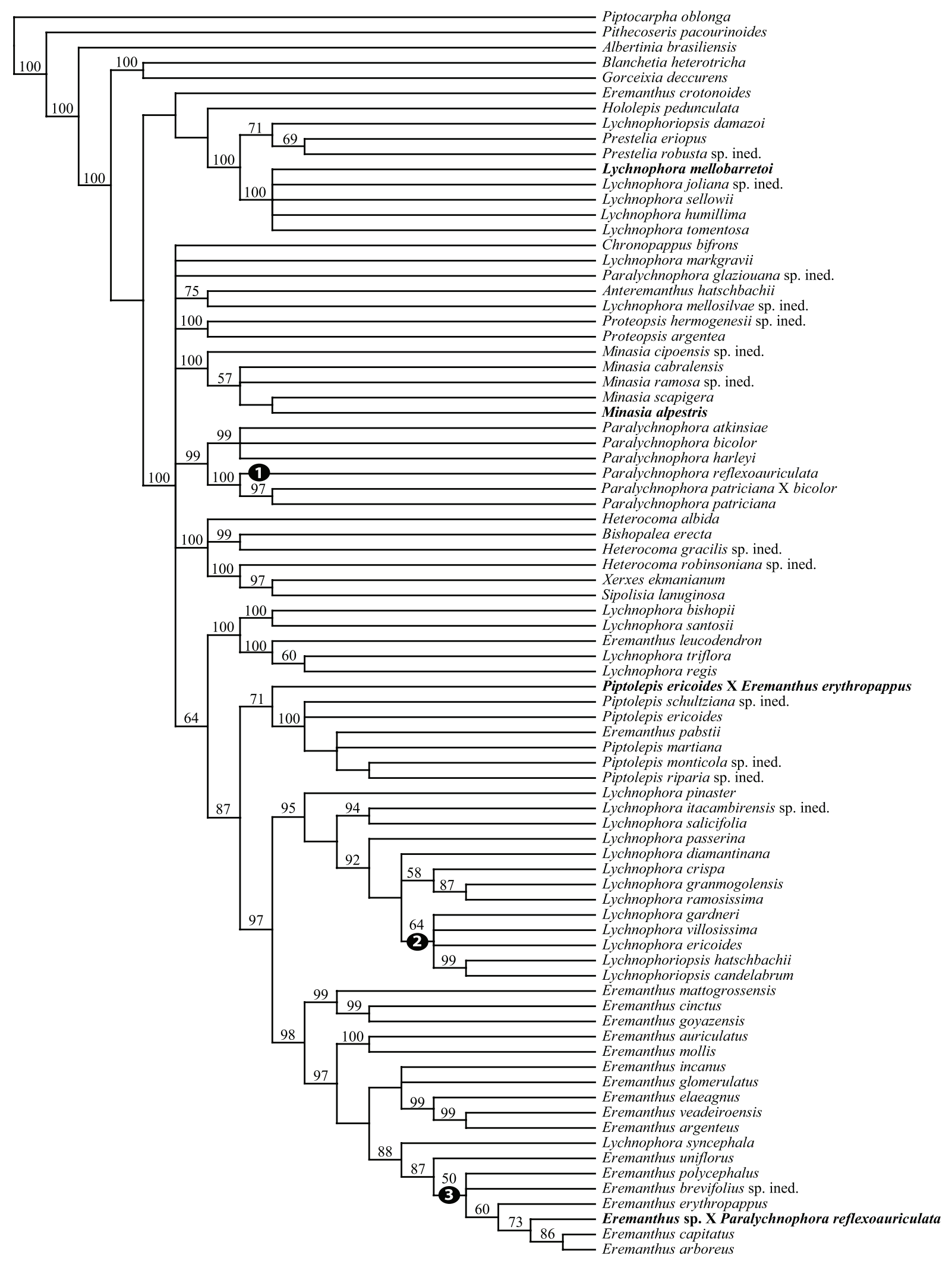


Fig. 3. Strict consensus tree of 12 equally most parsimonious trees based on the combined analysis (all molecular data). Tree length $=1968$ steps, $\mathrm{CI}=0.52, \mathrm{RI}=0.73$. Jackknife values $(\geq 50 \%)$ and Bayesian posterior probabilities $(\geq 0.9)$ are shown above and below the nodes. 


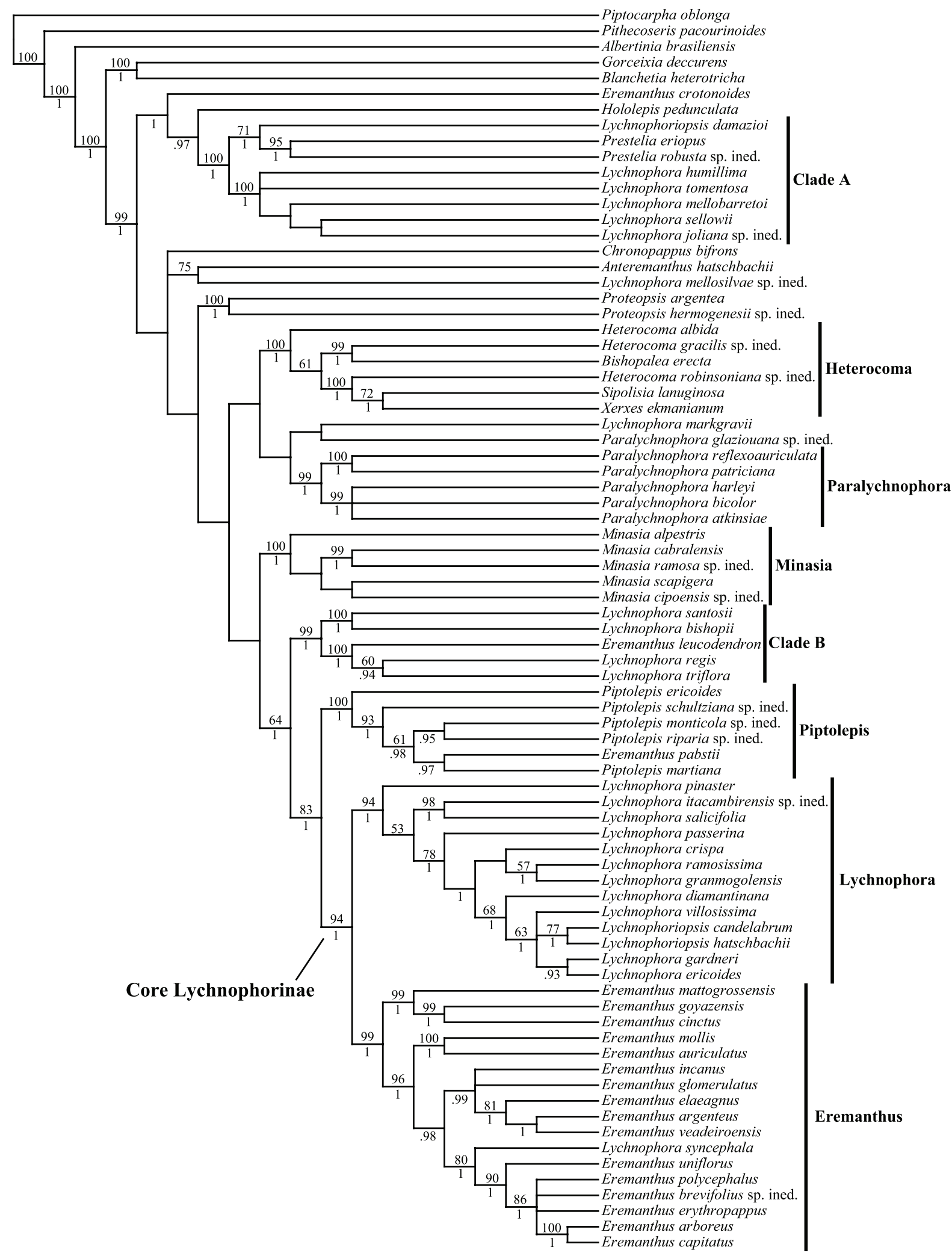


Fig. 4. Strict consensus tree of 44 equally most parsimonious trees based on the combined analysis with morphology and all molecular data. Tree length $=2624$ steps, $\mathrm{CI}=0.42, \mathrm{RI}=$ 0.68. Jackknife values $(\geq 50 \%)$ and Bayesian posterior probabilities $(\geq 0.9)$ are shown above and below the nodes. 


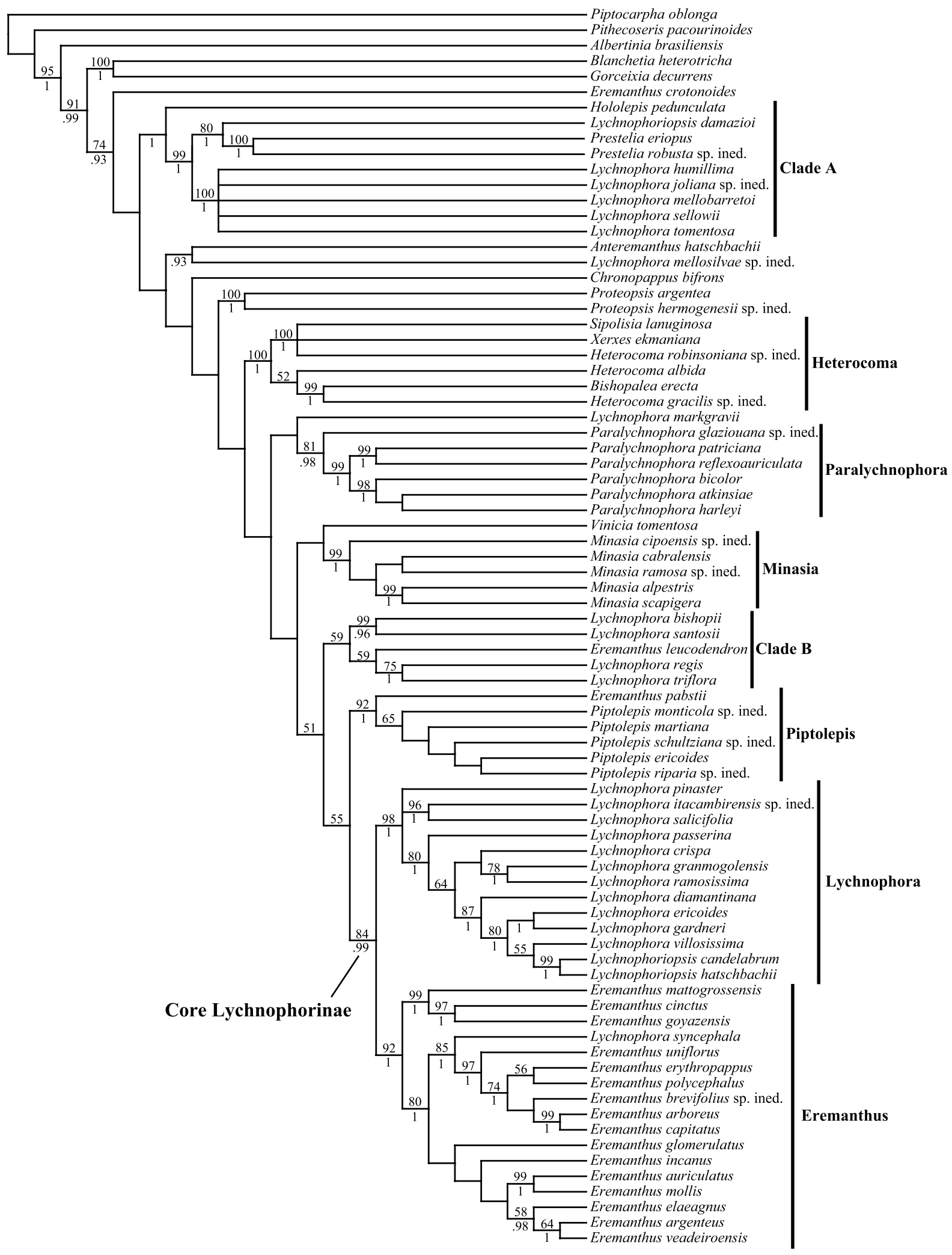



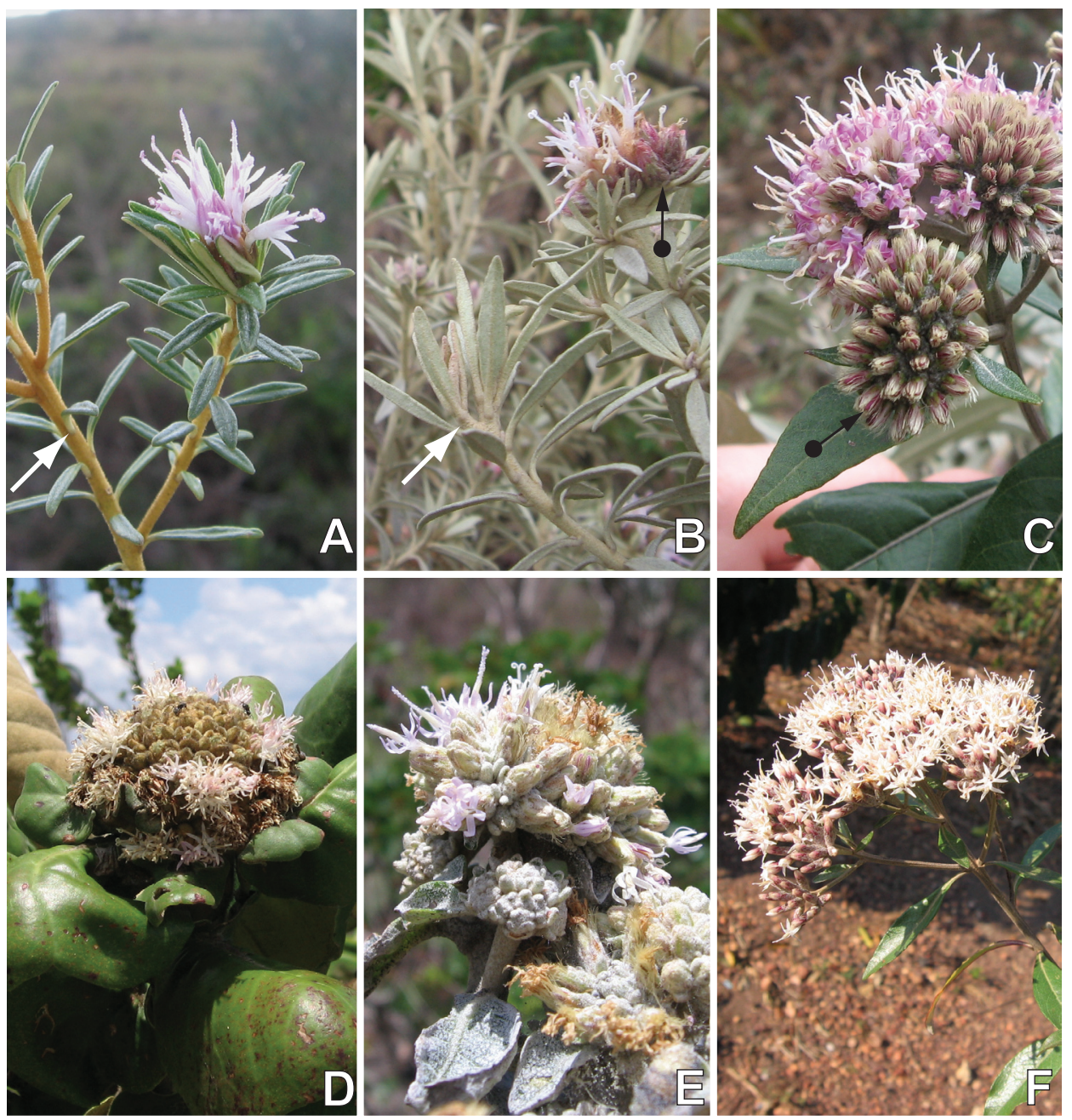

Fig. 5. Putative intergeneric hybrids.A.Piptolepis ericoides. B.Piptolepis ericoides $\times$ Eremanthus erythropappus. C. Eremanthus erythropappus. Note the pad-like leaf sheath (white arrows) and the capitula with imbricate phyllaries (black arrows). D. Paralychnophora reflexoauriculata. E. Eremanthus sp. $\times$ Paralychnophora reflexoauriculata. F. Eremanthus capitatus. 
Appendix 1. Species included in the molecular analyses, voucher information and GenBank accession numbers (ETS, ITS, $n d h \mathrm{~F}$ and $r p l 32-t r n \mathrm{~L}$ ). An en-dash indicates that a region was not sequenced for this taxon. An asterisk indicates a sequence previously published by Keeley \& al. (2007) or taken from Chapter 2 and Keeley et al. (unpub.).

Albertinia brasiliensis Spreng.: XXXXX, EF155744*; EF155656*; Brazil, Bahia State, Entre Rios, Popovkin 476 (HUEFS); XXXXX. Anteremanthus hatschbachii H. Rob.: Brazil, Minas Gerais, Grão Mogol, 6 Jun 2008, Loeuille et al. 441 (SPF); XXXXX, XXXXX, XXXXX, XXXXX. Bishopalea erecta H. Rob.: Brazil, Bahia, Mucugê, 23 May 2009, Roque 2047 (ALCB); XXXXX, XXXXX, XXXXX, XXXXX. Blanchetia heterotricha DC.: Brazil, Bahia, Morro do Chapéu, 4 Feb 2008, Loeuille et al. 394 (SPF); XXXXX, XXXXX, XXXXX, XXXXX. Chronopappus bifrons (DC. ex Pers.) DC.: Brazil, Minas Gerais, Catas Altas, 18 Nov 2008, Loeuille and Albergaria Pena 460 (SPF); XXXXX, XXXXX, XXXXX, XXXXX. Eremanthus arboreus (Gardner) MacLeish: Brazil, Ceará, Crato, 5 Sep 2009, Loeuille et al. 510 (SPF); XXXXX, XXXXX, XXXXX, XXXXX. Eremanthus argenteus MacLeish \& H. Schumach.: Brazil, Goiás, Alto Paraíso, 20 Jul 2007, Loeuille et al. 289 (SPF); —, XXXXX, XXXXX, XXXXX. Eremanthus auriculatus MacLeish \& H. Schumach.: Brazil, Goiás, Alto Paraíso, 19 Jul 2007, Loeuille et al. 279 (SPF); XXXXX, XXXXX, XXXXX, XXXXX. Eremanthus brevifolius Loeuille sp. ined.: Brazil, Minas Gerais, Congonhas do Norte, 20 Jan 2007, Loeuille et al. 71 (SPF); XXXXX, XXXXX, XXXXX, XXXXX. Eremanthus capitatus (Spreng.) MacLeish: Brazil, Bahia, Abaíra, 17 Sept 2007, Loeuille et al. 313 (SPF); XXXXX, XXXXX, XXXXX, XXXXX. Eremanthus cinctus Baker: Brazil, Minas Gerais, Uberlândia, 7 Aug 2007, Loeuille et al. 306 (SPF); XXXXX, XXXXX, XXXXX, XXXXX. Eremanthus crotonoides (DC.) Sch.Bip.: Brazil, Minas Gerais, Santana do Riacho, 22 Apr 2006, Loeuille et al. 25 (SPF); XXXXX, XXXXX, XXXXX, XXXXX. Eremanthus elaeagnus (Mart. ex DC.) Sch.Bip.: Brazil, Minas Gerais, Joaquim Felício, 3 Jun 2008, Loeuille et al. 430 (SPF); XXXXX, XXXXX, XXXXX, XXXXX. Eremanthus erythropappus (DC.) MacLeish: Brazil, Minas Gerais, Capítolio, 26 Oct 2006, Loeuille et al. 51 (SPF); XXXXX, XXXXX, XXXXX, XXXXX. Eremanthus glomerulatus Less.: Brazil, Minas Gerais, Francisco Sá, 5 Jun 2008, Loeuille et al. 438 (SPF); XXXXX, XXXXX, XXXXX, XXXXX. Eremanthus goyazensis (Gardner) Sch. Bip.: Brazil, Goiás, Pirenópolis, 22 Jul 2007, Loeuille et al. 295 (SPF); XXXXX, XXXXX, XXXXX, XXXXX. Eremanthus incanus (Less.) Less.: Brazil, Bahia, Abaíra, 19 Sept 2007, Loeuille et al. 344 (SPF); XXXXX, XXXXX, XXXXX, XXXXX. Eremanthus leucodendron Mattf.: Brazil, Bahia, Abaíra, 19 Sept 2007, Loeuille et al. 347 (SPF); XXXXX, XXXXX, XXXXX, XXXXX. Eremanthus mattogrossensis Kuntze: Brazil, Mato Grosso, Diamantino, 24 Aug 2008, Loeuille et al. 457 (SPF); XXXXX, XXXXX, XXXXX, XXXXX. Eremanthus mollis Sch.Bip.: Brazil, Goiás, Pirenópolis, 23 Jul 2007, Loeuille et al. 305 (SPF); XXXXX, XXXXX, XXXXX, XXXXX. Eremanthus pabstii G.M. Barroso: Brazil, Goiás, Cristalina, 15 Jun 1998, Romero et al. 5508 (UEC); XXXXX, XXXXX, XXXXX, XXXXX. Eremanthus 
polycephalus (DC.) MacLeish: Brazil, Minas Gerais, Grão Mogol, 6 Jun 2008, Loeuille et al. 442 (SPF); XXXXX, XXXXX, XXXXX, XXXXX. Eremanthus sp. X Paralychnophora reflexoauriculata (G.M. Barroso) MacLeish: Brazil, Bahia, Jacobina, 6 Feb 2008, Loeuille et al. 419 (SPF); XXXXX, XXXXX, XXXXX, XXXXX. Eremanthus uniflorus MacLeish \& H. Schumach.: Brazil, Goiás, Alto Paraíso, 19 Jul 2007, Loeuille et al. 280 (SPF); XXXXX, XXXXX, XXXXX, XXXXX. Eremanthus veadeiroensis H. Rob.: Brazil, Goiás, Alto Paraíso, 22 Jul 2007, Saavedra et al. 475 (SPF); XXXXX, XXXXX, XXXXX, - Gorceixia decurrens Baker: XXXXX*, EF155773*, EF155685*, XXXXX*. Heterocoma albida (DC. ex Pers.) DC.: Brazil, Minas Gerais, Serro, 9 Jun 2008, Loeuille et al. 450 (SPF); XXXXX, XXXXX, XXXXX, XXXXX. Heterocoma gracilis Loeuille, J.N. Nakaj. \& Semir sp. ined.: Brazil, Minas Gerais, São Gonçalo do Rio Preto, 9 Feb 2010, Loeuille et al. 520 (SPF); XXXXX, XXXXX, XXXXX, XXXXX. Heterocoma robinsoniana Loeuille, J.N. Nakaj. \& Semir sp. ined.: Brazil, Minas Gerais, São Roque de Minas, 15 May 2007, Loeuille et al. 266 (SPF); XXXXX, XXXXX, XXXXX, XXXXX. Hololepis pedunculata (DC. ex Pers.) DC.: Brazil, Minas Gerais, São Roque de Minas, 15 May 2007, Loeuille et al. 259 (SPF); XXXXX, XXXXX, XXXXX, XXXXX. Lychnophora bishopii H. Rob.: Brazil, Bahia, Mucugê, 16 Feb 2002, Oliveira 43 (HUEFS); XXXXX, XXXXX, XXXXX, XXXXX. Lychnophora crispa Mattf.: Brazil, Bahia, Rio de Contas, 18 Nov 1996, Harley et al. PCD 4427 (HUEFS); XXXXX, XXXXX, XXXXX, XXXXX. Lychnophora diamantinana Coile \& S.B. Jones: Brazil, Minas Gerais, Diamantina, 23 Jan 2007, Loeuille et al. 108 (SPF); XXXXX, XXXXX, XXXXX, XXXXX. Lychnophora ericoides Mart.: Brazil, Minas Gerais, Diamantina, 22 Jan 2007, Loeuille et al. 89 (SPF); XXXXX, XXXXX, XXXXX, XXXXX. Lychnophora gardneri Sch.Bip.: Brazil, Minas Gerais, Congonhas do Norte, 19 Jan 2007, Loeuille et al. 67 (SPF); XXXXX, XXXXX, XXXXX, XXXXX. Lychnophora granmogolensis (Duarte) Semir in D.J.N. Hind: Brazil, Minas Gerais, Cristália, 7 Jun 2008, Loeuille et al. 445 (SPF); XXXXX, XXXXX, XXXXX, XXXXX. Lychnophora humillima Sch.Bip.: Brazil, Minas Gerais, Santana de Pirapama, 11 Nov 2009, Zappi et al. 2325 (SPF); XXXXX, XXXXX, XXXXX, XXXXX. Lychnophora itacambirensis sp. ined.: Brazil, Minas Gerais, Itacambira, 27 Apr 2009, Mello-Silva et al. 3186 (SPF); XXXXX, XXXXX, XXXXX, XXXXX. Lychnophora joliana sp. ined.: Brazil, Minas Gerais, Santana do Riacho, 14 Feb 2007, Loeuille et al. 112 (SPF); XXXXX, XXXXX, XXXXX, XXXXX. Lychnophora markgravii G.M. Barroso: Brazil, Minas Gerais, Grão Mogol, 6 Jun 2008, Loeuille et al. 440 (SPF); XXXXX, XXXXX, XXXXX, XXXXX. Lychnophora mellobarretoi G.M. Barroso: Brazil, Minas Gerais, Santana do Riacho, 12 Jul 2009, Loeuille et al. 507 (SPF); XXXXX, XXXXX, XXXXX, XXXXX. Lychnophora mellosilvae sp. ined.: Brazil, Minas Gerais, Mato Verde, 13 Jun 1991, Mello-Silva et al. 463 (SPF); XXXXX, XXXXX, XXXXX, XXXXX. Lychnophora passerina (Mart. ex DC.) Gardner: Brazil, Bahia, Abaíra, 18 Nov 2007, Loeuille et al. 337 (SPF); XXXXX, XXXXX, XXXXX, XXXXX. Lychnophora pinaster Mart.: Brazil, Catas Altas, 26 Apr 2009, Oliveira et al. 471 (SPF); XXXXX, XXXXX, XXXXX, XXXXX. Lychnophora ramosissima Gardner: Brazil, Minas 
Gerais, Josenópolis, 8 Jun 2008, Loeuille et al. 448 (SPF); XXXXX, XXXXX, XXXXX, XXXXX. Lychnophora regis H. Rob.: Brazil, Bahia, Abaíra, 19 Sept 2007, Loeuille et al. 346 (SPF); XXXXX, XXXXX, XXXXX, XXXXX. Lychnophora salicifolia Mart.: Brazil, Minas Gerais, Botumirim, 17 Nov 2007, Mello-Silva et al. 3000 (SPF); XXXXX, XXXXX, XXXXX, XXXXX. Lychnophora santosii H. Rob.: Brazil, Bahia, Mucugê, 19 May 2007, Ferreira et al. 268 (HUEFS); XXXXX, XXXXX, XXXXX, XXXXX. Lychnophora sellowii Sch.Bip.: Brazil, Minas Gerais, Congonhas do Norte, 20 Jan 2007, Loeuille et al. 79 (SPF); XXXXX, XXXXX, XXXXX, XXXXX. Lychnophora syncephala (Sch.Bip.) Sch.Bip.: Brazil, Minas Gerais, Santana do Riacho, 11 Jul 2009, Loeuille et al. 483 a (SPF); XXXXX, XXXXX, XXXXX, XXXXX. Lychnophora tomentosa (Mart. ex DC.) Sch.Bip.: Brazil, Minas Gerais, Diamantina, 22 Jan 2007, Loeuille et al. 93 (SPF); XXXXX, XXXXX, XXXXX, XXXXX. Lychnophora triflora (Mattf.) H. Rob.: Brazil, Bahia, Abaíra, 17 Sept 2007, Loeuille et al. 333 (SPF); XXXXX, XXXXX, XXXXX, XXXXX. Lychnophora villosissima Mart.: Brazil, Minas Gerais, Congonhas do Norte, 21 Jan 2007, Loeuille et al. 81 (SPF); XXXXX, XXXXX, XXXXX, XXXXX. Lychnophoriopsis candelabrum (Sch.Bip.) H. Rob.: Brazil, Minas Gerais, Buenópolis, 3 Jun 2008, Loeuille et al. 435 (SPF); XXXXX, XXXXX, XXXXX, XXXXX. Lychnophoriopsis damazioi (P. Beauv.) H. Rob.: Brazil, Minas Gerais, Congonhas do Norte, 20 Jan 2007, Loeuille et al. 77 (SPF); XXXXX, XXXXX, XXXXX, XXXXX. Lychnophoriopsis hatschbachii $\mathrm{H}$. Rob.: Brazil, Minas Gerais, Diamantina, 21 Oct 2007, Rosa et al. 935 (HUFU); XXXXX, XXXXX, XXXXX, XXXXX. Minasia alpestris (Gardner) H. Rob.: Brazil, Minas Gerais, Diamantina, Nakajima et al. 4624 (SPF); XXXXX, XXXXX, XXXXX, XXXXX. Minasia cabralensis H. Rob.: Brazil, Minas Gerais, Joaquim Felício, 3 Jun 2008, Loeuille et al. 433 (SPF); XXXXX, XXXXX, XXXXX, XXXXX. Minasia cipoensis sp. ined.: Brazil, Minas Gerais, Santana do Riacho, 12 Jul 2009, Loeuille et al. 494 (SPF); XXXXX, XXXXX, XXXXX, XXXXX. Minasia scapigera H. Rob.: Brazil, Minas Gerais, Diamantina, 23 Jan 2007, Loeuille et al. 97 (SPF); XXXXX, XXXXX, XXXXX, XXXXX. Minasia ramosa Loeuille, H. Rob. \& Semir: Brazil, Minas Gerais, Joaquim Felício, 3 Jun 2008, Loeuille et al. 432 (SPF); XXXXX, XXXXX, XXXXX, XXXXX. Paralychnophora atkinsiae D.J.N. Hind: Brazil, Bahia, Mucugê, 19 May 2007, Ferreira et al. 267 (HUEFS); XXXXX, XXXXX, XXXXX, XXXXX. Paralychnophora bicolor (DC.) MacLeish: Brazil, Minas Gerais, Abaíra, 17 Sept 2007, Loeuille et al. 330 (SPF); XXXXX, XXXXX, XXXXX, XXXXX. Paralychnophora glaziouana Loeuille sp. ined.: Brazil, Minas Gerais, Serro, 9 Jun 2008, Loeuille et al. 451 (SPF); XXXXX, XXXXX, XXXXX, XXXXX. Paralychnophora harleyi (H. Rob.) D.J.N. Hind: Brazil, Bahia, Piatã, 16 Sept 2007, Loeuille et al. 309 (SPF); XXXXX, XXXXX, XXXXX, XXXXX. Paralychnophora patriciana D.J.N. Hind: Brazil, Bahia, Abaíra, 17 Sept 2007, Loeuille et al. 329 (SPF); XXXXX, XXXXX, XXXXX, XXXXX. Paralychnophora patriciana D.J.N. Hind X Paralychnophora bicolor (H. Rob.) D.J.N. Hind.: Brazil, Bahia, Abaíra, 17 Sept 2007, Loeuille et al. 326 (SPF); XXXXX, XXXXX, XXXXX, XXXXX. Paralychnophora reflexoauriculata (G.M. Barroso) MacLeish: Brazil, Bahia, Morro do Chapéu, 4 Feb 2008, Loeuille et al. 396 (SPF); XXXXX, 
XXXXX, XXXXX, XXXXX. Piptocarpha oblonga (Gardner) Baker: Brazil, Minas Gerais, Capitólio, 26 Oct 2006, Loeuille et al. 57 (SPF); XXXXX, XXXXX, XXXXX, XXXXX. Piptolepis ericoides Sch. Bip.: Brazil, Minas Gerais, Santana do Riacho, 21 Apr 2006, Loeuille et al. 17 (SPF); XXXXX, XXXXX, XXXXX, XXXXX. Piptolepis oleaster (Mart. ex DC.) Sch.Bip.: Brazil, Minas Gerais, São Gonçalo do Rio Preto, 9 Feb 2010, Loeuille et al. 517 (SPF); XXXXX, XXXXX, XXXXX, XXXXX. Piptolepis monticola Loeuille sp. ined.: Brazil, Minas Gerais, Santo Antônio de Itambé, 28 Jan 2009, Loeuille et al. 464 (SPF); XXXXX, XXXXX, XXXXX, XXXXX. Piptolepis riparia sp. ined.: Brazil, Minas Gerais, São Gonçalo do Rio Preto, 8 Feb 2010, Loeuille et al. 516 (SPF); XXXXX, XXXXX, 一, XXXXX. Piptolepis schultziana Loeuille \& D.J.N. Hind: Brazil, Minas Gerais, Congonhas do Norte, 20 Jan 2007, Loeuille et al. 72 (SPF); XXXXX, XXXXX, XXXXX, XXXXX. Pithecoseris pacourinoides Mart. ex DC.: Brazil, Bahia, Feira de Santana, 22 Sept 2007, Loeuille and França 350 (SPF); XXXXX, XXXXX, XXXXX, XXXXX. Prestelia eriopus Sch.Bip.: Brazil, Minas Gerais, Santana do Riacho, 14 Feb 2007, Loeuille et al. 113 (SPF); XXXXX, XXXXX, XXXXX, XXXXX. Prestelia robusta sp. ined.: Brazil, Minas Gerais, Diamantina, 14 Aug 2003, Mansanares and Verola 340 (UEC); XXXXX, XXXXX, XXXXX, XXXXX. Proteopsis argentea Mart. \& Zucc. ex DC.: Brazil, Minas Gerais, Grão Mogol, 7 Jun 2008, Loeuille et al. 444 (SPF); XXXXX, XXXXX, XXXXX, XXXXX. Proteopsis hermogenesii sp. ined.: Brazil, Minas Gerais, Botumirim, 18 Nov 2007, Mello-Silva et al. 3008 (SPF); XXXXX, XXXXX, XXXXX, XXXXX. Sipolisia lanuginosa Glaz. ex Oliv.: -, EF155798*, EF155710*, XXXXX*. Xerxes ekmanianum (Philipson) J.R. Grant: Brazil, Goiás, Cavalcante, 4 Feb 2007, Trovó et al. 440 (SPF); XXXXX, XXXXX, XXXXX, XXXXX. 
Appendix 2. Morphological characters and character states used for the combined phylogenetic analysis (see Supplemental Appendix 1). Characters 7 to 19 refer to leaf trichomes (adaxial and abaxial surfaces). For explanations on coding see Loeuille \& Pirani (in prep.) (see Chapter 1).

1. Life form: $0=$ herb, $1=$ caulirosuletum, $2=$ shrub, $3=$ treelet and tree. 2. Leaf margin: $0=$ flat, $1=$ revolute. 3 . Leaf margin II: $0=$ entire, $1=$ serrate to dentate. 4 . Leaf sheath: 0 $=$ absent, $1=$ present. 5. Leaf sheath II: $0=$ semi-amplexicaul to amplexicaul, $1=$ pad-like (character restricted to taxa with a leaf sheath). 6. Unbranched trichomes (without auriculate base): $0=$ absent, 1 = present. 7 . Unbranched auriculate trichomes: $0=$ absent, $1=$ present. 8. Not swollen T-shaped trichomes: $0=$ absent, $1=$ present. 9. Swollen T-shaped trichomes: $0=$ absent, $1=$ present. 10. Inverted Y-shaped trichomes: $0=$ absent, $1=$ present. 11. Stellate trichomes: $0=$ absent, $1=$ present. 12. 3- to 5-armed not swollen trichomes: $0=$ absent, $1=$ present. 13. 3- to 5-armed swollen trichomes: $0=$ absent, $1=$ present. 14. Curly trichomes: $0=$ absent, $1=$ present. 15 . Squared cells stalked trichomes: $0=$ absent, $1=$ present. 16 . Geminate trichomes: $0=$ absent, $1=$ present. 17. Porrect trichomes: $0=$ absent, $1=$ present. 18. Spurred trichomes: $0=$ absent, $1=$ present. 19. Capitulescence position I: $0=$ terminal, $1=$ axillary. 20. Capitulescence peduncle: $0=$ absent, $1=$ present. 21. Capitulescence first-order unit: $0=$ capitulum, $1=$ glomerule, $2=$ syncephalium. 22. Capitulescence branching pattern: $0=$ few terminal capitula/glomerule/syncephalia, $1=$ racemose, $2=$ cymose, $3=$ paniculate. 23. Syncephalium form: $0=$ hemispherical or pyramidal, $1=$ spherical. 24 . Syncephalium level: $0=$ second-order, 1 = third-order. 25. Syncephalium units: $0=$ unit of syncephalia evident, $1=$ not evident due to tissue/indument growth. 26. Syncephalium leaves: $0=$ reduced leaves between capitula, $1=$ no leaves between capitula. 27 . Secondary involucre: $0=$ absent, $1=$ present. 28. Number of florets per capitulum (quantitative character): minimum value = 1 and maximal value $=110$. 29. Capitulum peduncle: $0=$ absent, $1=$ present. 30. Involucre shape: $0=$ cylindrical, 1 = ovoid, 2 = obconic, 3 = campanulate. 31. Phyllary imbrication: 0 $=$ strong, $1=$ weak or none. 32. Phyllary duration: $0=$ persistent, $1=$ caducous or deciduous. 33. Phyllary indument: $0=$ glabrous, $1=$ pubescent. 34. Phyllary apex: $0=$ obtuse, $1=$ acute to acuminate, $2=$ with spiny appendage. 35 . Capitulum receptacle pitting: $0=$ smooth, $1=$ areolate or foveolate, $2=$ fimbrillate, $3=$ alveolate. 36. Palea: $0=$ absent, $1=$ present. 37. Tube/ limb ratio: $0=$ tube $>\operatorname{limb}, 1=$ tube $=\operatorname{limb}, 2=$ tube $<\operatorname{limb}$. 38. Corolla laticifer: $0=$ absent, $1=$ present. 39. Corolla apex: $0=$ glabrous, $1=$ pubescent. 40. Corolla lobe: $0=$ not revolute, $1=$ revolute. 41. Anther base tail: $0=$ absent, $1=$ present. 42. Anther appendage base: $0=$ straight, $1=$ constricted. 43 . Style base: $0=$ not expanded, $1=$ expanded. 44. Cypsela shape: $0=$ cylindrical, $1=$ turbinate, $2=$ prismatic. 45 . Phytomelanin on cypsela wall: $0=$ absent, $1=$ present. 46. Cypsela wall: $0=$ glabrous, $1=$ pubescent. 47. Carpopodium: $0=$ absent or inconspicuous, $1=$ prominent. 48 . Number of pappus series: $0=$ one, $1=$ two, $2=$ more than two. 49. Outer pappus duration: $0=$ persistent, $1=$ deciduous, $2=$ caducous. 50. Outer pappus fusion: $0=$ free, 1 = fused at base, $2=$ more than half fused. 51. Outer pappus relative size to 
inner series: $0=$ subigual or igual, $1=$ smaller, $2=$ residual. 52. Outer pappus type: $0=$ setose, $1=$ subpaleaceous, 2 = paleaceous. 53. Outer pappus seta base: $0=$ not enlarged, $1=$ enlarged. 54. Outer pappus seta apex: $0=$ not narrowed, $1=$ narrowed. 55. Inner pappus duration: 0 $=$ persistent, $1=$ deciduous, 2 = caducous. 56. Inner pappus form: $0=$ straight, $1=$ twisted. 57. Inner pappus type: $0=$ setose, $1=$ subpaleaceous, $2=$ paleaceous. 58. Inner pappus seta base: $0=$ not enlarged, $1=$ enlarged. 59. Inner pappus seta apex: $0=$ not enlarged nor narrowed, 1 = narrowed, 2 = enlarged. 60. Heliangolide derivatives I. Furanoheliangolide: 0 = absent, 1 = present. 61. Heliangolide derivatives II. Eremantholide: $0=$ absent, $1=$ present.

Appendix S1. The data matrix used in the morphological part of the phylogenetic analysis. Multiple states of characters are coded with the next letters: $a=(01), b=(12), c=(23), d=(02)$, $\mathrm{e}=(03),-=$ inapplicable data, $?=$ missing data. 


\begin{tabular}{|c|c|c|c|c|c|c|c|c|c|c|c|c|c|c|c|c|c|c|}
\hline $0-$ & 0 & ๙. & $\sigma$. & $\sigma$. & $\curvearrowright$. & ๙. & ๙. & a. & - & a. & ๙. & $\sigma$. & $\sigma$. & - & - & 0 & 0 & - \\
\hline 60 & 0 & $\sim$. & $\sim$. & $\sim$. & ๙. & $\sim$. & $\sim$. & $\sim$. & - & $\sigma$. & $\sim$. & $\sim$. & ๙. & - & - & - & 0 & - \\
\hline in a & 0 & 0 & 0 & $N$ & 0 & $\sim$ & 0 & 0 & 0 & 0 & 0 & 0 & 0 & 0 & 0 & 0 & 0 & 0 \\
\hline$n \infty$ & 0 & 0 & 0 & 0 & 0 & 0 & 0 & 0 & 0 & 0 & 0 & 0 & 0 & 0 & 0 & 0 & 0 & 0 \\
\hline$n N$ & 0 & 0 & 0 & - & - & $\sim$ & - & 0 & $\sim$ & $\sim$ & 0 & 0 & $\sim$ & 0 & 0 & 0 & $\sim$ & $\mathrm{N}$ \\
\hline in 6 & $\pi$ & 0 & 0 & 0 & 0 & 0 & 0 & 0 & 0 & - & - & 0 & 0 & 0 & 0 & 0 & 0 & 0 \\
\hline in in & 0 & $N$ & 0 & - & $N$ & $N$ & - & $N$ & 0 & 0 & $\pi$ & $N$ & 0 & - & 0 & $N$ & 0 & - \\
\hline$n \nabla$ & 0 & 0 & 0 & 0 & 0 & I & 0 & 0 & 0 & 0 & 0 & 0 & 0 & 0 & 0 & 0 & 0 & 0 \\
\hline$n m$ & 0 & 0 & - & - & 0 & , & - & 0 & 0 & 0 & 0 & 0 & 0 & - & 0 & 0 & - & - \\
\hline$n \mathrm{~N}$ & - & $\tau$ & - & $N$ & - & I & $N$ & 0 & $N$ & $N$ & 0 & 0 & $N$ & $N$ & - & 0 & $N$ & $N$ \\
\hline$n-$ & - & - & - & - & - & ' & - & - & - & - & 0 & - & - & - & - & - & - & - \\
\hline in 0 & 0 & 0 & 0 & - & 0 & I & - & 0 & - & - & 0 & 0 & - & 0 & 0 & 0 & - & - \\
\hline$\forall a$ & 0 & $N$ & 0 & 0 & $N$ & I & 0 & $N$ & 0 & 0 & $\pi$ & N & 0 & - & 0 & $N$ & 0 & - \\
\hline$\nabla \infty$ & - & - & - & - & - & 0 & - & $\sim$ & $N$ & $\sim$ & - & $N$ & $\sim$ & - & - & $\sim$ & $\sim$ & $\mathrm{N}$ \\
\hline$\nabla r$ & - & - & - & - & 0 & 0 & 0 & 0 & 0 & 0 & 0 & 0 & 0 & 0 & 0 & 0 & 0 & 0 \\
\hline$\nabla 6$ & 0 & $\pi$ & - & - & 0 & 0 & 0 & 0 & - & - & 0 & 0 & - & - & - & 0 & - & - \\
\hline$\nabla n$ & 0 & 0 & 0 & 0 & - & 0 & 0 & 0 & 0 & 0 & 0 & 0 & 0 & 0 & 0 & 0 & 0 & 0 \\
\hline$\nabla \nabla$ & $N$ & $\pi$ & 0 & 0 & $N$ & $N$ & $\sim$ & 0 & - & - & - & 0 & 0 & $N$ & $\sim$ & - & - & - \\
\hline$\nabla m$ & - & 0 & - & 0 & 0 & 0 & 0 & a. & 0 & 0 & 0 & 0 & 0 & 0 & 0 & 0 & 0 & 0 \\
\hline$\nabla N$ & 0 & - & - & - & 0 & - & 0 & ๙. & - & - & - & - & 0 & - & - & - & 0 & 0 \\
\hline ナ - & 一 & 0 & 0 & 0 & 0 & 0 & 0 & ๙. & 0 & 0 & 0 & 0 & 0 & 0 & 0 & 0 & 0 & 0 \\
\hline+0 & 0 & 0 & 0 & - & 0 & 0 & - & ๙. & 0 & 0 & 0 & 0 & 0 & 0 & 0 & 0 & 0 & 0 \\
\hline$m a$ & 0 & $\pi$ & 0 & - & - & 0 & - & a. & 0 & 0 & 0 & 0 & 0 & - & 0 & 0 & 0 & 0 \\
\hline$n \infty$ & 0 & 0 & 0 & 0 & - & 0 & - & a. & 0 & 0 & 0 & 0 & 0 & 0 & 0 & 0 & 0 & 0 \\
\hline$m r$ & - & 0 & 0 & $N$ & $N$ & 0 & 0 & a. & - & - & 0 & - & - & 0 & - & 0 & - & 0 \\
\hline$m o$ & 0 & 0 & 0 & 0 & - & 0 & 0 & 0 & 0 & 0 & 0 & 0 & 0 & 0 & 0 & 0 & 0 & 0 \\
\hline$m$ in & 0 & 0 & $\nabla$ & $N$ & 0 & $N$ & $N$ & - & 0 & 0 & - & - & 0 & $N$ & $N$ & $N$ & 0 & 0 \\
\hline$m \nabla$ & - & - & 0 & - & - & - & - & - & - & - & - & - & - & - & - & - & - & - \\
\hline$m m$ & 0 & - & - & - & - & - & - & - & - & - & - & - & - & - & - & - & 一 & - \\
\hline$m \sim$ & - & 0 & 0 & 0 & 0 & 0 & 0 & 0 & 0 & 0 & 0 & 0 & 0 & 0 & 0 & 0 & 0 & - \\
\hline$m-$ & - & 0 & 0 & 0 & - & 0 & - & 0 & 0 & 0 & 0 & 0 & 0 & 0 & 0 & 0 & 0 & 0 \\
\hline mo & 0 & 0 & $m$ & $m$ & $m$ & - & - & $N$ & $N$ & $N$ & $N$ & $\tau$ & $N$ & 0 & 0 & $N$ & - & - \\
\hline $\mathrm{Na}$ & 0 & 0 & - & - & - & - & 0 & - & 0 & 0 & - & $\pi$ & 0 & 0 & 0 & 0 & 0 & 0 \\
\hline$\sim \infty$ & 0 & 0 & - & $\forall$ & $N$ & - & - & 0 & 0 & 0 & 0 & 0 & 0 & 0 & 0 & 0 & 0 & 0 \\
\hline$N R$ & 0 & 0 & 0 & 0 & - & 0 & - & 0 & - & - & 0 & 0 & - & 0 & 0 & - & - & - \\
\hline$\sim 6$ & ' & - & ' & I & , & ' & ' & ' & - & - & ' & ' & - & ' & I & - & - & - \\
\hline$N$ in & 1 & 0 & ' & 1 & ' & ' & ' & ' & - & - & 1 & ' & - & ' & ' & - & 0 & - \\
\hline$N+$ & I & 0 & I & , & ' & I & I & I & 0 & 0 & I & I & 0 & I & I & 0 & 0 & 0 \\
\hline$\sim m$ & ' & - & ' & I & ' & ' & ' & I & - & - & ' & ' & 0 & 1 & ' & 0 & 0 & 0 \\
\hline$N \sim$ & - & - & - & $n$ & $N$ & $m$ & $m$ & $N$ & $N$ & $N$ & $N$ & $N$ & $N$ & $N$ & $N$ & $N$ & $N$ & $N$ \\
\hline $\mathrm{N}-$ & - & $\sim$ & 0 & 0 & 0 & 0 & - & - & $N$ & $\sim$ & - & - & $N$ & - & - & $N$ & $\sim$ & $\sim$ \\
\hline NO & 0 & - & - & - & - & - & - & - & - & - & - & - & - & - & - & - & - & - \\
\hline$-a$ & - & 0 & - & - & - & 0 & - & 0 & 0 & 0 & 0 & 0 & 0 & 0 & 0 & 0 & 0 & 0 \\
\hline$-\infty$ & 0 & 0 & 0 & 0 & - & 0 & 0 & 0 & 0 & 0 & 0 & 0 & 0 & 0 & 0 & 0 & 0 & 0 \\
\hline$-r$ & 0 & 0 & 0 & 0 & - & - & 0 & 0 & 0 & 0 & 0 & 0 & 0 & 0 & 0 & 0 & 0 & 0 \\
\hline-6 & 0 & 0 & 0 & 0 & 0 & - & - & 0 & 0 & 0 & 0 & 0 & 0 & 0 & 0 & 0 & 0 & 0 \\
\hline- in & 0 & 0 & 0 & 0 & 0 & - & 0 & 0 & 0 & 0 & 0 & 0 & 0 & - & 0 & 0 & 0 & 0 \\
\hline$-\nabla$ & 0 & 0 & 0 & 0 & 0 & 0 & 0 & 0 & 0 & 0 & 0 & 0 & 0 & 0 & 0 & 0 & 0 & 0 \\
\hline$-m$ & $0 \longdiv { \varrho }$ & & 0 & 0 & 0 & 0 & 0 & - & - & 0 & - & 0 & - & 0 & - & - & - & 一 \\
\hline$-N$ & 0 రై & 0 & 0 & 0 & - & 0 & - & 0 & 0 & - & 0 & - & 0 & - & 0 & 0 & - & 0 \\
\hline-- & 2- & & 0 & 0 & 0 & - & - & 0 & 0 & 0 ن & 0 & 0 & 0 & - & 0 & 0 & 0 & 0 \\
\hline-0 & & & 0. & 0 & 0 & 0 & 0 & 0 & 0 & $0 . \Xi$ & 0 & 0 & 0 & 0 & 0 & 0 & 0 & 0 \\
\hline$a$ & $\stackrel{500}{=} 0$. & & 0 年 & 0 & 0 & 0 & 0 & 0 & 0 & 0 : & 0 & 0 & 0 & 0 & 0 & & 0 & 0 \\
\hline$\infty$ & 00 & - & $-\frac{5}{8}$ & - & 0 & 0 & 0 & 0 & 0 & $0 \vdots$ & 0 & 0 & $0 \frac{y}{d}$ & & & & & 0 \\
\hline$r$ & & 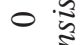 & 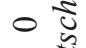 & 0 & 0.7 & 0 & 0 & 0 & 0 & & 0 & 0 & $0:$ & & 0 & 0 & 0 & 0 \\
\hline 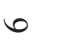 & & & & & - & 0 & $-\frac{0}{0}$ & 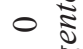 & 0 & $-\stackrel{0}{0}$ & & 0 & -5 & 08 & & & $0 \stackrel{N}{V}$ & 0 \\
\hline$n$ & & 4 & 1 & $0 \stackrel{0}{0}$ & $0 \$$ & 10 & $0 \stackrel{3}{3}$ & $1 \quad 0$ & D & 15 & 18 & 1 & 1 & & 1 & & 1 & \\
\hline$\checkmark$ & $\underset{2}{2} 0$. & 0 & $0 \leqslant$ & & -10 & 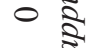 & & & 0 & $0 \vdots$ & & & & & & & & \\
\hline$m$ & 5 & $\Xi$ & $0 \Xi$ & $0 \frac{0}{0}$ & & -5 & $\sqrt{\mathfrak{\Xi}}$ & $0 \lesssim$ & $0 \leqq$ & $0 \sqrt{0}$ & $0 \sqrt{\frac{5}{3}}$ & 0. & $0 \cong$ & & 0 & & $0 \underset{\Xi}{\mathbb{2}}$ & \\
\hline$\sim$ & S 0 & $0 . \frac{2}{2}$ & 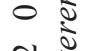 & & & 00 & & & 0 ఏ & & & $0 \Xi$ & & & $\begin{array}{lll}0 & 1 & 1\end{array}$ & & & 0 \\
\hline & $\bar{a} \quad \dot{a}$ & & & in & $\frac{\pi}{20}$ & & & m这 & $m \stackrel{0}{0}$ & & 党 & & & 这 & 过 & & $m$ 这 & \\
\hline
\end{tabular}




\begin{tabular}{|c|c|c|c|c|c|c|c|c|c|c|c|c|c|c|c|c|c|c|c|}
\hline $6-$ & & - & $\curvearrowright$. & - & - & a. & a. & - & 0 & $\sim$. & 0 & $\curvearrowright$. & a. & - & a. & 0 & $\sigma$. & - & 0 \\
\hline 60 & & 0 & $\sim$. & 0 & 0 & $\sim$. & a. & 0 & 0 & $\sim$. & 0 & $\sim$. & $\sigma$. & - & $\sim$. & - & $\sigma$. & - & - \\
\hline$n a$ & & 0 & 0 & 0 & 0 & 0 & 0 & 0 & 0 & ' & 0 & 0 & - & 0 & 0 & 0 & 0 & 0 & 0 \\
\hline$\infty$ & & 0 & 0 & 0 & 0 & 0 & 0 & 0 & 0 & 1 & 0 & 0 & 0 & 0 & 0 & 0 & 0 & 0 & 0 \\
\hline hr & & - & $N$ & $\sim$ & - & $\sim$ & 0 & 0 & $N$ & ' & $\sim$ & $N$ & $\sim$ & - & $\sim$ & $\sim$ & $\sim$ & $N$ & N \\
\hline$n 6$ & & 0 & $\pi$ & 0 & 0 & 0 & 0 & 0 & 0 & ' & - & - & 0 & 0 & - & - & - & - & - \\
\hline$n$ in & & - & - & - & 0 & 0 & $\sim$ & - & - & , & $N$ & $\sim$ & $N$ & - & - & - & $N$ & $N$ & $N$ \\
\hline$n \forall$ & & 0 & 0 & 0 & 0 & 0 & 0 & 0 & 0 & 0 & 0 & 0 & - & 0 & 0 & 0 & 0 & 0 & 0 \\
\hline$n m$ & & 0 & 0 & 0 & 0 & - & 0 & 0 & 0 & 0 & 0 & 0 & 0 & 0 & 0 & 0 & 0 & 0 & 0 \\
\hline$n \mathrm{~N}$ & & - & $N$ & $N$ & - & $\sim$ & 0 & 0 & $N$ & $\sim$ & $N$ & $N$ & $N$ & - & - & $N$ & $N$ & $N$ & $N$ \\
\hline$n-$ & & - & - & - & - & - & - & - & - & ' & $N$ & 0 & - & - & - & - & - & - & - \\
\hline in 0 & & - & 0 & - & - & 0 & 0 & 0 & - & $N$ & 0 & 0 & 0 & - & 0 & - & - & $\pi$ & 0 \\
\hline$\nabla a$ & & - & - & - & 0 & 0 & $N$ & - & - & 0 & 0 & $\sim$ & N & - & - & 0 & 0 & 0 & 0 \\
\hline$\nabla \infty$ & & $N$ & - & $\sim$ & - & - & $\sim$ & $N$ & - & 0 & - & - & - & - & - & - & - & - & - \\
\hline$\nabla r$ & & 0 & 0 & 0 & 0 & 0 & 0 & 0 & 0 & 0 & 0 & - & 0 & - & 0 & 0 & 0 & 0 & 0 \\
\hline+6 & & - & - & - & - & - & 0 & 0 & - & 0 & 0 & 0 & 0 & - & - & 0 & 0 & 0 & 0 \\
\hline$\nabla n$ & & 0 & 0 & 0 & 0 & 0 & 0 & 0 & 0 & 0 & - & - & - & 0 & 0 & 0 & 0 & 0 & 0 \\
\hline$\forall \forall$ & & 0 & 0 & - & - & - & - & 0 & 0 & $\sim$ & $N$ & $N$ & 0 & 0 & - & $N$ & $N$ & $N$ & $N$ \\
\hline$\nabla m$ & & 0 & 0 & 0 & 0 & 0 & 0 & 0 & 0 & 0 & 0 & 0 & 0 & 0 & 0 & a. & 0 & 0 & 0 \\
\hline$\nabla N$ & & 0 & 0 & 0 & - & 0 & - & - & - & - & 0 & 0 & - & - & - & a. & - & 0 & 0 \\
\hline$\nabla-$ & & 0 & 0 & 0 & 0 & 0 & 0 & 0 & 0 & 0 & 0 & 0 & 0 & 0 & 0 & $\sim$. & 0 & 0 & 0 \\
\hline+0 & & 0 & 0 & 0 & 0 & 0 & 0 & 0 & 0 & 0 & 0 & 0 & 0 & 0 & 0 & a. & 0 & 0 & 0 \\
\hline$m a$ & & 0 & 0 & 0 & - & 0 & 0 & 0 & - & 0 & 0 & - & - & - & 0 & a. & 0 & 0 & 0 \\
\hline$m \infty$ & & 0 & 0 & 0 & 0 & 0 & 0 & 0 & 0 & 0 & 一 & - & - & - & 0 & $\sim$. & 0 & 0 & 0 \\
\hline$m r$ & & - & - & - & 0 & 0 & $N$ & 0 & $N$ & 0 & $N$ & $N$ & 0 & $N$ & 0 & a. & 0 & 0 & 0 \\
\hline$m 6$ & & 0 & 0 & 0 & 0 & 0 & 0 & 0 & 0 & 0 & - & - & 0 & 0 & 0 & 0 & 0 & 0 & 0 \\
\hline$m i n$ & & 0 & 0 & 0 & 0 & 0 & 0 & 0 & $m$ & 0 & $N$ & 0 & $N$ & $N$ & - & $N$ & 0 & 0 & 0 \\
\hline$m \nabla$ & & - & - & - & 0 & - & - & - & - & $\sim$ & 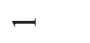 & - & - & - & - & - & 0 & 0 & 0 \\
\hline$m m$ & & - & - & - & - & - & - & - & - & - & - & - & - & - & 0 & - & - & - & 一 \\
\hline$m \sim$ & & - & 0 & 0 & - & - & 0 & 0 & 0 & 0 & 0 & 0 & 0 & 0 & 0 & - & 0 & 0 & 0 \\
\hline$m-$ & & 0 & 0 & 0 & 0 & - & 0 & 0 & 0 & - & - & - & - & - & 0 & - & 0 & 0 & 0 \\
\hline mo & & 0 & 0 & 0 & 0 & 0 & 0 & 0 & $m$ & 0 & $m$ & $m$ & $m$ & $m$ & 0 & 0 & 0 & 0 & 0 \\
\hline $\mathrm{Na}$ & & 0 & 0 & 0 & 0 & 0 & 0 & 0 & $\pi$ & 0 & 0 & - & 0 & - & 0 & 0 & 0 & 0 & 0 \\
\hline$\sim \infty$ & & 0 & - & 0 & 0 & 0 & 0 & 0 & - & 0 & $\nabla$ & $m$ & 6 & $m$ & 0 & 0 & - & 0 & 0 \\
\hline NT & & - & 0 & - & - & - & - & 0 & 0 & - & - & - & - & - & - & - & - & - & - \\
\hline$N G$ & & - & ' & - & - & - & - & ' & ' & - & ' & ' & 1 & ' & 0 & 0 & 0 & 0 & 0 \\
\hline N in & & - & 1 & 0 & - & 0 & 0 & ' & ' & 0 & I & 1 & I & ' & 0 & 0 & 0 & 0 & 0 \\
\hline$N \nabla$ & & 0 & ' & 0 & ' & 0 & 0 & ' & I & 0 & ' & 1 & ' & ' & 0 & 0 & 0 & 0 & 0 \\
\hline $\mathrm{Nm}$ & & - & , & 0 & - & 0 & 0 & , & I & 0 & ' & ' & , & , & 0 & 0 & 0 & 0 & 0 \\
\hline$N \sim$ & & $N$ & $N$ & $N$ & $N$ & 0 & $N$ & $N$ & $N$ & $m$ & 0 & $N$ & 0 & 0 & 0 & $\pi$ & 0 & 0 & 0 \\
\hline$N-$ & & $N$ & - & $\sim$ & $\sim$ & $N$ & $N$ & - & - & $N$ & 0 & 0 & $\pi$ & 0 & $N$ & $\sim$ & $\sim$ & $N$ & $N$ \\
\hline No & & 一 & - & - & 0 & - & - & - & - & - & 0 & - & - & - & 0 & - & 0 & $\pi$ & 0 \\
\hline$-a$ & & 0 & 0 & 0 & 0 & 0 & 0 & 0 & 0 & 0 & - & - & - & - & 0 & 0 & 0 & 0 & 0 \\
\hline$-\infty$ & & 0 & 0 & 0 & 0 & 0 & 0 & 0 & 0 & - & 0 & 0 & 0 & 0 & 0 & 0 & 0 & 0 & 0 \\
\hline$-r$ & & 0 & 0 & 0 & - & 0 & 0 & 0 & - & 0 & 0 & - & 0 & 0 & 0 & 0 & 0 & 0 & 0 \\
\hline-6 & & 0 & 0 & 0 & 0 & 0 & 0 & 0 & 0 & 0 & 0 & 0 & - & 0 & 0 & 0 & 0 & 0 & 0 \\
\hline$-n$ & & 0 & 0 & 0 & 0 & 0 & 0 & 0 & 0 & - & 0 & 0 & 0 & 0 & 0 & 0 & 0 & 0 & 0 \\
\hline$-\nabla$ & & 0 & 0 & 0 & 0 & 0 & 0 & 0 & 0 & 0 & 0 & 0 & 0 & 0 & 0 & 0 & 0 & 0 & 0 \\
\hline$-m$ & & - & - & - & - & - & - & - & - & 0 & 0 & 0 & 0 & 0 & - & - & 0 & 0 & 0 \\
\hline$-N$ & & 0 & 0 & 0 & - & 0 & 0 & 0 & - & - & 0 & 0 - & - & 0 & 0 & - & - & - & - \\
\hline-- & & 0 & 0 & 0 & 0 & 0 & 0 & 0 & 0 & - & - &.$- \Xi$ & 0 & 0 & 0 & 0 & 0 & 0 & 0 \\
\hline-0 & & 0 & 0 & 0 & 0 & 0 & 0 & 0 & 0 & 0 & 0 & $0 \ddot{2}$ & 0 & - & 0 & 0 & 0 & 0 & 0 \\
\hline a & & $0 \approx$ & $0 \tilde{y}$ & 0 & 0 & 0 & 0 & $0 . y$ & 0 & 0 & $\circ . \Xi$ & 0 & 0 & 0 & 0 & & 0 & 0 & 0 \\
\hline$\infty$ & & & 0 & 0 & 0 & 0 & 0 & $0 \stackrel{5}{\frac{2}{2}}$ & 0 & 0 & $0 \dot{1}$ & 0.5 & 0 & 0 & 0 & & & & 0 \\
\hline$r$ & & 0 & 0 & & 0 : & 0 & & 0. & & 0 & 0.2 & 0 & & & & 0 & $0: \frac{\pi}{\pi}$ & $0 \leqq$ & 0 \\
\hline 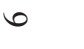 & & & 0 & & & 0 & & & & $0: \mathbb{Z}$ & & & & & & & & & 0 \\
\hline in & $\stackrel{\Xi}{\Xi}$ & & & $1 \stackrel{2}{\Xi}$ & ' & $-\div$ & , & & 1 & , $\mathbb{\sigma}$ & $0 \frac{5}{00}$ & $0^{\circ}$ & $0 \stackrel{5}{5}$ & & & 1 & 1 ప & 180 & \\
\hline$\checkmark$ & & 0 & -5 & $0 \overline{3}$ & 0 & - & 0 & 0 & 0 & $0 \cong$ & $-\cong$ & $-\approx$ & $-\approx$ & 0 & - & 0 & $0 \div$ & & \\
\hline m & & & 0. & & & & & & 0 & $-\delta$ & 0 రิ & $-\delta$ & -3 & & & & & & \\
\hline v & $\Xi$ & $0 \Xi$ & 0 ป & $0 \Xi$ & 0 క & 0 & & 0 : & 0.3 & & & & & & & & & $-\stackrel{1}{\Xi}$ & \\
\hline & 这 & $m$ 选 & $m$ 这 & $m$ 这 & $\sim \underbrace{5}$ & & & $m$ 这 & & & & & & & & & & & \\
\hline
\end{tabular}




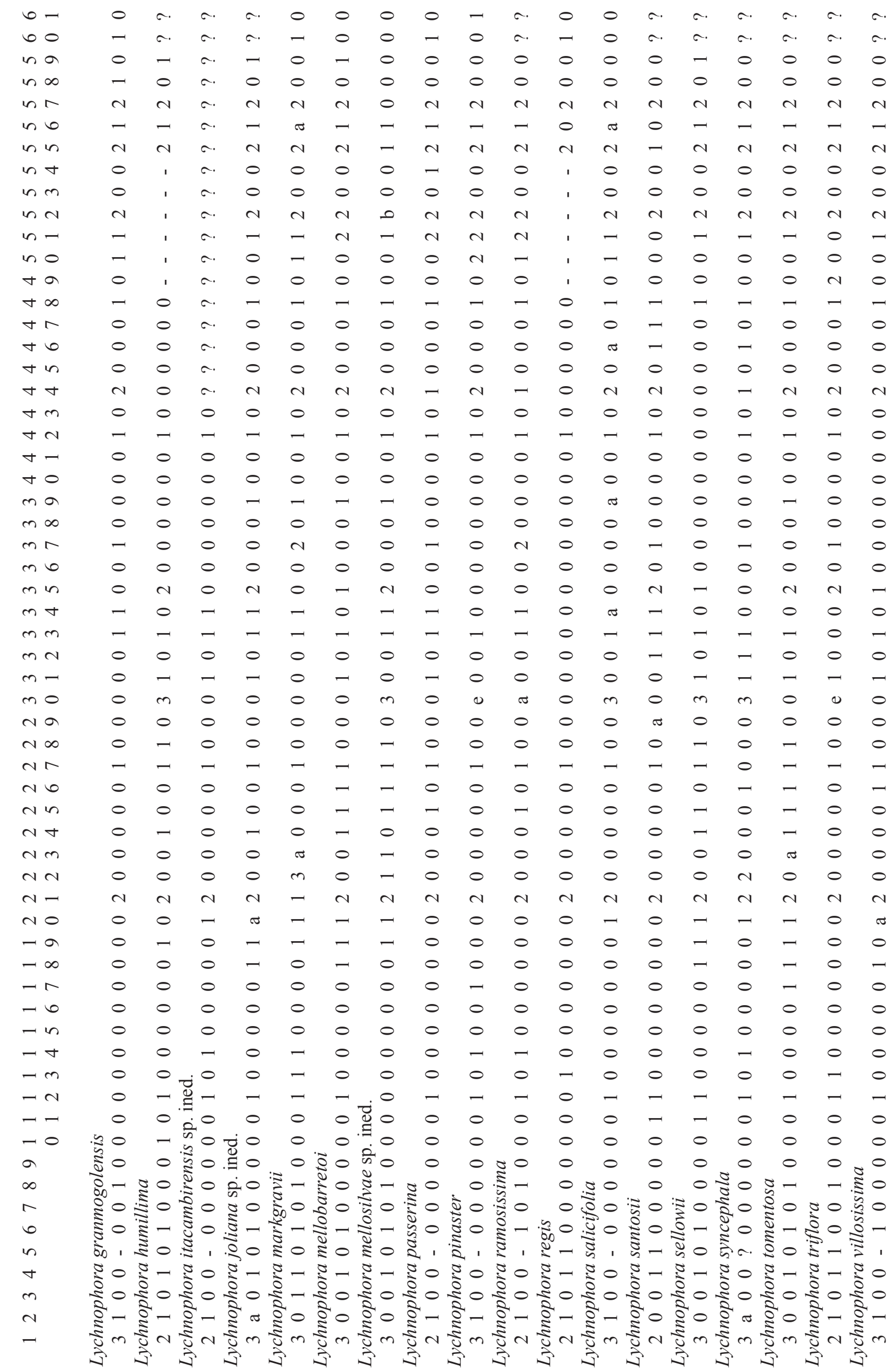




\begin{tabular}{|c|c|c|c|c|c|c|c|c|c|c|c|c|c|c|c|c|c|c|c|}
\hline $6-$ & & 0 & ๙. & a. & - & a. & a. & ๙. & a. & a. & $\sim$. & - & a. & ๙. & a. & 0 & $\sigma$. & $\sim$. & a. \\
\hline 60 & & 0 & $\sim$. & $\sigma$. & - & $\sigma$. & a. & a. & $\sigma$. & $\sigma$. & $\sigma$. & - & a. & $\sigma$. & ๙. & - & a. & a. & a. \\
\hline ra & & - & 0 & - & $\sim$ & $\sim$ & $N$ & $N$ & $N$ & 0 & $N$ & 0 & 0 & $N$ & - & 0 & - & - & 0 \\
\hline$n \infty$ & & 0 & 0 & 0 & 0 & 0 & 0 & 0 & 0 & 0 & 0 & 0 & 0 & 0 & 0 & - & - & - & 0 \\
\hline$n-$ & & $\sim$ & - & $N$ & 0 & 0 & 0 & 0 & 0 & - & $\pi$ & 0 & 0 & 0 & - & - & - & $N$ & - \\
\hline in 6 & & - & - & - & 0 & 0 & 0 & 0 & 0 & $\pi$ & $\pi$ & 0 & - & 0 & - & 0 & - & 0 & 0 \\
\hline$n$ in & & $N$ & 0 & $N$ & 0 & 0 & 0 & 0 & 0 & 0 & - & - & - & - & $\sim$ & $N$ & $N$ & $N$ & - \\
\hline$n+$ & & 0 & 0 & 0 & 0 & 0 & 0 & 0 & 0 & 0 & 0 & 0 & 0 & 0 & 0 & - & - & - & 0 \\
\hline$n m$ & & 0 & 0 & 0 & 0 & 0 & 0 & 0 & 0 & 0 & 0 & 0 & 0 & 0 & 0 & - & - & - & - \\
\hline$n \sim$ & & $\sim$ & - & $N$ & 0 & 0 & 0 & 0 & 0 & - & - & 0 & - & - & - & 0 & - & $N$ & 0 \\
\hline$n-$ & & - & - & - & - & - & - & - & - & - & - & - & - & - & - & - & 0 & 0 & 0 \\
\hline no & & $\pi$ & 0 & $\pi$ & 0 & 0 & 0 & 0 & 0 & 0 & 0 & 0 & 0 & 0 & 0 & 0 & 0 & 0 & 0 \\
\hline$\nabla a$ & & - & 0 & 0 & 0 & 0 & 0 & 0 & 0 & 0 & 0 & 0 & 0 & 0 & - & $N$ & $N$ & - & - \\
\hline$+\infty$ & & - & - & - & - & - & - & - & - & م & - & - & - & - & - & - & - & - & - \\
\hline$\nabla r$ & & 0 & 0 & 0 & - & - & - & - & - & 0 & - & 0 & - & - & - & 0 & 0 & 0 & 0 \\
\hline$\nabla 6$ & & 0 & 0 & 0 & - & - & - & - & - & - & 0 & 0 & 0 & 0 & 0 & 0 & 0 & 0 & 0 \\
\hline$\nabla n$ & & 0 & 0 & 0 & 0 & 0 & 0 & 0 & 0 & 0 & 0 & 0 & 0 & 0 & 0 & 0 & 0 & 0 & 0 \\
\hline$\nabla \forall$ & & $N$ & $N$ & $N$ & $\sim$ & $N$ & $\sim$ & $\sim$ & $\sim$ & $\sim$ & $\sim$ & $N$ & $\sim$ & $\sim$ & $\sim$ & $N$ & 0 & 0 & 0 \\
\hline$\nabla m$ & & 0 & 0 & 0 & 0 & 0 & 0 & 0 & 0 & 0 & 0 & 0 & 0 & 0 & 0 & 0 & 0 & 0 & 0 \\
\hline$\nabla C$ & & 0 & - & 0 & - & - & - & - & - & - & - & - & - & - & - & 0 & 0 & 0 & 0 \\
\hline$\nabla-$ & & 0 & 0 & 0 & - & - & - & - & - & 0 & 0 & 0 & 0 & 0 & 0 & 0 & 0 & 0 & 0 \\
\hline+0 & & 0 & 0 & 0 & 0 & 0 & 0 & 0 & 0 & 0 & 0 & 0 & 0 & 0 & 0 & 0 & 0 & 0 & 0 \\
\hline$m a$ & & - & - & 0 & - & - & - & - & - & - & - & - & - & - & - & - & - & - & - \\
\hline$m \infty$ & & 0 & 0 & 0 & 0 & 0 & 0 & 0 & 0 & 0 & 0 & 0 & 0 & 0 & 0 & 0 & 0 & 0 & 0 \\
\hline$m r$ & & $N$ & 0 & $\sim$ & 0 & 0 & - & 0 & 0 & 0 & 0 & 0 & 0 & 0 & 0 & 0 & 0 & 0 & 0 \\
\hline$m b$ & & 0 & 0 & 0 & 0 & 0 & 0 & 0 & 0 & 0 & 0 & 0 & 0 & 0 & 0 & 0 & 0 & 0 & 0 \\
\hline$m$ in & & - & $N$ & - & $N$ & $N$ & $N$ & $N$ & $N$ & 0 & $N$ & $N$ & $N$ & $N$ & $N$ & $N$ & - & - & - \\
\hline$m \nabla$ & & - & $N$ & 0 & 0 & - & - & - & 0 & - & - & - & - & $\pi$ & $\pi$ & - & - & - & - \\
\hline$m m$ & & - & - & 0 & - & - & - & 0 & - & - & - & - & - & - & - & - & - & - & - \\
\hline$m \sim$ & & 0 & 0 & 0 & 0 & 0 & 0 & 0 & 0 & 0 & - & 0 & - & - & - & - & - & - & - \\
\hline$m-$ & & 0 & - & 0 & 0 & 0 & - & 0 & - & 0 & - & - & - & - & - & - & - & - & - \\
\hline mo & & $m$ & $m$ & - & $m$ & $m$ & $m$ & $m$ & $m$ & - & 0 & 0 & $m$ & $m$ & 0 & $m$ & 0 & 0 & $m$ \\
\hline $\mathrm{Na}$ & & 0 & - & 0 & 0 & - & 0 & 0 & $\pi$ & 0 & 0 & 0 & 0 & 0 & 0 & 0 & - & 0 & 0 \\
\hline$\sim \infty$ & & - & $\nabla$ & - & $\sim$ & $N$ & $N$ & $N$ & $m$ & 0 & 0 & - & $N$ & - & 0 & - & $N$ & - & - \\
\hline $\mathrm{NT}$ & & 0 & 0 & 0 & - & 0 & - & 0 & 0 & - & - & $\neg$ & - & - & - & 0 & 0 & 0 & 0 \\
\hline$N G$ & & ' & ' & ' & ' & ' & 1 & ' & ' & - & - & - & - & 0 & - & ' & ' & I & I \\
\hline N n & & I & I & , & I & ' & I & I & I & - & - & - & 0 & - & - & , & I & ' & I \\
\hline$N \nabla$ & & ' & ' & 1 & ' & ' & ' & ' & ' & 0 & $\pi$ & 0 & 0 & 0 & 0 & ' & ' & ' & ' \\
\hline $\mathrm{Nm}$ & & I & 1 & I & I & I & I & I & I & 0 & $\pi$ & - & 0 & $\pi$ & - & I & , & I & I \\
\hline$\sim \sim$ & & 0 & 0 & 0 & 0 & $m$ & $m$ & 0 & $m$ & 0 & 0 & 0 & 0 & 0 & 0 & 0 & $N$ & 0 & 0 \\
\hline $\mathrm{N}-$ & & 0 & 0 & 0 & - & 0 & 0 & - & $\pi$ & $N$ & $\sim$ & $N$ & $\sim$ & $\sim$ & $N$ & 0 & - & - & 0 \\
\hline No & & 0 & 0 & 0 & - & - & - & - & - & - & - & - & - & - & - & 0 & 0 & 0 & 0 \\
\hline$-a$ & & 0 & 0 & 0 & - & - & - & - & - & - & - & - & - & - & - & 0 & 0 & 0 & 0 \\
\hline$-\infty$ & & 0 & 0 & 0 & 0 & 0 & 0 & 0 & 0 & 0 & 0 & - & 0 & 0 & 0 & 0 & 0 & 0 & 0 \\
\hline$-r$ & & 0 & 0 & 0 & 0 & 0 & 0 & 0 & 0 & 0 & 0 & - & 0 & 0 & 0 & 0 & 0 & 0 & 0 \\
\hline-6 & & 0 & 0 & 0 & 0 & 0 & 0 & 0 & 0 & 0 & 0 & 0 & 0 & 0 & 0 & 0 & 0 & 0 & 0 \\
\hline$-n$ & & 0 & 0 & 0 & 0 & 0 & 0 & 0 & 0 & 0 & 0 & 0 & 0 & 0 & 0 & 0 & 0 & 0 & 0 \\
\hline$-\forall$ & & - & 0 & 0 & 0 & 0 & 0 & 0 & 0 & - & 0 & 0 & 0 & 0 & 0 & 0 & 0 & 0 & 0 \\
\hline$-m$ & & 0 & 0 & 0 & 0 & 0 & 0 & 0 & 0 & -7 & - & - & - & - & 0 & - & - & - & - \\
\hline$-N$ & & - & - & - & 0 & 0 & 0 & 0 & 0 &.$- \Xi$ & - & - & - & - & - & - & - & - & - \\
\hline-- & & 0 & - & 0 & 0 & 0 & 0 & 0 & 0 & 0 & 0 & 0 & 0. & 0 & 0 & 0 & - & 0 & 0 \\
\hline-0 & & & $0: 3$ & 0 & 0 & 0 & 0 & 0 & 0 & 0 & 0 & 0 & $0 . \tilde{J}$ & 0 & 0 & 0 & & 0 & 0 \\
\hline$a$ & & & $0 \Omega$ & 0 & - & - ن & - & - & - & $0 \$$ & 0. & 0 & 0 & 0 : & 0 & 0 & $0 . \Xi$ & ○ ن & 0 \\
\hline$\infty$ & $\tilde{2}$ & 0 & 0 ర్ల & 0 & 0 & $0 . \Xi$ & & ○ प्ष्ठ & & $0 . \tilde{N}$ & & & & & 0 & 0 & $0 \dot{0}$ & 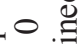 & 0 \\
\hline r & 0 & & 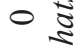 & 0 & 0. & 0 & 0 & 0.7 & 07 & $0 \frac{\vec{J}}{00}$ & & & 0 & & & 0 & $-\frac{1}{2}$ & & \\
\hline 6 & 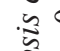 & & 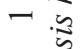 & 0. & 0 站 & 0 & 0 & 00 & 0 & - & 0.7 & & 0 & 0 & $0 . \mathbb{2}$ & & & 0.0 & 0 \\
\hline$n$ & & & & & & 0 & & & & & & & & & & & & & - \\
\hline $\begin{array}{l}\nabla \\
m \\
m\end{array}$ & $=$ & & & & & & & & $\overline{0}$ & & & & & & & & & & \\
\hline N & & -5 & & $\pi \cdot \frac{\pi}{\tilde{y}}$ & 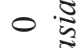 & $0 \cdot \sqrt[3]{3}$ & 0 & 0.5 & 0. & & & & $0 \$$ & & & & & $0 \frac{8}{1}$ & \\
\hline & & & & & & & & & & & & & & & & & & 40 & \\
\hline
\end{tabular}




\begin{tabular}{|c|c|c|c|c|c|c|c|c|c|}
\hline $0-$ & & $\sigma$. & 0 & $\sigma$. & 一 & $\sim$. & ๙. & $\sigma$. & 0 \\
\hline 60 & & a. & - & $\sigma$. & - & $\sigma$. & $\sigma$. & $\sigma$. & - \\
\hline ra & & - & - & - & - & - & - & 0 & - \\
\hline$\infty$ & & - & - & - & - & - & - & 0 & 0 \\
\hline$n \pi$ & & - & 0 & 0 & - & $N$ & $\sim$ & 0 & $N$ \\
\hline$n 6$ & & 0 & 0 & 0 & - & $\pi$ & 0 & 0 & 0 \\
\hline$n$ in & & $\sigma$ & 0 & 0 & $N$ & $N$ & $N$ & $N$ & $N$ \\
\hline$n \nabla$ & & - & - & - & ' & 0 & - & 0 & - \\
\hline$n m$ & & - & - & - & I & 0 & 0 & 0 & 0 \\
\hline$n \mathrm{~N}$ & & - & 0 & 0 & 1 & $N$ & $\sim$ & $N$ & $N$ \\
\hline$n-$ & & 0 & - & - & I & - & 0 & - & 0 \\
\hline no & & 0 & 0 & 0 & ' & 0 & 0 & 0 & 0 \\
\hline$\forall a$ & & $\pi$ & 0 & 0 & ' & 0 & $\sim$ & 0 & $N$ \\
\hline$+\infty$ & & - & $N$ & $\sim$ & 0 & - & - & - & - \\
\hline$\nabla r$ & & 0 & 0 & 0 & - & - & 0 & 0 & 0 \\
\hline$\nabla \sigma$ & & 0 & - & 0 & $\pi$ & - & 0 & - & 0 \\
\hline$\nabla n$ & & 0 & 0 & 0 & 0 & 0 & - & 0 & - \\
\hline$\nabla \forall$ & & 0 & 0 & 0 & 0 & 0 & 0 & 0 & 0 \\
\hline$\nabla m$ & & 0 & 0 & 0 & 0 & 0 & ๙. & 0 & 0 \\
\hline$\nabla N$ & & 0 & - & - & - & - & $\sigma$. & 一 & - \\
\hline$\nabla-$ & & 0 & 0 & 0 & 0 & 0 & $\sigma$. & 0 & 0 \\
\hline$\checkmark 0$ & & 0 & 0 & 0 & 0 & 0 & 0 & 0 & 0 \\
\hline$m a$ & & 0 & 0 & 0 & 0 & - & - & - & - \\
\hline$m \infty$ & & 0 & 0 & 0 & 0 & 0 & - & 0 & - \\
\hline$m r$ & & 0 & 0 & 0 & 0 & 0 & 0 & 0 & 0 \\
\hline$m o$ & & 0 & 0 & $\sigma$. & 0 & 0 & 0 & 0 & 0 \\
\hline$m i n$ & & 0 & - & $\sigma$. & $N$ & $N$ & $N$ & - & $N$ \\
\hline$m \nabla$ & & $\varpi$ & - & a. & $N$ & $\sim$ & - & - & - \\
\hline$m m$ & & - & - & ๙. & 0 & 0 & - & - & - \\
\hline$m \sim$ & & - & 0 & $\sigma$. & 0 & 0 & 0 & 0 & 0 \\
\hline$m-$ & & - & - & $\sigma$. & 0 & 0 & - & 0 & - \\
\hline$m o$ & & $m$ & $m$ & $\sim$. & $n$ & $m$ & $m$ & 0 & $m$ \\
\hline $\mathrm{Na}$ & & 0 & - & - & - & - & 0 & 0 & 0 \\
\hline$\sim \infty$ & & $N$ & 0 & ๙. & 0 & $a$ & $m$ & - & 0 \\
\hline$N-$ & & 0 & - & - & - & 0 & - & 0 & - \\
\hline$\sim \sigma$ & & 1 & 0 & 0 & ' & ' & 1 & 1 & ' \\
\hline$N$ in & & ' & 0 & 0 & ' & I & I & ' & I \\
\hline$\sim \nabla$ & & ' & 0 & 0 & ' & ' & ' & ' & I \\
\hline$N m$ & & 1 & 0 & 0 & I & 1 & ' & 1 & I \\
\hline$\sim N$ & & 0 & 0 & 0 & - & - & 0 & $m$ & 0 \\
\hline$N-$ & & 0 & $\sim$ & $\sim$ & - & - & - & - & $\pi$ \\
\hline NO & & 0 & $\pi$ & $\pi$ & - & - & - & - & - \\
\hline$-a$ & & 0 & - & $\neg$ & - & - & - & 0 & - \\
\hline$-\infty$ & & 0 & - & 0 & 0 & 0 & 0 & 0 & 0 \\
\hline$-r$ & & 0 & - & 0 & 0 & 0 & 0 & 0 & 0 \\
\hline-6 & & 0 & 0 & 0 & 0 & 0 & - & 0 & - \\
\hline$-n$ & & 0 & 0 & 0 & 0 & 0 & 0 & 0 & 0 \\
\hline$-ナ$ & & 0 & 0 & 0 & 0 & 0 & 0 & 0 & 0 \\
\hline$-m$ & & - & 0 & 0 & 0 & 0 & 0 & - & 0 \\
\hline$-\mathrm{N}$ & & - & - & - & 0 & 0 & - & 0 & - \\
\hline-- & & 0 & 0 & 0 & 0 & 0 & - & 0 & - \\
\hline-0 & D्త & 0 & 0 & - & 0 & 0 & 0 & 0 & 0 \\
\hline$a$ & & & 0 & 0 & 0. & 0 & 0 & - & 0 \\
\hline$\infty$ & & & $0 \circlearrowright$ & 0 & $0: \widetilde{y}$ & 0 & 0 & 0 & 0 \\
\hline$r$ & & - & $0^{\circ}$ & 0 & 0 క & E & 0 & 0 & 0 \\
\hline 6 & \pm & 0 & - & 0 & $E-$ & 00 & $0 \%$ & $0 \stackrel{2}{0}$ & - \\
\hline n & & - & 0 & 08 & & 0. & $00 \stackrel{2}{\Omega}$ & $0 \cdot \frac{\sqrt{3}}{3}$ & 0 \\
\hline$\nabla$ & 5 & - & -7 & - & - & -1 & & $-\bar{\Xi}$ & - \\
\hline$m$ & & 0 & 0.3 & 0 & 0 & & & & - \\
\hline$v$ & $\overrightarrow{0}$ & $0 \underset{\Xi}{\square}$ & $-\frac{\tilde{0}}{5}$ & -2 & Sू & & & 0 ป & 0 \\
\hline- & ¿ & & $-\frac{2}{2}$ & & & & & $N$ & \\
\hline
\end{tabular}


Fig. S1. Strict consensus tree of 10,000 equally most parsimonious trees based on the chloroplast ( $n d h \mathrm{~F}$ and $r p l 32-t r n \mathrm{~L}$ ) analysis. Tree length $=132$ steps, $\mathrm{CI}=0.66, \mathrm{RI}=0.83$. Jackknife values $(\geq 50 \%)$ are shown above the nodes. 


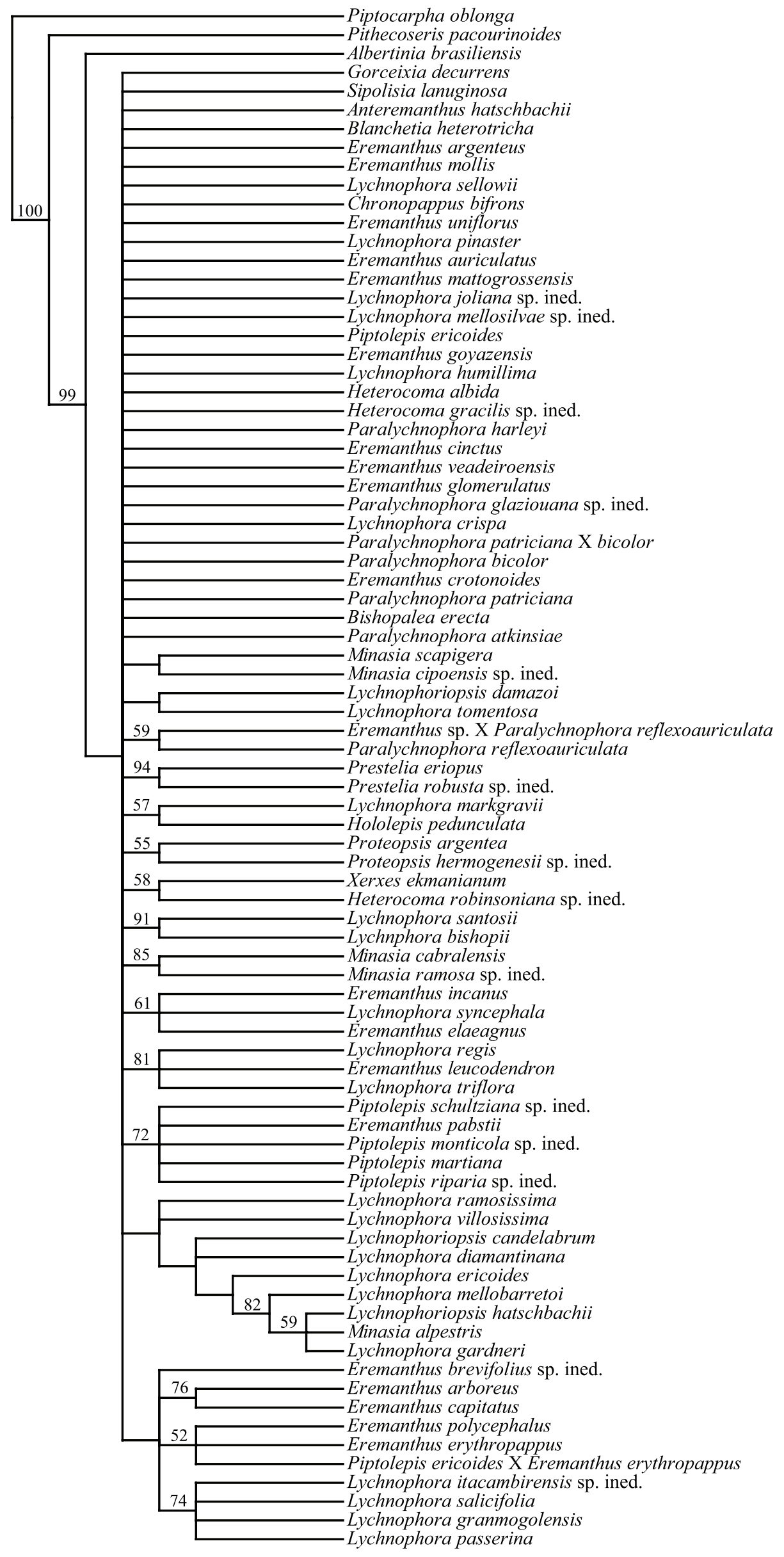


Fig. S2. Bayesian inference phylogram based on the combined analysis (all molecular data). Bayesian posterior probabilities $(\geq 0.9)$ are shown above the nodes. 


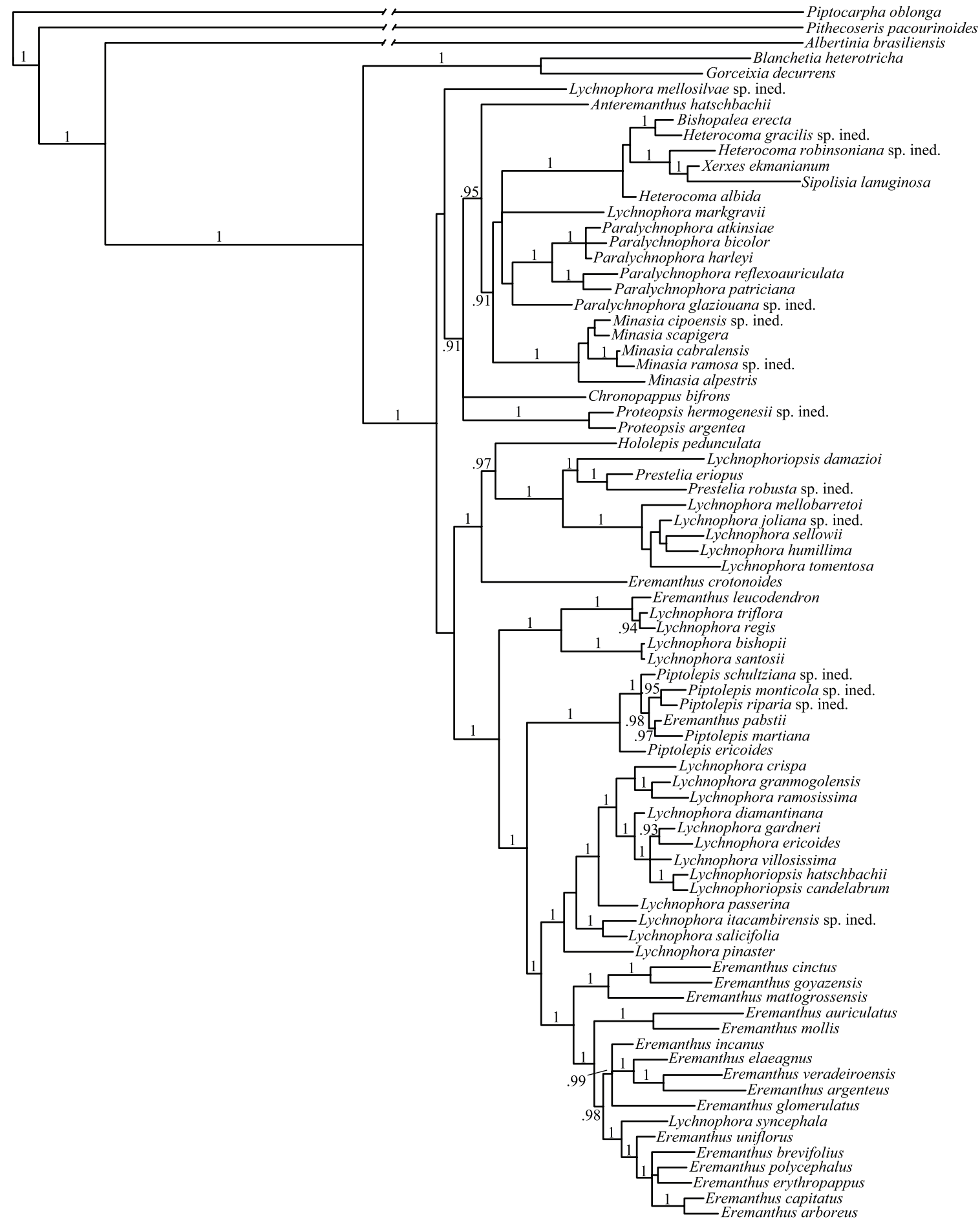

0.1 
Fig. S3. Bayesian inference phylogram based on the combined analysis with morphology and all molecular data. Bayesian posterior probabilities $(\geq 0.9)$ are shown above the nodes. 


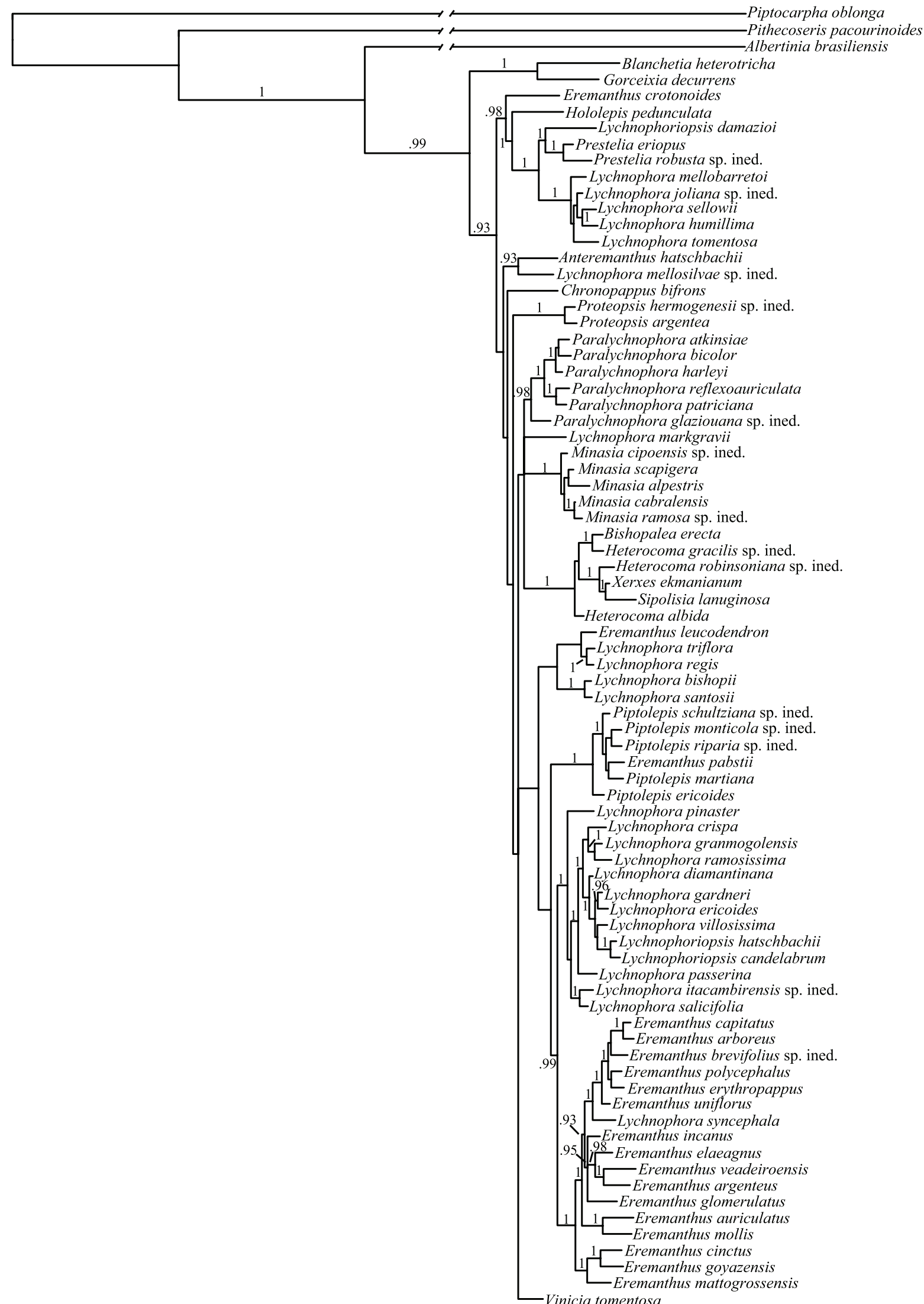





\section{CHAPTER 3}

Cladistic analysis of American Vernonieae and Lychnophorinae

(Asteraceae): contributions from a hierarchical homology approach 

Cladistic analysis of American Vernonieae and Lychnophorinae (Asteraceae): contributions from a hierarchical homology approach

Benoît Loeuille ${ }^{1}$, René Zaragüeta-Bagils ${ }^{2}$ and José R. Pirani ${ }^{1}$

${ }^{1}$ Laboratório de Sistemática Vegetal, Departamento de Botânica, Instituto de Biociências da Universidade de São Paulo, Rua do Matão, 277, CEP: 05508-090, São Paulo, SP, Brasil. e-mail: benoit_loeuille@yahoo.fr

${ }^{2}$ Laboratoire "Informatique et systématique”, UMR 5143 CNRS, université Pirre-et-MarieCurie (Paris-6), 12, rue Cuvier, 75005 Paris, France. 



\begin{abstract}
In order to compare the influence of a hierarchical representation of homology hypotheses on phylogenetic inference, two morphological datasets of American Vernonieae and Lychnophorinae (Asteraceae) have been analyzed using parsimony and three-item analysis. The results widely diverged not only in terms of topology but also in number of homologies recovered. The three-item analysis appears to retrieve a higher information content from the original datasets. Independently of the chosen approach to phylogenetic inference, all American Vernonieae emerged as paraphyletic or polyphyletic. A close relationship between the subtribe Sipolisiinae and some genera of Piptocarphinae (Blanchetia and Gorceixia) with the Lychnophorinae was found, as well as a the position of Soaresia within Elephantopinae rather than within Chrestinae. Similarly, both methods rejected the monophyly of most Lychnophorinae genera as currently circumscribed, except Minasia and Piptolepis. Nonetheless, the already acknowledged high level of homoplasy in Vernonieae morphological data is here confirmed and most of the clades are not supported by synapomorphies. Face to such an impressive extent of convergence, especially for characters whose adaptative value is uncertain (e.g., style basal node and other microcharacters), we stress the need of more, detailed morphological studies, in order to be able to formulate more robust homology hypotheses.
\end{abstract}

Keywords Compositae; phylogenetic inference; three-item analysis; parsimony; homoplasy 



\section{Introduction}

Systematics has been traditionally defined as 'the scientific study of the kinds and diversity of organisms and of any and all relationships among them' (Simpson 1961). In order to store efficiently the information (characters) collected about organisms and to make predictions, natural classifications are built through the discovery of synapomorphies. Most systematists consider synapomorphy as synonymous with homology (Patterson 1982; Stevens 1984; de Pinna 1991). The role of homology in systematics is summarized by Nelson (1989): 'for cladistics, discovery of apomorphies and discovery of taxa are one and the same'. Nelson (1994) extended the idea of the cladistic relationship to the data themselves, gathering both homology aspects distinguished in particular by Patterson (1982): the transformational aspect dealing with homologues and their modification, and the taxic aspect dealing with their implied relationships (Williams 2004). In other words, the taxic approach is concerned with monophyly of groups and the transformational approach with change not necessarily implying grouping (Patterson 1982). To sum up, the following equation may be drawn: synapomorphy = homology $=$ monophyly $=$ taxon.

Taxic and transformational homology approaches have sometimes been understood as different points of view (Patterson 1982; Rieppel 1988; Carine and Scotland 1999; Scotland 2000a,b). The latter author considered its modified 3ia as a strict taxic approach (Scotland 2000a) and standard analysis as compatible with a transformational view of homology. Williams (2004) argued that by understanding homology as a relationship this distinction is no longer relevant and cladistic homology embraces both aspects. This discussion echoes a more general philosophical problem: the general problem of change: 'How is change possible ? - logically possible, that is ? How can a thing change without losing its identity? If it remains the same, it does not change; yet if it loses its identity, then it is no longer that thing which has changed' (Popper 1998). Pre-Socratic Greek philosophers have formulated this paradox 26 centuries ago and proposed two solutions. For Heraclitus there are no stability in his world, 'everything is in flux, and nothing is at rest', things are not really things, they are processes and the apparent stability of things is merely due to the laws, the measures, which the processes in our world are subject to (Popper 1998). Parmenides offers the opposite solution in form of a proof that movement is impossible: (1) only being is (only what is, is); (2) the nothing, the non-being, cannot be; (3) the non-being would be the absence of being: it would be the void; (4) there can be no void; (5) the world is full: a block and (6) the movement (change) is impossible (Popper 1998). One of his premises is obviously wrong since we can observe movement and change. Nowadays, scientists understand the biological reality as a Heraclitean world (transformational homology approach). Notwithstanding, in order to study and make intelligible this reality the solution consists on to formalize the continuous change into descriptive concepts such as a hierarchy, a parmenidean world (taxic homology approach), i.e. to see the homology as a 
relationship (Nelson 1994).

Cladistic relationships are best represented by hierarchies (Brady 1982). Cao et al. (2007) have shown that characters necessarily need to have a hierarchical structure, for the consistency of the method, to produce a classificatory structure (i.e., a hierarchy which is mathematically isomorphic with a rooted tree). However, most phylogenetic inference (parsimony, maximum likelihood, etc.) methods are based only on a transformational homology approach, where the homology hypotheses are represented in a data matrix, and produce an unrooted tree. Several authors (Williams and Ebach 2006, Cao et al. 2007) have shown that such data matrices do not contain homology hypotheses (sensu Nelson 1994), i.e. they are unable to represent nested relationships. Consequently, these methods impose a hierarchy which could only be justified by an untenable hierarchical, branching model of evolution (by example Lee 2002) whereas the universality of the Tree of Life metaphor is questioned (Rieppel 2010).

Three-item analysis (3ia) is a phylogenetic method that uses hierarchical hypotheses of homology (Nelson and Ladiges 1991a,b, 1992; Nelson and Platnick 1991). Early critics concerning the addition of question marks (Kluge 1993) have been answered by Nelson and Ladiges (1993), Zaragüeta-Bagils and Bourdon (2007), and especially by the development of a computer program that uses no matrix (LisBeth, Ducasse et al. 2008). Other critics regarding the treatment of reversals (Kluge 1993, 1994; Farris 1997) were refuted by Siebert and Williams (1998) notably by showing the lack of evidence and observational support of the Farris and Kluge's claims. 3ia has been defended and compared with the usual form of parsimony analysis (herein referred to as standard analysis) (Carine and Scotland 1999; Scotland 2000a, b; Williams 2000 ; Williams and Humphries 2003; Nelson et al. 2003; Zaragüeta-Bagils and Bourdon 2007) and 3ia seems to bring solutions to several problems of standard analysis, like the treatment of missing data and inapplicable data (see Zaragüeta-Bagils and Bourdon 2007), or simply, some problems become irrelevant in 3ia, such as outgroups rooting (Barriel and Tassy 1998) and optimization (Platnick et al. 1996; Williams and Siebert 2000; Nelson 2004). As noted by Marques (2005), it is probably a secondary problem whether or not 3ia is a superior method to standard analysis, or if it should be considered as an improvement of cladistics or something else; more important is the possibility to treat homology hypotheses with hierarchical representation.

The use of 3ia for character data in empirical studies has still a limited repercussion in the scientific community, although in the published studies (Patterson and Johnson 1995; Udovicic et al. 1995; Williams 1996; Ladiges et al. 1999; Echternacht 2007) 3ia results differ from the ones obtained through standard analysis, usually finding less trees and a more resolved consensus tree.

In this study, we aimed to compare the influence of a hierarchical representation of homology and hypotheses on phylogenetic inference, addressing to morphological datasets of American Vernonieae and Lychnophorinae (Asteraceae) under parsimony and 3ia criteria. The Vernonieae is one of the major tribes of the largest family of flowering plants, the sunflower family (Compositae or Asteraceae) with ca. 1100 species placed into 129 genera (Keeley et al. 2007; 
Keeley and Robinson 2009). They are distributed in two main biodiversity centers (Brazil and Africa). If the delimitation of the tribe has posed few problems (but see Funk and Chan 2009 for the position of Distephanus), much more problematical are subtribal classification and delimitation of the genera (Bremer 1994). The only published cladistic analysis of Vernonieae based on morphological data is restricted to the genus Vernonia (Keeley and Turner 1990), in which the authors reported repeated parallelisms and reversals within a number of characters previously used to distinguish Vernonia taxa at all levels. This high level of homoplasy makes the Vernonieae to be considered among the most refractory of tribes to elucidating systematic relationships (Keeley etal.2007). Consequently, Keeley and Robison(2009) later stated that 'there are no morphological characters that can be used for tribal-wide phylogenetic reconstruction' but also noted that 'studies (...) have revealed useful combinations of characters (...) which can be used with success to delimit subtribes genera and species within geographically defined regions'. The subtribe Lychnophorinae (Asteraceae: Vernonieae) is currently the subject of phylogenetic studies (based on molecular and morphological data) aiming to understand better its relationships with the other American Vernonieae subtribes and to test its monophyly (see Chapter 1; Loeuille et al. in prep.) as well as delimiting monophyletic genera in this group and confirming or refuting the generic assignment of several species (see Chapter 2; Loeuille et al. in prep.). These studies confirmed the high level of homoplasy of morphological data, but also make us wonder if it is not partially linked to the application of a character model not general enough which discards evidence (Carpenter 1994; Williams and Siebert 2000; Nelson 2004). Marques (2005) pinpointed that the character model involved in 3ia is more tolerant notably by presuming that character evolution does not assume linearity.

\section{Materials and methods}

Outgroup choice and taxon sampling

Choice of outgroups (for standard analyses) and taxon sampling are detailed in Loeuille et al, in prep. (see Chapter 1 and 2). As no outgroup is used in 3ia and in order to minimize the difference between the datasets, only one outgroup was used in both standard analyses (Moquinia racemosa for Matrix 1 and Piptocarpha oblonga for Matrix 2).

Morphological data

Examination of herbarium specimens (Electronic Supplementary 5) and field observations initially provided 79 characters for the matrix 1 (American Vernonieae taxa), but exclusion of autapomorphic and polymorphic characters reduced the number to 57 qualitative characters and one quantitative character (florets number per capitulum), which are listed in Table 1, and compiled on a matrix (Electronic Supplementary Appendix 1). Similarly, 100 characters were 
initially obtained for the matrix 2 (Lychnophorinae taxa) and then reduced to 60 qualitative characters and one quantitative character (florets number per capitulum), which are listed in Table 2, and compiled on a matrix (Electronic Supplementary Appendix 2).

The only one quantitative character obtained has been coded using the gap weighting method of Thiele (1993) in ten states. Garcia-Cruz and Sosa (2006) have shown that this method performs better in recovering phylogenetic signal than other proposed methods for coding quantitative characters. Detailed explanations of the character sampling and coding are provided in Loeuille in Appendices 1 and 2. For the standard analysis, guidelines given by Hawkins (2000) were followed. Hawkins et al. (1997) have shown theoretical advantages of missing data approaches over multistate ones in the standard analysis context. For the 3ia, the same matrix was converted into the format proposed by Cao et al. (2007) by adding an additional row with the hierarchy of character states given in parentheses (Electronic Supplementary Appendices 3 and 4). Inapplicable data are represented by the plesiomorphic state and polymorphic data by the apomorphic state (i.e., the informative state) (Zaragüeta-Bagils and Bourdon 2007). Some characters have been represented differently in standard and three-item matrices (for details see Appendices 1 and 2).

Parsimony analyses

Parsimony uninformative characters were excluded from the analyses. Heuristic searches were conducted using NONA (Goloboff 1999) spawned by Winclada (Nixon 1999-2002). Treebisection-reconnection (TBR) swapping on Wagner trees were conducted from 10,000 random addition sequences with 20 trees held in each replicate initiations expanding the memory to 1,000,000 to do further TBR. A strict consensus tree was constructed. To increase the likelihood of exploring all possible tree-islands, an additional search strategy was applied: the parsimony ratchet procedure (Nixon 1999). Ten independent ratchet searches with 400 iterations each were performed, the results were combined and a strict consensus tree constructed after applying the commands "hard collapse unsupported nodes in all trees" and "keep best only". The two strict consensus trees obtained were then compared.

Three-item analyses

The three-items statements and their fractional weights were computed with LisBeth 1.0 (Ducasse et al. 2008) and heuristic searches with PAUP* (versão 4.0b10, Swofford 2002). Tree-bisection-reconnection (TBR) swapping on Wagner trees were conducted from 60 random addition sequences with 20 trees held in each replicate initiations. The large number of threeitems statements (e.g., 170,571 produced from the matrix 1) severely limited the number of replicates conducted (e.g., each replicate lasts about 15 and 24 hours respectively from matrix 1 and 2). In order to increase the exploration of more tree-islands, we ran separately four heuristic 
searches of 15 random addition sequences. An intersection tree (Cao et al. 2009) is computed with LisBeth from the most parsimonious trees obtained. The command 3iaout from LisBeth was used to assign a status of homology (if all informative states are synapomorphies) or homoplasy (if at least one state is not a homolog) to each character (Ducasse et al. 2008).

Standard analyses and 3ia are two different approaches to phylogenetic inference and comparison between indices (RI, CI, etc.) and branch support obtained with each method would be irrelevant and therefore branch support were not computed.

\section{Results}

Matrix 1 - American Vernonieae taxa

\section{Topologies}

The results of the standard analysis are given in Fig. 1 and Table 3 and those of the 3ia in Fig. 2 and Table 3. The topology of the strict consensus tree of the standard analysis differs widely from the topology of the intersection tree of the 3ia, in particular concerning the higher levels clades. In both analyses, none of American Vernonieae subtribes as currently circumscribed are monophyletic. Noteworthy is the basal position of the taxa Critoniopsis and Piptocarpha (subtribe Piptocarphinae) with Anteremanthus and Hololepis (clade A, Fig. 1) in the standard analysis, whereas the same group of taxa emerges as sister-group of the derived Lychnophorinae clade (clade E, Fig. 2) in 3ia. In both analyses, the subtribe Sipolisiinae (minus Hololepis in the standard analysis) is nested within the Lychnophorinae clade (clade E) as well as Blanchetia and Gorceixia. However, in the standard analysis three genera (Minasia, Prestelia and Proteopsis) emerge outside of this clade, while in the 3ia Proteopsis appears in a basal position. Most taxa of Chrestinae form a clade (clade D) with the exception of Soaresia, which is found more closely related to the Elephantopinae and Rolandra (clade C) (in both analyses), and in the standard analysis Chresta speciosa emerges in the Lychnophorinae clade (clade E). Most Lepidaploinae taxa are grouped in the clade B sister to the Chrestinae/Elephantopinae clade in the 3ia and two Vernoniinae genera (Vernonia and Vernonanthura) are nested within the Lepidaploinae clade. The Lepidaploinae do not form a clade in the standard analysis.

\section{Homologies}

In the standard analysis, five homologies (as exclusive apomorphies) passed the congruence test. Piptocarpha has for synapomorphy the presence of a short thick column on the receptacle (character 26). A large clade (not associated to any described taxonomic group) is defined by lophate pollen (character 39). Presence of geminate trichomes groups Blanchetia, Chronopappus and Sipolisiinae (minus Hololepis), the latter subtribe having for synapomorphy the phytomelanin in the cypselae walls and the last synapomorphy is the paleae of Bishopalea 
and Heterocoma.

In 3ia, a character is considered homoplastic if its paralogy has been demonstrated; if it has not, it is considered a potential homology. There is no reason to reject the homology hypothesis but neither to accept it as a synapomorphy, so these characters are placed at the root (i.e., as plesiomorphies). Therefore, the number of retained homologies in 3ia is higher than in a standard analysis. Another difference with the standard approach is that a character is considered as a homology only if all its states are demonstrated to be homologous. 14 homologies (including three potential ones) were found in the analysis of matrix 1. Additionally, eight characters have some homologous states (one of them as a plesiomorphy). The character 49 (carpopodium cells druse) defines a large clade comprising all American Vernonieae except the subtribe Leiboldiinae and Lessingianthus bishopii. The irregular five-lobed corolla (character 32) groups the Elephantopinae and Stokesiinae but also Chrestinae and most Lepidaploinae and Vernoniinae; one of its subclade comprising Chrysolaena, Vernonanthura and Vernonia s. str. has for homology the glands on apical anther appendages (character 36); another subclade groups Argyrovernonia, Chresta speciosa and Pithecoseris based on their clavate to lageniform sweeping style hairs (character 44). Even though the Lychnophorinae clade do not have synapomorphies, some of its subclades do. The presence of tailed anthers (character 34) defines the clade Critoniopsis, Minasia and Piptocarpha. The other subclade comprising most Lychnophorinae, Sipolisiinae and two genera (Blanchetia and Gorceixia) has for homology the spurred trichomes (character 14). Porrect trichomes (character 15) defines the group Sipolisiinae + Chronopappus + Blanchetia + Prestelia, geminate trichomes (character 13) supports the same group minus Prestelia. Finally, the presence of paleae (character 28) groups Bishopalea and Heterocoma.

Matrix 2 - Lychnophorinae taxa

\section{Topologies}

The results of the standard analysis are given in Fig. 3 and Table 3 and those of the 3ia in Fig. 4 and Table 3. The topology of the strict consensus tree of the standard analysis differs widely from the intersection tree of the 3ia, at nearly all levels. In both analyses a species of Lychnophora emerges as sister to the rest of Lychnophorinae. Several similar clades are found in both analyses but their relationships disagree considerably. The clade A is principally composed of species from Eremanthus subgen. Eremanthus and emerges as sister to the remainder Lychnophorinae (standard analysis) or in a more derived position as sister-group of the clade C + E (3ia). The clade B comprises Albertinia, Anteremanthus, Minasia, Proteopsis and Vinicia in both analyses (only differing by the addition of some taxa). This clade is nested in a polytomy with several species of Eremanthus subgen. Vanillosmopsis (standard analysis) or found as sister to the remainder Lychnophorinae (minus Lychonophora regis and clade B) (3ia). 
The large genus Lychnophora as currently circumscribed is polyphyletic in both analyses. In the standard analysis, most of its species are grouped in the clade $\mathrm{C}$ or in the clade D (comprising also Piptolepis, Prestelia and two species of Lychnophoriopsis), whereas they are mostly placed in the clade $\mathrm{C}+\mathrm{E}$, which also contains species of the genus Paralychnophora. Species of the latter genus (minus $P$. atkinsiae) (clade E) emerge in a derived position sister to the clade F (standard analysis). The latter clade comprises species of the subtribe Sipolisiinae and Chronopappus (both analyses). Additionally, the 3ia displays the clade $\mathrm{G}$ (not found in standard analysis) containing Blanchetia, Eremanthus crotonoides and Gorceixia.

\section{Homologies}

The standard analysis provided five synapomorphies: two of them placed close to the root (character 21 - presence of a syncephalium and character 33 - pubescent phyllaries), the presence of paleae (character 36) groups Bishopalea and Heterocoma, and the two last synapomorphies are the absence of a carpopodium (or an inconspicuous one, character 47) grouping all Lychnophorinae minus Lychnophora santosii and the strong phyllary imbrication (character 31) defining the next level (Lychnophorinae minus L. santosii and Eremanthus pabstii).

Ten homology hypotheses are accepted in the 3ia, additionally nine character states are homologous (three of them potentially). Five of the accepted homology hypotheses defined a clade excluding Lychnophora regis: presence of unbranched auriculate trichomes (char. 7), inverted Y-shaped trichomes (char. 10), revolute corolla lobes (char. 40), narrowed outer pappus seta apex (char. 54) and enlarged inner pappus seta base (char. 58). Three genera Anteremanthus, Minasia and Vinicia are grouped by the presence of swollen T-shaped trichomes (char. 9) and Minasia is defined by its tailed anther bases (char. 41). A subclade of the clade $\mathrm{C}+\mathrm{E}$ comprising several species of Lychnophora, Lychnophoriopsis candelabrum and Paralychnophora atkinsiae has for synapomorphy the presence of curly trichomes (char. 14).

\section{Discussion}

Our results clearly show that the representation of the homology hypotheses has a deep impact on phylogenetic inference in terms of topology and number of homologies recovered. The number of clades supported by a homology is higher in the 3ia of both matrices here analysed, and the secondary homologies (sensu de Pinna 1991) established in the standard analysis are not necessarily also found in 3ia. For example, the standard analysis of matrix 1 (Vernonieae taxa) recovers five synapomorphies (Fig. 1), but only two of them are also found in 3ia (only the state 3 of the character 45 is homologous), which accepts 14 homologies hypotheses (Fig. 2). Similarly of the five synapomorphies found by the standard analysis of matrix 2 (Lychnophorinae taxa, Fig. 3): two of them are linked to the use of an outgroup and two others are considered as plesiomorphic states in 3ia (Fig. 4).

In both analyses of the matrix 1, all the American Vernonieae subtribes appear as para- or 
polyphyletic. The subtribe Lychnophorinae is not monophyletic, but almost all of its members emerge in a clade with taxa of Sipolisiinae and two monotypic genera (Blanchetia and Gorceixia), Proteopsis appearing outside of this clade. The main difference between standard and 3ia approaches is the position of the clade with Anteremanthus, Minasia and two Pitpocarphinae genera: these genera emerge within the Lychnophorinae clade in the 3ia (whereas in a basal position in standard). Simultaneous analyses of morphological and molecular data (Loeuille et al. in prep.; see Chapter 2) are mostly similar to those of the 3ia concerning the Lychnophorinae clade, but also concerning the position of Soaresia, which is found more closely related to Elephantopinae than to Chrestinae, and Rolandra nested within the Elephantopinae clade.

Results of the analyses of matrix 2 (Lychnophorinae subtribe) contrast widely with those of the simultaneous analyses of morphological and molecular data (Loeuille et al. in prep.; Chapter 3). These discrepancies are probably due to the high level of homoplasy in the morphological datasets. Only the genera Minasia and Piptolepis are found monophyletic. Some of the relationships recovered in 3ia are similar to those of the simultaneous analyses of morphological and molecular data (Loeuille et al. in prep; Chapter 3), in particular the clades (Blanchetia, Gorceixia) and (Minasia, Vinicia); Nonetheless the differences are numerous, especially regarding Eremanthus taxa, which are comprised into two main clades more or less corresponding to the two subgenera Eremanthus and Vanillosmopsis of MacLeish (1987), but also including species excluded by MacLeish (1984b). Finally none of the three main Lychnophora lineages identified in Loeuille et al. in prep (Chapter 3) are found whether in standard analysis or 3ia.

The fact that a low number of homologies were recovered in all performed analyses, while in the same time well-resolved strict consensus (or intersection) trees were obtained, leads us to conclude that most of the resolution is probably due to homoplasy. A number of homologies recovered in 3ia are characters that have been poorly used in Vernonieae taxonomy such as trichome types. In the case of pollen, single characters seem to be more informative than pollen types (see Appendix 1). For example, lophate pollen groups the subtribe Chrestinae, Elephantopinae, Lepidaploinae and Vernoniinae (with few exceptions such Albertinia and some Lessingianthus) (Fig. 2). Trichome types provide several homologies to understand the relationships between Sipolisiinae, Lychnophorinae and Blanchetia (Fig. 2), but none were recovered in the analysis at the subtribal level (Fig. 4). Another difference between standard analysis and 3ia is, as noted by Marques (2005), the incorporation by 3ia of the inherent doubtfulness to the observation. This is especially of interest concerning phytochemical data such as sesquiterpene lactones (STLs) (see Appendices 1 and 2), of which production might be stimulated by environmental influences (Gobbo-Neto et al. 2010), and consequently the failure to isolate a STLs in a taxon may not be equivalent to its absence.

The hierarchical representation of homology hypotheses has a deep impact on phylogenetic inference as evidenced by the present study and, for that reason, on natural classifications derived from it. The high level of homoplasy found in the two Vernonieae datasets here analyzed invites 
us to reflect on the reasons for such extensive convergence (as defined by Scotland 2011), especially for characters of which its adaptative value is uncertain (e.g., style basal node and other microcharacters). It also appeals to the necessity of more morphological studies in order to formulate more robust homology hypotheses. Moreover, Loeuille et al. (in press; Chapter 3) stress the possible role of past hybridization on the evolutionary course of Lychnophorinae by documenting the existence of two putative intergeneric hybrids, thus identification and exclusion of taxa with a hybrid origin would also be a necessary step in these analyses.

\section{Acknowledgements}

This project represents part of the Ph.D. thesis of B.L. Authors thank CNPq, FAPESP and the Cuatrecasas Fellowship Award of the Smithsonian Institution for financial support; IBAMA and IF-MG for collection permits; Silvana Ferreira, Vera Klein, Renato Mello-Silva and Jimi Nakajima for assistance during field work, and the directors or curators of the following herbaria for the loan of (or access to) their collections: ALCB, BHCB, ESA, GA, GH, HRB, HUEFS, HUFU, IBGE, MBM, MO, NY, RB, SP, SPF, TEX, UB, UFG, UEC, US.

\section{References}

Almeida VL, Oliveira AB, Chiari E, Boaventura MAD (2006) Constituents of Hololepis pedunculata leaves and their trypanocidal activity. Chem Nat Compd 42: 734-735

Angulo MB, Dematteis, M (2010) Pollen morphology of the South American genus Lessingianthus (Vernonieae, Asteraceae) and its taxonomic implications. Grana 49: 12-25

Barriel V, Tassy P (1998) Rooting with multiple outgroups: consensus versus parsimony. Cladistics 14: 193-200

Barros DAD, Lopes JLC, Vichnewski W, Lopes JNC, Kulanthaivel P, Herz W (1985) Sesquiterpene lactones in the molluscidal extract of Eremanthus glomerulatus Planta Med 1985: 38-39

Blackmore S, Wortley AH, Skvarla JJ, Robinson H (2009) Evolution of pollen in the Compositae. In: Funk VA, Susanna A, Stuessy TF, Bayer RJ (Eds) Systematics, evolution and biogeography of Compositae, Wien: IAPT, pp. 101-130

Bohlmann F, Jakupovic J (1990) Progress in the chemistry of the Vernonieae (Compositae). P1 Syst Evol [Suppl. 4]: 3-43

Bohlmann F, King RM (1991) Sesquiterpene lactones from Episcothamnus candelabrum. Biochem Syst Ecol 19: 440.

Bohlmann F, Müller L, King RM, Robinson H (1981a) A guaianolide and other constituents from Lychnophora species. Phytochem 20: 1149-1151

Bohlmann F, Singh P, Robinson H, King RM (1982a) Epi-ilicic acid from Alcantara ekmaniana. Phytochem 21: 456-457

Bohlmann F, Zdero C, King RM, Robinson H (1979) Neue sesquiterpenlactone aus Stokesia laevis. Phytochem 18: 987-989 
Bohlmann F, Zdero C, King RM, Robinson H (1980a) Caryophyllene derivatives and a heliangolide from Lychnophora species. Phytochem 19: 2381-2385

Bohlmann F, Zdero C, King RM, Robinson H (1980b) Sesquiterpene lactones from Eremanthus species. Phytochem 19: 2663-2668

Bohlmann F, Zdero C, King RM, Robinson H (1980c) Seven guaianolides from the tribe Vernonieae. Phytochem 19: 2669-2673

Bohlmann F, Zdero C, King RM, Robinson H (1980d) Sesquiterpene lactones from Eremanthus species. Phytochem 19: 2263-2268

Bohlmann F, Zdero C, King RM, Robinson H (1981b) Two hirsutinolides and a germacranolide from Chresta sphaerocephala. Phytochem 20: 518-519

Bohlmann F, Zdero C, King RM, Robinson H (1982b) Germacranolides from Stilpnopappus species. Phytochem 21: 1045-1048

Bohlmann F, Zdero C, Robinson H, King RM (1981c) Germacranolides from Piptolepis ericoides and Vanillosmopsis species. Phytochem 20: 731-734

Bohlmann F, Zdero C, Robinson H, King RM (1982c) Germacranolides from Lychnophora species. Phytochem 21: 1087-1091

Bohlmann F, Gupta RK, Jakupovic J, Robinson H, King RM (1981d) Three germacranolides and other constituents from Eremanthus species. Phytochem 20: 1609-1612

Bohlmann F, Singh P, Zdero C, Ruhe A, King RM, Robinson H (1982d) Furanoheliangolides from two Eremanthus species and from Chresta sphaerocephala. Phytochem 21: 1669-1673

Borella JC, Lopes JLC, Vichnewski W, Cunha WR, Herz W (1998) Sesquiterpene lactones, triterpenes and flavones from Lychnophora ericoides and Lychnophora pseudovillosissima. Biochem Syst Ecol 26: 671-676

Brady RH (1982) Parsimony, hierarchy, and biological implications. In: Platnick NI, Funk V (Eds) Advances in Cladistics: proceedings of the second meeting of the Willi Hennig Society, Columbia University Press, London, pp. 49-60.

Bremer K (1994) Asteraceae. Cladistics \& classification. Timber Press, Portland, OR

Buskuhl H, Oliveira FL de, Blind LZ, Freitas RA de, Barison A, Campos FR, Corilo YE, Eberlin MN, Caramori GF, Biavatti MW (2010) Sesquiterpene lactones from Vernonia scorpioides and their in vitro cytotoxicity. Phytochem 71: 1539-1544

Cabrera AL (1944) Vernonieas Argentinas (Compositae). Darwiniana 6: 265-379

Cao N, Zaragüeta-Bagils R, Vignes-Lebbe R (2007) Hierarchical representation of hypotheses of homology. Geodiversitas 29: 5-15.

Cao N, Bourdon E, El Azawi M, Zaragüeta-Bagils R (2009) Three-item analysis and parsimony, intersection tree and strict consensus: a biogeographical example. Bull Soc géol Fr 180: $13-15$

Carine MA, Scotland RW (1999) Taxic and transformational homology: different ways of seeing. Cladistics 15: 121-129

Carlquist S (1976) Tribal interrelationships and phylogeny of the Asteraceae. Aliso 8: 465-492 
Carpenter JM (1994) Successive weighting, reliability and evidence. Cladistics 10: 215-220

Carrijo TT, Mendonça CBF, Esteves RL, Gonçalves-Esteves V (2005) Palinotaxonomia de espécies de Stilpnopappus Mart. ex DC. e Strophopappus DC. (Compositae). Hoehnea 32: 259-268

Coile NC, Jones SB Jr (1981) Lychnophora (Compositae: Vernonieae), a genus endemic to the Brazilian Planalto. Brittonia 33: 528-542

Coile NC, Jones SB Jr (1983) Haplostephium (Compositae: Vernonieae). Castanea 48: 232-236

Costa FN, Terfloth L, Gasteiger J (2005) Sesquiterpene lactone-based classification of three Asteraceae tribes: a study based on self-organizing neural networks applied to chemosystematics. Phytochem 66: 345-353

Crotti AEM, Cunha WR, Lopes NP, Lopes JLC (2005) Sesquiterpene lactones from Minasia alpestris. J Braz Chem Soc 16: 677-680

Dematteis M (2007) Vinicia tomentosa, nuevo género y especie de Lychnophorinae (Vernonieae, Asteraceae) de Minas Gerais, Brasil. Bonplandia 16: 259-264

Dematteis M (2009) Revisión taxonómica del género sudamericano Chrysolaena (Vernonieae, Asteraceae). Bol Soc Argent Bot 44: 103-170

Ducasse J, Cao N, Zaragüeta-Bagils R (2008) LisBeth. Three-item analysis software package. Laboratoire Informatique et Systématique, UPMC Univ Paris 06, UMR 7207 (CR2P) CNRS MNHN UPMC

Echternacht LA (2007) Phylogénie de Paepalanthus subgen. Xeractis Koern. (Eriocaulaceae), taxon endémique brésilien, basée sur des caractères morphologiques. Master's thesis, unpublished. Université Pierre et Marie Curie, Paris VI et Muséum d'Histoire Naturelle

Endress PK (2010) Disentangling confusions in inflorescence morphology: patterns and diversity of reproductive shoot ramification in angiosperms. J Syst Evol 48: 225-239

Evert RF (2006) Esau's Plant anatomy: meristems, cells, and tissues of the plant body: their structure, function, and development. John Wiley \& Sons, Inc., Hoboken, New Jersey

Farris JS (1997) Cycles. Cladistics 13: 131-144

Faust WZ, Jones SB (1973) The systematic value of trichome complements in a North American group of Vernonia (Compositae). Rhodora 75: 517-528

Fuchino H, Koide T, Takahashi M, Sekita S, Satake M (2001) New sesquiterpene lactones from Elephantopus mollis and their leishmanicidal activities. Planta Med 67: 647-653

Funk VA, Chan R (2009) Introduction to Cichorioideae. In: Funk VA, Susana A, Stuessy TF, Bayer RJ (Eds.) Systematics, Evolution, and Biogeography of Compositae. Vienna, Austria: International Association for Plant Taxonomy (IAPT), pp. 335-342

Galvão MN, Pereira ACM, Gonçalves-Esteves V, Esteves RL (2009) Palinologia de espécies de Asteraceae de utilidade medicinal para a comunidade da Vila Dois Rios, Ilha Grande, Angra dos Reis, RJ, Brasil. Acta Bot Bras 23: 247-258

Gamerro JC (1990) Identidad de Pseudostifftia con Moquinia (Compositae) y consideraciones sobre la ubicacion tribal del taxon. Darwiniana 30: 123-136 
Garcia-Cruz J, Sosa V (2006) Coding quantitative character data for phylogenetic analysis: a comparison of five methods. Syst Bot 31: 302-309

Gershenzon J, Pfeil RM, Liu YL, Mabry TJ, Turner BL (1984) Sesquiterpene lactones from two newly-described species of Vernonia: $V$. jonesii and $V$. pooleae. Phytochem 23: 777-780

Gobbo-Neto L, Lopes NP (2008) Online identification of chlorogenic acids, sesquiterpene lactones, and flavonoids in the Brazilian Arnica Lychnophora ericoides Mart. (Asteraceae) leaves by HPLC-DAD-MS and HPLC-DAD-MS/MS and a validated HPLC-DAD method for their simultaneous analysis. J Agric Food Chem 56: 1193-1204

Gobbo-Neto L, Guaratini T, Pessoa C, Moraes de MO, Costa-Lotufo LV, Vieira RF, Colepicolo P, Lopes NP (2010) Differential metabolic and biological profiles of Lychnophora ericoides Mart. (Asteraceae) from different localities in the Brazilian 'campos rupestres'. J Braz Chem Soc 21: 750-759

Goloboff P (1999) NONA, version 2. Tucumán, Argentina: published by the author, http:// www.cladistics.com/aboutNona.htm.

Grael CFF, Vichnewski W, Souza GEP de, Lopes JLC, Albuquerque S, Cunha WR (2000) A study of the trypanocidal and analgesic properties from Lychnophora granmogolense (Duarte) Semir \& Leitão Filho. Phytother Res 14: 203-206

Haque MZ, Godward MBE (1984) New records of the carpopodium in Compositae and its taxonomic use. Bot J Linn Soc 89: 321-340

Haro-Carrión X, Robinson, H (2008) A review of the genus Critoniopsis in Ecuador (Vernonieae: Asteraceae). Proc Biol Soc Wash 121: 1-18

Hawkins JA (2000) A survey of primary homology assessment: different botanists perceive and define characters in different ways. In: Scotland RW, Pennington RT (Eds), Homology and systematics: coding characters for phylogenetic analysis, Taylor and Francis, London, pp. $22-53$

Hawkins JA, Hughes CE, Scotland RW (1997) Primary homology assessment, characters and character states. Cladistics 13: 275-283

Herz W, Kumar N (1980) Cytotoxic sesquiterpene lactones of Eremanthus incanus and Heterocoma albida. Crystal structure and stereochemistry of eregoyazin. J Org Chem 45: 2503-2506

Herz W, Govindan SV, Blount JF (1981) Structures of the rolandrolides and isorolandrolides, unusual germacradienolides from Rolandra fruticosa. J Org Chem 46: 761-765

Isawumi MA (1984) Foliar trichome studies in the genus Vernonia, Tribe Vernonieae (Compositae) in West Africa. Niger J Sci 18: 52-69

Isawumi MA (1989) Leaf epidermal studies in the genus Vernonia Schreber Tribe Vernonieae (Compositae) in West Africa. Feddes Repert 100: 335-355.

Jakupovic J, Grenz M, Bohlmann F, Wasshausen DC, King RM (1989) Sesquiterpene lactones from Rolandra fruticosa. Phytochem 28: 1937-1941

Jakupovic J, Jia Y, Zdero C, Warning U, Bohlmann F, Jones SB (1987) Germacranolides from 
Elephantopus species. Phytochem 26: 1467-1469

Jakupovic J, Banerjee S, Castro V, Bohlmann F, Schuster A, Msonthi JD, Keeley, S (1986a)

Poskeanolide, a seco-germacranolide and other sesquiterpene lactones from Vernonia species. Phytochem 25: 1359-1364

Jakupovic J, Schmeda-Hirschmann G, Schuster A, Zdero C, Bohlmann F, King RM, Robinson H, Pickardt J (1986b) Hirsutinolides, glaucolides and sesquiterpene lactone from Vernonia species. Phytochem 25: 145-158

Jeffrey C (1988) The Vernonieae of East tropical Africa. Notes on the Compositae: V. Kew Bull 43: $195-277$

Jones SB (1979) Synopsis and pollen morphology of Vernonia (Compositae: Vernonieae) in the New World. Rhodora 81: 425-447

Jones SB (1981) Synoptic classification and pollen morphology of Vernonia (Compositae, Vernonieae) in the Old World. Rhodora 83: 59-75

Jordão CO (2003) Estudo fitoquímico e ensaios biológicos de Lychnophora gardneri SchultzBip. Dissertation, Universidade de São Paulo

Keeley SC, Jones SB Jr (1977) Taxonomic implications of external pollen morphology to Vernonia (Compositae) in the West Indies. Amer J Bot 64: 576-584

Keeley SC, Jones SB Jr (1979) Distribution of pollen types in Vernonia (Vernonieae: Compositae). Syst Bot 4: 195-202

Keeley SC, Robinson H (2009) Vernonieae In: Funk VA, Susanna A, Stuessy TF, Bayer RJ (Eds) Systematics, evolution and biogeography of Compositae, Wien: IAPT, pp. 439-469

Keeley SC, Turner BL (1990) A preliminary cladistic analysis of the genus Vernonia (Vernonieae: Asteraceae). P1 Syst Evol Suppl 4: 45-66

Keeley SC, Forsman ZH, Chan R (2007) A phylogeny of the "evil tribe" (Vernonieae: Compositae) reveals Old/New World long distance dispersal: support from separate and combined congruent datasets (trnL-F, ndhF, ITS). Mol Phyl Evol 44: 89-103

Kingham DL (1976) A study of the pollen morphology of Tropical African and certain other Vernonieae (Compositae). Kew Bull 31: 9-26

Kisiel W(1975) Phytochemical investigations of Vernonia flexuosa Sims. Part II. Vernoflexuoside and vernoflexin - new sesquiterpene lactones. Pol J Pharmacol Pharm 27: 461-467

Kluge AG (1993) Three-taxon information in phylogenetic inference: ambiguity and distortion as regards to explanatory power. Cladistics 9: 246-259

Kluge AG (1994) Moving targets and shell games. Cladistics 10: 403-413

Krishna Kumari GN, Masilamani S, Ganesh MR, Aravind S, Sridhar SR (2003) Zaluzanin D: a fungistatic sesquiterpene from Vernonia arborea. Fitoterapia 74: 479-482

Ladiges PY (1999) Phylogeny of Melaleuca, Callistemon, and related genera of the Beaufortia suballiance (Myrtaceae) based on 5S and ITS-1 spacer regions of nrDNA. Cladistics 15: $151-172$

Le Quesne PW, Menachery MD, Pastore MP, Kelley CJ, Brennan TF, Onan KD, Raffauf RF 
(1982) Antitumor plants 12. Further sesquiterpenoid constituents of Lychnophora affinis Gardn. (Compositae). X-ray structure analysis of lychnophorolide A. J Org Chem 47: 15191521

Lee MSY (2002) Divergent evolution, hierarchy and cladistics. Zoo Scr 31: 217-219

Lewinsohn TM (1991) The geographical distribution of plant latex. Chemoecology 2: 64-68

Lunardello MA, Tomaz JC, Vichnewski W, Lopes JLC (1995) Sesquiterpene lactones and flavonoids from Eremanthus mattogrossensis and Eremanthus eriopus. J Braz Chem Soc 6: $307-311$

Luque R, Menezes NL, Semir J (1999) Anatomía foliar de Lychnophora Mart. (Vernonieae: Asteraceae). Plantula 2: 141-152

Mabry TJ, Abdel-Baset Z, Padolina WG, Jones SB Jr (1975) Systematic implications of flavonoids and sesquiterpene lactones in species of Vernonia. Biochem Syst Ecol 2: 185-192

MacLeish NFF (1984a) Revision of Eremanthus Less. (Compositae: Vernonieae). PhD thesis, unpublished. University of Georgia

MacLeish NFF (1984b) Eight new combinations in Vernonia (Compositae: Vernonieae). Syst Bot 9: 133-136

MacLeish NFF (1985a) Revision of Glaziovianthus (Compositae: Vernonieae). Syst Bot 10: $347-352$

MacLeish NFF (1985b) Revision of Chresta and Pycnocephalum (Compositae: Vernonieae). Syst Bot 10: 459-470

MacLeish NFF (1987) Revision of Eremanthus (Compositae: Vernonieae). Ann Missouri Bot Gard 74: 265-290

Marques AC (2005) Three-taxon statement analysis and its relation with primary data: implications for cladistics and biogeography. In: Llorente Bousquets J, Morrone JJ (Eds) Regionalización biogeográfica en Iberoamárica y tópicos afines. Las Prensas de Ciencias UNAM, Mexico DF, pp. 171-180.

Mauro MRV, Tucci AN, Nasi T, Vichnewski W, Lopes JL, Diaz JG, Herz W (1993) Germacranolides from Eremanthus elaeagnus. J Braz Chem Soc 4: 30-33

Mendonça CBFM, Souza MA de, Gonçalves-Esteves V, Esteves RL (2007) Palinotaxonomia de espécies de Chrysolaena H. Rob., Echinocoryne H. Rob. e Stenocaphalum Sch. Bip. (Vernonieae-Compositae). Acta Bot Bras 21: 627-639

Mendonça CBFM, Gonçalves-Esteves V, Esteves RL, Nunes AD (2009) Palynotaxonomy of Vernonanthura H. Rob. (Vernonieae, Asteraceae) species from Southeast Brazil. Revista Brasil Bot 32: 647-662

Nelson G (1989) Cladistics and evolutionary models. Cladistics 5: 275-289

Nelson G (1994) Homology and systematics. In: Hall BK (Ed) Homology: the hierchical basis of comparative biology. London: Academic Press, pp. 101-149.

Nelson G (2004) Cladistics: its arrested development. In: Williams DM, Forey PL (Eds) Milestones in Systematics, CRC - The Systematics Association, London, pp. 127-147 
Nelson G, Ladiges PY (1991a). Standard assumption for biogeographic analysis. Aus Syst Bot 4: $41-58$

Nelson G, Ladiges PY (1991b) Three-area statements: standard assumption for biogeographic analysis. Syst Zool 40: 470-485

Nelson G, Ladiges PY (1992) Information content and fractional weight of three-items statements. Syst Biol 41: 490-494

Nelson G, Ladiges PY (1993) Missing data and three-item analysis. Cladistics 9: 111-113.

Nelson G, Platnick NI (1991) Three-taxon statements: a more precise use of parsimony ? Cladistics 7: 351-366

Nelson G, Williams DM, Ebach MC (2003) A question of conflict: three-item and standard parsimony compared. Syst Biodivers 1: 145-149

Nixon KC (1999) The parsimony ratchet, a new method for rapid parsimony analysis. Cladistics 15: $407-414$

Nixon KC (1999-2002) WinClada, version 1.00.08. Ithaca, New York: published by the author. http://www.cladistics.com/aboutWinc.htm.

Oliveira AB de, Saúde DA, Perry KSP, Duarte DS, Rasian DS, Boaventura MAD, Chiari E (1996) Trypanocidal sesquiterpenes from Lychnophora species. Phytother Res 10: 292-295

Pandey AK, Dhakal MR (2001) Phytomelanin in Compositae. Curr Sci 80: 933-940

Patterson C (1982) Morphological characters and homology. In: Joysey KA, Friday, AE (Eds) Problems of phylogenetic reconstruction, London: Academic Press, pp. 21-74.

Patterson C, Johnson GD (1995) The intermuscular bones and ligaments of teleostean fishes. Smithson Contrib Zool 559: 1-85

Peçanha AF, Mendonça CBF, Gonçalves-Esteves V, Esteves RL (2001) Palinotaxonomia de espécies de Piptocarpha R. Br. (Compositae, Vernonieae) do estado do Rio de Janeiro. Bol Mus Nac nov ser 112: 1-14

Peçanha AF, Esteves RL, Gonçalves-Esteves V (2008) Palinotaxonomia de Albertinia brasiliensis Spreng, Eremanthus bicolor (DC.) Backer e Vanillosmopsis erythropappa (DC.) Sch. Bip. (Compositae-Vernonieae). Acta Bot Bras 22: 313-321

de Pinna MCC (1991) Concepts and tests of homology in the cladistic paradigm. Cladistics 7: 367-394

Platnick NI, Humphries CJ, Nelson G, Williams DM (1996) Is Farris optimization perfect ?: three-taxon statements and multiple branching. Cladistics 12: 243-252

Pollora GC, Bardón A, Catalán CAN, Gedris TE, Herz W (2000) Sesquiterpene lactones from Chrysolaena platensis. Biochem Syst Ecol 28: 707-711

Pope G (1983) Cypselas and trichomes as a source of taxonomic characters in the erlangeoid genera. Kirkia 12: 203-231

Popper KR (1998) The world of Parmenides: essays on the pre-Socratic enlightenment. Peterson AF (ed). Routledge, London, New York.

Pruski JF (1992) Compositae of Guayana Highlands: VI. Huberopappus maigualidae 
(Vernonieae), a new genus and species from Venezuela. Novon 2: 19-25

Rieppel O (1988) Fundamentals of comparative biology. Birkhauser, Basel, Switzerland

Rieppel O (2010) The series, the network, and the tree: changing metaphors of order in nature. Biol Philos 25: 475-496

Robinson H (1980) Re-establishment of the genus Critoniopsis (Vernonieae: Asteraceae). Phytologia 46: 437-442

Robinson H (1981) Episcothamnus and Bishopalea, two new genera of Vernonieae (Asteraceae) from Brasil, and the resurrection of Sipolisia. Phytologia 48: 209-217

Robinson H (1983) Five new species of Lychnophora from Bahia, Brasil (Vernonieae: Asteraceae) Phytologia 53: 369-384

Robinson H (1987a) Studies in the Lepidaploa complex (Vernonieae: Asteraceae) I. The genus Stenocephalum. Proc Biol Soc Wash 100: 578-583

Robinson H (1987b) Studies in the Lepidaploa complex (Vernonieae: Asteraceae) II. A new genus, Echinocoryne. Proc Biol Soc Wash 100: 584-589

Robinson H (1987c) Studies in the Lepidaploa complex (Vernonieae: Asteraceae) III. Two new genera, Cyrtocymura and Eirmocephala. Proc Biol Soc Wash 100: 844-855

Robinson H (1988) Studies in the Lepidaploa complex (Vernonieae: Asteraceae) V. The new genus Chrysolaena. Proc Biol Soc Wash 101: 952-958

Robinson H (1990) Studies in the Lepidaploa complex (Vernonieae: Asteraceae) VII. The genus Lepidaploa. Proc Biol Soc Wash 103: 464-498

Robinson H (1992a) Notes on the Lychnophorinae from Minas Gerais, Brazil, a synopsis of Lychnophoriopsis Schultz-Bip., and the new genera Anteremanthus and Minasia (Vernonieae: Asteraceae). Proc Biol Soc Wash 105: 640-652

Robinson H (1992b) The Asteraceae of the Guianas, III: Vernonieae and restoration of the genus Xiphochaeta. Rhodora 94: 348-361

Robinson H(1993)A review of the genus Critoniopsis in Central and South America (Vernonieae: Asteraceae). Proc Biol Soc Wash 106: 606-627

Robinson H (1994) Notes on the tribes Eremothamneae, Gundelieae, and Moquinieae, with comparisons of their pollen. Taxon 43: 33-44

Robinson H (1999a) Generic and subtribal classification of American Vernonieae. Smithson Contrib Bot 89: 1-116

Robinson H (1999b) Two new subtribes, Stokesiinae and Pacourininae, of the Vernonieae (Asteraceae). Proc Biol Soc Wash 112: 216-219

Robinson H, Funk VA (1987) A phylogenetic analysis of Leiboldia, Lepidonia, and a new genus Stramentopappus (Vernonieae: Asteraceae) Bot Jahrb Syst 108: 213-228

Robinson H, Marticorena C (1986) A palynological study of the tribe Liabeae (Asteraceae) Smithson Contrib Bot 64: 1-50

Robinson H, Keeley SC, Skvarla JJ, Chan R(2008) Studies on the Gymnantheminae (Vernonieae: Asteraceae) III: restoration of the genus Strobocalyx and the new genus Tarlmounia. Proc 
Biol Soc Wash 121: 19-33

Sacilotto ACBC, Sartori FT, Vichnewski W (2002) Chemical constituents of Eremanthus veadeiroensis (Asteraceae). Biochem Syst Ecol 30: 897-900

Sakamoto HT, Flausino D, Castellano EE, Stark CBW, Gates PJ, Lopes NP (2003) Sesquiterpene lactones from Lychnophora ericoides. J Nat Prod 66: 693-695

Sakamoto HT, Laudares EP, Crotti AE, Lopes NP, Vichnewski W, Lopes JL, Heleno VC (2010) Sesquiterpene lactones and flavonoids from Eremanthus argenteus. Nat Prod Commun 5: $681-684$

Sartori FT, Barrachi AC, Sacilotto C, Lopes JLC, Lopes NP, Vichnewski W (2002) Phytochemical study of Lychnophora markgravii (Asteraceae). Biochem Syst Ecol 30: 609-612

Scotland RW (2000a) Taxic homology and three-taxon statement analysis. Syst Biol 49: 480500

Scotland RW (2000b) Homology, coding and three-taxon statement analysis. In: Scotland RW, Pennington RT (Eds), Homology and systematics: coding characters for phylogenetic analysis, Taylor and Francis, London, pp. 145-182

Scotland RW (2011) What is parallelism ? Evol Dev 13: 214-227

Seaman FC (1982) Sesquiterpene lactones as taxonomic characters in the Asteraceae. Bot Rev 48: $121-595$

Seaman FC, Funk VA (1983) Cladistic analysis of complex natural products: developing transformation series from sesquiterpene lactone data. Taxon 32: 1-27

Semir J (1991) Revisão taxonômica de Lychnophora Mart. (Vernonieae: Compositae). PhD thesis, unpublished. Universidade Estadual de Campinas, São Paulo.

Siebert DJ, Williams DM (1998) Recycled. Cladistics 14: 339-347

Simpson GG (1961) Principles of animal taxonomy. Columbia University Press, New York.

Skvarla JJ, DeVore ML, Chissoe WF (2005) Lophate sculpturing of Vernonieae (Compositae) pollen. Rev Palaeobot Palynol 133: 51-68

Small J (1919) The origin and development of the Compositae. New Phytol 18 (Reprint 11): $1-334+$ plates $1-6$

Smith GL, Coile NC (2007) Piptocarpha (Compositae: Vernonieae). Flora Neotrop Monogr 99: 1-94

Stevens PF (1984) Homology and phylogeny: morphology and systematics. Syst Bot 9: 395409

Stix E (1960) Pollenmorphologische untersuchungen an Compositen. Grana 2: 41-104

Swofford DL (2002) PAUP*. Phylogenetic Analysis Using Parsimony (*and Other Methods). Version 4.0b10. Sinauer Associates. Sunderland

Theobald WL, Krahulik JL, Rollins RC. 1979 [1980] Trichome description and classification. In: Metcalfe, CR, Chalk, L (Eds) Anatomy of the dicotyledons. I, Clarendon Press: Oxford, pp.40-53

Thiele K (1993) The Holy Grail of the perfect character: the cladistic treatment of morphometric 
data. Cladistics 9: 275-304

Udovicic F, McFadden GI, Ladiges PY (1995) Phylogeny of Eucalyptus and Angophora based on 5S rDNA spacer sequence data. Mol Phyl Evol 4: 247-256

Valdés DA, Bardón A, Catalán AN (1998) Goyazensolides and isogoyazensolides from Argentine Centratherum punctatum ssp. punctatum. Biochem Syst Ecol 26: 805-808

Vichnewski W, Gilbert B (1972) Schistosomicidal sesquiterpene lactone from Eremanthus elaeagnus. Phytochem 11: 2563-2566

Vichnewski W, Takahashi AM, Nasi AMT, Gonçalves DCRG, Dias DA, Lopes JNC, Goedken VL, Gutiérrez B, Herz W (1989) Sesquiterpene lactones and other constituents from Eremanthus seidelii, E. goyazensis and Vanillosmopsis erythropappa. Phytochem 28: 1444 1451

Weberling F (1992) Morphology of flowers and inflorescences. Cambridge University Press, Cambridge, UK

Williams DM (1996) Fossil species of the diatom genus Tetracyclus (Bacillariophyta, 'ellipticus' species group): morphology, interrelationships and the relevance of ontogeny. Philos Trans R Soc London B351: 1759-1782

Williams DM (2004) Homologues and homology, phenetics and cladistics: 150 years of progress. In : Williams DM, Forey PL (Eds) Milestones in Systematics, CRC - The Systematics Association, London, pp. 191-224

Williams DM, Ebach MC (2006) The data matrix. Geodiversitas 28: 409-420

Williams DM, Humphries CJ (2003) Component coding, three-item coding, and consensus methods. Syst Biol 52: 255-259

Williams DM, Siebert DJ (2000) Characters, homology and three-item analysis. In: Scotland RW, Pennington RT (Eds), Homology and systematics: coding characters for phylogenetic analysis, Taylor and Francis, London, pp. 183-208

Wortley AH, Funk VA, Skvarla JJ (2008) Pollen and evolution of Arctotidae (Compositae) Bot Rev 74: 438-466

Zaragëta-Bagils R, Bourdon E (2007) Three-item analysis: hierarchical representation and treatment of missing and inapplicable data. CR Palevol 6: 527-534

Zdero C, Bohlmann F, Robinson H, King RM (1981) Germacranolides from Proteopsis argentea. Phytochem 20: 739-741 
Table 1 Morphological characters and character states of the Matrix 1 (American Vernonieae taxa) with their associated hypothese of homology for the 3 ia.

1. Life form: shrub or tree (0); herb (1). Hypothese of homology: (0(1)).

2. Leaf position: cauline (0); rosulate or grouped near the base of stems (1). Hypothese of homology: (0(1)).

3. Leaf venation: pinnate (0); parallel (1); hyphodromous (2). Hypothese of homology: (0(1) (2)).

4. Leaf margin: entire (0); serrate to dentate (1). Hypothese of homology: (0(1)).

Leave are lobed in Argyrovernonia harleyi and Pithecoseris pacourinoides.

5. Leaf blade: not lobed (0); lobed (1). Hypothese of homology: (0(1)).

6. Leaf sheath: absent (0); semi-amplexicaul to amplexicaul (1); pad-like (2). Hypothese of homology: $(0(1)(2))$.

7. Unbranched trichomes: absent (0); present (1). Hypothese of homology: (0(1)).

8. T-shaped trichomes: absent (0); present (1). Hypothese of homology: (0(1)).

9. L-shaped trichomes: absent (0); present (1). Hypothese of homology: (0(1)).

10. 3- to 5-armed trichomes: absent (0); present (1). Hypothese of homology: (0(1)).

11. Stellate trichomes: absent (0); present (1). Hypothese of homology: (0(1)).

12. Curly trichomes: absent (0); present (1). Hypothese of homology: (0(1)).

13. Geminate trichomes: absent (0); present (1). Hypothese of homology: (0(1)).

14. Spurred trichomes: absent (0); present (1). Hypothese of homology: (0(1)).

15. Porrect trichomes: absent (0); present (1). Hypothese of homology: (0(1)).

16. Swollen trichomes: absent (0); present (1). Hypothese of homology: (0(1)).

17. Capitulescence position: axillary (0); terminal (1). Hypothese of homology: (0(1)).

18. Capitulescence of first-order type: 1-few terminal heads (0); racemose branching pattern (1); cymose branching pattern (2); paniculate pattern (3). Hypothese of homology: $(0(1)(2)(3))$.

19. Capitulescence of first-order showing internode reduction: no (0); yes but not syncephalia (1); syncephalia (2). Hypothese of homology: (0(1(2))).

20. Number of florets per head (quantitative character): minimum value $=1$ and maximal value $=110$. Hypothese of homology: $(0(1(2(3(4(5(6(7(8(9))))))))))$

21. Head bracteole: absent (0); present (1). Hypothese of homology: (0(1)).

22. Head peduncle: absent (0); present (1). Hypothese of homology: $(0(1))$.

23. Phyllary series: many (0); 5-8 (1); 4 or fewer (2). Hypothese of homology: $(0(1(2)))$.

24. Phyllary imbrication: strong (0); weak or none (1). Hypothese of homology: $(0(1))$.

25. Phyllary duration (any series): persistent (0); deciduous or caducous (1). Hypothese of homology: (0(1)).

26. Head receptacle shape: concave (0); flat (1); convex to conical (2); short thick column (3). Hypothese of homology: $(0(1(2(3))))$.

27. Head receptacle pitting: smooth (0); areolate or foveolate (1); fimbrillate (2); alveolate (3). 
Hypothese of homology: $(0(1)(2)(3))$.

28. Palea: absent (0); present (1). Hypothese of homology: (0(1)).

29. Corolla color (at anthesis): purple (lavender to lilac) or blue (0); white or cream (1); red (2). Hypothese of homology: $(0(1)(2))$.

30. Tube/limb ratio: tube $>\operatorname{limb}(0)$; tube $=\operatorname{limb}(1)$; tube $<$ limb. Hypothese of homology: $(0(1(2)))$.

31. Corolla laticifer: absent (0); present (1). Hypothese of homology: (0(1)).

32. Corolla of peripheral florets symmetry: regular 5-lobed (0); irregular 5-lobed (1). Hypothese of homology: (0(1)).

33. Anther base: ecalcarate (0); calcarate (1). Hypothese of homology: (0(1)).

34. Anther base tail: absent (0); present (1). Hypothese of homology: (0(1)).

35. Apical anther appendage cells: lacking conspicuous wall thickenings (0); with conspicuous wall thickenings (1). Hypothese of homology: (0(1)).

36. Apical anther appendage gland: absent (0); present (1). Hypothese of homology: (0(1)).

37. Apical anther appendage length: at least 3 times as long as wide (0); at least twice as long as wide (1); up to twice as long as wide (2). Hypothese of homology: (0(1)(2)).

38. Pollen aperture type: colporate (0); pororate (with the ectoaperture as a pore rather than a colpus) (1). Hypothese of homology: (0(1)).

For the conventional analysis:

39. Pollen macro-ornamentation: non-lophate (0), sublophate (having spines arranged in a pattern as if lophate) (1); lophate (2). Hypothese of homology: (0(1(2))).

For the three-item analysis, the state "non-lophate pollen" is not represented (only present in outgroup taxa). Consequently:

39. Pollen macro-ornamentation: sublophate (having spines arranged in a pattern as if lophate)

(0); lophate (1). Hypothese of homology: (0(1)).

40. Pollen tectum extension: covering less than $50 \%$ of pollen grain surface (semi-tectate) (0); covering more more than $50 \%$ but discontinuous (1); continuous (0). Hypothese of homology: $(0(1(2)))$.

41. Pollen tectum: not perforate (0); perforate (1). Hypothese of homology: (0(1)).

Characters restricted to taxa with lophate pollens:

42. Polar areole: absent (0); present (1). Hypothese of homology: $(0(1))$.

43. Style base: not expanded (0); expanded (1). Hypothese of homology: (0(1)).

44. Sweeping hairs shape: scabrid (0); subulate to acicular (1); clavate to lageniform (2).

In the three-item analysis no outgroup was used and therefore the state "scabrid" was not represented:

44. Sweeping hairs shape: subulate to acicular (0); clavate to lageniform (1). Hypothese of homology: (0(1)).

45. Phytomelanin on cypsela wall: absent (0); present (1). Hypothese of homology: (0(1)).

46. Cypsela wall: glabrous (0); pubescent (1). Hypothese of homology: (0(1)). 
For conventional analysis:

47. Cypsela rib: more than 10-ribbed (0); 8 to 10-ribbed (1); c. 5-ribbed (2). Hypothese of homology: $(0(1)(2))$.

For three-item analysis, the state "more than 10-ribbed" is not represented (only present in the outgroup), therefore:

47. Cypsela rib: 8 to 10-ribbed (0); c. 5-ribbed (1). Hypothese of homology: (0(1)).

48. Carpopodium: absent or inconspicuous (0); prominent (1). Hypothese of homology: $(0(1))$.

Characters restricted to taxa with carpopodia:

49. Carpopodium cells druze: absent (0); present (1). Hypothese of homology: (0(1)).

50. Carpopodium cells wall: thin-walled (0); thick-walled (1); thick-walled nearly occluding lumina (2). Hypothese of homology: (0(1(2))).

51. Number of pappus series: two (0); one (1); more than two (2). Hypothese of homology: $(0(1)(2))$.

52. Pappus duration (any part): persistent (0); deciduous or caducous (1). Hypothese of homology: (0(1)).

53. Pappus fusion (any part): free (0); fused (1). Hypothese of homology: (0(1)).

54. Outer pappus type: setose (0); paleaceous (1). Hypothese of homology: (0(1)).

55. Inner pappus type: setose (0); paleaceous (1). Hypothese of homology: (0(1)).

56. Guaianolide: absent (0); present (1). Hypothese of homology: (0(1)).

For the conventional analysis:

57. Germacranolide: absent (0); present (1).

Character restricted to taxa with germacranolide:

58. Germacranolide derivatives: germacrolide derivatives (0); heliangolide derivatives (1).

For the three-item analysis:

57. Germacranolide: absent (0); germacrolide derivatives (1); heliangolide derivatives (2).

Hypothese of homology: $((0(1)(2))$ 
Table 2 Morphological characters and characters states of the Matrix 2 (Lychnophorinae taxa).

1. Life form: shrub (0); caulirosuletum (1); treelet and tree (2). Hypothese of homology: $(0((1)$ (2))).

2. Leaf margin: flat (0); revolute (1). Hypothese of homology: (0(1)).

3. Leaf margin II: entire (0); serrate to dentate (1). Hypothese of homology: (0(1)).

4. Leaf sheath: absent (0); present (1). Hypothese of homology: $(0(1))$.

5. Leaf sheath II: semi-amplexicaul to amplexicaul (0); pad-like (1) (character restricted to taxa with leaf sheath). Hypothese of homology: (0(1)).

6. Unbranched trichomes (without auriculate base): absent (0); present (1). Hypothese of homology: $(0(1))$.

7. Unbranched auriculate trichomes: absent (0); present (1). Hypothese of homology: (0(1)).

8. Not swollen T-shaped trichomes: absent (0); present (1). Hypothese of homology: (0(1)).

9. Swollen T-shaped trichomes: absent (0); present (1). Hypothese of homology: (0(1)).

10. Inverted Y-shaped trichomes: absent (0); present (1). Hypothese of homology: (0(1)).

11. Stellate trichomes: absent (0); present (1). Hypothese of homology: (0(1)).

12. 3- to 5-armed not swollen trichomes: absent (0); present (1). Hypothese of homology: (0(1)).

13. 3- to 5-armed swollen trichomes: absent (0); present (1). Hypothese of homology: $(0(1))$.

14. Curly trichomes: absent (0); present (1). Hypothese of homology: (0(1)).

15. Long stalked stellate trichomes: absent (0); present (1). Hypothese of homology: (0(1)).

16. Geminate trichomes: absent (0); present (1). Hypothese of homology: (0(1)).

17. Porrect trichomes: absent (0); present (1). Hypothese of homology: (0(1)).

18. Spurred trichomes: absent (0); present (1). Hypothese of homology: (0(1)).

19. Capitulescence position I: axillary (0); terminal (1). Hypothese of homology: (0(1)).

20. Capitulescence peduncle: absent (0); present (1). Hypothese of homology: $(0(1))$.

21. Capitulescence first-order unit: capitulum (0); glomerule (1); syncephalium (2). Hypothese of homology: (0(1(2))).

22. Capitulescence branching pattern: few terminal capitula/glomerule/syncephalia (0); racemose (1); cymose (2); paniculate (3). Hypothese of homology: $(0(1)(2)(3))$.

23. Syncephalium form: hemispherical or pyramidal (0); spherical (1). Hypothese of homology: (0(1)).

24. Syncephalium level: second-order (0); third-order (1). Hypothese of homology: (0(1)).

25. Syncephalium units: unit of syncephalia evident (0); not evident due to tissue/indument growth (1). Hypothese of homology: (0(1)).

26. Syncephalium leaves: reduced leaves between capitula (0); no leaves between capitula (1). Hypothese of homology: $(0(1))$.

27. Secondary involucre: absent (0); present (1). Hypothese of homology: (0(1)).

28. Number of florets per capitulum (quantitative character): minimum value $=1$ and maximal value $=110$. Hypothese of homology: $(0(1(2(3(4(5(6)))))))$. 
29. Capitulum peduncle: absent (0); present (1). Hypothese of homology: (0(1)).

30. Involucre shape: cylindrical (0); ovoid (1); obconic (2); campanulate (3). Hypothese of homology: $(0(1)(2)(3))$.

31. Phyllary imbrication: strong (0); weak or none (1). Hypothese of homology: (0(1)).

32. Phyllary duration: persistent (0); caducous or deciduous (1). Hypothese of homology: (0(1)).

33. Phyllary indument: glabrous (0); pubescent (1). Hypothese of homology: (0(1)).

34. Phyllary apex: obtuse (0); acute to acuminate (1); with spiny appendage (2). Hypothese of homology: $(0(1(2)))$.

35. Capitulum receptacle pitting: smooth (0); areolate or foveolate (1); fimbrillate (2); alveolate

(3). Hypothese of homology: $(0(1)(2)(3))$.

36. Palea: absent (0); present (1). Hypothese of homology: (0(1)).

37. Tube/limb ratio: tube $>\operatorname{limb}(0)$; tube $=\operatorname{limb}(1)$; tube $<$ limb. Hypothese of homology: $(0(1(2)))$.

38. Corolla laticifer: absent (0); present (1). Hypothese of homology: (0(1)).

39. Corolla apex: glabrous (0); pubescent (1). Hypothese of homology: (0(1)).

40. Corolla lobe: not revolute (0); revolute (1). Hypothese of homology: (0(1)).

41. Anther base tail: absent (0); present (1). Hypothese of homology: (0(1)).

42. Anther appendage base: straight (0); constricted (1). Hypothese of homology: (0(1)).

43. Style base: not expanded (0); expanded (1). Hypothese of homology: (0(1)).

44. Cypsela shape: cylindrical (0); turbinate (1); prismatic (2). Hypothese of homology: (0(1) (2)).

45. Phytomelanin on cypsela wall: absent (0); present (1). Hypothese of homology: (0(1)).

46. Cypsela wall: glabrous (0); pubescent (1). Hypothese of homology: (0(1)).

47. Carpopodium: absent or inconspicuous (0); prominent (1). Hypothese of homology: (0(1)). 48. Number of pappus series: two (0); one (1); more than two (2). Hypothese of homology: $(0(1)(2))$.

49. Outer pappus duration: persistent (0); deciduous (1); caducous (2). Hypothese of homology: $(0(1(2)))$.

50. Outer pappus fusion: free (0); fused at base (1); more than half fused (2). Hypothese of homology: $(0(1(2)))$.

51. Outer pappus relative size to inner series: smaller (0); subigual or igual (1); residual (2). Hypothese of homology: $(0(1)(2))$.

52. Outer pappus type: setose (0); subpaleaceous (1); paleaceous (1). Hypothese of homology: $(0(1(2)))$.

53. Outer pappus seta base: not enlarged (0); enlarged (1). Hypothese of homology: (0(1)).

54. Outer pappus seta apex: not narrowed (0); narrowed (1). Hypothese of homology: $(0(1))$.

55. Inner pappus duration: persistent (0); deciduous (1); caducous (2). Hypothese of homology: $(0(1(2)))$.

56. Inner pappus form: straight (0); twisted (1). Hypothese of homology: (0(1)). 
57. Inner pappus type: setose (0); subpaleaceous (1); paleaceous (2). Hypothese of homology: $(0(1(2)))$.

58. Inner pappus seta base: not enlarged (0); enlarged (1). Hypothese of homology: $(0(1))$.

59. Inner pappus seta apex: not enlarged nor narrowed (0); narrowed (1); enlarged (2). Hypothese of homology: $(0(1)(2))$.

60. Heliangolide derivatives I. Furanoheliangolide: absent (0); present (1). Hypothese of homology: (0(1)).

61. Heliangolide derivatives II. Eremantholide: absent (0); present (1). Hypothese of homology: $(0(1))$. 


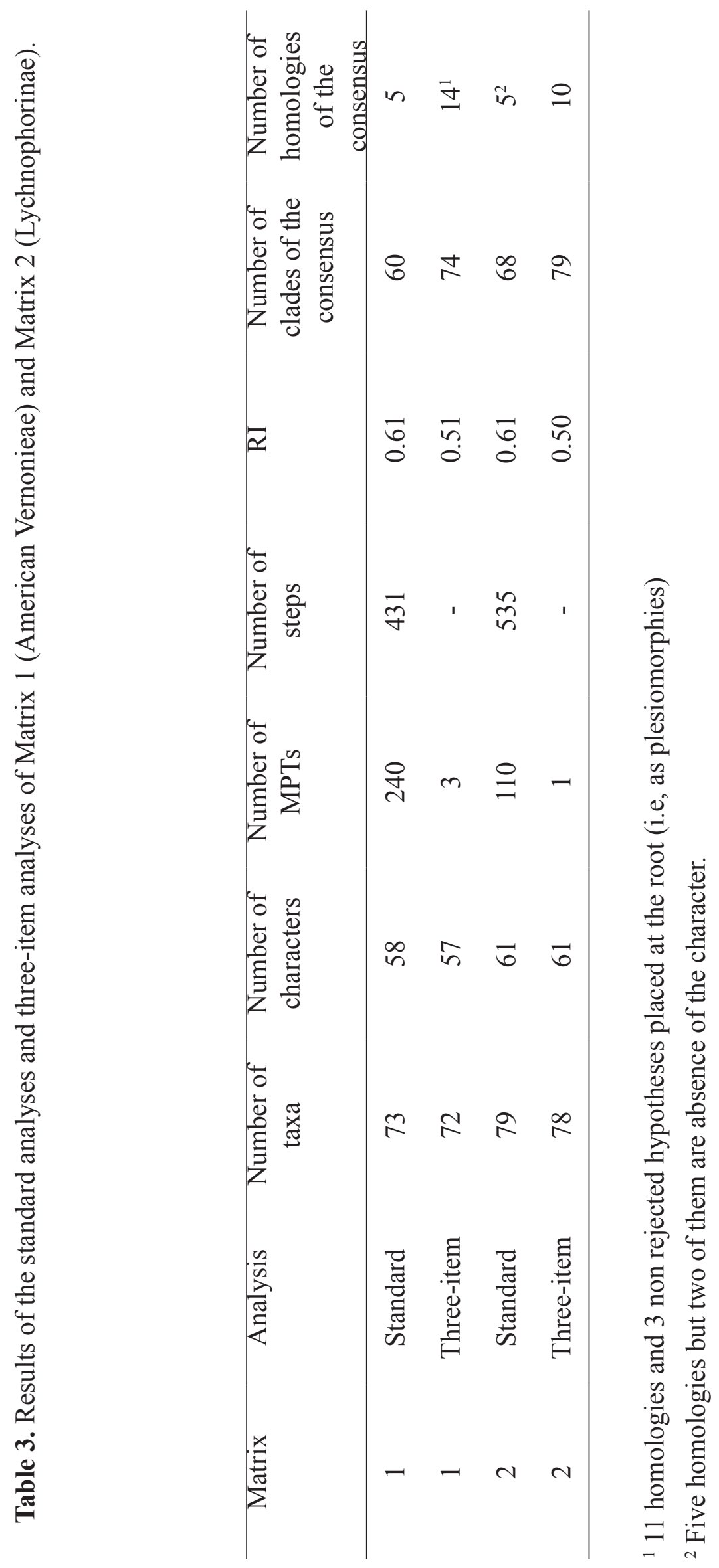


Fig. 1 Strict consensus tree of 240 most parsimonious trees based on the standard analysis of Matrix 1 (American Vernonieae taxa). Tree length $=431$ steps. Black symbols indicates synapomorphies. Vernonieae subtribes are indicated with three-letter abbreviations, CEN $=$ Centratherinae, CHR $=$ Chrestinae, ELE $=$ Elephantopinae, LEI $=$ Leiboldiinae, LYC $=$ Lychnophorinae, PIP $=$ Piptocarphinae, SIP $=$ Sipolisiinae, STO $=$ Stokesiinae, VER $=$ Vernoniinae and UNP = unplaced (taxa not placed in a subtribe). 


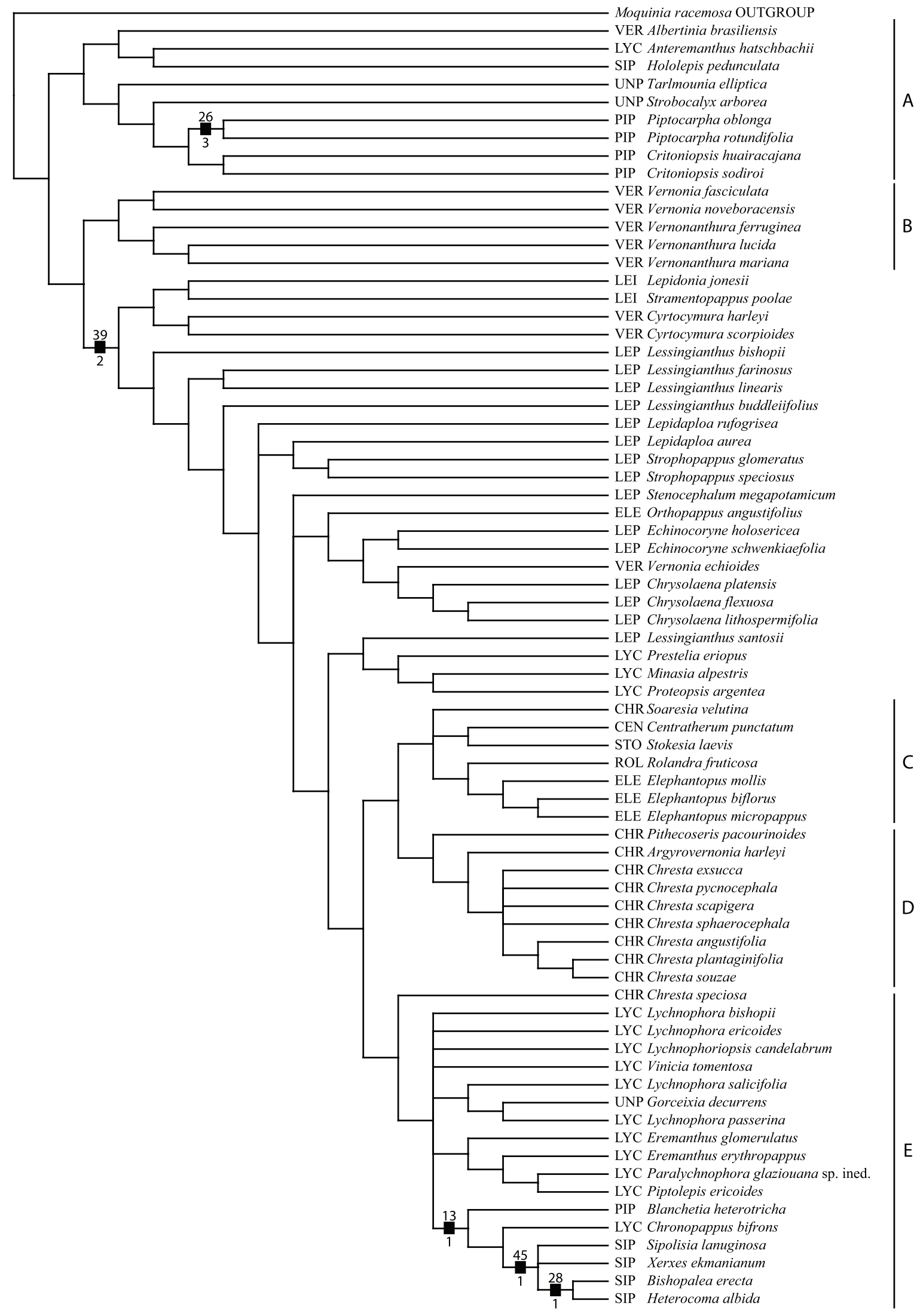


Fig. 2 Intersection tree of 3 optimal trees based on the 3ia of Matrix 1 (American Vernonieae taxa). Black symbols indicate hypothese of homology accepted. Blue symbols indicate a homologous state accepted. Characters placed at the root (grey symbols) indicate that there is no reason to reject the homology hypothesis but also no reason to accept the character as a synapormophy given the sampling. Red symbols indicate that there is no reason to reject or to accept the state as homologous given the sampling. Vernonieae subtribes are indicated with three-letter abbreviations (see legend of Fig. 1) 


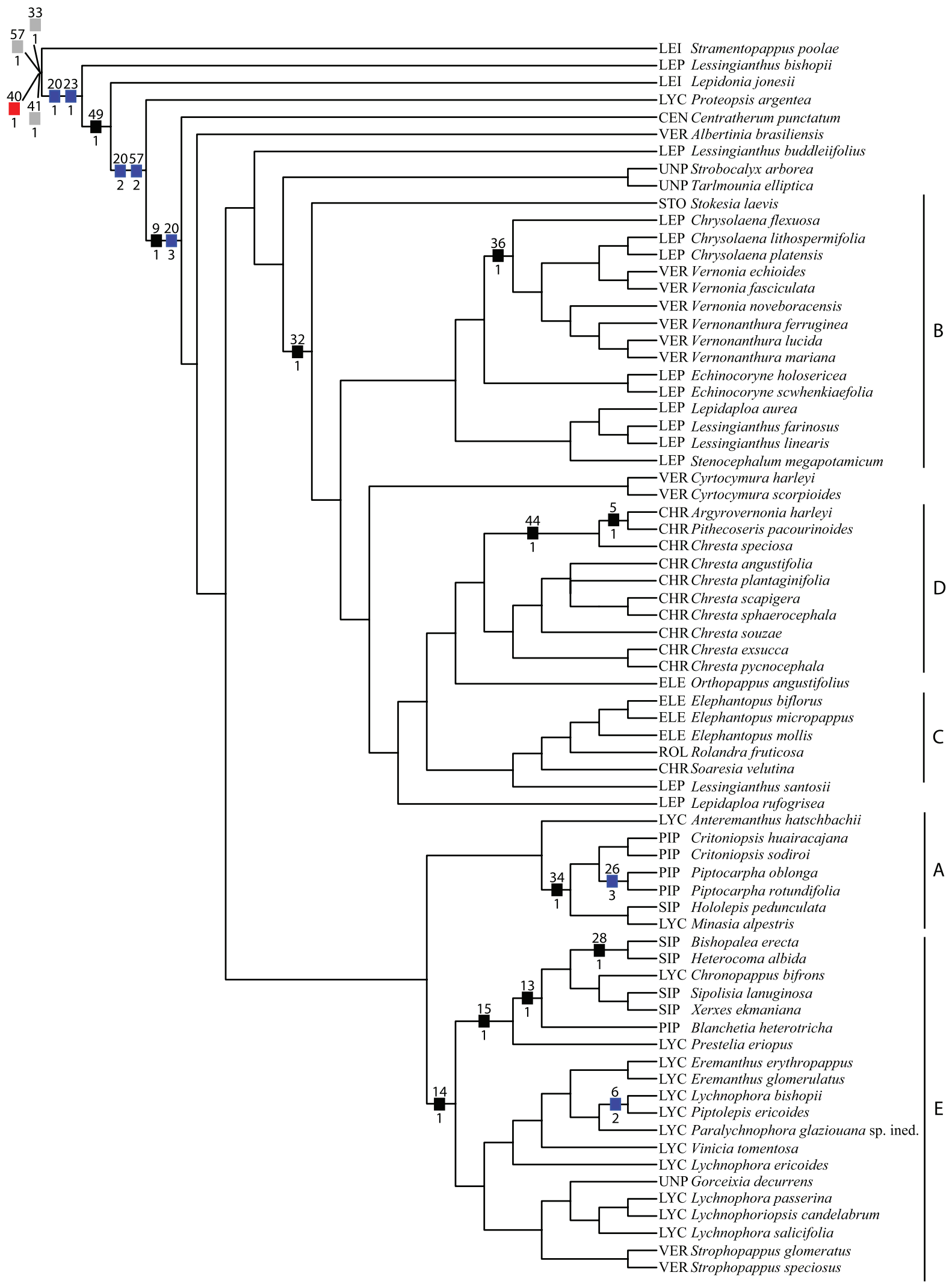


Fig. 3 Strict consensus tree of 110 most parsimonious trees based on the standard analysis of Matrix 2(Lychnophorinae taxa). Tree length $=535$ steps. Black symbols indicate synapomorphies. Grey symbols indicate absence of a character treated as synapomorphy. 


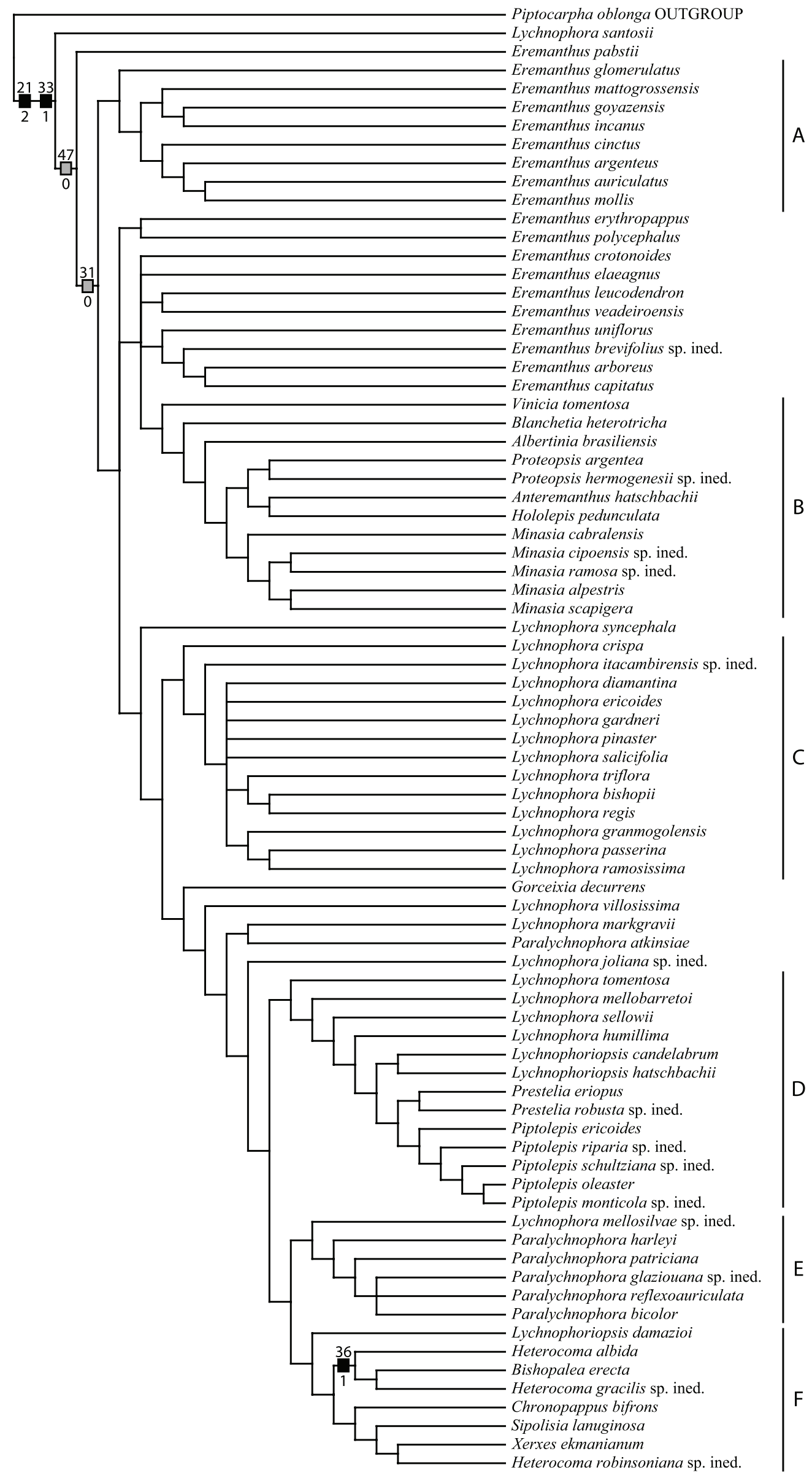


Fig. 4 Optimal tree based on the 3ia of Matrix 2. (Lychnophorinae taxa) Black symbols indicate hypothese of homology accepted. Blue symbols indicate a homologous state accepted. Characters placed at the root (red symbols) indicate that there is no reason to reject or to accept the state as homologous given the sampling. 


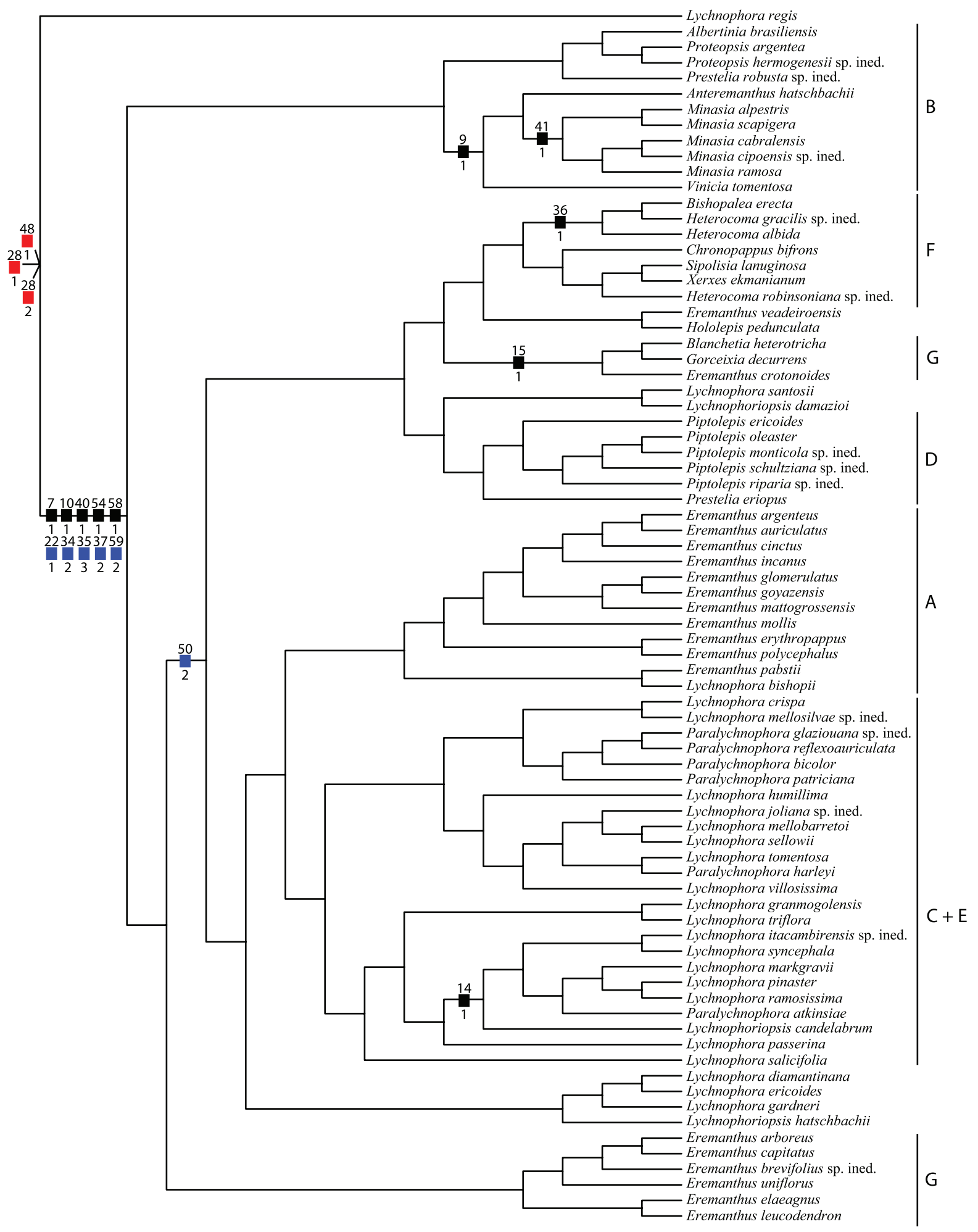



Appendix 1. Characters used in the cladistic analysis of the Matrix 1 (American Vernonieae). The numbers correspond to those in the data matrix (Table 1).

\section{Life form}

Life forms vary from small perennial herbs (some Lepidaploa are annuals but not included in this analysis) to $30 \mathrm{~m}$ high trees (Strobocalyx arborea) (Keeley and Robinson 2009, Robinson et al. 2008). Most Vernonieae are subshrubs and shrubs; consequently, the herbaceous habit is likely derived.

1. Life form: shrub or tree (0); herb (1). Hypothese of homology: (0(1)).

\section{Leaves}

Leaves in the American Vernonieae are most commonly alternate or rosulate but a few species have opposite leaves (in this dataset only Critoniopsis sodiroi has opposite leaves). Some Paralychnophora have leafy bracts opposite to subopposite, but the leaves are strictly alternate. Young plants of Pithecoseris pacourinoides have leaves grouped near the base of stems, but adult plants bear cauline leaves (the plant has been coded as polymorphic for this character).

2. Leaf position: cauline (0); rosulate or grouped near the base of stems (1). Hypothese of homology: (0(1)).

No taxa with trinervate leaves are included in the dataset; noteworthy is Hololepis having trinervate foliaceous subinvolucral bracts. Chresta speciosa has parallel-nerved leaves and Soaresia a unique pattern of nearly longitudinal veins. We consider this latter venation pattern similar to the $C$. speciosa one's. Hyphodromous leaves are common in sclerophyllous shrubs (some Lychnophora and Piptolepis).

3. Leaf venation: pinnate (0); parallel (1); hyphodromous (2). Hypothese of homology: (0(1) (2)).

4. Leaf margin: entire (0); serrate to dentate (1). Hypothese of homology: (0(1)).

Leave are lobed in Argyrovernonia harleyi and Pithecoseris pacourinoides.

5. Leaf blade: not lobed (0); lobed (1). Hypothese of homology: (0(1)).

Here we followed Semir (1991) interpreting the pad-like structure as a kind of leaf sheath and not a kind of petiole (Robinson 1983).

6. Leaf sheath: absent (0); semi-amplexicaul to amplexicaul (1); pad-like (2). Hypothese of homology: $(0(1)(2))$.

The diversity of leaf trichomes in Vernonieae have been used in taxonomy, especially with African taxa (Pope 1983, Isawumi 1984, 1989, Jeffrey 1988). The American taxa have been studied to a lesser extent: Critoniopsis (Haro-Carrión and Robinson 2008), Lychnophora (Luque et al. 1999) and Vernonia (Faust and Jones 1973). Stellate trichomes are commonly found in the subtribe Piptocarphinae (Critoniopsis, Piptocarpha). Non-glandular leaf trichomes of nearly all taxa included in this analysis have been recently studied (Loeuille et al. in prep.), trichomes data for the other species were taken from the following papers: Haro-Carrión and Robinson (2008) 
(Critoniopsis huairacajana), Robinson (1999b) (Stokesia laevis) and Robinson et al. (2008) (Strobocalyx arborea and Tarlmounia elliptica).

L-shaped and T-shaped trichomes co-occur in Centratherum punctatum leaves, consequently they cannot be considered as two homologues of a character "2-armed trichomes" (conjunction criteria). Following Evert (2006) and Theobald et al. (1979) only trichomes with more than five rays are called "stellate". We included the vermiform and goblet-shaped trichome of HaroCarrión and Robinson (2008) in a single category: "swollen trichome".

7. Unbranched trichomes: absent (0); present (1). Hypothese of homology: (0(1)).

8. T-shaped trichomes: absent (0); present (1). Hypothese of homology: (0(1)).

9. L-shaped trichomes: absent (0); present (1). Hypothese of homology: (0(1)).

10. 3- to 5-armed trichomes: absent (0); present (1). Hypothese of homology: (0(1)).

11. Stellate trichomes: absent (0); present (1). Hypothese of homology: (0(1)).

12. Curly trichomes: absent (0); present (1). Hypothese of homology: (0(1)).

13. Geminate trichomes: absent (0); present (1). Hypothese of homology: (0(1)).

14. Spurred trichomes: absent (0); present (1). Hypothese of homology: (0(1)).

15. Porrect trichomes: absent (0); present (1). Hypothese of homology: (0(1)).

16. Swollen trichomes: absent (0); present (1). Hypothese of homology: (0(1)).

\section{Capitulescence}

Capitulescence type varies greatly in the tribe Vernonieae, and it has been used in the taxonomy of the group, especially in Vernonia (Cabrera 1944, Jones 1979, 1981), and in syncephalous taxa (MacLeish 1984a). Capitulescence of first order-type categories are based on Endress (2010), syncephalous taxa have been codified as inapplicable for this character. The branching pattern is the one of the first-order axis, therefore a thyrse has been codified as "racemose branching pattern". As pointed out by Endress (2010) the paniculate pattern is somehow intermediate between the racemose and cymose pattern.

Internode reduction on the capitulescence is common in the American Vernonieae and leads to the formation of a cluster of heads or glomerule (Blanchetia, Proteopsis etc.). When the capitulescence exhibits a common (secondary) receptacle and usually a common (secondary) involucre to several heads it can be referred to as syncephalium (Weberling 1989). Position of the capitulescence in the three caulirosuletum genera of Lychnophorinae (Minasia, Prestelia and Proteopsis) is lateral (see chapter 5).

17. Capitulescence position: axillary (0); terminal (1). Hypothese of homology: $(0(1))$.

18. Capitulescence of first-order type: 1-few terminal heads (0); racemose branching pattern (1); cymose branching pattern (2); paniculate pattern (3). Hypothese of homology: $(0(1)(2)(3))$. 19. Capitulescence of first-order showing internode reduction: no (0); yes but not syncephalia (1); syncephalia (2). Hypothese of homology: $(0(1(2)))$. 


\section{Capitula, phyllaries, receptacle, paleae}

The number of florets per head is here analysed as a quantitative character and an ordered multistate transformation series (see Materials and Methods). Keeley and Turner (1990) consider that in Vernonieae there are three broad categories (1-9; 10-60 (75) and more than 100 florets per head) without further justification. Within the scope of the present analysis I was enable to recover such categories. Additionally to the data from the studied specimens, flora and revisions (when available) have been used to determine the means value for each taxa. The categories for the character 23 are based on the definitions given by Small (1919) for the ornamentation of the receptacle.

20. Number of florets per head (quantitative character): minimum value $=1$ and maximal value $=110$. Hypothese of homology: $(0(1(2(3(4(5(6(7(8(9))))))))))$

21. Head bracteole: absent (0); present (1). Hypothese of homology: (0(1)).

22. Head peduncle: absent (0); present (1). Hypothese of homology: (0(1)).

23. Phyllary series: many (0); 5-8 (1); 4 or fewer (2). Hypothese of homology: (0(1(2))).

24. Phyllary imbrication: strong (0); weak or none (1). Hypothese of homology: (0(1)).

25. Phyllary duration (any series): persistent (0); deciduous or caducous (1). Hypothese of homology: (0(1)).

26. Head receptacle shape: concave (0); flat (1); convex to conical (2); short thick column (3). Hypothese of homology: $(0(1(2(3))))$.

27. Head receptacle pitting: smooth (0); areolate or foveolate (1); fimbrillate (2); alveolate (3). Hypothese of homology: $(0(1)(2)(3))$.

28. Palea: absent (0); present (1). Hypothese of homology: $(0(1))$.

\section{Corollas}

Corolla color in American Vernonieae is to a large extent purple, varying from lavender to bluish purple (lilac), sometimes pinkish or white (Robinson 1999a). Yellowish or blue corollas rarely occur and two species of Chresta have red corolla with yellow bands at base of lobes (MacLeish 1985a). Most of purple corollas become whitish after anthesis with age. As noted by Keeley and Turner (1990), the length of the tube relative to the limb varies and was found to be informative. Corolla laticifers have first been reported by Carlquist (1976) for Heterocoma and some Vernonanthura (Lewinsohn 1991). In the course of the present study laticifers were found in several others genera: Bishopalea, Chronopappus, Hololepis, Sipolisia and Xerxes. Noteworthy exceptions to the regular 5-lobed corollas are found in Elephantopus, Orthopappus and Stokesia.

29. Corolla color (at anthesis): purple (lavender to lilac) or blue (0); white or cream (1); red (2). Hypothese of homology: $(0(1)(2))$.

30. Tube/limb ratio: tube $>\operatorname{limb}(0)$; tube $=\operatorname{limb}(1)$; tube $<$ limb. Hypothese of homology: $(0(1(2)))$.

31. Corolla laticifer: absent (0); present (1). Hypothese of homology: (0(1)). 
32. Corolla of peripheral florets symmetry: regular 5-lobed (0); irregular 5-lobed (1). Hypothese of homology: (0(1)).

\section{Anthers}

Anthers are calcarate with rare exceptions (Centratherum, Elephantopus and Orthopappus). Distinctly tailed anthers are rare (some Critoniopsis, some Minasia, Piptocarpha etc.). Glandular apical anther appendages are found in Chrysolaena and some Vernonia.

33. Anther base: ecalcarate (0); calcarate (1). Hypothese of homology: (0(1)).

34. Anther base tail: absent (0); present (1). Hypothese of homology: $(0(1))$.

35. Apical anther appendage cells: lacking conspicuous wall thickenings (0); with conspicuous wall thickenings (1). Hypothese of homology: (0(1)).

36. Apical anther appendage gland: absent (0); present (1). Hypothese of homology: (0(1)).

37. Apical anther appendage length: at least 3 times as long as wide (0); at least twice as long as wide (1); up to twice as long as wide (2). Hypothese of homology: $(0(1)(2))$.

\section{Pollen}

Since the six pollen types (A-F) named by Keeley and Jones (1977, 1979), more characters have then been incorporated (Robinson 1992b, 1999a) and now about ten main pollen types are recognised in the Vernonieae (Angulo and Dematteis 2010). However, as pointed out by Blackmore et al. (2009), the more complex pollen types become by incorporating new features, the less likely they are to form a meaningful pattern. Several taxa do not conform to any type at all (by example, Orthopappus angustifolius) (Robinson 1992b). Therefore, it is more likely to provide more rigorous homology hypothesis of pollen morphology using single characters.

All taxa included in the analysis have echinate pollen grains (i.e. having ornementation at least $1 \mu \mathrm{m}$ in size, following Wortley et al. 2008). The terms "lophate" and "non-lophate" are used regardless of whether grains are echinate or not (following Blackmore et al. 2009).

The terms "sublophate" and "subechinolophate" are here considered synonymous (Skvarla et al. 2005).

Pollen data were extracted from the following publications: Angulo and Dematteis (2010), Carrijo et al. (2005), Coile and Jones (1981, 1983), Dematteis (2007, 2009), Galvão et al. (2009), Gamerro (1990), Kingham (1976), Loeuille et al. (see Annex), MacLeish (1985a,b), Mendonça et al. (2007, 2009), Peçanha et al. (2001, 2008), Pruski (1992), Robinson (1980, 1981, 1983, 1987a, b, c, 1988, 1990, 1992a,b, 1993, 1994, 1999a, b), Robinson and Funk (1987), Robinson and Marticorena (1986), Robinson et al. (2008), Skvarla et al. (2005), Smith and Coile (2007) and Stix (1960).

38. Pollen aperture type: colporate (0); pororate (with the ectoaperture as a pore rather than a colpus) (1). Hypothese of homology: (0(1)).

For the standard analysis:

39. Pollen macro-ornamentation: non-lophate (0), sublophate (having spines arranged in a 
pattern as if lophate) (1); lophate (2). Hypothese of homology: $(0(1(2)))$.

For the three-item analysis, the state "non-lophate pollen" is not represented (only present in outgroup taxa). Consequently:

39. Pollen macro-ornementation: sublophate (having spines arranged in a pattern as if lophate) (0); lophate (1). Hypothese of homology: (0(1)).

40. Pollen tectum extension: covering less than $50 \%$ of pollen grain surface (semi-tectate) (0); covering more more than $50 \%$ but discontinuous (1); continuous (0). Hypothese of homology: $(0(1(2)))$.

41. Pollen tectum: not perforate (0); perforate (1). Hypothese of homology: (0(1)).

Characters restricted to taxa with lophate pollens:

42. Polar areole: absent (0); present (1). Hypothese of homology: (0(1)).

\section{Style}

The presence or the lack of a style node (extended base of the style usually partially embedded on the top of the nectary) has been widely used in Vernonieae taxonomy (Robinson 1999). However some intermediate stages between the complete lack and a well developed node was found like in Echinocoryne holosericea, in which the node is limited to a ring of sclerified cells. The majority of American Vernonieae have long fusiform to acicular sweeping hairs. Some shape variation is found in Chrestinae. MacLeish (1984a) described the sweeping hairs of Argyrovernonia as acuminate, acute and bipartite. In the present study, the sweeping hairs of A. harleyi appear similar to those of Chresta speciosa and Pithecoseris pacourinoides: clavate to lageniform. Moquinia racemosa has thickened scabrid styles (similar to those found in Arctotidae) (Robinson 2007). The sweeping hairs are sometimes septate but this character appeared to be highly variable even between the hairs of the same style and consequently was discarded.

43. Style base: not expanded (0); expanded (1). Hypothese of homology: (0(1)).

44. Sweeping hairs shape: scabrid (0); subulate to acicular (1); clavate to lageniform (2).

In the three-item analysis no outgroup was used and therefore the state "scabrid" was not represented:

44. Sweeping hairs shape: subulate to acicular (0); clavate to lageniform (1). Hypothese of homology: (0(1)).

\section{Cypsela}

The only taxa with dimorphic cypselae included in the analysis is Pithecoseris pacourinoides; its character states have been codified as polymorphic when necessary. Another taxon, Lychnophoriopsis candelabrum, has been described having dimorphic cypselae but it has never been seen in any specimens (Robinson 1992a, Semir 1991). Phytomelanin was once thought to be restricted to Athroismeae and Heliantheae alliance (Pandey et al. 1989); however it occurs in the Sipolisiinae (except for Hololepis) (see Chapter 4). The carpopodium of American 
Vernonieae, when present, is non-interrupted (Haque and Godward 1984) and its cells vary from thin- to thick-walled; in some cases the lumina is almost occluded. The shape of the raphids in the wall of the cypsela have been used by Robinson (1999a), but they are often hard to see and in some cases several shapes have been observed in the same cypsela (Eremanthus eryrthropappus). Further detailed anatomical studies are necessary to obtain reliable and secure data of this character.

45. Phytomelanin on cypsela wall: absent (0); present (1). Hypothese of homology: (0(1)).

46. Cypsela wall: glabrous (0); pubescent (1). Hypothese of homology: (0(1)).

For standard analysis:

47. Cypsela rib: more than 10-ribbed (0); 8 to 10-ribbed (1); c. 5-ribbed (2). Hypothese of homology: (0(1)(2)).

For three-item analysis, the state "more than 10-ribbed" is not represented (only present in the outgroup), therefore:

47. Cypsela rib: 8 to 10-ribbed (0); c. 5-ribbed (1). Hypothese of homology: (0(1)).

48. Carpopodium: absent or inconspicuous (0); prominent (1). Hypothese of homology: $(0(1))$.

Characters restricted to taxa with carpopodia:

49. Carpopodium cells druze: absent (0); present (1). Hypothese of homology: (0(1)).

50. Carpopodium cells wall: thin-walled (0); thick-walled (1); thick-walled nearly occluding lumina (2). Hypothese of homology: $(0(1(2)))$.

\section{Pappus}

The pappus has usually two series, sometimes only one (some Elephantopus, Stokesia, Soaresia etc.) and less often more than two (Chrestinae, Eremanthus, Lepidonia etc.); in the latter case the number of series is not fixed and varies in the same species between three and five, rarely up to ten. Following MacLeish (1984a) we used the arbitrary $0.1 \mathrm{~mm}$ width to set apart setose from paleaceous pappus. It is quite difficult to draw a distinct line between paleaceous pappus and awns, therefore we choosed to consider the latter as an extreme form of the former. Few species display a ring or collar (like Gorceixia), the structure is here interpreted as a paleaceous outer pappus with fused elements.

51. Number of pappus series: two (0); one (1); more than two (2). Hypothese of homology: $(0(1)(2))$.

52. Pappus duration (any part): persistent (0); deciduous or caducous (1). Hypothese of homology: (0(1)).

53. Pappus fusion (any part): free (0); fused (1). Hypothese of homology: (0(1)).

54. Outer pappus type: setose (0); paleaceous (1). Hypothese of homology: $(0(1))$.

55. Inner pappus type: setose (0); paleaceous (1). Hypothese of homology: (0(1)).

\section{Chemistry. Sesquiterpene lactones}

The biosynthetic routes which generate the different sesquiterpene lactones (STL) are currently 
unknown (Costa et al. 2005) and only hypothetical pathways between the different groups have been suggested (Seaman 1982, Seaman and Funk 1983, Bohlmann and Jakupovic 1990). Here, we used a classification of STLs skeleton in types and subtypes proposed by Costa et al. (unpublished data) which rely mainly on carbon connectivity. The three types of STLs skeleton represented in our dataset are: guaianolide, elemanolide and germacranolide. Only Gymnanthemum amygdalinum in this analysis displays elemanolide. The germacranolide are divided into two subtypes, germacrolide and heliangolide.

Only reports of STLs with a taxonomic voucher have been used, except in the few cases where a botanical authority in Vernonieae taxonomy was acknowledged. Each voucher identity have been checked. Doubtful reports were discarded.

STLs reports used in this dataset are from the following publications: Almeida et al. (2006), Barros et al. (1985), Bohlmann and King (1991), Bohlmann et al. (1979, 1980a, c, 1981a, b, c, d, 1982a, b, d), Borella et al. (1998), Buskuhl et al. (2010), Crotti et al. (2005), Fuchino et al. (2001), Gershenzon et al. (1984), Gobbo-Neto and Lopes (2008), Herz and Kumar (1980), Herz et al. (1981), Jakupovic et al. (1986a, b, 1987, 1989), Kisiel (1975), Krishna Kumari et al. (2003), Lunardello et al. (1995), Mabry et al. (1975), Pollora et al. (2000), Sakamoto et al. (2003), Valdés et al. (1998), Vichnewski et al. (1989) and Zdero et al. (1981).

56. Guaianolide: absent (0); present (1). Hypothese of homology: (0(1)).

For the standard analysis:

57. Germacranolide: absent (0); present (1).

Character restricted to taxa with germacranolide:

58. Germacranolide derivatives: germacrolide derivatives (0); heliangolide derivatives (1).

For the three-item analysis:

57. Germacranolide: absent (0); germacrolide derivatives (1); heliangolide derivatives (2). Hypothese of homology: ((0(1)(2)) 
Appendix 2. Characters used in the cladistic analysis of the Matrix 2 (Lychnophorinae). The numbers correspond to those in the data matrix (Table 2).

\section{Life forms}

Most of Lychnophorinae are woody plants (herbaceous members are not included in the present study). A detailed account of life forms in Lychnophorinae is presented in Chapter 5. As pointed out by Robinson (1983) and Hind (1995), most species of Lychnophora are not shrubs but treelets and trees. Three genera (Minasia, Prestelia, Proteopsis) are caulirosulate plants (sensu Cuatrecasas and Robinson in press.) (see also Chapter 5).

1. Life form: shrub (0); caulirosuletum (1); treelet and tree (2). Hypothese of homology: $(0((1)$ (2))).

\section{Leaves}

2. Leaf margin: flat (0); revolute (1). Hypothese of homology: $(0(1))$.

3. Leaf margin II: entire (0); serrate to dentate (1). Hypothese of homology: (0(1)).

4. Leaf sheath: absent (0); present (1). Hypothese of homology: $(0(1))$.

5. Leaf sheath II: semi-amplexicaul to amplexicaul (0); pad-like (1) (character restricted to taxa with leaf sheath). Hypothese of homology: (0(1)).

Luque et al. (1999) studied the leaf trichomes of several Lychnophorinae (Chronopappus, Lychnophora, Paralychnophora and Piptolepis). Non-glandular leaf trichomes of all taxa included in the analysis have been recently studied (Loeuille et al. in prep.) (see Fig. 5 in Chapter 5).

6. Unbranched trichomes (without auriculate base): absent (0); present (1). Hypothese of homology: (0(1)).

7. Unbranched auriculate trichomes: absent (0); present (1). Hypothese of homology: (0(1)).

8. Not swollen T-shaped trichomes: absent (0); present (1). Hypothese of homology: (0(1)).

9. Swollen T-shaped trichomes: absent (0); present (1). Hypothese of homology: (0(1)).

10. Inverted Y-shaped trichomes: absent (0); present (1). Hypothese of homology: (0(1)).

11. Stellate trichomes: absent (0); present (1). Hypothese of homology: (0(1)).

12. 3- to 5-armed not swollen trichomes: absent (0); present (1). Hypothese of homology: (0(1)).

13. 3- to 5-armed swollen trichomes: absent (0); present (1). Hypothese of homology: (0(1)).

14. Curly trichomes: absent (0); present (1). Hypothese of homology: (0(1)).

15. Long stalked trichomes: absent (0); present (1). Hypothese of homology: (0(1)).

16. Geminate trichomes: absent (0); present (1). Hypothese of homology: (0(1)).

17. Porrect trichomes: absent (0); present (1). Hypothese of homology: (0(1)).

18. Spurred trichomes: absent (0); present (1). Hypothese of homology: (0(1)). 


\section{Capitulescence}

We defined the syncephalium by the presence of a secondary receptacle, sometimes accompanied by a secondary involucre. The latter might be hardly distinguishable from densely leafy stem apices in several Lychnophora species (Hind 1995). As noted by Good (1956) when the secondary involucre is not recognizable and the aggregations of capitula scarcely circumscribed at all, it is difficult to say just which species have a syncephalium. Relying on the presence of a secondary receptacle all syncephalous Lychnophorinae cited in the litterature have been recognized as such. Branching pattern has been defined based on Endress (2010) and independently of the unit of the capitulescence (i.e., capitulum, glomerule or syncephalium). Characters 18 to 21 have been used in the revision of Eremanthus (MacLeish 1987) and Lychnophora (Semir 1991) (there are restricted to taxa with syncephalia). Third-order syncephaly is found in some species of Lychnophora and seldom in Eremanthus mollis and Paralychnophora glaziouana (see Chapter 4). Harris (1999) noted that tertiary condensation is only found in four genera of Asteraceae (Gundelia, Lagascea, Paralychnophora, Platycarpha), and that all primary capitula are reduced to one-flowered state. However, none of the Lychnophorinae exhibiting third-order syncephalia have one floret per capitulum (4-15 in Lychnophora and 2-4 in P. glaziouana).

19. Capitulescence position I: axillary (0); terminal (1). Hypothese of homology: (0(1)).

20. Capitulescence peduncle: absent (0); present (1). Hypothese of homology: (0(1)).

21. Capitulescence first-order unit: capitulum (0); glomerule (1); syncephalium (2). Hypothese of homology: $(0(1(2)))$.

22. Capitulescence branching pattern: few terminal capitula/glomerule/syncephalia (0); racemose (1); cymose (2); paniculate (3). Hypothese of homology: $(0(1)(2)(3))$.

23. Syncephalium form: hemispherical or pyramidal (0); spherical (1). Hypothese of homology: (0(1)).

24. Syncephalium level: second-order (0); third-order (1). Hypothese of homology: (0(1)).

25. Syncephalium units: unit of syncephalia evident (0); not evident due to tissue/indument growth (1). Hypothese of homology: (0(1)).

26. Syncephalium leaves: reduced leaves between capitula (0); no leaves between capitula (1). Hypothese of homology: (0(1)).

27. Secondary involucre: absent (0); present (1). Hypothese of homology: (0(1)).

\section{Capitula, phyllaries, receptacle, paleae}

The number of florets per capitulum varies from 1 to 110 . Additionally to the data from the studied specimens, flora and revisions (when available) have been used to determine the means value for each taxa. The categories for the character 31 are based on the definitions given by Small (1919) for the ornementation of the receptacle (see also chapter 4).

28. Number of florets per capitulum (quantitative character): minimum value $=1$ and maximal value $=110$. Hypothese of homology: $(0(1(2(3(4(5(6)))))))$.

29. Capitulum peduncle: absent (0); present (1). Hypothese of homology: (0(1)). 
30. Involucre shape: cylindrical (0); ovoid (1); obconic (2); campanulate (3). Hypothese of homology: $(0(1)(2)(3))$.

31. Phyllary imbrication: strong (0); weak or none (1). Hypothese of homology: (0(1)).

32. Phyllary duration: persistent (0); caducous or deciduous (1). Hypothese of homology: (0(1)).

33. Phyllary indument: glabrous (0); pubescent (1). Hypothese of homology: $(0(1))$.

34. Phyllary apex: obtuse (0); acute to acuminate (1); with spiny appendage (2). Hypothese of homology: $(0(1(2)))$.

35. Capitulum receptacle pitting: smooth (0); areolate or foveolate (1); fimbrillate (2); alveolate (3). Hypothese of homology: $(0(1)(2)(3))$.

36. Palea: absent (0); present (1). Hypothese of homology: (0(1)).

\section{Corollas}

Short corolla tube is typical of Anteremanthus, Bishopalea, Heterocoma and some species of Eremanthus. Corolla laticifers reported in Heterocoma by Carlquist (1976) were also discovered in the present study in Bishopalea, Chronopappus, Heterocoma, Hololepis, Sipolisia and Xerxes. The character 38 is based on field observation.

37. Tube/limb ratio: tube $>\operatorname{limb}(0)$; tube $=\operatorname{limb}(1)$; tube $<$ limb. Hypothese of homology: $(0(1(2)))$.

38. Corolla laticifer: absent (0); present (1). Hypothese of homology: (0(1)).

39. Corolla apex: glabrous (0); pubescent (1). Hypothese of homology: (0(1)).

40. Corolla lobe: not revolute (0); revolute (1). Hypothese of homology: (0(1)).

\section{Anthers}

Anthers in Lychnophorinae are calcarate. Distinctly tailed anthers are only found in Minasia. 41. Anther base tail: absent (0); present (1). Hypothese of homology: (0(1)).

42. Anther appendage base: straight (0); constricted (1). Hypothese of homology: (0(1)).

\section{Style}

Lychnophorinae taxa don't exhibit a style node. Sweeping hairs are sometimes septate in some species Eremanthus and Lychnophora mainly.

43. Style base: not expanded (0); expanded (1). Hypothese of homology: (0(1)).

\section{Cypsela}

The only taxa with dimorphic cypselae included in the analysis is Pithecoseris pacourinoides, its character states have been codified as polymorphic when necessary. See Appendix 1 for the comment about dimorphic cypselae in Lychnophoriopsis. The shape of the cypsela varies from cylindrical to prismatic; Hind (2000) noted that Paralychnophora has cylindrical cypsela coarsely angled (termed in the present study as prismatic) unlike Eremanthus and Lychnophora cylindrical to turbinate but not angled. Phytomelanin is present in the cypsela walls of 
Bishopalea, Heterocoma, Sipolisia and Xerxes (see Chapter 4).

44. Cypsela shape: cylindrical (0); turbinate (1); prismatic (2). Hypothese of homology: (0(1) (2)).

45. Phytomelanin on cypsela wall: absent (0); present (1). Hypothese of homology: (0(1)).

46. Cypsela wall: glabrous (0); pubescent (1). Hypothese of homology: $(0(1))$.

47. Carpopodium: absent or inconspicuous (0); prominent (1). Hypothese of homology: $(0(1))$.

\section{Pappus}

The pappus characteristics have been used extensively in the taxonomy of Lychnophorinae by Candolle (1836), Schultz-Bipontinus $(1861,1863)$ and more recently by Coile and Jones (1981, 1983 ) and MacLeish (1987). Uniseriate pappus is uncommon in Lychnophorinae (Blanchetia, Gorceixia, some Lychnophora, Proteopsis argentea). Based on its position and morphology, primary homology hypotheses of the uniseriate pappus has been established with the outer or inner pappus series (the characters for the other serie have been coded as inapplicable). The distinction between caducous and deciduous pappus is here relevant; the pappus is said caducous when it falls off prematurely or easily and deciduous when it falls off with maturity (Candolle, 1819; Hind, 2009). Subpaleaceous seta is here arbitrarily defined having a width bewteen 0.08 and $0.1 \mathrm{~mm}$ and paleacous more than $0.1 \mathrm{~mm}$. The distinction between subpaleaceous and paleaceous has been used in the taxonomy of Eremanthus (MacLeish, 1987).

48. Number of pappus series: two (0); one (1); more than two (2). Hypothese of homology: $(0(1)(2))$.

49. Outer pappus duration: persistent (0); deciduous (1); caducous (2). Hypothese of homology: $(0(1(2)))$.

50. Outer pappus fusion: free (0); fused at base (1); more than half fused (2). Hypothese of homology: (0(1(2))).

51. Outer pappus relative size to inner series: smaller (0); subigual or igual (1); residual (2). Hypothese of homology: $(0(1)(2))$.

52. Outer pappus type: setose (0); subpaleaceous (1); paleaceous (1). Hypothese of homology: $(0(1(2)))$.

53. Outer pappus seta base: not enlarged (0); enlarged (1). Hypothese of homology: (0(1)).

54. Outer pappus seta apex: not narrowed (0); narrowed (1). Hypothese of homology: $(0(1))$.

55. Inner pappus duration: persistent (0); deciduous (1); caducous (2). Hypothese of homology: $(0(1(2)))$.

56. Inner pappus form: straight (0); twisted (1). Hypothese of homology: (0(1)).

57. Inner pappus type: setose (0); subpaleaceous (1); paleaceous (2). Hypothese of homology: $(0(1(2)))$.

58. Inner pappus seta base: not enlarged (0); enlarged (1). Hypothese of homology: (0(1)).

59. Inner pappus seta apex: not enlarged nor narrowed (0); narrowed (1); enlarged (2). Hypothese of homology: (0(1)(2)). 


\section{Chemistry. Sesquiterpene lactones.}

Several reports of STLs have been published with a wrong identification of the voucher. And in some cases (without voucher but identified by botanical authority in Vernonieae taxonomy), the locality cited is outside of the distributional range of the species. Consequently these reports have been discarded.

STLs reports used in this dataset are from the following publications: Almeida et al. (2006), Bohlmann and King (1991), Bohlmann et al. (1980a, b, c, d, 1981c, d, 1982c, d), Borella et al. (1998), Crotti et al. (2005), Gobbo-Neto and Lopes (2008), Grael et al. (2000), Herz and Kumar (1980), Jordão (2003), Le Quesne et al. (1982), Lunardello et al. (1995), Mauro et al. (1993), Oliveira et al. (1996), Sacilotto et al. (2002), Sakamoto et al. (2010), Sartori et al. (2002), Vichnewski and Gilbert (1972), Vichnewski et al. (1989) and Zdero et al. (1981).

60. Heliangolide derivatives I. Furanoheliangolide: absent (0); present (1). Hypothese of homology: $(0(1))$.

61. Heliangolide derivatives II. Eremantholide: absent (0); present (1). Hypothese of homology: $(0(1))$.

Electronic Supplementary Appendix 1 The data matrix 1. Multiple states of characters are coded with the next letters: $\mathrm{a}=(01), \mathrm{b}=(12),-=$ inapplicable data, $?=$ missing data. 


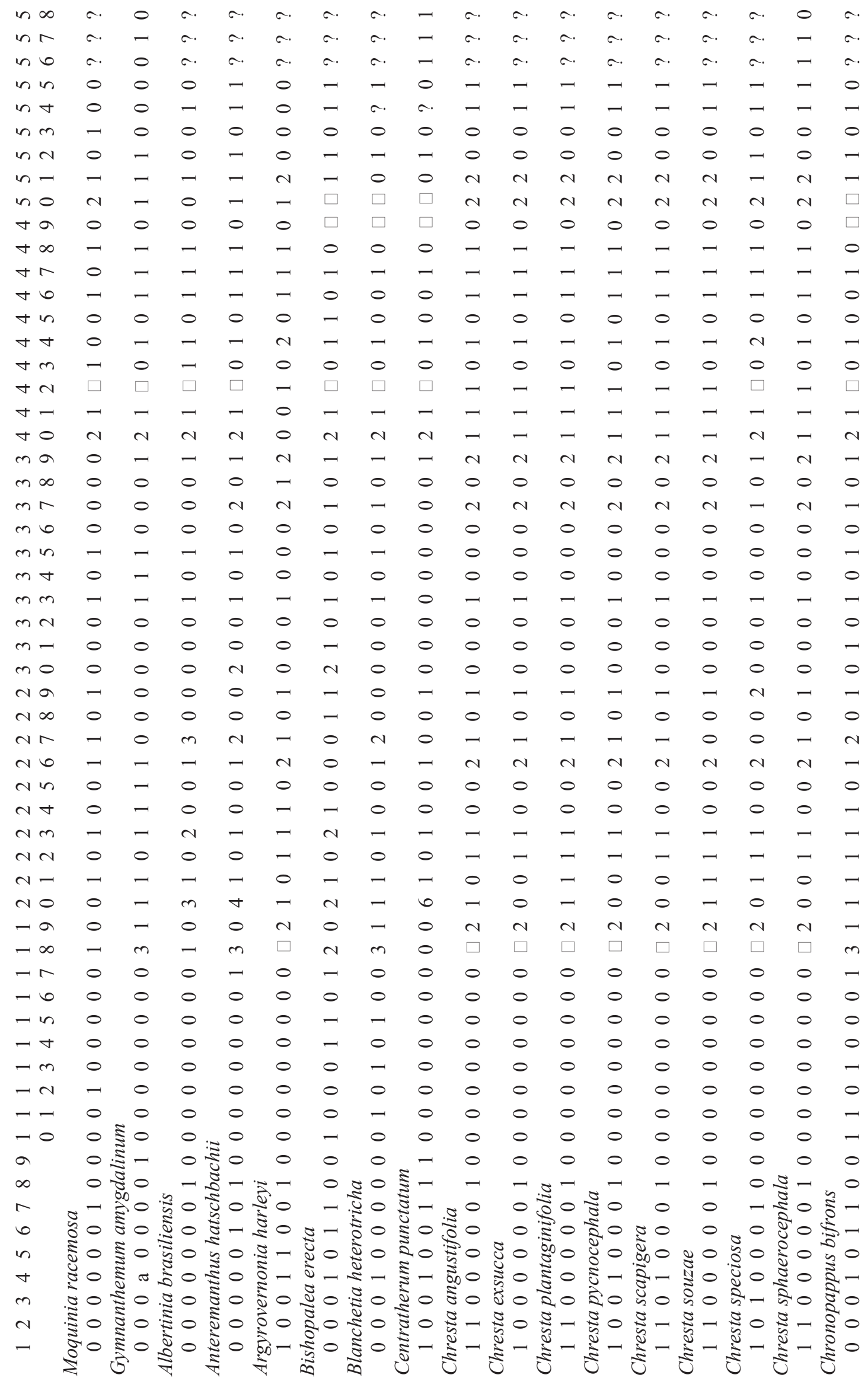




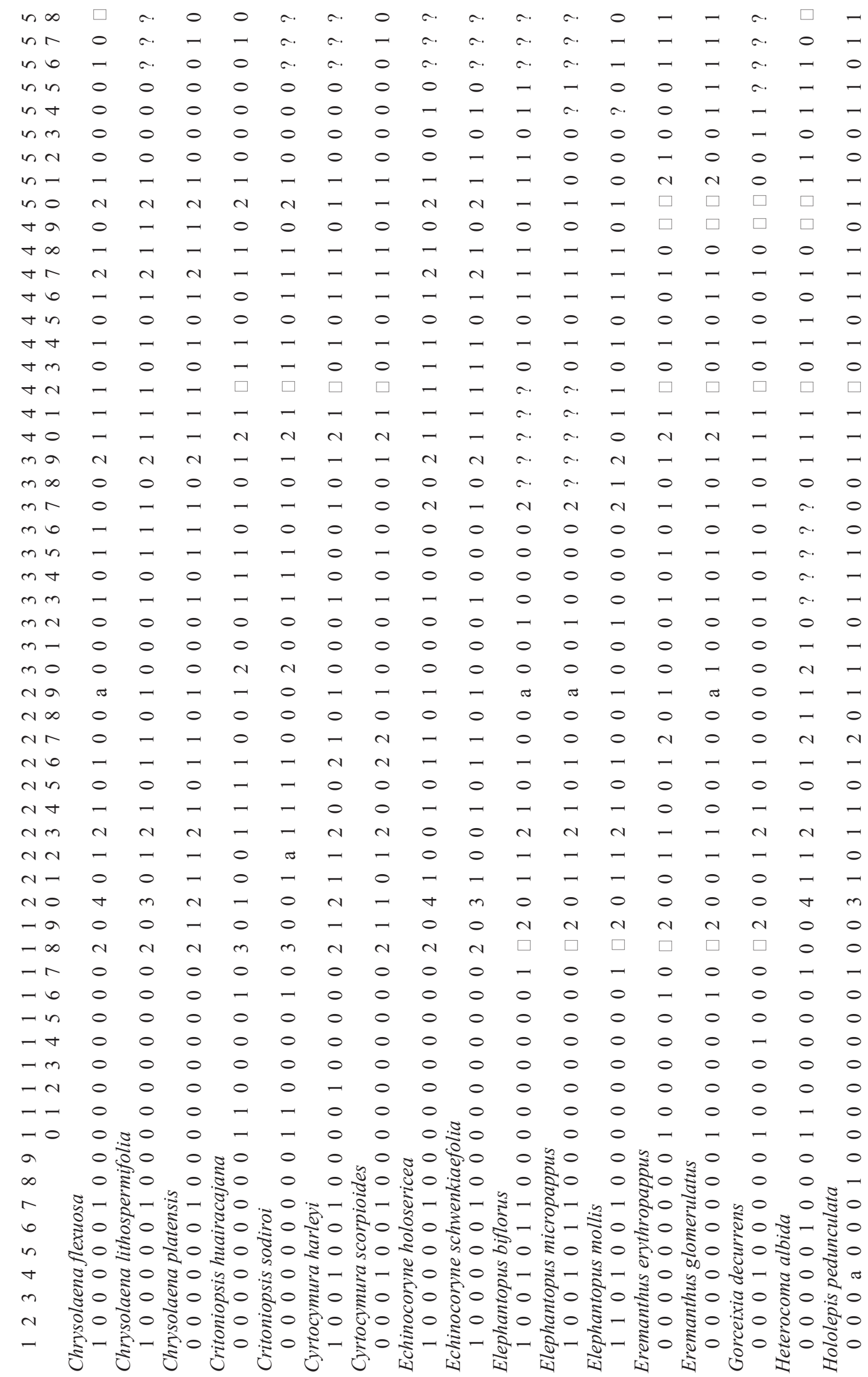




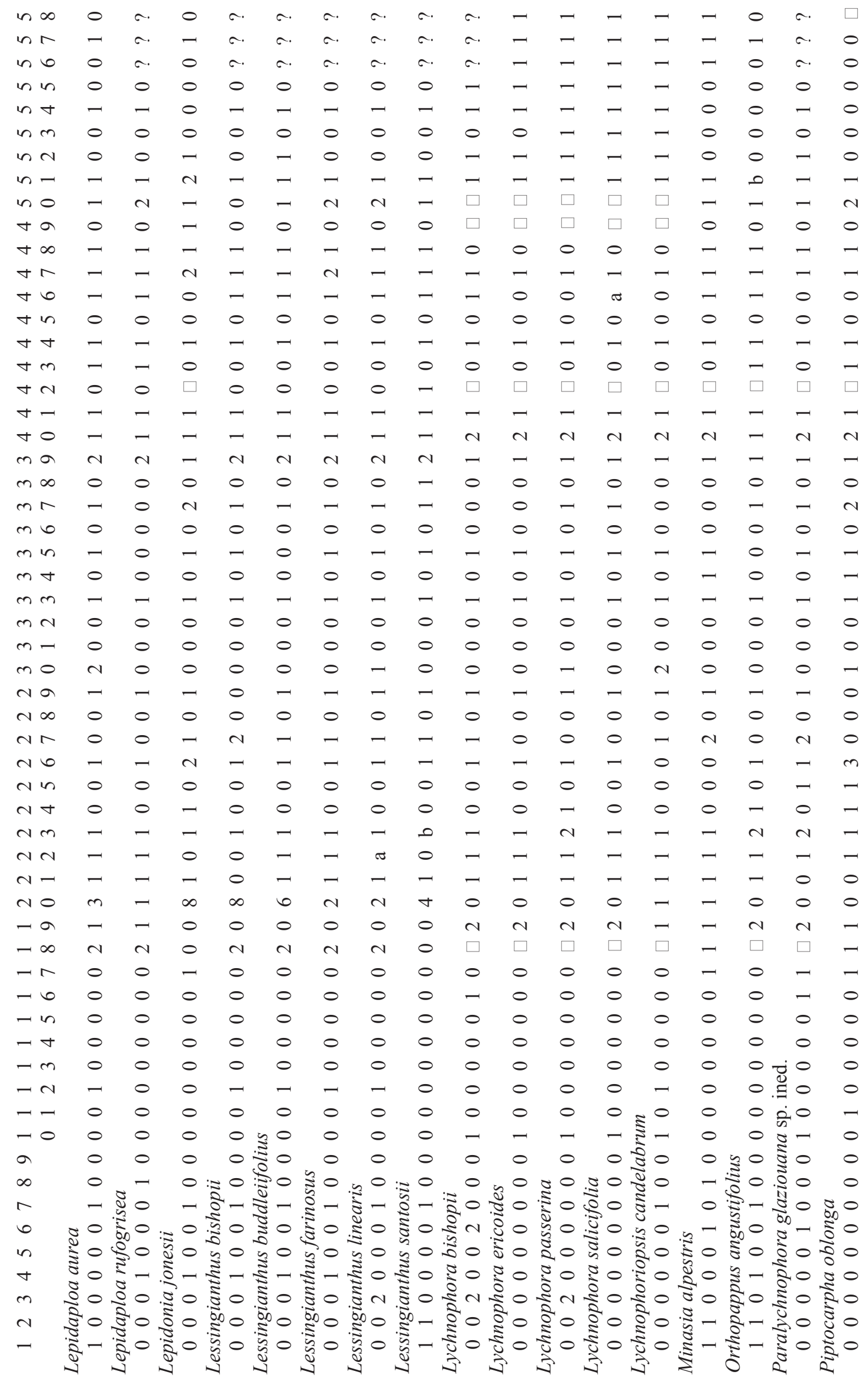




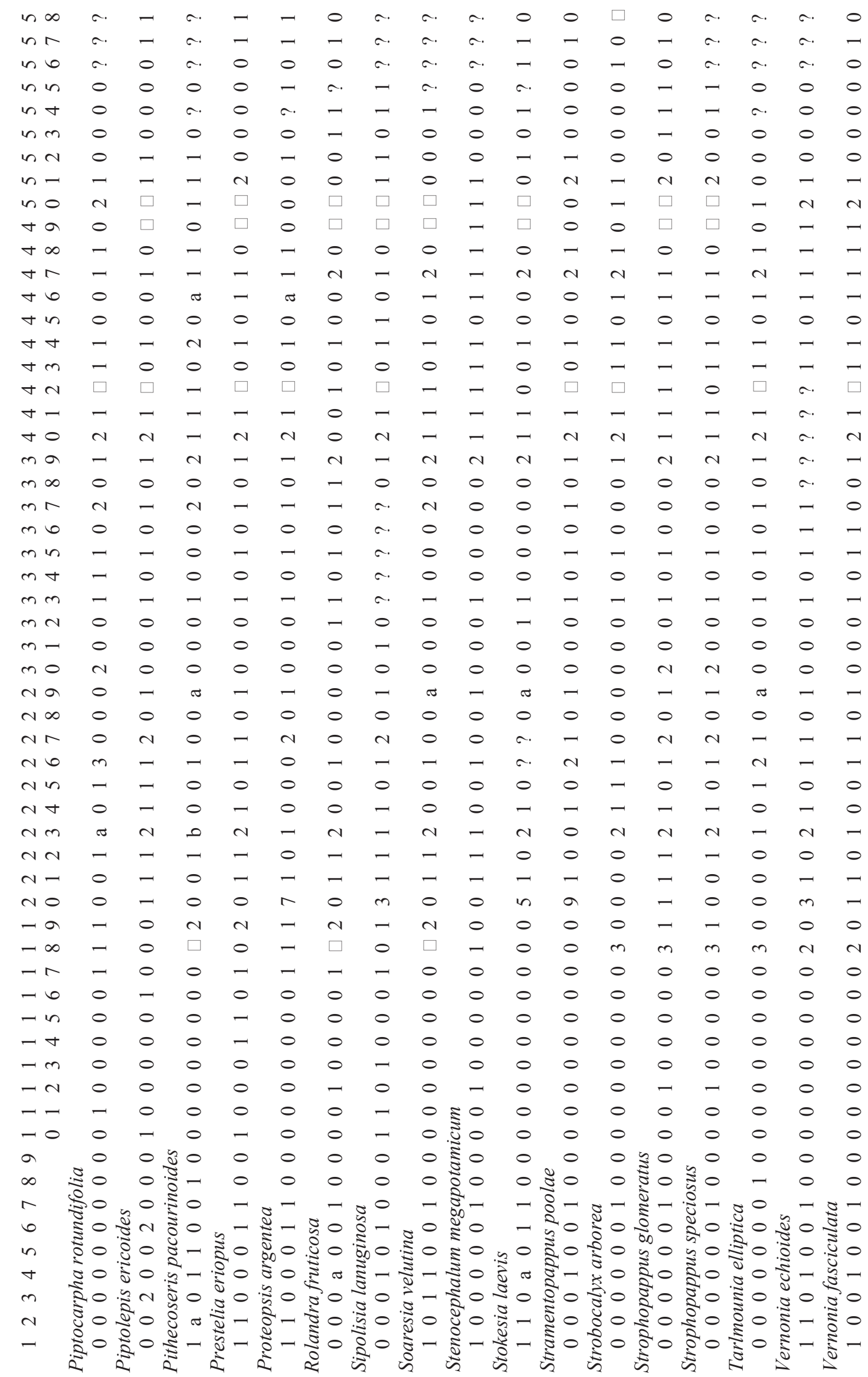




\begin{tabular}{|c|c|c|c|c|c|c|c|}
\hline$n \alpha$ & & 0 & ๙. & ๙. & 0 & - & c. \\
\hline in & & - & a. & ๙. & - & - & ๙. \\
\hline in 6 & & 0 & ๙. & ๙. & - & 0 & ๙. \\
\hline in er & & 0 & 0 & 0 & 0 & - & 0 \\
\hline$n$ & & 0 & 0 & 0 & 0 & - & - \\
\hline$n c$ & & 0 & 0 & 0 & 0 & 0 & 0 \\
\hline inc & & 0 & 0 & - & - & - & - \\
\hline$n-$ & & - & - & - & - & - & - \\
\hline$n<$ & & $N$ & $N$ & $N$ & $N$ & $\square$ & $\square$ \\
\hline$\nabla 0$ & & - & - & - & - & $\square$ & $\square$ \\
\hline$\nabla \alpha$ & & - & - & - & - & 0 & 0 \\
\hline$\nabla r$ & & - & - & - & - & - & - \\
\hline$\nabla c$ & & - & - & - & - & 0 & - \\
\hline$\nabla r$ & & 0 & 0 & 0 & 0 & - & 0 \\
\hline$\nabla$ & & - & - & - & - & - & - \\
\hline$\nabla c$ & & - & - & - & - & 0 & 0 \\
\hline$\nabla c$ & & $\square$ & $\square$ & $\square$ & $\square$ & $\square$ & $\square$ \\
\hline$\nabla$ & & - & - & - & - & - & - \\
\hline$\nabla c$ & & $N$ & $N$ & $N$ & $N$ & $N$ & $\sim$ \\
\hline mo & & - & - & - & - & - & - \\
\hline$m \alpha$ & & 0 & 0 & 0 & 0 & 0 & 0 \\
\hline$m r$ & & 0 & 0 & 0 & 0 & 0 & 0 \\
\hline$m b$ & & - & 0 & 0 & 0 & 0 & 0 \\
\hline m ir & & - & - & - & - & - & - \\
\hline$m=$ & & 0 & 0 & 0 & 0 & 0 & 0 \\
\hline$m \mathrm{cr}$ & & - & - & - & - & - & - \\
\hline$m c$ & & 0 & - & - & - & 0 & 0 \\
\hline m- & & 0 & - & 0 & 0 & - & 0 \\
\hline$m c$ & & 0 & 0 & 0 & 0 & 0 & 0 \\
\hline $\mathrm{NO}$ & & - & $\pi$ & - & $\pi$ & - & - \\
\hline$N \propto$ & & 0 & 0 & 0 & 0 & 0 & 0 \\
\hline N & & - & - & - & - & N & - \\
\hline $\mathrm{N}$ & & - & - & - & - & - & - \\
\hline $\mathrm{Nu}$ & & 0 & 0 & 0 & 0 & 0 & 0 \\
\hline$N$ & & 0 & - & - & - & - & 0 \\
\hline $\mathrm{NO}$ & & - & - & $N$ & $\sim$ & - & - \\
\hline $\mathrm{NO}$ & & 0 & - & 0 & - & - & - \\
\hline$N-$ & & 0 & - & - & - & - & - \\
\hline $\mathrm{NC}$ & & $\nabla$ & $N$ & - & - & 6 & - \\
\hline-0 & & 0 & 0 & 0 & 0 & $\pi$ & - \\
\hline$-\infty$ & & $N$ & $N$ & $N$ & $N$ & 0 & $m$ \\
\hline$-r$ & & 0 & 0 & 0 & 0 & - & 0 \\
\hline-6 & & 0 & 0 & 0 & 0 & 0 & - \\
\hline$-v$ & & 0 & 0 & 0 & 0 & 0 & 0 \\
\hline-7 & & 0 & 0 & 0 & 0 & 0 & 0 \\
\hline$-c$ & & 0 & 0 & 0 & 0 & - & 0 \\
\hline-0 & & 0 & 0 & 0 & 0 & 0 & 0 \\
\hline-- & & 0 & 0 & 0 & 0 & - & 0 \\
\hline$-c$ & & 0 & 0 & 0 & 0 & 0 & - \\
\hline$a$ & & & - & - & - & 0 & 0 \\
\hline$\infty$ & & b & 0 & $0 ミ$ & 0 & 0 & - \\
\hline$r$ & & - & - & 0 & - & - & 0 \\
\hline 6 & & & 0 & $0 \stackrel{\Xi}{\Xi}$ & & & $\Xi-$ \\
\hline n & & 0 & $0 \approx$ & 0 & & & $\cong 0$ \\
\hline ナ & & & & & & & \\
\hline$n$ & & 3 & 0 క & $0 \Omega$ & & & \\
\hline N & & & & & & 0.3 & : 30 \\
\hline & & & & & & 0 & $\Xi$ \\
\hline
\end{tabular}


Electronic Supplementary Appendix 2 The data matrix 2. Multiple states of characters are coded with the next letters: $a=(01), b=(12), c=(23), d=(02), e=(03),-=$ inapplicable data, $?=$ missing data. 


\begin{tabular}{|c|c|c|c|c|c|c|c|c|c|c|c|c|c|c|c|c|c|}
\hline $6-$ & 0 & ๙. & ح. & ๙. & ๙. & ๙. & ๙. & - & a. & $\sigma$. & ๙. & $\sigma$. & - & - & 0 & 0 & - \\
\hline 60 & 0 & a. & a. & ๙. & ๙. & a. & a. & - & $\sim$. & ๙. & ๙. & $\sigma$. & - & - & - & 0 & - \\
\hline$n a$ & 0 & 0 & N & 0 & $N$ & 0 & 0 & 0 & 0 & 0 & 0 & 0 & 0 & 0 & 0 & 0 & 0 \\
\hline$n \infty$ & 0 & 0 & 0 & 0 & 0 & 0 & 0 & 0 & 0 & 0 & 0 & 0 & 0 & 0 & 0 & 0 & 0 \\
\hline$n \pi$ & 0 & 0 & - & - & $\sim$ & - & 0 & $N$ & $\sim$ & 0 & 0 & $N$ & 0 & 0 & 0 & $N$ & N \\
\hline$n$ & $\pi$ & 0 & 0 & 0 & 0 & 0 & 0 & 0 & - & - & 0 & 0 & 0 & 0 & 0 & 0 & 0 \\
\hline$n n$ & 0 & 0 & - & $\sim$ & $N$ & - & $N$ & 0 & 0 & $\pi$ & $N$ & 0 & - & 0 & $N$ & 0 & - \\
\hline$n \nabla$ & 0 & 0 & 0 & 0 & I & 0 & 0 & 0 & 0 & 0 & 0 & 0 & 0 & 0 & 0 & 0 & 0 \\
\hline$n m$ & 0 & - & - & 0 & ' & - & 0 & 0 & 0 & 0 & 0 & 0 & - & 0 & 0 & - & - \\
\hline$n N$ & - & - & $N$ & - & , & $N$ & 0 & $N$ & $\sim$ & 0 & 0 & $N$ & $N$ & - & 0 & $N$ & $N$ \\
\hline$n-$ & - & - & - & - & I & - & - & - & - & 0 & - & - & - & - & - & - & - \\
\hline no & 0 & 0 & - & 0 & ' & - & 0 & - & - & 0 & 0 & - & 0 & 0 & 0 & - & - \\
\hline$\forall a$ & 0 & 0 & 0 & $N$ & 1 & 0 & $N$ & 0 & 0 & $\pi$ & $N$ & 0 & - & 0 & $N$ & 0 & - \\
\hline$\nabla \infty$ & 一 & - & - & - & 0 & - & $N$ & $\sim$ & $\sim$ & - & $N$ & $\sim$ & - & - & $N$ & $N$ & $\sim$ \\
\hline$\nabla r$ & $\neg$ & - & - & 0 & 0 & 0 & 0 & 0 & 0 & 0 & 0 & 0 & 0 & 0 & 0 & 0 & 0 \\
\hline$\nabla 6$ & 0 & - & 一 & 0 & 0 & 0 & 0 & - & - & 0 & 0 & 一 & - & - & 0 & - & - \\
\hline$\nabla n$ & 0 & 0 & 0 & - & 0 & 0 & 0 & 0 & 0 & 0 & 0 & 0 & 0 & 0 & 0 & 0 & 0 \\
\hline$\checkmark \forall$ & $N$ & 0 & 0 & $N$ & $N$ & $N$ & 0 & - & - & - & 0 & 0 & $N$ & $N$ & - & - & - \\
\hline$\nabla m$ & - & 一 & 0 & 0 & 0 & 0 & ๙. & 0 & 0 & 0 & 0 & 0 & 0 & 0 & 0 & 0 & 0 \\
\hline$\nabla N$ & 0 & - & - & 0 & - & 0 & $\sigma$. & - & - & - & - & 0 & - & - & - & 0 & 0 \\
\hline$\nabla-$ & - & 0 & 0 & 0 & 0 & 0 & ๙. & 0 & 0 & 0 & 0 & 0 & 0 & 0 & 0 & 0 & 0 \\
\hline+0 & 0 & 0 & - & 0 & 0 & - & $\sigma$. & 0 & 0 & 0 & 0 & 0 & 0 & 0 & 0 & 0 & 0 \\
\hline$m a$ & 0 & 0 & - & - & 0 & - & a. & 0 & 0 & 0 & 0 & 0 & - & 0 & 0 & 0 & 0 \\
\hline$m \infty$ & 0 & 0 & 0 & - & 0 & - & $\sigma$. & 0 & 0 & 0 & 0 & 0 & 0 & 0 & 0 & 0 & 0 \\
\hline$m r$ & - & 0 & $\sim$ & $\sim$ & 0 & 0 & $\sigma$. & - & - & 0 & - & - & 0 & - & 0 & - & 0 \\
\hline$m o$ & 0 & 0 & 0 & - & 0 & 0 & 0 & 0 & 0 & 0 & 0 & 0 & 0 & 0 & 0 & 0 & 0 \\
\hline$m$ in & 0 & $\nabla$ & $\sim$ & 0 & $\sim$ & $N$ & - & 0 & 0 & - & - & 0 & $N$ & $N$ & $N$ & 0 & 0 \\
\hline$m+$ & - & 0 & - & - & - & - & - & - & - & - & - & - & - & - & - & - & - \\
\hline$m m$ & 0 & - & 一 & - & - & - & 一 & - & - & - & - & 一 & - & - & - & - & - \\
\hline$m \sim$ & - & 0 & 0 & 0 & 0 & 0 & 0 & 0 & 0 & 0 & 0 & 0 & 0 & 0 & 0 & 0 & - \\
\hline$m-$ & - & 0 & 0 & - & 0 & - & 0 & 0 & 0 & 0 & 0 & 0 & 0 & 0 & 0 & 0 & 0 \\
\hline mo & 0 & $m$ & $m$ & $m$ & - & - & $\sim$ & $N$ & $\sim$ & $N$ & $\tau$ & $\sim$ & 0 & 0 & $\sim$ & - & - \\
\hline $\mathrm{Na}$ & 0 & - & - & - & - & 0 & - & 0 & 0 & - & $\pi$ & 0 & 0 & 0 & 0 & 0 & 0 \\
\hline$\sim \infty$ & 0 & - & $\nabla$ & $\sim$ & - & - & 0 & 0 & 0 & 0 & 0 & 0 & 0 & 0 & 0 & 0 & 0 \\
\hline$N$ & 0 & 0 & 0 & - & 0 & - & 0 & - & - & 0 & 0 & - & 0 & 0 & - & - & - \\
\hline$\sim 6$ & ' & I & I & I & I & ' & ' & - & - & ' & ' & - & I & ' & - & - & - \\
\hline$N \backsim$ & ' & 1 & 1 & 1 & ' & ' & ' & - & - & 1 & ' & - & 1 & ' & - & 0 & - \\
\hline$N \nabla$ & I & ' & 1 & 1 & ' & ' & ' & 0 & 0 & 1 & 1 & 0 & 1 & 1 & 0 & 0 & 0 \\
\hline $\mathrm{Nm}$ & I & ' & ' & ' & ' & ' & ' & 一 & 一 & I & ' & 0 & ' & I & 0 & 0 & 0 \\
\hline$\sim \sim$ & - & - & $m$ & $N$ & $m$ & $m$ & $\sim$ & $N$ & $\sim$ & $N$ & $N$ & $N$ & $N$ & $N$ & $N$ & $N$ & $N$ \\
\hline$N-$ & - & 0 & 0 & 0 & 0 & - & - & $N$ & $N$ & - & - & $N$ & - & - & $N$ & $N$ & $N$ \\
\hline No & 0 & - & - & - & - & - & - & - & - & 一 & - & - & - & - & - & - & - \\
\hline$-a$ & - & - & - & - & 0 & - & 0 & 0 & 0 & 0 & 0 & 0 & 0 & 0 & 0 & 0 & 0 \\
\hline$-\infty$ & 0 & 0 & 0 & - & 0 & 0 & 0 & 0 & 0 & 0 & 0 & 0 & 0 & 0 & 0 & 0 & 0 \\
\hline$-r$ & 0 & 0 & 0 & - & - & 0 & 0 & 0 & 0 & 0 & 0 & 0 & 0 & 0 & 0 & 0 & 0 \\
\hline-6 & 0 & 0 & 0 & 0 & - & - & 0 & 0 & 0 & 0 & 0 & 0 & 0 & 0 & 0 & 0 & 0 \\
\hline$-n$ & 0 & 0 & 0 & 0 & - & 0 & 0 & 0 & 0 & 0 & 0 & 0 & - & 0 & 0 & 0 & 0 \\
\hline$-\sigma$ & 0 & 0 & 0 & 0 & 0 & 0 & 0 & 0 & 0 & 0 & 0 & 0 & 0 & 0 & 0 & 0 & 0 \\
\hline$-m$ & 0 & 0 & 0 & 0 & 0 & 0 & - & - & 0 & - & 0 & - & 0 & - & - & - & - \\
\hline$-\mathrm{N}$ & 0 & 0 & 0 & - & 0 & - & 0 & 0 & - & 0 & - & 0 & - & 0 & 0 & - & 0 \\
\hline-- & & 0 & 0 & 0 & - & - & 0 & 0 & ن & 0 & 0 & 0 & - & 0 & 0 & 0 & 0 \\
\hline-0 & & 0 & 0 & 0 & 0 & 0 & 0 & 0 & $0 . \Xi$ & 0 & 0 & 0 & 0 & 0 & 0 & 0 & 0 \\
\hline$a$ & $\equiv$ & $0 \frac{0}{3}$ & 0 & 0 & 0 & 0 & 0 & 0 & $0:$ & 0 & 0 & 0 & 0 & & & 0 & 0 \\
\hline$\infty$ & & -5 & - & 0 & 0 & 0 & 0 & 0 & 0 & 0 & 0 & 0 & & & & & 0 \\
\hline$r$ & & & 0 & 0.5 & 0 & 0 & 0 & 0 & & 0 & 0 & 0 & & & & 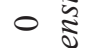 & \\
\hline 6 & & & & $-\overline{0}$ & 0 & $-\frac{0}{8}$ & & & & & & & & & & & 0 \\
\hline$n$ & & 1 & $0 \stackrel{0}{0}$ & $0 \frac{\bar{\Omega}}{0}$ & ' & $0 \stackrel{3}{3}$ & & I & $1 \doteq$ & 1 & & ' & & 1 & & $1 \quad 8$ & \\
\hline$\nabla$ & $\approx$ & $0=$ & -9 & -7 & 0 & -5 & 0 & 0 & $0 \overline{3}$ & 03 & 0 & $0 \leqslant$ & & 0 & $0 y$ & 03 & \\
\hline$m$ & $\lesssim$ & 0 & & & - & 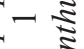 & & & & & & & & & & & \\
\hline$N$ & & $\begin{array}{c}1 \\
0 \\
0\end{array}$ & 0 ) & & $0 \pm$ & & $0 \cong$ & & & & & & & & & 0 ミ & \\
\hline & & & & $\sqrt{\frac{\pi}{2}}$ & त ड & & & n这 & & & & & $m \stackrel{0}{\stackrel{0}{ \pm}}$ & $m \frac{2}{10}$ & & $m$ 这 & \\
\hline
\end{tabular}




\begin{tabular}{|c|c|c|c|c|c|c|c|c|c|c|c|c|c|c|c|c|c|c|c|}
\hline $6-$ & & - & a. & - & - & a. & a. & - & 0 & ๙. & 0 & $\sigma$. & a. & - & o. & 0 & $\sigma$. & - & 0 \\
\hline 60 & & 0 & ๙. & 0 & 0 & a. & a. & 0 & 0 & $\sigma$. & 0 & $\curvearrowright$. & ๙. & - & $\sigma$. & - & $\sim$. & - & - \\
\hline$n a$ & & 0 & 0 & 0 & 0 & 0 & 0 & 0 & 0 & I & 0 & 0 & - & 0 & 0 & 0 & 0 & 0 & 0 \\
\hline$n \infty$ & & 0 & 0 & 0 & 0 & 0 & 0 & 0 & 0 & ' & 0 & 0 & 0 & 0 & 0 & 0 & 0 & 0 & 0 \\
\hline$n \pi$ & & - & $N$ & $\sim$ & - & $\sim$ & 0 & 0 & $N$ & , & $N$ & $\sim$ & $\sim$ & - & $N$ & $N$ & $N$ & $N$ & $N$ \\
\hline$n 6$ & & 0 & $\pi$ & 0 & 0 & 0 & 0 & 0 & 0 & ' & - & - & 0 & 0 & - & - & - & - & - \\
\hline$n$ in & & - & - & - & 0 & 0 & $N$ & - & - & ' & $N$ & $\sim$ & $\sim$ & - & - & - & $N$ & $N$ & $\sim$ \\
\hline$n \nabla$ & & 0 & 0 & 0 & 0 & 0 & 0 & 0 & 0 & 0 & 0 & 0 & - & 0 & 0 & 0 & 0 & 0 & 0 \\
\hline$n m$ & & 0 & 0 & 0 & 0 & - & 0 & 0 & 0 & 0 & 0 & 0 & 0 & 0 & 0 & 0 & 0 & 0 & 0 \\
\hline$n \sim$ & & - & $N$ & $N$ & - & $N$ & 0 & 0 & $N$ & $\sim$ & $N$ & $\sim$ & $N$ & - & - & $N$ & $N$ & $N$ & $N$ \\
\hline$n-$ & & - & - & - & - & - & - & - & - & ' & $\sim$ & 0 & - & - & - & - & - & - & - \\
\hline no & & - & 0 & - & - & 0 & 0 & 0 & - & $N$ & 0 & 0 & 0 & - & 0 & - & - & $\pi$ & 0 \\
\hline$\forall a$ & & - & - & - & 0 & 0 & $N$ & - & - & 0 & 0 & $N$ & $N$ & - & - & 0 & 0 & 0 & 0 \\
\hline$\nabla \infty$ & & $N$ & - & $N$ & - & - & $\sim$ & $\sim$ & - & 0 & - & - & - & - & - & - & - & - & - \\
\hline$\nabla r$ & & 0 & 0 & 0 & 0 & 0 & 0 & 0 & 0 & 0 & 0 & - & 0 & - & 0 & 0 & 0 & 0 & 0 \\
\hline+6 & & - & - & - & - & - & 0 & 0 & - & 0 & 0 & 0 & 0 & - & - & 0 & 0 & 0 & 0 \\
\hline$\nabla n$ & & 0 & 0 & 0 & 0 & 0 & 0 & 0 & 0 & 0 & - & - & - & 0 & 0 & 0 & 0 & 0 & 0 \\
\hline$\checkmark \forall$ & & 0 & 0 & - & - & - & - & 0 & 0 & N & $N$ & $N$ & 0 & 0 & - & $N$ & $N$ & $N$ & $N$ \\
\hline$\nabla m$ & & 0 & 0 & 0 & 0 & 0 & 0 & 0 & 0 & 0 & 0 & 0 & 0 & 0 & 0 & $\sigma$. & 0 & 0 & 0 \\
\hline$\nabla \sim$ & & 0 & 0 & 0 & - & 0 & - & - & - & - & 0 & 0 & - & - & 一 & $\sigma$. & - & 0 & 0 \\
\hline ナ - & & 0 & 0 & 0 & 0 & 0 & 0 & 0 & 0 & 0 & 0 & 0 & 0 & 0 & 0 & a. & 0 & 0 & 0 \\
\hline+0 & & 0 & 0 & 0 & 0 & 0 & 0 & 0 & 0 & 0 & 0 & 0 & 0 & 0 & 0 & $\sigma$. & 0 & 0 & 0 \\
\hline$m a$ & & 0 & 0 & 0 & - & 0 & 0 & 0 & - & 0 & 0 & - & - & - & 0 & ๙. & 0 & 0 & 0 \\
\hline$m \infty$ & & 0 & 0 & 0 & 0 & 0 & 0 & 0 & 0 & 0 & - & - & - & - & 0 & $\sigma$. & 0 & 0 & 0 \\
\hline$m-$ & & - & - & - & 0 & 0 & $N$ & 0 & $N$ & 0 & $\sim$ & $\sim$ & 0 & $N$ & 0 & $\sigma$. & 0 & 0 & 0 \\
\hline$m o$ & & 0 & 0 & 0 & 0 & 0 & 0 & 0 & 0 & 0 & - & - & 0 & 0 & 0 & 0 & 0 & 0 & 0 \\
\hline$m$ in & & 0 & 0 & 0 & 0 & 0 & 0 & 0 & $n$ & 0 & 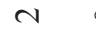 & 0 & $\sim$ & $N$ & - & N & 0 & 0 & 0 \\
\hline$m \nabla$ & & - & - & - & 0 & - & - & - & - & $N$ & - & - & - & - & - & - & 0 & 0 & 0 \\
\hline$m m$ & & - & - & - & - & 一 & - & - & - & 一 & - & - & - & - & 0 & - & 一 & - & - \\
\hline$m \sim$ & & - & 0 & 0 & - & - & 0 & 0 & 0 & 0 & 0 & 0 & 0 & 0 & 0 & - & 0 & 0 & 0 \\
\hline$m-$ & & 0 & 0 & 0 & 0 & - & 0 & 0 & 0 & - & - & - & - & - & 0 & - & 0 & 0 & 0 \\
\hline mo & & 0 & 0 & 0 & 0 & 0 & 0 & 0 & $m$ & 0 & $m$ & $m$ & $m$ & $m$ & 0 & 0 & 0 & 0 & 0 \\
\hline $\mathrm{Na}$ & & 0 & 0 & 0 & 0 & 0 & 0 & 0 & $\pi$ & 0 & 0 & - & 0 & - & 0 & 0 & 0 & 0 & 0 \\
\hline$N \infty$ & & 0 & - & 0 & 0 & 0 & 0 & 0 & - & 0 & $\nabla$ & $n$ & 6 & $m$ & 0 & 0 & - & 0 & 0 \\
\hline$N R$ & & - & 0 & - & - & - & - & 0 & 0 & - & - & - & - & - & - & - & - & - & - \\
\hline$\sim 6$ & & - & I & - & - & - & - & I & ' & - & I & ' & I & ' & 0 & 0 & 0 & 0 & 0 \\
\hline N n & & - & 1 & 0 & - & 0 & 0 & ' & ' & 0 & 1 & ' & 1 & 1 & 0 & 0 & 0 & 0 & 0 \\
\hline$\sim \nabla$ & & 0 & ' & 0 & ' & 0 & 0 & ' & ' & 0 & ' & ' & 1 & 1 & 0 & 0 & 0 & 0 & 0 \\
\hline$N m$ & & - & I & 0 & - & 0 & 0 & I & ' & 0 & ' & ' & ' & ' & 0 & 0 & 0 & 0 & 0 \\
\hline$\sim N$ & & $N$ & $N$ & $N$ & $N$ & 0 & $N$ & $N$ & $N$ & $m$ & 0 & $N$ & 0 & 0 & 0 & $\pi$ & 0 & 0 & 0 \\
\hline$N-$ & & $N$ & - & $N$ & $N$ & $N$ & $N$ & - & - & 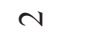 & 0 & 0 & $\pi$ & 0 & $N$ & $\sim$ & $N$ & $N$ & $N$ \\
\hline No & & - & - & - & 0 & - & - & - & 一 & - & 0 & - & - & - & 0 & - & 0 & $\pi$ & 0 \\
\hline$-a$ & & 0 & 0 & 0 & 0 & 0 & 0 & 0 & 0 & 0 & - & - & - & - & 0 & 0 & 0 & 0 & 0 \\
\hline$-\infty$ & & 0 & 0 & 0 & 0 & 0 & 0 & 0 & 0 & - & 0 & 0 & 0 & 0 & 0 & 0 & 0 & 0 & 0 \\
\hline-1 & & 0 & 0 & 0 & - & 0 & 0 & 0 & - & 0 & 0 & - & 0 & 0 & 0 & 0 & 0 & 0 & 0 \\
\hline-6 & & 0 & 0 & 0 & 0 & 0 & 0 & 0 & 0 & 0 & 0 & 0 & - & 0 & 0 & 0 & 0 & 0 & 0 \\
\hline$-n$ & & 0 & 0 & 0 & 0 & 0 & 0 & 0 & 0 & - & 0 & 0 & 0 & 0 & 0 & 0 & 0 & 0 & 0 \\
\hline$-\sigma$ & & 0 & 0 & 0 & 0 & 0 & 0 & 0 & 0 & 0 & 0 & 0 & 0 & 0 & 0 & 0 & 0 & 0 & 0 \\
\hline$-m$ & & - & - & - & - & - & - & - & - & 0 & 0 & 0 & 0 & 0 & - & - & 0 & 0 & 0 \\
\hline$-N$ & & 0 & 0 & 0 & - & 0 & 0 & 0 & - & - & 0 & 0 ن & - & 0 & 0 & - & - & - & 一 \\
\hline-- & & 0 & 0 & 0 & 0 & 0 & 0 & 0 & 0 & - & - &.$- \Xi$ & 0 & 0 & 0 & 0 & 0 & 0 & 0 \\
\hline-0 & & 0 & 0 & 0 & 0 & 0 & 0 & 0 & 0 & 0 & $\circ \dot{~}$ & $0 \dot{1}$ & 0 & - & 0 & 0 & 0 & 0 & 0 \\
\hline$a$ & & & 0 & 0 & 0 & $0 y$ & 0 & $0 . y$ & 0 & 0 & $\circ . \Xi$ & $0 \stackrel{\infty}{0}$ & 0 & 0 & 0 & & 0 & 0 & 0 \\
\hline$\infty$ & & $0 \div$ & 0 & 0 & 0 & $0 \frac{3}{0}$ & 0 & $0 \frac{5}{2}$ & 0 & 0 & $0 \dot{0}$ & $0 . \tilde{\Xi}$ & 0 & 0 & 0 & $0 . \$$ & 0 & 0 & 0 \\
\hline$r$ & & & & & 0 & 07 & & 0. & 0 & 0 & 0.3 & 05 & & $0: \overrightarrow{\widetilde{\Omega}}$ & 0 & 0 & & $0 \equiv$ & 0 \\
\hline 6 & & & & & & & & & $-\stackrel{\bar{\nu}}{=}$ & 0 & & & & & & & & & 0 \\
\hline$n$ & & & & 1 & $1 \bar{\Xi}$ & $-\overrightarrow{0}$ & 1 & 1 & 1 క & $1 \approx$ & 0.5 & $0 ?$ & $0 \stackrel{\Xi}{0}$ & & -3 & 1 & $\begin{array}{l}1 \\
1 \\
0\end{array}$ & $\begin{array}{r}10 \\
10\end{array}$ & \\
\hline$\nabla$ & & $0 \cong$ & $\overline{7}$ & 0 & 0 政 & -1 & 0 & 0 & $0 \approx$ & $0 \cong$ & $-\cong$ & $-\Xi$ & $-\approx$ & 00 & $-\frac{0}{0}$ & 0 & 0 పั & 0 & \\
\hline$m$ & & & 0. & & & & & & $0 . \overline{3}$ & $-\delta$ & 0 రิ & $-\delta$ & & & & & & & \\
\hline N & & $0 \Xi$ & 0 & $0 \lesssim$ & $0 \stackrel{\Xi}{\Xi}$ & $0 \Xi$ & 0 క & 0 స్ & $0 \cdot \overline{\tilde{U}}$ & 0 & & 0. & & & & $-\stackrel{\Xi}{\Xi}$ & - & & \\
\hline & 过 & $m$ 这 & & $m$ 这 & 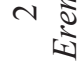 & $N \underset{\frac{1}{2}}{ }$ & $m \frac{5}{5}$ & $m \frac{ \pm}{5}$ & & $m \frac{\mathbb{J}}{\mathbb{\Xi}}$ & $N \frac{\Xi}{ \pm}$ & & & & & & & & \\
\hline
\end{tabular}




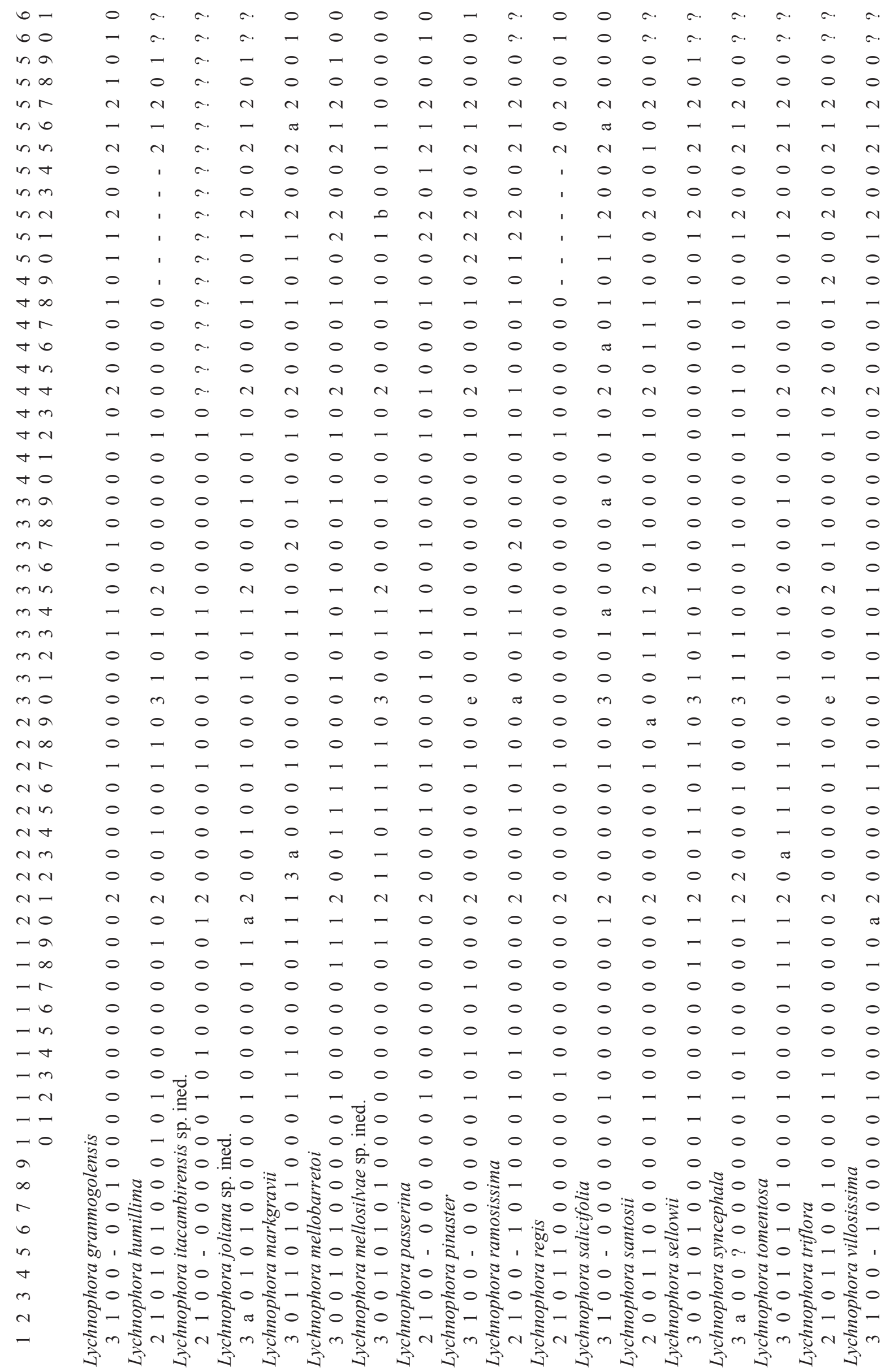




\begin{tabular}{|c|c|c|c|c|c|c|c|c|c|c|c|c|c|c|c|c|c|c|c|}
\hline $6-$ & & 0 & ๙. & a. & - & a. & a. & ๙. & a. & a. & $\sim$. & - & a. & ๙. & a. & 0 & $\sigma$. & $\sim$. & a. \\
\hline 60 & & 0 & $\sim$. & $\sigma$. & - & $\sigma$. & a. & a. & $\sigma$. & $\sigma$. & $\sigma$. & - & a. & $\sigma$. & ๙. & - & a. & a. & a. \\
\hline ra & & - & 0 & - & $\sim$ & $\sim$ & $N$ & $N$ & $N$ & 0 & $N$ & 0 & 0 & $N$ & - & 0 & - & - & 0 \\
\hline$n \infty$ & & 0 & 0 & 0 & 0 & 0 & 0 & 0 & 0 & 0 & 0 & 0 & 0 & 0 & 0 & - & - & - & 0 \\
\hline$n-$ & & $\sim$ & - & $N$ & 0 & 0 & 0 & 0 & 0 & - & $\pi$ & 0 & 0 & 0 & - & - & - & $N$ & - \\
\hline in 6 & & - & - & - & 0 & 0 & 0 & 0 & 0 & $\pi$ & $\pi$ & 0 & - & 0 & - & 0 & - & 0 & 0 \\
\hline$n$ in & & $N$ & 0 & $N$ & 0 & 0 & 0 & 0 & 0 & 0 & - & - & - & - & $\sim$ & $N$ & $N$ & $N$ & - \\
\hline$n+$ & & 0 & 0 & 0 & 0 & 0 & 0 & 0 & 0 & 0 & 0 & 0 & 0 & 0 & 0 & - & - & - & 0 \\
\hline$n m$ & & 0 & 0 & 0 & 0 & 0 & 0 & 0 & 0 & 0 & 0 & 0 & 0 & 0 & 0 & - & - & - & - \\
\hline$n \sim$ & & $\sim$ & - & $N$ & 0 & 0 & 0 & 0 & 0 & - & - & 0 & - & - & - & 0 & - & $N$ & 0 \\
\hline$n-$ & & - & - & - & - & - & - & - & - & - & - & - & - & - & - & - & 0 & 0 & 0 \\
\hline no & & $\pi$ & 0 & $\pi$ & 0 & 0 & 0 & 0 & 0 & 0 & 0 & 0 & 0 & 0 & 0 & 0 & 0 & 0 & 0 \\
\hline$\nabla a$ & & - & 0 & 0 & 0 & 0 & 0 & 0 & 0 & 0 & 0 & 0 & 0 & 0 & - & $N$ & $N$ & - & - \\
\hline$+\infty$ & & - & - & - & - & - & - & - & - & م & - & - & - & - & - & - & - & - & - \\
\hline$\nabla r$ & & 0 & 0 & 0 & - & - & - & - & - & 0 & - & 0 & - & - & - & 0 & 0 & 0 & 0 \\
\hline$\nabla 6$ & & 0 & 0 & 0 & - & - & - & - & - & - & 0 & 0 & 0 & 0 & 0 & 0 & 0 & 0 & 0 \\
\hline$\nabla n$ & & 0 & 0 & 0 & 0 & 0 & 0 & 0 & 0 & 0 & 0 & 0 & 0 & 0 & 0 & 0 & 0 & 0 & 0 \\
\hline$\nabla \forall$ & & $N$ & $N$ & $N$ & $\sim$ & $N$ & $\sim$ & $\sim$ & $\sim$ & $\sim$ & $\sim$ & $N$ & $\sim$ & $\sim$ & $\sim$ & $N$ & 0 & 0 & 0 \\
\hline$\nabla m$ & & 0 & 0 & 0 & 0 & 0 & 0 & 0 & 0 & 0 & 0 & 0 & 0 & 0 & 0 & 0 & 0 & 0 & 0 \\
\hline$\nabla C$ & & 0 & - & 0 & - & - & - & - & - & - & - & - & - & - & - & 0 & 0 & 0 & 0 \\
\hline$\nabla-$ & & 0 & 0 & 0 & - & - & - & - & - & 0 & 0 & 0 & 0 & 0 & 0 & 0 & 0 & 0 & 0 \\
\hline+0 & & 0 & 0 & 0 & 0 & 0 & 0 & 0 & 0 & 0 & 0 & 0 & 0 & 0 & 0 & 0 & 0 & 0 & 0 \\
\hline$m a$ & & - & - & 0 & - & - & - & - & - & - & - & - & - & - & - & - & - & - & - \\
\hline$m \infty$ & & 0 & 0 & 0 & 0 & 0 & 0 & 0 & 0 & 0 & 0 & 0 & 0 & 0 & 0 & 0 & 0 & 0 & 0 \\
\hline$m r$ & & $N$ & 0 & $\sim$ & 0 & 0 & - & 0 & 0 & 0 & 0 & 0 & 0 & 0 & 0 & 0 & 0 & 0 & 0 \\
\hline$m b$ & & 0 & 0 & 0 & 0 & 0 & 0 & 0 & 0 & 0 & 0 & 0 & 0 & 0 & 0 & 0 & 0 & 0 & 0 \\
\hline$m$ in & & - & $N$ & - & $N$ & $N$ & $N$ & $N$ & $N$ & 0 & $N$ & $N$ & $N$ & $N$ & $N$ & $N$ & - & - & - \\
\hline$m \nabla$ & & - & $N$ & 0 & 0 & - & - & - & 0 & - & - & - & - & $\pi$ & $\pi$ & - & - & - & - \\
\hline$m m$ & & - & - & 0 & - & - & - & 0 & - & - & - & - & - & - & - & - & - & - & - \\
\hline$m \sim$ & & 0 & 0 & 0 & 0 & 0 & 0 & 0 & 0 & 0 & - & 0 & - & - & - & - & - & - & - \\
\hline$m-$ & & 0 & - & 0 & 0 & 0 & - & 0 & - & 0 & - & - & - & - & - & - & - & - & - \\
\hline mo & & $m$ & $m$ & - & $m$ & $m$ & $m$ & $m$ & $m$ & - & 0 & 0 & $m$ & $m$ & 0 & $m$ & 0 & 0 & $m$ \\
\hline $\mathrm{Na}$ & & 0 & - & 0 & 0 & - & 0 & 0 & $\pi$ & 0 & 0 & 0 & 0 & 0 & 0 & 0 & - & 0 & 0 \\
\hline$\sim \infty$ & & - & $\nabla$ & - & $\sim$ & $N$ & $N$ & $N$ & $m$ & 0 & 0 & - & $N$ & - & 0 & - & $N$ & - & - \\
\hline $\mathrm{NT}$ & & 0 & 0 & 0 & - & 0 & - & 0 & 0 & - & - & $\neg$ & - & - & - & 0 & 0 & 0 & 0 \\
\hline$N G$ & & ' & ' & ' & ' & ' & 1 & ' & ' & - & - & - & - & 0 & - & ' & ' & I & I \\
\hline N n & & I & I & , & I & ' & I & I & I & - & - & - & 0 & - & - & , & I & ' & I \\
\hline$N \nabla$ & & ' & ' & 1 & ' & ' & ' & ' & ' & 0 & $\pi$ & 0 & 0 & 0 & 0 & ' & ' & ' & ' \\
\hline $\mathrm{Nm}$ & & I & 1 & I & I & I & I & I & I & 0 & $\pi$ & - & 0 & $\pi$ & - & I & , & I & I \\
\hline$\sim \sim$ & & 0 & 0 & 0 & 0 & $m$ & $m$ & 0 & $m$ & 0 & 0 & 0 & 0 & 0 & 0 & 0 & $N$ & 0 & 0 \\
\hline $\mathrm{N}-$ & & 0 & 0 & 0 & - & 0 & 0 & - & $\pi$ & $N$ & $\sim$ & $N$ & $\sim$ & $\sim$ & $N$ & 0 & - & - & 0 \\
\hline No & & 0 & 0 & 0 & - & - & - & - & - & - & - & - & - & - & - & 0 & 0 & 0 & 0 \\
\hline$-a$ & & 0 & 0 & 0 & - & - & - & - & - & - & - & - & - & - & - & 0 & 0 & 0 & 0 \\
\hline$-\infty$ & & 0 & 0 & 0 & 0 & 0 & 0 & 0 & 0 & 0 & 0 & - & 0 & 0 & 0 & 0 & 0 & 0 & 0 \\
\hline$-r$ & & 0 & 0 & 0 & 0 & 0 & 0 & 0 & 0 & 0 & 0 & - & 0 & 0 & 0 & 0 & 0 & 0 & 0 \\
\hline-6 & & 0 & 0 & 0 & 0 & 0 & 0 & 0 & 0 & 0 & 0 & 0 & 0 & 0 & 0 & 0 & 0 & 0 & 0 \\
\hline$-n$ & & 0 & 0 & 0 & 0 & 0 & 0 & 0 & 0 & 0 & 0 & 0 & 0 & 0 & 0 & 0 & 0 & 0 & 0 \\
\hline$-\forall$ & & - & 0 & 0 & 0 & 0 & 0 & 0 & 0 & - & 0 & 0 & 0 & 0 & 0 & 0 & 0 & 0 & 0 \\
\hline$-m$ & & 0 & 0 & 0 & 0 & 0 & 0 & 0 & 0 & -7 & - & - & - & - & 0 & - & - & - & - \\
\hline$-N$ & & - & - & - & 0 & 0 & 0 & 0 & 0 &.$- \Xi$ & - & - & - & - & - & - & - & - & - \\
\hline-- & & 0 & - & 0 & 0 & 0 & 0 & 0 & 0 & 0 & 0 & 0 & 0. & 0 & 0 & 0 & - & 0 & 0 \\
\hline-0 & & & $0 \stackrel{0}{0}$ & 0 & 0 & 0 & 0 & 0 & 0 & 0 & 0 & 0 & 0 & 0 & 0 & 0 & & 0 & 0 \\
\hline$a$ & & & $0:$ & 0 & - & - ن & - & - & - & $0 \$$ & 0. & 0 & 0 & 0 : & 0 & 0 & $0 . \Xi$ & ○ ن & 0 \\
\hline$\infty$ & $\tilde{2}$ & 0 & $0 \widehat{్}$ & 0 & 0 & $0 . \Xi$ & & ○ प्ष्ठ & & $0 . \tilde{N}$ & & & & & 0 & 0 & $0 \dot{0}$ & & 0 \\
\hline r & 0 & & 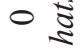 & 0 & 0. & 0 & 0 & 0.7 & 07 & $0 \frac{\vec{J}}{00}$ & & & 0 & & & 0 & $-\frac{1}{2}$ & & \\
\hline 6 & 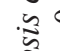 & 0. & - & 0. & 0 站 & 0 & 0 & 00 & 0 & - & 0.7 & & 0 & 0 & 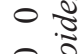 & & & 0.0 & 0 \\
\hline$n$ & & & & & & 0 & & & & & & & & & & & & & - \\
\hline $\begin{array}{l}\nabla \\
m \\
m\end{array}$ & $=$ & & 0 & & & & & & $\overline{0}$ & & & & & & & & & & \\
\hline N & & - & 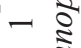 & $\pi \cdot$ & 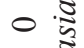 & $0 \cdot \sqrt[3]{3}$ & 0 & 0.5 & 0. & & & & $0 \$$ & & & & & $0 \frac{8}{1}$ & \\
\hline & & & & & & & & & & & & & & & & & & 40 & \\
\hline
\end{tabular}




\begin{tabular}{|c|c|c|c|c|c|c|c|c|c|}
\hline $6-$ & & $\sigma$. & 0 & $\sigma$. & 一 & ๙. & ๙. & $\sigma$. & 0 \\
\hline 60 & & a. & - & $\sigma$. & - & $\sigma$. & $\sigma$. & $\sigma$. & - \\
\hline Co & & - & - & - & - & - & - & 0 & - \\
\hline $2 \alpha$ & & - & - & - & - & - & - & 0 & 0 \\
\hline$n \pi$ & & - & 0 & 0 & - & $\sim$ & $\sim$ & 0 & $N$ \\
\hline$n v$ & & 0 & 0 & 0 & - & $\pi$ & 0 & 0 & 0 \\
\hline$n$ is & & ఠ & 0 & 0 & $N$ & $N$ & $N$ & $N$ & $N$ \\
\hline in & & - & - & - & ' & 0 & - & 0 & - \\
\hline$n \mathrm{n}$ & & - & - & - & I & 0 & 0 & 0 & 0 \\
\hline in & & - & 0 & 0 & 1 & $N$ & $\sim$ & $N$ & $N$ \\
\hline$n-$ & & 0 & - & - & 1 & - & 0 & - & 0 \\
\hline$n c$ & & 0 & 0 & 0 & ' & 0 & 0 & 0 & 0 \\
\hline+0 & & $\approx$ & 0 & 0 & ' & 0 & $\sim$ & 0 & $N$ \\
\hline$\nabla \alpha$ & & - & $N$ & $N$ & 0 & - & - & - & - \\
\hline$\nabla r$ & & 0 & 0 & 0 & - & - & 0 & 0 & 0 \\
\hline$\nabla v$ & & 0 & - & 0 & $\pi$ & - & 0 & - & 0 \\
\hline$\nabla v$ & & 0 & 0 & 0 & 0 & 0 & - & 0 & - \\
\hline$\nabla$ & & 0 & 0 & 0 & 0 & 0 & 0 & 0 & 0 \\
\hline$\nabla C$ & & 0 & 0 & 0 & 0 & 0 & ๙. & 0 & 0 \\
\hline$\nabla c$ & & 0 & - & - & - & - & $\sigma$. & 一 & - \\
\hline$\nabla$ & & 0 & 0 & 0 & 0 & 0 & $\sigma$. & 0 & 0 \\
\hline$\nabla c$ & & 0 & 0 & 0 & 0 & 0 & 0 & 0 & 0 \\
\hline mo & & 0 & 0 & 0 & 0 & - & - & - & - \\
\hline$m \alpha$ & & 0 & 0 & 0 & 0 & 0 & - & 0 & - \\
\hline$m r$ & & 0 & 0 & 0 & 0 & 0 & 0 & 0 & 0 \\
\hline$m v$ & & 0 & 0 & $\sigma$. & 0 & 0 & 0 & 0 & 0 \\
\hline$m v$ & & 0 & - & $\sigma$. & $N$ & $N$ & $N$ & - & $N$ \\
\hline$m-$ & & 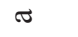 & - & a. & $N$ & $\sim$ & - & - & - \\
\hline$m \mathrm{~m}$ & & - & - & ๙. & 0 & 0 & - & - & - \\
\hline$m c$ & & - & 0 & $\sigma$. & 0 & 0 & 0 & 0 & 0 \\
\hline$m-$ & & - & - & $\sigma$. & 0 & 0 & - & 0 & - \\
\hline$m c$ & & $m$ & $m$ & $\sim$. & $m$ & $m$ & $m$ & 0 & $m$ \\
\hline NO & & 0 & - & - & - & - & 0 & 0 & 0 \\
\hline$N \propto$ & & $N$ & 0 & ๙. & 0 & $a$ & $m$ & - & 0 \\
\hline $\mathrm{Nr}$ & & 0 & - & - & - & 0 & - & 0 & - \\
\hline $\mathrm{N}$ & & 1 & 0 & 0 & ' & ' & 1 & 1 & ' \\
\hline $\mathrm{Nu}$ & & ' & 0 & 0 & 1 & ' & 1 & 1 & I \\
\hline$N$ & & ' & 0 & 0 & ' & ' & ' & ' & I \\
\hline $\mathrm{NA}$ & & 1 & 0 & 0 & I & 1 & ' & 1 & I \\
\hline $\mathrm{NO}$ & & 0 & 0 & 0 & - & - & 0 & $m$ & 0 \\
\hline $\mathrm{N}-$ & & 0 & $\sim$ & $\sim$ & - & - & - & - & $\pi$ \\
\hline $\mathrm{NC}$ & & 0 & $\pi$ & $\pi$ & - & - & - & - & - \\
\hline-0 & & 0 & - & $\neg$ & - & - & - & 0 & - \\
\hline$-\infty$ & & 0 & - & 0 & 0 & 0 & 0 & 0 & 0 \\
\hline$-r$ & & 0 & - & 0 & 0 & 0 & 0 & 0 & 0 \\
\hline-6 & & 0 & 0 & 0 & 0 & 0 & - & 0 & - \\
\hline$-v$ & & 0 & 0 & 0 & 0 & 0 & 0 & 0 & 0 \\
\hline-7 & & 0 & 0 & 0 & 0 & 0 & 0 & 0 & 0 \\
\hline$-c$ & & - & 0 & 0 & 0 & 0 & 0 & - & 0 \\
\hline-0 & & - & - & - & 0 & 0 & - & 0 & - \\
\hline-- & & 0 & 0 & 0 & 0 & 0 & - & 0 & - \\
\hline$-c$ & 过 & 0 & 0 & - & 0 & 0 & 0 & 0 & 0 \\
\hline$a$ & & & 0 & 0 & 0 & 0 & 0 & - & 0 \\
\hline$\infty$ & & & 0 & 0 & $0: \widetilde{y}$ & 0 & 0 & 0 & 0 \\
\hline$r$ & & - & $0^{\circ}$ & 0 & $0 \frac{\pi}{2}$ & - & 0 & 0 & 0 \\
\hline 6 & \pm & 0 & - & $0 \stackrel{1}{3}$ & $E-\infty$ & 0 & $0 \%$ & $0 \stackrel{2}{0}$ & - \\
\hline in & & - & 0 & 0 : & $\$ 0$ & $0 . \bar{\theta}$ & $00 \stackrel{2}{\Omega}$ & $0 \cdot \frac{\sqrt{3}}{3}$ & 0 \\
\hline$\nabla$ & $\tilde{\omega}$ & - & -7 & - & -1 & - & & $-\bar{\Xi}$ & - \\
\hline$m$ & & 0. & 0. & 0 & 0 & & & & - \\
\hline$v$ & $\widetilde{0}$ & 0 I & $-\widetilde{\Xi}$ & $-\vec{a}$ & Sू & & & 0 ป & 0 \\
\hline- & 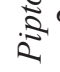 & & $-\frac{2}{2}$ & & & & & $N$ & \\
\hline
\end{tabular}


Electronic Supplementary Appendix 3 The 3ia data matrix 1. The second line indicates the hypotheses of homology. 


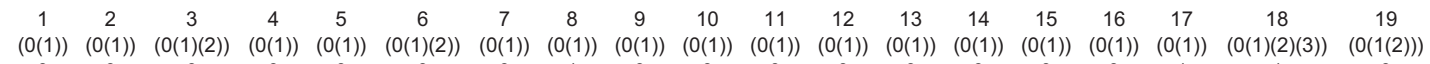

Albbra Anthat Arghar Blahet Cenpun Chreang Chreex

Chrepla

Chrepyc

Chresca

Chresph

Chrobif

Chryfle

Chrylit

Chrypla

Crihua

Crisod

Cyrhar

Cyrsco

Elebif

Elemic

Elemo

Ereery

Ereglo

Glaspe

Gordec

Holped

Lepaur

Lepruf

Lepnjon

Lesbis

Lesbud

Lesfar

Leslin

Lessan

\begin{tabular}{|c|c|c|c|c|c|c|c|c|c|c|c|}
\hline 0 & 0 & 1 & 0 & 0 & 0 & 0 & 0 & 0 & 0 & 0 & \\
\hline 1 & 0 & 1 & 0 & 0 & 0 & 0 & 0 & 0 & 0 & 0 & \\
\hline 0 & 0 & 1 & 0 & 0 & 0 & 0 & 0 & 0 & 0 & 0 & \\
\hline 1 & 1 & 0 & 0 & 1 & 0 & 0 & 0 & 1 & 1 & 0 & \\
\hline 0 & 0 & 0 & 0 & 0 & 1 & 0 & 1 & 0 & 1 & 0 & \\
\hline 0 & 1 & 1 & 1 & 0 & 0 & 0 & 0 & 0 & 0 & 0 & \\
\hline 0 & 0 & 1 & 0 & 0 & 0 & 0 & 0 & 0 & 0 & 0 & \\
\hline 0 & 0 & 1 & 0 & 0 & 0 & 0 & 0 & 0 & 0 & 0 & \\
\hline 0 & 0 & 1 & 0 & 0 & 0 & 0 & 0 & 0 & 0 & 0 & \\
\hline 0 & 0 & 1 & 0 & 0 & 0 & 0 & 0 & 0 & 0 & 0 & \\
\hline 0 & 0 & 1 & 0 & 0 & 0 & 0 & 0 & 0 & 0 & 0 & \\
\hline 0 & 0 & 1 & 0 & 0 & 0 & 0 & 0 & 0 & 0 & 0 & \\
\hline 0 & 0 & 1 & 0 & 0 & 0 & 0 & 0 & 0 & 0 & 0 & \\
\hline 1 & 1 & 0 & 0 & 1 & 1 & 0 & 1 & 0 & 0 & 0 & \\
\hline 0 & 1 & 0 & 0 & 0 & 0 & 0 & 0 & 0 & 0 & 0 & \\
\hline 0 & 1 & 0 & 0 & 0 & 0 & 0 & 0 & 0 & 0 & 0 & \\
\hline 0 & 1 & 0 & 0 & 0 & 0 & 0 & 0 & 0 & 0 & 0 & \\
\hline 0 & 0 & 0 & 0 & 1 & 1 & 0 & 0 & 0 & 0 & 1 & \\
\hline 0 & 0 & 0 & 0 & 1 & 1 & 0 & 0 & 0 & 0 & 1 & \\
\hline 0 & 1 & 0 & 0 & 0 & 0 & 1 & 0 & 0 & 0 & 0 & \\
\hline 0 & 1 & 0 & 0 & 0 & 0 & 0 & 0 & 0 & 0 & 0 & \\
\hline 0 & 1 & 0 & 0 & 0 & 0 & 0 & 0 & 0 & 0 & 0 & \\
\hline 0 & 1 & 0 & 0 & 0 & 0 & 0 & 0 & 0 & 0 & 0 & \\
\hline 1 & 1 & 0 & 0 & 0 & 0 & 0 & 0 & 0 & 0 & 0 & \\
\hline 1 & 1 & 0 & 0 & 0 & 0 & 0 & 0 & 0 & 0 & 0 & \\
\hline 0 & 1 & 0 & 0 & 0 & 0 & 0 & 0 & 0 & 0 & 0 & \\
\hline 0 & 0 & 0 & 0 & 1 & 0 & 0 & 0 & 0 & 0 & 1 & \\
\hline 0 & 0 & 0 & 0 & 1 & 0 & 0 & 0 & 0 & 0 & 1 & \\
\hline 0 & 1 & 0 & 0 & 0 & 0 & 0 & 0 & 0 & 0 & 0 & \\
\hline 0 & 0 & 0 & 0 & 1 & 0 & 0 & 0 & 1 & 0 & 0 & \\
\hline 1 & 0 & 0 & 0 & 1 & 1 & 0 & 0 & 0 & 0 & 0 & \\
\hline 0 & 0 & 1 & 0 & 0 & 0 & 0 & 0 & 0 & 0 & 0 & \\
\hline 0 & 1 & 0 & 0 & 0 & 0 & 1 & 0 & 0 & 0 & 0 & \\
\hline 0 & 0 & 1 & 0 & 0 & 0 & 0 & 0 & 0 & 0 & 0 & \\
\hline 0 & 1 & 0 & 0 & 0 & 0 & 0 & 0 & 0 & 0 & 0 & \\
\hline 0 & 1 & 0 & 0 & 0 & 0 & 1 & 0 & 0 & 0 & 0 & \\
\hline 0 & 1 & 0 & 0 & 0 & 0 & 1 & 0 & 0 & 0 & 0 & \\
\hline 0 & 1 & 0 & 0 & 0 & 0 & 1 & 0 & 0 & 0 & $c$ & \\
\hline 0 & 1 & 0 & 0 & 0 & 0 & 1 & 0 & 0 & 0 & 0 & \\
\hline 0 & 1 & 0 & 0 & 0 & 0 & 0 & 0 & 0 & 0 & 0 & \\
\hline
\end{tabular}

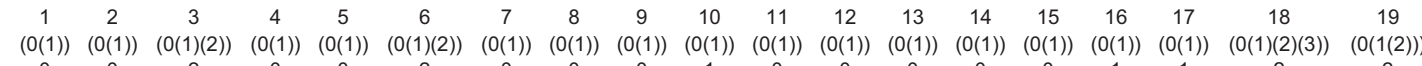

Lycbis

Lyceri

Lycpas

Lycican

Minalp

Ortang

Parbic

Pipcob

Pipcrot

Pitpac

Preeri

Rolfru

Siplan

Soavel

Stemeg

Stiglo

Stispe

Stolae

Strapoo

Strxarb

Tarell

Verech

Vernov

Vertfer

Vertluc

Xerekm

Victom

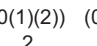

$\begin{array}{cccccccccccc}(0(1)) & (0(1)) & (0(1)) & (0(1)) & (0(1)) & (0(1)) & (0(1)) & (0(1)) & (0(1)) & (0(1)) & (0(1)(2)(3)) & (0(1(2)) \\ 0 & 0 & 1 & 0 & 0 & 0 & 0 & 0 & 1 & 1 & ? & 2 \\ 0 & 0 & 1 & 0 & 0 & 0 & 0 & 0 & 0 & 1 & ? & 2\end{array}$

$\begin{array}{lllllllllllllllllll}0 & 0 & 0 & 0 & 0 & 0 & 0 & 0 & 0 & 1 & 0 & 0 & 0 & 0 & 0 & 0 & 1 & ? \\ 0 & 0 & 2 & 0 & 0 & 0 & 0 & 0 & 0 & 1 & 0 & 0 & 0 & 0 & 0 & 0 & 1 & ? & 2\end{array}$

$\begin{array}{lllll}0 & 0 & 0 & 0 & 0 \\ 0 & 0 & 0 & 0 & 0\end{array}$

0

0 


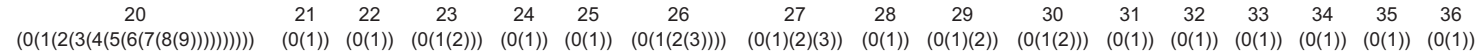

Albbra

Arghar

Bisere

Blahet

Cenpun

Chreang

Chreex

Chrepla

Chrepyc

Chresou

Chresph

Chrobif

Chryfle

Chrypla

Crihua

Crisod
Cyrhar

Cyrsco

Echhol

Echsch

Elemic

Elemol

Ereery

Ereglo
Glaspe

Gordec

Hetalb
Holped

Lepaur

Lepruf

Lepnjon

Lesbis

Lesbud

Lesfar

Leslin
Lessan

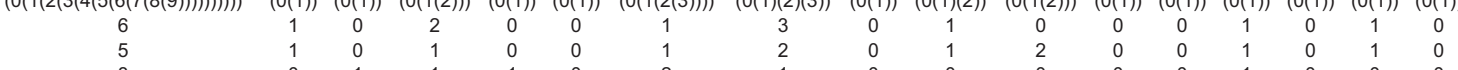

8
7

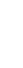

9
8




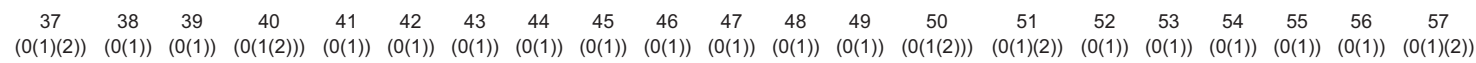

Albbra Anthat

$\begin{array}{lllllllllllllllllllll}0 & 0 & 0 & 2 & 1 & 0 & 1 & 0 & 0 & 1 & 0 & 1 & 0 & 0 & 0 & 0 & 0 & 1 & 0 & ? & ?\end{array}$

$\begin{array}{lllll}\text { Anthat } & 2 & 0 & 0 & 2\end{array}$

Bisere

Cenpun

Chreang

Chreex

Chrepyc

Chrepy

Chreso

Chresph

Chrobif

Chryfle

Chrylit

Crihua

Crisod

Cyrhar

Cyrsco

Echhol

Elemic

Elemol

Ereery

Ereglo

Glaspe

Gordec

Holped

Lepruf

Lepnjon

Lesbis

Lesbud

Lesfar

Lessan

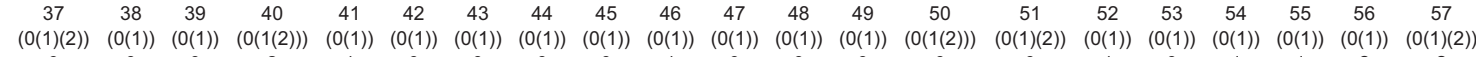

Lycbis $\begin{array}{ccccccccccccccccccccc}0 & 0 & 0 & 2 & 1 & 0 & 0 & 0 & 0 & 1 & 0 & 0 & 0 & 0 & 0 & 1 & 0 & 1 & 1 & ? & ? \\ 0 & 0 & 0 & 2 & 1 & 0 & 0 & 0 & 0 & 0 & 0 & 0 & 0 & 0 & 0 & 1 & 0 & 1 & 1\end{array}$

Lycpas

Lycsal

Minalp

Ortang

Parbic

Pipcobl

Pipcrot

Pitpac

Proarg

Rolfru

Siplan

Soavel

Stispe

Stolae

Strapoo

Verech

Verfas

Vernov

Verter

Vertluc

Xerekm

Victom

$\begin{array}{ll}2 & 1 \\ 2 & 1 \\ 2 & 1 \\ 2 & 1 \\ 2 & 1 \\ 1 & 1 \\ 2 & 1 \\ 2 & 1 \\ 2 & 1 \\ 2 & 1 \\ 1 & 1 \\ 2 & 1 \\ 2 & 1 \\ 0 & 0 \\ 2 & 1 \\ 1 & 1 \\ 1 & 1 \\ 1 & 1 \\ 1 & 1 \\ 1 & 1 \\ 2 & 1 \\ 2 & 1 \\ 2 & 1 \\ ? & ? \\ 2 & 1 \\ 2 & 1 \\ 2 & 1 \\ 2 & 1 \\ 2 & 1 \\ 2 & 1 \\ 2 & 1 \\ & \end{array}$

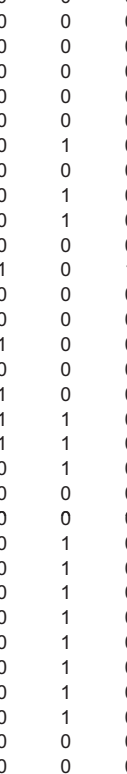

$\begin{array}{lll}0 & 0 \\ 0 & 0 \\ 0 & 0 \\ 0 & 0 \\ 0 & 0 \\ 0 & 0 \\ 0 & 0 \\ 0 & 0 \\ 0 & 0 \\ 1 & 0 \\ 0 & 0 \\ 0 & 0 \\ 0 & 0 \\ 0 & 1 \\ 0 & 0 \\ 0 & 0 \\ 0 & 0 \\ 0 & 0 \\ 0 & 0 \\ 0 & 0 \\ 0 & 0 \\ 0 & 0 \\ 0 & 0 \\ 0 & 0 \\ 0 & 0 \\ 0 & 0 \\ 0 & 0 \\ 0 & 0 \\ 0 & 1 \\ 0 & 0\end{array}$

$\begin{array}{llll}0 & 0 & 0 & 0\end{array}$

$\begin{array}{lllllll}0 & 1 & 1 & 1 & 1 & 1 & 2 \\ 0 & 1 & 1 & 1 & 1 & 1 & 2\end{array}$

.
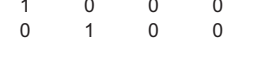

$\begin{array}{lllllll}0 & 0 & 0 & 1 & 0 & ? & ? \\ 0 & 1 & 0 & 1 & 1 & ? & ? \\ 2 & 0 & 0 & 0 & 0 & ? & ? \\ 0 & 1 & 0 & 1 & 1 & ? & ? \\ 1 & 1 & 0 & 0 & 1 & ? & ? \\ 1 & 1 & 0 & 0 & 0 & 1 & 2 \\ 2 & 0 & 0 & 1 & 1 & ? & ? \\ 2 & 0 & 0 & 1 & 1 & ? & ? \\ 2 & 0 & 0 & 1 & 1 & ? & ? \\ 2 & 0 & 0 & 1 & 1 & ? & ? \\ 2 & 0 & 0 & 1 & 1 & ? & ? \\ 2 & 0 & 0 & 1 & 1 & ? & ? \\ 2 & 0 & 0 & 1 & 1 & 1 & 2 \\ 0 & 1 & 0 & 1 & 0 & ? & ? \\ 0 & 0 & 0 & 0 & 0 & 1 & 0 \\ 0 & 0 & 0 & 0 & 0 & ? & ? \\ 0 & 0 & 0 & 0 & 0 & 0 & 1 \\ 0 & 0 & 0 & 0 & 0 & 0 & 1 \\ 0 & 0 & 0 & 0 & 0 & ? & ? \\ 0 & 0 & 0 & 0 & 0 & ? & ? \\ 0 & 0 & 0 & 0 & 0 & 0 & 1 \\ 0 & 0 & 0 & 1 & 0 & ? & ? \\ 0 & 1 & 0 & 1 & 0 & ? & ? \\ 0 & 1 & 0 & 1 & 1 & ? & ? \\ 1 & 0 & 0 & 0 & 1 & ? & ? \\ 1 & 0 & 0 & 0 & 0 & 1 & 1 \\ 2 & 1 & 0 & 0 & 0 & 1 & 2 \\ 2 & 0 & 0 & 1 & 1 & 1 & 2 \\ 0 & 1 & 0 & 1 & 1 & ? & ? \\ 1 & 0 & 1 & 1 & 0 & ? & ? \\ 0 & 1 & 0 & 1 & 1 & 1 & 0 \\ 0 & 0 & 0 & 1 & 1 & 0 & 2 \\ 0 & 0 & 0 & 1 & 0 & 0 & 1 \\ 0 & 0 & 0 & 1 & 0 & ? & ? \\ 2 & 1 & 0 & 0 & 0 & 0 & 1 \\ 0 & 0 & 0 & 1 & 0 & ? & ? \\ 0 & 1 & 0 & 1 & 0 & ? & ? \\ 0 & 0 & 0 & 1 & 0 & ? & ? \\ 0 & 0 & 0 & 1 & 0 & ? & ? \\ 0 & 0 & 0 & 1 & 0 & ? & ?\end{array}$


Electronic Supplementary Appendix 4 The 3ia data matrix 2. The second line indicates the hypotheses of homology. 


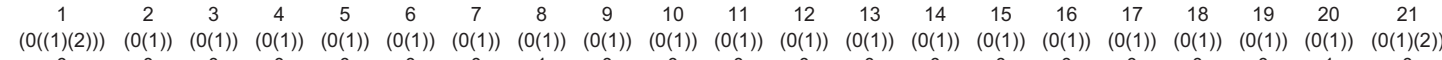

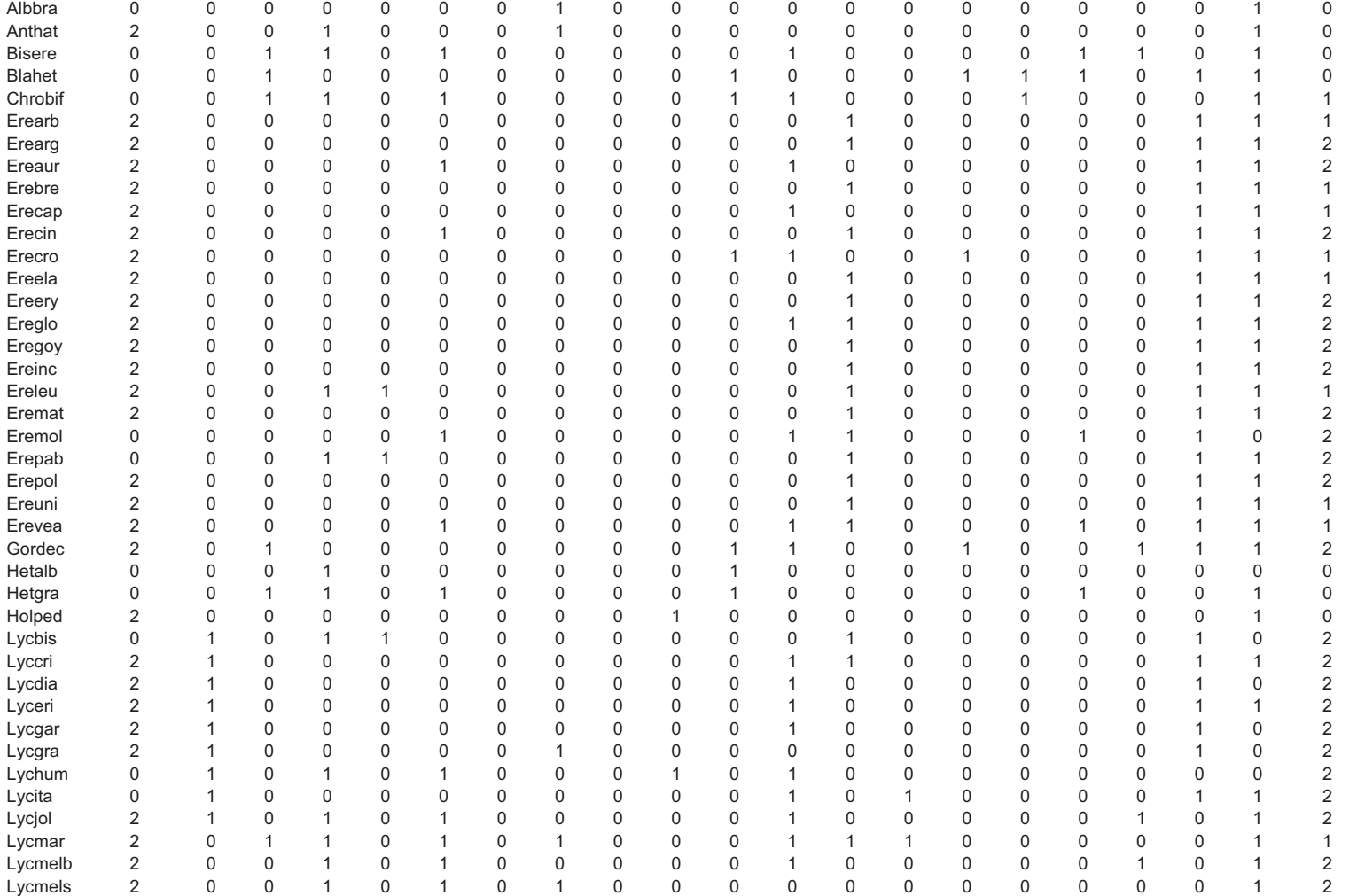

$\begin{array}{ccccccccccccccccccccc}1 & 2 & 3 & 4 & 5 & 6 & 7 & 8 & 9 & 10 & 11 & 12 & 13 & 14 & 15 & 16 & 17 & 18 & 19 & 20 & 21 \\ (0((1)(2))) & (0(1)) & (0(1)) & (0(1)) & (0(1)) & (0(1)) & (0(1)) & (0(1)) & (0(1)) & (0(1)) & (0(1)) & (0(1)) & (0(1)) & (0(1)) & (0(1)) & (0(1)) & (0(1)) & (0(1)) & (0(1)) & (0(1)) & (0(1)(2))\end{array}$

$\begin{array}{llll}\text { Lycpas } & 0 & 1 \\ \text { Lycpin } & 2 & 1 \\ \text { Lycram } & 0 & 1 \\ \text { Lycreg } & 0 & 1 \\ \text { Lycsal } & 2 & 1 \\ \text { Lycsan } & 0 & 0 \\ \text { Lycsel } & 2 & 0 \\ \text { Lycsyn } & 2 & 1 \\ \text { Lyctom } & 2 & 0 \\ \text { Lyctri } & 0 & 1 \\ \text { Lycvil } & 2 & 1 \\ \text { Lycican } & 0 & 1 & \\ \text { Lycidam } & 2 & 1 & \\ \text { Lycihat } & 0 & 1 \\ \text { Minalp } & 1 & 0 \\ \text { Mincab } & 1 & 0 \\ \text { Mincip } & 1 & 0 \\ \text { Minsca } & 1 & 0 \\ \text { Minram } & 1 & 0 \\ \text { Paratk } & 2 & 1 \\ \text { Pargla } & 2 & 0 \\ \text { Parhar } & 2 & 0 \\ \text { Parpat } & 2 & 0 \\ \text { Parref } & 2 & 1 \\ \text { Parbic } & 2 & 1 \\ \text { Pipleri } & 0 & 1 \\ \text { Piplmar } & 0 & 0 \\ \text { Piplpse } & 2 & 0 \\ \text { Piplrip } & 0 & 1 \\ \text { Piplsch } & 0 & 0 \\ \text { Preeri } & 1 & 1 \\ \text { Presp } & 1 & 1 \\ \text { Proarg } & 1 & 0 \\ \text { Herbis } & 1 & 0 \\ \text { Siplan } & 0 & 0 \\ \text { Vintom } & 0 & 0 \\ \text { Xerekm } & 0 & 0 \\ \text { Hetrob } & 0 & 0 \\ & & \end{array}$

$\begin{array}{ccccc}(0(1)) & (0(1)) & (0(1)) & (0(1)) & (0(1)) \\ 0 & 0 & 0 & 0 & 0 \\ 0 & 0 & 0 & 0 & 0 \\ 0 & 1 & 0 & 0 & 0 \\ 0 & 0 & 0 & 0 & 0 \\ 0 & 0 & 0 & 0 & 0 \\ 0 & 0 & 0 & 0 & 1 \\ 0 & 0 & 0 & 0 & 1 \\ 0 & 0 & 0 & 0 & 0 \\ 0 & 1 & 0 & 0 & 0 \\ 0 & 1 & 0 & 0 & 0 \\ 0 & 0 & 0 & 0 & 0 \\ 0 & 0 & 0 & 0 & 0 \\ 0 & 0 & 0 & 0 & 1 \\ 0 & 0 & 0 & 0 & 0 \\ 0 & 0 & 1 & 0 & 0 \\ 0 & 0 & 1 & 0 & 0 \\ 0 & 0 & 1 & 0 & 0 \\ 0 & 0 & 1 & 0 & 0 \\ 0 & 0 & 1 & 0 & 0 \\ 0 & 0 & 0 & 0 & 0 \\ 0 & 0 & 0 & 0 & 0 \\ 0 & 0 & 0 & 0 & 0 \\ 0 & 0 & 0 & 0 & 0 \\ 0 & 0 & 0 & 0 & 0 \\ 0 & 0 & 0 & 0 & 0 \\ 0 & 0 & 0 & 0 & 0 \\ 1 & 0 & 0 & 0 & 1 \\ 1 & 0 & 0 & 0 & 0 \\ 1 & 0 & 0 & 0 & 0 \\ 1 & 0 & 0 & 0 & 0 \\ 0 & 0 & 0 & 0 & 0 \\ 0 & 0 & 0 & 1 & 0 \\ 0 & 0 & 0 & 0 & 0 \\ 1 & 0 & 0 & 0 & 0 \\ 0 & 0 & 0 & 0 & 1 \\ 0 & 0 & 1 & 0 & 0 \\ 0 & 0 & 0 & 0 & 1 \\ 0 & 0 & 0 & 0 & 0 \\ & & & & \end{array}$




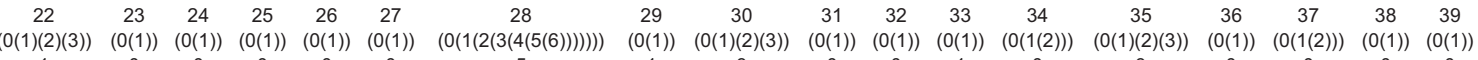

Albbra

Anthat

Buhet

Chrobif

rearb

Erearg

Ereaur

Erebre

Erecap

Erecro

Ereela

Ereglo

Erey

Ereinc

Ereleu

Eremol

Erepab

Erepol

Ereuni

Gordec

Hetalb

Hetgra

olped

Lycbis

Lycdia

Lyceri

Lycgar

Lycgra

Lycita

Lycjol

Lycjol

Lycmar

Lycmelb
Lycmels

$\begin{array}{lllllll}1 & 0 & 0 & 0 & 0 & 0 & 5 \\ 3 & 0 & 0 & 0 & 0 & 0 & 2\end{array}$

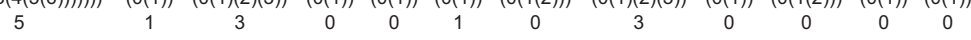

$\begin{array}{llllll}2 & 0 & 0 & 0 & 0 & 1\end{array}$

4

6

6

6

6

6
6
5

6

2

3
6

6
6
5
6

6

6
6
5

6
6

6
6

$\begin{array}{llllll}22 & 23 & 24 & 25 & 26\end{array}$

$\begin{array}{lcccccc} & (0(1)(2)(3)) & (0(1)) & (0(1)) & (0(1)) & (0(1)) & (0(1)) \\ \text { Lycpas } & 0 & 0 & 0 & 1 & 0 & 1 \\ \text { Lycpin } & 0 & 0 & 0 & 0 & 0 & 1 \\ \text { Lycram } & 0 & 0 & 0 & 1 & 0 & 1 \\ \text { Lycreg } & 0 & 0 & 0 & 0 & 0 & 1 \\ \text { Lycsal } & 0 & 0 & 0 & 0 & 0 & 1 \\ \text { Lycsan } & 0 & 0 & 0 & 0 & 0 & 1 \\ \text { Lycsel } & 0 & 0 & 1 & 1 & 0 & 1 \\ \text { Lycsyn } & 2 & 0 & 0 & 0 & 1 & 0 \\ \text { Lyctom } & 0 & 1 & 1 & 1 & 1 & 1 \\ \text { Lyctri } & 0 & 0 & 0 & 0 & 0 & 1 \\ \text { Lycvil } & 0 & 0 & 0 & 0 & 1 & 1 \\ \text { Lycican } & 0 & 0 & 0 & 0 & 0 & 0 \\ \text { Lycidam } & 0 & 0 & 0 & 0 & 0 & 0 \\ \text { Lycihat } & 0 & 0 & 0 & 0 & 0 & 0 \\ \text { Minalp } & 0 & 0 & 0 & 0 & 0 & 1 \\ \text { Mincab } & 3 & 0 & 0 & 0 & 0 & 0 \\ \text { Mincip } & 3 & 0 & 0 & 0 & 0 & 1 \\ \text { Minsca } & 0 & 0 & 0 & 0 & 0 & 0 \\ \text { Minram } & 3 & 0 & 0 & 0 & 0 & 0 \\ \text { Paratk } & 0 & 0 & 0 & 1 & 1 & 1 \\ \text { Pargla } & 0 & 1 & 1 & 1 & 1 & 1 \\ \text { Parhar } & 0 & 1 & 0 & 1 & 1 & 1 \\ \text { Parpat } & 0 & 0 & 0 & 0 & 1 & 1 \\ \text { Parref } & 0 & 1 & 0 & 1 & 0 & 1 \\ \text { Parbic } & 0 & 1 & 0 & 1 & 1 & 1 \\ \text { Pipleri } & 0 & 0 & 0 & 0 & 0 & 0 \\ \text { Piplmar } & 2 & 0 & 0 & 0 & 0 & 0 \\ \text { Piplpse } & 0 & 0 & 0 & 0 & 0 & 0 \\ \text { Piplrip } & 0 & 0 & 0 & 0 & 0 & 0 \\ \text { Piplsch } & 0 & 0 & 0 & 0 & 0 & 0 \\ \text { Preeri } & 0 & 0 & 0 & 0 & 0 & 0 \\ \text { Presp } & 0 & 0 & 0 & 0 & 0 & 0 \\ \text { Proarg } & 1 & 0 & 0 & 0 & 0 & 1 \\ \text { Herbis } & 1 & 0 & 0 & 0 & 0 & 0 \\ \text { Siplan } & 0 & 0 & 0 & 0 & 0 & 1 \\ \text { Vintom } & 3 & 0 & 0 & 0 & 0 & 0 \\ \text { Xerekm } & 0 & 0 & 0 & 0 & 0 & 1 \\ \text { Hetrob } & 0 & 0 & 0 & 0 & 0 & 1 \\ & & & & & & \end{array}$

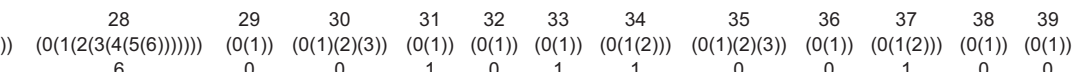




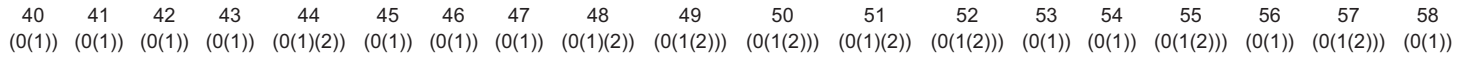

$\begin{array}{lll}\text { Albbra } & 0 & 0 \\ \text { Anthat } & 1 & 0 \\ \text { Bisere } & 0 & 0 \\ \text { Blahet } & 0 & 0 \\ \text { Chrobif } & 1 & 0 \\ \text { Erearb } & ? & ? \\ \text { Erearg } & 0 & 0 \\ \text { Ereaur } & 0 & 0 \\ \text { Erebre } & 0 & 0 \\ \text { Erecap } & 0 & 0 \\ \text { Erecin } & 0 & 0 \\ \text { Erecro } & 0 & 0 \\ \text { Ereela } & 0 & 0 \\ \text { Ereery } & 0 & 0 \\ \text { Ereglo } & 0 & 0 \\ \text { Eregoy } & 0 & 0 \\ \text { Ereinc } & 0 & 0 \\ \text { Ereleu } & 0 & 0 \\ \text { Eremat } & 0 & 0 \\ \text { Eremol } & 0 & 0 \\ \text { Erepab } & 0 & 0 \\ \text { Erepol } & 0 & 0 \\ \text { Ereuni } & 0 & 0 \\ \text { Erevea } & 0 & 0 \\ \text { Gordec } & 0 & 0 \\ \text { Hetalb } & 0 & 0 \\ \text { Hetgra } & 0 & 0 \\ \text { Holped } & 0 & 0 \\ \text { Lycbis } & 0 & 0 \\ \text { Lyccri } & ? & ? \\ \text { Lycdia } & 0 & 0 \\ \text { Lyceri } & 0 & 0 \\ \text { Lycgar } & 0 & 0 \\ \text { Lycgra } & 0 & 0 \\ \text { Lychum } & 0 & 0 \\ \text { Lycita } & 0 & 0 \\ \text { Lycjol } & 0 & 0 \\ \text { Lycmar } & 0 & 0 \\ \text { Lycmelb } & 0 & 0 \\ \text { Lycmels } & 0 & 0 \\ & & \end{array}$

\begin{tabular}{|c|c|c|c|}
\hline$(1)(2))$ & $(0(1))$ & $(0(1))$ & $(0(1)$ \\
\hline 0 & 0 & 1 & 1 \\
\hline 0 & 0 & 1 & 1 \\
\hline 2 & 1 & 0 & 0 \\
\hline 2 & 0 & 0 & 0 \\
\hline 2 & 0 & 0 & 0 \\
\hline 0 & 0 & 0 & 0 \\
\hline 1 & 0 & 1 & 0 \\
\hline 1 & 0 & 1 & 0 \\
\hline 1 & 0 & 0 & 0 \\
\hline 0 & 0 & 0 & 0 \\
\hline 0 & 0 & 1 & 0 \\
\hline 2 & 0 & 1 & 0 \\
\hline 2 & 0 & 1 & 0 \\
\hline 1 & 0 & 0 & 0 \\
\hline 1 & 0 & 1 & 0 \\
\hline 1 & 0 & 1 & 0 \\
\hline 0 & 0 & 1 & 0 \\
\hline 0 & 0 & 1 & 0 \\
\hline 1 & 0 & 1 & 0 \\
\hline 1 & 0 & 1 & 0 \\
\hline 1 & 0 & 1 & 0 \\
\hline 1 & 0 & 0 & 0 \\
\hline 0 & 0 & 0 & 0 \\
\hline 0 & 0 & 1 & 0 \\
\hline 2 & 0 & 0 & 0 \\
\hline 2 & 1 & 0 & 0 \\
\hline 2 & 1 & 0 & 1 \\
\hline 0 & 0 & 1 & 1 \\
\hline 1 & 0 & 1 & 0 \\
\hline 2 & 0 & 0 & 0 \\
\hline 2 & 0 & 0 & 0 \\
\hline 2 & 0 & 0 & 0 \\
\hline 2 & 0 & 0 & 0 \\
\hline 2 & 0 & 0 & 0 \\
\hline 0 & 0 & 0 & 0 \\
\hline$?$ & $?$ & ? & ? \\
\hline 2 & 0 & 0 & 0 \\
\hline 2 & 0 & 0 & 0 \\
\hline 2 & 0 & 0 & 0 \\
\hline 2 & 0 & 0 & 0 \\
\hline
\end{tabular}

$\begin{array}{lllll}0 & 0 & 0 & 0 & \\ 0 & 0 & 1 & 0 & 2 \\ 0 & 2 & 0 & 0 & 1 \\ 1 & 0 & 0 & 0 & \\ 0 & 0 & 1 & 0 & 2 \\ 2 & 2 & 0 & 0 & 0 \\ 2 & 0 & 1 & 0 & 2 \\ 2 & 0 & 1 & 0 & 2 \\ 0 & 1 & 0 & 1 & 0 \\ 2 & 2 & 0 & 0 & 0 \\ 2 & 0 & 1 & 0 & 2 \\ 0 & 1 & 0 & 0 & 2 \\ 0 & 0 & 0 & 0 & 1 \\ 2 & 2 & 0 & 0 & 0 \\ 2 & 0 & 1 & 0 & 2 \\ 2 & 1 & 1 & 0 & 2 \\ 2 & 1 & 1 & 0 & 1 \\ 0 & 1 & 0 & 0 & 2 \\ 2 & 1 & 1 & 0 & 2 \\ 0 & 0 & 1 & 0 & 1 \\ 0 & 0 & 0 & 0 & 2 \\ 2 & 2 & 0 & 0 & 0 \\ 2 & 1 & 0 & 0 & 0 \\ 0 & 1 & 1 & 0 & 2 \\ 1 & 0 & 2 & 0 & 2 \\ 0 & 0 & 0 & 2 & 2 \\ 0 & 2 & 0 & 1 & 2 \\ 0 & 1 & 1 & 0 & 1 \\ 0 & 1 & 0 & 0 & 1 \\ 0 & 0 & 1 & 0 & 2 \\ 0 & 0 & 1 & 0 & 2 \\ 0 & 0 & 1 & 0 & 2 \\ 0 & 0 & 0 & 0 & 2 \\ 0 & 0 & 1 & 0 & 2 \\ 1 & 0 & 0 & 0 & 0 \\ ? & ? & ? & ? & ? \\ 0 & 0 & 0 & 0 & 2 \\ 0 & 0 & 1 & 0 & 2 \\ 0 & 0 & 0 & 2 & 2 \\ 0 & 0 & 0 & 0 & 2 \\ & & & & \end{array}$

$\begin{array}{llllll}1 & 0 & 0 & 0 & 0 & 0 \\ 1 & 0 & 1 & 0 & 1 & 0 \\ 0 & 0 & 2 & 0 & 1 & 0 \\ 0 & 0 & 2 & 0 & 2 & 0 \\ 1 & 0 & 1 & 0 & 1 & 0 \\ 0 & 0 & 2 & 0 & 0 & 0 \\ 0 & 0 & 0 & 0 & 2 & 0 \\ 0 & 0 & 0 & 1 & 2 & 0 \\ 0 & 0 & 1 & 1 & 0 & 0 \\ 0 & 0 & 2 & 0 & 0 & 0 \\ 0 & 0 & 0 & 0 & 2 & 0 \\ 1 & 0 & 1 & 0 & 0 & 0 \\ 0 & 0 & 0 & 0 & 0 & 0 \\ 0 & 0 & 2 & 0 & 0 & 0 \\ 1 & 0 & 0 & 0 & 2 & 0 \\ 1 & 0 & 1 & 0 & 2 & 0 \\ 0 & 0 & 1 & 0 & 1 & 0 \\ 0 & 0 & 1 & 1 & 2 & 0 \\ 0 & 0 & 1 & 0 & 2 & 0 \\ 0 & 0 & 0 & 0 & 1 & 0 \\ 1 & 0 & 0 & 0 & 2 & 0 \\ 0 & 0 & 2 & 0 & 0 & 0 \\ 0 & 0 & 1 & 0 & 0 & 0 \\ 0 & 0 & 1 & 0 & 2 & 0 \\ 0 & 0 & 0 & 0 & 0 & 0 \\ 0 & 0 & 2 & 1 & 2 & 0 \\ 0 & 0 & 2 & 1 & 2 & 0 \\ 0 & 0 & 1 & 0 & 1 & 0 \\ 0 & 0 & 1 & 1 & 2 & 0 \\ 0 & 0 & 1 & 1 & 2 & 0 \\ 0 & 0 & 2 & 1 & 2 & 0 \\ 0 & 0 & 2 & 1 & 2 & 0 \\ 0 & 0 & 2 & 1 & 2 & 0 \\ 0 & 0 & 2 & 1 & 2 & 1 \\ 0 & 0 & 2 & 1 & 2 & 0 \\ ? & ? & ? & ? & ? & ? \\ 0 & 0 & 2 & 1 & 2 & 0 \\ 0 & 0 & 2 & 1 & 2 & 0 \\ 0 & 0 & 2 & 1 & 2 & 0 \\ 0 & 0 & 1 & 1 & 0 & 0\end{array}$

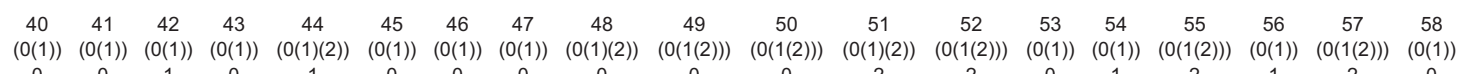
Lycpas

Lycpin 000 Lycreg

Lycsal

Lycsel

Lycsyn

Lyctom

Lyctri

Lycvil

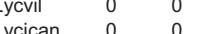

Lycidam

Lycihat

Minalp

Mincab

Mincip

Minsca

Minram

Paratk

Pargla

Parhar

Parref

Parbic

Pipleri

Piplma

Piplpse

Piplrip

Proeri

Preeri

Proarg

Herbis

Siplan

Vintom

Hetrob

$\begin{array}{llll}0 & 1 & 0 & 0 \\ 0 & 2 & 0 & 0\end{array}$

$\begin{array}{ccccccccc}(0(1(2))) & (0(1)(2)) & (0(1(2))) & (0(1)) & (0(1)) & (0(1(2))) & (0(1)) & (0(1(2))) & (0(1) \\ 0 & 2 & 2 & 0 & 1 & 2 & 1 & 2 & 0\end{array}$ 
$\begin{array}{ccc}59 & 60 & 61 \\ (0(1)(2)) & (0(1)) & (0(1))\end{array}$

$\begin{array}{llll}\text { Albbra } & 0 & ? & ? \\ \text { Anthat } & 2 & ? & ? \\ \text { Bisere } & 0 & ? & ? \\ \text { Blahet } & 2 & ? & ? \\ \text { Chrobif } & 0 & ? & ? \\ \text { Erearb } & 0 & ? & ? \\ \text { Erearg } & 0 & 1 & 1 \\ \text { Ereaur } & 0 & ? & ? \\ \text { Erebre } & 0 & ? & ? \\ \text { Erecap } & 0 & ? & ? \\ \text { Erecin } & 0 & ? & ? \\ \text { Erecro } & 0 & 1 & 1 \\ \text { Ereela } & 0 & 1 & 1 \\ \text { Ereery } & 0 & 1 & 0 \\ \text { Ereglo } & 0 & 0 & 0 \\ \text { Eregoy } & 0 & 1 & 1 \\ \text { Ereinc } & 0 & 0 & 1 \\ \text { Ereleu } & 0 & ? & ? \\ \text { Eremat } & 0 & 0 & 1 \\ \text { Eremol } & 0 & 0 & 1 \\ \text { Erepab } & 0 & ? & ? \\ \text { Erepol } & 0 & ? & ? \\ \text { Ereuni } & 0 & 0 & 1 \\ \text { Erevea } & 0 & 0 & 0 \\ \text { Gordec } & 0 & ? & ? \\ \text { Hetalb } & 0 & 0 & 0 \\ \text { Hetgra } & 0 & ? & ? \\ \text { Holped } & 0 & 1 & 1 \\ \text { Lycbis } & 0 & ? & ? \\ \text { Lyccri } & 0 & 1 & 0 \\ \text { Lycdia } & 0 & ? & ? \\ \text { Lyceri } & 0 & 1 & 1 \\ \text { Lycgar } & 0 & 1 & 0 \\ \text { Lycgra } & 0 & 1 & 0 \\ \text { Lychum } & 1 & ? & ? \\ \text { Lycita } & ? & ? & ? \\ \text { Lycjol } & 1 & ? & ? \\ \text { Lycmar } & 0 & 1 & 0 \\ \text { Lycmelb } & 1 & 0 & 0 \\ \text { Lycmels } & 0 & 0 & 0 \\ & & & \end{array}$

$\begin{array}{llll}\text { Lycmelb } & 1 & 0 & 0 \\ \text { Lycmels } & 0 & 0 & 0\end{array}$

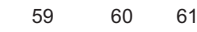

Lycpas $\quad(0(1)(2)) \quad(0(1)) \quad(0(1))$

Lycpin

$\begin{array}{lll} & 1 & 0 \\ \text { Lycram } & 0 & 0\end{array}$

$\begin{array}{lll} & 1 & \end{array}$

ycsal 0

lycsan ? ?

Lycsel ? ?

Lycsyn ? ?

$\begin{array}{llll}\text { Lyctom } & 0 & ?\end{array}$

Lycvil $\quad 0$ ? ?

$\begin{array}{lll}\text { Lycican } & 1 & 0 \\ ? & 0\end{array}$

1

$\begin{array}{llll}\text { Minalp } & 2 & 1 & 1\end{array}$

Mincab 2 ?

Mincip 2 ? ?

$\begin{array}{lll}\text { Minsca } & 2 & ?\end{array}$

Paratk 0 ? ?

Pargla 2 ?

$\begin{array}{llll}\text { Parhar } & 0 & 1 & 1\end{array}$

Parpat ? ?

Parref ? ?

$\begin{array}{llll}\text { Parbic } & 1 & ? & ? \\ \text { Pipleri } & 0 & 1 & 0\end{array}$

Piplpse 1 ? ?

$\begin{array}{lll}\text { Piplrip } & 0 & ?\end{array}$

$\begin{array}{lll}\text { Preeri } 1 & 1 & 1\end{array}$

$\begin{array}{llll}\text { Presp } & 1 & ?\end{array}$

$\begin{array}{llll}\text { Proarg } & 1 & 1 & 1\end{array}$

Herbis ? ?

Siplan

$\begin{array}{llll}\text { Xerekm } & 1 & 1 & 0 \\ \text { Hetrob } & 1 & ? & ?\end{array}$ 
Electronic Supplementary Appendix 5 List of specimens examined. The following abbreviations designate the states of Brazil: BA Bahia, CE Ceará, DF Distrito Federal, GO Goiás, MT Mato Grosso, MG Minas Gerais, PR Paraná, RS Rio Grande do Sul, SC Santa Catarina, SP São Paulo.

Albertinia brasiliensis Spreng., Brazil: BA, Rio de Contas, Giulietti and Andrade 2277 (SPF); Salvador, Queiroz 1331 (SPF). Anteremanthus hatschbachii H. Rob., Brazil: MG, Grão Mogol, Giulietti et al. CFCR 9864 (SPF); ibidem, Loeuille et al. 441 (SPF). Argyrovernonia harleyi (H. Rob.) MacLeish, Brazil: BA, Licínio de Almeida, Souza-Silva et al. 238 (HUEFS); Oliveira dos Brejinhos, Loeuille et al. 377 (SPF). Bishopalea erecta H. Rob., Brazil: BA, Mucugê, King and Bishop 8729 (UB). Blanchetia heterotricha DC. Brazil: BA, Abaíra, Stannard et al. H 51879 (HUEFS); Morro do Chapéu, Harley et al. PCD 6092 (HUEFS). Centratherum punctatum Cass., Brazil: BA, Feira de Santana, Loeuille and Moraes 348 (SPF); Lençóis, Hind PCD 3802 (SPF). Chresta angustifolia Gardner, Brazil: GO, Alto Paraíso, Loeuille et al. 291 (SPF); ibidem, Marquete et al. 2308 (IBGE). Chresta exsucca DC., Brazil: DF, Brasília, Calago 148 (SPF); GO, Pirenópolis, Loeuille et al. 303 (SPF). Chresta plantaginifolia (Less.) Gardner, Brazil: MG, Gouveia, Cavalcanti et al. CFCR 10326 (SPF); São Roque de Minas, Romero et al. 4611 (SPF). Chresta pycnocephala DC., Brazil: GO, Planaltina de Goiás, Loeuille et al. 272 (SPF); MG, Botumirim, Fiaschi et al. 841 (SPF). Chresta scapigera (Less.) Gardner, Brazil: MG, Itutinga, Mello-Silva 2931 (SPF); Loeuille et al. 255, MG, São Roque de Minas (SPF). Chresta souzae H. Rob., Brazil: GO, Alto Paraíso, Sano et al. 3875 (SPF); MG, Sacramento, Costa et al. 105 (SPF). Chresta speciosa Gardner, Brazil: GO, Niquelândia, Moraes and Oliveira 533 (UEC); ibidem, Oliveira et al. 815 (IBGE). Chresta sphaerocephala DC., Brazil: GO, Posse, Forzza et al. 1545 (SPF); SP, Mogi Guaçu, Handro 499 (SPF). Chronopappus bifrons (DC. ex Pers.) DC., Brazil: MG, Catas Altas, Loeuille and Albergaria Pena 460 (SPF); Santo Antônio do Itambé, Loeuille et al. 465 (SPF). Chrysolaena flexuosa (Sims) H. Rob. Brazil: SC, Lages, Loeuille and Wagner 357 (SPF); Urupema, Loeuille et al. 139 (SPF). Chrysolaena lithospermifolia (Hieron.) H. Rob., Brazil: PR, Jaguariaíva, Fiaschi and Marcato 805 (SPF); SC, Lages, Loeuille and Wagner 359 (SPF). Chrysolaena platensis (Spreng.) H. Rob, Brazil: SC, Lages, Loeuille and Wagner 363 (SPF); Paraguay: Concepción, Sargento José E. López, Zardini and Guerrero 54009 (SPF). Critoniopsis huairacajana (Hieron.) H. Rob., Ecuador: Azuai, Carretera Chiquintad, Jaramillo and Valencia 8882 (US); Cañar, Cuenca, King and Almeda 7743 (US). Critoniopsis sodiroi (Hieron.) H. Rob., Ecuador: Cotopaxi, Holm-Nielsen and Andrade 18510 (US); Imbabura, Cotacachi Canton, Cuamacás et al. 89 (US). Cyrtocymura harleyi (H. Rob.) H. Rob., Brazil: BA, Milagres, Hatschbach et al. 75800 (SPF); Morro do Chapéu, Loeuille et al. 383 (SPF). Cyrtocymura scorpioides (Lam.) H. Rob., Brazil: MG, Santana do Riacho, Borges et al. 27 (SPF); SP, Ibiúna, Camargo s.n. (SPF 176673). Echinocoryne holosericea (Mart.) H. Rob., Brazil: BA, Abaíra, Ganev 428 (SPF); MG, Itacambira, Pirani et al. 4378 (SPF). Echinocoryne schwenkiaefolia (Mart. ex DC.) H. Rob., Brazil: MG, Diamantina, 
Mello-Silva et al. CFCR 7965 (SPF); ibidem, Roque et al. 209 (SPF). Elephantopus biflorus (Less.) Sch. Bip., Brazil: MG, São Roque de Minas, Loeuille et al. 256 (SPF); ibidem, Loeuille et al. 268 (SPF). Elephantopus micropappus Less., Brazil: MG, Belo Horizonte, Roth 1333 (SPF); Botumirim, Fiaschi et al. 180 (SPF). Elephantopus mollis Kunth, Brazil: SC, Urupema, Loeuille et al. 140 (SPF); Paraguay: Paraguarí, Taruma Fondo, Zardini and Guerrero 37715 (SPF). Eremanthus arboreus (Gardner) MacLeish, Brazil: CE, Crato, Loeuille et al. 510 (SPF); ibidem, Loeuille et al. 512 (SPF). Eremanthus argenteus MacLeish \& H. Schumach., Brazil: GO, Alto Paraíso, Loeuille et al. 289 (SPF); Teresina de Goiás, Souza et al. 24698 (SPF). Eremanthus auriculatus MacLeish \& H. Schumach., Brazil: GO, Alto Paraíso, Aparecida da Silva 2291 (SPF); ibidem, Loeuille et al. 279 (SPF). Eremanthus brevifolius Loeuille sp. ined., Brazil: MG, Congonhas do Norte, Loeuille et al. 71 (SPF). Eremanthus capitatus (Spreng.) MacLeish, Brazil: BA, Abaíra, Loeuille et al. 345 (SPF); Lençóis, Grillo and Conceição 47 (SPF). Eremanthus cinctus Baker, Brazil: MG, Uberlândia, Loeuille et al. 306 (SPF); MT, Pedra Preta, Monteiro s.n. (UEC 13506). Eremanthus crotonoides (DC.) Sch. Bip., Brazil: MG, Catas Altas, Pirani et al. 5336 (SPF); Lavras Novas, Santos et al. 460 (HUFU); Eremanthus elaeagnus (Mart. ex DC.) Sch. Bip., Brazil: MG, Diamantina, Roque et al. 206 (SPF); MG, Joaquim Felício, Loeuille et al. 430 (SPF). Eremanthus erythropappus (DC.) MacLeish, Brazil: MG, Nova Lima, Tameirão Neto 3475 (SPF); Santana do Riacho, Pereira and Loucca 818 (UEC). Eremanthus glomerulatus Less., Brazil: MG, Lavras, Arbo et al. 3891 (SPF); Santana do Riacho, Loeuille et al. 27 (SPF). Eremanthus goyazensis (Gardner) Sch. Bip., Brazil: DF, Brasília, Vieira et al. 1861 (SPF); GO, Luziânia, Melo and França 710 (SPF). Eremanthus incanus (Less.) Less., Brazil: MG, Grão-Mogol, Pirani et al. CFCR 13294 (SPF); ibidem, Pirani et al. CFCR 13467 (SPF). Eremanthus leucodendron Mattf., Brazil: BA, Rio de Contas, Harley et al. PCD 4277 (SPF); ibidem, Harley et al. PCD 4469 (SPF). Eremanthus mattogrossensis Kuntze, Brazil: SP, Estreito, Marcondes Ferreira et al. 1214 (SPF); Pedregulho, Sasaki and Junqueira 542 (SPF). Eremanthus mollis Sch. Bip., Brazil: DF, Brasília, Heringer 8201 (SP); MG, Capitólio, Loeuille et al. 39 (SPF). Eremanthus pabstii G.M. Barroso, Brazil: GO, Água Fria de Goiás, Hatschbach et al. 70631 (SPF); Cristalina, Hatschbach and Kummrow 46603 (SPF). Eremanthus polycephalus (DC.) MacLeish, Brazil: MG, Diamantina, Roque et al. 246 (SPF); Grão-Mogol, Souza et al. 25838 (SPF). Eremanthus uniflorus MacLeish \& H. Schumach, Brazil: GO, Alto Paraíso, Loeuille et al. 286 (SPF); Colinas do Sul, Magenta et al. 268 (SPF). Eremanthus veadeiroensis H. Rob., Brazil: GO, Alto Paraíso, Anderson et al. 6494 (UB); ibidem, King and Bishop 8831 (UB). Gorceixia decurrens Baker, BA, Livramento da Nossa Senhora, Souza et al. 5238 (ESA); MG, Leme do Prado, Tameirão Neto 3308 (ESA). Heterocoma albida (DC. ex Pers.) DC., Brazil: MG, Serro, Loeuille et al. 450 (SPF). Heterocoma gracilis Loeuille, J.N. Nakaj. \& Semir sp. ined., Brazil: MG, São Gonçalo do Rio Preto, Loeuille et al. 520 (SPF); ibidem, Viana and Mota 1843 (BHCB). Heterocoma robinsoniana Loeuille, J.N. Nakaj. \& Semir sp. ined., Brazil: MG, São Roque de Minas, Romero et al. 1708 (HUFU); ibidem, Romero and Nakajima 3533 (HUFU). Hololepis pedunculata (DC. ex Pers.) DC., 
Brazil: MG, São Roque de Minas, Loeuille et al. 259 (SPF); ibidem, Nakajima et al. 1174 (SPF). Lepidaploa aurea (Mart. ex DC.) H. Rob., Brazil: DF, Brasília, Boaventura 135 (SPF); GO, Alto Paraíso, Loeuille et al. 283 (SPF). Lepidaploa rufogrisea (A. St. -Hil.) H. Rob., Brazil: MG, Buritizeiro, Hatschbach et al. 71953 (SPF); SP, Pedregulho, Sasaki and Junqueira 478 (SPF). Lepidonia jonesii (B.L. Turner) H. Rob. \& V. A. Funk, Mexico: Oaxaca, Ixtlán, López-Luna and Martin 649 (US). Lessingianthus bishopii (H. Rob.) H. Rob., Brazil: GO, Pirenópolis, Loeuille et al. 302 (SPF); ibidem, Saavedra et al. 427 (SPF). Lessingianthus buddleiifolius (Mart. ex DC.) H. Rob., Brazil: MG, Retiro, Roque et al. CFCR 15131 (SPF); SP, Pedregulho, Sasaki and Calió 936 (SPF). Lessingianthus farinosus (Baker) H. Rob., Brazil: BA, Abaíra, Ganev 161 (SPF); ibidem, Ganev 191 (SPF). Lessingianthus linearis (Spreng.) H. Rob., Brazil: BA, Abaíra, Ganev 3268 (SPF); MG, Santana do Riacho, Roque and Hervêncio 471 (SPF). Lessingianthus santosii (H. Rob.) H. Rob., Brazil: BA, Abaíra, Ganev 359 (SPF); ibidem, Ganev 611 (SPF). Lychnophora bishopii H. Rob., Brazil: BA, Mucugê, Harley et al. CFCR 14267 (SPF); Rio de Contas, Sano et al. CFCR 14714 (SPF). Lychnophora crispa Mattf., Brazil: BA, Mucugê, Hind et al. PCD 3551 (SPF); Rio de Contas, Harley et al. PCD 4427 (SPF). Lychnophora diamantinana Coile \& S.B. Jones, Brazil: MG, Diamantina, Forzza et al. 622 (SPF); ibidem, Loeuille et al. 108 (SPF). Lychnophora ericoides Mart., Brazil: GO, Cocalzinho, Vieira et al. 1879 (SPF); MG, Diamantina, Semir et al. CFCR 9551 (SPF). Lychnophora gardneri Sch. Bip. Brazil: MG, Congonhas do Norte, Loeuille et al. 67 (SPF); Serro, Pirani et al. 4070 (SPF). Lychnophora granmogolensis (Duarte) Semir in D.J.N. Hind, Brazil: MG, Cristália, Loeuille et al. 445 (SPF); Josenópolis, Loeuille et al. 447 (SPF). Lychnophora humillima Sch. Bip., Brazil: MG, Santana de Pirapama, Zappi et al. 1959 (SPF); ibidem, Zappi and Taylor 2257 (SPF). Lychnophora itacambirensis sp. ined., Brazil: MG, Itacambira, Mello-Silva et al. 631 (SPF); ibidem, Mello-Silva et al. 3186 (SPF). Lychnophora joliana sp. ined., Brazil: MG, Jaboticatubas, Roque et al. 119 (SPF); Santana do Riacho, Loeuille et al. 112 (SPF). Lychnophora markgravii G.M. Barroso, Brazil: MG, Grão-Mogol, Mello-Silva et al. 446 (SPF); ibidem, Loeuille et al. 440 (SPF). Lychnophora mellobarretoi G.M. Barroso, Brazil: MG, Santana do Riacho, Loeuille et al. 507 (SPF); ibidem, Pirani et al. 5074 (SPF). Lychnophora mellosilvae sp. ined., Brazil: MG, Mato Verde, Mello-Silva et al. 463 (SPF); Rio Pardo de Minas, Pirani et al. 4298 (SPF). Lychnophora passerina (Mart. ex DC.) Gardner, Brazil: BA, Abaíra, Ganev 85 (SPF); MG, Santana do Riacho, Sato et al. 10 (SPF). Lychnophora pinaster Mart., Brazil: MG, Catas Altas, Mello-Silva and Borges 2880 (SPF); Ouro Branco, Pirani et al. CFCR 11191 (SPF). Lychnophora ramosissima Gardner, Brazil: MG, Josenópolis, Loeuille et al. 448 (SPF). Lychnophora regis H. Rob., Brazil: BA, Mucugê, Hind et al. PCD 3537 (SPF); ibidem, Hind et al. PCD 3643 (SPF). Lychnophora salicifolia Mart., Brazil: BA, Abaíra, Ganev 128 (SPF); MG, Santana do Riacho, Loeuille et al. 109 (SPF). Lychnophora santosii H. Rob., Brazil: BA, Abaíra, Ganev 2277 (SPF); ibidem, Ganev 2280 (SPF). Lychnophora sellowii Sch. Bip., Brazil: MG, Santana do Riacho, Borges et al. 301 (SPF); ibidem, Pirani et al. 5043 (SPF). Lychnophora syncephala (Sch. Bip.) Sch. Bip., 
Brazil: MG, Santana de Pirapama, Zappi et al. 1614 (SPF); Santana do Riacho, Loeuille et al. 483A (SPF). Lychnophora tomentosa (Mart. ex DC.) Sch. Bip., Brazil: MG, Datas, Pirani and Mello-Silva CFCR 11010 (SPF); Diamantina, Hatschbach et al. 69584 (SPF). Lychnophora triflora (Mattf.) H. Rob., Brazil: BA, Abaíra, Loeuille et al. 333 (SPF); Rio de Contas, Queiroz et al. 4938 (SPF). Lychnophora villosissima Mart., Brazil: MG, Brumadinho, Martens 372 (SPF); Datas, Pirani et al. 5221 (SPF). Lychnophoriopsis candelabrum (Sch. Bip.) H. Rob., Brazil: MG, Joaquim Felício, Pirani et al. 4647 (SPF); ibidem, Roque et al. CFCR 15180 (SPF). Lychnophoriopsis damazioi (P. Beauv.) H. Rob., Brazil: MG, Santana do Riacho, Giulietti et al. CFSC 12659 (SPF); ibidem, Stehmann and Franceschinelli 2363 (SPF). Lychnophoriopsis hatschbachii H. Rob., Brazil: MG, Diamantina, Rosa et al. 935 (SPF); ibidem, Semir et al. CFCR 9552 (SPF). Minasia alpestris (Gardner) H. Rob., Brazil: MG, Datas, Zappi et al. CFCR 10660 (SPF); Diamantina, Roque et al. 295 (SPF). Minasia cabralensis H. Rob., Brazil: MG, Joaquim Felício, Lewinsohn et al. PIC 97010 (UEC); ibid., Lewinsohn et al. PIC 97012 (UEC). Minasia cipoensis sp. ined., Brazil: MG, Santana do Riacho, Loeuille et al. 494 (SPF); ibidem, Souza et al. 25075 (SPF). Minasia scapigera H. Rob., Brazil: MG, Couto de Magalhães de Minas, Wanderley et al. CFCR 4618 (SPF); Diamantina, Roque et al. 296 (SPF). Minasia ramosa Loeuille, H. Rob. \& Semir, Brazil: MG, Joaquim Felício, Loeuille et al. 432 (SPF); ibidem, Mello-Silva 3223 (SPF). Moquinia racemosa (Spreng.) DC., Brazil: BA, Abaíra, Loeuille et al. 311 (SPF); MG, Rio Vermelho, Cavalcanti et al. CFCR 10193 (SPF). Orthopappus angustifolius (Sw.) Gleason, Brazil: GO, Chapadão do Céu, Souza et al. 8312 (SPF); SP, Itirapina, Fantinati 110 (SPF). Paralychnophora atkinsiae D.J.N. Hind, Brazil: BA, Mucugê, Oliveira 42 (SPF); ibidem, Roque et al. 1446 (ALCB). Paralychnophora bicolor (DC.) MacLeish, Brazil: BA, Abaíra, Ganev 671 (SPF); Barra da Estiva, Bautista and RodríguezOubiña 2304 (HRB). Paralychnophora glaziouana Loeuille sp. ined., Brazil: MG, GrãoMogol, Hatschbach et al. 41421 (MBM); Serro, Loeuille et al. 451 (SPF). Paralychnophora harleyi (H. Rob.) D.J.N. Hind, Brazil: BA, Piatã, Loeuille and Ferreira 309 (SPF); Rio de Contas, Harley et al. 25372 (SPF). Paralychnophora patriciana D.J.N. Hind, Brazil: BA, Abaíra, Loeuille et al. 328 (SPF); ibidem, Stannard et al. H 51189 (SPF). Paralychnophora reflexoauriculata (G.M. Barroso) MacLeish, Brazil: BA, Morro do Chapéu, Loeuille et al. 396 (SPF); ibidem, Souza et al. 4790 (ESA). Piptocarpha oblonga (Gardner) Baker, Brazil: MG, São Roque de Minas, Lombardi 1835 (SPF); SP, São Paulo, Garcia 159 (SPF). Piptocarpha rotundifolia (Less.) Baker, Brazil: DF, Brasília, Sampaio et al. 121 (SPF); GO, Niquelândia, Walter et al. 1557 (SPF). Piptolepis ericoides Sch. Bip., Brazil: MG, Santana do Riacho, Arbo et al. 4683 (SPF); ibidem, Loeuille et al. 17 (SPF). Piptolepis oleaster (Mart. ex DC.) Sch. Bip., Brazil: MG, São Gonçalo do Rio Preto, Loeuille et al. 517 (SPF); ibidem, Lombardi et al. 3683 (BHCB). Piptolepis monticola Loeuille sp. ined., Brazil: MG, Santo Antônio de Itambé, Anderson et al. 35817 (RB); ibidem, Loeuille et al. 464 (SPF). Piptolepis riparia sp. ined., Brazil: MG, São Gonçalo do Rio Preto, Loeuille et al. 516 (SPF). Piptolepis schultziana Loeuille \& D.J.N. Hind, Brazil: MG, Congonhas do Norte, Loeuille et al. 72 (SPF); ibidem, 
Loeuille et al. 76 (SPF). Pithecoseris pacourinoides Mart. ex DC., Brazil: BA, Feira de Santana, Loeuille and França 350 (SPF); Lençóis, Grillo and Conceição 12 (SPF). Prestelia eriopus Sch. Bip., Brazil: MG, Congonhas do Norte, Pirani et al. 4168 (SPF); Santana do Riacho, Arbo et al. 4610 (SPF). Prestelia robusta sp. ined., Brazil: MG, Diamantina, Mansanares and Verola 340 (UEC). Proteopsis argentea Mart. \& Zucc. ex DC., Brazil: MG, Santana do Riacho, Loeuille et al. 24 (SPF); ibidem, Roque et al. CFSC 13056 (SPF). Proteopsis hermogenesii sp. ined., Brazil: MG, Botumirim, Mello-Silva and Forzza 2727 (SPF); Itacambira, Cordeiro et al. CFCR 9132 (SPF). Rolandra fruticosa (L.) Kuntze, Brazil: BA, Maraú, Carvalho et al. 275 (HUEFS); Mascote, Mello-Silva et al. 3128 (SPF). Sipolisia lanuginosa Glaz. ex Oliv., Brazil: MG, Diamantina, Brade 13392 (SPF). Soaresia velutina Sch. Bip., Brazil: DF, Brasília,Heringer 6660 (IBGE); GO, Luziânia, Melo and França 534 (UB). Stenocephalum megapotamicum (Spreng.) Sch. Bip., Brazil: MG, Baependi, Nogueira 147 (SPF); SP, Campos de Jordão, Robim 525 (SPF). Stokesia laevis (Hill) Greene, USA: Mississippi, Forest Co., Webster and Wilbur 3389 (US); Gulfport, Knobloch 1426 (US). Stramentopappus poolae (B.L. Turner) H. Rob. \& V.A. Funk, Mexico: Oaxaca, La Esperanza, Funk et al. 2729 (US); ibidem, Villaseñor and Téllez 457 (US). Strobocalyx arborea (Buch. -Ham.) Sch. Bip., Malaysia: Malacca, Sungei Udang, Grant s.n. (US 3524834); Thailand: Nakhon Si Thammarat, Snan 768 (US) Strophopappus glomeratus (Gardner) R. Esteves, Brazil: GO, Alto Paraíso, Loeuille et al. 278 (SPF); Cristalina, Pirani et al. 1578 (SPF). Strophopappus speciosus (Less.) R. Esteves, Brazil: SP, Pedregulho, Sasaki 455 (SPF); ibidem, Sasaki 487 (SPF). Tarlmounia elliptica (DC.) H. Rob., S.C. Keeley, Skvarla \& R. Chan, Thailand: Loie, Pasithan, Ploenchit 1300 (US); USA: Hawaii, Maui, Starr and Martz 980204-10 (US). Vernonanthura ferruginea (Less.) H. Rob., Brazil: BA, Piatã, Ganev 994 (SPF); GO, Pirenópolis, Loeuille et al. 297 (SPF). Vernonanthura lucida (Less.) H. Rob., Brazil: MG, Santana do Riacho, Loeuille et al. 135 (SPF); ibidem, Roque CFSC 13004 (SPF). Vernonanthura mariana (Mart. ex Baker) H. Rob., Brazil: MG, Diamantina, Loeuille et al. 95 (SPF); Jequitinhonha, Souza et al. 5622 (SPF). Vernonia echioides Less., Brazil: RS, Canoas, Miguel 14329 (SPF); SC, Urupema, Loeuille et al. 371 (SPF). Vernonia fasciculata Michx., USA: Colorado, Yuma Co., Weber 12965 (US); Iowa, Warren Co., Van Bruggen 3738 (US). Vernonia noveboracensis (L.) Willd., USA: South Carolina, Georgetown, Godfrey and Tryon 1702 (US); Virginia, Shenandoah Co., Fosberg 34918 (US). Vinicia tomentosa Dematt., Brazil: MG, Joaquim Felício, Souza et al. 25483 (ESA). Xerxes ekmanianum (Philipson) J.R. Grant, Brazil: GO, Alto Paraíso, Cavalcanti et al. 1338 (CEN); ibidem, Hatschbach et al. 36328 (MBM). 



\section{CHAPTER 4}

Taxonomic studies in Lychnophorinae (Asteraceae: Vernonieae) 



\section{PART 4.1}

Taxonomic novelties in Eremanthus (Compositae: Vernonieae) from Brazil 

Taxonomic novelties in Eremanthus (Compositae: Vernonieae) from Brazil

Benoît Loeuille ${ }^{1}$, Jenifer C. Lopes ${ }^{1}$, and José R. Pirani ${ }^{1}$

${ }^{1}$ Laboratório de Sistemática Vegetal, Departamento de Botânica, Instituto de Biociências da Universidade de São Paulo, Rua do Matão, 277, CEP: 05508-090, São Paulo, SP, Brasil.

Accepted for publication in KEW BULLETIN (14/01/2011) 
Summary. The description and illustration of a new species of Eremanthus (Asteraceae: Vernonieae), E. brevifolius, endemic to Minas Gerais State, is presented and its affinities assessed. Eremanthus graciellae and E. pohlii are newly synonymised under E. capitatus, and E. seidelii under E. elaeagnus.

Key Words. Asteraceae, Taxonomy, Vanillosmopsis. 


\section{Introduction}

Eremanthus Less. is a member of the Vernonieae subtribe Lychnophorinae Benth. Its species are almost all endemic to cerrado of the arid Central Plateau of Brazil. They are characteristically small trees or shrubs with compound cymes of capitula arranged in glomerules or sometimes synflorescences, the capitula are few-flowered and the cypselae possess persistent, deciduous or caducous pappus setae in 2-5 intergrading series.

Generic limits between Eremanthus, Lychnophora Mart., and Paralychnophora MacLeish are highly problematic (see Hind 2000 for a recent review). Molecular and morphological phylogenies of the subtribe and of Eremanthus are underway by the first author and should help to resolve this problem. The narrower concept of Eremanthus, i.e. including Vanillosmopsis Sch. Bip. but not Paralychnophora (MacLeish 1987, Hind 2000), is here followed (for a different point of view, see Robinson 1997, 1999, 2006). The last review of Eremanthus by MacLeish (1987) included 18 species and only one species has since been described by Robinson (1995) that fits the narrower concept ( $E$. hatschbachii H. Rob.). Additionally, preliminary data from the molecular phylogeny has indicated that Vernonia veadeiroensis (H. Rob.) MacLeish (MacLeish 1984a) is better placed into Eremanthus as originally described (Robinson 1980), giving a current total of 20 species in the genus.

The present study provides preliminary results of an ongoing taxonomic review of Eremanthus and intensive fieldwork in the Brazilian cerrado between 2006 and 2010. A new species is described and new synonyms, two for Eremanthus capitatus and one for Eremanthus elaeagnus, are provided as a result of this investigation.

\section{Recircumscription of Eremanthus capitatus, with two new synonyms}

Eremanthus capitatus (Spreng.) MacLeish, E. graciellae MacLeish \& H. Schumach. and E. pohlii (Baker) MacLeish belong to the subgenus Vanillosmopsis (Sch.Bip.) MacLeish, distinguished by its cylindrical glabrate cypselae and its caducous filiform pappus (MacLeish 1987). Two groups have been recognised in this subgenus (Schultz-Bipontinus 1863, MacLeish 1987): section Nectaridium (Sch.Bip.) MacLeish characterized by 'Heads cylindric, solitary or in pairs, slightly appressed basally. Pappus never twisted' (MacLeish 1987: 281), containing E. brasiliensis (Gardner) MacLeish, E. graciellae and E. pohlii, while section Vanillosmopsis (Sch. Bip.) MacLeish has 'Heads cylindric or obconic. Heads per glomerule (2-)5-12. Pappus often twisted' (MacLeish 1987: 283), comprising E. arboreus (Gardner) MacLeish, E. capitatus, E. erythropappus (DC.) MacLeish, E. polycephalus (DC.) MacLeish and E. uniflorus MacLeish $\&$ H. Schumach. Alternatively, Baker (1873) defined three informal groups within Eremanthus, based on the degree of fusion of the capitula and the nature of its attachment. To separate $E$. graciellae from E. pohlii, MacLeish (1987: 281) used the number of florets per capitula (two vs. three) and leaf length $(4.5-6.5 \mathrm{~cm}$ vs. $6.5-7.5 \mathrm{~cm})$.

Though Schultz-Bipontinus (1861) considered Polypappus discolor DC. to be conspecific 
with Vanillosmopsis capitata (Spreng.) Sch.Bip. (=E. capitatus), Baker (1873) excluded it from synonymy and provided the new combination $V$. discolor (DC.) Baker. Baker distinguished this latter species from E. capitatus by its appressed capitula or frequently distinctly pedunculate capitula (vs. appressed capitula that are never pedunculate), with the base of the capitula never connate (vs. slightly connate) and always with three florets (vs. two - three). Interestingly, Baker placed this species in the same group as V. pohlii Baker (=E. pohlii), differentiating from $V$. discolor by the involucre shape (turbinate vs. cylindric-turbinate) and the indumentum of the outer phyllaries (densely vs. scarcely hoary). MacLeish (1987) did not share Baker's concept of $E$. capitatus, considered $V$. discolor a synonym and disagreed on the number of florets per capitulum (two - three vs. three - four in Baker's description of $V$. capitata). She commented on this synonymy in her thesis by saying 'in addition, specimens which exhibit smaller and more obovate leaves are frequently identified as 'discolor', a distinction which is not considered to be specifically unique in the present study' (MacLeish 1984b: 144 -145). In the herbaria of Brazil, most collections of $V$. discolor have been identified using Baker's key that does not consider leaf shape. Accepting this synonymy, the close relationship between E. pohlii and E. capitatus is therefore obvious.

In addition to morphological characters, MacLeish \& Schumacher (1984) took the geographic distribution of these species into account to distinguish them. Eremanthus capitatus is restricted to the northeastern arm of the Central Plateau (the states of Bahia, northeastern Minas Gerais and Sergipe), E. graciellae to the Serra Geral de Goiás (Bahia and Goiás) and E. pohlii to the Chapada dos Veadeiros (Goiás) and northwestern Minas Gerais (Map 1.). However, the distributions of Eremanthus graciellae and E. pohlii are separated geographically only by the very narrow basin of the Rio Paranã (Vão do Paranã region) in extreme northeastern Goiás, and some populations of E. pohlii cited by MacLeish (1987: 281) from northeastern Minas Gerais (Heringer 11531) are separated from populations of Chapada dos Veadeiros (Goiás) by the same basin and several minor basins of Rio São Francisco's tributaries. Thus, populations of both species cannot be considered geographically isolated from each other. By contrast, the large basin of the Rio São Francisco in western Bahia apparently separates populations of $E$. capitatus from the two others. This geographic distribution pattern might be explained by habitat preference: the three species occur in cerrado and/or campos rupestres at high elevations (above ca. $800 \mathrm{~m}$ ) except for some populations of E. capitatus found in restinga (Atlantic coastal strand vegetation on sandy soils at low altitude). Since low altitude cerrado occupies the basin of the Rio São Francisco, these Eremanthus species do not occur there. This gap in the distribution found in other plant species, for example Gaylussacia brasiliensis (Spreng.) Meisn. is reported from campos rupestres in mountain ranges of Goiás, the Distrito Federal, and the Espinhaço mountain range (Bahia, Minas Gerais), campos de altitude of the Serra do Mar (Paraná and São Paulo) and restinga, with no documented presence in the Rio São Francisco basin (Alves et al. 2007, Rizzini 1997).

In the last two decades, a tremendous collecting effort in the distribution range of these species 
(especially in Chapada Diamantina) has made available a large number of specimens. Analysis of this material has revealed that the twisted pappus is highly variable even at specific level and useless for taxonomic purposes. Table 1 shows the main characters that have been used to separate the three species. The other two characters used at subgeneric level (involucre shape and number of capitula per glomerule), overlap (Map 1). The number of florets per capitulum has been used to distinguish these three species: E. graciellae has two florets per capitulum, E. pohlii three and E. capitatus three to four (MacLeish 1987). However, a careful analysis of specimens indicates that this character also varies (Table 1); most capitula on the holotype of $E$. graciellae have two florets but there some have three. None of the remaining minor characters cited in Table 1 could satisfactorily be employed for taxonomic purpose in this species group. Our conclusion, therefore, is that there are no consistent morphological characters that separate the three species, despite the disjunct distribution pattern, and thus, E. graciellae and E. pohlii are synonymized under E. capitatus, as follows:

Eremanthus capitatus (Spreng.) MacLeish (1987: 285). Type: Brazil, Bahia: inter Victoria et Bahia (now Salvador), Sellow s.n. (lectotype K [scan seen], selected by MacLeish, 1987: 285; isolectotype GH!).

Conyza capitata Spreng. (1826: 507).

Vernonia capitata (Spreng.) Less. (1829: 270).

Albertinia capitata (Spreng.) DC. (1836: 82).

Polypappus discolor DC. (1838: 281). Type: Brazil, Bahia: 'in montibus Jacobinae propè Bahiam', Blanchet 2591 (holotype G; isotypes BM, BR, C (photo of C: F), G, GH!, K [scan seen], MO, NY![×3], P!, US!).

Vanillosmopsis capitata (Spreng.) Sch.Bip. (1861: 167).

Vanillosmopsis albertinioides Sch.Bip. (1861: 168). Type: Brazil, Sellow s.n. (holotype B †).

Vanillosmopsis discolor (DC.) Baker (1873: 17).

Vanillosmopsis pohlii Baker (1873: 18). Type: Brazil, 'in Brasilia centrali, loco speciali non addicto' [Foz do Viera], Pohl 556 (holotype K [scan seen]; isotypes B†, F, GH! [fragment], NY!, W, photo of B: GH, F, US!), syn. nov.

Eremanthus graciellae MacLeish \& H.Schumach. (1984: 87). Type: Brazil, Bahia: BR 020 Brasília richtung Barreiras, $15 \mathrm{~km}$ weiter in richtung Barreiras von Fazenda Prainha, km 374, Schumacher 1048 (holotype RB!; isotypes GA!, K [scan seen], M, MB), syn. nov. Eremanthus pohlii (Baker) MacLeish (1987: 281). Type: as for V. pohlii, syn. nov.

SELECTED COLLECTIONS EXAMINED. BRAZIL. Bahia State: Mun. de Abaíra, Catolés Distr., Campo do Bicota, 13²0’22”S, 4150’01”S, 1491 m, 19 Sept. 2007, fl. fr., Loeuille et al. 345 (HUEFS, K, SPF); Mun. de Barreiras, Brasília richtung Barreiras, bei Km 323, kurz nach grenze GO/BA auf der hochebene, 5 July 1983, fl. fr., Schumacher 3048 (MB,UEC); Mun. de Canavieiras, rodovia BR 101 - Canavieiras, a $33 \mathrm{~km}$ da BR 101, 23 Oct. 1980, fr., 
MacLeish \& Soares Nunes 758 (GH, NY, RB, US); Mun. de Conde, Fazendo do Bu, 1200'54'S, 3741'16”W, 11 Nov. 1996, fr., Ferreira \& Jost 1056 (HRB); Mun. de Correntina, Fazenda Jatobá, grameal, parcela 41, $13^{\circ} 00^{\prime} \mathrm{S}, 46^{\circ} 45^{\prime} \mathrm{W}, 19$ July 1992, fl. fr., Aparecida da Silva et al. 1527 (UB); Velha da Galinha, trecho entre o aeroporto e a entrada para o bar Estrela Galdina, 24 Aug. 1995, fr., Mendonça et al. 2329 (IBGE, US); Mun. de Morro do Chapéu, estrada Morro do Chapéu - Utinga, Km 6, 1206’S, 41ํ04'S, 1100 m, 22 Sept. 1992, fl. fr., Coradin et al. 8694 (CEN, SPF); Mun. de Rio de Contas, $5 \mathrm{~km}$ da cidade na estrada para Livramento do Brumado, $13^{\circ} 37^{\prime}$ 'S, 41 ${ }^{\circ} 49^{\prime}$ W, 600 - 800 m, 25 Oct. 1988, fl., Harley et al. 25396 (ALCB, HUEFS, K, SPF); Mun. de Rio de Pires, capão da Mata de Zé do Amabica (Marques), caminho Outeiro-Marques, 1346'S, 42²2'W, 1200 m, 5 Aug. 1993, fl. fr., Ganev 2009 (ALCB, HUEFS, K, SPF, US); Mun. de Salvador, Parque Metropolitano de Pituaçu, 04 Sept. 2001, fl. fr., Teles \& Faustino 35 (HRB, SPF); Mun. de Santa Luzia, rodovia BA 270 que liga Santa Luzia, Canavieiras e Uma, Km 15, 15³0’05’'S, 39¹3’32”S, 7 Oct. 2000, fl. fr., Mattos Silva et al. 4274 (ALCB, HUEFS, NY, SPF); Goiás State: Mun. de Alto Paraíso: Chapada dos Veadeiros, 5 - 10 km north of Veadeiros, valley of Rio Paranã, 19 July 1964, fl. fr., Prance \& Silva 58251 (NY, UB, US); Brasília richtung Campos Belos, 15 km nach Alto Paraíso, 28 Aug. 1981, fr., Schumacher 1032 (MB, UEC); estrada GO 118 para Cavalcante, 15 km depois de Alto Paraíso, 20 July 2007, fl. fr., Loeuille et al. 287 (K, MBM, SPF, UFG, UB, US); id., fl. fr., Loeuille et al. 288 (K, SPF, UFG); Minas Gerais State: Mun. de Águas Vermelhas, BR 116, a 4 km da fronteira MG/BA, 975 m, 17 Sept. 1998, fl. fr., Bautista \& Ortiz 2656 (HRB); Mun. de Burutizeiro, rodovia BR 365, próximo do trevo para Vereda da Onça, 2 July 2003, fr., Hatschbach et al. 75998 (MBM, US); Mun. de João Pinheiro, 15 Aug. 1967, fr., Heringer 11531 (NY, RB, UB); rodovia BR 040, 24 June 1983, fl. fr., Hatschbach \& Kummrow 46632 (MBM, US); Mun. de Pedra Azul, ligação rodovia BR 116 Divisopolis, 13 Sept. 1984, fl. fr., Hatschbach 48178 (MBM, NY, SPF, US); Mun. de São Gonçalo do Abaeté, 16 July 1998, fl. fr., Hatschbach et al. 67936 (BHCB, MBM, US); Mun. de Teófilo Otoni, BR 116, Teófilo Otoni richtung Bahia, 65 km nach Teófilo Otoni, 6 Sept. 1981, fl. fr., Schumacher 1080 (MB, UEC, US); Pernambuco State: Mun. de Buíque, Serra de Catimbal, 19 Oct. 1995, fl. fr., Félix et al. 7457 (IPA); Sergipe State: Mun. de Japaratuba, a margem da rodovia, 2 Oct. 1974, fr., Vandely 106 (RB). [246 collections studied.]

\section{An expanded synonymy for Eremanthus elaeagnus}

Eremanthus elaeagnus (Mart. ex DC.) Sch.Bip. and E. seidelii MacLeish \& H.Schumach. belong to the subgenus Pseuderemanthus Sch.Bip., characterized by its hemispherical glomerule, capitula slightly appressed and free, with $3-4$ florets per capitulum, setuliferous cylindric cypselas and persistent subpaleaceous pappus setae (MacLeish 1987). MacLeish \& Schumacher (1984) set apart E. seidelii from E. elaeagnus using differences in the number of capitula per glomerule, leaf shape, pappus colour, flowering period as well as a disjunct distribution pattern (see map in MacLeish 1987: 278).

Field work undertaken in the Espinhaço mountain range during the last two decades by 
personnel from IBUSP (Instituto de Biociências de Universidade de São Paulo) and in Serra da Canastra by Jimi Nakajima (Nakajima 2000, Nakajima \& Semir 2001) has provided nearly one hundred collections of E. elaeagnus and E. seidelii. Attempts to identify these collections brought to light the necessity to re-evaluate the characters used to distinguish both species.

The main character used by MacLeish (in the identification key, MacLeish 1987: 270) to differentiate both species was the number of capitula per glomerule: $1-7$ vs. $9-20$, for $E$. seidelii and E. elaeagnus respectively. Nakajima (2000) obtained similar values 3 - 7 vs. 10 20 for plants from Serra da Canastra. In the present study, we have found different values: 3 11 vs. 4 - 11 for the putative species; interestingly, Baker (1873: 165) obtained a similar value for E. elaeagnus: 3 - 9. These discrepancies are probably related to different concepts of the glomerule: here, we follow Hind (2009): 'strictly an indeterminate dense cluster of sessile or subsessile flowers, but in the Compositae it refers to a condensed fascicle of capitula, typically on the terminal branches of an inflorescence'. However we recognise only sessile capitula, because 'subsessile' is a subjective notion that confuses limits between glomerules. In any case, ours results clearly show that there are no differences in the number of capitula per glomerule between the both species.

MacLeish \& Schumacher (1984) also distinguished both species by the leaf shape: elliptic for E. elaeagnus and narrowly elliptic for E. seidelii. This character is highly inconsistent because most specimens exhibit narrow elliptic and elliptic leaves on the same shoot. The same authors affirmed that the pappus of E. elaeagnus is mostly purple, whilst straw-coloured in E. seidelii. This is the only mention in the literature of a purple pappus in E. elaeagnus: all specimens examined in this study (including the holotype) display a stramineous pappus. Candolle (1836: 81) described it as 'rufescens', Schultz-Bipontinus (1863: 395) as "brunneus" and Baker (1873: 165) as 'rufescens'. Phenological data do not set apart the species either: E. elaeagnus blooms between May and September and E. seidelii between May and July. The last criterion used by the authors is not stated in the text but is obvious on the map provided in the generic revision (MacLeish 1987: 278), which restricts E. seidelii to the Serra da Canastra and Furnas reservoir in southwestern Minas Gerais and E. elaeagnus to the Espinhaço mountain range. Nevertheless, extensive fieldwork carried out by Jimi Nakajima in the Serra da Canastra revealed the presence of E. elaeagnus (Nakajima 2000, Nakajima \& Semir 2001) (Map 2).

In summary, morphological, phenological and geographical data clearly indicate that $E$. seidelii should be treated as a synonym of E. elaeagnus. The revised synonymy is as follows:

Eremanthus elaeagnus (Mart. ex. DC.) Sch.Bip. (1863: 395). Type: Brazil, Minas Gerais, altis lapidosis Serro Frio prope Tejuco (now Diamantina), Martius s.n. (holotype M [scan seen]). Albertinia elaeagnus Mart. ex DC. (1836: 81). Type: as above.

Vernonia elaeagnus (Mart. ex DC.) Sch.Bip. (1861: 166).

Eremanthus seidelii MacLeish \& H. Schumach. (1984: 89). Type: Brazil, Minas Gerais: Furnas richtung Piuí, kurz von Staumauer, Schumacher 1006 (holotype RB!; isotypes GA!, K[scan 
seen], M, MB, US!), syn. nov.

SELECTED COLLECTIONS EXAMINED. BRAZIL. Minas Gerais state: Mun. de Capitolió, Represa de Furnas, 2 July 1987, fl. fr., Vichnewski \& Lopes s.n. (UEC); estrada depois do Paraíso Perdido, 25 Oct. 2006, fr., Loeuille et al. 41 (HUFU, SPF); Mun. de Diamantina, 20

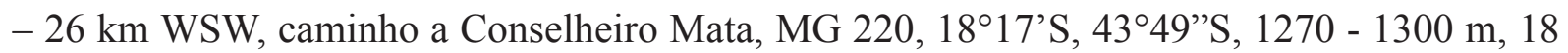
May 1990, fl. fr., Arbo et al. 4385 (CTES, SI, SPF); estrada para Mendanha, Km 571.5, 14 July 1996, fl. fr., Roque et al. 206 (NY, SPF); Mun. de Formiga, Formiga richtung Passos, bei Km 288, 4 June 1983, fl. fr., Schumacher 3027 (MB, UEC); Mun. de Furnas, Represa de Furnas, área em torno das eclusas da represa, 1 July 1994, fr., Lombardi 556 (BHCB, UEC); Mun. de Grão Mogol, Córrego Escurona, 16³5'S, 4258'S, 750 m, 16 July 1990, fl. fr., Simão Bianchini et al. CFCR 13174 (K, SPF, UEC); Mun. de Joaquim Felício, Serra do Cabral, subida, 5 June 2004, fl. fr., Hatschbach et al. 77414 (MBM, US); estrada Joaquim Felício - Várzea da Palma, 1743'38'S, 44¹1'02”'S, 950 m, 3 June 2008, fl. fr., Loeville et al. 430 (HAW, K, SPF); Mun. de Patrocínio, Fazendas DATERRA, Boa Vista, 14 July 1998, fr., Farah \& Freitas 372 (ESA); Mun. de Sacramento, 16 km da divisa MG/SP, 7 km do ribeirão Canabrava, em direção a Araxá, 6 July 1996, fl. fr., Souza et al. 12060 (ESA, HUFU, K); Mun. de São Roque de Minas, Parque Nacional da Serra da Canastra, próximo à portaria de Sacramento, 19 Aug. 1983, fr., Ramalho \& Mota 2601 (HUFU); cachoeira da Casca d'Anta, 12 May 1995, fl. fr., Nakajima et al. 1057 (HUFU, SPF); próximo ao Centro de Visitantes, 15 May 2007, fl. fr., Loeuille et al. 258 (K, SPF, US); São Paulo state: Mun. de Estreito, perto da Fazenda 3 Irmãos, 12 July 1995, fr., Marcondes Ferreira et al. 1215 (SPF, UEC). [126 collections studied.]

\section{A new species of Eremanthus}

Eremanthus brevifolius Loeuille sp. nov. affinis E. hatschbachii foliis parvis et pappo biseriali sine serie exteriore reducto sed foliis anguste oblongis ad elliptica, raro oblanceolatis vel lanceolatis (non ovatis), supra dense nigra glanduloso-punctata et tomentosa (non glabra), floribus $4-7$ (non 2 - 3) differt. Typus: Brazil, Minas Gerais: Mun. de Congonhas do Norte: Serra Talhada, Fazenda Imbaúbas, 20 Jan. 2007, Loeuille et al. 71 (holotypus: SPF!; isotypi K!, US!).

Treelet to $1 \mathrm{~m}$; bark \pm fissured longitudinally. Stems well-branched in upper part, leafy at first becoming leafless, greyish tomentose with triangular leaf-scars following leaf falls. Leaves alternate, simple, petiole $25-45 \mathrm{~mm}$ long, blade narrowly oblong to elliptic, rarely oblanceolate or lanceolate, $2-2.5 \times 0.6-0.8 \mathrm{~cm}$, venation brochidodromous to weakly eucamptodromous in upper part, midrib furrowed, adaxially densely black glandular dotted, grey tomentose, abaxially dirty white yellowish, densely tomentose, tomentum of simple, uniseriate hairs, margins entire, usually flat to slightly revolute on lower part, apex obtuse to acute, base decurrent to cuneate. Glomerulescence a cyme of 2-4 glomerules. Capitula homogamous, discoid, sessile, $5-10$ per glomerule, interspersed with leaf-like bracts, slightly appressed at base and free; involucre $4-$ 
5-seriate, imbricate, cylindrical to slightly urceolate, rarely obconical; outer phyllaries ovate to lanceolate, $2.5-3.6 \times 0.75-1.1 \mathrm{~mm}$, margins scarious, apex obtuse to slightly acute, lanate to tomentose, purple apex, inner phyllaries linear to lanceolate, $4.8-6.5 \times 1-1.4 \mathrm{~mm}$, margins subscarious, apex obtuse to slightly acute, tomentulose to glabrescente, apex purple; receptacle flat, foveolate with some isolated fimbriae to c. $0.15 \mathrm{~mm}$. Florets $4-7$ per capitulum, bisexual, fertile; corollas actinomorphic, deeply 5-lobed, lilac becoming whitish, corolla tube $2.8-4.9$ $\times 0.5-0.8 \mathrm{~mm}$, glabrous, corolla lobes $2.5-3.2 \times 0.5-0.6 \mathrm{~mm}$, glandular-punctate at base of lobes, apex acute; apical anther appendages narrowly trullate, acute, anther base sagittate, acute; style shaft $4.3-7.6 \mathrm{~mm}$ long, lilac to pale pink, glabrous throughout except for pubescent upper $0.9-1.1 \mathrm{~mm}$ beneath style-arms, style-arms $2.6-2.8 \mathrm{~mm}$ long, apex acute, pubescent outside, hairs acute, style-base glabrous, lacking basal node. Cypsela turbinate, $0.8-1.5 \times 0.4-0.8 \mathrm{~mm}$, strongly 10-ribbed, glabrous, densely glandular-punctate; carpopodium minute; pappus setae biseriate, equal length, stramineous, persistent or deciduous, $5-6 \times 0.1-0.2 \mathrm{~mm}, \pm$ barbellate, twisted throughout length or limited to proximal half (Fig. 1).

DISTRIBUTION. South America: Endemic to Minas Gerais State, Brazil (Map 2).

MATERIAL EXAMINED. BRAZIL. Minas Gerais State: Mun. de Congonhas do Norte, Serra Talhada (setor nordeste da Serra do Cipó), $9 \mathrm{~km} \mathrm{~S}$ de Congonhas do Norte na estrada para Conceição do Mato Dentro, entrada para Extrema seguindo 11 km - Fazenda Imbaúbas (propriedade do Sr. Helvécio Lacerda de Queiroz), 1855'48’S, 4340’17’'W, 1130 m, 20 Jan. 2007, Loeuille et al. 71 (holotype SPF, isotypes K, US).

HABITAT. In campos rupestres, among rocks.

CONSERVATION ASSESSMENT. According to available information about Eremanthus brevifolius, it can be scored using IUCN conservation criteria (IUCN 2001) as Vulnerable (VU), since its area of occupancy is very restricted VU (criteria D2). The single locality known is outside of a protection area and thus, prone to the effects of human activities.

NOTE. Preliminar data from the molecular phylogeny has conflicted with the infrageneric classification proposed by MacLeish (1987), thus Eremanthus brevifolius is not being assigned to any infrageneric categories at this moment. It is related to E. hatschbachii H. Rob., by the small size of its leaves and a biseriate pappus without an outer reduced series, but this new species differs by the leaf shape (narrowly oblong to elliptic, rarely oblanceolate or lanceolate vs. ovate), the indument of adaxial face (densely black glandular dotted, tomentose vs. glabrous) and the number of florets (4-7 vs. $2-3$ ). Eremanthus brevifolius is also similar superficially to E. elaeagnus in habit, indumentum of abaxial leaves and capitula sessile slightly appressed and free, but differs in leaf size $(2-2.5 \times 0.6-0.8 \mathrm{~cm}$ vs. $5-12 \times 1.5-3 \mathrm{~cm})$, the indumentum of the adaxial surface (densely black glandular dotted, tomentose vs. sparsely lepidote), the number of florets per capitulum (4-7 vs. $3-4)$ and the number of series of pappus setae (2 vs. $3-5)$.

In terms of distribution, E. hatschbachii is presently known only from Serra do Cabeludo (Mun. Mucugê) in the state of Bahia, and E. elaeagnus is a common species in Minas Gerais 
especially in the Espinhaço moutain range as well as in Serra da Canastra, while E. brevifolius is currently known only from the type collection in Serra Talhada, a northeastern extension of Serra do Cipó, the region is well known to have many endemics in the Compositae. Two other species of Eremanthus (E. elaeagnus and E. erythropappus) have been recorded, at the moment, in Serra Talhada. Eremanthus brevifolius is probably a microendemic to this region, a distribution pattern common in the Lychnophorinae. The type locality has been very poorly collected until now which probably explains why we have found only a single collection even after visiting most of the brazilian herbaria. Even if it might be considered challenging to describe a new species based on a single collection, such characteristics as the number of series of pappus setae and of florets per capitulum clearly prevent us to consider it as conspecific with E. elaeagnus.

\section{Acknowledgements}

The drawings were prepared by Leonardo M. Borges of the Departamento de Botânica, Instituto de Biociências, Universidade de São Paulo. The authors would like to thank the curators of all the herbaria listed in the text for loaning the specimens as well as Nicholas Hind and John Pruski for valuable suggestions on the paper

\section{References}

Alves, R. J. V., Cardin, L. \& Kropf, M. S. (2007). Angiosperm disjunction "Campos rupestres - restingas": a re-evaluation. Acta Bot. Bras. 21: 675-685.

Baker, J. G. (1873). Compositae I. Vernoniaceae. In C. F. P. von Martius $\uparrow \&$ A. W. Eichler (eds) Flora Brasiliensis 6(2): 5 - 180. Fried. Fleischer, Münich, Vienna, Leipzig.

Candolle, A. P. de (1836). Vernoniaceae. Prodromus Systematis Naturalis Regni Vegetabilis, ... v. 5, p $9-103$. Treutel et Würtz, Paris.

Candolle, A. P. de (1838). Mantissa Compositarum. pp. 263 - 287 [Trib. III. Asteroideae: 271 287]. Prodromus Systematis Naturalis Regni Vegetabilis, ... vol. 7,. Treutel et Würtz, Paris.

Hind, D. J. N. (2000). Two new species of Paralychnophora (Compositae: Vernonieae) from Bahia. Kew Bull. 55: 367 - 379.

Hind, D. J. N. (2009). Glossary. In An annoted preliminary checklist of the Compositae of Bolivia. Published on the internet http://www.kew.org/science/tropamerica/boliviacompositae/ index.html [accessed August 2009].

IUCN (2001). IUCN Red List Categories: version 3.1. Prepared by the IUCN Species Survival Commission. IUCN, Gland, Switzerland and Cambridge, U.K. http://www.iucnredlist.org/ technical-documents/categories-and-criteria/2001-categories-criteria

Lessing, C. F. (1829). De synantheris herbarii regii berolinensis dissertatio prima. Vernonieae. Linnaea 4: 240 - 356.

MacLeish, N. F. F. (1984a). Eight new combinations in Vernonia (Compositae: Vernonieae). Syst. Bot. 9: 133 - 136. 
MacLeish, N. F. F. (1984b). Revision of Eremanthus Less. (Compositae: Vernonieae). PhD thesis, unpublished. University of Georgia.

MacLeish, N. F. F. (1987). Revision of Eremanthus (Compositae: Vernonieae). Ann. Missouri Bot. Gard. 74: $265-290$.

MacLeish, N. F. F. \& Schumacher, H. (1984). Six new species of Eremanthus (Vernonieae: Compositae) from Brazil. Syst. Bot. 9: 85 - 95.

Nakajima, J. N. (2000). A família Asteraceae no Parque Nacional da Serra da Canastra, MG. $\mathrm{PhD}$ thesis, unpublished. Universidade Estadual de Campinas.

Nakajima, J. N. \& Semir, J. (2001). Asteraceae do Parque Nacional da Serra da Canastra, Minas Gerais, Brasil. Revista Brasil. Bot. 24: 471 - 478.

Rizzini, C. T. (1997). Tratado de Fitogeografia do Brasil. 2 ed. Rio de Janeiro, Âmbito Cultural Edições, Ltd.

Robinson, H. (1980). Notes on the Lychnophorine genera Chresta and Eremanthus (Vernonieae: Asteraceae). Phytologia 45: 89 - 100.

Robinson, H. (1995). New combinations and new species in American Vernonieae (Asteraceae). Phytologia 78: 384 - 399.

Robinson, H. (1997). The Paralychnophora group of Eremanthus (Vernonieae: Asteraceae). Rhodora 98(no. 893): 85 - 93.

Robinson, H. (1999). Generic and subtribal classification of American Vernonieae. Smithsonian Contr. Bot. 89: 1 - 116.

Robinson, H. (2006) [2007]. Vernonieae. In J. Kadereit \& C. Jeffrey (vol. eds) Vol. 8: Asterales. The families and genera of vascular plants (K. Kubitzki, series ed.): $149-174$. Springer. Berlin, Heidelberg, New York.

Schultz-Bipontinus, C. H. (1861). Cassiniaceae uniflorae, oder Verzeichniss der Cassiniaceen mit 1-blüthigen Köpfchen. Jahresber. Pollichia 18/19: 157 - 190.

Schultz-Bipontinus, C. H. (1863) [1864]. Lychnophora Martius! und einige benachbarte Gattungen. Jahresber. Pollichia 20/21: $321-439$.

Sprengel, C. (1826). Systema vegetabilium, ed. 16, pp. 1 - 936. Göttingae [Göttingen]. 


\begin{tabular}{|c|c|c|c|}
\hline \multirow{2}{*}{ Characters } & \multicolumn{3}{|c|}{ Putative species of Eremanthus } \\
\hline & capitatus & graciellae & pohlii \\
\hline Leaf length $(\mathrm{cm})$ & $3-7.7$ & $3-5(-7.1)$ & $4-8.3$ \\
\hline Leaf width $(\mathrm{cm})$ & $1.1-3.2$ & $1.3-2.4(-3.3)$ & $1.5-2.8$ \\
\hline Leaf form & $\begin{array}{c}\text { elliptic, rarely } \\
\text { oblong or ovate to } \\
\text { obovate }\end{array}$ & elliptic & $\begin{array}{l}\text { elliptic to ovate, } \\
\text { rarely oblong or } \\
\text { obovate }\end{array}$ \\
\hline Leaf base & \multicolumn{3}{|c|}{ cuneate rarely acute } \\
\hline Leaf apex & \multicolumn{3}{|c|}{ acute to obtuse, sometimes rounded } \\
\hline $\begin{array}{l}\text { Number of capitula } \\
\text { per glomerule }\end{array}$ & $(1-) 2-3(-7)$ & $(1-) 2-3(-4)$ & $(1-) 2-3(-7)$ \\
\hline $\begin{array}{l}\text { Involucre length } \\
(\mathrm{mm})\end{array}$ & $4-6.9$ & $4.4-6.5$ & $4.3-6.5(-8.3)$ \\
\hline $\begin{array}{l}\text { Involucre diam. } \\
(\mathrm{mm})\end{array}$ & $1.5-2.7$ & $1.5-2.4$ & $1.5-2.4$ \\
\hline $\begin{array}{l}\text { Number of florets per } \\
\text { capitulum }\end{array}$ & $2-4(-5)$ & $2-3$ & $2-3$ \\
\hline $\begin{array}{l}\text { Capitulum } \\
\text { attachment }\end{array}$ & \multicolumn{3}{|c|}{ distinctly petiolate or sessile } \\
\hline Capitulum fusion & \multicolumn{3}{|c|}{ capitula appressed or free } \\
\hline Involucre colour & \multicolumn{3}{|c|}{ light to dark brown } \\
\hline Involucre shape & \multicolumn{3}{|c|}{ turbinate to cylindric } \\
\hline Inner phyllary shape & $\begin{array}{l}\text { elliptic to ovate, } \\
\text { rarely oblong or } \\
\text { obovate }\end{array}$ & elliptic to ovate & $\begin{array}{l}\text { elliptic to ovate, } \\
\text { rarely oblong }\end{array}$ \\
\hline $\begin{array}{l}\text { Inner phyllary } \\
\text { indumentum }\end{array}$ & glabrescent or pilose & glabrescent & usually glabrescent \\
\hline $\begin{array}{l}\text { Inner phyllary apex } \\
\text { colour }\end{array}$ & \multicolumn{3}{|c|}{ purple to marrom } \\
\hline Outer phyllary shape & \multicolumn{3}{|c|}{ ovate to deltate } \\
\hline Pappus colour & $\begin{array}{l}\text { white, stramineous } \\
\text { or purple }\end{array}$ & $\begin{array}{l}\text { white, stramineous } \\
\text { rarely purple }\end{array}$ & $\begin{array}{l}\text { white, stramineous, } \\
\text { sometimes purple }\end{array}$ \\
\hline
\end{tabular}

Tab. 1. Morphological characters used to separate the putative species: Eremanthus capitatus, E. graciellae and E. pohlii. 


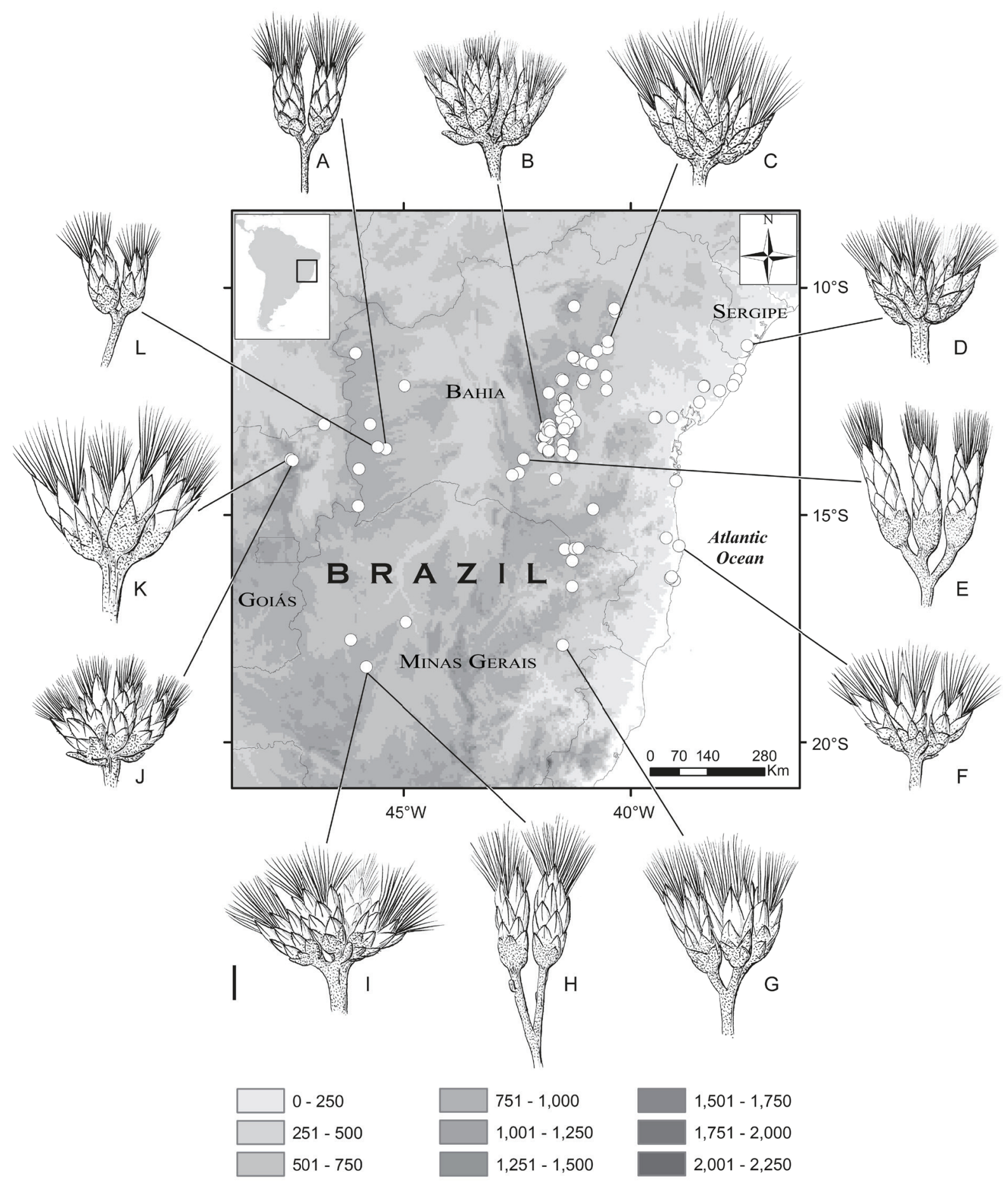

Map 1. Geographical distribution of Eremanthus capitatus, depicting variation of glomerules and involucres (A - Mendonça et al. 2329; B - Loeville et al. 345; C - Coradin et al. 8694; D - Vandely 106; E - Ganev 2009; F - Macleish \& Soares Nunes 758; G - Schumacher 1080; H \& I - Hatschbach et al. 67936; J - Loeuille et al. 287; K - Schumacher 1032; L - Aparecida da Silva 1527). 


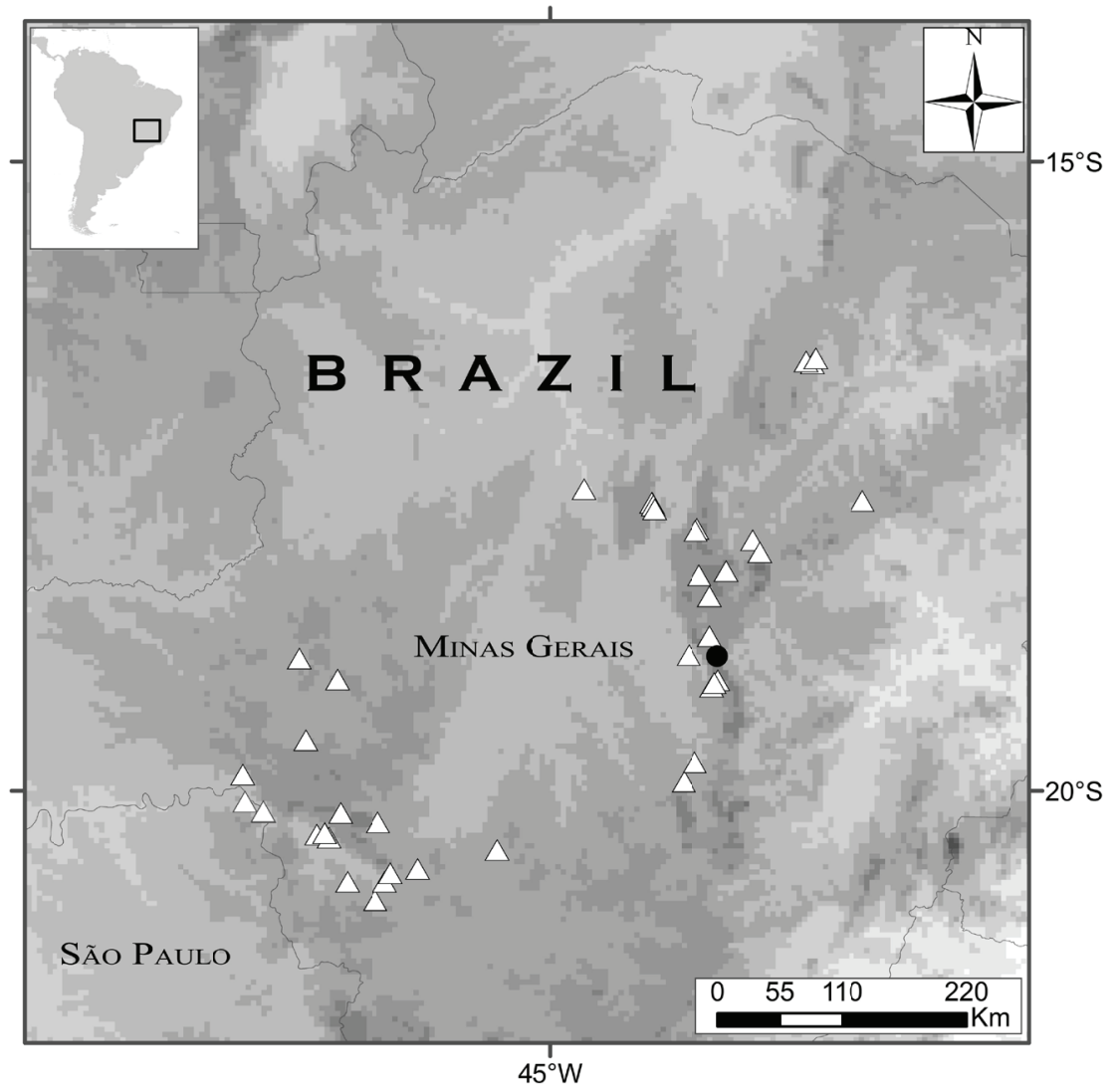

Altitude (m)

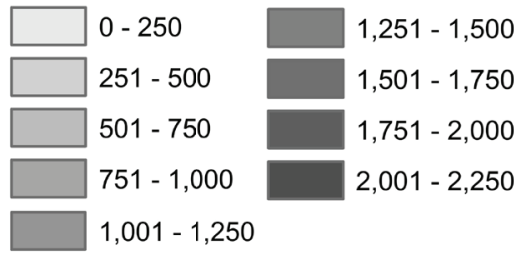

- Eremanthus brevifolius

$\triangle$ Eremanthus elaeagnus

Map 2. Geographical distribution of Eremanthus brevifolius and E. elaeagnus. 


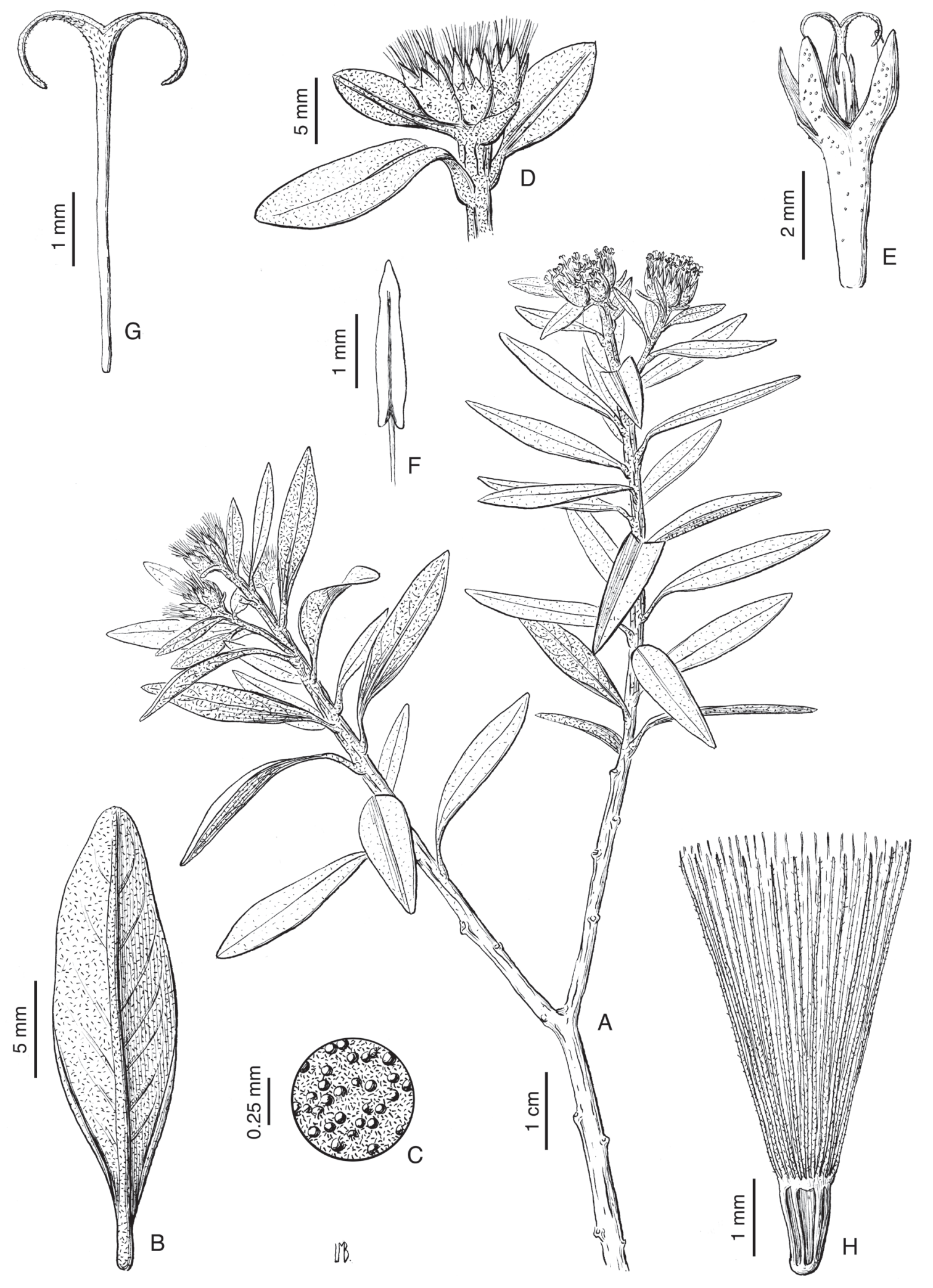

Fig. 1. Eremanthus brevifolius. A habit; B leaf, abaxial surface; C magnified abaxial surface of leaf; D glomerule; E corolla; F anther; G style; H cypsela and pappus. 



\section{PART 4.2}

Two New Species of Heterocoma (Asteraceae: Vernonieae) and a Broadened Concept of the Genus 

Two New Species of Heterocoma (Asteraceae: Vernonieae) and a Broadened Concept of the Genus

Benoît Loeuille ${ }^{1,5}$, Jimi Naoki Nakajima², Denise Maria Trombert Oliveira ${ }^{3}$, João Semir ${ }^{4}$, and José Rubens Pirani ${ }^{1}$

${ }^{1}$ Departamento de Botânica, Instituto de Biociências, Universidade de São Paulo, Rua do Matão 277, 05508-090, São Paulo, São Paulo, Brazil.

${ }^{2}$ Instituto de Biologia, Universidade Federal de Uberlândia, C.P. 593, 38400-902, Uberlândia, Minas Gerais, Brazil.

${ }^{3}$ Departamento de Botânica, ICB, Universidade Federal de Minas Gerais, Avenida Antônio Carlos, 6627, Pampulha, C.P. 486, 31270-901, Belo Horizonte, Minas Gerais, Brazil. ${ }^{4}$ Departamento de Botânica, Universidade Estadual de Campinas, C.P. 6109, 13083-970, Campinas, São Paulo, Brazil.

${ }^{5}$ Author for correspondence (benoit_loeuille@yahoo.fr) 

Abstract - A new concept of the genus Heterocoma is presented based on morphological and anatomical evidence. Preliminary results of a molecular phylogeny indicate its monophyly. The genus is characterized by the combination of foliose subinvolucral bracts, fimbrillate or paleaceous receptacle, glabrous cypsela and caducous biseriate pappus (at least the inner series). A putative synapormophy is the presence of phytomelanin in the cypselae walls. The monospecific genera Bishopalea, Sipolisia and Xerxes are synonymized under Heterocoma with the following new combinations: Heterocoma ekmaniana, Heterocoma erecta and Heterocoma lanuginosa. Two new species, Heterocoma gracilis and Heterocoma robinsoniana, are described and illustrated. The genus is endemic of the campos rupestres of the Brazilian Central Plateau A key to the six species here recognized in Heterocoma is provided.

Keywords - Compositae, Phytomelanin, Sipolisiinae, Taxonomy. 

The subtribe Sipolisiinae H. Rob. (Asteraceae: Vernonieae) is composed of five genera: Hololepis DC., Bishopalea H. Rob., Heterocoma DC., Sipolisia Glaz. ex Oliv. and Xerxes J. R. Grant, the latter four monotypic (Robinson 1999). They are coarse herbs (except for Hololepis, a small tree), with solitary or clustered heads, receptacle fimbriated or with paleae, walls of cypselae usually with phytomelanins and are nearly restricted to campos rupestres areas of the Brazilian Central Plateau (Robinson 1999; Robinson 2006; Keeley and Robinson 2009).

Robinson (1999) established the subtribe Sipolisiinae with the five genera. He considered that "aristiferous or paleaceous receptacles are the most significant and consistent characteristic of the subtribe" (Robinson 1999: 13) but he also noted that the presence of phytomelanin in the walls of cypselae relates Bishopalea, Heterocoma, Sipolisia and Xerxes J. R. Grant. The latter name had been proposed by Grant (1994) to replace Alcantara, considered a later homonym of Alcantarea (E. Morren \& Mez) Harms (Bromeliaceae).

The taxonomic history of the subtribe is relatively complex. Candolle (1810) described Heterocoma and Hololepis to accommodate three species previously placed in Serratula L.: Heterocoma albida (DC. ex Pers.) DC., H. bifrons (DC. ex Pers.) DC. and Hololepis pedunculata (DC. ex Pers.) DC., setting apart both genera by the structure of the pappus: a smaller outer series and a caducous inner one in Heterocoma and subequal persistent series in Hololepis. Erroneously, he considered these three species as having receptacle with entire pales, but later he corrected the mistake (Candolle 1836), since only $H$. albida has a paleate receptacle. Consequently he put Hololepis under synonymy with Vernonia Schreb. and established a new genus, Chronopappus DC., to shelter H. bifrons. Baker (1873), Bentham (1873) and Hoffmann (1890) followed Candolle's treatment without modification.

Oliver (1894) described and validated a new genus and species, Sipolisia lanuginosa Glaz. ex Oliver, based on a collection of Glaziou ( $\left.n^{\circ} 19470\right)$. Main characteristics of Sipolisia are the dense lanate indumentum and the heads clustered at the apex of axillary flowering branch. This latter feature lead Oliver (1.c.) to suggest a relationship with Proteopsis Mart. \& Zucc. ex Sch. Bip. or to some members of the subtribe Lychnophorinae. At that time Proteopsis contained two species: P. argentea Mart. \& Zucc. ex Sch.Bip. and P. sellowii Sch.Bip. and was defined mainly by its silverish adpressed indumentum and heads clustered at the apex of a flowering branch or scape.

Glaziou (1909) proposed a new genus with two new species: Alcantara isabellae Glaz. and A. petroana Glaz., respectively based on his own collections Glaziou 21668 and 21667. However, both names are considered nomen nudum in the absence of a description, diagnose or illustration according to ICBN Art. 32.1 (McNeill et al. 2006).

Philipson (1938) considered that Proteopsis and Sipolisia differed in no essential characters and proposed the new combination, P. lanuginosa (Glaz. ex Oliv.) Philipson. In the same work, two new species are described based on Glaziou's collections: P. insculpta Philipson (Glaziou 14974) and P. ekmaniana Philipson (Glaziou 21668). He was probably unaware that this latter collection had already been cited by Glaziou (1909) in the description of Alcantara isabellae. 
Barroso (1969) validated Alcantara Glaz. ex G. M. Barroso and the species A. petroana Glaz. ex G. M. Barroso (Glaziou 21667), without any comment on A. isabellae. While stating a close relationship of Alcantara to Heterocoma, she argued that the former differs from the latter by the foliose subinvolucral bracts, epaleacous receptacle and uniseriate pappus.

Robinson (1981) started to clarify the relationships between these genera and species. First, he re-established Sipolisia, arguing that: "Philipson overlooked the presence of long palealike projections from the receptacle of the former [Sipolisia]" (Robinson 1981: 213). Then he refined the concept of Proteopsis, transferring P. ekmaniana to Alcantara and synonymising A. petroana under A. ekmaniana. He considered Alcantara and Sipolisia closely related by the lanate pubescence, hairy tips on the corolla lobes and almost identical long palea-like projections from the receptacle. However, he pointed out that Alcantara was distinct by the leaves with broadened imbricated sheathing bases and long narrow petioles, the long pedunculate axillary inflorescences and the extremely large paired foliose bracts subtending the heads. Finally, $P$. sellowii was synonymised under Heterocoma albida (Robinson 1981) as well as P. insculpta in a later work (Robinson 1999). Proteopsis, therefore, became restricted to P. argentea and differing from the other genera by its involucral phyllaries with spreading spine (Robinson 1981; Robinson 1999).

Robinson (1981) also described a new genus and species, Bishopalea erecta H. Rob., characterized by the combination of a panicle inflorescence and a paleaceous receptacle. Later Robinson (1999) stated that Bishopalea and Heterocoma have a close relationship since they shared a paleacous receptacle and short corolla tube.

Hololepis hatschbachii H. Rob. was described differing from $H$. pedunculata by its narrower more flexuous peduncles, smaller heads and reddish pappus bristles (Robinson 1995). This is the only species of the group which occurs outside the Brazilian Central Plateau, in Espírito Santo State.

Recent treatments of the subtribe created some confusion about the number of recognized species of Hololepis and Xerxes, the former having two or three species and the latter two (Robinson 2007; Keeley and Robinson 2009). In fact, these authors hastily incorporated the results of an unpublished thesis (Nakajima 2000) in which new species of both genera are described. Actually there are two published species in Hololepis and only one in Xerxes.

Preliminar results of a phylogenetic study of the American Vernonieae based on molecular and morphological data (Loeuille et al., unpubl. data) have shown that the subtribe Sipolisiinae is paraphyletic as actually defined, but the exclusion of Hololepis would turn it monophyletic. A putative synapormorphy of the re-circumscribed Sipolisiinae is the presence of phytomelanin in the cypselae walls. In the present study, the characters traditionally used in classification of the Sipolisiinae have been scrutinized. In the light of the phylogenetic results (Loeuille et al., unpubl. data), and based on intensive field work carried out in the campo rupestre areas of Brazil, we re-evaluate the generic status of Bishopalea, Heterocoma, Sipolisia and Xerxes. This work proposes a new broadened concept of Heterocoma (incl. Bishopalea, Sipolisia and 
Xerxes), with six species, including three following combinations and two new species.

\section{Material And Methods}

The study was based on field collections made by the authors and on the examination of specimens from the following herbaria: BHCB, BHZB, CEN, G, G-DC, GH, HAW, HUFU, IBGE, JPB, K, MBM, MO, NY, P, R, RB, SPF, UB, UEC and US (acronyms following Thiers 2010). All cited specimens were seen by the authors, except otherwise indicated. The identifications were made by comparison with the original descriptions and with the type material or photographs of types. We follow Harris and Harris (2001) for the general morphological terminology,, Endress (2010) for inflorescence terms, and Hind (2009) for specific Compositae terminology.

Appendix 1 presents the specimens that have been examined in order to assess morphological differences between the genera of Sipolisiinae in greater detail.

Anatomical studies were performed on mature cypselae fixed in FAA 50 for 48 hours (Johansen 1940), dehydrated in an ethanol series and embedded in methacrylate (Leica $\square$ ) following the manufacturer's recommendations. Both transversal and longitudinal sections 8 $\mu \mathrm{m}$ thick were prepared using a rotary microtome, stained with $0.05 \%$ toluidine blue at $\mathrm{pH} 4.7$ (O’Brien et al. 1964), and subsequently mounted in synthetic resin.

\section{Results AND Discussion}

Scarcity of collections of the Sipolisiinae and lack of field data mislead the previous workers of the group to accurately apprehend the constancy or variability of the morphological characters they were using to distinguish different genera.

The failure to distinguish between paleae and fimbriae in the receptacle comes from the description of Heterocoma and Hololepis by Candolle (1810) as pointed out by Cassini (1820: 56; 1821: 309). Cassini (1818) differentiates squamelles with florets in their axils from fimbrilles, which are more numerous than the florets and surround them. The former are usually interpreted as rudimentary bracts (Stuessy and Spooner 1988; Hind 2009) and correspond to paleas in modern terminology, while the receptacle is treated as paleaceous (Small 1919). The fimbrilles (fimbriae) are considered receptacular projections (Cassini 1820; Bentham 1873) and the receptacle is then said fimbrillate (Small 1919). We follow the terminology given by Small (1919) which lies mainly on Cassini's description of the clinanthe (1818: 146-147) and Bentham (1873). Small (1919: 137) noted that "Cassini's analysis of the various forms assumed by the receptacle and its appendages is more precise than Bentham's but the terms given by the latter [...] are in more general use". Unfortunately Small used the term palea for these projections even without considering this kind of receptacle being paleacous. Therefore we prefer to use the term fimbria (pl. fimbriae) for the receptacular projections in order to avoid further confusion.

Bishopalea and Heterocoma have a receptacle with paleae, but the latter also presents fimbriae 
(Toledo 1941). Hololepis and Xerxes have a fimbrillate receptacle with one of the fimbriae well developed. Finally Sipolisia has a special kind of appendages on the receptacle: the ridges are flat-bottomed with articulated and deciduous setae on the top (see Fig. 2 in Oliver's (1894) description of $S$. lanuginosa).

Characters used to separate Xerxes from Heterocoma or Sipolisia are especially confusing. Barroso (1968) and Robinson $(1981,2007)$ assert that foliose subinvolucral bracts, characterized Xerxes, but such bracts are present in Sipolisia (between the heads within the cluster or surrounding the cluster), Heterocoma and Bishopalea. Even though Barroso (1968: 1) notes that Xerxes has an uniseriate pappus, a careful observation of the cypsela apex clearly shows two concentric rings of pappus setae scars. Robinson (1981: 213) states that Sipolisia is distinguished from Xerxes by its petiolate leaves and long pedunculate axillary inflorescences, and later adds that species of Xerxes are mostly acaulescent, while Sipolisia are large caulescent plants (Robinson 2007: 179). Our analysis of the collection of these two genera and field observations (for Xerxes) consistently show that the acaulescent aspect of some collections is due to the marcescent leaves (like in Bishopalea, Heterocoma and Sipolisia), which are usually lacking in herbaria specimens because collectors tend to cut below the green leaves. Xerxes ekmanianum is in fact an erect shrub or subshrub commonly reaching $2 \mathrm{~m}$, with some collection labels indicating $3.5 \mathrm{~m}$ tall. Furthermore, the leaves of Xerxes are clearly sessile with semi-amplexicaul sheath, very similar to Sipolisia ones. Both genera display heads clustered at the apex of flowering branch; Xerxes usually bear fewer heads than Sipolisia, but both genera may produce a solitary head.As previously noted, the habit of these plants have been poorly understood. Our field observations reveal that the four genera (except Hololepis) share o common architecural model, with a monopodial trunk which grows rhythmically, and so develops tiers of flowering branches, leaves are mainly restricted to the main axis and are marcescent; as pointed out by Semir (1991) this model is similar to the Rauh's model (Hallé et al. 1978).

Robinson (1981) discards a close relationship between Heterocoma and Bishopalea due to the panicle and the tomentose indumentum of Bishopalea (vs. solitary head and indumentum formed of appressed trichomes). He also highlights the uniqueness of the Bishopalea pubescence: "The pubescence on the upper surface of the leaves is also unique in its details, having the hairs diverge along the veins. The resulting appearance shows the polygonal areoles as though they were bullate, in spite of the fact that the upper leaf surface is actually flat" (Robinson 1981: 212). The leaf cross section we prepared from the holotype of B. erecta undeniably shows that the upper is in fact bullate (Fig. 1), like the leaves of Sipolisia and Xerxes. Later, the same author recognized two informal groups in the Sipolisiinae, the first characterized by short corolla tube and paleaceous receptacle (Heterocoma and Bishopalea) and the second by long corolla tube and fimbrillate receptacle (Sipolisia and Xerxes) (Robinson 1999).

Another character which supports a close relationship between these four genera is the presence of phytomelanin in the cyspelae walls (Fig. 2). Phytomelanin is a mechanically hard and resistant black layer in the fruit wall of cypselae, which plays an important role in the 
protection of the embryo and in the process of seed germination (Pandey and Dhakal, 2001). It was once thought to be restricted to Athroismeae and Heliantheae alliance (Pandey et al. 1989); however it occurs as a parallelism in the Sipolisiinae (except for Hololepis). Finally these four genera also share a caducous bisseriate pappus (at least the inner setae serie), except for Hololepis, which have a persistent pappus.

Altogether these morphological observations show that Hololepis (two spp.) is evidently at odd in the subtribe Sipolisiinae, differing by its petiolate leaves, glabrous upper surfaces of the leaves, persistent pappus, lack of phytomelanins in the cypselae walls, as well as its contrasting habit. According to Robinson (1999) it is the fimbriae of the receptacle that seem to relate Hololepis to Sipolisiinae and their paleaceous or fimbrillate receptacle. Nonetheless, if paleas have a scattered occurence among other American Vernonieae, such as Bolanosa and Lepidonia (Leiboldiinae) from Central America (Robinson 1999), fimbriae are much more common and occuring in apparently non related genera such as Cyrtocymura (Vernoniinae) and Proteopsis (Lychnophorinae). Preliminary results of molecular phylogenetic analyses, which are underway by the first author (BL), indicate that in order to keep the subtribe Sipolisiinae monophyletic, Hololepis must be excluded from it. Our morphological analysis corroborate this conclusion.

The high number of monotypic genera is a characteristic of the tribe Vernonieae: out of the 128 recognized genera 53 are monotypic. This situation reflects the fact that most of the relationships among tribal members are unresolved as has been the case since the tribe's original description (Keeley et al. 2007). With the exclusion of Hololepis, the subtribe Sipolisiinae is composed of four monotypic genera which forms a morphologically related (Robinson 1999) and monophyletic group (based on preliminar phylogenetic data). On the other hand, there are no relevant morphological characters reliable to clearly support Heterocoma, Bishopalea, Sipolisia and Xerxes at the generic level, and thus, the three latter genera are synonymized under Heterocoma.

\section{TAXONOMIC TREATMENT}

Heterocoma DC., Ann. Mus. Natl. Hist. Nat. 16: 190, t. 7. 1810.-TYPE: H. albida (DC. ex Pers.) DC.

Sipolisia Glaz. ex Oliv., Hooker's Icon. P1. 23: t. 2281. 1894.—TYPE: S. lanuginosa Glaz. ex Oliv. [= H. lanuginosa (Glaz. ex Oliv.) Loeuille, J. N. Nakaj. \& Semir].

Alcantara Glaz. ex G.M. Barroso, Loefgrenia 36: 1. 1969, non Alcantarea (Morren ex Mez)

Harms.-TYPE: A. petroana Glaz. ex G.M. Barroso [= H. ekmaniana (Philipson) Loeuille, J. N. Nakaj. \& Semir].

Bishopalea H. Rob., Phytologia 48: 211. 1981.—TYPE: B. erecta H. Rob. [= H. erecta (H. Rob.) Loeuille, J. N. Nakaj. \& Semir].

Xerxes J.R. Grant, Nordic J. Bot. 14: 287. 1994.—TYPE: X. ekmanianum (Philipson) J.R. Grant [= H. ekmaniana (Philipson) Loeuille, J. N. Nakaj. \& Semir].

Coarse subshrubs or shrubs, rarely treelets to $3.5 \mathrm{~m}$ tall. Stems monopodial, simple to poorly 
branched, densely white lanate or tomentose, rarely sericeous. Leaves alternate, sessil with a semi to amplexicaul sheath, margins commonly crenate, marcescent. Inflorescence axillary, sessile or pedunculate; capitula arranged in a dense cluster or in a panicle, rarely solitary; subinvolucral bracts foliose; receptacle fimbrillate or paleaceous. Florets 20-75, bissexual, fertile; corolla actinomorphic, 5-lobed, lobes apices densely pilose or seldom spiculiferous; apical anther appendages lanceolate, basal anther appendages shortly sagittate and partly sclerified; style lacking a basal node, with nectariferous disc. Pollen tricolporate, non-lophate. Cypsela with phytomelanin, glabrous; pappus biseriate, equal or subequal, subpaleaceous or paleaceous, caducous, seldom outer series reduced, coroniform and persistent. Characteristic terpenoids: furanoheliangolides and few eudesmane derivatives.

\section{Key to SPECIES OF HETEROCOMA}

1. Receptacle paleaceous; corolla tube shorter than corolla lobes.

2. Stems and leaves with appressed hairs; heads sessile, solitary at each upper axil; outer pappus coroniform and persistent H. albida

2. Stems and leaves tomentose, velutinous to lanulose; heads pedunculate, arranged in a loosely branched panicle; outer pappus paleaceous and caducous.

3. Apices of outer phyllaries caudate and nodding; florets ca. 20; Bahia H. erecta

3. Apices of outer phyllaries acute to pungent; florets 34-47; Minas Gerais H. gracilis

1. Receptacle epaleaceous; corolla tube longer than corolla lobes.

4. Receptacle with flat-bottomed ridges bearing articulated deciduous setae; cluster of (2)3-6 divaricate heads or rarely a solitary head H. lanuginosa

4. Receptacle fimbrillate; heads usually solitary, sometimes on a cluster of 2-3, not spreading away from each other.

5. Stems densely lanate, rarely lanulose; leaf blades $11.5-26.5 \times 5-10 \mathrm{~cm}$; inner phyllaries margins usually entire H. ekmaniana

5. Stems villous to lanulose; leaf blades 4.5-13.5 × 1.4-5.9 cm; inner phyllaries margins fimbrillate H. robinsoniana

1. Heterocoma Albida (DC. ex Pers.) DC., Ann. Mus. Natl. Hist. Nat. 16: 155, 191, t. 3. 1810. Serratula albida DC. ex Pers., Syn. P1. 2: 391. 1807.-TYPE: BRAZIL. Without other data, Veloso de Miranda s.n. (holotype: G-DC! [photo: G-DC!]).

Proteopsis sellowii Sch.Bip., Jahresber. Pollichia 20-21: 434. 1863.-TYPE: BRAZIL. Without other data, Sellow 1287 (holotype: B [destroyed] [photo: F!, US!]; isotype: B [destroyed]). Proteopsis insculpta Philipson, Bull. Misc. Inform. Kew 7: 299. 1938.-TYPE: BRAZIL. Minas Gerais, Carãça [Caraça], entre les rochers, Glaziou 14974 (holotype: K! [photo: $\mathrm{K}$ !, US!]; isotypes: G!, P!).

Distribution-Minas Gerais. 
2. Heterocoma ekmaniana (Philipson) Loeuille, J. N. Nakaj. \& Semir, comb. nov. Basionym: Proteopsis ekmaniana Philipson, Bull. Misc. Inform. Kew 7: 300. 1938. Alcantara ekmaniana (Philipson) H. Rob., Phytologia 48: 213. 1981. Xerxes ekmanianum (Philipson) J.R. Grant, Nordic J. Bot. 14: 287. 1994.—TYPE: BRAZIL. Goiás, Serra da Baliza, entre les rochers à Vargem Grande, Glaziou 21668 (holotype: K! [photo: K!, US!]; isotypes: P! [photo: US!], B [destroyed], K!, G!).

Alcantara isabellae Glaz., Bull. Soc. Bot. (Mém. 3d) 56: 367. 1909, nom. nud.

Alcantara petroana Glaz. ex G.M. Barroso, Loefgrenia 36: 1. 1969. —TYPE: BRAZIL. Goiás, Chapadão dos Veadeiros, entre les rochers, Glaziou 21667 (holotype: K!; isotypes: P! [photo: US!], B, G!).

Distribution — Goiás, Minas Gerais.

3. Heterocoma erecta (H. Rob.) Loeuille, J. N. Nakaj. \& Semir, comb. nov. Basionym: Bishopalea erecta H. Rob., Phytologia 48: 211. 1981.-TYPE: BRAZIL. Bahia, main valley north of Mucugê from 3-8 km north of town, 31 Jan 1981, King \& Bishop 8729 (holotype: UB! [photo: US!]; isotype: US!).

Distribution-Bahia.

4. Heterocoma gracilis Loeuille, J. N. Nakaj. \& Semir, sp. nov.-TYPE: BRAZIL. Minas Gerais, São Gonçalo do Rio Preto, Parque Estadual do Rio Preto, estrada para Vargem das Estrelas, $18^{\circ} 07^{\prime} 45^{\prime}$ 'S, 43²2'43.1”W, 1,040 m alt., 9 Feb 2010, B. Loeuille et al. 520 (holotype: SPF!; isotypes: BHCB!, K!, NY!, MBM!, MO!, RB!, US!).

Species Heterocoma erectis similis, sed apicibus caudatis cernuis bractearum exteriorum (non acutis vel pungentibus extus) et floribus 34-47 (non c. 20).

Coarse shrub to $2.5 \mathrm{~m}$ tall. Stems poorly branched, cylindrical, slightly canaliculate, greenish-ochreous lanulose, becoming dark greyish with age. Leaves spirally arranged, usually clustered towards stems apices, alternate, simple, semi-amplexicaul sheath, sessile, discolors; blade 6.6-25 × 1.9-9.2 cm, lanceolate, narrow elliptic to elliptic, apex acute, rarely obtuse, base auriculate, yellowish green to green, densely velutinous, more rarely slightly ferrugineous above, dirty white to greyish, velutinous to tomentose beneath, older leaves dark greyish marcescent, hairs unbranched, 3- to 5-armed and stellate, reticulate venation prominent beneath, membranaceous to slightly cortaceous, minutely bullate, venation camptodromous, margins irregularly crenulate, conspicuously involute when young. Inflorescence axillary, poorly branched panicle of 4-14 capitula, inflorescence branches with foliose bracts, these similar to leaves of the main axis but patent and conspicuously involute at margin. Capitula homogamous, discoid, peduncle 1-7 cm long, cylindrical, slender, greenish-ochre lanulose, foliose subinvolucral bracts $2-4,1.5-1.9 \times 0.4-0.8 \mathrm{~cm}$, lanceolate to ovate, densely whitish to greenish lanulose, margins crenulate, apices obtuse to acute; involucre $0.8-1.5 \mathrm{~cm}$ long, 
widely campanulate; phyllaries ca. 40, 4-5 - seriate, weakly imbricate, outer phyllaries 1-1.6 $\times$ 0.4-1 cm, widely ovate, scarious, densely whitish to greenish lanate, apices caudate, foliaceous, nodding, margins crenulate, inner phyllaries 9-11 × 1.1-1.7 mm, lanceolate to linear, scarious, light brown, densely white lanate towards apices; receptacle flat, paleate, palea $0.9-1.1 \mathrm{~cm}$ long, lanceolate to linear, carenate, apice densely white lanulose. Florets 34-47, bisexual, fertile; corolla actinomorphic, 5-lobed, lilac, tube 1.39-1.75 mm long, cylindrical, glabrous, lobes 5.7-8.8 mm long, linear-lanceolate, apices acute, thickened, densely pilose, glandularpunctate; apical anther appendages lanceolate, twice longer than wide, basal anther appendages shortly sagittate; style $1.2-1.5 \mathrm{~cm}$ long, style shaft glabrous throughout except for pubescent upper ca. $2 \mathrm{~mm}$ beneath style arms, style base glabrous, lacking basal node, with nectariferous disc, style arms 2.9-4 mm long, short pubescent outside throughout. Cypsela 2.9-4.5 × 1.1-1.5 $\mathrm{mm}$, terete, 10-costate, with phytomelanin, glabrous, glandular-punctate, carpopodium annular; pappus biseriate, equal or subequal, light stramineous, caducous, setae numerous, $7.2-8.2 \mathrm{~mm}$ long, barbellate, paleaceous, twisted. Figure 3A-L.

Etymology - The specimens of $H$. gracilis have been previously identified as H. erecta, but they strikingly differ by the slender ('gracilis' in latin) overall aspect.

Distribution and Habitat - Heterocoma gracilis is only known from Parque Estadual do Rio Preto and an adjacent area (Felício dos Santos) in the eastern part of the Planalto de Diamantina (Minas Gerais State). It grows in campos rupestre, amongst rocks.

Conservation Status - Insufficient data available (IUCN 2001).

Additional Specimens Examined-BRAZIL. Minas Gerais, Mun. Felício dos Santos, A.P.A. Felício, 10 Aug 2004, Viana \& Mota 1843 (BHCB); Mun. São Gonçalo do Rio Preto, P.E. do Rio Preto, trilha para o riacho das Éguas, 20 Mar 2007, Teles et al. 333 (BHCB).

Heterocoma gracilis resembles to $H$. erecta by its panicle, paleaceous receptacles and corollas with short basal tube, but differs mainly by its outer phyllaries with nodding caudate apices (vs. acute to pungent apices) and 34-47 florets per head (vs. ca. 20). The other species in the genus with paleaceous receptacle, $H$. albida, is easily set apart by its appressed-tomentellous adaxial leaves (vs. velutinous) and sessile heads in each upper axil (vs. pedunculate and panicle inflorescence). Additionally the three species have distinct geographical distributions: $H$. gracilis is restricted to the eastern part of the Planalto de Diamantina (Minas Gerais State), H. erecta is endemic of Mucugê in the Chapada Diamantina (Bahia State) and H. albida occurs in Serra do Caraça and southeastern part of Planalto de Diamantina (Minas Gerais State). It is worth noting that only young plants have been collected with inflorescences. The older plants seen on field (Fig. 1A) are larger (up to $2.5 \mathrm{~m}$ ) with bigger leaves but did not bear any inflorescences.

5. Heterocoma lanuginosa (Glaz. ex Oliv.) Loeuille, J. N. Nakaj. \& Semir, comb. nov. Basionym: Sipolisia lanuginosa Glaz. ex Oliv., Hooker's Icon. P1. 23: t. 2281. 1894. Proteopsis lanuginosa (Glaz. ex Oliv.) Philipson, Bull. Misc. Inform. Kew 7: 300. 
1938.-TYPE: BRAZIL. Minas Gerais, São Gonçalo près Biribiry [in protologue: near Diamantina], Glaziou 19470 (holotype: K! [photo: K!]; isotypes: B [destroyed] [photo: F!, US!], K! [photo: K!], P!, G!, RB! [2 specimens]).

Distribution-Minas Gerais.

6. Heterocoma robinsoniana Loeuille, J. N. Nakaj. \& Semir, sp. nov.-TYPE: BRAZIL. Minas Gerais, São Roque de Minas, Parque Nacional da Serra da Canastra, morro após o vale da nascente do rio São Francisco, 11 Jan 1995, R. Romero et al. 1708 (holotype: HUFU!; isotypes: SPF!, UEC!, US!).

Species Heterocoma ekmanianis similis, sed caule villoso vel lanuloso (non dense lanoso vel raro lanuloso) graciliore (0.9-7, non 12-29 mm diam.) et foliis minoribus (4.5-13.5 × 1.4-5.9 $\mathrm{cm}$, non $11.5-26.5 \times 5-10 \mathrm{~cm})$.

Coarse subshrub $0.3-1.5 \mathrm{~m}$ tall. Stems simple or poorly branched, 0.9-7 mm diam., cylindrical, slightly decumbent, villous to lanulose. Leaves alternate, simple, patent, with a semi-amplexicaul sheath, sessile; blade 4.5-13.5 × 1.4-5.9 cm, ovate-lanceolate, oblanceolate to wide elliptic, apex acute, base attenuate, densely lanate to lanulose, whitish to silverish canescent, older leaves marcescents, dark greyish, 3- to 5-armed hairs and stellate hairs, venation camptodromous, reticulate venation prominent beneath, membranaceous, slightly bullate, margin entire, crenate on upper part. Inflorescence axillary, a raceme of few capitula, seldom a solitary capitulum. Capitula homogamous, discoid, peduncle 1-23.2 cm long, 0.25-3.7 mm diam., cylindrical, densely white lanate, foliose subinvolucral bracts $2-6,2.5-4 \times 0.7-1.5 \mathrm{~cm}$, ovate, apices acute, densely white lanate; involucre campanulate, $2.2-2.7 \mathrm{~cm}$ long; phyllaries ca. 70, 5-6 - seriate, subimbricate to imbricate, scarious, outer phyllaries 6-10 $\times 0.75-1 \mathrm{~mm}$, ovate-lanceolate, densely white lanate, glandular-punctate, inner phyllaries 16-17 × 1-1.5 mm, lanceolate, margin fimbriate, setose, densely glandular-punctate; receptacle somewhat convex, glabrous, fimbriate with some isolated fimbriae up to ca. $5 \mathrm{~mm}$. Florets ca. 70, bisexual, fertile; corolla actinomorphic, 5-lobed, lilac, tube $1.3-1.6 \mathrm{~cm}$ long, cylindrical, glabrous, lobes 5-6.5 $\mathrm{mm}$ long, linear-lanceolate, apices acute, thickened, pilose, glandular-punctate; apical anther appendages ovate, more than twice longer than wide, basal anther appendages long-sagittate; style 1.5-2.3 cm long, style shaft glabrous throughout except for pubescent upper ca. $1.5 \mathrm{~mm}$ beneath style arms, style base glabrous, lacking a basal node, with nectariferous disc, style arms 4-4.3 mm long, short pubescent outside throughout. Cypsela terete 2.5-4.5 × 0.8-0.9 mm, 10-costate, with phytomelanin, glabrous, glandular-punctate, carpopodium annular, scarcely visible; pappus biseriate, light stramineous, deciduous, twisted, setae 15-20, outer series 2-5.2 $\mathrm{mm}$ long, inner series 8-13 mm long, barbellate, flattened, apices acute, thickened. Figure 4A$\mathrm{K}$.

Etymology - The epithet honors Dr. Harold Robinson of the National Museum of Natural History, Smithsonian Institution (US), a synantherologist who have published numerous papers on the tribe Vernonieae, which have greatly increased our understanding of the tribe. 
Phenology - Heterocoma robinsoniana has been collected with flowers from December to January and from March to September, flowering peaks are in January and Mai.

Distribution and Habitat - Heterocoma robinsoniana is restricted to the Serra da Canastra and the region of the Furnas reservoir in southwestern Minas Gerais. This species is found in campos rupestres or rocky outcrops.

Conservation Status - The new species, according to IUCN Red list category (IUCN 2010), is considered Vulnerable (VU, B1abiii), since its area of occurrence is smaller than $20,000 \mathrm{~km}^{2}$, it is known at less than ten localities. Some of these locaties are outside of the limits of the Parque Nacional da Serra da Canastra and thus, prone to the effects of human activities

Additional Specimens Examined-BRAZIL. Minas Gerais, Mun. Alpinópolis, 25 Jul 1972, Emygdio et al. 3606 (NY, R); Mun. Capitolió, Represa de Furnas, estrada Furnas - Capitolió, às margens da represa, 13 Feb 1998, Goldenberg et al. 496 (HUFU, UEC), ibidem, estrada para Pedreira Souza, ca. 2 km da rodovia MG 050, 30 Sep 2005, Nakajima et al. 3944 (HUFU), ibid., estrada para a pedreira Gabi Exploração, 20³7’25”S, 46¹7’48”W, 1,094 m, 26 Oct 2006, Loeuille et al. 48 (HUFU, SPF); Mun. Delfinópolis, estrada para Casa Branca, Fazenda Paraíso, 'Sete Cidades', 20²2'04'S, 4645'23”W, 1,178 m, 10 Apr 2002, Romero \& Nakajima 6285 (HUFU, SPF), ibid., 8 Oct 2002, Volpi et al. 229 (HUFU, SPF), ibid., 12 Mar 2003, Pacheco et al. 521 (HUFU), estrada para Gurita, 20¹6’52”S, 4652’16”W, 816 m, 14 May 2003, Romero et al. 6831 (HUFU), Condominio das Pedras, 17 May 2003, Pacheco et al. 609 (HUFU), ibid., 17 May 2003, Volpi et al. 654 (HUFU); Mun. Furnas, 25 Jun 1972, Tavares s.n. (JPB), limite Parque Nacional da Serra da Canastra-Usina de Furnas, 7 Jul 1995, Lombardi 879 (BHCB, UEC); Mun. Sacramento, Parque Nacional da Serra da Canastra, Guarita de Sacramento, próximo da captação de água, 8 Jul 1996, Nakajima et al. 1850 (HUFU); Mun. São Roque de Minas, Parque Nacional da Serra da Canastra, estrada São Roque - Sacramento, após a torre de observação, 11 Dec 1994, Nakajima \& Romero 766 (HUFU), ibid., topo do morro após o São Francisco, 11 Jan 1995, Romero et al. 1708 (HUFU), ibid., estrada para Fazenda do Fundão, 13 Mai 1995, Romero et al. 2263 (HUFU), ibid., estrada São Roque - Sacramento, após a torre de observação, 15 Mai 1995, Nakajima et al. 1117 (HUFU), ibid., Córrego do Quilombo, 12 Jan 1996, Romero et al. 3265 (HUFU, SPF), ibid., Cachoeira dos Rolinhos, 21 Mar 1996, Nakajima \& Romero 1669 (HUFU), ibid., estrada para o sítio João Domingos, 26 Mai 1996, Nakajima \& Romero 1822 (HUFU), ibid., estrada para Sacramento, km 51, 27 Mai 1996, Romero \& Nakajima 3522 (HUFU, SPF), ibid., base do morro próximo a sede administrativa, 27 Mai 1996, Romero \& Nakajima 3533 (HUFU), ibid., Chapadão do Diamante, após a antena, 9 Jul 1996, Nakajima et al. 1916 (HUFU), ibid., 18 Apr 1997, Nakajima et al. 2334 (HUFU, SPF), ibid., Garagem das Pedras, descida para o Vale dos Cândidos, 16 Oct 1997, Romero \& Nakajima 4668 (HUFU), ibid., Guarita de Sacramento, captação de água, 11 Jan 1998, Romero et al. 4979 (HUFU), ibid., próximo às 3 Matinhas, 12 Jan 1998, Romero et al. 5029 (HUFU), ibid., morro atrás do Centro de Visitantes, 15 Mai 2007, Loeuille et al. 266 (SPF).

Heterocoma robinsoniana is closely related to H. ekmaniana and sets apart by its villous to 
lanulose stems (vs. densely lanate, very rarely lanulose) and slender (0.09-0.7 cm vs. 1.2-2.9 cm diam.), smaller leaves $(4.5-13.5 \times 1.4-5.9 \mathrm{~cm}$ vs. $11.5-26.5 \times 5-10 \mathrm{~cm})$ and fimbrillate margins of inner phyllaries (vs. usually entire). The new species is smaller and never presents a dense lanate indumentum such as $H$. ekmaniana. Both species hardly occur in sympatry: $H$. ekmaniana is found in the Chapada dos Veadeiros, Serra dos Pireneus, Chapadão de Catalão in the Goiás State and rarely in Minas Gerais State (few collections in western part of Serra da Canastra), H. robinsoniana occurs in the Serra da Canastra and Furnas reservoir region (Minas Gerais State). H. ekmaniana grows in rocky soil close to water streams or waterfalls usually in more shadier spots than $H$. robinsoniana which inhabits drier rocky outcrops.

Acknowledgments. Thanks are due to Leonardo M. Borges for the line illustrations, to Mariana de Andrade Wagner Loeuille for leaf cross section of Heterocoma erecta, to CNPq (Brazil) for the fellowships awarded to first author. The authors would like to thank the curators of all the herbaria listed in the text for loaning the specimens. JR Pirani is grateful to CNPq for financial support.

\section{Literature Cited}

Baker, J. G. 1873. Compositae I. Vernoniaceae. Pp. 5-180 in Flora Brasiliensis, 6(2), eds C. F. P. von Martius $\dagger$ and A. W. Eichler, Fried. Fleischer, Münich, Vienna, Leipzig.

Barroso, G. M. 1969. Novitates Compositarum, II. Loefgrenia 36: 1-3, pl. 1-6.

Bentham, G. 1873. Compositae. Pp. 163-533 in Genera Plantarum, 2(1), eds G. Bentham and J. D. Hooker, Reeve \& Co., London and Williams and Norgate, London.

Candolle, A. P. de. 1810. Observations sur les plantes composées, ou syngenèses. Second mémoire. Monographies de quelques genres de Cinarocéphales. Annales du Muséum d'Histoire Naturelle 16: 181-208, pl. 6-15.

Candolle, A. P. de. 1836. Vernoniaceae. Pp. 9-103 in Prodromus Systematis Naturalis Regni Vegetabilis, ... v. 5, Ed. A. P. de Candolle, Treutel et Würtz, Paris. Masson, Paris.

Cassini, H. 1818. Composées ou Synanthérées. Pp. 132-159 in Dictionnaire des Sciences Naturelles dans lequel on traite méthodiquement des différents êtres de la Nature, 2nd edition, 10, Ed. F. Cuvier, Levrault, Strasbourg. Le Normant, Paris.

Cassini, H. 1820. Fimbrilles. Pp. 56 in Dictionnaire des Sciences Naturelles dans lequel on traite méthodiquement des différents êtres de la Nature, 2nd edition, 17, Ed. F. Cuvier, Levrault, Strasbourg. Le Normant, Paris.

Cassini, H. 1821. Hololépide. Pp. 307-309 in Dictionnaire des Sciences Naturelles dans lequel on traite méthodiquement des différents êtres de la Nature, 2nd edition, 21, Ed. F. Cuvier, Levrault, Strasbourg. Le Normant, Paris.

Endress, P. K. 2010. Disentangling confusions in inflorescence morphology: patterns and diversity of reproductive shoot ramification in angiosperms. Journal of Systematics and Evolution 48: 225-239. 
Glaziou, A. F. M. 1909. Plantae Brasiliae centralis a Glaziou lectae. Liste des plantes du Brésil central recueillies en 1861-1895. Bulletin de la Société Botanique de France 56, Mémoire 3e: 297-392.

Grant, J. R. 1994. Xerxes, a new name to replace Alcantara (Asteraceae: Vernonieae). Nordic Journal of Botany 14: 287-288.

Hallé, F., Oldeman, R. A. A. and P. B. Tomlinson. 1978. Tropical trees and forests: an architectural analysis. Springer-Verlag, Berlin, Heidelberg, New York.

Harris, J. G. and M. W. Harris. 2001. Plant identification terminology: an illustrated glossary. 2nd edition, Spring Lake Publishing, Spring Lake.

Hind, D. J. N. 2009. Glossary in: An annoted preliminary checklist of the Compositae of Bolivia. Published on the internet http://www.kew.org/science/tropamerica/boliviacompositae/ index.html [accessed October 2010].

Hoffmann, O. 1890. Compositae, Tubuliflorae-Vernonieae. Pp. 120-131 in Die natürlichen Pflanzenfamilien, 4(5), eds A. Engler \& K. Prantl, Wilhelm Engelmann, Leipzig. IUCN. 2010. Guidelines for Using the IUCN Red List Categories and Criteria. Version 8.1. Prepared by the Standards and Petitions Sub-Committee in March 2010. Available from: http://intranet.iucn.org/webfiles/doc/SSC/RedList/RedListGuidelines.pdf [accessed February 2011].

Johansen, D. A. 1940. Plant microtechnique. New York: McGraw-Hill.

Keeley, S. C. and H. Robinson. 2009. Vernonieae. Pp. 439-469 in Systematics, evolution and biogeography of Compositae, eds V. A. Funk, A. Susanna, T. F. Stuessy and R. J. Bayer, IAPT, Wien.

Keeley, S. C., Forsman, Z. H. and R. Chan. 2007. A phylogeny of the "evil tribe" (Vernonieae: Compositae) reveals Old/New World long distance dispersal: support from separate and combined congruent datasets (trnL-F, ndhF, ITS). Molecular Phylogenetics and Evolution 44: 89-103.

McNeill, J., Barrie, F. R., Burdet, H. M., Demoulin, V., Hawksworth, D. L., Marhold, K., Nicolson, D. H., Prado, J., Silva, P. C., Skog, J. E., Wiersema, J. H. and N. J. Turland (eds.). 2006. International code of botanical nomenclature (Vienna Code): Adopted by the Seventeenth International Botanical Congress Vienna, Austria, July 2005. Regnum Vegetabile 146. Ruggell: Gantner.

Nakajima, J. N. 2000. A família Asteraceae no Parque Nacional da Serra da Canastra, MG. $\mathrm{PhD}$ thesis, unpublished. Universidade Estadual de Campinas, São Paulo.

O’Brien, T. P., Feder, N. and McCully, M. E. 1964. Polychromatic staining of plant cell walls by toluidine blue O. Protoplasma 59: 368-373.

Oliver, D. 1894. Sipolisia lanuginosa. P1. 2281 in Hooker's Icones Plantarum, ser. 4, 3 (v. 23), Ed. J. D. Hooker. London.

Pandey, A. K. and M. R. Dhakal. 2001. Phytomelanin in Compositae. Current Science 80: 933-940. 
Pandey, A. K., Wilcox, L. W., Sack, F. D. and T. F. Stuessy. 1989. Development of the phytomelanin layer in fruits of Ageratum conyzoides (Compositae). American Journal of Botany 76: 739-746.

Philipson, W. R. 1938. Four new species of Vernonieae collected by Glaziou in Brazil. Bulletin of Miscellaneous Information, Royal Gardens, Kew 7: 298-300.

Robinson, H. 1981. Episcothamnus and Bishopalea, two genera of Vernonieae (Asteraceae) from Brasil, and the resurrection of Sipolisia. Phytologia 48: 209-217.

Robinson, H. 1995. New combinations and new species in American Vernonieae (Asteraceae). Phytologia 78: 384-399.

Robinson, H. 1999. Generic and subtribal classification of American Vernonieae. Smithsonian Contributions to Botany 89: 1-116.

Robinson, H. 2007 [2006]. Vernonieae. Pp. 149-174 in Vol. 8: Asterales, vol. eds. J. Kadereit and C. Jeffrey,. The families and genera of vascular plants, series ed. K. Kubitzki, Springer. Berlin, Heidelberg, New York.

Semir, J. 1991. Revisão taxonômica de Lychnophora Mart. (Vernonieae: Compositae). PhD thesis, unpublished. Universidade Estadual de Campinas, São Paulo.

Small, J. 1919. The origin and development of the Compositae. New Phytologist 18 (Reprint 11): $1-334+$ pl. $1-6$.

Stuessy, T. F. and D. M. Spooner. 1988. The adaptive and phylogenetic significance of receptacular bracts in the Compositae. Taxon 37: 114-126

Thiers, B. (continuously updated). Index Herbariorum: a global directory of public herbaria and associated staff. New York Botanical Garden's Virtual Herbarium. http://sweetgum.nybg. org/ih [accessed October 2010].

Toledo, J. F. 1941. Notas sôbre o gênero monotípico Heterocoma DC. Compositae Vernonieae. Arquivos de Botânica do Estado de São Paulo 1: 71-73, pl.87. 
APPENDIX 1. List of material examined in order to assess morphological differences between the genera of Sipolisiinae.

Heterocoma albida. BRAZIL. Minas Gerais, Mun. Catas Altas, Serra do Caraça, Inficionado Peak, 5 Apr 2007, Teles et al. 382 (BHCB). Mun. Santa Bárbara, Serra do Caraça, 14 Apr 1933, Mello Barreto 3832 (BHCB, US); ibid., 22 Mar 1957, Pereira \& Pabst 2581 (RB); ibid., ca. 10 km W of Barão de Cocais, 23 Jan 1971, Irwin et al. 28979 (NY, RB). Mun. Serro, Mato Grosso, Pedra do Cruzeiro, 1841'37’'S, 43²7’30”W, 1132 m, Nakajima \& Romero 3074 (HUFU, SPF); distrito de Augusto Clementino, Pedra do Cruzeiro, 1841'37'S, 4347’30'W, 774 m, 774 m, Loeuille et al. 450 (HAW, K, MO, SPF, US). Locality unknown: Jan 1917, Ule 2607 (R, US); Damazio s.n. (RB). Heterocoma ekmaniana. BRAZIL. Goiás, Mun. Alto Paraíso de Goiás, Chapada dos Veadeiros, ca. 12 km NW of Veadeiros [Alto Paraíso de Goiás], road to Cavalcante, 21 Oct 1965, Irwin et al. 9391 (NY, UB, US); ibid., ca. 15 km NW of Veadeiros [Alto Paraíso de Goiás], 14 Feb 1966, Irwin et al. 12837 (NY, US); ibid., ca. 20 km N of Alto Paraíso de Goiás, 19 Mar 1971, Irwin et al. 32148 (NY, US); ibid., GO-12, 20 Feb 1975, Hatschbach et al. 36328 (MBM, NY, US); ibid., $20 \mathrm{~km}$ N of Alto Paraíso de Goiás along road to Monte Alegre de Goiás, 7 Feb 1981, King \& Bishop 4148 (US); ibid., 5-12 km S of Alto Paraíso de Goiás, mostly E of road to São João da Aliança, 8 Feb 1981, King \& Bishop 8896 (US); ibid., 16 km de Alto Paraíso de Goiás, km 184 da rodovia GO188, próximo ao rio Preto, 14 May 1994, Aparecida da Silva et al. 2017 (IBGE, US); ibid., estrada para Teresina de Goiás (GO-118), 1560 m, 24 May 1994, Walter et al. 2115 (UB); ibid., entrada do belvedere Paraíso, a ca. de 4 km N de Alto Paraíso de Goiás, 1408’'S, 47²7’ W, 1380 m, 14 Mar 1995; ibid., próximo a nascente do rio Preto, 15 Jun 1995, Gonzales \& Martins 01 (IBGE); ibid., GO-118, estrada Alto Paraíso de Goiás - Teresina de Goiás, km 182, 30 Oct 1995, Vichnewski 35177 (UEC); ibid., Fazenda Santo Antônio, 1404’08'S, 47¹9’35”W, 6 Jul 1996, Felfili et al. 352 (IBGE, US); ibid., P. N. da Chapada dos Veadeiros, próximo à descida da cachoeira

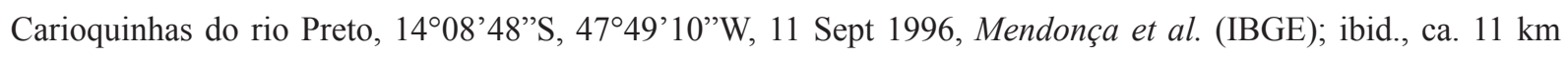
da cidade, 14¹0'09'S, 47³6’37’W, 1115 m, 16 Jun 1998, Romero et al. 5550 (UEC); ibid., P. N. da Chapada dos Veadeiros, caminho para Pouso Alto, 04 Dec 2007, Trovó et al. 440 (SPF). Mun. Cavalcante, Chapada dos Veadeiros, estrada para cachoeira Santa Bárbara, 4 Feb 2004, Bringel et al. 91 (CEN). Mun. Pirenópolis, Serra dos Pireneus, 8 Feb 1987, Semir et al. s.n. (UEC 20544). Mun. Teresina de Goiás, ca. 26 km N of Alto Paraíso de Goiás, $13^{\circ} 45^{\prime} \mathrm{S}, 4^{\circ} 15^{\prime} \mathrm{W}, 21$ Feb 1992, Filgueiras et al. 2094 (IBGE). Minas Gerais: Divisa de Mun. Araxá e Sacramento, Serra do Taquaral, 5 Aug 1943, Burle Marx \& Mello Barreto 11539 (BHZB, NY, US). Heterocoma erecta. BRAZIL. Bahia, Mun. Mucugê, 1 km W of Mucugê, 31 Jan 1981, King \& Bishop 8729 (GH, UB, US). Heterocoma lanuginosa. BRAZIL. Minas Gerais, Mun. Belo Horizonte, 1935, Marques Lisboa s.n. (US). Mun. Buenópolis, Serra do Cabral, ca. $50 \mathrm{~km} \mathrm{~N}$ de Corinto, estrada para Buenópolis, 15 May 1977, Gibbs et al. 5156 (MBM, UEC); ibid., 7 km da cidade, 12 Oct 1988, Harley et al. 24885 (MBM, US); Serra dos Macacos, Curimataí, 19 May 2001, Hatschbach et al. 72231 (BHCB, MBM, US). Mun. Diamantina, Barão, near summit of Serra de Capão, 19 May 1931, Mexia 5872 (NY, US); Conselheiro Mata, Jun 1934, Brade 13392 (NY, RB, UB, US). 


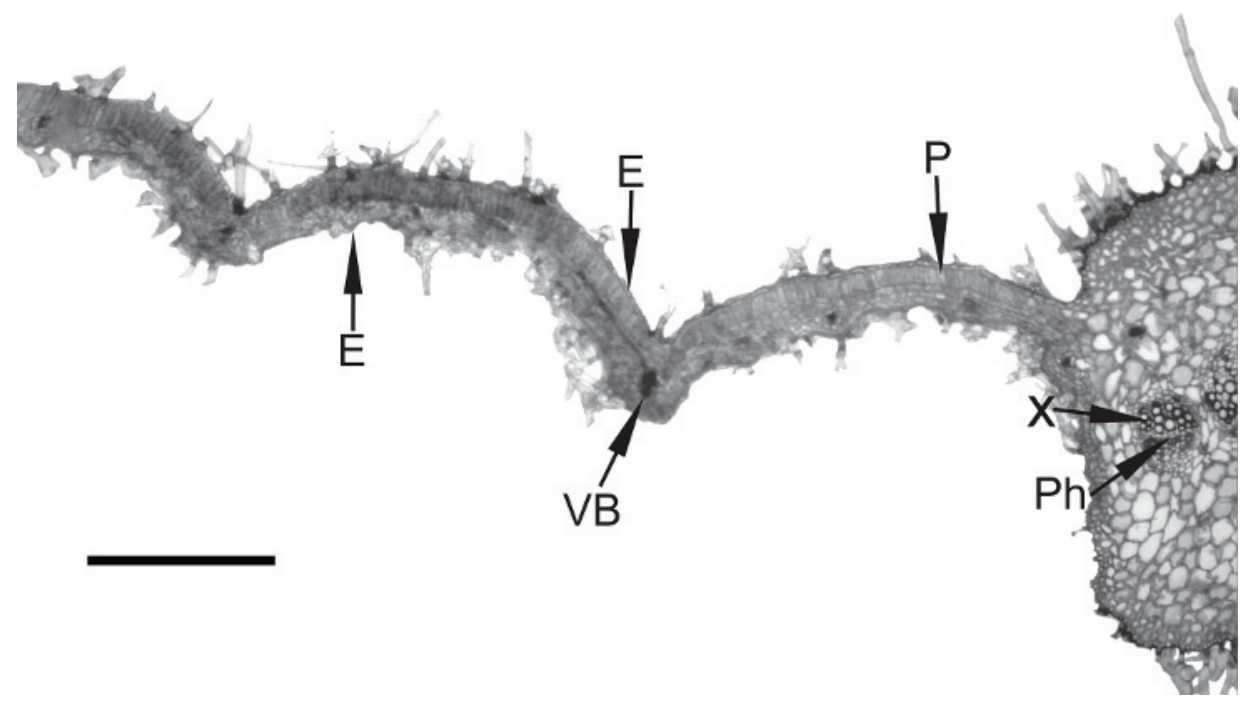

FIG. 1. Leaf cross section of Heterocoma erecta (King \& Bishop 8729, UB; scale $=100 \mu \mathrm{m})$. $\mathrm{E}=$ epiderm; $\mathrm{P}=$ palissadic parenchyme $\mathrm{Ph}=$ phloem $; \mathrm{VB}=$ vascular bundle $; \mathrm{X}=$ xylem. 


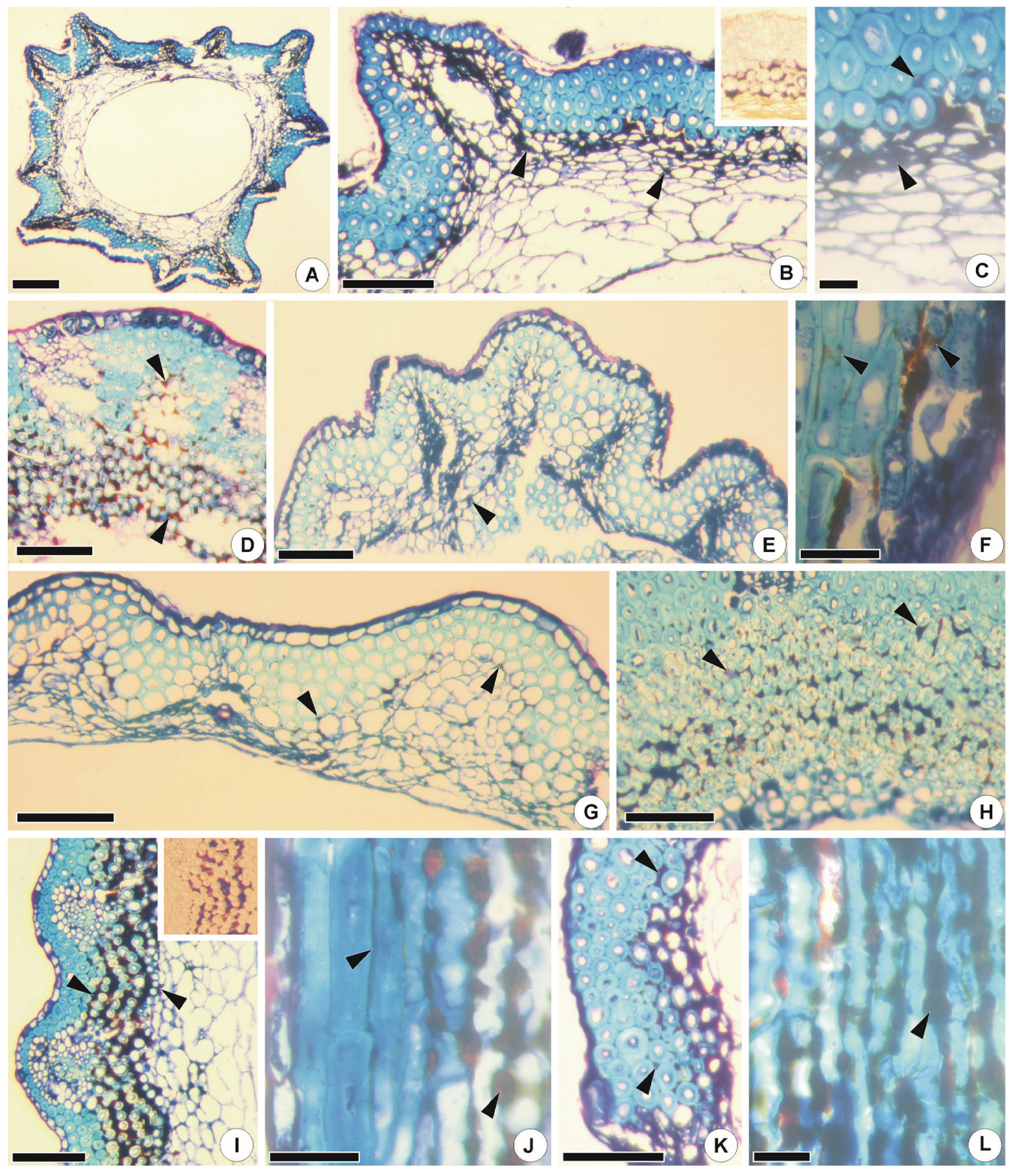

FIG. 2.Cypselae of Heterocoma species, showing phytomelanin (A-E, G-I, K, cross sections; F, J,L, longitudinal sections). A-C, Heterocoma albida; A, General view; B, Lateral view, detaching a rib; in detail, note the phytomelanin in a non-stained preparation; $\mathrm{C}$, Detail of fibers and phytomelanin deposits; D, Heterocoma ekmaniana, next to the carpopodium; E-F, Heterocoma erecta; E, next to the carpopodium; F, lateral view, with phytomelanin inner and between fibers; G-H, Heterocoma gracilis; G, lateral view; H, next to the floral disk; I-J, Heterocoma lanuginosa; I, lateral view; in detail, note the phytomelanin in a non-stained preparation; J, lateral view, with phytomelanin inner and between fibers; K-L, Heterocoma robinsoniana; K, lateral view; L, tangential view. Arrowheads: phytomelanin. Scale bars: A, K $=200 \mu \mathrm{m}$; B, D-E, G-I, L $=100 \mu \mathrm{m} ; \mathrm{C}, \mathrm{F}, \mathrm{J}=20 \mu \mathrm{m}$. 

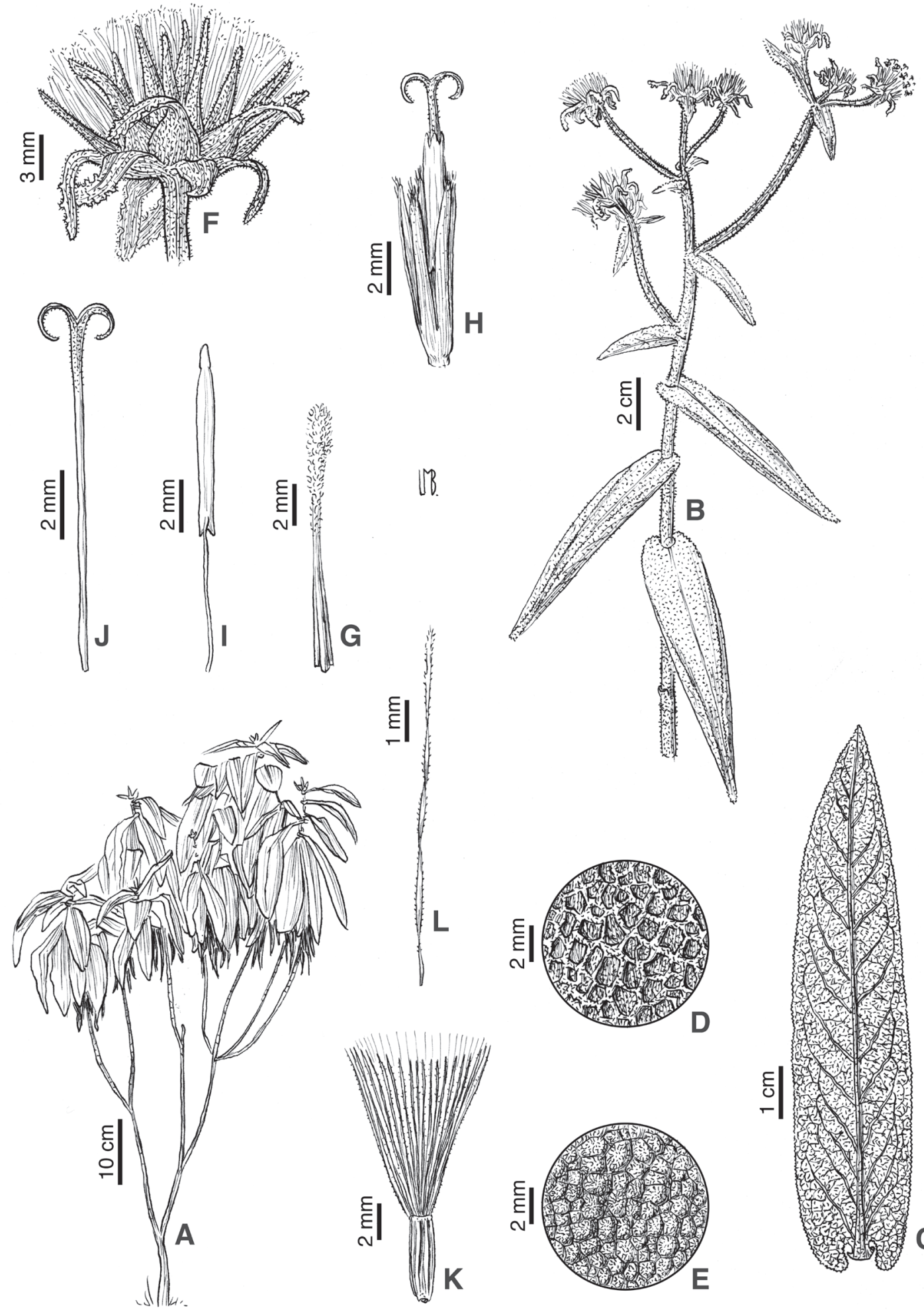

G
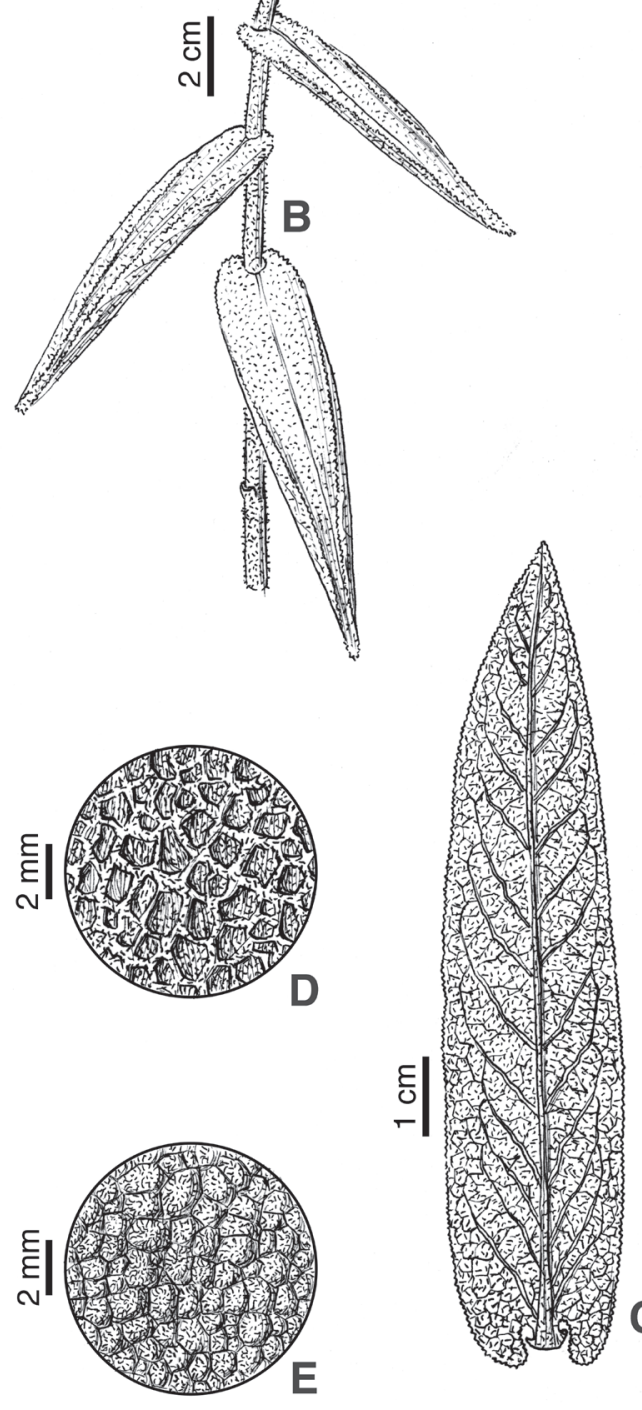

$B$
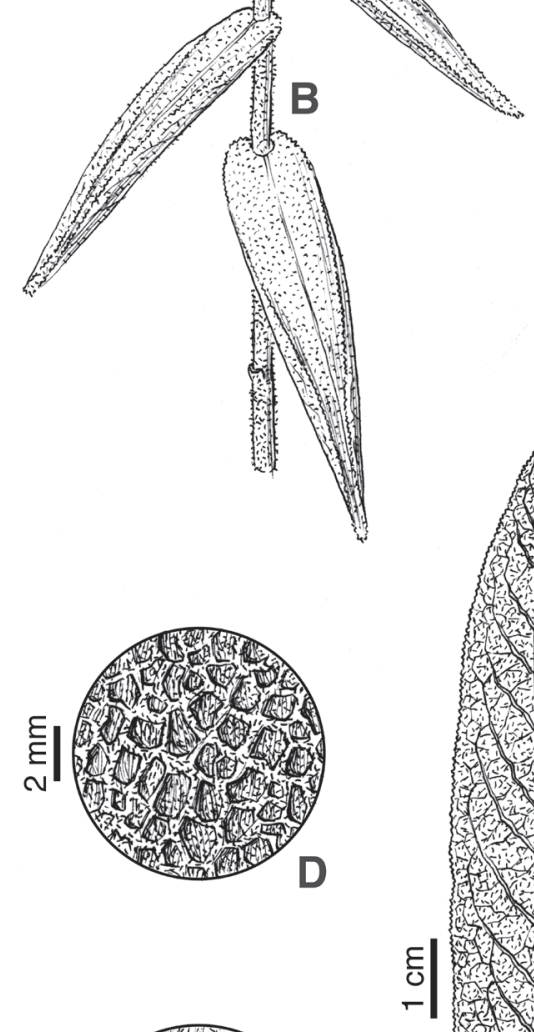


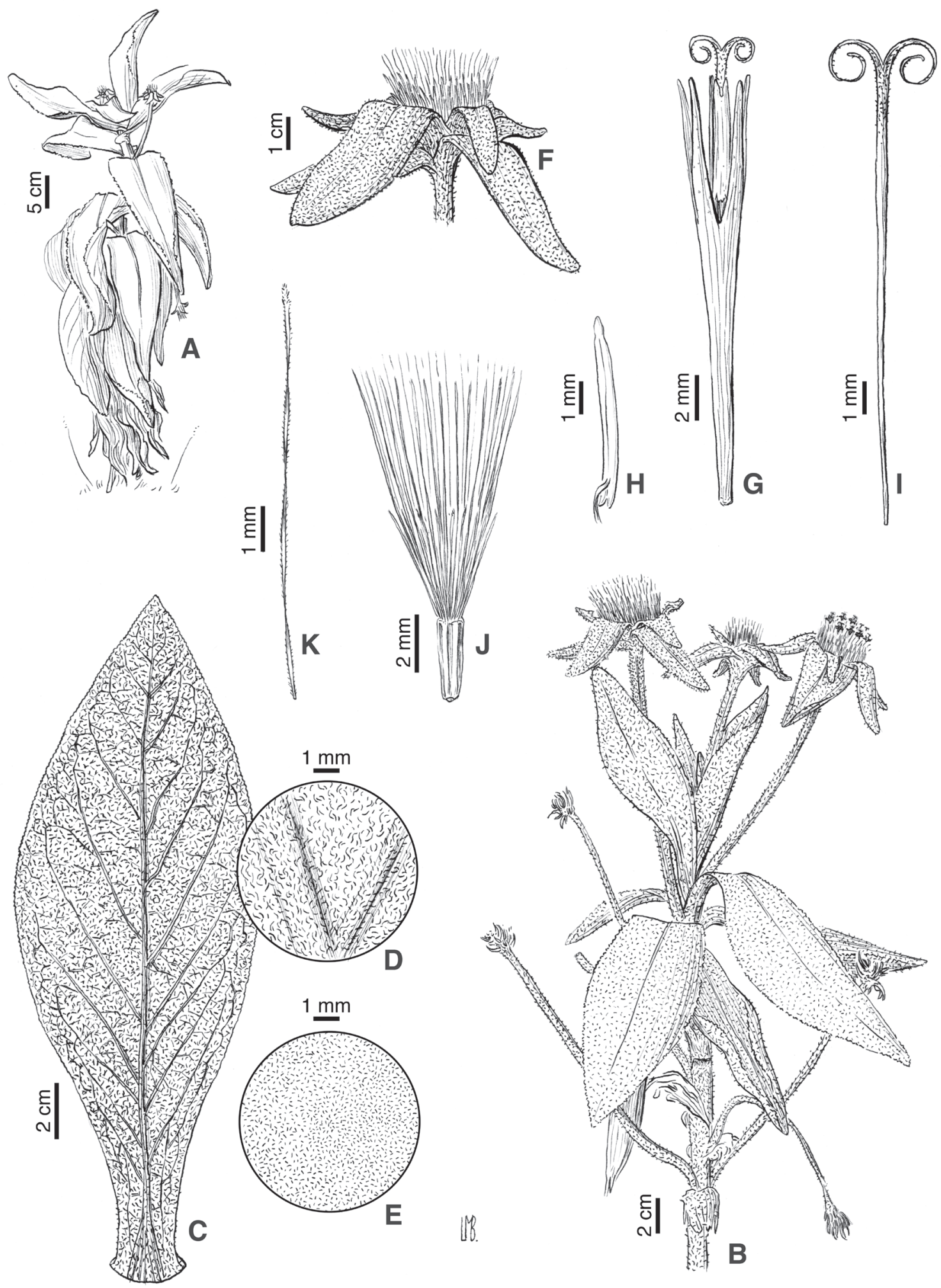

FIG. 4. Heterocoma robinsoniana. A. Habit (From a photograph). B. Flowering branch. C. Leaf, abaxial surface. D. Detail of leaf abaxial surface. E. Detail of leaf adaxial surface. F. Capitulum. G. Corolla. H. Anther. I. Style. J. Cypsela and pappus. K. Inner pappus seta. (From the holotype). 


\section{PART 4.3}

Minasia ramosa (Asteraceae: Vernonieae), a new species from the Serra do Cabral, Minas Gerais, Brazil 

Minasia ramosa (Asteraceae: Vernonieae), a new species from the Serra do Cabral, Minas Gerais, Brazil

\author{
Benoît Loeuille ${ }^{1}$, Harold Robinson ${ }^{2}$, and João Semir ${ }^{3}$ \\ ${ }^{1}$ Departamento de Botânica, Instituto de Biociências, Universidade de São Paulo, Rua do \\ Matão 277,05508-090,São Paulo,Brazil; email: benoit_loeuille@yahoo.fr \\ ${ }^{2}$ Department of Botany, National Museum of Natural History, Smithsonian Institution, \\ Washington, D.C.20560 U.S.A.email: robinsoh@si.edu \\ ${ }^{3}$ Departamento de Botânica, Instituto de Biologia, Universidade Estadual de Campinas, \\ Campinas, SP, Brazil
}





\begin{abstract}
Minasia ramosa, a new species from Brazil, is here described and illustrated. The species is endemic to the campos rupestres of the Serra do Cabral, a western extension of the Espinhaço Range of mountains in Minas Gerais. Minasia ramosa is characterized by its narrow ensiform leaves, paniculate inflorescence and totally setuliferous cypselae. The affinities of this species are discussed.
\end{abstract}

Key words: Lychnophorinae, Espinhaço Range, Compositae, campos rupestres. 



\section{Introduction}

Minasia Robinson (1992: 648) is a small genus of six species of the subtribe Lychnophorinae (Vernonieae: Asteraceae), endemic of the campos rupestres of the Espinhaço Range of mountains (Minas Gerais State) in southeastern Brazil (Loeuille 2010). Minasia species are characteristically perennial rosettiform silvery herbs, with scapose inflorescences and crowded or pedunculate heads (Robinson 2007). The greatest diversity of Minasia species is found in the Planalto de Diamantina, with five of the six species previously described (Semir \& Jesus 2004). With the exception of M. splettiae Robinson (1995: 397), all the species have been listed as critically endangered due to their restricted distributions and small population sizes (COPAM 1997; Fundação Biodiversitas 2005; Nakajima et al. 2009). Furthermore, Jesus et al. (2009) have found that the genetic variation of Minasia species is low, and that a substantial portion of genetic diversity could be lost in case of extinction of a single population.

Robinson (1996) considered one Minasia specimen (G. Hatschbach et al. 64718) from the Serra do Cabral different from all other specimens ascribed to Minasia species seen at that time, including M. cabralensis Robinson (1996: 350), which occurrs in the same area. The totally setuliferous cypsela and general inflorescence form are similar to M. pereirae Robinson (1992: 650), but the specimen (G. Hatschbach et al. 64718) does not have the typical oblanceolate leaves typical of that species. Robinson (1996) considered a more complete representation of M. pereirae necessary to identify this specimen.

In the course of their genetic study of Minasia, Jesus et al. (2009) noticed an interesting allozyme variation for M. cabralensis, the only species of Minasia known at that time for Serra do Cabral. Of the six populations sampled for the area and ascribed by Jesus et al. (2009) to $M$. cabralensis, two populations ( $c a b-e$ and $c a b-f$ ) differed noticeably from the other four populations sampled ( $c a b-a, c a b-b, c a b-c$ and $c a b-d$ ), which in terms of genetic distance ended closer to the other Minasia species studied rather than closer to conspecific populations. Further, variation in the overall size and color of the leaves among the populations of Minasia from Serra do Cabral was also observed in the field by these authors.

During the preparation of a synopsis for the subtribe Lychnophorinae by the first author (BL), it became clear that two different species occur in the Serra do Cabral. Therefore, a new species of Minasia, M. ramosa Loeuille, Robinson \& Semir, is here described and its affinities are discussed. 


\section{Taxonomic treatment}

Minasia ramosa Loeuille, Robinson \& Semir, sp. nov. (Fig. 1)

Species M. cabralensi similis sed inflorescentia paniculata (non capitulo plerumque solitario) et foliis longioribus differt.

Type:- BRAZIL: Minas Gerais: Joaquim Felício, Serra do Cabral, início da subida, 900 m, fl.

fr., 14 April 1996, G. Hatschbach, A. Schinini \& J.M. Silva 64718 (holotype: ESA, isotypes: CTES [not seen], MBM, US [×2]).

Perennial herb to $1.5 \mathrm{~m}$ tall; xylopodium obconic or napiform; stem $2.5-8 \mathrm{~cm}$ tall, obscured by surrounding leaf sheaths. Leaves forming rosettes, simple, sessile, sheaths $0.4-1.5 \mathrm{~cm}$ long, whitish lanulose, rarely glabrescent; blade $6.18-26.2 \times 0.11-1.25 \mathrm{~cm}$, very narrowly ensiform, rarely lanceolate, usually carinate, argenteus to dark green tomentulose on both sides, T-shaped hairs, densely appressed, midrib prominent and furrowed beneath, slightly prominent above, venation pinnate, ascending veins inconspicuous, margins entire, apex attenuate, base slightly truncate. Inflorescence scapose, 50.8-88.4 cm long, scape partially with foliose bracts, 1 or 2 per rosette, greyish to ferrugineous tomentose, panicle sparsely branched, internodes 1.64-10.28 $\mathrm{cm}$ long, lateral branches $2-9 \mathrm{~cm}$ long, with 2 to 8 capitula, more or less congested; scape bracts sessile, linear to narrowly elliptic, $0.75-8.4 \times 0.08-0.3 \mathrm{~cm}$. Capitula homogamous, discoid, sessile to pedunculate, peduncles up to $2 \mathrm{~cm}$ long; involucre campanulate, 5-11 $\times 4.2-10 \mathrm{~mm}$; phyllaries 5-6-seriate, weakly imbricate, outer phyllaries narrow to widely ovate, sometimes triangular, 2-4.1 × 0.9-2.6 mm, apex obtuse, rarely acute, densely tomentose, stramineous with apical portion usually dark brown, margins membranaceous and fimbrillate, inner phyllaries lanceolate, rarely narrowly elliptic, 6.2-7.8 $\times 0.9-1.5 \mathrm{~mm}$, apex acute, glabrous except apical portion densely pilose, stramineous with apical portion dark brown, margins slightly fimbrillate; receptacle flat, glabrous, fimbrillate with fimbriae unequal in length up to ca. 2 $\mathrm{mm}$. Florets 24 to 46, bissexual, fertile; corolla actinomorphic, 5-lobed, lilac, tube 5.3-7.7 $\times$ 0.5-1.3 mm, glandular-punctate, lobes $2.2-3.5 \times 0.4-0.7 \mathrm{~mm}$, apices acute, tomentulose; apical anther appendages narrowly ovate, more or less twice as long as wide, basal anther appendages sagittate; style $0.9-1.4 \mathrm{~cm}$, style shaft glabrous throughout except for pubescent upper ca. 2 $\mathrm{mm}$ beneath style arms, style base glabrous, lacking basal node, with nectariferous disc, style arms 1.7-2.9 mm long, short pubescent outside throughout. Cypsela 2.1-3.6 × 0.9-1.3 mm, 4-angled, 10-ribbed, setuliferous indumentum usually denser towards the base, twin-hairs with cells fused to near the tip, glandular-punctate; carpopodium annular; pappus biseriate, setose, pale stramineous, rarely reddish, straight or slightly twisted, persistent, outer series 1.1-2.3 mm long, barbellate, inner series 5.2-7.3 mm long, barbellate, apices slightly dilated.

Distribution:- Currently known only from Serra do Cabral in the Espinhaço Range, Minas Gerais state, southeastern Brazil. It grows in campos rupestres, frequently found in small patches of white sand, at 900-1050 m elevation. 
Conservation Status:- The new species, according to IUCN Red list category (IUCN 2010), is considered Vulnerable (B1a, B2a) ), since its area of occurrence is smaller than 20,000 $\mathrm{km}^{2}$, its area of occupancy is smaller than $2,000 \mathrm{~km}^{2}$, and it is known from no more than ten localities.

Etymology:- The specific epithet refers to the branched pattern of the inflorescence of the species.

Additional specimens examined (paratypes):- BRAZIL: Minas Gerais: Joaquim Felício, estrada pela Serra do Cabral, 17 April 1981, L. Rossi et al. CFCR 1064 (K, SPF); Serra do Cabral, curva do Córrego Jucão, $17^{\circ}$ 41' 49.8” S, 44 16’ 42.6” W, 27 April 1997, T.M. Lewinsohn et al. PIC97001 (UEC); Serra do Cabral, 17 41' 51.6” S, 44 15' 47.4" W, 27 April 1997, T.M. Lewinsohn et al. PIC 97013 (UEC); Garimpo, próximo a casa do garimpeiro, 17 41'36" S, 44 11'31.8" W, 28 April 1997, T.M. Lewinsohn et al. PIC 97019 (UEC); Paredão do Topo, $17^{\circ}$ 42' 27” S, 44 11'31.2” W, 28 April 1997, T.M. Lewinsohn et al. PIC 97022 (UEC); Serra do Cabral, 2 May 2000, E.L. Borba 572 (UEC); estrada Joaquim Felício-Várzea da Palma, $17^{\circ} 42^{\prime}$ 27' S, 44 11'37.1” W, 1026 m, 3 June 2008, B. Loeuille et al. 432 (HAW, K, MO, SPF, US);

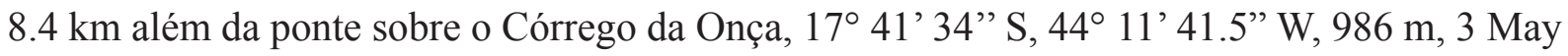
2009, R. Mello-Silva 3223 (SPF).

Discussion:- The overall size of Minasia ramosa is similar to M. alpestris and M. scapigera, but these two species differ from the new species by their more congested inflorescences of fewer heads and cypselae with glabrous to glabrescent distal half (vs. totally setuliferous). The new species appears to be related to $M$. pereirae by its determinate inflorescence and totally setuliferous cypselae but $M$. ramosa is more robust with narrowly ensiform leaves (not oblanceolate) up to $25 \mathrm{~cm}$ long (vs. $8 \mathrm{~cm}$ long). M. lewinsohnii may have pedunculate heads like in the new species but it differs by its smaller scape (9.3-26 cm long vs. $50.8-88 \mathrm{~cm}$ long), shorter and more fleshy leaves and has been found only in the Planalto de Diamantina (Semir \& Jesus 2004). Minasia cabralensis is easily distinguished from the new species by its always pedunculate and usually solitary heads, as well as by its smaller leaves (up to $16 \mathrm{~cm}$ long). Minasia ramosa is sympatric with $M$. cabralensis, both endemics of the Serra do Cabral region.

Allozyme variation has been studied for two from the Serra do Cabral (Jesus 2001; Jesus et al. 2009). The specimens cited by (Jesus 2001) as vouchers for populations $c a b-a, c a b-b, c a b-c$ and cab-d (Lewinsohn PIC 97001, 97013, 97019 and 97022 respectively), and identified as Minasia cabralensis by these authors correspond with M. ramosa. Lewinsohn PIC 97010 and Lewinsohn PIC 97012, the vouchers of the populations cab-e and cab-f respectively, correspond with Minasia cabralensis. 


\section{Diagnostic key to the species of Minasia}

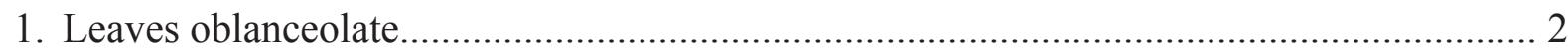

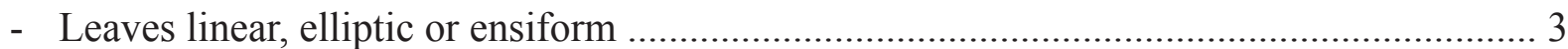

2. Leaves 12-22 cm long, 2.5-4.5 cm wide; florets 20-25; cypselae with setiluferous base and glabrous distal half M. alpestris

- Leaves 5-8 cm long, 0.5-1 cm wide; florets ca. 40; cypselae with numerous setulae over whole surface M. pereirae

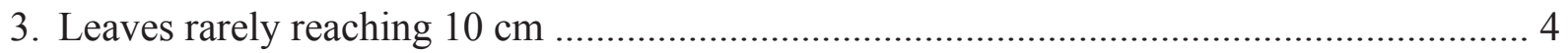

- Leaves mostly longer than $10 \mathrm{~cm}$ long (up to $30 \mathrm{~cm}$ long)............................................... 5

4. Leaves $0.2-0.8 \mathrm{~cm}$ wide, subfleshy; florets $21-43$...................................... M. lewinsohnii

- Leaves $0.1-0.2 \mathrm{~cm}$ wide, thin; florets $12-15$...................................................... splettiae

5. Inflorescence with heads congested in subspherical clusters ............................. . scapigera

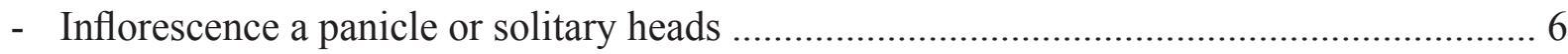

6. Leaves 10-16 cm long, 0.4-0.7 mm wide; heads always pedunculate; cypselae with setiluferous base and glabrous distal half M. cabralensis

- Leaves 6.18-26.2 cm long, 0.11-1.25 cm wide; heads sessile to pedunculate; cypselae totally setuliferous

M. ramosa

\section{Acknowledgments}

Thanks are due to Leonardo M. Borges for the line illustrations, to CNPq (Brazil) and the Cuatrecasas Travel Award Committee for the fellowships awarded to first author. The authors would like to thank the curators of all the herbaria listed in the text for loaning the specimens, D.J.N. Hind, M. Dematteis and an anonymous reviewer are thanked for their comments on the manuscript.

\section{References}

COPAM - Conselho Estadual de Política Ambiental (1997) Lista de espécies ameaçadas de extinção da flora do Estado de Minas Gerais. Deliberação COPAM 085/97. Available from: http://www.biodiversitas.org.br/florabr/MG-especies-ameacadas.pdf (09/28/2010).

Fundação Biodiversitas (2005) Lista da flora brasileira ameaçada de extinção. Workshop "Revisão da Lista da flora brasileira ameaçada de extinção". Available from: http://www. biodiversitas.org.br/cepf/edital/flora_brasil.pdf(09/28/2010).

IUCN (2010) Guidelines for Using the IUCN Red List Categories and Criteria. Version 8.1. Prepared by the Standards and Petitions Sub-Committee in March 2010. Available from: http://intranet.iucn.org/webfiles/doc/SSC/RedList/RedListGuidelines.pdf (4 February 2011).

Jesus, F.F. (2001) Variabilidade genética em Proteopsis Mart. \& Zucc. e Minasia H. Rob. (Asteraceae: Vernonieae), gêneros endêmicos de campos rupestres. M.Sc. Thesis. Universidade Estadual de Campinas, Campinas. 
Jesus, F.F., Abreu, A.G., Semir, J., \& Solferini, V.N. (2009) Low genetic diversity but local genetic differentiation in endemic Minasia (Asteraceae) species from Brazil. Plant Systematics and Evolution 277 (3-4): 187-196.

Loeuille, B. (2010) Minasia. In: Forzza, R.C. et al. (eds), Catálogo de Plantas e Fungos do Brasil, volume 1. Andrea Jakobsson Estúdio, Instituto de Pesquisas Jardim Botânico do Rio de Janeiro, Rio de Janeiro, p 727.

Nakajima, J.N., Teles, A.M., Ritter, M., Mondin, C.A., Dematteis, M., Heiden, G., Borges, X.B., Rivera, V.L., Bringer Jr., J.B.A., Saavedra, M., de Cássia Araújo Pereira, R., \& Salesde-Melo, M.R.C. (2009) Asteraceae. In: Giulietti, A.M. et al. (eds): Plantas raras do Brasil. Conservação Internacional, Universidade Estadual de Feira de Santana, Belo Horizonte, pp. $76-89$.

Robinson, H. (1992) Notes on Lychnophorinae from Minas Gerais, Brazil, a synopsis of Lychnophoriopsis Schultz-Bip., and the new genera Anteremanthus and Minasia (Vernonieae: Asteraceae). Proceedings of the Biological Society of Washington 105 (3): 640-652.

Robinson, H. (1995) New combinations and new species in American Vernonieae (Asteraceae). Phytologia 78 (5): 384-399.

Robinson, H. (1996). A new species of Minasia from the Serra do Cabral, Minas Gerais, Brazil (Vernonieae: Asteraceae). Phytologia 80 (5): 350-351.

Robinson, H. (2007) [2006]. Tribe Vernonieae. In: Kadereit, J. \& Jeffrey, C. (vol. eds), Vol. 8: Asterales. The families and genera of vascular plants, (K. Kubitzki, series ed.). Springer. Berlin, Heidelberg, New York, pp. 149-174.

Semir, J. \& Jesus, F.F. (2004). A new species of Minasia (Asteraceae, Vernonieae) from the Planalto de Diamantina, Minas Gerais, Brazil. 


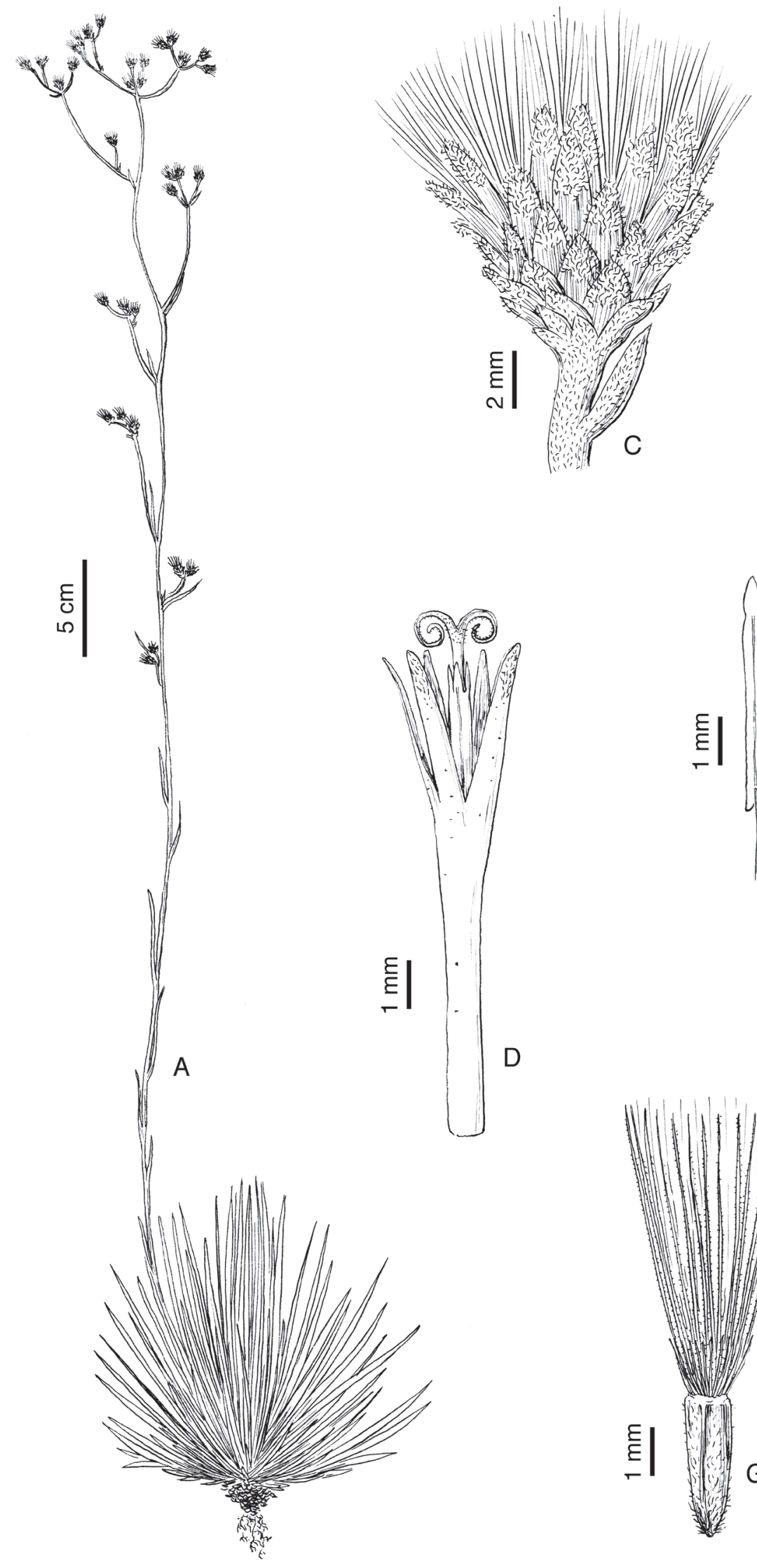



\section{PART 4.4}

A new species of Paralychnophora (Asteraceae: Vernonieae) and comments on the identity of $P$. bicolor 

A new species of Paralychnophora (Asteraceae: Vernonieae) and comments on the identity of $P$. bicolor

Benoît Loeuille ${ }^{1}$, João Semir ${ }^{2}$, and José Rubens Pirani ${ }^{1}$

${ }^{I}$ Departamento de Botânica, Instituto de Biociências, Universidade de São Paulo, Rua do Matão 277, 05508-090, São Paulo, Brazil.E-mail: benoit_loeuille@yahoo.fr

${ }^{2}$ Departamento de Botânica, Universidade Estadual de Campinas, C.P. 6109, 13083-970, Campinas, São Paulo, Brazil. E-mail: semir@unicamp.br 



\begin{abstract}
The type of the name Paralychnophora bicolor was found to represent another species of the genus, recently described, known as $P$. santosii. The misapplication of the name P. bicolor name is reviewed. A new species is here proposed, P. glaziouana, for the plants identified by recent authors as $P$. bicolor, since the only available name, $P$. schwackei, is an illegitimate combination.
\end{abstract}

Key words: Asteraceae, nomenclature, Vernonieae. 

Albertinia bicolor DC. was described by Candolle in 1836, based on a collection of Martius from Minas Gerais, Brazil. Schultz-Bipontinus (1863) recognized it as a member of a distinct genus, Sphaerophora. However, it was transferred to Eremanthus Less. by Baker (1873). Later MacLeish (1984a) acknowledged it again as a separate genus and proposed a new name: Paralychnophora MacLeish to replace Sphaerophora Sch. Bip., a later homonym of Sphaerophora Blume (Blume, 1850), and stated putative relationships to Eremanthus Less. and Lychnophora Mart. Further that species has been variously considered under Eremanthus (following the sense of Baker, 1873; see Robinson, 1997, 1999, 2006) or under Lychnophora (Semir, 1991). A review of this controversy can be found in Hind (2000). Currently the genus Paralychnophora contains six species.

A wide taxonomic circumscription has prevailed for Paralychnophora bicolor (DC.) MacLeish until the recognition by MacLeish (1984a, 1984b) of two others species in the genus: P. schwackei (Glaz.) MacLeish (see below) and P. reflexoauriculata (G.M. Barroso) MacLeish, both taxa initially described as members of Eremanthus by Glaziou (1909) and Barroso (1962). Robinson (1997) refined the concept of P. bicolor (as Eremanthus bicolor (DC.) Baker), describing two new species, E. harleyi H. Rob. and E. santosii H. Rob. upon material previously identified as P. bicolor from Bahia, northeastern Brazil.

Robinson (1997) put Paralychnophora schwackei (Glaz.) MacLeish under synonymy with P. bicolor. Despite noting that the material determined as $P$. schwackei differs from typical material of $P$. bicolor by shape and size of leaves, he concluded that E. bicolor and E. schwackei are the same species as both types are from Minas Gerais and Candolle and Baker's descriptions state that there are 2-3 florets per head. A similar conclusion had been reached by Semir (1991) in his unpublished revision of Lychnophora. Subsequently the name Paralychnophora bicolor has been applied to plants occurring in Minas Gerais using the identification key of Robinson (1997) or Semir (1991).

In the course of systematic studies on the subtribe Lychnophorinae, the first author examined type material of all species of the genus Paralychnophora. Unexpectedly the type material of $P$. bicolor matches perfectly the description of $P$. santosii and not the one provided for $P$. bicolor in Robinson (1997): the leaf base of the Martius collection is typicaly narrowly cuneate and broadly recurved. On the other hand, the type material of $P$. schwackei utterly agrees with the description of $P$. bicolor in the same paper. Interestingly, in an unpublished revision of Paralychnophora MacLeish (1984b) reached the same conclusion, but she was not able to notice the existence of more than one species among the material usually identified as $P$. bicolor from Bahia.

In the light of the examination of the type material of Albertinia bicolor (the basionym of Paralychnophora bicolor) it seems clear that the name $P$. bicolor must be applied to the plants previously known as $P$. santosii, andthe proper synonyms are formally presented below. 
Paralychnophora bicolor (DC.) MacLeish, Taxon 33: 106. 1984. Albertinia bicolor DC., Prodr. 5: 81. 1836. Lychnocephalus bicolor Mart. ex DC., nom. illeg. pro syn., Prodr. 5: 81. 1836. Vanillosmopsis bicolor (DC.) Sch. Bip., Jahresber. Pollichia 18 - 19: 168 (1861). Sphaerophora bicolor (DC.) Sch. Bip., Jahresber. Pollichia 20 - 21: 403. 1863. Eremanthus bicolor (DC.) Baker in Mart., Fl. bras. 6(2): 165. 1873. Type: Brazil. Minas Gerais: 'Habitat in altis ; Provinciae Minarum', Martius s.n. (530) (holotype: M [digital image M-0029459]; isotypes: M n.v., P).

Eremanthus santosii H. Rob., Rhodora 98: 88. 1996 [1997]. Paralychnophora santosii (H. Rob.) D. J. N. Hind, Kew Bull. 55: 370. 2000. Type: Brazil. Bahia: Santa Maria Eterna, 1 a $2 \mathrm{~km}$ de estrada de Canavieires [Canavieiras], 18 May 1970, Santos 820 (holotype: CEPEC n.v.; isotype: US). syn. nov.

An ultimate fact remains unexplained: the label of $P$. bicolor type collection indicates 'Habitat in altis; Provinciae Minarum' [Minas Gerais state]. However, the species has never again been collected in Minas Gerais; all other specimens of P. bicolor further collected are from Bahia. A similar case is reported by Semir (1991) with the holotype of Lychnophora uniflora Sch. Bip., a collection by Martius whose label indicates Minas Gerais while all other known specimens come from Bahia. The question remains whether that species has a wider distribution than currently thought, or if it is truly endemic to Bahia, with the citation to Minas Gerais a matter of mistake on the type label.

On the other hand, another name is necessary for the plants previously identified as P. bicolor. Unfortunately Glaziou (1909) failed to validly publish Eremanthus schwackei (nomen nudum), and consequently the combination proposed by MacLeish is illegitimate. So these plants are described here as a new species, P. glaziouana Loeuille, as follows.

Paralychnophora glaziouana Loeuille, sp. nov.Type: Brazil. Minas Gerais: Diamantina, estrada para Conselheiro Mata, km 185, 26 July 1986, Mello-Silva et al. CFCR 9962 (holotype: SPF; isotypes: $\mathrm{BHCB}, \mathrm{F}, \mathrm{K}$ )

Eremanthus schwackei Glaz., nom. nud., Bull. Soc. France 56, Mém. 3e: 380. 1909. Paralychnophora schwackei (Glaz.) MacLeish, comb. illeg., Taxon 33: 106. 1984.

Species Paralychnophora bicolori similis, sed foliis plerumque late oblongis vel ovatis rarioribus late ellipticis, ellipticis vel obovatis (non oblanceolatis), basi rotundata et truncata (non cuneata), supra pagina ordinate minute alveolata (non minute bullata vel rugulosa) et margine nullo modo revoluto (non saepe late revoluto).

Tree or treelet, 1-5 m, sparsely branched. Stems cylindrical, light ochraceous to grey, becoming darker with age, velutinous to lanulose, leaf scars linear. Leaves alternate, simple, 
with a semi-amplexicaul sheath, $0.37-1 \times 0.37-0.8 \mathrm{~cm}$, petiolate, petioles $0.52-3.5 \mathrm{~cm}$ long, furrowed, lanulose; blade 3.9-14 × 2.3-7.2 cm, coriaceous, wide oblong or ovate, more rarely wide elliptic to elliptic or narrow to wide obovate, green to greyish, glabrate, tomentulose when young, slightly scrobiculate to minutely faveolate above, dirty white to greyish, lanulose beneath, stellate hairs, midrib sunken and furrowed above, prominent and sulcate beneath, venation brochidodromous, secondary veins 7-18, margins entire, apices obtuse to rounded, sometimes emarginate, base slightly asymmetrical, rounded, truncate. Inflorescence a syncephalium (secondary order inflorescence), terminal on long axillary side branch, usually solitary, rarely 2-3 syncephalia juxtaposed into a tertiary order inflorescence, the side branches $7.2-29.8 \mathrm{~cm}$ long, 0.15-2.4 mm diam., sulcate, cylindrical, light ochraceous, velutinous to lanulose, with median leaf-like bracts, $0.9-4.5 \times 0.3-2.15 \mathrm{~cm}$, subopposite or opposite, sometimes alternate, upper leaf-like bracts forming a sub-syncephalium whorl, syncephalium 0.9-3.6 cm tall, 1.6$4.2 \mathrm{~cm}$ diam, hemispherical to subspherical. Capitula 80-150, homogamous, discoid, sessile, closely appressed, fused entire length; involucre 4.35-7 mm long, cylindrical; phyllaries in 3-4 subequal series, 3.85-6.3 × 0.4-0.75 mm, linear, paleaceous, stramineous, brown towards the apices, upper half densely white lanate, apices acute, becoming recurved after cypsela dispersal, margins entire, inner phyllaries deciduous; receptacle flat, with few fimbriae up to ca. $1 \mathrm{~mm}$. Florets (2-) 3-4, hermaphrodite, fertile; corolla actinomorphic, 5-lobed, light lilac to pinkish; corolla tube 1.85-4.35 mm long, cylindrical, glabrous; corolla lobes $1.75-3.5 \mathrm{~mm}$ long, acuminate, with few hairs distally not extending beyond lobe tip, sometimes glabrous, glandular-punctate; apical anther appendages lanceolate, three to four times longer than wide, basal anther appendages sagittate; style 4.3-9.8 mm long, style shaft glabrous throughout except for pubescent upper ca. $1 \mathrm{~mm}$ beneath style arms, style base glabrous, lacking basal node, with nectariferous disc, style arms 1.9-2.5 mm long, short pubescent outside throughout. Cypsela 1.95-3.75 × 0.7-1.7 mm, fusiform to slightly turbinate, angled, glabrous, light brown, darker towards the apex, carpopodium annular; pappus bisseriate, whitish to light stramineous, deciduous, bristles strigose, outer series setae $0.95-2.38 \mathrm{~mm}$ long, paleaceous to subpaleaceous, straight, inner series setae 4.2-6.4 mm long, subpaleaceous or filiform, straight or rarely twisted, apices somewhat broadened, sometimes slightly fused at the base with the outer setae.

Distribution and habitat. - Endemic to the Espinhaço Range in Minas Gerais state, Brazil. It occurs in campos rupestres, amongst rocks at 750 to $1520 \mathrm{~m}$ elevation.

Conservation status. - P. glaziouana has been listed (under the name P. bicolor) as vulnerable due to its restricted distribution (COPAM, 1997). However, the species does not appear on the "Plantas Raras do Brasil" list (Nakajima et al., 2009). Based on current available information about P. glaziouana, it can be scored as Least Concern (LC), according to IUCN conservation criteria (IUCN, 2001).

Etymology. - Paralychnophora glaziouana is named in honor of Auguste François Marie Glaziou (1828-1906), the first to perceive this species as distinct from P. bicolor but failed to validly publish it (see above). 
Additional material examined. BRAZIL. Minas Gerais: Mun. Bocaiúva, National Park Sempre Vivas, caminho entre Campos de São Domingos e Serra do Landi, 1754'08'S, 4346’23”W, 1282 m, 29 Apr. 2007, Almeida et al. 879 (BHCB); Mun. Curvelo, Diamantina richtung Curvelo, 16 km nach Curvelo, 1200 m, 7 Sept 1981, Schumacher 1123 (MB, RB); Mun. Datas, a 2 km de Datas, 18¹9'31'S, 4341'34”W, 1520 m, 21 Sept 1998, Bautista \& Ortiz 2779 (HRB); Mun. Diamantina, 1 Feb 1947, Egles s.n. (RB); ca. 12 km SW of Diamantina, 18¹6'S, 4342'W, 23 Jan 1969, Irwin et al. 22485 (NY, UB); ca. 18 km E of Diamantina, 18¹1'02”'S, 43॰32'12’'W, 19 Mar 1970, Irwin et al. 27887 (NY, UB, US); Serra do Cruzeiro, 11 May 1979, Ferreira et al. 868 (RB); estrada Diamantina-Conselheiro Mata, km 190, 18 July 1980, Menezes et al. CFCR 101 (SPF, UEC); between Mendanha and Diamantina, $10 \mathrm{~km}$ NE of Diamantina on estrada 367, 4 Oct 1980, Macleish et al. 701 (GA, GH, NY, RB, US); estrada Diamantina-Conselheiro Mata, $5 \mathrm{~km}$ de Diamantina, 30 Aug 1981, Giulietti et al. CFCR

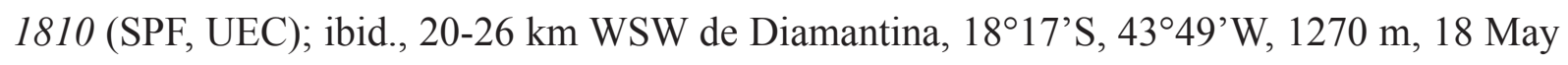
1990, Arbo et al. 4353 (CTES, SPF, UEC); ibid., 6 Aug 1990, Sakuragui \& Souza 237 (ESA); ibid., a 22 km da estrada Diamantina-Gouveia, 18¹7'43”S, 4350'34'W, 1180 m, 8 July 2001, Souza et al. 25417 (ESA, K, MBM); ibid., km 190, 18¹5'43'’S, 4341'39'W, 1280 m, 22 Jan 2007, Loeuille et al. 94 (MBM, SPF); Mun. Gouveia, ca. $35 \mathrm{~km} \mathrm{SW}$ of Gouveia, km 243 on MG 259, 2 Feb 1972, Anderson et al. 35116 (NY, RB, US); 1100 m, 3 June 1985, Martins et al. s.n. (UEC, UFMT); estrada para Barão de Guarani, 24 July 1998, Hatschbach et al. 68170 (BHCB, ESA, MBM, US); Mun. Grão Mogol, summit of Serra Grão Mogol, 900 m, 17 Aug 1960, Maguire et al.49247 (NY, RB, US); Ribeirão, 23 Apr 1978, Hatschbach 41421 (MBM, NY, US); em direção NE da cidade, 16³2'S, 4255'W, 1066 m, 22 May 1982, Mamede et al. CFCR 3466 (BHCB, K, SPF); estrada para Botumirim, Morro do Chapéu, entre Mombucas e Boa Vista do Bananal, 22 July 1985, Martinelli et al. 11267 (BHCB, NY, RB); Jambeiro, à 7 km de Grão Mogol, 5 Nov 1985, Cavalcanti et al. CFCR 8518 (SPF, UEC); Ribierão dos Bois, 890 m, 2 Nov 1986, Cordeiro \& Mello-Silva CFCR 10009 (BHCB, K, SPF, UEC); montanha à esquerda do riacho Ribeirão, trilha da Tropa, 16³3'S, 42 $54^{\circ}$ 'W, 850 m, 3 Nov 1987, Cordeiro et al. CFCR 11407 (K, SPF, UEC); subida para Pasto, 17 May 1988, Hatschbach et al. 52102 (MBM, US); descida do Morro Papo da Ema para Jambeiro, 1000 m, 15 June 1990, Pirani et al. CFCR 13078 (K, SPF, UEC); Mun. Itacambira, a ca. $2 \mathrm{~km}$ da cidade na estrada para Juramento,

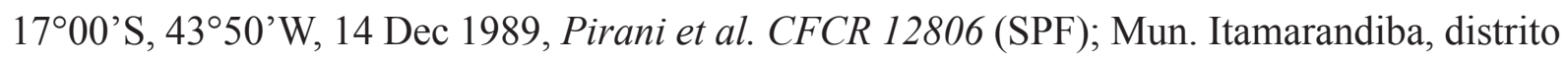
de Penha da França, 1850’S, 4350’W, 1000 m, 11 Mar 1995, Splett 868 (BONN, UB, US); Mun. Itambé do Mato Dentro, proximidades do Canta-Galo, 28 May 1990, Stehmann s.n. (BHCB); Mun. Paracatú, Serra da Anta, ca. 10 NW of Paracatú, 3 Feb 1970, Irwin et al. 25887 a (NY, UEC); Mun. Santana do Riacho [Santana do Pirapama], Serra do Cipó, Fazenda Inhame, 1903'07'S, 4343'55'W, 1222 m, 25 July 2009, Zappi \& Taylor 2233 (K, SPF); Mun. Santana do Pirapama, Serra do Cipó, início da trilha da Senhorinha, 1857'49”S, 4346’30”W, 773 m, 27 Feb 2009, Zappi et al. 1600 (K, SPF); Mun. São Gonçalo do Rio Preto, State Park Rio Preto, trilha para a cascata do Córrego das Éguas, $18^{\circ} 06^{\prime} 54^{\prime}$ 'S, $43^{\circ} 20^{\prime} 28^{\prime}$ 'W, 19 Oct 2000, Lombardi 
4172 (BHCB); próximo da Lapa da Santa, 1100 m, 10 Aug 2004, Viana \& Mota 1820 (BHCB); subida para o alojamento da Chapada, próximo da Lapa da Santa, 20 Mar 2007, Teles et al. 348 (BHCB); base do Pico Dois Irmãos, 20 Mar 2007, Teles et al. 357 (BHCB); Mun. Serro, ca. 3-5 km E of Serro, road to Diamantina, 9 Aug 1960, Maguire et al. 49119 (NY, RB, US); Distrito Augusto Clementino, Pedra do Cruzeiro, 1841'37’'S, 43²7’30'W, 774 m, 9 June 2008, Loeuille et al. 451 (K, HAW, SPF).

Paralychnophora glaziouana is closely related to $P$. bicolor by its low number of florets per capitulum (2-4 in the former, 2-3 in the latter species), the other species of the genus having more than six florets per capitulum. However, the new species is easily distinguished from P. bicolor by its usually wide oblong or ovate leaves with rounded and truncate bases (vs. oblanceolate with cuneate bases), the upper surface of the leaf is regularly minutely alveolate (vs. minutely bullate or rugulose) and the margins are never revolute (vs. often broadly revolute) (Fig. 2). P. glaziouana can be confused with P. harleyi, but that species has 5-12 florets per capitulum and larger syncephalia. In terms of distribution, $P$. glaziouana is known only from the Espinhaço Range in Minas Gerais state, while P. bicolor occurs in the Chapada Diamantina and Serra das Lontras (Bahia state) (Amorim et al., 2010) and $P$. harleyi is restricted to the Chapada Diamantina.

\section{Acknowledgments}

The drawings were prepared by Leonardo M. Borges of the Departamento de Botânica, Instituto de Biociências, Universidade de São Paulo. The authors would like to thank the herbarium Botanische Staatssammlung München for the digital image of the holotype of Albertinia bicolor. The first and third authors acknowledge CNPq for financial support.

\section{Literature Cited}

Amorim, M. A., Jardim, J. G., Mendes Lopes, M. M., Fiaschi, P., Borges, R. A. X., Perdiz, R. D. de, \& Thomas, W. W. 2010. Angiospermas em remanescentes de floresta montana no sul da Bahia, Brasil. Biota Neotropica 9: 313-348.

Baker, J. G. 1873. Compositae I. Vernoniaceae. In: C. F. P. von Martius \& A. W. Eichler (eds.), Flora brasiliensis 6(2): 5-180. Fried. Fleischer, Münich, Vienna, Leipzig.

Barroso, G. M. 1960-1961 [1962]. Compositae Novae. Rodriguésia 35/36: 5-9.

Blume, C. L. 1850. Museum Botanicum, Lugduno-Batavum sive stirpium exoticarum, novarum vel minus cognitarum ex vivis aut siccis. 1(12): 179. Leiden (E. J. Brill).

Candolle, A. P. de. 1836. Vernoniaceae. In: A. P. de Candolle, Prodromus Systematis Naturalis Regni Vegetabilis 5: 9-94. Masson, Paris.

COPAM - Conselho Estadual de Política Ambiental. 1997. Lista de espécies ameaçadas de extinção da flora do Estado de Minas Gerais. Deliberação COPAM 085/97. Available from: http://www.biodiversitas.org.br/florabr/MG-especies-ameacadas.pdf [accessed October 2010]. Glaziou, A. F. M. 1909. Plantae Brasiliae centralis a Glaziou lectae. Liste des plantes du Brésil 
central recueillies en 1861-1895. Bull. Soc. Bot. France 56, Mém. 3e: 297-392.

Hind, D. J. N. 2000. Two new species of Paralychnophora (Compositae: Vernonieae) from Bahia. Kew Bulletin 55: 367-379.

IUCN. 2001. IUCN Red List Categories: version 3.1. Prepared by the IUCN Species Survival Commission. IUCN, Gland, Switzerland and Cambridge, U.K. http://www.iucnredlist.org/ technical-documents/categories-and-criteria/2001-categories-criteria [accessed October 2010]. MacLeish, N. F. F. 1984a. Argyrovernonia and Paralychnophora: new names in the tribe Vernonieae (Asteraceae/Compositae). Taxon 33: 105-106.

1984b. Revision of Eremanthus Less. (Compositae: Vernonieae). PhD thesis, unpublished. University of Georgia.

1987. Revision of Eremanthus (Compositae: Vernonieae). Annals of Missouri Botanical Garden 74: 265-290.

Nakajima, J. N., Teles, A. M., Ritter, M., Mondin, C. A., Dematteis, M., Heiden, G., Borges, X. B., Rivera, V. L., Bringer Jr., J. B. A., Saavedra, M., de Cássia Araújo Pereira, R., \& Salesde-Melo, M. R. C. 2009. Asteraceae. In: A. M. Giulietti et al. (eds): Plantas raras do Brasil. Conservação Internacional, Universidade Estadual de Feira de Santana, Belo Horizonte, pp. 76-89.

Robinson, H. 1997. The Paralychnophora group of Eremanthus (Vernonieae: Asteraceae). Rhodora 98 (no. 893): 85-93.

1999. Generic and subtribal classification of American Vernonieae. Smithsonian Contributions to Botany 89: 1-116.

2006 [2007]. Vernonieae. In: J. Kadereit, C. Jeffrey (vol. eds), Vol. 8: Asterales. The families and genera of vascular plants (K. Kubitzki, series ed.): 149-174. Springer. Berlin, Heidelberg, New York.

Schultz-Bipontinus, C. H. 1863 [1864]. Lychnophora Martius! und einige benachbarte Gattungen. Jahresbericht der Pollichia 20/21: 321-439.

Semir, J. 1991. Revisão taxonômica de Lychnophora Mart. (Vernonieae: Compositae).PhD thesis, unpublished. Universidade Estadual de Campinas, São Paulo. 


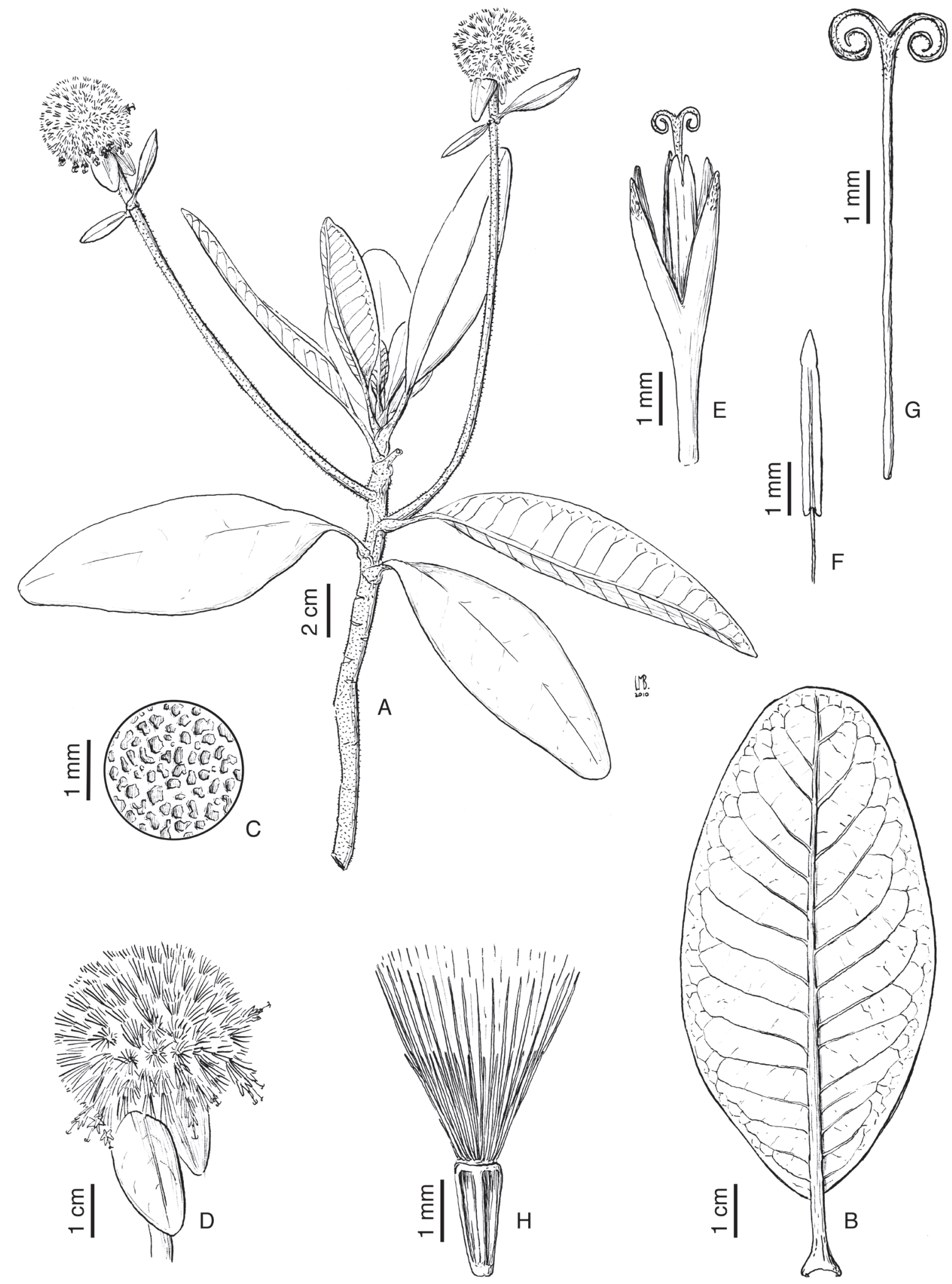

FIG. 1. Paralychnophora glaziouana. A. Habit. B. Leaf, abaxial surface. C. Detail of leaf adaxial surface. D. Syncephalium. E. Corolla. F. Anther. G. Style. H. Cypsela and pappus. (Drawn from the holotype). 

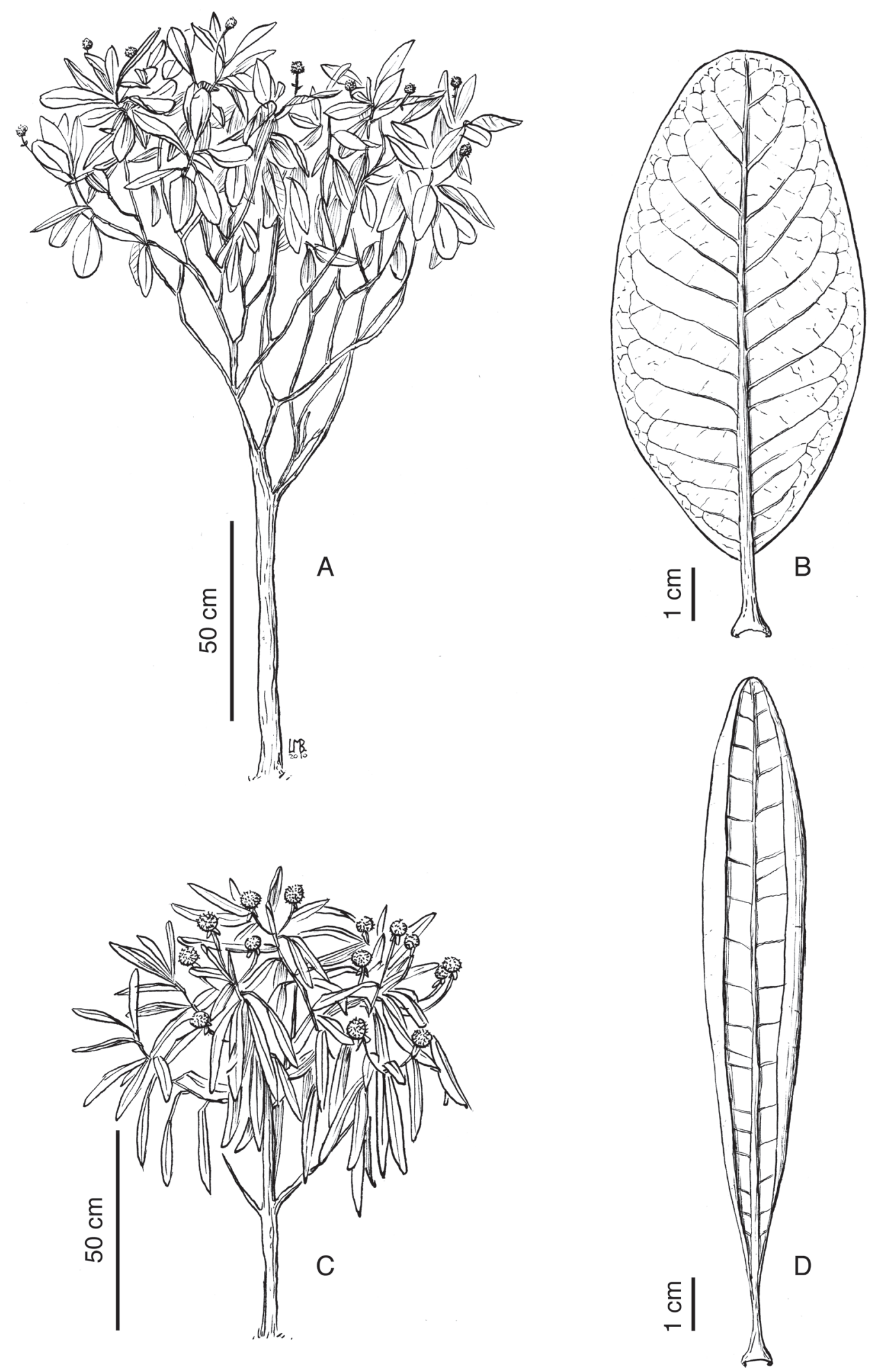

FIG. 2. Paralychnophora glaziouana. A. Habit. (Drawn from a photograph). B. Leaf, abaxial surface. (Drawn from the holotype). Paralychnophora bicolor. C. Habit. (Drawn from a photograph). D. Leaf, abaxial surface. (Drawn from Bondar 2601, SP). 


\section{PART 4.5}

Three new species of Piptolepis (Compositae: Vernonieae) from Minas Gerais, Brazil 

Three new species of Piptolepis (Compositae: Vernonieae) from Minas Gerais, Brazil Benoît Loeuille ${ }^{1}$, João Semir ${ }^{2}$, David .J.N. Hind ${ }^{3}$, and José R. Pirani

${ }^{1}$ Departamento de Botânica, Instituto de Biociências, Universidade de São Paulo, Rua do Matão 277, 05508-090, São Paulo, Brazil.E-mail: benoit_loeuille@yahoo.fr ${ }^{2}$ Departamento de Botânica, Instituto de Biologia, Universidade Estadual de Campinas, Campinas, SP, Brazil.

${ }^{3}$ Herbarium, Royal Botanic Gardens, Kew, Richmond, Surrey, TW9 3AB, U.K. 

Summary. Three new species of Piptolepis, P. campestris, P. monticola and P. schultziana, are described and illustrated from Minas Gerais State, Brazil. Diagnostic characters, descriptions and taxonomic comments on the species are given. Their affinities are assessed and IUCN threatened categories noted.

Key Words. Asteraceae, taxonomy, Lychnophorinae, new species. 



\section{Introduction}

Piptolepis Sch.Bip. (Compositae) is a small genus of Vernonieae subtribe Lychnophorinae endemic to the campos rupestres of the Espinhaço Range in Minas Gerais, Brazil. Its species are characteristically shrubs with a solitary terminal capitulum or with a few capitula in a dense terminal cluster, deciduous inner phyllaries, biseriate pappus of flattened bristles, the outer series sometimes shorter than the inner, and usually deciduous (Hind, 2003; Robinson, 2006).

Schultz-Bipontinus (1863) recognised two sections: sect. Microphyllum Sch.Bip.(= sect. Piptolepis by typification of the genus by Jeffrey and Hind (1994)), defined by small leaves and solitary capitula, including P. buxoides (Less.) Sch.Bip., P. ericoides Sch.Bip., P. imbricata (Gardner) Sch.Bip. and P. leptospermoides (Mart. ex DC.) Sch.Bip.; and sect. Macrophyllum Sch.Bip., defined by larger leaves and cluster of capitula, including P. martiana (Gardner) Sch. Bip., P. oleaster (Mart. ex DC.) Sch.Bip. and P. pseudomyrtus (A. St.-Hil.) Sch.Bip.

Baker (1873) presented the last treatment of the genus. He basically proposed three informal groups via his use of a trichotomous key, two of them identical to Schultz-Bipontinus's sections and a third to accommodate $P$. martiana, which he erroneously considered to bear solitary capitula. He also described a new species, P. gardneri Baker. Beauverd (1913) described another species, $P$. glaziouana Beauverd. These two latter species have not been assigned to a section. The genus then included nine species.

The present study brings preliminary results of an ongoing taxonomic review of Piptolepis, based on intensive field work in the campos rupestres of Eastern Brazil. We report three new species that have been found during this investigation.

\section{Descriptions}

Piptolepis campestris Semir \& Loeuille. sp. nov. affinis $P$. oleastra foliis supra argentea canescentia et fasciculis capitulorum paucorum sed foliis ellipticis, raro anguste oblongis ad anguste obovata (non oblanceolatis ad linearia-lanceolata) et floribus 19 - 21 (non $15-16$ ) differt. Typus: Brazil, Minas Gerais: Mun. de Diamantina: Estrada para Conselheiro Mata, a 2 km do asfalto, 11 April 1982, Rossi et al. CFCR3339 (holotypus SPF!; isotypus UEC!).

Shrub or subshrub to $2 \mathrm{~m}$. Stems well-branched, slightly flattened, furrowed, pubescent to velutinous, canescent when young, becoming cylindrical, subglabrescent with ochreous remaining indument with age, leaf scars triangular, distinctive on leafless portions of stem. Leaves alternate, simple, imbricate to subrosulate towards stems apices, patent to slightly ascending, shortly petiolate, petioles pad-like, $1.1-3 \mathrm{~mm}$ long; blade elliptic, more rarely narrow oblong to narrow obovate, $1.1-1.9 \times 0.6-0.9 \mathrm{~cm}$, densely velutinous to subsericeous, silverish canescent, black glandular dotted (sometimes scarcely visible) adaxially, densely velutinous to sericeous, silverish green abaxially, hairs simple, uniseriate, midrib prominent 
beneath, sunken above, venation brochidodromous, margins entire and smooth, apex obtuse to rounded, base rounded, sometimes slightly attenuate. Inflorescence terminal, seldom axillary, a solitary capitulum or a simple, 2 - 5-headed pseudoglomerule, often surrounded by foliage leaves. Capitula homogamous, discoid, sessile; involucre cylindrical to campanulate, 7.3 - 13 $\times 3.8-7 \mathrm{~mm}$; phyllaries 5 - 6-seriate, imbricate, outer phyllaries widely trullate to ovate, $2.4-4.9 \times 0.7-1.7 \mathrm{~mm}$, apex acute, tomentose to subvillous, greyish brown, inner phyllaries linear to lanceolate, $5.9-7 \times 0.7-0.8 \mathrm{~mm}$, apex acute to apiculate, glabrescent, greyish brown to stramineous, persistente or deciduous; receptacle flat, weakly fimbriate. Florets $19-21$, hermaphrodite, fertile; corolla actinomorphic, 5-lobed, lilac, corolla tube $4.5-6.2 \times 0.5-1$ $\mathrm{mm}$, glandular-punctate, corolla throat $1-2 \times 0.5-0.8 \mathrm{~mm}$, corolla lobes $2.4-3.2 \times 0.4-$ $0.6 \mathrm{~mm}$, apices acute, mamillose; apical anther appendages acute, more than twice as long as wide, anther base long-sagittate; style $0.9-1.1 \mathrm{~cm}$, style shaft glabrous throughout except for pubescent upper ca. $0.8 \mathrm{~mm}$ beneath style arms, style base glabrous, lacking basal node, style arms $1.5-2.5 \mathrm{~mm}$ long, short pubescent outside throughout. Cypsela $1.95-3 \times 0.45-0.92 \mathrm{~mm}$, 4-angled, shallowly ribbed, glabrous or with sparse short setulae scarcely visible, glandularpunctate, carpopodium annular, scarcely visible; pappus biseriate, equal, stramineous or rarely pinkish, straight or slightly twisted, deciduous, setae 4-7 mm long, barbellate, narrowing from base upwards (Fig. 1).

DISTRIBUTION. Endemic to Minas Gerais and known only from the Diamantina region.

BRAZIL. Minas Gerais State: Mun. de Diamantina, 1400 m, June 1934, Brade 13570 (RB!); Estrada para Conselheiro Mata, km 190, 18 July 1980, Menezes et al. CFCR 96 (SPF!, UEC!); ibidem km 180, 18 July 1980, Menezes et al. CFCR 129 (SPF!, UEC!); 8 km da rodovia, 13 Dec. 1980, Cordeiro et al. CFCR 573 (SPF!, UEC!); Margem da estrada Diamantina - Conselheiro Mata, 5 km de Diamantina, 30 Aug. 1981, Giulietti et al. CFCR 1796 (K!, SPF!, UEC!); 24 km da estrada Diamantina - Conselheiro Mata, 30 Aug. 1981, Giulietti et al. CFCR 1837 (K!, SPF!, UEC!); Estrada Diamantina - Curvelo, a 8 km de Diamantina, 30 Aug. 1981, Giulietti et al. CFCR 2302 (SPF!, UEC!); Estrada para Conselheiro Mata, a $2 \mathrm{~km}$ do asfalto, $18^{\circ} 16^{\prime}$ S, 4343’W, 11 April 1982, Rossi et al. CFCR 3327 (SPF!, UEC!); Estrada para Conselheiro Mata, a $2 \mathrm{~km}$ do asfalto, 11 April 1982, Rossi et al. CFCR3339 (holotype SPF!; isotype UEC!); Estrada para Conselheiro Mata, km 185, 26 July 1986, Mello-Silva et al. CFCR 9966 (K!, HUFU, SPF!); Rodovia Guinda - Conselheiro Mata, 16 March 1987, Hatschbach et al. 50927 (MBM!, US); Estrada Diamantina - Gouveia, 10 km de Gouveia, planalto de Guinda, 18 April 1987, Zappi et al. CFCR 10638 (K!, HUFU, SPF!); 20 - 26 km WSW de Diamantina, camino a

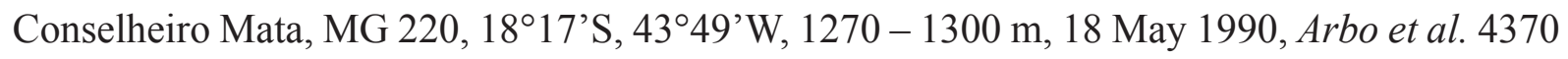
(CTES, K!, SPF!, US!).

HABITAT. Campos rupestres, amongst rocks.

CONSERVATION ASSESSMENT. According to available information about $P$. campestris, it can be scored, using IUCN conservation criteria (IUCN 2001), as Endangered (EN), since its area of occurrence is smaller than $5,000 \mathrm{~km}^{2}$, its area of occupancy is smaller than $500 \mathrm{~km}^{2}$, and 
it is known from no more than five localities EN (criteria B1a, B2a).

ETYMOLOGY. This species epithet denotes its habitat in open formations bound to a mosaic of rocky outcrops and shallow white sands above $1000 \mathrm{~m}$ in Central and Eastern Brazil - the campos rupestres.

NOTE. Following Schultz-Bipontinus (1863), Piptolepis campestris belongs to sect. Macrophyllum Sch.Bip. It is closely related to P. oleaster by its silverish canescent adaxial leaves and cluster of few heads, but easily sets apart by the shape of leaves (elliptic, more rarely narrow oblong to narrow obovate vs. oblanceolate to linear-lanceolate) and number of florets per head (19-21 vs. $15-16)$. It is also similar to P. schultziana, the other new species described below, by the shape and size of the leaves, but the adaxial surface is velutinous to subsericeous and silverish canescent (vs. glabrescent, shiny and green). Geographically, $P$. campestris is restricted to the campos rupestres of the Planalto de Diamantina which is the center of diversity of the genus (ten species occur in this region and eight are endemics).

Piptolepis schultziana Loeuille \& D.J.N. Hind. sp. nov. a P. buxoide foliis latioribus (4 - 7 mm, non 3-4 mm) et floribus $17-29$ (non 12 - 13) differt. Typus: Brazil, Minas Gerais: Mun. de Congonhas do Norte, Fazenda Imbaúbas, Loeuille et al. 76 (holotypus SPF!; isotypus K!).

Shrub to $1.5 \mathrm{~m}$. Stems well-branched, slightly flattened, furrowed, yellowish green tomentose when young, becoming cylindrical and greyish brown with age, leaf scars triangular, distinctive on leafless portions of stem. Leaves alternate, simple, slightly imbricate, patent to ascending, shortly petiolate; petioles pad-like $1.7-3.4 \mathrm{~mm}$ long; blade narrow elliptic to wide elliptic, more rarely ovate or obovate, $1-1.8 \times 0.4-0.7 \mathrm{~cm}$, glabrescent, shiny and green, black glandular dotted adaxially, light green, densely velutinous abaxially, hairs simple, uniseriate, midrib prominent beneath, sunken above, venation brochidodromous, margins entire, fringed when young, apex obtuse, base attenuate to obtuse. Capitula homogamous, discoid, sessile, often surrounded by foliage leaves, terminal on upper branches; involucre campanulate, $7.5-10 \times$ $5-7 \mathrm{~mm}$; phyllaries 5-seriate, weakly imbricate, outer phyllaries widely trullate, $2.25-5 \times 0.6$ $-2 \mathrm{~mm}$, apex acute, tomentose to subvillous, rarely glabrescent, stramineous, inner phyllaries linear to lanceolate, $6.6-8.8 \times 0.95-2.1 \mathrm{~mm}$, apex obtuse to acute, glabrescent, stramineous, apical portion brownish, deciduous; receptacle flat, naked. Florets 17 - 29, hermaphrodite, fertile; corolla actinomorphic, 5-lobed, lilac to whitish, corolla tube $4.4-7.9 \times 0.4-1.2 \mathrm{~mm}$, glandular-punctate, corolla throat $1.6-2.3 \times 0.9-1.3 \mathrm{~mm}$, corolla lobes $1.1-3.7 \times 0.4-0.6$ $\mathrm{mm}$, apices acute, mamillose; apical anther appendages acute, more than twice longer than wide, anther base long-sagittate; style $0.95-1.4 \mathrm{~cm}$ long, style shaft glabrous throughout except for pubescent upper ca. $0.8 \mathrm{~mm}$ beneath style arms, style arms $2.1-2.9 \mathrm{~mm}$ long, short pubescent outside throughout length, style base glabrous, lacking basal node. Cypsela $1.7-2.2 \times 0.65-$ $1.2 \mathrm{~mm}$, shallowly ribbed, glabrous, glandular-punctate, carpopodium annular, scarcely visible; pappus biseriate, equal, stramineous, straight, persistent or somewhat deciduous, setae $5.3-7.5$ 
mm long, barbellate, narrowing from base upwards (Fig. 2).

DISTRIBUTION. Endemic to Brazil (Minas Gerais).

BRAZIL. Minas Gerais State: Mun. de Congonhas do Norte, Estrada para Santana do Riacho, $18^{\circ} 56^{\prime}$ S, 4341' W, 1200 m, 3 March 1998, Pirani et al. 4179 (K!, SPF!); 9 km S de Congonhas do Norte na estrada para Conceição do Mato Dentro, entrada para Extrema seguindo ca. 11

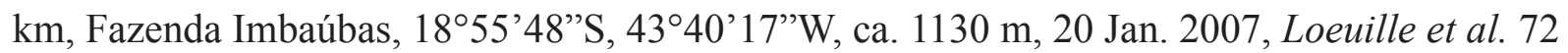
(K!, SPF!); ibid., Estrada para Lapinha, 1856’14.8”S, 4341'6.1”W, ca. 1250 m, 20 Jan. 2007, Loeuille et al. 76 (holotype SPF!, isotype K!). Mun. de Santana do Pirapama, Distr. de São José da Cachoeira, Serra da Lapa, trilha do João Carrinho, 1902'52.8”S, 4344'19.3”'W, 756 1080 m.s.m., 18 Feb. 2007, Souza et al. 32693 (BHCB!, ESA!, K!, SPF!). Mun. de Santana do Riacho, Lapinha, elevações imediatamente a nordeste de Lapinha, nas nascentes do córrego do Boqueirão, trilha para o alto do paredão, 1906'21.2”S, 4340’32”'W, 1315 m, 22 April 2006, Loeuille et al. 20 (K!, SPF!, US!).

HABITAT. Campos rupestres, amongst rocks.

CONSERVATION ASSESSMENT. According to available information P.schultziana can be scored, using IUCN conservation criteria (IUCN 2001), as Endangered (EN), since its area of occurrence is smaller than $5,000 \mathrm{~km}^{2}$, its area of occupancy is smaller than $500 \mathrm{~km}^{2}$, and it is known from no more than five localities EN (criteria B1a, B2a).

ETYMOLOGY. This species is named after the German physician and botanist, Carl Heinrich Schultz (1805 - 1867), name often written as Carl Heinrich Schultz Bipontinus, who described the genus Piptolepis in 1863.

NOTE. Piptolepis schultziana combines characteristics of both of Schultz-Bipontinus's sections: possessing larger leaves and solitary capitula, so it is not assigned to any section and indicates the need for further studies in the genus before proposing a new infrageneric classification. Piptolepis schultziana can be confused with P. buxoides, but that species has narrower leaves ( $3-4 \mathrm{~mm}$ vs. $4-7 \mathrm{~mm}$ ) and fewer florets per capitulum (12 - 13 vs. 17 - 29). To date, P. schultziana is known only from the northwestern extension of Serra do Cipó and south of the Planalto de Diamantina.

Piptolepis monticola Loeuille sp. nov. a P. buxoide foliis magnis $(1.5-2.5 \times 0.5-1 \mathrm{~cm}$, non $1-1.6 \times 0.3-0.4 \mathrm{~cm}$ ), fasciculis capitulorum paucorum (non capitulo solitario) et floribus 15 - 18 (non 12 - 13) differt. Typus: Brazil, Minas Gerais: Mun. de Santo Antônio de Itambé, Pico do Itambé, Loeuille et al. 464 (holotypus SPF!; isotypi K!, US!).

P. pseudomyrtus Baker (1873: 145). Type: Brazil, Minas Gerais: 'habitat in Serra Itambé do Mato Dentro', Martius s.n. (545) (holotype M, photo F neg. \# 20618 US!; isotype P). hom. illeg.

Shrub or treelet to $2 \mathrm{~m}$. Stems well-branched, furrowed, glaucescent, canescent tomentose, dark greyish with age, leaf scars triangular. Leaves alternate, simple, slightly imbricate, subsessile 
to short-petiolate, pad-like petioles 2.5 - $6 \mathrm{~mm}$ long; blade oblanceolate, linear-obovate to spatulate, $1.5-2.5 \times 0.5-1 \mathrm{~cm}$, pubescent to sericeous, glaucous, canescent, black glandular dotted (sometimes scarcely visible) above, tomentose, glaucous, light grey beneath, midrib prominent beneath, sunken above, venation brochidodromous, margins entire, apex acute to obtuse, base cuneate. Inflorescences terminal, a simple, 3 - 4-headed pseudoglomerule, often surrounded by foliage leaves. Capitula homogamous, discoid, sessile; involucre cylindrical to subcampanulate, $6.5-8 \times 5.2-6.5 \mathrm{~mm}$; phyllaries $5-6$-seriate, weakly imbricate, outer phyllaries, triangular to widely trullate, $2.7-6.7 \times 1.1-1.6 \mathrm{~mm}$, apex acute, tomentose, stramineous to greyish, inner phyllaries linear to lanceolate, $7.1-8.2 \times 1-1.4 \mathrm{~mm}$, apex obtuse to acute, glabrescent or tomentose towards apices, deciduous; receptacle flat, weakly fimbriate. Florets $15-18$, hermaphrodite, fertile; corolla actinomorphic, 5-lobed, lilac to magenta, corolla tube $5.3-6.5 \times 0.3-0.5 \mathrm{~mm}$, glandular-punctate, corolla throat $2-3 \times 0.7-1 \mathrm{~mm}$, glandularpunctate, corolla lobes $2.9-3.4 \times 0.3-0.5 \mathrm{~mm}$, apices acute, sparsely pilose; apical anther appendages lanceolate, more than twice as long as wide, anther base long-sagittate; style 0.7 $-1.3 \mathrm{~cm}$, style shaft glabrous throughout except for pubescent upper ca. $1.5 \mathrm{~mm}$ beneath style arms, style base glabrous, lacking basal node, style arms $1.3-2 \mathrm{~mm}$ long, short pubescent outside throughout. Cypsela $1.8-2.5 \times 0.75-1 \mathrm{~mm}$, shallowly ribbed, glabrous, glandularpunctate, carpopodium annular, scarcely visible; pappus biseriate, equal, stramineous, straight, deciduous, setae $6.1-6.6 \mathrm{~mm}$ long, barbellate, narrowing from base upwards (Fig. 3).

DISTRIBUTION. Endemic to Minas Gerais and known only from Pico do Itambé (see Note). BRAZIL. Minas Gerais State: Mun. de Itambé do Mato Dentro, Martius 545 (M, photo F neg. \# 20618, US!, P). Mun. de Santo Antônio de Itambé, Pico do Itambé, 5 May 1942, Magalhães 1575 (BHCB!); ibid., 1700 m, 11 Feb. 1972, Anderson et al. 35817 (NY!, MO, RB!, US!); ibid., 18²4'S, 4321' W, 2050 m, 5 April 1982, Furlan et al. CFCR 3024 (SPF!, UEC!); Parque Estadual do Pico de Itambé, 10 May 2006, Teles et al. 244 (RB, SPF!); ibid., 18²3'51'S, 4319'59.6”W, 1764 m, 11 Nov. 2006, Versieux et al. 326 (SPF!); ibid., 18²3'53”'S, 43¹9'35”'W, 1614 m, 28 Jan. 2009, Loeuille et al. 463 (K!, SPF!, US!); ibid., Loeuille et al. 464 (holotype: SPF!; isotypes: $\mathrm{K}$ !, US!).

HABITAT. Campos rupestres, amongst rocks.

CONSERVATION ASSESSMENT. According to available information about $P$. monticola, it can be scored using IUCN conservation criteria (IUCN 2001) as Critically Endangered (CR), since its area of occurrence is smaller than $100 \mathrm{~km}^{2}$, its area of occupancy is smaller than 10 $\mathrm{km}^{2}$, and it is known from only one locality CR (criteria B1a, B2a).

ETYMOLOGY. The species epithet derives from the name Albertinia monticola Mart., in sched., which appears on the label of the oldest collection.

NOTE. Piptolepis monticola differs from P. buxoides by its larger leaves $(1.5-2.5 \times 0.5-1$ cm vs. $1-1.6 \times 0.3-0.4 \mathrm{~cm}$ ), $3-4$-headed pseudoglomerule (vs. a solitary capitulum) and higher number of florets per capitulum $(15-18$ vs. $12-13)$. It is closely related to P. oleaster 
by the number of capitula per inflorescence and by the number of florets per capitulum, but the latter species has leaves longer $(1.5-2.5 \mathrm{~cm}$ vs. $2-5 \mathrm{~cm})$ and distinctly petiolate (vs. subsessile to shortly petiolate). The new species is also similar to P. gardneri, but the leaves of the latter are linear-elliptic to linear-oblong (vs. oblanceolate, linear-obovate to spatulate) and not glaucous (vs. glaucous). Most collections of $P$. monticola available come from Pico do Itambé, while the label of the Martius' collection indicates "Itambé do Mato Dentro", another locality in Minas Gerais. Nevertheless, it seems more likely that there has been some confusion with these similar names than a wider distribution of the species at the time of Martius'collection now restricted to the Pico do Itambé.

\section{MISAPPLICATION OF THE NAME PIPTOLEPIS PSEUDOMYRTUS}

Vernonia pseudomyrtus A. St.-Hil. (St. Hilaire, 1833), is a taxonomic synonym of Vernonia buxoides Less., (Lessing, 1829). When Schultz-Bipontinus (1863) described the genus Piptolepis, he provided the combination P. pseudomyrtus (A. St.-Hil.) Sch.Bip. as well as a description of the taxon based on the collection Martius 545. He also noticed that this material differred from the holotype of Vernonia pseudomyrtus (Saint Hilaire B1-910) by its solitary capitula and black glandular dotted adaxial leaves. It seems clear to us that Schultz-Bipontinus did not see the latter collection and only knew that species through the descriptions of Saint Hilaire (1833: 94, 367) and Candolle (1836: 17). These two collections belong to two different species, as Baker (1873: 144 vs. 145) noted; however by using an existing name and simultaneously excluding its type, Baker created the illegitimate later homonym P. pseudomyrtus Baker (ICBN, Art. 48.1; McNeill et al., 2006). The plants traditionally assigned to P. pseudomyrtus are not conspecific with the type collection but with the Martius collection. Since no other legitimate name has been published for these plants, they are here described as a new species.

\section{Acknowledgements}

The drawings of the three species were prepared by Leonardo M. Borges of the Departamento de Botânica, Instituto de Biociências, Universidade de São Paulo. The authors would like to thank the curators of all the herbaria listed in the text for loaning material, as well as John Pruski and an anonymous reviewer for comments that improved the manuscript. JRP is grateful to CNPq for financial support.

\section{References}

Baker, J. G. (1873). Compositae I. Vernoniaceae. In C. F. P. von Martius $\uparrow \&$ A. W. Eichler (eds) Flora Brasiliensis 6(2): 5 - 180. Fried. Fleischer, Münich, Vienna, Leipzig.

Beauverd, G. (1913). Contribution à l'étude des Composées (suite VIII). Bull. Soc. Bot. Genève, series II, 5: 239-244.

Candolle, A. P. de (1836). Vernoniaceae. Prodromus Systematis Naturalis Regni Vegetabilis, ... 
v. 5, p. 9 - 103. Treutel et Würtz, Paris.

Hind, D. J. N. (2003). Flora of Grão-Mogol, Minas Gerais: Compositae (Asteraceae). Bol. Bot. Univ. São Paulo 21(1): 179-234.

Hind, D. J. N. (2009). Glossary. In An annoted preliminary checklist of the Compositae of Bolivia. Published on the internet http://www.kew.org/science/tropamerica/boliviacompositae/ index.html [accessed June 2010].

IUCN (2001). IUCN Red List Categories: version 3.1. Prepared by the IUCN Species Survival Commission. IUCN, Gland, Switzerland and Cambridge, U.K. http://www.iucnredlist.org/ technical-documents/categories-and-criteria/2001-categories-criteria [accessed June 2010].

Jeffrey, C. F. \& Hind, D. J. N. (1994). The typification of Piptolepis Sch. Bip. (Compositae), nom. cons. Taxon 43: $94-96$.

Lessing, C. F. (1829). De synantheris herbarii regii berolinensis dissertatio prima. Vernonieae. Linnaea 4: $240-356$.

McNeill, J., Barrie, F. R., Burdet, H. M., Demoulin, V., Hawksworth, D. L., Marhold, K., Nicolson, D. H., Prado, J., Silva, P. C., Skog, J. E., Wiersema, J. H. \& Turland, N. J. (ed.). 2006. International code of botanical nomenclature (Vienna Code): Adopted by the Seventeenth International Botanical Congress Vienna, Austria, July 2005. Regnum Vegetabile 146. Ruggell: Gantner.

Robinson, H. (2006) [2007]. Vernonieae. In J. Kadereit \& C. Jeffrey (vol. eds) Vol. 8: Asterales. The families and genera of vascular plants (K. Kubitzki, series ed.): 149 - 174. Springer. Berlin, Heidelberg, New York.

Saint-Hilaire, A. (1833). Voyage dans le district des diamants et sur le littoral du Brésil, vol. 1. Librairie Gide. Paris.

Schultz-Bipontinus, C. H. (1863) [1864]. Lychnophora Martius! und einige benachbarte Gattungen. Jahresber. Pollichia 20/21: $321-439$. 


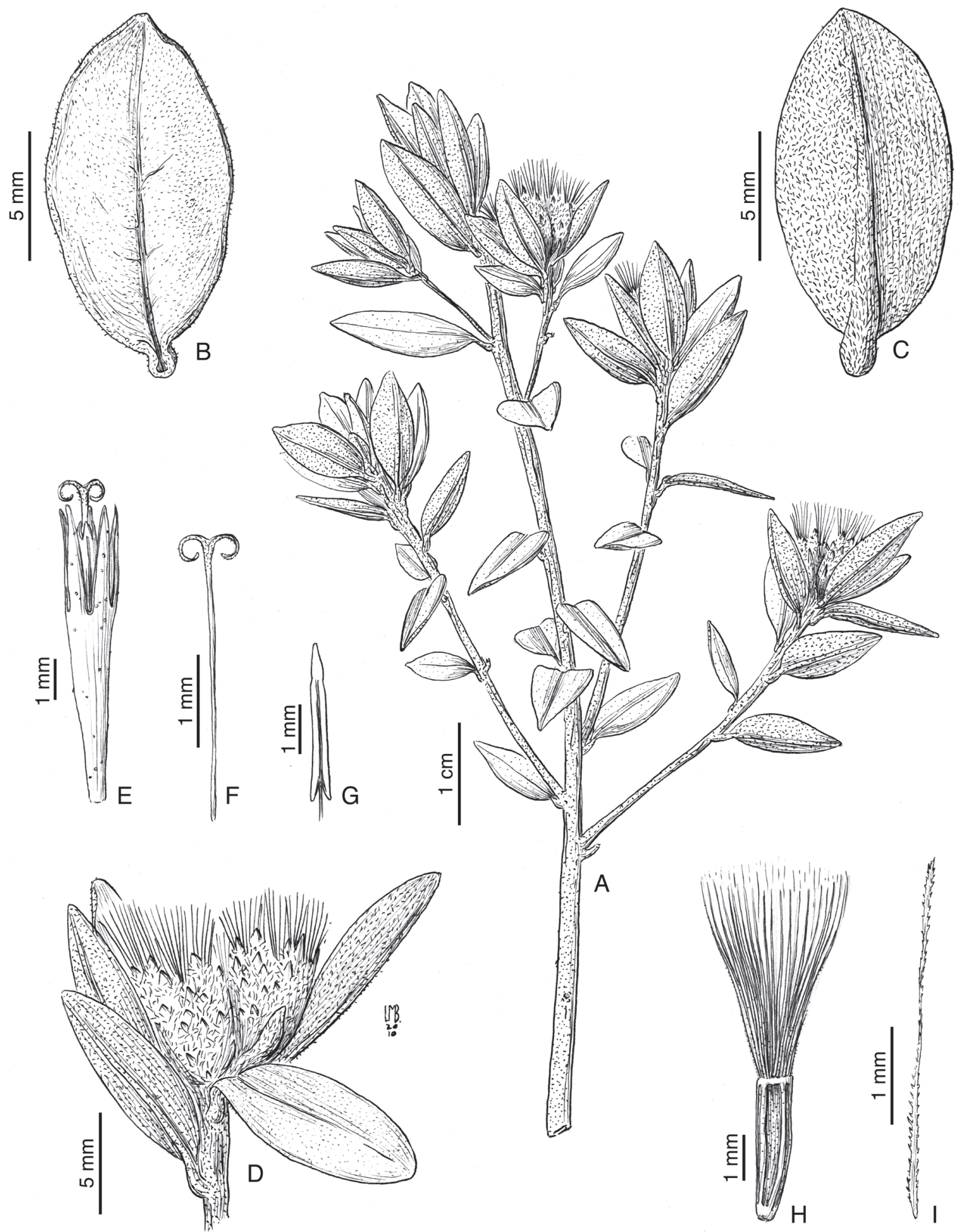

A
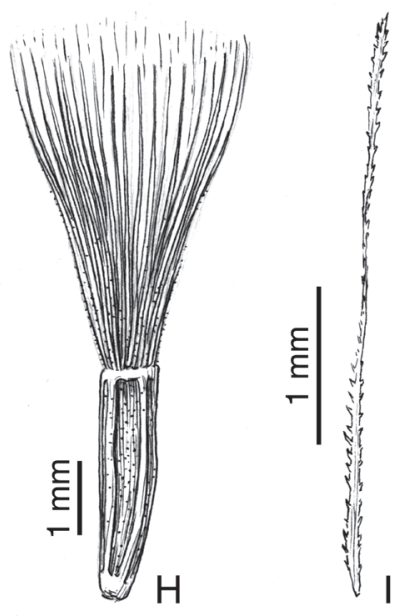

Fig. 1. Piptolepis campestris. A habit; B leaf, adaxial surface; C leaf, abaxial surface; D pseudoglomerule; E corolla; F style; G anther; H cypsela and pappus; I pappus seta. All from the holotype (SPF). 


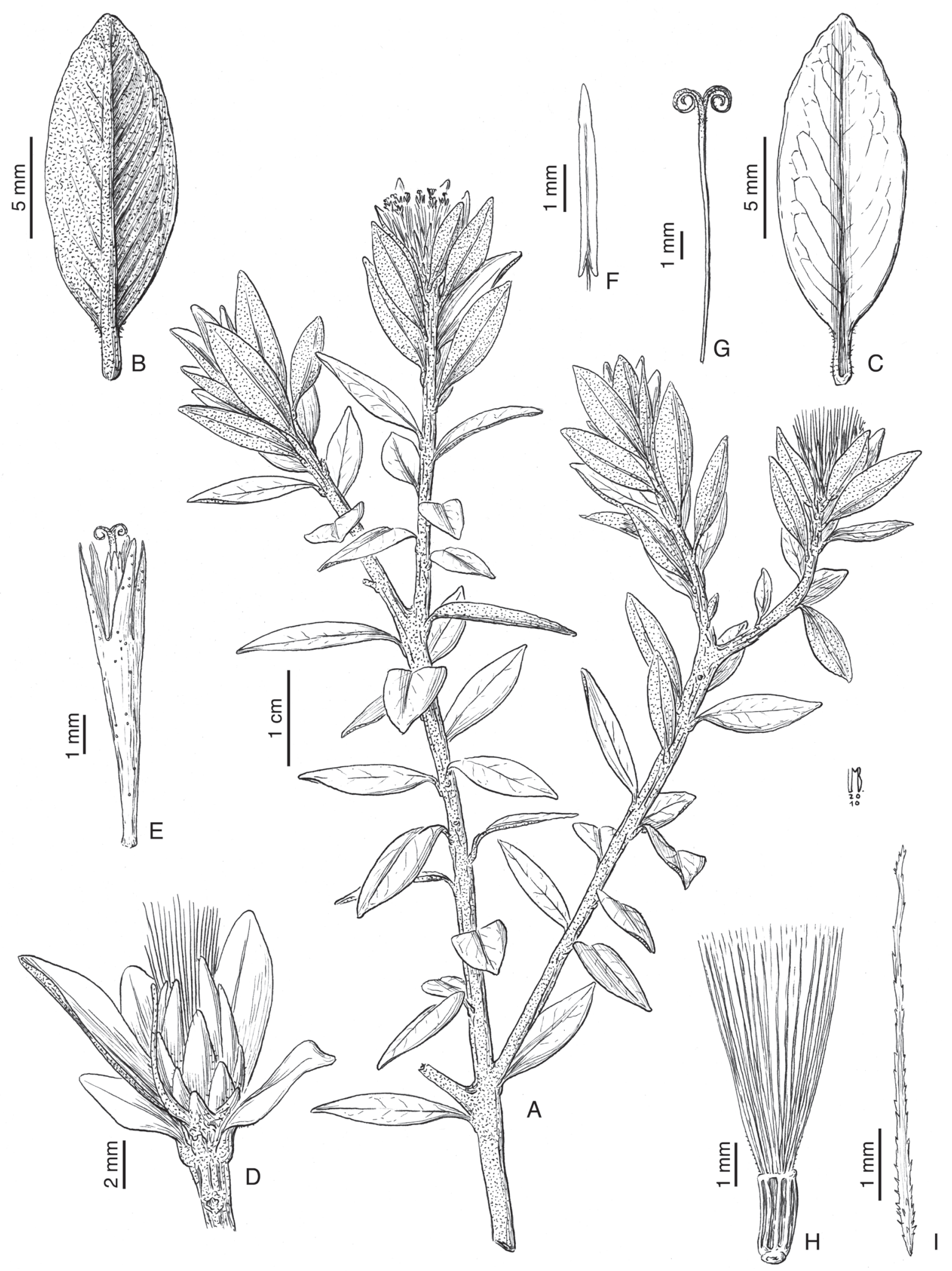

Fig. 2. Piptolepis schultziana. A habit; B leaf, abaxial surface; C leaf, adaxial surface; D capitulum; E corolla; F anther; G style; H cypsela and pappus; I pappus seta. All from the holotype (SPF). 


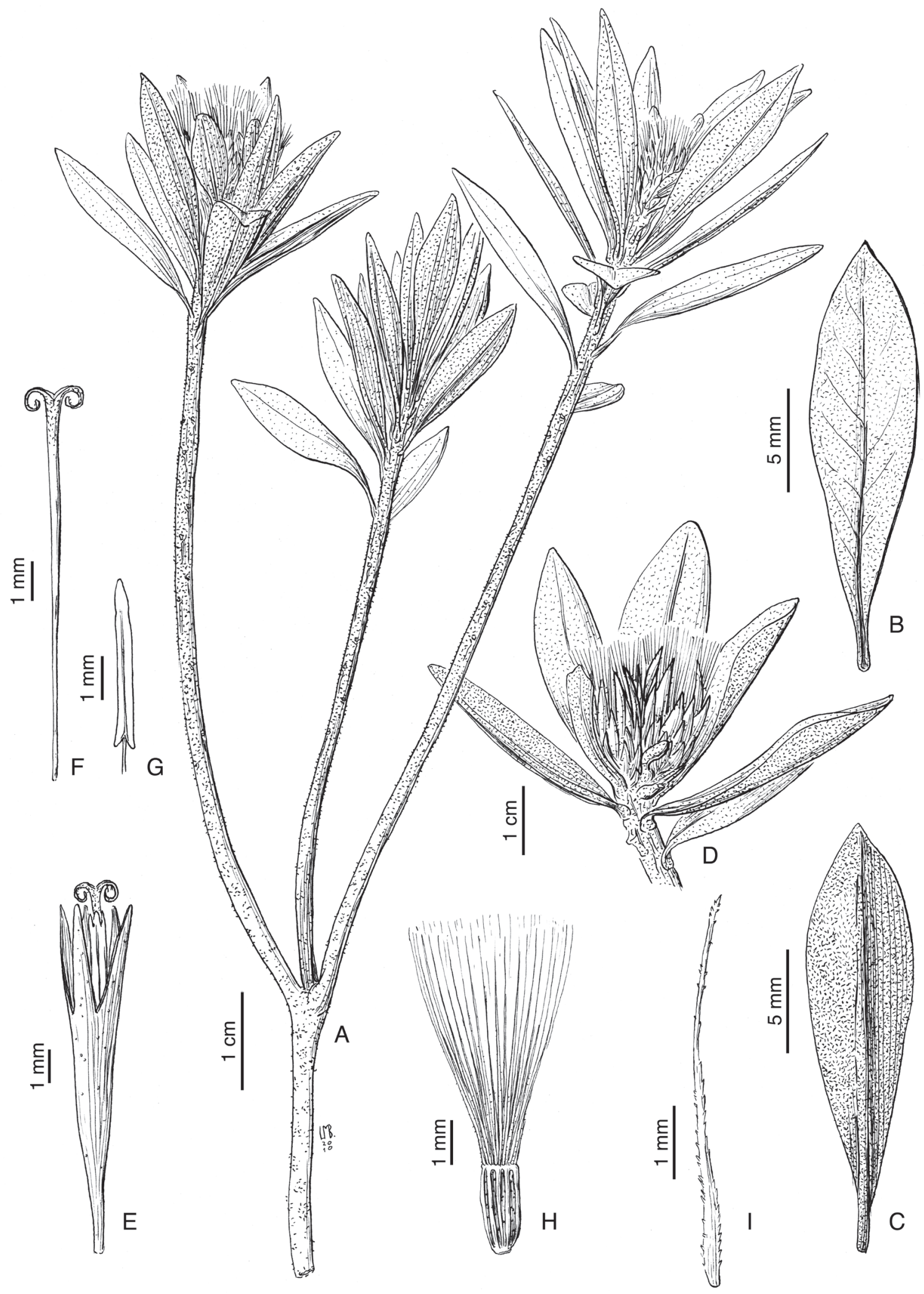

Fig. 3. Piptolepis monticola. A habit; B leaf, adaxial surface; C leaf, abaxial surface; D pseudoglomerule; E corolla; F style; $\mathrm{G}$ anther; H cypsela and pappus; I pappus seta. All from the holotype (SPF). 



\section{CHAPTER 5}

A synopsis of the subtribe Lychnophorinae (Asteraceae: Vernonieae) 



\section{A synopsis of the subtribe Lychnophorinae (Asteraceae: Vernonieae)}

\section{BENOÎT LOEUILLE ${ }^{1}$, JOÃO SEMIR ${ }^{2}$, and JOSÉ R. PIRANI ${ }^{1}$}

${ }^{1}$ Departamento de Botânica, Instituto de Biociências, Universidade de São Paulo, Rua do Matão 277, 05508-090, São Paulo, Brazil. E-mail: benoit_loeuille@yahoo.fr; pirani@usp.br

2 Departamento de Botânica, Universidade Estadual de Campinas, C.P. 6109, 13083-970, Campinas, SP, Brazil. E-mail: semir@unicamp.br 

Abstract. Based on the results of phylogenetic analyses, a new classification of the subtribe Lychnophorinae is here proposed. The subtribes Centratherinae and Sipolisiinae are reduced to synonymy of Lychnophorinae and three genera (Albertinia, Blanchetia, Gorceixia) are transferred to the subtribe. As now circumscribed, Lychnophorinae comprises 18 genera and 104 species distributed mostly in the cerrado domain of the Brazilian Central Plateau. Oiospermum is synonymized under Centratherum, and Irwinia under Blanchetia. Because Lychnophora as currently circumscribed was shown to be paraphyletic, it is here dismantled into three monophyletic genera: Lychnophora s.s., Lychnocephalus and a new genus described herein, Lychnophorella. 17 new combinations are proposed as well as 10 new synonymies.

Keywords: Compositae, Centratherinae, Sipolisiinae, taxonomy, classification. 

The subtribe Lychnophorinae (Asteraceae: Vernonieae) consists mostly of shrubs and treelets growing in the cerrados and campos rupestres of the Brazilian Central Plateau, where some of them often are the dominantlife form. The subtribe was defined by Bentham (1873) to accommodate plants with few flowered-capitula arranged in a syncephalium, with a paleaceous pappus. The circumscription was later modified by Robinson et al. (1980) and Robinson (1992, 1999). The results of recent phylogenetic studies (Loeuille et al., in prep.; see Chapter 2 and Loeuille et al., in prep; see Chapter 3), based on morphological and molecular (ITS, $n d h \mathrm{~F}, r p l 32$ $\operatorname{trn} \mathrm{L}$ ) data, provide the basis for an amplified concept of the group with the inclusion of two small subtribes (Centratherinae and Sipolisiinae) as well as the genera Blanchetia and Gorceixia. The main non-molecular synapomorphy of the subtribe is the presence of heliangolides (a class of sesquiterpene lactones) in the aerial parts. As here defined, the subtribe Lychnophorinae is monophyletic and comprises 18 genera and 104 species. Even though no other morphological synapomorphy has been found for it, most members are woody plants and have apical anthers appendages with conspicuous wall thickenings (except Centratherum), style without a basal node (except Albertinia) and sublophate pollen. This combination of characters is highly similar to the one proposed by Robinson (1992). Additionally, the following characters are commonly found in the group and rarely outside of it: 3- to 5-armed trichomes, leaf sheath, syncephaly, paleaceous and deciduous to caducous pappus.

Striking field features of most Lychnophorinae are the thick indumentum covering leaves and stems, a likely efficient protection against fire, and the large syncephalia which may enhance reproductive success as wel as offer a protection against herbivory. The group has also received the attention of phytochemists due to the richness in flavonoids and in particular sesquiterpene lactones. More than 100 different molecules of this class have been isolated from plants of Lychnophorinae, and several of them display biological activities such as antimicrobial, antiinflammatory, tripanocidal, toxicity, analgesic and antinociceptive (Keles et al., 2010). One of the most widespread species of the subtribe, Eremanthus erythropappus is explored for its essential oil rich in $\alpha$-bisabolol, used in cosmetic preparations (Sousa et al., 2008). Several species are used as medicinal plants in folk medicine ('Arnica', Lychnophora spp.; 'Candeia', Eremanthus spp.). Ornamental use of Lychnophorinae is, to our knowledge, limited to Centratherum punctatum.

Few revisions of genera of Lychnophorinae are available, mainly Eremanthus by MacLeish (1987) and Lychnophora by Coile and Jones (1981) and Semir (1991). As the result of increasing collecting efforts in Brazil, a considerable number of new species and new genera in the group have been described in the last decades. As a first step towards a complete revision of the subtribe Lychnophorinae, we present here a synopsis of the group, providing the taxonomic status, data on nomeclatural types, geographical distribution, and taxonomic notes for each species. 
This study was based on observation of 5,000 herbarium specimens belonging to 20 institutions, which acronyms cited in the text follow Thiers (2011). All specimens cited were seen by either one or all the authors unless indicated otherwise in the case of some type specimens. Martius's collections contain frequently several numbers. We only considered the number on the original label with Martius's handwriting as the collector number; some of these are also found in his field books to the corresponding plants. Another number written on a white strip is also indicated because it is much more commonly cited than the collector number and has been considered as such by Coile and Jones (1981) and Semir (1991). A third number associated to Martius's collections corresponds to Herbarium Florae Brasiliensis's numbers (Martius, 1837), these collections were distributed with specific labels 'Martii Herbar Florae Brasil'. In the case of Gardner's collections, only a sheet containing the annotation 'Herb. Gardner' (sometimes written on the verso) was considered as a holotype; sets of duplicates of specimens lacking such information were considered as syntypes, and one of them will be soon designated as lectotype. Full typification is beyond the scope of the present treatment, and therefore lectotypification of syntypes is deferred until all syntypes can be examined.

The terminology used to describe two-dimensional shapes is that of Hickey (1979); venation patterns are those of Ellis et al. (2009); the indumentum descriptions follows Payne (1978) and types of trichomes follow Evert (2006) and Theobald et al. (1979); the general patterns of inflorescences by Endress (2010) were adopted, with additions for syncephalia taken from MacLeish (1984a), and Harris (1995, 1999). Morphological characters of Vernonieae follow articles by Hind (2000a, b) and Robinson (1999, 2007); receptacle and pappus characters follow Small (1919) and detailed explanations of these are provided in Loeuille and Pirani (in prep.) (see Chapter 1).

For each species one representative specimen per state is presented, except in the cases where the species is restricted to one state, when three specimens are cited. A list of all material examined can be obtained under request to the first author.

\section{TAXONOMIC History}

1796. Roemer, in "Scriptores de plantis hispanicis, lusitanicis, brasiliensibus...", describes two plants of what is now subtribe Lychnophorinae based on material collected by Joaquim Velloso de Miranda, using polynomial names.

1807. Persoon validly publishes these first two species, Serratula albida DC. ex Pers. and Serratula bifrons DC. ex Pers. based on the same material as Roemer's with Candolle annotations.

1810. Candolle establishes the two first genera of the group: Heterocoma and Hololepis. 
1817. Cassini publishes Centratherum with one species (C. punctatum) based on a collection by J. de Jussieu from Panama.

1819. Cassini establishes the tribe Vernonieae.

1821. Sprengel describes the monotypic genus Albertinia (A. brasiliensis).

1822. Martius describes the genus Lychnophora with eight species based on his collections from Minas Gerais State, southeastern Brazil.

1828. Cassini places the genera Centratherum, Heterocoma, Hololepis and Lychnophora in 'Quatrième Section,Vernoniées-Prototypes, II. Vernoniées-Prototypes vraies' along with other genera including Vernonia.

1829. Lessing transfers seven of the eight species of Lychnophora to Vernonia Sectio II. He also establishes the genera Eremanthus and Oiospermum, and adds one new species to Albertinia (A. incana).

1831. Lessing dissolves Albertinia transferring the type species into Vernonia and A. incana into Eremanthus.

1832. Lessing in 'Synopsis generum Compositarum' places all the genera of the group in the subtribe Vernonieae.

1836. Candolle places the genera of the group in 'Subtribo Vernonieae, Divisio Euvernonieae', most in 'Subdivisio Albertinieae' (except Oiospermum in 'Subdivisio Ethulieae', and Centratherum and Heterocoma in 'Subdivisio Heterocomeae'). He synonymizes Hololepis under Vernonia and establishes four new genera (Blanchetia, Chronopappus, Haplostephium and Lychnocephalus) and describes 21 new species of the group. He places all the species of Eremanthus in Albertinia, considering the type-species ( $A$. brasiliensis) as having one floret per capitulum and fused capitula.

1846. Gardner describes 18 new species of the group, mostly in Vernonia and Lychnophora, based on his own collections in Brazil. He synonymizes Haplostephium with Lychnophora.

1861. Schultz-Bipontinus re-establishes Albertinia with only its type-species, correcting the erroneous interpretation of Candolle: he demonstrates that $A$. brasiliensis has in fact multiflowered capitula and a receptacle surface with deep holes (alveolae). He also re-establishes Eremanthus, defined by its 1 floret, rarely 3 florets per capitulum, and persistent pappus. He describes the new genus Vanillosmopsis, with capitula bearing 3 florets, rarely 1, and a deciduous pappus. He adds four new species to the two latter genera.

1863. Schultz-Bipontinus publishes the first revision of Lychnophora, containing 29 species, 14 of them new, placed in a confusing infrageneric classification. He synonymizes Lychnocephalus under Lychnophora. He considers the two new genera Lychnophoriopsis (with dimorphic cypselae) and Soaresia, and the 'Hololepidae' group closely related to Lychnophora but distinct from Haplostephium (with an uniseriate pappus). The 'Hololepidae' group comprises Hololepis and two other new genera: the monotypic Proteopsis and Piptolepis (composed of six species previously placed in Vernonia). In 
the same work, he also describes the new genus Sphaerophora. These are all based on plants from Brazil.

1864. The monotypic genus Prestelia is described by Schultz-Bipontinus, based on plant from Minas Gerais State, Brazil.

1873 (April). Bentham in 'Genera plantarum' establishes the subtribe Lychnophorinae with the following definition 'Capitula 1-pauci-flora, in glomerulos densos capituliformes aggregata. Pappus paleaceus, simplex duplexve, v. rarius setosus' (Table 1). He places the other genera of the group in the subtribe Euvernonieae. Prestelia is synonymized under Eremanthus.

1873 (June). The circumscription of Lychnophorinae by Baker in Martius' 'Flora Brasiliensis' comprises the same genera than in Bentham (1873) (except Spiracantha which does not occur in Brazil) (Table 1). He describes ten new species in Eremanthus, Lychnophora and Vanillosmopsis.

1882. Baker describes Gorceixia, suggesting its is probably related to Oliganthes.

1890. Hoffman follows Bentham's circumscription of Lychnophorinae and adds Gorceixia to this subtribe.

1894. Oliver describes the monotypic genus Sipolisia based on a collection by Glaziou from Minas Gerais State, Brazil.

1909. Glaziou publishes in 'Liste des plantes du Brésil central recueillies en 1861-1895' several new species belonging to the Lychnophorinae group, but since nearly all of them lack a diagnose, all these names are considered as nomina nuda.

1923. Mattfeld describes one species of Haplostephium and five from Lychnophora based on collections mostly in Bahia made by Lützelburg.

1938. Philipson synonymizes Sipolisia under Proteopsis and adds two new species to that genus.

1969. Barroso validates the genus Alcantara described by Glaziou. She states that the new genus is closely related to Heterocoma.

1980 (February). Robinson resurrects the genus Chresta from synonymy in Eremanthus, based mainly on its herbaceous habit. Two new species of Eremanthus and Lychnophora are also described.

1980 (October). Robinson et al. propose a classification of the tribe Vernonieae based on phytochemical data. The subtribe Centratherinae is established comprising Centratherum and Oiospermum. They propose a new circumscription of Lychnophorinae, excluding some syncephalous taxa (Elephantopus, Rolandra, Spiracantha and Telmatophila) and including genera with separate capitula (Albertinia, Piptolepis and Proteopsis). Both subtribes have furanoheliangolides as distinctive sesquiterpene lactones.

1981 (January). Kirkman publishes a revision of Centratherum. Based on pollen data and chromosome numbers, she distinguishes Centratherum and Phyllocephalum. Centratherum comprises two species.

1981 (June). Robinson describes two new Brazilian genera: Bishopalea and Episcothamnus and 
re-establishes Sipolisia.

1981 (October). Coile and Jones publish a revision of Lychnophora. They synonymize Lychnophoriopsis under Lychnophora and reestablish Haplostephium. As circumscribed by these authors the genus contains 11 species.

1983 (July). Robinson describes five new species of Lychnophora from Bahia State, Brazil. He considers Haplostephium as synonym of Lychnophora and Lychnophoriopsis as a distinct genus.

1983 (September). Coile and Jones publish a revision of Haplostephium considered by them as monotypic.

1984 (February). MacLeish proposes the name Paralychnophora for Sphaerophora Sch. Bip., a later homonym of Sphaerophora Blume (Rubiaceae).

1984 (March). MacLeish and Schumacher publish six new species of Eremanthus from Brazil.

1987. MacLeish publishes a revision of Eremanthus. As circumscribed, the genus comprises 18 species including all the ones formerly considered as belonging to Vanillosmopsis.

1992. Robinson refines the limits of the subtribe Lychnophorinae using pubescence, style bases, anther appendages and pollen characteristics. Chresta and Soaresia are excluded from the subtribe. Episcothamnus is synonymized under Lychnophoriopsis. He provides an amplified concept of the latter by the transfer of two species of Lychnophora to Lychnophoriopsis and describing a new species in the latter. He also describes two new genera Anteremanthus and Minasia from eastern Brazil. He rejects the concept of Eremanthus of MacLeish by synonymizing Paralychnophora under that genus and maintaining Vanillosmopsis as a distinct genus.

1994. Bremer follows Robinson's delimitation of Lychnophorinae butconsiders Paralychnophora as a distinct genus and Vanillosmopsis as a synonym of Eremanthus.

1997. Robinson describes two new Brazilian species of Eremanthus of the 'Paralychnophora group'.

1999. Robinson excludes Pithecoseris from Lychnophorinae and creates a new subtribe, Sipolisiinae, to accomodate Bishopalea, Heterocoma, Hololepis, Sipolisia, Xerxes. This subtribe is mostly defined by its 'aristiferous or paleaceous receptacle'. He reestablishes Prestelia.

2007. Dematteis establishes a new monotypic genus, Vinicia, from Minas Gearis state, Brazil. 


\section{Life-forms}

The group displays a large array of life-forms, ranging from small herbs of a few centimeters to trees reaching 7 meters. They can be classified as follows:

Herbs. This is the less common life-form in the subtribe, only found in the genus Centratherum; frequently older stems become woody with age (Fig. 2 A).

Caulirosulas. The term has been coined by Cuatrecasas (1934) for the life-form of several species of the subtribe Espeletiinae (Asteraceae, Heliantheae), and the concept is explained in details in Cuatrecasas and Robinson (in press.). The simple, erect, short stem of Prestelia has been inapproprietaly referred as a rootstock (MacLeish, 1984a; Robinson, 2007), but field observations have helped to clearly identify a transition zone between the xylopodium and the stem, which is lignified. Here the stem is monopodial and tightly surrounded by closely imbricated and appressed leaf sheaths and with a crowded rosette of leaves on the top. The size of stem in Prestelia is conspicuously smaller than the one in other caulirosan genera (Espeletia, Dendrosenecio etc.), which can be giant scapose plants, but similar to Draba chionophila (Brassicaceae). This fact probably explains why the concept of caulirosulas had not yet been applied to small plants as Prestelia. The same life-form is found in the relatively larger Minasia and Proteopsis (Fig. 2 C, D). Hind (2003) described Proteopsis as having 'stems simple, unbranched, with rosette of leaves at apex of short shoot', i.e. the definition of caulirosula. The adaptative value of this life-form has been widely studied (Smith and Young, 1987 and references within), in particular to buffer the plants against the extreme diurnal environmental fluctuations, characteristic of tropical alpine habitats, as well as a protection against fire. Fire is a very common disturbance in the habitat of these caulirosulan genera, whose meristematic parts and young leaves remain tightly involved in a crowded rosette above the ground level, with additional protection provided by marcescent leaf sheaths (Givnish et al., 1986).

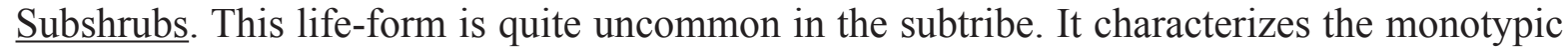
genus Vinicia, and is restricted to a few species in other genera, as Heterocoma robinsoniana (Fig. 2 B), Lychnocephalus humillima, Piptolepis pabstii and some species of Lychnophora.

Shrubs. This is one of the most frequent life-form in Lychnophorinae but, as pointed out by Robinson (1983) and Hind (1995), the term has been misapplied to several species of Lychnophora which are in fact treelets or trees. In shrubby Lychnophorinae, the usual monopodial growth of the stem is soon inhibited, and a profusion of ramifications is produced in all directions close to its base. In some rare cases, the same species may exhibit either a shrubby or a treelet habit, like Chronopappus bifrons and Piptolepis monticola (Fig. 3 B). The shrubby habit is characteristic of the genera Blanchetia, Lychnophorella (Fig. 3 A), most species of Piptolepis, some of Lychnophora and is uncommon in Eremanthus (occurring only in E. mollis and E. veadeiroensis).

Heterocomoid habit. Semir (1991) coined this term for the habit of Lychnophora markgravii and most species of Heterocoma. These plants usually have a unbranched and often tall, 
monopodial trunk, which grows rhythmically and so develops tiers of flowering branches; the leaves are mainly restricted to the main axis and are marcescent. This model is similar to the Rauh's model of tree architecture (Hallé et al., 1978) (Fig. 1 F).

Treelets and trees. Treelets are common in Lychnophorinae, sometimes candelabriform like in Lychnophora (L. salicifolia (Fig. 3 D), L. ericoides etc.) and rarely in other genera (Lychnocephalus sellowii, Lychnophorella leucodendron). This habit is characteristic of, Eremanthus (Fig. 3 E), Gorceixia and Paralychnophora (Fig. 3 C), rare in other genera (Lychnocephalus mellobarretoi (Fig. 3 F). The tallest plants in the subtribe are Gorceixia decurrens reaching up to seven meters (Hind et al., 2006), and Eremanthus arboreus, reaching five meters. Most trees are poorly to moderately branched and ramifications are commonly subdichotomous with leaves restricted to the apices of the branches.

\section{Branches}

The branches of Lychnophorinae are usually cylindrical, flattened only in Chronopappus and winged only in Gorceixia. They are covered by a dense indumentum and usually become partially to completely glabrous with age. The indumentum varies from felted (as 'lepidote' in Macleish, 1987) to lanate in some species of Heterocoma and Lychnophora. In these latter species the indumentum thickness may reach 2 centimeters, and is likely to avoid excessive transpiration and protect against the fire (Luque and Menezes, 2003), as well as against herbivory by reducing insect movements (Wagner et al., 2004). Stem indumentum is composed of the same trichomes described below for the leaves. The only exception is found in Blanchetia, where dark multicellular unbranched trichomes are only found in the stems. In Lychnophora, the leaf scars often give a tesselated aspect to the stems. The branches of Lychnophora and Paralychnophora are sometimes very stout and Coile and Jones (1981) described them as pachycladous. Luque and Menezes (2003) studied the stem anatomy of eleven species of Lychnocephalus, Lychnophora and Lychnophorella: the epidermis is single-layered with stomas, remaining a long time even after secondary growth has become established, and the medulla occupies the largest proportion of the stem.

\section{Leaves}

The group displays a very large variety of leaf shapes and textures. More information can be found in the description of each genera; in the present section we will address to the main characteristics which are usefull in the taxonomy of the group.

Phyllotaxy. The leaves are alternate and sometimes arranged in multiple spirals (Luque and Menezes, 2003).

Petiole. Leaves are petiolate or sessile. Gorceixia has a winged pseudopetiole (Bell, 2008). Noteworthy are the leaves of Lychnophora villosissima, which are shortly petiolate but their petioles are completely hidden by the stem indumentum so that the leaves appear sessile. Leaf sheath. This character has been ignored by most authors until the revision of Lychnophora 
by Semir (1991). Three main kinds of sheaths are here recognized: (1) The pad-like sheath was described by Robinson (1983) and interpreted as a petiole but stating that it could correspond to a reduced sheath. Semir (1991) and Luque and Menezes (2003) considered the structure as a sheath and not a petiole, an interpretation followed in the present study. The pad-like sheath characterizes the genera Piptolepis and Lychnophorella (Fig. 1 G; Fig. 4 A). A related structure, the obtriangulate leaf sheath, more reduced and nearly inconspicuous, is found in the Lychnophora brunioides group (see Incertae Sedis section). (2) The semi-amplexicaul leaf sheath is the most frequent one and occurs in most genera (Anteremanthus, Chronopappus, Heterocoma, Lychnocephalus, Minasia, Paralychnophora, Prestelia and Vinicius) (Fig. 4 B). (3) The amplexicaul leaf sheath is uncommon, only present in Proteopsis and in some species of Heterocoma and Lychnocephalus (Fig. 4 C). Semir (1991) and Luque and Menezes (2003) suggest that a fusion of sheaths with the stem would explain the sheathless leaves of Lychnophora, thus interpreting the pad-like sheath as an intermediate stage. Phylogenetic analyses furnishes evidence that the lack of sheath in Lychnophora is probably secondary, but the hypothesis of the pad-like sheath as an intermediate stage remains dubious (Loeuille et al., in prep.; see Chapter 3).

Venation. Lychnophorinae leaves have normally camptodromous pinnate venation, frequently eucamptodromous or brochidodromous (or sometimes a mixed pattern as in Lychnophora salicifolia). Reticulodromous venation is uncommon (Eremanthus reticulatus, Lychnophora villosissima), while a hyphodromous pattern is common in groups with ericoid leaves (Lychnophora spp., Lychnophorella, Piptolepis). Proteopsis and some Heterocoma present an actinodromous pattern and a mixed pattern brochidodromous-acrodromous is found in Prestelia. Noteworthy is the uncommon parallelodromous venation of Lychnocephalus sellowii (also found in Chresta speciosa, another species of Vernonieae) (Handro et al., 1970; Alencastro, 1978; Semir, 1991).

Indumentum and trichomes. Leaf indumentum varies from tomentose to densely lanate, adaxial surface often becoming partially to completely glabrous with age. The only fully glabrescent leaves are sometimes encountered in specimens of Centratherum punctatum. A recent anatomical study (Loeuille et al., in press) included 86 taxa of the subtribe and revealed a considerable variety of non-glandular trichomes (Fig. 5). Most species usually have two to several types of trichomes. Unbranched trichomes (Fig. 5 A-E) are not frequent but nearly all species of Piptolepis have unbranched ones with auriculate bases. T-shaped trichomes are more common in basal lineages (Albertinia, Centratherum, Anteremanthus etc.) (Fig. 5 F-G) and swollen T-shaped trichomes are only found in Minasia and Vinicia (Fig. 5 H-I). Inverted Y-shaped trichomes are found in Hololepis and in some species of Lychnocephalus (Fig. $5 \mathrm{~J}$ ). 3- to 5-armed are the most common types among Lychnophorinae (Fig. $5 \mathrm{~K}-\mathrm{Q}$ ), the swollen subtype (Fig. 5 L) is responsible for the typical indumentum of Eremanthus leaves (lepidote or felted) but is also found in other genera (Lychnophorella, Vinicia etc.). Stellate trichomes (Fig. $5 \mathrm{R}-\mathrm{W})$ are frequent in basal lineages such as Heterocoma, Gorceixia and especially Blanchetia 
where the subtype with forked arms (Fig. $5 \mathrm{~W}$ ) is a putative synapomorphy of the genus. In addition to these main categories, these trichomes are sometimes geminate (Chronopappus, Heterocoma spp.) (Fig. 5 C, O, U), porrect (Heterocoma spp.) (Fig. 5 N, T), with side-arms (Gorceixia, Lychnocephalus spp.) (Fig. 5 D, Q) or curly (Lychnophora spp.) (Fig. 5 E, M). Finally, the long multicellular (more than two) stalked stellate trichomes are encountered only in Gorceixia (Fig. 5. P, Q).

\section{Morphology of Reproductive Structures}

\section{Capitula arrangement}

Capitula are usually arranged in capitulescences in Lychnophorinae, the solitary capitulum being uncommon in the group (Centratherum, Hololepis and Heterocoma albida). The capitulescence is placed in an axillary or terminal position. It is usually a panicle (Albertinia, Minasia), sometimes with very short internodes (Blanchetia). When two or more capitula are closely arranged, they form either a glomerule if they are sessile (Fig. 6A) or a pseudoglomerule if they are pedunculate (Fig. 6 B); solitary glomerules or pseudoglomerules are common in Minasia, Piptolepis and Proteopsis; in the latter genus the pseudoglomerule is surrounded by a secondary involucre of subinvolucral bracts (Fig. 6 C). A secondary involucre is also common in Heterocoma and Hololepis but here it encloses a single capitulum. Gomerules and pseudoglomerules of capitula may form a panicle-like inflorescence in Minasia (Fig. 6 F) or a cyme (simple or compound) in Eremanthus. One of the most striking features of the Lychnophorinae is the formation of a syncephalium (or secondary heads) (Harris, 1999), which is mostly defined by the presence of a secondary receptacle and usually a secondary involucre. Second-order syncephalia (Fig. 6 D) are found in Eremanthus, Gorceixia, Lychnophora, Lychnophorella, Paralychnophora, Piptolepis pabstii and Prestelia. Lychnocephalus displays third-order syncephalia (Fig. 6 E), which constitute a synapomorphy of this genus. Characteristics of the syncephalium (degree of fusion between capitula, presence of reduced leaves etc.) are widely used in the taxonomy at the species level since they appear quite constant for a species. In Lychnophora and Lychnophorella, secondary involucres are frequently hardly distinguishable from the distal leaves. Two species of Lychnophora (previously placed in Lychnophoriopsis) have capitula arranged in a spikelike capitulescence and do not form a syncephalium. Usually syncephalia are solitary either in a terminal position (Gorceixia, Lychnophora and Lychnophorella) or in an axillary position (Paralychnophora and Prestelia), however they are arranged in a cyme (simple or compound) in several species of Eremanthus (Fig. 6 G).

\section{Involucre and receptacle}

Most of Lychnophorinae have a campanulate involucre, its shape varying from cylindrical (Eremanthus spp., Gorceixia, Lychnophora spp.), ovoid (Blanchetia and Chronopappus), to 
turbinate (Eremanthus spp.). The number of series of phyllaries, degree of imbrication and duration show more variation and thus are more important in taxonomy; for example, a weakly imbricate caducous involucre defines the genus Piptolepis.

The receptacle is frequently areolate or fimbrillate (Fig. 7 A, B), seldom naked. Two species of Heterocoma ( $H$. albida and H. erecta) have paleaceous receptacle (see Loeuille et al. in prep.; Chapter 4, for a discussion on the receptacle ornamentation in Heterocoma). Albertinia receptacle is conspicuously alveolate (Fig. 7 C), a character unique in the Lychnophorinae and in the tribe as a whole.

\section{Florets}

Corolla. The corolla is typically 5-lobed, with the tube either shorter than the limbs (Heterocoma spp., Eremanthus spp., Hololepis, Lychnophora spp., etc.) or, more often, equal or longer than the limbs. The lobes are usually ascending, rarely revolute (Blanchetia and Chronopappus). The corolla is frequently glandular and sometimes with pilose lobes. Laticifers have been found in the corolla lobes of Chronopappus, Heterocoma and Hololepis.

Anthers apical appendages. These appendages have conspicuous wall thickenings (except in Albertinia) and do not have glands. Some of their features (ratio length/width, constriction at the base, etc.) are constant in some species groups (for example nearly all Piptolepis species have appendages constricted at the base), but the variation is too remarkable to be useful at the generic level.

Anther bases. Nearly all Lychnophorae anthers are calcarate without a steril tail. The two exceptions are: Centratherum with ecalcarate anthers, and Minasia with tailed calcarate anthers. Style basal node. A basal node is lacking in styles of all Lychnophorinae, but it may be noted that Albertinia has a small sclerified node.

\section{Cypselae}

Cypsela and pappus have been extensively used by botanists to classify the subtribe. Glabrous, often glandular, cypselae are as common (Blanchetia, Chronopappus, Gorceixia, Heterocoma, Paralychnophora spp., Piptolepis, etc.) as pubescent ones (Albertinia, Eremanthus spp., Lychnophora spp. etc.), the indumentum always composed of twin-hairs. The shape of the cypsela varies from cylindrical, turbinate to prismatic (i.e., angled) but the variation is probably more helpful at low taxonomic level than at generic level. Noteworthy is the presence of phytomelanin in the walls of Heterocoma cypselae (see Loeuille et al. in prep.; Chapter 4), a feature that appears to be a synapomorphy of the genus. Finally, a carpopodium is often poorly developed and inconspicuous, but sometimes prominent (Albertinia, Anteremanthus, Heterocoma spp., Hololepis, Minasia, Paralychnophora spp. and Proteopsis).

\section{Pappus}

The pappus is normally biseriate, sometimes uniseriate (Centratherum, Gorceixia, Proteopsis, 
etc.) and rarely 3- to 5-seriate (Eremanthus, Prestelia). The outer series is frequently smaller than inner series and seldom reduced and coroniform (Lychnophora spp.); its setae may be fused to various degrees or rarely form a collar (Gorceixia). Paleaceous pappus is very frequent (Heterocoma spp., Eremanthus spp., Lychnocephalus spp., Lychnophora spp.), whereas setose pappus is quite rare (Minasiai, Paralychnophora spp., Piptolepis spp., Prestelia). MacLeish's (1987) use of subpaleaceous pappus (width bewteen 0.08 and $0.1 \mathrm{~mm}$ ) in the taxonomy of Eremanthus reveals to be quite useful at the species level in the Lychnophorinae. Twisted setae of the inner pappus are quite frequent (Heterocoma spp., Lychnocephalus, Lychnophora, Lychnophorella spp., Proteopsis). The duration of the pappus also is taxonomically important. Caducous (falling before the anthesis) is here distinguished from deciduous (falling after the anthesis) following the definition given by Candolle (1819: 517). The two cases are frequent in Lychnophorinae, caducous pappus is found in Blanchetia, Eremanthus spp., Heterocoma, Lychnocephalus, Lychnophora, etc. and deciduous in Anteremanthus, Chronopappus, Eremanthus spp., Hololepis, Lychnophorella spp. The base of the pappus setae is sometimes enlarged (Albertinia,Piptolepis, Prestelia and Proteopsis) and the apex is clavate(Anteremanthus, Minasia, Piptolepis spp.) or seldom narrowed (Lychnocephalus).

\section{Pollen}

The pollen grains of Lychnophorinae are tricolporate, echinate, sublophate with a perforated tectum continuous between colpi (type "A") (Robinson, 1992, 1999; Keeley and Robinson, 2009). The endoaperture is usually lalongate (Peçanha et al., 2008). The type "A" pollen is considered a reversion from more strongly lophate ancestors in the Vernonieae, but it is nevertheless one of the most common forms in the tribe, and is consistent in many groups such as the Piptocarphinae, Vernonia s.s. and Vernonanthura (Robinson, 1990, 1992, 1999). Studies of Lychnophorinae pollen are limited to some species of Albertinia and Paralychnophora (Peçanha et al., 2008) and Eremanthus (Loeuille et al., in prep.). These results indicate that palynological data are not significant in the delimitation at specific level and probably at generic level in the subtribe Lychnophorinae.

\section{CITOLOGY AND CHEMISTRY}

\section{Chromosome number}

The chromosome number reports of Lychnophorinae (Table 2) were scarce but several recent publications have improved our knowledge focusing mainly on Lychnophora (Mansanares and Semir, 2001; Mansanares et al. 2002, 2007a, 2007b); numbers are also available for Blanchetia (Salles-de-Melo et al., 2010), Centratherum (Kirkman, 1981; Salles-de-Melo et al., 2010), Eremanthus (Turner et al., 1979; Watanabe et al., 2007; Salles-de-Melo et al., 2010), Lychnocephalus (Mansanares and Semir, 2001; Mansanares et al., 2002), Lychnophorella (Mansanares et al., 2007a), Minasia (Dematteis, 1998, as Vernonia alpestris) and 
Paralychnophora (Mansanares et al., 2007b). The chromosome numbers are $n=17,18,19$ with one report of $n=15$ (Eremanthus elaeagnus) (Turner et al., 1979), of $n=16$ (Centratherum) and of $n=23$ (Blanchetia) (Salles-de-Melo et al., 2010). A polyploid population of Lychnophora staavioides $(n=34)$ was reported by Mansanares et al. (2002).

\section{Sesquiterpene lactones}

These represent the most diverse class of secondary metabolites in the subtribe Lychnophorinae (Keles et al., 2010) and probably in the tribe Vernonieae. The presence of heliangolides in the aerial parts is a synapomorphy of the group (Loeuille et al., in prep; see chapter 2). Within the subtribe other groups of sesquiterpene lactones (STLs) occur, such as guaianolides and eudesmanolides (see Loeuille et al., in prep; Chapter 1 for the classification of STLs adopted here). The two main derivatives of heliangolides found in the group are furanoheliangolides and eremantholides, but both derivatives frequently co-occur and their presence do not seem taxonomically helpful at the generic level. Kelles et al. (2010) reviewed the diversity of structures and pharmacological activities found in Lychnophorinae. Activities of STLs as deterrents against herbivores and anti-fungal, anti-bacterial allelopathic agents were reviewed by Picman (1986).

\section{GeOgRAPHic Distribution}

The wide range of the subtribe Lychnophorinae depicted in Figure 8 is due to the distribution of a single species, Centratherum punctatum, the only pantropical weed of the group. This species occurs from Northern Argentina to Central America and has been introduced to Australia and the Philippines. Several tropical American plants have likely been introduced into the Philippines and Australia via trade routes established by Portuguese and Spanish travelers during the XVI e century (Merrill, 1954; Kirkman, 1981). Bean (2004) argued that C. punctatum was introduced in Australia as an ornamental plant in the mid 20th century; however Cassini (1828) described Ampherephis pulchella (=C. punctatum) based on material collected around 1825 in a garden at Port Jackson [Sydney]. Introduction in Taiwan (Chen et al., 1999), Florida (U.S.A) (Strother, 2006) and Hawaii (USA) (Starr et al., 2010) are likely more recent and these distribution records reflect the fact that the exact distribution of that species is not completely known.

The core-area of the subtribe (103 of 104 spp.) is almost exclusively centered in Brazil, with a few species of Eremanthus occurring in the department of Santa Cruz in Bolivia (shaded area in Fig. 8). Thus the distribution of Lychnophorinae largely mirrors the area of the Cerrado Domain, with the exception of the southern limit since no member of the group has ever been reported in Paraguay. The Cerrado is the world's most species-rich tropical savanna, and the Lychnophorinae shows its higher levels of diversity and endemism in a particular geomorphological formation included in the Cerrado Domain: the Espinhaço Range of mountains in Bahia and Minas Gerais 
States, specially in the latter, and mostly in the campo rupestre vegetation. Microendemism is very frequent in the subtribe for taxa restricted to the campo rupestre; these taxa may, nonetheless, be locally abundant. Less often, some Lychnophorinae occur outside of campos rupestres and cerrados: Blanchetia is found in the Caatinga and Atlantic forest, Gorceixia in semideciduous and deciduous forests, some species of Eremanthus frequently inhabit secondary woods and may occupy the coastal restingas or the border of gallery forests (Hololepis, Eremanthus spp.). Several species of Eremanthus (in particular E. erythropappus, but also E. elaeagnus and E. incanus) commonly form dense and extense populations (locally called 'candeial'), which dominate the communities mostly in cerrado or forest areas. Dense populations of several species of Lychnophora (L. ericoides, L. salicifolia, etc.) may constitute a peculiar landscape in some campo rupestre and cerrado areas.

The wealth of the Lychnophorinae in the open savanic formations of Eastern Brazil, mostly on higher altitudes, suggests a history of diversification probably related to geographic isolation and/or to pressures of habit and habitat selection. The high endemicity level observed in many plant families in the island-like campos rupestres on top of the Espinhaço Range of mountains has been hypothesized by several authors (e.g. Giulietti and Pirani, 1988; Giulietti et al., 1997) as a consequence of local speciation, probably related to past climatic fluctuations. Some recent time-calibrated phylogenies suggest that Cerrado lineages started to diversify less than 10 million years ago, 'with most lineages diversifying at 4 Mya or less, coinciding with the rise to dominance of flammable C4 grasses and expansion of the savanna biome worldwide' (Simon et al., 2009). These authors pointed out that the studied Cerrado lineages seem to be strongly associated with adaptations to fire, and have sister groups in largely fire-free nearby forests or subtropical grassland, suggesting recent events of adaptive shifts to resist fire in those lineages. As discussed in the previous morphology section, many features of several Lychnophorinae genera are likely to be protective against fire, and thus the great diversification of the group in the Cerrado and campo rupestre may have followed the general history proposed by Simon et al. (2009). However, until dated phylogenies - with the necessary restrictions to such data (Zaragëta-Bagils et al., 2004; Nelson and Ladiges, 2009) - are available for the group, we cannot be sure whether or not the diversification of the Lychnophorinae in South America occurred contemporaneously with the already studied Cerrado lineages of other plant groups.

\section{Phylogenetics Relationships}

Phylogenetic relationships among American Vernonieae have been recently studied based on morphological and molecular (ITS, $n d h \mathrm{~F}, r p l 32-t r n \mathrm{~L}$ ) data (Loeuille et al., in prep.; see Chapter 2). These results (Fig. 9) lead to a new circumscription of Lychnophorinae in order to keep the subtribe monophyletic. Two small subtribes (Centratherinae, Sipolisiinae) and three monotypic 
genera (Albertinia, Blanchetia and Gorceixia) are transferred herein to Lychnophorinae, which has the presence of heliangolide in aerial parts as a synapomorphy. Based on morphological and molecular (ETS, ITS, $n d h \mathrm{~F}, r p l 32-t r n \mathrm{~L}$ ) data, Loeuille et al. (in prep.; see Chapter 3) propose a phylogenetic hypothesis for the relationships within Lychnophorinae (Fig. 9) which provided the foundations for the present synopsis. The polyphyly of Lychnophora conducted us to split that genus into three monophyletic smaller taxa: Lychnophorella - a new genus described herein, Lychnocephalus - a genus described by Candolle here re-established, and Lychnophora s. str. With minor adjustments, most clades are associated with some existing generic concept and can be defined by a simple combination of morphological characters. The eighteen genera recognized in the present study are therefore monophyletic and diagnosable. The relations between the most basal lineages (Centratherum, Albertinia, Blanchetia and Gorceixia) are well established as well as between the most derived genera (Eremanthus, Lychnophora, Lychnophorella, Piptolepis). However, the relationships between the other genera remain poorly resolved and more studies are necessary for a better understanding. Some species emerging as isolated lineages (Eremanthus crotonoides), or which relationships with other genera are poorly supported (Lychnophora markgravii), or which position should be confirmed by a denser taxonomic sampling (Lychnophora damazioi) are placed in the Incertae Sedis section to avoid either unecessary new combinations and creation of new monotypic genera.

Lychnophorinae Benth. in Benth. \& Hook. f., Gen. pl. 2: 171. 1873. TYPE: Lychnophora salicifolia Mart.

Synonyms: Albertinieae DC., Prodr. 5: 78. 1836, pro parte

Hololepidae Sch. Bip., Jahresber. Pollichia 20-21: 377. 1863.

Centratherinae H. Rob., R. M. King, \& F. Bohlmann, Phytologia 46: 425. 1980. TYPE: Centratherum punctatum Cass., syn. nov.

Sipolisiinae H. Rob., Smithsonian Contr. Bot. 89: 13. 1999. TYPE: Sipolisia lanuginosa Glaz. ex Oliv. (= Heterocoma lanuginosa (Glaz. ex Oliv.) Loeuille, J. N. Nakaj. \& Semir), syn. nov.

Trees, shrubs, caulirosulas, rarely subshrubs or herbs; trichomes unbranched, T-shaped, 3- to 5 -armed or stellate. Leaves alternate, often expanded at the base forming a sheath, venation pinnate or rarely parallelodromous. Inflorescence (capitulescence) terminal or axillary, capitula (heads) often arranged in a glomerule (a cluster of heads) or in a syncephalium (a capitulescence that exhibits a common receptacle and usually a common involucre to several heads). Phyllaries usually persistent, sometimes caducous. Receptacle areolate to fimbrillate, seldom naked, rarely paleaceous. Florets 1-110 in a capitulum; corolla purple to whitish; apical anthers appendages with conspicuous wall thickenings (except Centratherum); style without basal node (except Albertinia). Cypsela glabrous to pubescent, sometimes with phytomelanin on walls; carpopodium infrequently prominent; pappus often paleaceous, twisted, frequently 
deciduous to caducous. Pollen tricolporate, echinate, sublophate, perforated tectum continuous between colpi. Sesquiterpene lactones: furanoheliangolides. Chromosome number: $n=15,16$, $17,18,19$ e 23 .

18 genera, 104 species. Mostly Brazil.

The name Albertinieae DC. was published at a different rank ('subdivisio') than Lychnophorinae Benth. ('subtribus') and therefore has no priority over the latter name (ICBN, Art. 11.2; McNeill et al., 2006). The same applies to Hololepidae Sch. Bip. published without assigning a rank to this name.

\section{Artificial Key to the Genera of Lychnophorinae}

The following does not include the seven taxa placed in Incertae Sedis.

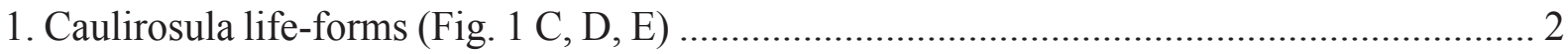

1. Trees, treelets, shrubs, subshrubs or herbs (Fig. 1 A, B, Fig. 2) ….......................................... 4

2. Capitula arranged in a syncephalium; phyllaries 3-4 series; cypselae with inconspicuous carpopodium Prestelia

2. Capitula arranged in a solitary glomerule or panicle of glomerules; phyllaries 5-6 series; cypselae with prominent carpopodium

3. Leaf indumentum composed of T-shaped swollen trichomes (Fig. $4 \mathrm{H}$ ); phyllaries apices without spiny appendages; florets 20-50; anthers tailed Minasia

3. Leaf indumentum composed of unbranched trichomes (Fig. 4 A); phyllaries apices with spiny appendages; florets 80-100; anthers not tailed Proteopsis

4. Herbs (Fig. 1 A), rarely subshrubs and then outermost phyllaries foliaceous; anthers ecalcarate, apical appendages without conspicuous wall thickenings Centratherum 4. Shrubs (Fig. 1 B; Fig. 2 A, B), treelets (Fig. 2 C, D, F) or trees (Fig. 2 E), rarely subshrubs and then outermost phyllaries not foliaceous; anthers calcarate, apical appendages with conspicuous wall thickenings

5. Leaf sheath absent

5. Leaf sheath present, pad-like to amplexicaul (Fig. 3 A-C) 11

6 . Receptacle deeply alveolate; style with basal node; leaf indumentum composed of symmetric T-shaped with long arms (Fig. 4F) Albertinia

6. Receptacle naked, areolate to fimbrillate; style without basal node; leaf indumentum composed of unbranched (Fig. 4 A-E), 3- to 5-armed (Fig. 4 K-Q), stellate (Fig. 4 R-W) and T-shaped trichomes with short arms or asymmetric long arms (Fig. 4 G-I) .....

7. Solitary capitulum with foliaceous trinerved subinvolucral bracts Hololepis

7. Capitula arranged in a inflorescence (glomerule, syncephalium, cyme or panicle), when solitary with pinnate subinvolucral bracts 8

8. Leaf margins serrate to dentate; leaf indumentum composed of stellate trichomes with long 
multicellular stalk (Fig. 4 P, Q)

8. Leaf margins entire; leaf indumentum trichomes T-shaped or 3-5-armed, when stellate with short stalk

9. Shrubs; stems not winged; capitula arranged in a panicle with short internodes; involucre ovoid Blanchetia

9. Trees or treelets; stems winged; capitula arranged in a syncephalium; involucre cylindrical .....

Gorceixia

10. Leaf margins flat; capitula arranged in a cyme of glomerules or of syncephalia; pappus 2-5-seriate. Eremanthus

10. Leaf margins revolute; capitula arranged in a solitary syncephalium or rarely in a congested spike Lychnophora

11. Leaf usually with pad-like sheath (Fig. 3 A); if semi-amplexicaul sheath then phyllaries caducous

11. Leaf with semi-amplexicaul to amplexicaul sheath (Fig. $3 \mathrm{~B}, \mathrm{C}$ ); phyllaries persistent, rarely deciduous 13

12. Phyllaries strongly imbricate and persistent (Bahia State). Lychnophorella

12. Phyllaries weakly imbricate and caducous (Minas Gerais and Goiás States)

Piptolepis

13. Capitula arranged in a syncephalium 14

13. Capitula variously arranged in a glomerule or panicle or rarely solitary 15

14. Third-order syncephalium; inner series pappus setae apices narrowed Lychnocephalus

14. Second-order syncephalium; inner series pappus setae apices not narrowed

Paralychnophora

15. Cypselae glabrous; capitula with foliaceous subinvolucral bracts; leaf indument composed of stellate (Fig. 4 R), 3- to 5-armed trichomes (Fig. 4 K), commonly geminate (Fig. 4 O, U) . .16 15. Cypselae pubescent; capitula without foliaceous subinvolucral bracts; leaf indument composed of T-shaped trichomes (Fig. 4 I).

16. Leafadaxial suface strongly muricate, not marcescent; involucre ovoid; florets 8-11; cypselae walls without phytomelanin

Chronopappus

16. Leaf adaxial surface smooth, not muricate, marcescent; involucre campanulate; florets 20-75; cypselae walls with phytomelanin Heterocoma

17. Leaf petiolate; capitula pedunculate; florets 45-60; cypselae with inconspicuous carpopodium Anteremanthus

17. Leaf sessile; capitula sessile; florets 8-12; cypselae with prominent carpopodium Vinicia 
I. Albertinia Spreng., Neue Entdeck. Pflazenk. 2: 133. 1821. TYPE: A. brasiliensis Spreng. Synonym: Symblomeria Nutt., Trans. Amer. Philos. Soc. Ser. 2. 7: 284. 1841. TYPE: S. baldwiniana Nutt. (= Albertinia brasiliensis Spreng.).

Shrubs, usually subscandent, stems poorly branched. Indumentum pubescent, composed of T-shaped trichomes with long arms. Leaves alternate, petiolate, sheathless, blade chartaceous, slightly discolorous or concolorous, margin entire, flat (notrevolute), venation eucamptodromous. Inflorescence an axillary, pedunculate, panicle of capitula. Capitulum pedunculate. Involucre campanulate; phyllaries 4-5, imbricate, persistent, pubescent; receptacle deeply alveolate. Florets 6-12; corolla cream, tube longer than limb; corolla lobes apices glabrous; anthers calcarate; style with basal node. Cypsela cylindrical, pubescent, carpopodium prominent; pappus biseriate, persistent, stramineous, outer series subpaleaceous, smaller than inner series, setae base slightly enlarged, inner series setose. Chromosome number: unknown.

A monotypic genus from eastern Brazil. Candolle (1836) assumed that Albertinia brasiliensis Spreng. had one floret per capitulum and fused capitula, like observed in several species of Lychnophorinae. However, since Schultz-Bipontinus $(1861,1863)$ inflorescence in Albertinia is considered as a multiflowered capitulum with an alveolate receptacle - surface with deep holes enclosing the full length of the cypselae (Robinson, 1999).

1. Albertinia brasiliensis Spreng., Neue Entdeck. Pflazenk. 2: 133. 1821. TYPE: A. brasiliensis Spreng. TYPE: BRAZIL. No other data, F. Sello(w) s.n. (Holotype: presumably B [destroyed]). Synonyms: Vernonia brasiliensis (Spreng.) Less., Linnaea 6: 682. 1831.

Symblomeria baldwiniana Nutt., Trans. Amer. Philos. Soc. Ser. 2. 7: 284. 1841. TYPE: BRAZIL. W. Baldwin (Holotype not localized).

Vernonia platycephala Gardner, London J. Bot. 5: 212. 1846. TYPE: BRAZIL. Rio de Janeiro: in low woods on the ascent of the Corcovado, near Rio de Janeiro, January 1841, G. Gardner 5508 (Syntypes: BM [not seen], K [2 specimens] [scan seen]).

Distribution and habitat: Brazil (Bahia, Espírito Santo, Minas Gerais, Rio de Janeiro, Sergipe). Margins of rainforests and secondary woods; up to $1200 \mathrm{~m}$.

A common species easily recognized by its deeply alveolate receptacle. The protologue is Sprengel (1821) and not "Syst. Veg. (ed. 16) 3: 434. 1826" as often cited (e.g., Robinson, 1999). In the latter publication the Sello(w) material is cited.

Representative specimens: BRAZIL. Bahia: Abaíra, estrada Catolés-Barra, 3-5 km de

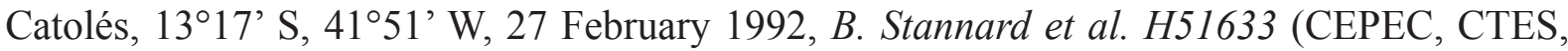
HUEFS, K, SP, SPF, US). Espírito Santo: Santa Teresa, Mata da prefeitura, São Lourenço, 7 June 1984, W. A. Hofmann 132 (BHCB, MBML, RB). Minas Gerais: Águas Vermelhas, rodovia BR 116, 20 November 1985, G. Hatschbach \& J. M. Silva 50024 (MBM, US). Rio de Janeiro: Teresópolis, Serra dos Orgãos, 24 September 1980, N. F. F. MacLeish et al. 669 (GA, NY, RB). Sergipe: Santa Luzia de Itanhy, Mata do Crasto, 19 April 1995, M. Landim 331 (RB). 
II. Anteremanthus H. Rob., Proc. Biol. Soc. Wash. 105: 646. 1992. TYPE: A. hatschbachii H. Rob.

Treelets, stems mostly branched towards apices. Indumentum pubescent, composed of T-shaped trichomes. Leaves alternate, petiolate, with a semi-amplexicaul leaf sheath, blade coriaceous, discolorous, margin entire, flat (not revolute), venation eucamptodromous. Inflorescence an axillary, pedunculate, panicle of capitula. Capitulum pedunculate. Involucre campanulate; phyllaries 4-5 series, strongly imbricate, persistent, pubescent; receptacle fimbrillate. Florets 45-60; corolla cream, tube shorter than limb; corolla lobes apices revolute, pubescent; anthers calcarate; style lacking a basal node. Cypsela cylindrical, pubescent, carpopodium prominent; pappus biseriate, paleaceous, stramineous, outer series smaller than inner series, persistent, setae base slightly enlarged, inner series deciduous, setae apices clavate. Chromosome number: unknown.

A monotypic genus restricted to the Espinhaço Range of mountains in Minas Gerais, Brazil.

1. Anteremanthus hatschbachii H. Rob., Proc. Biol. Soc. Wash. 105: 646. 1992. TYPE: BRAZIL. Minas Gerais: Grão-Mogol, Rio Itacambiruçu, 15 May 1988, G. Hatschbach \& O. S. Ribas 52026 (Holotype: MBM; Isotype: US).

Synonym: Vernonia hatschbachii (H. Rob.) D. J. N. Hind, Kew Bull. 49: 514. 1994.

Distribution and habitat: Brazil, endemic of Grão-Mogol region, northeastern Minas Gerais. Campo rupestre; 700-1000 m.

The main distinctive characters of the species are the discolorous petiolate leaves and paniculate inflorescences with pedunculate capitula.

Representative specimens: BRAZIL. Minas Gerais: Cristália, estrada Grão-Mogol Cristália, ponte sobre o Rio Itacambiruçu, 18 July 1998, G. Hatschbach et al.67975 (MBM, US). Grão-Mogol, Córrego Escurinha, 23 May 1982, A. M. Giulietti et al. CFCR 9864 (BHCB, K, SPF, UEC); ibid., Vale do Córrego das Mortes, 16³4’48” S, 42 54’07” W, 820 m, 6 June 2008, B. Loeuille et al. 441 (SPF).

III. Blanchetia DC., Prodr. 5: 75. 1836. TYPE: B. heterotricha DC.

Synonym: Irwinia G. M. Barroso, Rodriguésia 32: 11. 1980. TYPE: I. coronata G. M. Barroso (= Blanchetia coronata Loeuille, Semir \& Pirani), syn. nov.

Shrubs, sometimes subscandent, stems branched. Indumentum pubescent, composed of dark multicellular unbranched trichomes, pale stellate trichomes with forked arms, sometimes porrect or geminate. Leaves alternate, shortly petiolate, sheathless, blade papiraceous to subcoriaceous, discolorous, margin serrate to dentate, flat (not revolute), venation eucamptodromous. Inflorescence a terminal, pedunculate panicle of capitula with short internodes. Capitulum shortly pedunculate. Involucre ovoid; phyllaries 3-4 series, strongly imbricate, persistent, pubescent; receptacle sometimes with thin partitions. Florets 5-10; corolla cream, tube longer than limb; corolla lobes apices glabrous; anthers calcarate; style lacking basal node. Cypsela 
prismatic, glabrous, carpopodium inconspicuous; pappus uni- or biseriate, caducous (except outer series in B. coronata), paleaceous, whitish. Chromosome number: $n=23$ (B. heterotricha).

A genus of two species from the Caatinga domain in Bahia state. The many features shared by these species (type of trichomes, involucre, etc.) clearly indicate a close relationship between them, so their placement in two monotypic genera (Blanchetia and Irwinia) is not accepted here.

1. Blanchetia coronata (G. M. Barroso) Loeuille, Semir \& Pirani, comb. nov.

Basionym: Irwinia coronata G. M. Barroso, Rodriguésia 32: 11. 1980. TYPE: BRAZIL. Bahia: ca. 28 km N de Seabra, estrada para Água de Rega, 1000 m.s.m., 27 February 1971, H. S. Irwin et al. 31174 (Holotype: RB; Isotypes: F [scan seen], NY, US).

Distribution and habitat: Brazil (Bahia). Caatinga, gallery forest and secondary forest; up to $1000 \mathrm{~m}$.

A rarely collected species, easily sets apart from Blanchetia heterotricha by its subscandent habit (vs. erect), number of florets per capitulum (5 vs. 8-10) and bisseriate pappus.

Representative specimens: BRAZIL. Bahia: Itaberaba, Chapada Diamantina, $13^{\circ} 43^{\prime} \mathrm{S}$, 3908' W, 30 April 2006, M. L. Guedes et al. 12288 (ALCB). Maracás, quilômetros 16 a 18 da rodovia Maracás-Contendas de Sincorá (BA 250), 27 April 1978, T. S. Santos et al. 3212 (CEPEC, HRB). Wagner, próximo a Dourados, $12^{\circ} 17^{\prime} \mathrm{S}, 41^{\circ} 07^{\prime} \mathrm{W}, 550 \mathrm{~m}, 2$ April 1986, H. P. Bautista \& A. C. Sarmento 1085 (HRB).

2. Blanchetia heterotricha DC., Prodr. 5: 75. 1836. TYPE: BRAZIL. Bahia: in Brasiliâ ad Caxocira ab urbe Bahiâ leucis 15 dist., J. S. Blanchet 488 (Holotype: G [scan seen], photo at US; Isotypes: presumably F [scan seen], K [scan seen], presumably MO [scan seen], NY).

Distribution and habitat: Brazil (Alagoas, Bahia, Paraíba, Pernambuco and Sergipe). Caatinga, rarely in campo rupestre or secondary forest; up to $1500 \mathrm{~m}$.

A common species. Differences with Blanchetia coronata are discussed under that species. Two sets of Blanchet collections of $B$. heterotricha were found in herbaria with no collector number, and all of them are usually considered isotypes. Here specimens with labels indicating 1839 , a posterior date of the publication of that species, were not considered as types (the NY specimen with this date has an additional label ' 868 ' which is probably the Blanchet collector number). Insofar the remaining specimens (at F and $\mathrm{MO}$ ) do not present date or collector number so it is impossible to know if they are isotypes or not, whereas the $\mathrm{K}$ specimen is labelled with the same locality annotation cited in the protologue.

Representative specimens: BRAZIL. Alagoas: Satuba, 1 June 1988, M. N. R. Staviski 588 (HRB, MAC). Bahia: Morro do Chapéu, margem esquerda do Rio Ventura, 11 40 '44.3" S, 4100'21.1" W, 737 m, 4 February 2008, B. Loeuille et al. 394 (HAW, K, SPF). Paraíba: Campina Grande, 5 September 1977, M. F. Agra 225 (RB). Pernambuco: Caruaru, W of Recife, 25 September 1976, P. H. Davis \& D. Andre-Lima D 61102 (UEC). Sergipe: Tobias Barreto, 
próximo a comunidade Borda da Mata, $11^{\circ} 08^{\prime} 20^{\prime}$ S, 3754’32” W, 187 m, 22 August 2005, D. S. Carneiro-Torres et al. 444 (HUEFS).

IV. Centratherum Cass., Bull. Sci. Soc. Philom. Paris. 1817: 31. 1817. TYPE: C. punctatum Cass.

Synonyms: Ampherephis Kunth in Humb., Bonpl. \& Kunth, Nov. Gen. Sp. Pl. 4 (ed. folio): 24. 1818 (ed. qu. 31. 1820). TYPE: A. mutica Kunth (=Centratherum punctatum Cass.). Spixia Schrank, Pl. Rar. Hort. Monac. tab. 80. 1819. TYPE: S. Schrank (=Centratherum punctatum Cass.).

Amphibecis Schrank, Syll. Ratisb. 1: 86. 1824. TYPE: A. violacea Schrank (= Centratherum punctatum Cass.).

Oiospermum Less., Linnaea 4: 339. 1829. TYPE: O. involucratum (Nees \& Mart.) Less. (=C. repens (Spreng.) Loeuille, Semir \& Pirani), syn. nov.

Crantzia Vell., Fl. Flum. Icones 8: tab. 153. 1827 [1831]. TYPE: C. ovata Vell. (= Centratherum punctatum Cass.).

Annual to perennial herbs or subshrubs, decumbent to erect, stems branched. Indumentum glabrescent to villous, composed of unbranched, T-shaped and L-shaped trichomes. Leaves alternate, sessile to shortly petiolate, sheathless, blade papiraceous, discolorous, margin serrate to dentate, lobed, flat (not revolute), eucamptodromous. Inflorescence a terminal, pedunculate, capitulum, usually solitary, rarely $2-3$ capitula in a corymbe. Capitulum pedunculate, with foliaceous subinvolucral bracts. Involucre campanulate; phyllaries ca. 4 series, weakly imbricate, persistent, pubescent, outermost foliaceous and innermost scarious, apices rounded to long-awned; receptacle naked. Florets 25-100; corolla purple to reddish-purple, tube longer than limb, sometimes pubescent; anthers ecalcarate; style lacking basal node. Cypsela cylindrical to obconic, glabrous or pubescent, carpopodium inconspicuous; pappus uniseriate, deciduous to caducous, setose, stramineous, sometimes lacking. Chromosome number: $n=16$ (C. punctatum).

A genus of three species from Tropical America and introduced in Australia, Hawaii, the Philippines and Taiwan. Its herbaceous to subshrubby habit, the usually solitary capitula and the foliaceous subinvolucral bracts are distinctive features in the subtribe. The monotypic genus Oiospermum was set apart from Centratherum by the lack of pappus and a unique kind of cypsela setulae. However, Centratherum cardenasii also lacks pappus and consequently we synonymize here Oiospermum under Centratherum.

1. Centratherum cardenasii H. Rob., Phytologia 46: 444. 1980. TYPE: BOLIVIA. Santa Cruz: San Miserato-Chiquitos, 900 m, May 1966, M. Cárdenas 6253 (Holotype: US; Isotype: NY).

Distribution and habitat: Bolivia (Santa Cruz). Open grassland or cerrado; 500-900 m.

Only known from few collections of the Chiquitos area. Easily recognized by the lack of pappus, T-shaped indument nearly hiding the glandular punctations and bases of leaves and 
phyllaries winged.

Representative specimens: BOLIVIA. Santa Cruz: Chiquitos, ca. $50 \mathrm{~km} \mathrm{NW}$ of Roboré, 1804' S, 605' W, 500 m, 6 February 1995, J. R. Abbott \& B. Mostacedo 16135 (US). Ibidem, 85-90 km W of Roboré on road to San José de Chiquitos, 700 m, 10 April 1998, J. R. I. Wood \& F. Mamami 13447 (K, SPF).

2. Centratherum repens (Spreng.) Loeuille, Semir \& Pirani, comb. nov.

Basionym: Calydermos repens Spreng., Neue Entdeck. Pflazenk. 1: 278. 1821. TYPE: BRAZIL. (Espírito Santo ?) Ad Victoria. F. Sello(w) 778 (syntypes: B [possibly destroyed], K [scan seen], P [not seen]).

Synonyms: Ethulia involucrata Nees \& Mart., Nova Acta Phys.-Med. Acad. Caes. Leop.Carol. Nat. Cur. 12: 3. 1824. TYPE: BRAZIL. In Brasiliae arenosis circa San Pedro de Alcantara, C. F. P. von Martius s.n. (syntypes: presumably BR, presumably M). Ampherephis psilocarpa Nees \& Mart., Nova Acta Phys.-Med. Acad. Caes. Leop.Carol. Nat. Cur. 12: 4. 1824. TYPE: BRAZIL. C. F. P. von Martius s.n. (syntypes: presumably BR, presumably M).

Oiospermum involucratum (Nees \& Mart.) Less., Linnaea 4: 339. 1829.

Distribution and habitat: Brazil (Bahia, Espírito Santo ?). Open formations in disturbed areas.

A rarely collected species. Similar to Centratherum cardenasii by its annual life cycle (vs. perennial) and cypsela lacking pappus, but $C$. repens has glabrous leaves and cypselae covered by small divergently tipped setulae.

Representative specimens: BRAZIL. Bahia: Canavieiras, Vale do Rio Pardo, October 1952, G. C. P. Pinto 52253 (ALCB). Euclides da Cunha, 10³0’ S, 3900’ W, 20 March 2004, M. L. Guedes et al. 10899 (ALCB). Itabuna, CEPLAC, 9 July 1964, N. T. da Silva s.n. (K, NY, RB).

3. Centratherum punctatum Cass. in Cuvier, Dict. Sci. Nat. 7: 384. 1817. TYPE: "Cette plante a été recueillie dans l'isthme de Panama par J. de Jussieu, et se trouve dans l'herbier de son illustre neveu sous le nom de jacea panamensis» (Holotype: P-JU [not seen]).

Synonyms: Ampherephis aristata Kunth in Humb., Bonpl. \& Kunth, Nov. Gen. Sp. P1. 4 (ed. folio): 25.1818 (ed. qu. 32. 1820). TYPE: "Crescit in ripa fluvii Orinoci juxta pagum Maypures" (Holotype: P-Bonpl. [not seen]).

Ampherephis mutica Kunth in Humb., Bonpl. \& Kunth, Nov. Gen. Sp. Pl. 4 (ed. folio): 25. 1818 (ed. qu. 32. 1820). TYPE: VENEZUELA "Crescit locis temperatis Novæ Andalusieæ in monte summo Cocollard, alt. 410 hex.", [A. von Humboldt \& Bonpland 278, Cumana (Cocollar)] (Holotype: P-Bonpl. [not seen]).

Spixia violacea Schrank, Pl. Rar. Hort. Monac. tab. 80. 1819. TYPE: BRAZIL. «Patria Brasilia, unde D. Martius semina misit» (syntypes: presumably BR, presumably M). Amphibecis violacea (Schrank) Schrank, Syll. Ratisb. 1: 86. 1824. 
Centratherum brevispinum Cass. in Cuvier, Dict. Sci. Nat. 57: 346. 1828, nom. illegit. superfl. pro Ampherephis aristata Kunth.

Centratherum longispinum Cass. in Cuvier, Dict. Sci. Nat. 57: 346. 1828, nom. illegit. superfl. pro Centratherum punctatum Cass.

Ampherephis pilosa Cass. in Cuvier, Dict. Sci. Nat. 57: 346. 1828, nom. illegit. superfl. pro Ampherephis mutica Kunth.

Ampherephis pulchella Cass. in Cuvier, Dict. Sci. Nat. 57: 346. 1828. TYPE: «Nous avons fait cette description sur deux échantillons sec, en très mauvais état, donnés à $\mathrm{M}$. Mérast, en 1825, par MM. d'Urville et Lesson: ces échantillons proviennent d'individus cultivés dans le jardin du port Jackson, où ils y ont étés transplantés, dit-on, de la Nouvelle Zélande».

Ampherephis intermedia Link, Icon. Pl. Rar. (Link \& Otto) Abbild. 5: 65, tab. 29. 1829. TYPE: Habitat in Brasilia. (Holotype: B [not seen]).

Centratherum intermedium (Link) Less., Linnaea 4: 320. 1829.

Centratherum muticum (Kunth) Less., Linnaea 4: 320. 1829.

Crantzia ovata Vell., Fl. Flumin. Icon. 8: tab. 153. 1827 [1831]. TYPE: lost; the plate will be designated as a lectotype in the near future.

Centaurea riparia A. Cunn ex DC., Prodr. 6: 602. 1838 [1837]. TYPE: AUSTRALIA. New South Wales: Hastings River, near Port Macquarie, [May 1819], A. Cunningham s.n. (Holotype: G-DC [not seen]), syn. nov.

Centratherum pulchellum (Cass.) Steud., Nomencl. Bot., ed. 2: 324. 1840.

Centratherum holtonii Baker in Mart. \& Eichler, Fl. bras. 6(2): 12. 1873. TYPE: COLOMBIA. Ibagué, 18 January 1853, I. F. Holton 301 (Holotype: K [scan seen]).

Centratherum brachylepis Sch. Bip. ex Baker in Mart. \& Eichler, Fl. bras. 6(2): 12. 1873. TYPE: BRAZIL. Bahia. Ad Almada, S. Pedro d'Alcantara et ad ripas fluvio Itahypé: C. F. P. von Martius 461 (Lectotype: M [not seen], photos at GH [not seen], NY [not seen], TEX [not seen], designated by Kirkman 1981).

Centratherum punctatum Cass. var. $\beta$ parviflorum Baker in Mart. \& Eichler, Fl. bras. 6(2): 12. 1873. TYPE: BRAZIL. Bahia, J. S. Blanchet 3689 (Holotype: K [scan seen]; Isotypes: BR [not seen], F [scan seen], G [not seen], LE [not seen], MO [not seen], P [not seen]).

Centratherum parviflorum Moricand ex Baker in Mart. \& Eichler, Fl. bras. 6(2): 12. 1873, nom. nud. pro syn.

Centratherum fruticosum S. Vidal, Revis. Pl. Vasc. Filip. 159. 1886. TYPE: PHILIPPINES. Moutain Province: Lepanto District, S. Vidal y Soler 1502 (Syntypes: GH [not seen]; MA [not seen]; PNH [not seen]).

Baccharoides punctatum (Cass.) Kuntze, Revis. Gen. P1. 1: 320. 1891.

Baccharoides violaceum (Schrank) Kuntze, Revis. Gen. P1. 1: 320. 1891.

Baccharoides muticum (Kunth) Kuntze, Revis. Gen. P1. 1: 320. 1891. 
Baccharoides brachylepis (Sch. Bip. ex Baker) Kuntze, Revis. Gen. Pl. 1: 320.1891. Baccharoides holtonii (Baker) Kuntze, Revis. Gen. P1. 1: 320. 1891.

Centratherum aristatum (Kunth) Cass. ex B. D. Jacks., Index Kew. 1: 478. 1895.

Centratherum punctatum var. foliosum Chodat, Bull. Herb. Boissier ser. 2, 2: 298. 1902. TYPE: PARAGUAY. Amambay: "In arenosis pr. Vaqueria Capibary», August 1898-1899, E. Hassler 4378 (Holotype: G [not seen]; Isotypes: BM [not seen], G [2 specimens] [not seen], K [scan seen], NY [scan seen], P [not seen]).

Centratherum punctatum subsp. camporum Hassl., Repert. Spec. Nov. Regni Veg. 12: 369. 1913. TYPE: PARAGUAY. Caaguazú: "In regione fluminis Yhú, in campis siccis", October 1905, E. Hassler 9572 (Lectotype: G [not seen], selected by Ramella et al. (2009); Isolectotypes: BM [not seen], G [2 specimens] [not seen], GH [not seen], K [scan seen], MO [not seen], MPU [not seen], NY [not seen], P [not seen], S [not seen], $\mathrm{UC}[$ not seen]).

Centratherum punctatum var. longipes Hassl., Repert. Spec. Nov. Regni Veg. 12: 369. 1913. TYPE: PARAGUAY. Concepción: "Nordl. Paraguay $\left(22-23^{\circ}\right.$ lat) zwischen Rio Apa und Rio Aquidaban, Centurion", January 1908-1909, K. Fiebrig 4532 (Holotype: $\mathrm{G}$ [not seen]; Isotypes: B [probably destroyed] as photo at F [scan seen], G [not seen], $\mathrm{K}$ [scan seen], LE [not seen], SI [not seen]).

Centratherum punctatum var. viscosissimum Hassl., Repert. Spec. Nov. Regni Veg. 12: 369. 1913. TYPE: PARAGUAY. Amambay: «In campo in regione cursus superioris fluminis Apa», November 1901-1902, E. Hassler 7745 (Lectotype: G [not seen], selected by Ramella et al. (2009)).

Centratherum punctatum f. brachyphyllum Hassl., Repert. Spec. Nov. Regni Veg. 12: 369. 1913. TYPE: PARAGUAY. Canindeyú: “In dumeto pr. Ygatimi”, November 1898-1899, E. Hassler 4768 (Lectotype: G [not seen]; Isolectotypes: BM [not seen], G [3 specimens] [not seen], GH [not seen], MO [not seen], MPU [not seen], NY [scan seen], P [not seen], S [seen]).

Centratherum punctatum f. foliosum (Chodat) Hassl., Repert. Spec. Nov. Regni Veg. 12: 369.1913.

Centratherum punctatum var. albicans Hassl., Repert. Spec. Nov. Regni Veg. 12: 369. 1913. TYPE: PARAGUAY. Caaguazú: "In regione fluminis Yhú, in campis siccis", October 1905, E. Hassler 9572 (Lectotype: G [not seen], selected by Ramella et al. (2009); Isolectotypes: BM [not seen], G [2 specimens] [not seen], GH [not seen], K [scan seen], MO [not seen], MPU [not seen], NY [not seen], P [not seen], S [not seen], $\mathrm{UC}[$ not seen]).

Centratherum violaceum (Schrank) Gleason, N. Amer. Fl. 33: 49. 1922.

Centratherum camporum (Hassl.) Malme, Ark. Bot. 24A: 15. 1932.

Centratherum camporum var. albicans (Hassl.) Malme, Ark. Bot. 24A: 15. 1932.

Centratherum camporum var. longipes (Hassl.) Malme, Ark. Bot. 24A: 16. 1932. 
Centratherum punctatum subsp. fruticosum (S. Vidal) K. Kirkman, Rhodora 83: 20. 1981.

Centratherum confertum K. Kirkman, Rhodora 83: 21. 1981, nom. illeg. superfl. pro Centratherum camporum (Hassl.) Malme.

Centratherum punctatum subsp. australianum K. Kirkman, Rhodora 83: 21. 1981. TYPE: AUSTRALIA. New South Wales. North Coast: west of Wingham on Bulga road, 12 April 1953, J. Vickery 23846 (Holotype: NSW [scan seen]; Isotypes: L [not seen], MO [scan seen]). syn. nov.

Centratherum australianum (K. Kirkman) A. R. Bean, Austrobaileya 6: 977. 2004, comb. illeg.

Centratherum riparium (A. Cunn ex DC.) A. R. Bean, Austrobaileya 8: 97. 2009, syn. nov.

Distribution and habitat: Widespread pantropical weed from Florida (U.S.A) to Argentina, introduced in Australia, India, the Philippines and Taiwan. Disturbed areas.

A common, polymorphic species. Nomenclature and synonymy are based on Hind (2009) and Ramella et al. (2009). Several lectotypifications made by Kirkman (1981) were unnecessary and should not be considered. Centratherum punctatum is easily set apart from the two other species of the genus by the cypsela with a pappus. Bean $(2004,2009)$ considered Centratherum riparium native to Australia and stated that $C$. punctatum was introduced to Australia in the mid-20th century. However, the type from Ampherephis pulchella has been collected in a garden from Sydney around 1825 (Cassini, 1828). In addition, the several characters outlined in the key to distinguish both species (Bean, 2004) encompass the variation observed in C. punctatum collections of Tropical America.

Representatives specimens: BRAZIL. Goiás: Alto Paraíso, Chapada dos Veadeiros, estrada GO-239 para São Jorge, próximo a estrada para o Paraíso das Pandavas, 19 July 2007, B. Loeuille et al. 284 (SPF). PARAGUAY. Yacyreta: Dam Island Reserve, eastern area, Aña Cua, 27²3'45” S, 56³9'08” W, 23 October 1999, E. M. Zardini \& R. Gamarra 51855 (AS, K, MO, SPF). PERU. Loreto: vicinity of Iquitos, $03^{\circ} 44^{\prime} 53^{\prime \prime}$, $, 78^{\circ} 14^{\prime} 50^{\prime \prime} \mathrm{W}, 22$ July 1972, T. B. Croat et al. $18292(\mathrm{MO}, \mathrm{RB})$.

V. Chronopappus DC., Prodr. 5: 84. 1836. TYPE: C. bifrons (DC. ex Pers.) DC.

Shrubs or treelets, stems moderately branched, flexuose, flattened. Indumentum lanate, composed of unbranched, stellate and 3- to 5-armed trichomes, commonly geminate. Leaves alternate, petiolate, semi-amplexicaul leaf sheath, blade coriaceous, discolorous, margin crenate, flat (not revolute), venation brochidodromous, adaxial surface strongly muricate. Inflorescence an axillary, pedunculate, condensed panicle of capitula. Capitulum sessile, with foliaceous subinvolucral bracts. Involucre ovoid; phyllaries 4-5 series, weakly imbricate, persistent, pubescent; receptacle fimbrillate. Florets 8-11; corolla purple to magenta, tube longer than limb; corolla lobes with laticifers, revolute and pubescent; anthers ecalcarate; style lacking basal 
node. Cypsela prismatic, glabrous, carpopodium inconspicuous; pappus biseriate, stramineous, outer series smaller than inner series, persistent, paleaceous, setae base slightly enlarged, inner series deciduous, subpaleaceous. Chromosome number: unknown.

A monotypic genus from the Espinhaço Range of mountains in Minas Gerais, Brazil.

1. Chronopappus bifrons (DC. ex Pers.) DC., Prodr. 5: 84. 1836.

Basionym: Serratula bifrons DC. ex Pers., Syn. Pl. 2: 391. 1807. TYPE: BRAZIL. No other data (Holotype: G-DC [scan seen], photo at UEC).

Synonym: Heterocoma bifrons (DC. ex Pers.) DC., Ann. Mus. Natl. Hist. Nat. 16: 191, pl. 8. 1810.

Distribution and habitat: Brazil (Minas Gerais). Campo rupestre and margins of secondary forest; $1300-1800 \mathrm{~m}$.

A rarely collected species, distinguished by its petiolate leaves with a muricate adaxial surface. Semir (1991) argued that the type material was probably collected by J. Veloso de Miranda, but the holotype label only bear Candolle's handwriting.

Representative specimens: BRAZIL. Minas Gerais: Catas Altas, Serra do Caraça, Pico da Carapuça, 18 November 2008, B. Loeuille \& M. A. Pena 460 (K, SPF, US). Santo Antônio de Itambé, Pico do Itambé, 7 April 1998, V. C. Souza et al. 21080 (ESA, SPF). São Gonçalo do Rio Preto, P.E. do Rio Preto, Pico Dois Irmãos, 2 April 2004, P. L. Viana et al. 1495 (BHCB).

VI. Eremanthus Less., Linnaea 4: 317. 1829. TYPE: E. glomerulatus Less.

Synonym: Vanillosmopsis Sch. Bip., Jahresber. Pollichia 18-19: 166. 1861. TYPE: V. glomerata Sch. Bip. (= Eremanthus erythropappus (DC.) MacLeish).

Treelets to trees, rarely shrubs, stems branched. Indumentum tomentose to lepidote, rarely velutinous, composed of 3- to 5-armed swollen trichomes, sometimes not swollen, rarely unbranched trichomes. Leaves alternate, sessile to petiolate, sheathless, blade strongly coriaceous to chartaceous, usually discolorous, margin entire, flat (not revolute), venation eucamptodromous, seldom brochidodromous or reticulodromous. Inflorescence a terminal, pedunculate, cyme of glomerules of capitula or cyme of syncephalia (second-order), sometimes with a secondary involucre. Capitulum commonly sessile. Involucre cylindrical or obconic, rarely ovoid or campanulate; phyllaries 4-7 series, strongly imbricate, persistent or rarely deciduous, pubescent, receptacle naked or rarely fimbrillate. Florets 1-11; corolla purple to white, tube longer than limb or equal, rarely shorter; corolla lobes glabrous or seldom pubescent; anthers calcarate; style lacking a basal node. Cypsela turbinate or sometimes cylindrical, rarely prismatic (E. veadeiroensis), glabrous or pubescent, carpopodium inconspicuous; pappus 3-5-seriate, sometimes biseriate, persistent to caducous, setose to paleaceous, stramineous, often whitish or reddish, outer series smaller than inner series, rarely subequal (E. brevifolius). Chromosome number: $n=15$ (E. elaeagnus), 17 (E. erythropappus, E. syncephalus). 
The largest genus of the subtribe, with 21 species from the Cerrado and campos rupestres of the Brazilian Central Plateau. The monophyly of Eremanthus as here defined is strongly supported by molecular and morphological data (Loeuille et al. in prep.; see chapter 3) and the genus is characterized by the following combination of characters: trees or treelets (rarely shrubs) bearing sheathless leaves with flat margins, 3- to 5-armed swollen trichomes (very rarely absent), terminal cymose pedunculate inflorescence, turbinate or sometimes cylindrical cypselae with multiseriate usually straight pappus (rarely two series). The present circumsciption of the genus is similar to that proposed by MacLeish (1987), mainly regarding the inclusion of Vanillosmopsis and exclusion of Paralychnophora. However, in the light of the phylogenetic analyses, some species (E. mollis, E. veadeiroensis etc.) excluded from Eremanthus by MacLeish (1984b) are here considered as members of the genus. Some problematic species delimitations (mainly E. capitatus) have been clarified by Loeuille et al. (in press; see Chapter 4). Hybrids are not uncommon but probably occur to a lesser extent than suggested in MacLeish (1987).

1. Eremanthus arboreus (Gardner) MacLeish, Ann. Missouri Bot. Gard. 74: 286. 1987.

Basionym: Albertinia arborea Gardner, London J. Bot. 5: 236. 1846. TYPE: BRAZIL. Ceará:

Serra do Araripe, November 1838, G. Gardner 1713 (Syntypes: B [destroyed] photos at F and US, BM [not seen], BR [not seen], F [not seen], G [not seen], GH [2 specimens], NY [2 specimens], P [not found] photo at F, W [scan seen]).

Vanillosmopsis arborea (Gardner) Baker in Mart. \& Eichler, Fl. bras. 6(2): 16. 1873.

Distribution and habitat: Brazil (Ceará). Cerrado and margin of secondary forests; 700-970 m.

Very similar to E. capitatus, from which it is set apart by its lower number of capitula per glomerule: (1-)2-3(-7) vs. 6-9. Additionally, these are allopatric species. Eremanthus arboreus is endemic to the Chapada do Araripe and Chapada of Ibiapaba (Ceará), and does not occur in sympatry with any other species of the genus.

Representative specimens: BRAZIL. Ceará: Crato, Chapada do Araripe, $12 \mathrm{~km}$ southwest of Crato on road to Exú, 7¹4'56” S, 39²9'54” W, 700 m, 30 July 1997, W. W. Thomas et al. 11676 (HRB, NY); ibidem, estrada Molhada Bonita - Belmonte, 7¹7’55.8” S, 39²7’32.6” W, 955 m, 5 September 2009, B. Loeuille et al. 512 (K, SPF, US). Viçosa do Ceará, Chapada da Ibiapaba, 9 August 1985, A. Fernandes \& Matos s.n. (EAC).

2. Eremanthus argenteus MacLeish \& H. Schumach., Syst. Bot. 9: 84. 1984. TYPE: BRAZIL. Goiás: 33 km N of Alto Paraíso towards Calvacante, 1370 m, 14 October 1980, N. F. F. MacLeish et al. 734 (Holotype: RB; Isotypes: F [not seen], G [not seen], GA, GH [scan seen], MO [not seen], NY, UB, US).

Distribution and habitat: Brazil (Goiás). Campo rupestre and cerrado; 1000-1600 m.

A species readily recognized by the combination of silvery leaves and syncephalia. Known from a few collections mostly from the Chapada dos Veadeiros; the only record outside that area 
comes from Caldas Novas (see below), a disjunct distribution also reported for Heterocoma ekmaniana (Philipson) Loeuille, J. N. Nakaj. \& Semir.

Representative specimens: BRAZIL. Goiás: Alto Paraíso, Chapada dos Veadeiros, estrada GO-118 para Cavalcante, 20 July 2007, B. Loeuille et al. 289 (K, MBM, NY, SPF, UFG, US). Caldas Novas, Serra de Caldas Novas, 23 May 1970, J. A. Rizzo \& A. Barbosa 5224 (UEC, UFG). Teresina de Goiás, Chapada dos Veadeiros, 31 July 2000, V. C. Souza et al. 24698 (ESA, SPF).

3. Eremanthus auriculatus MacLeish and H. Schumach., Syst. Bot. 9: 86. 1984. TYPE: BRAZIL. Goiás: Brasília richtung Campos Belos, 22 km nach Alto Paraíso, 1500 m, 28 August 1981, H. Schumacher 1037 (Holotype: RB; Isotypes: GA [not found], MB [not seen], fragment of RB: US).

Distribution and habitat: Brazil (Goiás and Mato Grosso). Campo rupestre and cerrado.

A rarely collected species, resembling E. glomerulatus but with auriculate leaf bases.

Representative specimens: BRAZIL. Goiás: Alto Paraíso, Chapada dos Veadeiros, 19 July 2007, B. Loeuille et al. 279 (K, SPF, UFG); P.N. Chapada dos Veadeiros, 7 September 1994, M. Aparecida da Silva 2291 (IBGE, US). Mato Grosso: Chapada dos Guimarães, P.N. Chapada dos Guimarães, 1 March 1997, A. G. Nave et al. 1277 (ESA, K, UFMT).

4. Eremanthus brasiliensis (Gardner) MacLeish, Ann. Missouri Bot. Gard. 74: 282. 1987.

Basionym: Monosis brasiliensis Gardner, London J. Bot. 5: 230. 1846. TYPE: BRAZIL. 'Pernambuco' [now Bahia]: woods in the district of Rio Preto, September 1834, G. Gardner 2897 (Syntypes: BM [not seen], G [not seen] photos at F and US, fragment at F, GH, K [2 specimens] [scan seen], W [2 specimens] [scan seen] photos at F and US). Vernonia brasiliensis (Gardner) Sch. Bip., Jahresber. Pollichia 18-19: 161. 1861, nom. illeg. [nom. rej. pro Vernonia brasiliensis (Spreng.) Less., Linnaea 6: 681-682 (1831)]. Vanillosmopsis brasiliensis (Gardner) Sch. Bip., Jahresber. Pollichia 20-21: 400. 1863.

Distribution and habitat: Brazil (Bahia); cerrado (?).

Known only from the type collection. Similar to E. uniflorus but with capitula slightly appressed but free (vs. basally adherent) and 1-2 capitula per glomerule (vs. 3-9).

5. Eremanthus brevifolius Loeuille, Kew Bull. (in press; see Chapter 4). TYPE: BRAZIL. Minas Gerais: Congonhas do Norte, Serra Talhada (setor NW da Serra do Cipó), Fazenda Imbaúbas, 20 January 2007, B. Loeuille et al. 71 (Holotype: SPF; Isotypes: K, US).

Distribution and habitat: Brazil (Minas Gerais). Campo rupestre.

Known only from the type collection in the northwest sector of the Serra do Cipó. It is superficially similar to E. elaeagnus in the habit, indument of abaxial leaves and sessile capitula slightly appressed and free, but differs from it in the smaller leaves $(2-2.5 \times 0.6-0.8 \mathrm{~cm}$ vs. $5-12 \times 1.5-3 \mathrm{~cm}$ ) with densely black glandular-dotted, tomentose adaxial surface (vs. sparsely 
lepidote), in the number of florets per capitulum (4-7 vs. 3-4), and in the number of series of the pappus (2 vs. $3-5)$.

6. Eremanthus capitatus (Spreng.) MacLeish, Ann. Missouri Bot. Gard. 74: 285. 1987.

Basionym: Conyza capitata Spreng., Syst. Veg. 3: 507. 1826. TYPE: BRAZIL. Bahia: inter Victoria et Bahia [now Salvador], F. Sello(w) s.n. (Lectotype: K [scan seen], selected by MacLeish 1987; Isolectotype: GH).

Synonym: Vernonia capitata (Spreng.) Less., Linnaea 4: 2701829.

Albertinia martii Colla, Herb. Pedem. iii. 291. 1834. TYPE: BRAZIL. Bahia: Porto Seguro, 1828, C. F. P. von Martius s.n. (Holotype: TOR [scan seen]), syn. nov. Albertinia capitata (Spreng.) DC., Prodr. 5: 82. 1836.

Polypappus discolor DC., Prodr. 7: 281. 1838. TYPE: BRAZIL. Bahia: Jacobina, January 1843, J. S. Blanchet 2591 (Holotype: G [not seen]; Isotypes: BM [not seen], BR [not seen], C [not seen] photos at F and US, G [not seen], GH, K [2 specimens] [scan seen], MO [not seen], NY [3 specimens], P).

Vanillosmopsis capitata (Spreng.) Sch. Bip., Jahresber. Pollichia 18-9: 167. 1861.

Vanillosmopsis albertinioides Sch. Bip., Jahresber. Pollichia 18-19: 168. 1861. TYPE:

BRAZIL. No other data, F. Sello(w) s.n. (Holotype: B [destroyed]).

Vanillosmopsis discolor (DC.) Baker in Mart. \& Eichler, Fl. bras. 6(2): 17. 1873.

Vanillosmopsis pohlii Baker in Mart. \& Eichler, Fl. bras. 6(2): 18. 1873. TYPE: BRAZIL. Foz do Viera, J. E. Pohl 556D/3312 (Holotype: K [scan seen]; Isotypes: B [destroyed] photos at GH, F and US, F [not seen], GH [fragment], K [scan seen], NY).

Eremanthus pohlii (Baker) MacLeish, Ann. Missouri Bot. Gard. 74: 281. 1987.

Eremanthus graciellae MacLeish and H. Schumach., Syst. Bot. 9: 87. 1984. TYPE: BRAZIL. Bahia: BR 020 Brasília richtung Barreiras, $15 \mathrm{~km}$ weiter in richtung Barreiras von Fazenda Prainha, km 374, 800 m, 28 August 1981, H. Schumacher 1048 (Holotype: RB; Isotypes: GA, K [scan seen], M [not seen], MB [not seen]).

Distribution and habitat: Brazil (Bahia, Goiás, Minas Gerais, Pernambuco and Sergipe). Campo rupestre, cerrado, restinga and margins of secondary forests; 50-1700 m.

A common variable species with 2-4 florets per capitulum. Very similar to E. arboreus: see that species for a discussion of the differences. Synonymy is discussed in detail by Loeuille et al. (in press; see Chapter 4).

Representative specimens: BRAZIL. Bahia: Abaíra, Catolés, Campos de Ouro Fino, 16 July 1992, W. Ganev 674 (HUEFS, K, SPF, US). Goiás: Alto Paraíso, Chapada dos Veadeiros, estrada GO 118 para Cavalcante, 20 July 2007, B. Loeuille et al 288 (K, SPF, UFG). Minas Gerais: Pedra Azul, 13 September 1984, G. Hatschbach 48178 (MBM, SPF, US). Pernambuco: Buíque, Serra de Catimbal, 19 October 1995, L. P. Félix et al. 7457 (IPA). Sergipe: Estância, ca. $18 \mathrm{~km}$ da BR 101 para a praia dos Abáis, 8 October 1993, J. G. Jardim et al. 330 (CEPEC, HRB, US). 
7. Eremanthus cinctus Baker in Mart. \& Eichler, Fl. bras. 6(2): 162. 1873. TYPE: BRAZIL. Mato Grosso: 'Cuyaba' [Cuiabá], 1834, A. L. da Silva Manso 55 (Holotype: BR [not seen]). Synonym: Eremanthus pandurifolius Baker in Mart. \& Eichler, Fl. bras. 6(2): 162. 1873. TYPE: BRAZIL. No other data, Tamberlik s.n. (Holotype: W [scan seen], photos at F, TEX and US).

Distribution and habitat: Brazil (Goiás, Mato Grosso, Mato Grosso do Sul and Minas Gerais). Cerrado; 500-800 m.

Known only from three locations at the time of MacLeish's revision (1987), further recorded several times. Nevertheless, its distribution appears highly fragmented and each population fairly isolated. Similar to E. auriculatus and E. glomerulatus in the overall aspect, but easily recognized by its prominent extraglomerular bracts and total fusion of capitula.

Representative specimens: BRAZIL. Goiás: Serranópolis, Pousada das Araras, 18 August 1998, M. Aparecida da Silva 3875 (IBGE, SP, US). Mato Grosso: Pedra Preta, 12 April 1982, J. R. B. Monteiro 13506 (UEC). Mato Grosso do Sul: Campo Grande, próximo ao Jockey Club, 24 March 1983, Syll 1903 (RB). Minas Gerais: Uberlândia, Reserva do Clube Caça e Pesca Itororó, 7 August 2007, B. Loeuille et al. 306 (HUFU, SPF).

8. Eremanthus elaeagnus (Mart. ex. DC.) Sch. Bip., Jahresber. Pollichia 20-21: 395. 1863.

Basionym: Albertinia elaeagnus Mart. ex DC., Prodr. 5: 81. 1836. TYPE: BRAZIL. Minas Gerais: altis lapidosis Serro Frio prope Tejuco [now Diamantina], C. F. P. von Martius s.n. (533) (Holotype: M [scan seen]).

Synonym: Vernonia elaeagnus (Mart. ex DC.) Sch. Bip., Jahresber. Pollichia 18-19: 166. 1861. Eremanthus seidelii MacLeish \& H. Schumach., Syst. Bot. 9:89. 1984. TYPE: BRAZIL. Minas Gerais: Furnas richtung Piuí, kurz von Staumauer, 800 m, 25 August1981, $H$. Schumacher 1006 (Holotype: RB; Isotypes: GA, K [scan seen], M [not seen], MB [not seen], US).

Distribution and habitat: Brazil (Minas Gerais and São Paulo). Campo rupestre and cerrado; 650-1400 m.

A common species, characterized by gray leaves, capitula slightly appressed with $3-4$ free florets and a persistent pappus. Synonymy with E. seidelii is discussed in detail by Loeuille et al. (in press; see Chapter 4).

Representative specimens: BRAZIL. Minas Gerais: between Gouveia and Diamantina, 3 October 1980, N. F. F.MacLeish et al. 689 (GA, GH, RB, US); São Roque de Minas, P.N. Serra da Canastra, 15 May 2007, B. Loeuille et al. 258 (K, SPF, US). São Paulo: Pedregulho, Usina de Estreito, D. Sasaki et al. 560 (NY, RB, SPF, UEC). 
9. Eremanthus erythropappus (DC.) MacLeish, Ann. Missouri Bot. Gard. 74: 284. 1987.

Basionym: Albertinia erythropappa DC., Prodr. 5: 82. 1836. TYPE: BRAZIL. Minas Gerais: 'Marianna', M. Vauthier 334 (Holotype: G-DC [not seen]; Isotypes: G [not seen], GH [2 specimens]).

Synonyms: Chresta lanceolata Vell., Fl. Flum. Icon. 8: t. 151. 1827 [1831]. nom. inval.

Albertinia candolleana Gardner, London J. Bot. 5: 235. 1846. TYPE: BRAZIL. Minas Gerais: near Villa do Principe, August 1840, G. Gardner 4812 (Syntypes: BM [not seen], F [not seen], G [not seen], GH [2 specimens], NY [3 specimens], S [not seen], US).

Vernonia glomerata Sch.Bip., Bot. Zeitung (Berlin) 3: 155. 1845, nom. nud.

Vanillosmopsis erythropappa (DC.) Sch. Bip., Jahresber. Pollichia 18-19: 167. 1861.

Vanillosmopsis glomerata Sch. Bip., Jahresber. Pollichia 18-19: 167. 1861. TYPE:

BRAZIL. Minas Gerais, April-August 1840, P. Claussen 2063 (Lectotype: G [not seen], selected by MacLeish 1987; Isolectotypes: G [not seen], GH [2 specimens], M [scan seen], MO [not seen], US).

Albertinia claussenii Sch. Bip. ex Baker in Mart. \& Eichler, Fl. bras. 6(2): 15. 1873. nom. nud. pro syn.

Vanillosmopsis lanceolata (Vell.) Kuntze, Revis. Gen. P1. 3(3): 183. 1898. nom. inval.

Distribution and habitat: Brazil (Distrito Federal, Espírito Santo, Goiás, Minas Gerais, Rio de Janeiro and São Paulo). Campo rupestre, cerrado and secondary forest; 400-2200 m.

A widespread species, characterized by nearly connation of capitula with 3-4 florets. Sometimes misidentified as E. incanus, but the latter species has spherical glomerules (vs. hemispherical) and one floret per capitulum (vs. 3-4). One binomial predates the accepted one: Chresta lanceolata Vell. (1831). Vellozo published also a second name in Chresta Vell. ex DC. (C. cordata $(=C$. sphaerocephala DC.)). Vellozo names are usually considered valid on the basis of the plates with details, but Chresta was originally described without a description and therefore it is an illegitimate generic name, as well as its included species.

Representative specimens: BRAZIL. Distrito Federal: Brasília, 22 March 1978, E. P. Heringer 18090 (IBGE, SP, US). Espírito Santo: Domingos Martins, BR-262, próximo ao rio Araguaia, 12 October 1992, G. Hatschbach et al. 57980 (MBM, US). Goiás: Chapadão do Céu, P.N. das Emas, 8 March 1999, M. A. Batalha 3033 (UEC). Minas Gerais: Lima Duarte, P. E. do Ibitipoca, trilha da Ponte de Pedra para a cantina, $21^{\circ} 41^{\prime} 00^{\prime}$ 'S, 4352'00'W, $1500 \mathrm{~m}$, 10 August 2005, R. C. Forzza et al. 4141 (K, RB, SPF). Rio de Janeiro: Rio de Janeiro, P.N. da Tijuca, estrada da Boa Vista, 16 September 1980, N. F. F. MacLeish et al. 660 (GA, GH, RB). São Paulo: Caraguatatuba, P.E. da Serra do Mar, 25 April 2000, J. P. Souza et al. 3477 (ESA, SPSF, UEC, UNIP). 
10. Eremanthus glomerulatus Less., Linnaea 4: 317. 1829. TYPE: BRAZIL. F. Sello(w) s.n. (Holotype: P; Isotypes: B [destroyed] photo at B, TEX [not seen]).

Synonyms: Albertinia glomerulata (Less.) DC., Prod. 5: 82. 1836.

Albertinia rufiseta DC., Prodr. 5: 81. 1836. TYPE: BRAZIL. Minas Gerais: siccis apricis montosis Serro Frio, C. F. P. von Martius s.n. (534) (Holotype: M [scan seen]). Albertinia pallidiseta DC., Prodr. 5: 81. 1836. TYPE: BRAZIL. Minas Gerais: campis editis ad Calumbi Praed. Serro Frio, C. F. P. von Martius s.n. (536) (Holotype: M [scan seen]; Isotype: $\mathrm{P}$ ).

Albertinia obtusata Mart. ex DC., Prodr. 5: 81. 1836, nom. nud in synon.

Albertinia stellata Gardner, London J. Bot. 5: 235. 1846. TYPE: BRAZIL. 'Pernambuco' (now Bahia): in campis graminosis prope Santa Rosa, Distr. Rio Preto, September 1839, G. Gardner 2896 (Holotype: BM [not seen] photo at GA; Isotypes: G [not seen], GH, F [fragment] [not seen], K [2 specimens] [not seen] photo at GA, NY [4 specimens], P [4 specimens], US, W [not seen] photo at F and US).

Eremanthus stellatus (Gardner) Sch. Bip., Jahresber. Pollichia 18-19: 164. 1861.

Eremanthus pallidisetus (DC.) Sch. Bip., Jahresber. Pollichia 18-19: 165. 1861.

Eremanthus stellatus var. gardneriana Sch. Bip., Jahresber. Pollichia 20-21: 394. 1863. nom. illegit superfl. pro Eremanthus stellatus (Gardner) Sch. Bip. var. stellatus.

Eremanthus stellatus var. pohliana Sch. Bip., Jahresber. Pollichia 20-21: 394. 1863. TYPE: BRAZIL. In summitate montium S. Felis prope Engenh. S. Anna, J. E. Pohl 174/1968P (Holotype: W [scan seen]; Isotypes: F [fragment] [not seen], NY [2 specimens], P).

Distribution and habitat: Brazil (Bahia, Distrito Federal, Goiás and Minas Gerais). Campo rupestre and cerrado; 700-1600 $\mathrm{m}$.

A widespread and variable species, easily recognized by reddish-brown tomentose stems, capitula connate $1 / 4-1 / 2$ of length and its paleaceous pappus. The broad concept of Baker (1873) and MacLeish (1987) is here retained. It is similar to E. goyazensis (Gardner) Sch. Bip., which differs in its capitula entirely connate, and strongly coriaceous, adaxially willow green leaves (vs. subcoriaceous, slightly greyish ivy green), especially on herbarium material.

Representative specimens: BRAZIL. Bahia: Piatã, Pai Inácio, Três Morros, 5 November 1996, D. J. N. Hind et al. PCD 4076 (ALCB, HRB, HUEFS, K, SPF). Distrito Federal: Brasília, Fazenda Água Limpa, 12 November 1981, B. A. .S. Pereira 43 (IBGE, UB, US). Goiás: Alto Paraíso, Chapada dos Veadeiros, estrada GO-118 para Cavalcante, $30 \mathrm{~km}$ depois de Alto Paraíso, 20 July 2007, B. Loeuille et al. 290 (SPF). Minas Gerais: Santana do Riacho, Serra do Cipó, 9-11 km beyond the Cipó Veraneio Hotel which is adjacent to the bridge over the Rio Cipó, 30 January 1980, R. M. King \& F. Almeda 8354 (UB, US). 
11. Eremanthus goyazensis (Gardner) Sch. Bip., Jahresber. Pollichia 18-19: 165. 1861.

Basionym: Albertinia goyazensis Gardner, London J. Bot. 6: 425. 1847. TYPE: BRAZIL. Goiás: hilly campos near Villa de Arrayas, April 1840, G. Gardner 3804 (Holotype: BM [not seen], photo at GA; Isotypes: B [destroyed] photos at F, GH, TEX and US, G [not seen], F [fragment of G] [not seen], NY [3 specimens], P, US, W [scan seen]).

Synonym: Eremanthus weddellii Sch. Bip., Jahresber. Pollichia 18-19: 165. 1861. TYPE: BRAZIL. Goiás: env. de Salinas, May 1844, H. A. Weddell 2032 (Holotype: P).

Distribution and habitat: Brazil (Distrito Federal, Goiás and Minas Gerais). Campo rupestre and cerrado; 400-1700 $\mathrm{m}$.

A species marked by strongly coriaceous, adaxially willow green leaves, and capitula entirely connate. Differences with E. glomeratus are discussed under this species, both species grow sympatrically.

Representative specimens: BRAZIL. Distrito Federal: Lagoa Paranoá, cerrado slopes immediately E of Lagoa Paranoá, 12 December 1965, H. S. Irwin et al. 11234 (NY, SP, UB, US). Goiás: Pirenópolis, P.E. Serra dos Pireneus, 3 Picos, 22 July 2007, B. Loeuille et al. 295 (K, SPF, UFG). Minas Gerais: Passos, estrada entre Furnas e Passos, ca. 16 km do Rio Turvo (em direção a Furnas), Fazenda Paredão (Usina Açucareira Passos), 1 July 1996, V. C. Souza et al. 11488 (ESA).

12. Eremanthus hatschbachii H. Rob., Phytologia 78: 390. 1995. TYPE: BRAZIL. Bahia: Mucugê, Serra do Cabeludo, 16 September 1984, G. Hatschbach et al. 48277 (Holotype: MBM; Isotype: US).

Distribution and habitat: Brazil (Bahia). Campo rupestre.

Known only from the type collection. The combination of small ovate leaves, 2-3 florets per capitulum and glabrous cypselae distinguishes E. hatschbachii from E. brevifolius (oblong to elliptic leaves, 4-7 florets, glabrous cypselae) and E. rondoniensis (narrowly elliptic leaves, 1 floret, cypselae with sericeous base).

13. Eremanthus incanus (Less.) Less., Linnaea 6: 682. 1831.

Basionym: Albertinia incana Less., Linnaea 4: 342. 1829. TYPE: BRAZIL. F. Sello(w) s.n. (Lectotype: B [scan seen], selected by MacLeish 1987; Isolectotypes: BR [not seen], F [fragment] [not seen], P).

Synonyms: Albertinia bicolor Gardner in Baker in Mart. \& Eichler, Fl. bras. 6(2): 162. 1873. nom. nud.

Cacalia incana (Less.) Kuntze, Revis. Gen. Pl. 2: 970. 1891.

Distribution and habitat: Brazil (Bahia and Minas Gerais). Campo rupestre, cerrado and margins of secondary forests; rare in caatinga and only one record in restinga; 600-1700 m.

Best recognized by the following combination of characters: grey lepidote stems, capitula connate nearly their entire length, cypsela cylindrical and pappus subpaleaceous. Some populations in the state of Bahia have capitula connate $1 / 2$ of length and have been misidentified 
as E. glomerulatus, but in the other characters they clearly differ from the latter species. The name "Albertinia bicolor Gardner, non DC." is cited by Baker $(1873: 161)$ in the synonymy of $E$. incanus; however Gardner (1846) wrote at the end of the description of Albertinia candolleana: "Near A. bicolor, DC., but abundantly distinct". We understand that Gardner did not intended to publish a new name.

Representative specimens: BRAZIL. Bahia: Abaíra, Catolés, Campo do Bicota, $13^{\circ} 20^{\prime 22}$ " S, 4150'01” W, 1491 m, 19 September 2007, B. Loeuille et al. 344 (HUEFS, K, SPF, US). Minas Gerais: Gouveia, Fazenda Contagem, 29 August 1981, A. M. Giulietti et al. CFCR 1753 (BHCB, F, IPA, R, SPF); Santana do Riacho, Serra do Cipó, 27 June 1991, M. Pereira et al. 872 (BHCB, MBM, US).

14. Eremanthus mattogrossensis Kuntze, Revis. Gen. Pl. 3(2): 145. 1898. TYPE. BRAZIL. 'Mattogrosso' (now Mato Grosso), July 1892, O. Kuntze s.n. (Holotype: NY; Isotype: B [destroyed], photos at F, GH, TEX and US).

Distribution and habitat: Bolivia (Santa Cruz), Brazil (Distrito Federal, Goiás, Mato Grosso, Minas Gerais, Pará and São Paulo). Cerrado (rarely campo rupestre); 250-1000 m.

The combination of grey tomentose stems, capitula connate $1 / 2$ of length and pilose nectary is diagnostic of this species. Its peduncle are more slender and its cyme less dense than in $E$. glomerulatus and E. goyazensis.

Representative specimens: BOLIVIA. Santa Cruz: Velasco, P.N. Noel Kempff, Los Fierros, 12 june 1994, T. Killeen \& H. Gonzáles 6454 (MBM, MO, US, USZ). BRAZIL. Distrito Federal: Brasília, bacia do Rio São Bartolomeu, 5 July 1983, B. A. S. Pereira 644 (HRB, IBGE, US). Goiás: Chapadão do Céu, P.N. das Emas, 2 November 1998, M. A. Batalha 2213 (UEC). Mato Grosso: Diamantino, Fazenda Pequeno Figueiredo, 24 August 2008, B. Loeuille et al. 457 (SPF). Minas Gerais: São Roque de Minas, P.N. Serra da Canastra, Vale dos Cândidos, 27 June 1997, R. Romero et al. 4310 (HUFU, SPF). Pará: São Félix do Xingú, 12 June 1978, C. S. Rosário 68 (MG, RB). São Paulo: Pedregulho, Usina do Estreito, 24 May 2003, D. Sasaki \& A. B. Junqueira 542 (HUFU, SPF, UEC).

15. Eremanthus mollis Sch. Bip., Jahresber. Pollichia 18-19: 166. 1861. TYPE: BRAZIL. Goiás: Montes Claros et Ponte Alto, ante Bomfim, J. E. Pohl 171/2690 (Lectotype: W [scan seen], selected by MacLeish 1984b: 134; Isolectotypes: B [destroyed] as photos at F, GH and TEX, F [fragment] [not seen], NY![×2]).

Synonyms: Eremanthus pannosus Baker in Mart. \& Eichler, Fl. bras. 6(2): 164. 1873. TYPE: BRAZIL. Goiás: Curralinho, [1835], A. L. da Silva Manso 1 (Holotype: BR [not seen]). Albertinia mollis Sch. Bip. ex Baker in Mart. \& Eichler, Fl. bras. 6(2): 164. 1873. nom. nud. pro syn. Vernonia pannosa (Baker) MacLeish, Syst. Bot. 9: 134. 1984.

Distribution and habitat: Brazil (Distrito Federal, Goiás and Minas Gerais). Cerrado, more 
rarely campo rupestre; $800-1500 \mathrm{~m}$.

A species distincted by the combination of a shrubby habit, leaves with prominent raised reticulate venation and syncephalia.

Representative specimens: BRAZIL. Distrito Federal: Brasília, between Taguatinga and Brasilândia, 1300 m, 23 February 1966, H. S. Irwin et al. 13117 (NY, SP, US). Goiás: Pirenópolis, Serra dos Pireneus, Sítio Vereda de Cristal, 1549’29” S, 4853’22” W, 23 July 2007, B. Loeuille et al. 305 (K, MBM, SPF, UFG, US). Minas Gerais: Capitólio, estrada depois do Paraíso Perdido, 20³2'17” S, 46¹9’34” W, 842 m, 25 October 2006, B. Loeuille et al. 39 (HUFU, SPF).

16. Eremanthus polycephalus (DC.) MacLeish, Ann. Missouri Bot. Gard. 74: 283. 1987.

Basionym: Albertinia polycephala DC., Prodr. 5: 82. 1836. TYPE: BRAZIL. Minas Gerais: planitie alta ad Piedade Villam, June 1818, C. F. P. von Martius 1440 (527) (Holotype: $\mathrm{M}$ [scan seen]; Isotype: $\mathrm{M}$ [not seen]).

Synonyms: Albertinia saligna Mart. ex DC., Prodr. 5: 82. 1836. TYPE: BRAZIL. Minas Gerais: in editis siccis rupestribus montium Serro Frio, C. F. P. von Martius s.n. (529) (Holotype: M [scan seen]).

Albertinia multiflora Mart. ex DC., Prodr. 5: 82. 1836, nom. nud. pro syn. Vanillosmopsis polycephala (DC.) Sch. Bip., Jahresber. Pollichia 18-19: 168. 1861. Vanillosmopsis saligna (DC.) Sch. Bip., Jahresber. Pollichia 18-19: 168. 1861.

Distribution and habitat: Brazil (Minas Gerais). Campo rupestre and cerrado; 650-1500 m. Easily recognized by its lanceolate leaves, capitula connate $1 / 4$ to $1 / 2$ of length and one floret per capitulum.

Representative specimens: BRAZIL. Minas Gerais: Diamantina, $14 \mathrm{~km}$ NE of Diamantina towards Mendanha, 4 October 1980, N. F. F. MacLeish et al. 720 (GA, GH, UB, US); GrãoMogol, estrada para Josenópolis, 17 July 1998, G. Hatschbach et al. 67962 (MBM, US); Santana do Riacho, Serra do Cipó, 2 July 1989, J. Semir s.n. (UEC 25611) (UEC).

17. Eremanthus reticulatus (Gardner) Loeuille, Semir \& Pirani, comb. nov.

Basionym: Lychnophora reticulata Gardner, London J. Bot. 5: 233. 1846. TYPE: BRAZIL. Minas Gerais: near Formigas [now Formiga], July 1840, G. Gardner 4828 (Holotype: BM [scan seen]; Isotypes: B [destroyed] photo at F, K [2 specimens] [scan seen], NY [scan seen], P [not seen], W [not seen]).

Distribution and habitat: Brazil (Minas Gerais). Campo rupestre.

Very rare species, known only by two collections. Easily recognized by the oblong leaves with a prominent and evident reticulate venation on the abaxial face. Similar to E. syncephalus, which differs from E. reticulatus in its narrower linear to lanceolate leaves and lower number of florets per capitulum (3-4 vs. 5 in E. reticulatus).

Representative specimens: BRAZIL. Minas Gerais: no other data, 2007, C. Verola 96/07 
(UEC).

18. Eremanthus rondoniensis MacLeish \& H. Schumach., Syst. Bot. 9: 89. 1984. TYPE:

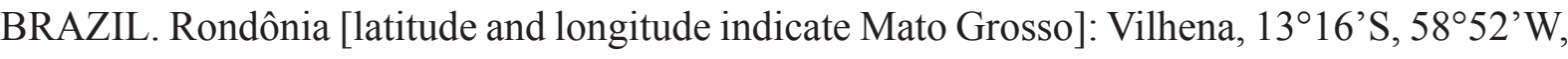
18 April 1977, Bantel and Silva s.n. (Holotype: RB).

Distribution and habitat: Bolivia (Santa Cruz), Brazil (Mato Grosso and Rondônia). Cerrado. A distinctive species characterized by relatively small leaves and capitula connate $1 / 4$ of length. Similar to E. mattogrossensis but leaves of the latter species are larger $(6-16 \mathrm{~cm} \times 2-10 \mathrm{~cm}$ vs. $2-7 \times 0.5-1.5 \mathrm{~cm}$ ) and capitula are connate $1 / 2$ of length.

Representative specimens: BOLIVIA. Santa Cruz: José Miguel de Velasco, P.N. Noel Kempff, campamento Huanchaca II a $5 \mathrm{~km}$ hacia la antigua pista, 14³1'27” S, 6044'40" W, 600 m, 8 March 1997, S. Jiménez \& E. Gutiérrez 1323 (NY, US, USZ). BRAZIL. Mato Grosso: Arenápolis, Chapada dos Parecis, 12 May 1995, G. Hatschbach et al. 62692 (MBM, US). Rondônia: Colorado do Oeste, BR 364 Porto Velho-Cuiabá, estrada para Colorado do Oeste, Km 25, $12^{\circ} 13^{\prime} \mathrm{S}, 61^{\circ} 01^{\prime} \mathrm{W}, 7$ June 1984, C. A. Cid et al. 4313 (NY, RB, US).

19. Eremanthus syncephalus (Sch. Bip.) Loeuille, Semir \& Pirani, comb. nov.

Basionym: Vanillosmopsis syncephala Sch. Bip., Jahresber. Pollichia 18-19: 168. 1861. TYPE: BRAZIL. No other data, F. Sello(w) 948 (Holotype: B [destroyed] photos at F, RB and US; Isotypes: BR [not seen], P [not seen]).

Synonyms: Lychnophora syncephala (Sch. Bip.) Sch. Bip., Jahresber. Pollichia 20-21: 404. 1863.

Lychnophora penninervia Sch. Bip., Jahresber. Pollichia 20-21: 405. 1863. TYPE: BRAZIL. In campis sterilibus Serra d'Ouro-Branco, February 1835, L. Riedel 2952 (Holotype: LE; Isotype: P [not seen]).

Distribution and habitat: Brazil (Minas Gerais). Campo rupestre.

A species marked by the leaf abaxial surface with a prominent and evident reticulate venation, and capitula with 3-4 florets. Very similar to E. reticulatus: see that species for a discussion of the differences.

Representative specimens: BRAZIL. Minas Gerais: Ouro Preto, 1883-1884, A. F. M. Glaziou 14968 (LE, P); Santana do Pirapama, Serra do Cipó, acesso pela Fazenda Inhame, início da trilha da Senhorinha, 1857’49” S, 43॰46’30” W, 773 m, D. C. Zappi et al. 1614 (K, SPF); Santana do Riacho, Serra do Cipó, APA Morro da Pedreira, estrada da Usina Dr. Pacífico Mascarenhas (ramal da rodovia MG 010), além da ponte sobre o Rio Capivara, rumo ao Vau da Lagoa, casa da Turbina, 19¹3'4.3” S, 43³5'17.6” W, 1180 m, 11 July 2009, B. Loeuille et al. $483 a(\mathrm{SPF})$. 
20. Eremanthus uniflorus MacLeish \& H. Schumach., Syst. Bot. 9: 93 1984. TYPE: BRAZIL. Goiás: 33 km N of Alto Paraíso towards Cavalcante, 1370 m, 14 October 1980, N. F. F. MacLeish et al. 736 (Holotype: RB; Isotypes: F [not seen], G [not seen], GA, K [scan seen], M [not seen], NY, P, S [not seen], UB, US [2 specimens]).

Distribution and habitat: Brazil (Bahia, Goiás, Mato Grosso). Campo rupestre and cerrado; 620-1220 m.

Similar to E. brasiliensis: see that species for a discussion of the differences. It was thought to be restricted to the Chapada dos Veadeiros (Goiás) but two other records widely expand its distribution to southeastern Bahia and to Mato Grosso.

Representative specimens: BRAZIL. Bahia: Cocos, Fazenda Trijunção, área da sede Santa Luzia, 1453’26” S, 4552'00” W, 6 July 2001, M. L. Fonseca et al. 2870 (IGBE, US). Goiás: Alto Paraíso, Chapada dos Veadeiros, estrada GO 239 para São Jorge, 19 July 2007, B. Loeuille et al. 285 (K, MBM, SPF, UFG, US). Mato Grosso: margem do Rio Verde, $14^{\circ} 23^{\prime} \mathrm{S}, 58^{\circ} 15^{\prime}$ W, 7 April 1978, D. L. Amaral 16 (HRB).

21. Eremanthus veadeiroensis H. Rob., Phytologia 45: 94. 1980. TYPE: BRAZIL. Goiás: Chapada dos Veadeiros, ca. 20 km N of Alto Paraíso, 1250 m, 20 March 1971, H. S. Irwin et al. 32752 (Holotype: UB; Isotypes: GH [scan seen], NY, US).

Synonym: Vernonia veadeiroensis (H. Rob.) MacLeish, Syst. Bot. 9: 133. 1984.

Distribution and habitat: Brazil (Goiás), restrict to the Chapada dos Veadeiros area. Campo rupestre; $1220-1600 \mathrm{~m}$.

A striking species recognized by silverish oblanceolate leaves and 8-11 florets per capitulum. Few records available.

Representative specimens: BRAZIL. Goiás: Alto Paraíso, Chapada dos Veadeiros, 6 April 1972, J. A. Rizzo 7935 (RB); ibid. west of road to Monte Alegre de Goiás, 12-20 km N of Alto Paraíso, 7 February 1981, R. M. King \& L. E. Bishop 8831 (UB, US); ibid., estrada para Teresina de Goiás (GO 118), a 22 km de Alto Paraíso, 1358'19” S, 47²9'17” W, 1523 m, 22 July 2007, M. M. Saavedra et al. (RB, SPF).

VII. Gorceixia Baker, J. Bot. 20: 225. 1882. TYPE: G. decurrens Baker.

Trees, stems branched, winged. Indumentum pubescent, composed of 3- to 5-armed trichomes with long multicellular stalk, usually glabrescent with age. Leaves alternate, pseudopetiolate, sheathless, blade chartaceous, usually discolorous, margin sparsely minutely denticulate, flat (not revolute), venation eucamptodromous. Inflorescence a terminal, pedunculate panicle of syncephalia (second-order) with secondary involucre. Capitulum sessile. Involucre cylindrical, phyllaries 3 series, weakly imbricate, persistent, pubescent, apices caudate or cuspidate; receptacle naked. Florets 5; corolla whitish, tube longer than limb; corolla lobes glabrous; anthers calcarate; style lacking basal node. Cypsela prismatic, glabrous, carpopodium inconspicuous; 
pappus uniseriate, persistent, laciniate collar, brown. Chromosome number: unknown.

A monotypic genus from semideciduous and deciduous forests of eastern Brazil.

1. Gorceixia decurrens Baker, J. Bot. 20: 225. 1882. TYPE: BRAZIL. Minas Gerais: Antonio Pereira [on the label of K: Rio de Janeiro: Antonio Sereira; see Hind et al., 2006], A. F. M. Glaziou 12803 (Holotype: K [scan seen]; Isotypes: C [not seen] photo at US, K [scan seen], P [not seen]).

Distribution and habitat: Brazil (Bahia, Espírito Santo, Minas Gerais). Semideciduous and deciduous forests; 250-750 m.

An uncommon species. Easily recognized by its winged branches, pedunculated syncephalia with secondary involucre of reduced leaf-like bracts (Hind et al. 2006).

Representative specimens: BRAZIL. Bahia: Rio de Contas, estrada real, $13^{\circ} 36^{\prime} 46^{\prime \prime} \mathrm{S}$, 4148'55” W, 25 January 2001, A. M. Giulietti \& R. M. Harley 54071 (HUEFS, MBM). Espírito Santo: Santa Teresa, estrada do 25 de Julho, terreno do Fracalossi, 250 m, 10 February 1999, L. Kollmann \& E. Bausen 1897 (BHCB, MBML). Minas Gerais: Francisco Sá, 15 km S., 20 March 1980, G. Hatschbach et al. 42825 (MBM, NY, US).

VIII. Heterocoma DC., Ann. Mus. Natl. Hist. Nat. 16: 190, t. 7. 1810. TYPE: H. albida (DC. ex Pers.) DC.

Synonyms: Sipolisia Glaz. ex Oliv., Hooker's Icon. P1. 23: t. 2281. 1894. TYPE: S. lanuginosa Glaz. ex Oliv. (= Heterocoma lanuginosa (Glaz. ex Oliv.) Loeuille, J. N. Nakaj. \& Semir).

Alcantara Glaz. ex G.M. Barroso, Loefgrenia 36: 1. 1969. non Alcantarea (Morren ex Mez) Harms. TYPE: A. petroana Glaz. ex G.M. Barroso (= Heterocoma ekmaniana (Philipson) Loeuille, J. N. Nakaj. \& Semir).

Bishopalea H. Rob., Phytologia 48: 211. 1981. TYPE: B. erecta H. Rob. (= Heterocoma erecta (H. Rob.) Loeuille, J. N. Nakaj. \& Semir).

Xerxes J.R. Grant, Nordic J. Bot. 14: 287. 1994. TYPE: X. ekmanianum (Philipson) J.R. Grant (= Heterocoma ekmaniana (Philipson) Loeuille, J. N. Nakaj. \& Semir).

Coarse subshrubs or shrubs, rarely treelets; stems simple to poorly branched. Indumentum densely white lanate or tomentose, rarely sericeous, composed of stellate, 3- to 5-armed, rarely unbranched trichomes, commonly geminate, porrect and/or side-armed. Leaves alternate, sessile, with semi- to amplexicaul sheath, blade membranaceous to cartaceous, discolorous or concolorous, margin commonly crenate, flat (not revolute), marcescent, venation eucamptodromous or actinodromous. Inflorescence an axillary, sessile or pedunculate glomerule of capitula or panicle of capitula, seldom a solitary capitulum. Capitulum sessile or rarely pedunculate, subinvolucral bracts foliaceous. Involucre campanulate; phyllaries 3-6 series, weakly imbricate, persistent, pubescent; receptacle fimbrillate and/or paleaceous. Florets 20-75; corolla purple, tube longer or shorter than limb; corolla lobes apices densely pubescent 
or seldom spiculiferous; anthers calcarate; style lacking a basal node. Cypsela cylindrical or prismatic, walls with phytomelanin, glabrous, carpopodium usually inconspicuous; pappus biseriate, series equal or subequal, caducous, subpaleaceous or paleaceous, stramineous to whitish, seldom outer series reduced, coroniform and persistent, inner series sometimes twisted. Chromosome number: unknown.

A genus of six species from the Brazilian Central Plateau. The present expanded concept of the genus is discussed in detail by Loeuille et al. (in prep.; see Chapter 4) where an identification key to the species is provided. A synapomorphy of the genus is the presence of phytomelanin on the walls of the cypselae.

1. Heterocoma albida (DC. ex Pers.) DC., Ann. Mus. Natl. Hist. Nat. 16: 155, 191, t. 3. 1810. Basionym: Serratula albida DC. ex Pers., Syn. P1. 2: 391. 1807. TYPE: BRAZIL. No other data, [J. Velloso de Miranda s.n.] (Holotype: G-DC [scan seen]).

Synonym: Proteopsis sellowii Sch. Bip., Jahresber. Pollichia 20-21:397. 1863. TYPE: BRAZIL.

No other data, F. Sello(w) 1287 (Holotype: B [destroyed] photos at F and US; Isotype: B [destroyed]).

Proteopsis insculpta Philipson, Kew Bull. Misc. Inform. 7: 299. 1938. TYPE: BRAZIL. Minas Gerais: Carãça [Caraça], entre les rochers, A. F. M. Glaziou 14974 (Holotype: K [scan seen] photo at US; Isotypes: G [not seen], P [not seen]).

Distribution and habitat: Brazil (Minas Gerais). Campo rupestre.

An uncommon species, easily recognized by its appressed tomentellum and upper axillary capitula. An earlier polynomial name (Cnicus foliis semiamplexicaulibus, etc.) for Heterocoma albida is found in "Scriptores de plantis hispanicis, lusitanicis, brasiliensibus..." (Roemer 1796); the text brought the information that the plant has been collected by "Vellozo" (i.e., Joaquim Velloso de Miranda according to Urban (1906)).

Representative specimens: BRAZIL. Minas Gerais: Santa Barbara, Serra do Caraça, 22 March 1957, E. Pereira \& E. P. Pabst 2581 (RB); ibidem, ca. 10 km W of Barão de Cocais, 23 January 1971, H. S. Irwin et al. 28979 (NY, RB); Serro, Distrito de Augusto Clementino, Pedra do Cruzeiro, 1841'37” S, 4327’30” W, 774 m, 9 June 2008, B. Loeuille et al. 450 (HAW, K, MO, SPF, US).

2. Heterocoma ekmaniana (Philipson) Loeuille, J. N. Nakaj. \& Semir, Syst. Bot. (in prep.; see Chapter 4).

Basionym: Proteopsis ekmaniana Philipson, Kew Bull. Misc. Inform. 7: 300. 1938. TYPE: BRAZIL. Goiás: Serra da Baliza, entre les rochers à Vargem Grande, A. F. M. Glaziou 21668 (Holotype: K [scan seen] photo at US; Isotypes: P [not seen] photo at US, B [destroyed], K [not seen], G [not seen]).

Synonyms: Alcantara isabellae Glaz., Bull. Soc. Bot. (Mém. 3d) 56: 367. 1909, nom. nud. Alcantara petroana Glaz. ex G.M. Barroso, Loefgrenia 36: 1. 1969. TYPE: BRAZIL. 
Goiás: Chapadão dos Veadeiros, entre les rochers, A. F. M. Glaziou 21667 (Holotype: K [not seen]; Isotypes: P [not seen] photo at US, B [destroyed], G [not seen])

Alcantara ekmaniana (Philipson) H. Rob., Phytologia 48: 213. 1981.

Xerxes ekmanianum (Philipson) J.R. Grant, Nordic J. Bot. 14: 287. 1994.

Distribution and habitat: Brazil (Goiás, Minas Gerais). Campo rupestre; 1000-1560 m.

A distinct species by presenting densely lanate stems, large leaves and capitula with ca. 75 florets. Heterocoma robinsoniana is related to it, but differs from it in its villous to lanulose slender stems and smaller leaves $(4.5-13.5 \times 1.4-5.9 \mathrm{~cm}$ vs. $11.5-26.5 \times 5-10 \mathrm{~cm})$. Also $H$. lanuginosa resemble this species but it is distinct by presenting capitula in clusters (vs. usually solitary) and 25-50 florets per capitulum (vs. ca.75). The allopatric geographic distribution also helps to set apart the three species: H. lanuginosa is restricted to the mountains of the Espinhaço Range (Minas Gerais), H. ekmaniana occurs in Goiás State mountain areas (rarely in southwestern Minas Gearis) and H. robinsoniana is found in the Serra da Canastra (southwestern Minas Gerais).

Representative specimens: BRAZIL. Minas Gerais: divisa de Araxá e Sacramento, Serra do Taquaral, 5 August 1943, R. Burle Marx \& H. L. de Mello Barreto 11539 (BHZB, NY, US). Goías: Alto Paraíso, Chapada dos Veadeiros, ca. $12 \mathrm{~km} \mathrm{NW}$ of Veadeiros, road to Calvacante, 21 October 1965, H. S. Irwin et al. 9391 (NY, UB, US); Pirenópolis, Serra dos Pireneus, 8 December 1987, J. Semir et al. 2943 (UEC).

3. Heterocoma erecta (H. Rob.) Loeuille, J. N. Nakaj. \& Semir, Syst. Bot. (in prep.; see Chapter 4).

Basionym: Bishopalea erecta H. Rob., Phytologia 48: 211. 1981. TYPE: BRAZIL. Bahia: main valley north of Mucugê from 3-8 km N of town, 31 January 1981, R. M. King \& L. E. Bishop 8729 (Holotype: UB photo at US; Isotype: US).

Distribution and habitat: Brazil (Bahia). Campo rupestre. Altitude range unknown.

Known from very few collections. Distinctive features are the cymose branching inflorescences, paleaceous receptacles and cylindrical corolla with short basal tube and throat. Similar to $H$. gracilis but this species differs in its outer phyllaries with nodding caudate apices (vs. acute to pungent apices) and the number of florets per capitulum (34-47 vs. ca. 20).

Representative specimens: BRAZIL. Bahia: Mucugê, trilha Cruzeiro dos Bêbados, 23 May 2009, N. Roque et al. 2047 (ALCB).

4. Heterocoma gracilis Loeuille, J. N. Nakaj. \& Semir, Syst. Bot. (in prep.; see Chapter 4). TYPE: BRAZIL. Minas Gerais: São Gonçalo do Rio Preto, P. E. do Rio Preto, estrada para Vargem das Estrelas, $18^{\circ} 07^{\prime} 45^{\prime}$ ' S, 4322'43.1” W, 1040 m, 9 February 2010, B. Loeuille et al. 520 (Holotype: SPF; Isotypes: BHCB, K, NY, MBM, MO, RB, US).

Distribution and habitat: Brazil (Minas Gerais). Campo rupestre.

A poorly documented species. Similar to H. erecta: see that species for a discussion of the 
differences.

Representative specimens: BRAZIL. Minas Gerais: Felício dos Santos, A.P.A. Felício, 10 August 2004, P. L. Viana \& N. F. O. Mota 1843 (BHCB); São Gonçalo do Rio Preto, P. E. do Rio Preto, trilha para o riacho das Éguas, 20 Mar 2007, A. M. Teles et al. 333 (BHCB).

5. Heterocoma lanuginosa (Glaz. ex Oliv.) Loeuille, J. N. Nakaj. \& Semir. Syst. Bot. (in prep.; see Chapter 4).

Basionym: Sipolisia lanuginosa Glaz. ex Oliv., Hooker's Icon. P1. 23: t. 2281. 1894. TYPE: BRAZIL. Minas Gerais: São Gonçalo près Biribiry [near Diamantina], A. F. M. Glaziou 19470 (Holotype: K [scan seen]; Isotypes: B [destroyed] photo at F and US, K [scan seen], P [not seen], G [not seen], RB [2 specimens]).

Proteopsis lanuginosa (Glaz. ex Oliv.) Philipson, Kew Bull. Misc. Inform. 7: 300. 1938.

Distribution and habitat: Brazil (Minas Gerais). Campo rupestre.

Known only from a few collections. Typical features are the cluster of 2-6 capitula and the receptacle with flat-bottomed ridges bearing articulated deciduous setae. Similar to $H$. ekmaniana: see that species for a discussion of the differences.

Representative specimens: BRAZIL. Minas Gerais: Buenópolis, Serra do Cabral, $7 \mathrm{~km}$ da

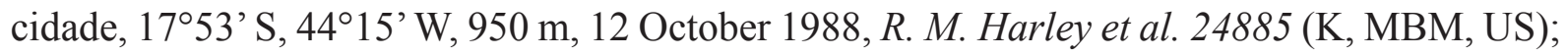
Diamantina, Conselheiro Mata [“Conselheiro Matto"], June 1934, A. C. Brade 13392 (HUFU, NY, RB, SPF, UB, US); Gouveia, $6 \mathrm{~km}$ by road N of Gouveia on road to Diamantina, 10 April 1973, W. R. Anderson et al. 8576 (NY, RB).

6. Heterocoma robinsoniana Loeuille, J. N. Nakaj. \& Semir, Syst. Bot. (in prep.; see Chapter 4). TYPE: BRAZIL. Minas Gerais: São Roque de Minas, P. N. da Serra da Canastra, morro após o vale da nascente do rio São Francisco, 11 January 1995, R. Romero et al. 1708 (Holotype: HUFU; Isotypes: SPF, UEC, US).

Distribution and habitat: Brasil (Minas Gerais). Campo rupestre; 800-1180 m.

An endemic species of the Serra da Canastra (southwestern Minas Gerais). Similar to $H$. ekmaniana: see that species for a discussion of the differences.

Representative specimens: BRAZIL. Minas Gerais: Alpinópolis, Furnas, 25 July 1972, L. Emygdio et al. 3606 (NY, R); Capitólio, Represa de Furnas, estrada Furnas-Capitólio, 13 February 1998, R. Goldenberg et al. 496 (HUFU, UEC); São Roque de Minas, P. N. da Serra da Canastra, morro atrás do Centro de Visitantes, 15 May 2007, B. Loeuille et al. 266 (SPF).

IX. Hololepis DC., Ann. Mus. Natl. Hist. Nat. 16: 155, 189. 1810. TYPE: H. pedunculata (DC. ex Pers.) DC.

Shrubs or trees; stems branched. Indumentum pubescent, composed of inverted Y-shaped trichomes. Leaves alternate, petiolate, sheathless, blade coriaceous, discolorous, margin entire, 
flat (not revolute), venation eucamptodromous. Inflorescence an axillary, pedunculate, solitary capitulum. Capitulum pedunculate, subinvolucral bracts foliaceous, trinerved. Involucre campanulate; phyllaries 4-5 series, weakly imbricate, persistent, pubescent; receptacle fimbrillate. Florets 30-40; corolla purple, tube shorter than limb; corolla lobes with laticifers, pubescent; anthers calcarate; style lacking basal node. Cypsela cylindrical, pubescent, carpopodium prominent; pappus biseriate, deciduous, subpaleaceous, stramineous or reddish, outer series smaller than inner series. Chromosome number: unknown.

A genus of two species, easily recognized by the subinvolucral trinerved bracts.

1. Hololepis hatschbachii H. Rob., Phytologia 78: 390. 1995. TYPE: BRAZIL. Espírito Santo: Alfredo Chaves, São Bento de Urânia, rodovia para Castelinho, 1000 m, 8 October 1994, G. Hatschbach et al. 61125 (Holotype: MBM; Isotype: US).

Distribution and habitat: Brazil (Espírito Santo).

Known only from the type collection, this species is distinct by the reddish pappus. Very similar to $H$. pedunculata, from which it only differs by narrower and more flexuous peduncles and smaller capitula. Additional material of this species is needed to determine whether it is or not conspecific with $H$. pedunculata.

2. Hololepis pedunculata (DC. ex Pers.) DC., Ann. Mus. Natl. Hist. Nat. 16: 190, t. 2. 1810.

Basionym: Serratula pedunculata DC. ex Pers., Syn. P1. 2: 391. 1807. TYPE: BRAZIL. No other data, [J. Velloso de Miranda s.n.] (Holotype: G-DC [scan seen]).

Synonyms: Haynea pedunculata (Pers.) Spreng., Syst. Veg. 3: 391. 1826.

Vernonia involucrata Less., Linnaea 4: 246. 1829. TYPE: BRAZIL. No other data, F. Sello(w) s.n. (Holotype: B [destroyed]; Isotype: K [scan seen]).

Vernonia pedunculata (DC. ex Pers.) DC., Prodr. 5: 16. 1836.

Hololepis involucrata (Less.) Sch. Bip., Jahresber. Pollichia 20-21: 380. 1863.

Proteopsis glauca (Mart.) ex Baker in Mart. \& Eichler, Fl. bras. 6(2): 20. 1873. nom. nud. pro syn.

Distribution and habitat: Brazil (Minas Gerais). Campo rupestre, gallery forest margins; 840-1800 m.

A quite variable species. Easily recognized by its ovate subinvolucral bracts and stramineous pappus. Very similar to $H$. hatschbachii: see that species for a discussion of the differences. An earlier polynomial name (Cnicis foliis lato-lanceolatis, etc..) for Hololepis pedunculata is found in "Scriptis de plantis hispanicis, lusatinicis, brasiliensibus..." (Roemer, 1796); the text brought the information that the plant has been collected by "Vellozo" (i.e., Joaquim Velloso de Miranda according to Urban (1906)). The only specimen of Hololepis pedunculata at G-DC bears a label with Candolle's handwriting but also a posterior label written " $\mathrm{n}$ ' 292 herbier du Brésil Vauthier 1833 Serra do Frio" - this label is probable unrelated to the specimen.

Representative specimens: BRAZIL. Minas Gerais: Catas Altas, Serra do Caraça, first plateau 
in direction of the ascent of Inficcionado Peak, 4 April 2007, A. M. Teles et al. 370 (BHCB); Santana do Riacho, Serra do Cipó, rodovia Belo Horizonte-Conceição do Mato Dentro, MG010, sede do IBAMA do Alto do Palácio, 1300 m, 8 June 2002, J. R. Pirani et al. 5066 (K, SPF, UEC); São Roque de Minas, P. N. da Serra da Canastra, nascente do Rio São Francisco, 15 May 2007, B. Loeuille et al. 259 (K, SPF).

X. Lychnocephalus Mart. ex DC., Prodr. 5: 83. 1836. TYPE: L. tomentosus Mart. ex DC.

Treelets, sometimes candelabriform, rarely subshrubs to shrubs; stems poorly branched. Indumentum densely tomentose to lanate, composed of usually unbranched with side-arms and 3- to 5-armed trichomes, rarely stellate, T-shaped and inverted Y-shaped trichomes. Leaves alternate, sessile or petiolate, with semi-amplexicaul or amplexicaul sheath, blade coriaceous, discolorous, margin entire, flat to rarely revolute, venation eucamptodromous or sometimes parallelodromous or actinodromous. Inflorescence an axillary or terminal, pedunculate or sessile, solitary, rarely 2-3 syncephalia (third-order). Capitulum sessile. Involucre cylindrical or campanulate; phyllaries 2-4 series, weakly imbricate, persistent, pubescent; receptacle areolate to fimbrillate. Florets 4-15; corolla purple, rarely white, tube longer than limb; corolla lobes glabrous or pubescent; anthers calcarate; style lacking a basal node. Cypsela cylindrical or prismatic, glabrous, carpopodium inconspicuous; pappus bi- or rarely uniseriate, paleaceous, whitish to stramineous, outer series smaller than inner series, sometimes residual, persistent, inner series caducous, twisted, setae apices narrowed. Chromosome number: $n=19$ ( $L$. mellobarretoi, L. sellowii, L. tomentosus).

A genus of four species endemic of the central portion of the Espinhaço Range of mountains in Minas Gerais, southeastern Brazil. The presence of a syncephalium of third-order is the main diagnostic feature of the genus, published by Candolle (1836) and here re-established based on strong phylogenetic evidence. Even though its species were placed before in Lychnophora, leaf characters (size, shape, margins not revolute) and the third-order syncephalium of Lychnocephalus sharply differ from that genus. Descriptions and an identification key are found in Semir (1991).

1. Lychnocephalus humillimus (Sch. Bip.) Loeuille, Semir \& Pirani, comb. nov.

Basionym: Lychnophora humillima Sch. Bip., Jahresber. Pollichia 20-21: 371. 1863. TYPE: BRAZIL. Minas Gerais: Serra da Lapa, in glaerosis, December1824, L. Riedel 1159 (Holotype: LE photo at F, GH and RB; Isotypes: BR [not seen], F [not seen], GH, K [scan seen], LE, P [not seen] photos at F and US, US)

Distribution and habitat: Brazil (Minas Gerais). Campo rupestre.

A rarely collected species. Easily recognized by its decumbent habit and sessile leaves. Related to L. mellobarretoi, which differs from L. humillimus by having an erect habit and petiolate leaves. 
Representative specimens: BRAZIL. Minas Gerais: Santana de Pirapama, Serra do Cipó, acesso pela Faz. Inhame, trilha da Senhorinha, topo da serra, 1856’05” S, 4344’39” W, 1326 m, 27 July 2009, D. C. Zappi \& N. P. Taylor 2257 (K, SPF); ibidem, Capela de S. José, subida do da Senhorinha, segundo platô, 1856'51.03" S, 4345'27.67" W, 1340 m, 11 November 2009, D. C. Zappi et al. 2325 (K, SPF).

2. Lychnocephalus mellobarretoi (G. M. Barroso) Loeuille, Semir \& Pirani, comb. nov.

Basionym: Lychnophora mellobarretoi G. M. Barroso, Arch. Jar. Bot. Rio de Janeiro 14: 261. 1956. TYPE: BRAZIL. Minas Gerais: Santa Luzia, Serra do Cipó, km 138, estrada do Pilar, 2 November 1938, H. L. de Mello Barreto 8971 (Holotype: RB; Isotype: F [scan seen]).

Distribution and habitat: Brazil (Minas Gerais). Campo rupestre.

Known only from Serra do Cipó. Distinctive features are the petiolate leaves with eucamptodromous venation. Similar to L. tomentosa, which has a more robust habit than L. mellobarretoi, 5-10 florets per capitulum (vs. 4-6) and lacks an extremely reduced outer pappus. Also resembling L. humillimus: see that species for a discussion of the differences.

Representatives specimens: BRAZIL. Minas Gerais: Santana do Riacho, Serra do Cipó, km 128 da rodovia Belo Horizonte-Conceição do Mato Dentro, Alto do Palácio, 30 May 1991, J. R. Pirani et al. CFSC 12328 (SPF, UEC); ibidem, 1300 m, 8 June 2002, J. R. Pirani et al. 5074 (SPF, UEC); ibidem, 19¹5’37.7” S, 43³1'58.5” W, 1350 m, 12 July 2009, B. Loeuille et al. 507 (SPF).

3. Lychnocephalus sellowii (Sch. Bip.) Loeuille, Semir \& Pirani, comb. nov.

Basionym: Lychnophora sellowii Sch. Bip., Jahresber. Pollichia 20-21: 372. 1863. TYPE: BRAZIL. Minas Gerais: Serra do Vento, 1836, F. Sello(w) 996 (Holotype: B, photos at F and US, GH, RB; Isotype: P [not seen]).

Synonym: Lychnophora saxosa Krasch., Not. Syst. Herb. Hort. Petrop. 3: 160. 1922. TYPE: BRAZIL. Minas Gerais: in saxosis Serra da Lapa, December 1824, L. Riedel 1126 (Holotype: LE; Isotypes: LE [2 specimens]), syn. nov.

Distribution and habitat: Brazil (Minas Gerais). Campo rupestre; 1150-1350 m.

Occurs in the Diamantina Plateau and the Serra do Cipó. Distinctive characters are the parallelodromous leaves, glabrous leaf sheath and capitulum with 7-12 florets.

Representatives specimens: BRAZIL. Minas Gerais: Congonhas do Norte, Serra do Cipó, Serra Talhada, $9 \mathrm{~km} \mathrm{~S}$ de Congonhas do Norte na estrada para Conceição do Mato Dentro, 1856’15” S, 4341'06” W, 1250 m, 20 January 2007, B. Loeuille et al. 78 (SPF); Gouveia, 11 km NE of Gouveia, SW of Diamantina on estrada BR 259, 5 October 1980, G. L. Smith et al. 1017 (GA, NY); Santana do Riacho, Serra do Cipó, 26 km ao sul de Conceição do Mato Dentro, km 123, $19^{\circ} 11^{\prime}$ S, 4332' W, 1250 m, 27 October 1988, R. M. Harley et al. 25416 (BHCB, SPF, US). 
4. Lychnocephalus tomentosus Mart. ex DC., Prodr. 5: 83. 1836. TYPE: BRAZIL. Minas Gerais: in campis sterilibus, Serro Frio, 25 May1818, C. F. P. von Martius 1313 (515) (Holotype: $\mathrm{M}$ [not seen]; Isotype: $\mathrm{P}$ [not seen]).

Synonym: Lychnophora tomentosa (Mart. ex DC.) Sch. Bip., Jahresber. Pollichia 20-21: 369. 1863.

Distribution and habitat: Brazil (Minas Gerais). Campo rupestre; 1000-1360 m.

A common species, easily recognized by its robust habit, petiolate leaves, glabrous adaxial surface when aged and capitulum with 5-10 florets. Closely resembling L. mellobarretoi: see that species for a discussion of the differences.

Representative species: BRAZIL. Minas Gerais: Congonhas do Norte, Serra do Cipó, Serra Talhada, $6.8 \mathrm{~km} \mathrm{SW}$ da estrada Congonhas do Norte-Gouveia, entrada a $3.7 \mathrm{~km}$ NW de Congonhas do Norte, 18 $8^{\circ} 50^{\prime} 33^{\prime}$ ' S, 4345’32” W, 1200 m, 19 January 2007, B. Loeuille et al. 68 (K, SPF, US); Diamantina, Córrego Soberbo, rodovia BR 367, 23 October 1999, G. Hatschbach et al. 69584 (MBM, NY, SPF, US); Santana do Riacho, Serra do Cipó, P. N. da Serra do Cipó, Serra da Bandeirinha, 10 September 1987, C. Kameyama et al. CFSC 10562 (F, K, MBM, MO, $\mathrm{RB}, \mathrm{SPF})$.

XI. Lychnophora Mart., Denkschr. Königl.-Baier. Bot. Ges. Regensburg 2: 148. 1822. TYPE: L. salicifolia Mart.

Synonyms: Haplostephium Mart. ex DC., Prodr. 5: 78. 1836. TYPE: H. passerina Mart. ex DC. (= Lychnophora passerina (Mart. ex DC.) Gardner).

Lychnophoriopsis Sch. Bip., Jahresber. Pollichia 20-21:375. 1863. TYPE: L. heterotheca Sch. Bip. (=L. candelabrum (Sch. Bip.) H. Rob).

Episcothamnus H. Rob., Phytologia 48: 210. 1981. TYPE: E. candelabrum (Sch. Bip.) H. Rob. (= L. candelabrum (Sch. Bip.) H. Rob.).

Treelets, often candelabriform, shrubs, rarely subshrubs, rarely decumbent; stems moderately branched. Indumentum lanate to villose or tomentose, composed of 3- to 5-armed trichomes, infrequently swollen, rarely T-shaped and unbranched trichomes. Leaves alternate, sessile, rarely inconspicuously petiolate (L. villosissima), sheathless, blade usually ericoid, coriaceous, discolorous, margin entire, revolute, apices often mucronate, venation usually eucamptodromous, brochidodromous or mixed, sometimes hyphodromous. Inflorescence a terminal, pedunculate or sessile, solitary syncephalium (second-order) or rarely a congested spike of capitula. Capitulum sessile. Involucre cylindrical, rarely campanulate or ovoid; phyllaries (2-)4-6(-7) series, strongly to weakly imbricate, persistent or rarely caducous (L. crispa), pubescent or rarely glabrous; receptacle naked to foveolate, rarely fimbrillate. Florets 1-25; corolla purple, tube longer, equal or shorter than limb; corolla lobes glabrous, rarely pubescent; anthers calcarate; style lacking basal node. Cypsela prismatic or infrequently cylindrical, glabrous, carpopodium 
inconspicuous; pappus biseriate, paleaceous, stramineous or seldom whitish, outer series smaller than inner series or residual, persistent, inner series caducous, twisted. Chromosome number: $n=17,18$.

The second largest genus of the subtribe, with 18 species from the campos rupestres of the Brazilian Central Plateau. Phylogenetic analyses helped to clarify the circumscription of Lychnophora. Lychnophoriopsis and Haplostephium are considered as synonyms of Lychnophora and species with a leaf sheath are excluded from our concept of Lychnophora. As circumscribed, the genus is monophyletic and recognized by the following combination of characters: treelets frequently candelabriform or rarely shrubs, with sheathless revolute leaves, indumentum of 3- to 5-armed trichomes, terminal second-order syncephalium (except for L. candelabrum and L. hatschbachii), and glabrous prismatic cypselae with a biseriate pappus whose inner series is paleaceous twisted caducous. Some species delimitations would clearly be improved by further taxonomic studies and population analysis. Most of the species circumscriptions adopted here are those of Semir (1991), where an identification key is provided. Hybrids in this group are not uncommon.

1. Lychnophora candelabrum Sch.Bip., Jahresber. Pollichia 20-21:345. 1863. TYE: BRAZIL. Minas Gerais: Serra do Vento, 20 October 1818, F. Sello(w) 995 (Holotype: B [destroyed] photo at F; Isotypes: BR [not seen], P [not seen]).

Synonyms: Lychnophoriopsis heterotheca Sch. Bip., Jahresber. Pollichia 20-21: 376. 1863.

Lychnophoriopsis macrocephala Glaz., Bull. Soc. Bot. (Mém. 3d) 56: 380. 1909, nom. nud.

Lychnophora heterotheca (Sch. Bip.) Jones \& Coile, Brittonia 33: 534. 1981, syn. nov. TYPE: BRAZIL. Minas Gerais: in saxosis Serra da Lapa, November 1824, L. Riedel 1009 (Holotype: LE; Isotypes: BR, F, P photos at P: BR, F, GH, US).

Episcothamnus candelabrum (Sch. Bip.) H. Rob., Phytologia 48: 210. 1981.

Lychnophoriopsis candelabrum (Sch. Bip.) H. Rob., Proc. Biol. Soc. Wash. 105: 644. 1992.

Distribution and habitat: Brazil (Minas Gerais). Campo rupestre; 760-1200 m.

A broad concept of this species is accepted here; distinctive features are the capitula with 1125 florets and the mucronate, squarrose, villose to lanate involucral bracts. Closely related to $L$. hatschbachii but the latter species has glabrous phyllaries and a naked capitulum receptacle (vs. foveolate). Neotypification of L. candelabrum by Robinson (1981) was unnecessary due to the existence of duplicates of Sello(w) 995 at BR and P. As more specimens are available, it becomes evident now that the characters proposed by Robinson (1992) to set apart L. heterotheca from L. candelabrum are extremely variable and cannot be used.

Representatives specimens: BRAZIL. Minas Gerais: Buenópolis, Serra do Cabral, estrada Joaquim Felício-Buenópolis, 1754’42” S, 44¹3’07” W, 975 m, 3 June 2008, B. Loeuille et al. 435 (SPF); Gouveia, Fazenda Contagem, 24 February 1986, J. Semir et al. CFCR 9571 
(BHCB, HUEFS, K, MBM, NY, SPF, UEC); Jaboticatubas, Serra do Cipó, 15 February 1960, M. Magalhães s.n. (RB, UB).

2. Lychnophora crispa Mattf., Notizbl. Bot. Gart. Berlin-Dahlem 8: 429. 1923. TYPE: BRAZIL. Bahia: 'Minas de Contas', Carrascogebiet, July 1913, P. von Lützelburg 59 (Holotype: M [not seen], photo at UEC; Isotype: B [destroyed] photo at F, RB).

Synonym: Vernonia crispa (Mattf.) MacLeish, Syst. Bot. 9: 134. 1984.

Distribution and habitat: Brazil (Bahia, Minas Gerais). Campo rupestre; 850-1250 m.

A rarely collected species. Easily recognized by its weakly imbricate caducous phyllaries, and fimbrillate receptacle.

Representative specimens: BRAZIL. Bahia: Mucugê, estrada Andaraí-Mucugê, ao lado da torre da Embratel, 1257'26” S, 41 '19'14” W, 1250 m, 12 July 1996, D. J. N. Hind et al. PCD 3551 (ALCB, HUEFS, SPF); Rio de Contas, Pé da Serra Marsalina, 13³4'45”S, 41 ${ }^{\circ} 50^{\prime 2} 28^{\prime \prime}$, 1015 m, 18 November 1996, R. M. Harley et al. PCD 4427 (ALCB, HUEFS, SPF). Minas Gerais: Grão-Mogol, arredores, 16 May 1988, G. Hatschbach et al. 52059 (MBM, US).

3. Lychnophora diamantinana Coile \& Jones, Brittonia 33: 532. 1981. TYPE: BRAZIL. Minas Gerais: 19 miles from Diamantina on route to Curvelo, 23 December 1959, B. Maguire 44757 (Holotype: NY; Isotypes: GH, RB, US).

Distribution and habitat: Brazil (Minas Gerais). Campo rupestre; 950-1390 m.

Endemic to the Diamantina Plateau. The main distinctive features are: lanceolate to falciform leaves with margins slightly revolute or not, acute apices, brochidodromous venation with fimbrial veins, winged and flattened midvein on the abaxial surface, spherical syncephalium of 5-12-flowered capitula. L. salicifolia is related to it, but easily distinguished from $L$. diamantinana by its leaves with scrobiculate adaxial surface, a mixed brochidodromouseucamptodromous venation pattern and a prominent midvein enlarged basally on abaxial face; additionally, the outter pappus is coroniform (vs. free in L. diamantinana). Also similar to $L$. pohlii: see that species for a discussion of the differences.

Representative specimens: BRAZIL. Minas Gerais: Diamantina, Rio dos Cristais, 21 November 1964, A. P. Duarte \& E. Pereira 8526 (F, HB, NY, UB, UEC); ibidem, estrada Diamantina-São João da Chapada, 18¹0'56” S, 4342’18” W, 1140 m, 14 January 1998, $R$. C. Forzza et al. 622 (K, SPF, UEC); ibidem, estrada para Biribiri, ca. 4 km antes de Biribiri, 18¹0’13” S, 4336’54” W, 950 m, 23 January 2007, B. Loeuille et al. 108 (K, SPF, US).

4. Lychnophora ericoides Mart., Denkschr. Königl.-Baier. Bot. Ges. Regensburg 2: 151. 1822. TYPE: BRAZIL. Minas Gerais: in campis deserti occid. montis adamantini Serra de S. Antonio sive de Grand Major, C. F. P. von Martius s.n. (Holotype: M [not seen]; Isotype: P [not seen]). Synonyms: Vernonia proteaeformis Less., Linnaea 4: 249. 1829, based on the same type as $L$. ericoides Mart. 
Lychnophora proteaeformis (Less.) DC., Prodr. 5: 80. 1836.

Lychnophora cinerea Sch. Bip., Jahresber. Pollichia 20-21: 358. 1863. TYPES: BRAZIL. Minas Gerais: Diamond District, July 1840, G. Gardner 4833 (Holotype: BM [scan seen]; Isotypes: A [not seen], K [2 specimens] [scan seen], P [not seen], W [not seen], US); Minas Gerais, "Serra de Chrystaës, d'Ourada, de Paranahyba", J. E. Pohl 564 (Syntype: B [destroyed] photo at F and US).

Lychnophora ericoides var. leucopholis Glaz., Bull. Soc. Bot. (Mém. 3d) 56: 378 (1909), nom. nud.

Lychnophora trichocarpha var. robusta Glaz., Bull. Soc. Bot. (Mém. 3d) 56: 379 (1909), nom. nud.

Distribution and habitat: Brazil (Distrito Federal, Goiás, Minas Gerais, and São Paulo). Campo rupestre; $700-1500 \mathrm{~m}$.

A widespread species. Very similar to L. pinaster, L. ericoides can be set apart by the following combination of characters: a larger habit and more robust branches (vs. smaller habit and more delicate branches), leaves up to $15 \mathrm{~cm}$ long (vs. usually shorter leaves, rarely exceeding $6 \mathrm{~cm}$ ) with a lanate to subvillose indument (vs. tomentose to subvelutinous), acute leaf apices (vs. obtuse to rounded), and winged and flattened midvein (vs. quadrangulate). Resembling also $L$. salicifolia, but differing from this species by the fimbrial veins and glabrous cypselae.

Representative specimens: BRAZIL. Distrito Federal: Brasília, bacia do rio São Bartolomeu, 5 July 1980, E. P. Heringer et al. 4604 (IBGE, US). Goiás: Alto Paraíso, P. N. da Chapada dos Veadeiros, ca. $1 \mathrm{~km}$ da sede do P. N., 7 February 1987, J. R. Pirani et al. 1726 (K, SPF, UB). Minas Gerais: Diamantina, estrada Conselheiro-Mata-Diamantina, km 166, 23 February 1986, J. Semir et al. CFCR 9551 (CTES, G, MO, R, SPF, UEC). São Paulo: Pedregulho, distrito Estreito, 20 April 1997, M. C. E. Amaral et al. 97 (SPF, UEC).

5. Lychnophora gardneri Sch. Bip., Jahresber. Pollichia 20-21: 350. 1863. TYPE: BRAZIL. Minas Gerais: Serro do Frio, August 1840, G. Gardner 4829 pro parte (Holotype: W [not seen]; Isotypes: BM [scan seen] [sheet BM000939728], F [fragment] [scan seen], K [scan seen] [pro parte lower branch], NY [sheet XXX], R [not seen], S [not seen]).

Synonym: Lychnophora riedelli Sch. Bip., Jahresber. Pollichia 20-21: 351. 1863. TYPE: BRAZIL. Minas Gerais: in mont. siccis, 1824, L. Riedel s.n. (Holotype: LE).

Distribution and habitat: Brazil (Minas Gerais). Campo rupestre; 1100-1250 m.

A species from the southern portion of the Espinhaço Range (Belo Horizonte to Diamantina), best recognized by its glaucous leaves and abaxial secondary veins and midvein osbscured by a persistent villous indument. Similar to L. pohlii but the leaves of the latter have evident glabrous midveins, which are winged and flattened (vs. semicylindric to quadrangulate). It can be confused with $L$. staavioides, which differs from $L$. gardneri by having a leaf apex rounded to ermaginate with a trichome tuft exceeding the apex (vs. obtuse to acute without a trichome tuft exceeding the apex). Also similar to L. rosmarinifolia: see that species for a discussion of 
the differences. As noted by Semir (1991), the samples on Gardner $n^{\circ} 4829$ are a mixture of two different species, L. gardneri Sch. Bip. and L. pohlii Sch. Bip., which grow sympatrically. Sheets of Gardner 4829 at BM (sheet BM000939727), GH, NY (sheet $\mathrm{n}^{\circ}$ XXX) and US are samples of $L$. pohlii. The sheet at $\mathrm{K}$ is composed of two different branches, the upper one is a sample of L. pohlii and the lower one of L. gardneri.

Representative specimens: BRAZIL. Minas Gerais: Belo Horizonte, Serra do Curral, BR 3, km 15, 16 July 1956, L. Roth 1657 (RB); Congonhas do Norte, Serra do Cipó, Serra Talhada, $6.8 \mathrm{~km} \mathrm{SW}$ da estrada Congonhas do Norte-Gouveia, Retiro das Pedras, nascentes do Rio Preto, 1848'27” S, 4345'15” W, 1220 m, 19 January 2007, B. Loeuille et al. 67 (SPF, K); Diamantina, Caminho dos Escravos, 30 July 1989, R. Simão-Bianchini 65 (SPF).

6. Lychnophora granmogolensis (Duarte) Semir in D. J. N. Hind, Kew Bull. 49: 513. 1994. Basionym: Haplostephium granmogolense Duarte, Revista Brasil. Biol. 34: 661. 1974. TYPE: BRAZIL. Minas Gerais: Serra do Grão Mogol "ad ripam rivi Itacambira-açú in saxosis areniticis et in savannae petrosis ad viam Cristalia", 12 November 1970, A. P. Duarte 12957 (Holotype: RB; Isotypes: MO [scan seen], NY, US).

Distribution and habitat: Brazil (Bahia, Minas Gerais). Cerrado and Campo rupestre; 700$1240 \mathrm{~m}$.

A widespread species very distinct by its oval to subulate leaves with apices bearing a long pungent mucro and a tuft of long trichomes at the insertion point of the leaf with the stem.

Representative specimens: BRAZIL. Bahia: Rio de Contas, estrada Rio de Contas-Marcolino Moura, ca. 2.8 km de Rio de Contas, 13³5'40” S, 4147’17” W, 1050 m, 18 November 2000, F. Juchum et al. 79 (CEPEC, NY, US). Minas Gerais: Buritizeiro, borda da Chapada dos Gerais, rodovia BR 365, próximo ao km 204, 19 March 1995, G. Hatschbach \& M. Hatschbach 62053 (MBM, US); Cristália, estrada Grão-Mogol-Cristália, ca. 2-3 km depois a ponte sobre o Rio Itacambiruçu, 16³9’36” S, 4252’45” W, 705 m, 7 June 2008, B. Loeuille et al. 445 (SPF).

7. Lychnophoriopsis hatschbachii H. Rob., Proc. Biol. Soc. Wash. 105: 644. 1992. TYPE: BRAZIL. Minas Gerais: Diamantina, rodovia Guinda-Conselheiro Mata, km 20, 21 May 1989, G. Hatschbach 53058 (Holotype: MBM; Isotype: US).

Distribution and habitat: Brazil (Minas Gerais). Campo rupestre.

A rarely collected species, quite distinct by the glabrous phyllaries. Similar to L. candelabrum: see that species for a discussion of the differences.

Representative specimens: BRAZIL. Minas Gerais: Diamantina, estrada Conselheiro MataDiamantina, km 166, 23 February 1986, J. Semir et al. CFCR 9552 (SPF, UEC); ibidem, rodovia Guinda-Conselheiro Mata, 19 March 1997, G. Hatschbach et al. 66511 (MBM, NY, US); ibidem, estrada para o Telésforo, morro próximo a cidade, $18^{\circ} 16^{\prime} 52^{\prime}$ S, $43^{\circ} 58^{\prime} 15^{\prime}$ W, 1062 m, 21 October 2007, P. O. Rosa et al. 935 (HUFU, SPF). 
8. Lychnophora martiana Gardner, London J. Bot. 5: 232. 1846. TYPE: BRAZIL. Minas Gerais: between the Diamond District and the Rio de São Francisco, G. Gardner 4824 (Syntypes: BM [not seen] [2 specimens] photo at F, K [scan seen] [2 specimens], P [not seen]).

Synonym: Lychnophora lanigera Pohl ex Sch. Bip., Jahresber. Pollichia 20-21: 341. 1863. TYPE: BRAZIL. Minas Gerais: inter Vieira do Matro et Columbis, J. E. Pohl 569/3167 (Holotype: W [scan seen] photo at F and US; Isotypes: F [fragment], K [scan seen], NY, $\mathrm{P}[$ not seen]).

Distribution and habitat: Brazil (Minas Gerais). Campo rupestre.

A rarely collected species, very similar to L. salicifolia but L. martiana is more robust and differs by the denser and thicker branch indument, longer and wider leaves and sessile to subsessile inflorescences. Also similar to L. villosissima, but this species has petiolate leaves with reticulodromous pattern venation. Two different samples of L. martiana are mounted on the same sheet at K, the lower branch being from Gardner 4824 (K484701) (isotype of $L$. martiana) and the upper branch from Pohl 569 (K484702) (isotype of L. lanigera).

Representative specimens: BRAZIL. Minas Gerais: Diamantina, Pinheiro près Diamantina, 26 April 1892, A. F. M. Glaziou 19476 (K, LE, P, R); ibidem, Jequitinhonha, a 110 km de Diamantina, 16 August 1970, A. P. Duarte 12821 (RB, UEC); Itacambira, estrada Pau d'ÓleoItacambira, 16 $6^{\circ} 7^{\prime} 49^{\prime}$ ' S, 43³3'48” W, 20 October 2001, J. A. Lombardi et al. 4473 (BHCB, SPF).

9. Lychnophora passerina (Mart. ex DC.) Gardner, London J. Bot. 5: 230. 1846.

Basionym: Haplostephium passerina Mart. ex DC., Prodr. 5: 78. 1836. TYPE: BRAZIL. Minas Gerais: in summo Monte Itambé, C. F. P. von Martius s.n. (Holotype: M [not seen], photos at F and RB; Isotype: $\mathrm{P}$ [not seen]).

Synonyms: Lychnophora subulata Gardner, London J. Bot. 5: 231. 1846. TYPE: BRAZIL. Minas Gerais: Diamond district, 1841, G. Gardner 4822 (Syntypes: BM [not seen] photos at F and RB, K [scan seen] [2 specimens], P [not seen], S [not seen]).

Haplostephium passerina (Mart. ex DC.) Gardner var. subulatum (Gardner) Baker in Mart. \& Eichler, Fl. bras. 6(2): 149. 1873.

Haplostephium pinnifolium Duarte, Revista Brasil. Biol. 34: 661. 1974. TYPE: BRAZIL. Minas Gerais: in saxosis, ad marginem viae Cristalia parvulae pagus in vicinia Grão Mogol, no date, A. P. Duarte 13770 (Holotype: RB [not seen]).

Distribution and habitat: Brazil (Bahia, Minas Gerais). Campo rupestre; 800-1700 m.

A common and variable species recognized by its linear to subulate leaves and extremely reduced outer pappus. Very similar to L. ramosissima, which differs by its samller ovate leaves, with a pungent mucro (vs. not pungent).

Representative specimens: BRAZIL. Bahia: Abaíra, estrada Catolés-Boa Vista, 4 km de Catolés, margem da estrada, 13¹8' S, 4152’ W, 1100 m, 21 March 1992, B. Stannard et al. H 52768 (CEPEC, HUEFS, K, SPF, US, W). Minas Gerais: Diamantina, estrada para o povoado 
de Três Barras, 3 km de Diamantina, 15 April 1987, J. Prado et al. CFCR 10504 (K, SPF); Santana do Riacho, Serra do Cipó, estrada para a Usina Dr. Pacífico Mascarenhas, $1.3 \mathrm{~km}$ da estrada Lagoa Santa-Conceição do Mato Dentro (MG 010), 19¹6’47” S, 43³5’60” W, 1037 m, 24 April 2006, B. Loeuille et al. 35 (K, SPF).

10. Lychnophora phylicifolia DC., Prodr. 5: 79. 1836. TYPE: BRAZIL. Bahia: in altis ad Sincorá, C. F. P. von Martius s.n. 500 (Holotype: M [not seen] photos at F and RB; Isotype: P [not seen]).

Synonym: Lychnophora jeffreyi H. Rob., Phytologia 53: 377-378. 1983. TYPE: BRAZIL. Bahia: Serra do Sincorá, W of Barra da Estiva on the road to Jussiape, 23 March 1980, R. M. Harley et al. 20802 (Holotype: CEPEC [not seen] photo at NY and US; Isotypes: $\mathrm{R}$ [not seen], US).

Distribution and habitat: Brazil (Bahia). Campo rupestre.

Known from only two collections. Diagnostic is the combination of canescent branches, strongly imbricate discolorous ovate-lanceolate to ovate leaves with cordate bases, and coroniform outer pappus. Similar to L. granmogolensis by its cordate bases and leaves with pungent mucro, but L. phylicifolia differs in the size of the leaves (0.4-0.5 vs. $1-2.5 \mathrm{~cm}$ long), the number of florets (1-3 vs. 1) and the completely fused setae of the outer pappus series (vs. free or partially fused).

11. Lychnophora pinaster Mart., Denkschr. Königl.-Baier. Bot. Ges. Regensburg 2: 152. 1822. TYPE: BRAZIL. Minas Gerais: in montium districtus adamantini jugis ex. gr. in Serra da Lapa, C. F. P. von Martius s.n. (501) (Holotype: M [not seen]; Isotype: P [not seen]).

Synonym: Vernonia pinaster (Mart.) Less., Linnaea 4: 249. 1829.

Vernonia trichocarpha Spreng., Syst. Veg. 3: 437. 1826. TYPE: BRAZIL, F. Sello(w) s.n. (Holotype: B [destroyed]; Isotypes: P [not seen], UC [scan seen]).

Lychnophora trichocarpha (Spreng.) Spreng., Syst. IV. Cur. Post. (Pt. II): 298. 1827.

Piptocoma lychnophorioides Less., Linnaea: 4: 316. 1829.

Lychnophora affinis Gardner, London J. Bot. 5: 233. 1846. TYPE: BRAZIL, Minas Gerais: Serra de Curral del Rey, September 1840, G. Gardner 4832 (Syntypes: BM [not seen], K [2 specimens], P [not seen], S [not seen]).

Lychnophora rosmarinus Pohl ex Sch. Bip., Jahresber. Pollichia 20-21: 361. 1863. TYPE: not cited, nom. illeg. pro syn.

Lychnophora rosmarinus f. pinifolia Sch. Bip., Jahresber. Pollichia 20-21: 362. 1863, 'pinifoliae'. TYPE: BRAZIL. Minas Gerais: in siccis. Mont., 1824, L. Riedel s.n. (Holotype: LE [scan seen]).

Lychnophora rosmarinus f. rugosa Sch. Bip., Jahresber. Pollichia 20-21: 361. 1863, 'rugosae'. TYPE: not cited.

Lychnophora rosmarinus var. eurosmarinus Sch. Bip., Jahresber. Pollichia 20-21: 362. 
1863. TYPE: BRAZIL. Inficionado, J. E. Pohl 567/3562 (Holotype: W [not seen]; Isotypes: K [scan seen], NY [scan seen]).

Lychnophora rosmarinus var. normalis Sch. Bip., Jahresber. Pollichia 20-21:362. 1863. TYPE: BRAZIL. C. F. P. von Martius s.n. ( $n^{\circ}$ Herbarium Florae 792) (Lectotype: M [not seen], selected by Coile and Jones (1981); Isolectotypes: BM [scan seen], F [scan seen], G [not seen], LE, M [not seen]; MO [scan seen], NY [scan seen], P [not seen], W [not seen]).

Lychnophora rosmarinus var. affinis Sch. Bip., Jahresber. Pollichia 20-21: 363. 1863. TYPE: BRAZIL. No other data, F. Sello(w) 797 (Holotype: B [destroyed]; K [scan seen]).

Lychnophora piptocoma Sch. Bip. ex Baker in Mart. \& Eichler, Fl. bras. 6(2): 155. 1873, nom. nud. pro syn.

Lychnophora brunioides var. affinis (Gardner) Baker in Mart. \& Eichler, Fl. bras. 6(2): 155. 1873.

Lychnophora brunioides var. pinifolia Baker in Mart. \& Eichler, Fl. bras. 6(2): 155. 1873. TYPE: BRAZIL. Serra da Caraça, Claussen s.n. (Lectotype: G [not seen], selected by Coile and Jones (1981); Isolectotype: G [not seen]).

Distribution and habitat: Brazil (Minas Gerais). Campo rupestre; 865-1900 m.

A common and variable species characterized by its leaves with a rough and bullate adaxial surface and an abaxial one covered by a short tomentose indument not hiding the prominent secondary veins. Very similar to L. ericoides: see that species for a discussion of the differences. Two different samples of $L$. pinaster are mounted on the same sheet at $\mathrm{K}$, the branch on the right being from Gardner 4832 (K000677877) (isotype of L. affinis) and the one on the left from Pohl 567 (K000677876) (isotype of L. rosmarinus var. eurosmarinus). In the second sheet, the same situation is displayed with a sample from Gardner 4832 (K000677875) (isotype of $L$. affinis) on the left and a sample from Riedel s.n. (K000677874) (not a type material).

Representative specimens: BRAZIL. Minas Gerais: Itabirito, Serra de Itabirito, ca. $45 \mathrm{~km}$ SE of Belo Horizonte, 8 February 1968, H. S. Irwin et al. 19564 (F, NY, UB, US); Juramento, Serra do Catuni, Pau d'Óleo, 13 March 1999, A. Rapini et al. 773 (SPF); Santa Bárbara, Serra do Caraça, Cascatinha, SW de Catas Altas, Ladera de cerro, $20^{\circ} 05^{\prime} \mathrm{S}, 4^{\circ} 27^{\prime} \mathrm{W}, 1270 \mathrm{~m}, 14$ May 1990, M. M. Arbo et al. 4036 (CTES, SPF, UEC).

12. Lychnophora pohlii Sch. Bip, Jahresber. Pollichia 20-21: 353. 1863. TYPE: BRAZIL. In campis siccis, Serra da Lapa, November 1824, L. Riedel 1021 (Holotype: LE; Isotypes: LE [2 specimens]).

Synonyms: Lychnophora microphylla Sch. Bip., Jahresber. Pollichia 20-21: 354. 1863. TYPE BRAZIL. Serra do Vento, 2 October 1818, F. Sello(w) 796 (Holotype: B [destroyed] photo at F and US; Isotypes: GH, P [not seen]).

Lychnophora staavioides var. microphylla Baker ex Glaz., Bull. Soc. Bot. (Mém. 3d) 
56: 379. 1909, nom. nud.

Distribution and habitat: Brazil (Minas Gerais). Campo rupestre; 990-1280 m.

This species has a very variable habit: from candelabriform shrubs or treelets to rosette-like subshrubs. Candelabriform individuals resemble that of L. gardneri, L. staavioides and $L$. rosmarinifolia, but $L$. pohlii is easily set apart from these species by the combination of leaves with brochidodromous venation and winged flattened glabrous midvein. It is also similar to L. diamantinana, but the latter has wider leaves $(0.3-1.7 \mathrm{~cm}$ vs. $0.15-0.4 \mathrm{~cm}), 5-12$-flowered capitula (vs. 3-4-flowered-capitula) and strigose cypselae apices (vs. glabrous). Rosette-like individuals are similar to L. uniflora: see that species for a discussion of the differences.

Representative specimens: BRAZIL. Minas Gerais: Congonhas do Norte, estrada para Costa Sena, ca. 23 km de Congonhas do Norte, 18³9'09” S, 4340’24” W, 990 m, 21 January 2007, B. Loeuille et al. 82 (SPF); Diamantina, estrada Diamantina-Conselheiro Mata, km 185, 23 February 1986, J. Semir et al. CFCR 9501 (SPF, UEC); Gouveia, Barro Preto, torre da TELEMIG, 14 September 1985, G. Hatschbach \& R. Kummrow 49696 (MBM, SPF).

13. Lychnophora ramosissima Gardner, London J. Bot. 5: 232. 1846. TYPE: BRAZIL. Minas Gerais: bushy places in the Diamond district, July 1840, G. Gardner 4821 (Syntypes: $\mathrm{B}$ [destroyed] photos at F and US, BM [not seen] photos at F and RB, GH, K [scan seen] [2 specimens], P [not seen], S [not seen], W [not seen]).

Synonym: Haplostephium ramosissimum (Gardner) Sch. Bip., Jahresber. Pollichia 20-21: 375. 1863.

Distribution and habitat: Brazil (Minas Gerais). Campo rupestre.

Known only by the type collection from Diamantina until recently, this species was collected in 2008 on a further northward region by the first author. It is easily recognized by the small ovate leaves with a subpungent mucro and the extremely reduced outer pappus. Similar to $L$. passerina: see that species for a discussion of the differences.

Representative specimen: BRAZIL. Minas Gerais: Josenópolis, estrada Grão-MogolJosenópolis, 16³1'57” S, 4243'20” W, 828 m, 8 June 2008, B. Loeuille et al. 448 (SPF).

14. Lychnophora rosmarinifolia Mart., Denkschr. Königl.-Baier. Bot. Ges. Regensburg 2: 155. 1822. TYPE: BRAZIL. Minas Gerais: in summis jugis montium ad Tejuco et Milho Verde districtus adamantini, July 1818, C. F. P. von Martius s.n. (503) (Holotype: M [scan seen] photo at $\mathrm{F}$ and RB; Isotype: $\mathrm{P}$ [not seen]).

Synonym: Lychnophora bahiensis Mattf., Notizbl. Bot. Gart. Berlin-Dahlem 8: 430. 1923.

TYPE: BRAZIL. Bahia: caatingazone, 1914, P. von Lützelburg 12460 (Holotype: M [scan seen]; Isotype: B [destroyed], photos at F, GH and US), syn. nov.

Distribution and habitat: Brazil (Bahia, Minas Gerais). Campo rupestre; 800-1380 m.

A species widespread in the Espinhaço Range, best recognized by its lanceolate leaves with acute apices and cordate to auriculate bases, and capitula with 1 to 5 florets. It can be confused 
with L. gardneri, which differs from L. rosmarinifolia in its leaves with obtuse to slightly rounded apices, attenuate bases and secondary veins obscured by a villous indument on abaxial face. Also similar to L. staavioides and L. pohlii: see these species for a discussion of the differences. Some controversies exist concerning the identity of L. bahiensis, L. rosmarinifolia and L. uniflora. Coile and Jones (1981) suggested a hybrid origin for the two former species ( $L$. staavioides $\times$ L. uniflora) but that hypothesis was discarted by subsequent authors (Robinson, 1983; Semir, 1991; Hind, 1995). However, Robinson (1983) and Hind (1995) applied the name L. bahiensis for plants identified here as L. uniflora (following Semir (1991)). The conspecificity of $L$. bahiensis with $L$. rosmarinifolia is quite clear upon the distinctive leaf morphology shared by all studied specimens. See comment under L. salicifolia for the publication of the name $L$. bahiensis in Lützelburg (1922).

Representative specimens: BRAZIL. Bahia: Piatã, estrada Piatã-Ribeirão, 1307'15" S, 4149’34” W, 1380 m, 1 November 1996, H. P. Bautista et al. PCD 3865 (ALCB, SPF). Minas Gerais: Diamantina, planalto, 14 July 1970, A. P. Duarte 12816 (RB, UEC); Santana do Riacho, Serra do Cipó, 10-20 km NE de Cardeal Mota, camino a Conceição do Mato Dentro, 19²0' S, 433'' W, 1050 m, 16 May 1990, M. M. Arbo et al. 4219 (CTES, SPF, UEC).

15. Lychnophora salicifolia Mart., Denkschr. Königl.-Baier. Bot. Ges. Regensburg 2: 148. 1822. TYPE: BRAZIL. Minas Gerais: in summis alpestribus jubis Montis Itambé da Villa, districtus adamantini, C. F. P. von Martius s.n. (510) (Holotype: M [not seen] photos at F, RB and US; Isotype: P [not seen]).

Synonyms: Lychnophora hakeaefolia Mart., Denkschr. Königl.-Baier. Bot. Ges. Regensburg 2: 156. 1822. TYPE: BRAZIL. Minas Gerais: in summo monte districtus adamantini Itambé da Villa, July, C. F. P. von Martius s.n. (498) (Holotype: M [not seen], photo at F, RB and US; Isotype: P [not seen]).

Vernonia hakeaefolia (Mart.) Less., Linnaea 4: 249. 1829.

Vernonia salicifolia (Mart.) Less., Linnaea 4: 249. 1829.

Lychnophora platyneura Sch. Bip., Jahresber. Pollichia 20-21: 357. 1863. TYPE: BRAZIL. Minas Gerais: in campis sterilibus pr. Andrequece, inter Paracatu et Rio St. Francisco, October 1834, L. Riedel 2949 (Holotype: LE [not seen]; Isotypes: GH, P [not seen]), syn. nov.

Cacalia salicifolia (Mart.) Kuntze, Revis. Gen. P1. 2: 971. 1891.

Lychnophora arrojadoana Mattf., Notizbl. Bot. Gart. Berlin-Dahlem 8: 431. 1923. TYPE: BRAZIL. Bahia: 'Minas de Contas', Carrascogebiet, 1914, P. von Lützelburg 66 (Holotype: M [not seen]; Isotype: B photo at F, K, RB and US).

Lychnophora columnaris Mattf., Notizbl. Bot. Gart. Berlin-Dahlem 8: 433. 1923. TYPE: BRAZIL. Bahia: 'Minas de Contas', Carrascogebiet, July 1913, P. von Lützelburg 13700 (Holotype: M [scan seen]; Isotype: B [destroyed] photo of B at F, K, RB and US).

Lychnophora luetzelburgii Mattf., Notizbl. Bot. Gart. Berlin-Dahlem 8: 431. 1923. 
TYPE: BRAZIL. Bahia: carrasco mit Vellozia, 1914, P. von Lützelburg 198 (Holotype:

$\mathrm{M}$ [scan seen]; Isotype: B [destroyed] photo at F, RB and US).

Lychnophora urbaniana Glaz., Bull. Soc. Bot. (Mém. 3d) 56: 378. 1909, nom. nud.

Distribution and habitat: Brazil (Bahia, Distrito Federal, Goiás and Minas Gerais). Campo rupestre, rarely cerrado; 700-1700 m.

A widespread and variable species, which can be recognized by the combination of sessile leaves with scrobiculate adaxial surface, a mixed brochidodromous-eucamptodromous venation and a prominent midvein enlarged basally on abaxial face. Similar to L. villosissima, but the latter has petiolate leaves witha reticulodromous venation. Differences with $L$. diamantinana, $L$. ericoides, L. martiana are discussed under each of these species. Lützelburg (1922) published a list of Lychnophora's names (L. arrojadoana, L. bahiensis, L. columnaris and L. luetzelburgii) without any diagnosis and indicated Mattfeld as the author of these binomials. These names were then validly published by Mattfeld (1923).

Representative specimens: BRAZIL. Bahia: Rio de Contas, ca. $6 \mathrm{~km} \mathrm{~N}$ of the town of Rio de Contas on road to Abaíra, 133' S, 414ㄱ' W, 1000 m, 16 January 1974, R. M. Harley et al. 15129 (CEPEC, NY, RB, US). Distrito Federal: Brasília, Brazlândia, a 10 km de Brazlândia em direção a Padre Bernardo, 1540' S, 48¹2' W, 9 July 1991, R. F. Vieira et al. 822 (CEN, NY). Goiás: Alto Paraíso, Chapada dos Veadeiros, $30 \mathrm{~km} \mathrm{~N}$ of Alto Paraíso de Goiás, along road to Monte Alegre de Goiás, 7 February 1981, R. M. King \& L. E. Bishop 8818 (UB, US). Minas Gerais: Santana do Riacho, Serra do Cipó, A.P.A. Morro da Pedreira, rodovia MG 010, vale da Mãe d'Água, 19¹8’37” S, 4335'54” W, 1020 m, 16 January 2007, B. Loeuille et al. 61 (K, SPF).

16. Lychnophora staavioides Mart., Denkschr. Königl.-Baier. Bot. Ges. Regensburg 2: 154. 1822. TYPE: BRAZIL. Minas Gerais: in summis alpestribus districtus adamantini, July 1818, C. F. P. von Martius s.n. (511) (Holotype: M [not seen], photo at F; Isotype: P [not seen]). Synonyms: Vernonia staavioides (Mart.) Less., Linnaea 4: 249. 1829.

Dialesta staavioides Mart. ex DC., Prod. 5: 79. 1836, nom. illegit. superfl. pro syn. Lychnophora gorceixii Glaz., Bull. Soc. Bot. (Mém. 3d) 56: 379. 1909, nom. nud.

Distribution and habitat: Brazil (Minas Gerais). Campo rupestre; 1250-1300 m.

Endemic to the Diamantina Plateau, this species is distinct by the oblong leaves with rounded apices bearing a trichome tuft. It is similar to L. rosmarinifolia, but the latter species has lanceolate leaves with acute apices and lacking a trichome tuft. Also resembling are L. gardneri and L. pohlii: see these species for a discussion of the differences.

Representative specimens: BRAZIL. Minas Gerais: Datas, Morro do Coco, rodovia DatasGouveia, 3 km NW de Datas, 18²5’26” S, 4340'55” W, 1358 m, 21 January 2001, R. MelloSilva et al. 2432 (K, MBM, SPF, UEC, US); Diamantina, $3 \mathrm{~km}$ da estrada Diamantina-Belo

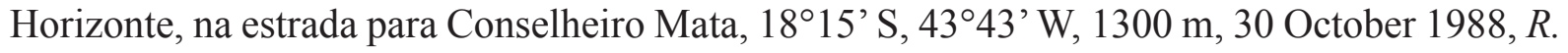
M. Harley et al. 25461 (SPF, US); Gouveia, Morro da torre da televisão, 18²5'24' S, 4343'24" 
W, 1280 m, 22 January 2007, B. Loeuille et al. 84 (K, SPF).

17. Lychnophora uniflora Sch. Bip, Jahresber. Pollichia 20-21: 347. 1863. TYPE: BRAZIL. Minas Gerais: in editis campis ad Tejuco alibi in districto adamantino et Serra do Grao Major, C. F. P. von Martius s.n. (517) (Holotype: M [not seen]; Isotype: P [not seen]).

Distribution and habitat: Brazil (Bahia, Minas Gerais ?). Campo rupestre; 1000-1300 m. A striking species, easily recognized by its rosette-like habit and heterophyly. Some individuals of $L$. polhii show a similar habit but have a different number of florets per capitulum (1 vs. 3-4). Most collections (including the type material) consist only of secondary branches without the base of the plant, in which cases they look like L. rosmarinifolia, but L. uniflora differs from that species by the leaf shape (subulate to linear-lanceolate with rounded base vs. lanceolate with cordate to auriculate base) and by the number of florets per capitulum (1 vs. 1-5). The label on the holotype of L. uniflora indicates Minas Gerais, while all other known collections come from Bahia. The question remains whether that species has a wider distribution, or if it is truly endemic to Bahia, with the citation to Minas Gerais a matter of mistake on the type label. The same problem is documented for another Martius collection (the type of Paralychnophora bicolor) (Loeuille et al., in prep.; see chapter 4).

Representative specimens: BRAZIL. Bahia: Abaíra, Gerais do Pastinho, estrada velha Abaíra-Catolés, $13^{\circ} 15^{\prime}$ S, 41 45' W, 900-1000 m, 31 January 1992, D. J. N. Hind et al. H51414 (CEPEC, HUEFS, K, SPF, US); Barra da Estiva, Morro do Ouro, $9 \mathrm{~km}$ ao $\mathrm{S}$ da cidade na

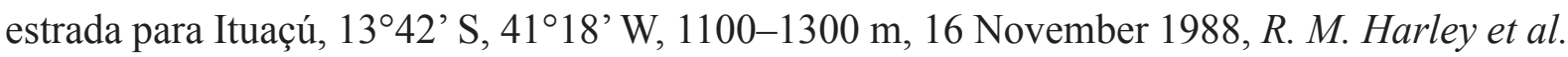
26459 (K, MO, NY, SP, SPF, UEC); Rio de Contas, aeroporto, arredores, 17 March 1998, G. Hatschbach et al. 67864 (MBM, US).

18. Lychnophora villosissima Mart., Denkschr. Königl.-Baier. Bot. Ges. Regensburg 2: 153. 1822. TYPE: BRAZIL. Minas Gerais: in campis altis petrosis siccis districtus adamantinis prope Tejuco ad tres barras et alibi, May 1818, C. F. P. von Martius 1329 (518) (Holotype: M [not seen] photo at F, RB and US; Isotype: P [not seen]).

Synonym: Vernonia villosissima (Mart.) Less., Linnaea 4: 249. 1829.

Distribution and habitat: Brazil (Minas Gerais). Campo rupestre; 1000-1400 m.

Endemic to the central portion of the Espinhaço Range in Minas Gerais state. Best recognized by its petiolate leaves (this character needs a careful examination because the lanate indument of the petiole can totally cover it, giving a 'sessile' aspect) and a reticulodromous venation. Similar to L. martiana and L. salicifolia: see these species for a discussion of the differences.

Representative specimens: BRAZIL. Minas Gerais: Congonhas do Norte, estrada para Costa Sena, ca. 15 km de Congonhas do Norte, 1842’34” S, 4341'05” W, 1010 m, 21 January 2007, B. Loeuille et al. 81 (K, SPF); Datas, rodovia Datas-Gouveia, a $3 \mathrm{~km}$ NW de Datas, baixada aos pés do Morro do Coco, $18^{\circ} 25^{\prime} 53^{\prime}$ ' S, 4340’41” W, 1231 m, 21 January 2004, J. R. Pirani et al. 5221 (MBM, SPF); Diamantina, estrada para Milho Verde, 20 October 1997, J. R. Stehmann 
XII. Lychnophorella Loeuille, Semir \& Pirani, gen. nov. TYPE: Lychnophora regis H. Rob.

Genus ad Lychnophorinae pertinens. Frutices vel arbusculae. Folia saepe ericiformia, sessilia, vaginis podiformis instructa. Inflorescentiae in ramis terminales. Capitula 1-5-floribus, plerumque in syncephala aggregata; squamae involucri imbricatae persistentes. Corollae lilacinae, lobis glabris; antherae calcaratae; basis stylorum non noduliferis. Cypselae cylindricae vel prismaticae, raro turbinatae, pubescentes, raro glabrae; carpopodia obsoleta; setae pappi stramineae vel rubrescentes paleaceae, series exteriores breves vel fere aequantes persistentes ad deciduas, series interiores deciduae ad caducas, rectae vel tortiles.

Shrubs, rarely treelets, sometimes candelabriform; stems densely branched. Indumentum tomentose to subvelutinous, rarely puberulous to villose, composed of 3- to 5-armed swollen trichomes, sometimes not swollen, rarely T-shaped and stellate trichomes. Leaves alternate, sessile, with a pad-like sheath, blade usually ericoid, coriaceous, discolorous, margin entire, flat or revolute, apex sometimes mucronate, venation usually hyphodromous, seldom eucamptodromous. Inflorescence a terminal, sessile or rarely pedunculate, solitary syncephalium (second-order) or rarely a congested dichasium of glomerules of capitula (L. leucodendron). Capitulum sessile, seldom subsessile. Involucre cylindrical, rarely campanulate; phyllaries (4-)5-6(-8) series, strongly imbricate, persistent, glabrous or sometimes pubescent; receptacle naked to foveolate, rarely fimbrillate. Florets $1-5$; corolla purple, tube longer or the same size as limb; corolla lobes glabrous; anthers calcarate; style lacking basal node. Cypsela cylindrical or prismatic, infrequently turbinate, pubescent, rarely glabrous, carpopodium inconspicuous; pappus biseriate or seldom uniseriate (L. regis), paleaceous, stramineous or often reddish, outer series smaller than inner series or subequal, persistent to caducous, inner series deciduous to caducous, twisted or straight. Chromosome number: $n=17$ (L. leucodendron).

This new genus comprises eight species previously placed in Lychnophora plus Eremanthus leucodendron. It is characterized by the presence of a pad-like leaf sheath, second-order syncephalia (except L. leucodendron), persistent phyllaries strongly imbricate, glabrous corolla lobes and anther appendage constricted at the base. The genus is restricted to the campos rupestres of the Chapada Diamantina in the Bahia State, Brazil. A similar group has been identified by Hind (2000b), defined as small dome-headed 'ericoid' profusely branched trees; however the delimitation of the genus is here slightly different, by including Eremanthus leucodendron and excluding Lychnophora granmogolensis (kept in Lychnophora s.s). The genus emerged as monophyletic in both the molecular and the simultaneous phylogenetic analyses (as clade B) (Loeuille et al., in prep.; see Chapter 3). 
1. Lychnophorella blanchetii (Sch. Bip.) Loeuille, Semir \& Pirani, comb. nov.

Basionym: Lychnophora blanchetii Sch. Bip., Jahresber. Pollichia 20-21: 364. 1863. TYPE:

BRAZIL. Bahia: 'Igrezia Velha, Serra Jacobine', J. S. Blanchet 3396 (Holotype: C [not seen], photo at F, RB and US; Isotypes: B [destroyed], C [not seen], F [scan seen], G [not seen], GH [2 specimens, one as a fragment], K [scan seen], LE, MO [scan seen], NY [2 specimens] [scan seen], P [not seen], W [not seen]).

Distribution and habitat: Brazil (Bahia). Probably in campo rupestre.

Known only from the type collection. The tessellated stem and the coroniform outer pappus are diagnostic. The species can be confused with L. morii and L. triflora, but the pad-like leaf sheaths of these species are less evident, their blades are usually arcuate and their outer pappus is extremely reduced. 'Flora 33: 30 (1850)' is often cited as the place of publication of Lychnophora blanchetii; however it is a mere list of plant names without any diagnose and therefore we consider the protologue published in 'Jahresber. Pollichia 20-21: 364 (1863)'.

2. Lychnophorella bishopii (H. Rob.) Loeuille, Semir \& Pirani, comb. nov.

Basionym: Lychnophora bishopii H. Rob., Phytologia 53: 372. 1983. TYPE: BRAZIL. Bahia: by Rio Cumbuca ca. $3 \mathrm{~km} \mathrm{~S}$ of Mucugê, near site of small dam on road to Cascavel, alt. ca. $850 \mathrm{~m}, 41^{\circ} 21^{\prime} \mathrm{S}, 13^{\circ} 01^{\prime} \mathrm{W}, 4$ February 1974], R. M. Harley et al. 15924 (Holotype: CEPEC [not seen], photos at: C, F, MO and NY; Isotypes: K [not seen], IPA [not seen], MO [not seen], US).

Distribution and habitat: Brazil (Bahia). Campo rupestre; 960-1670 m.

Endemic to the Serra do Sincorá and Catolés area, in the Chapada Diamantina, central Bahia. Its mains diagnostic characters are the linear leaves, strigose cypselae and outer pappus elements not fused in a ring.

Representative specimens: BRAZIL. Bahia: Abaíra, distrito de Catolés, caminha Barra-

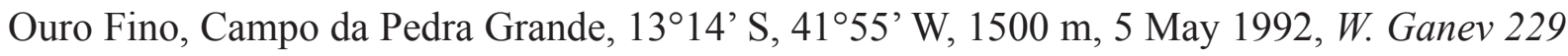
(HUEFS, NY, SPF, US); Mucugê, a $3 \mathrm{~km}$ ao S na estrada que vai para Jussiape, $1000 \mathrm{~m}, 22$ December 1979, S. A. Mori \& F. P. Benton 13160 (CEPEC, NY, RB, US); Rio de Contas, rio Brumadinho, 20 January 1984, G. Hatschbach 47388 (C, F, HB, HUEFS, MBM, MO, NY, SPF, US).

3. Lychnophorella leucodendron (Matff.) Loeuille, Semir \& Pirani, comb. nov.

Basionym: Eremanthus leucodendron Matff., Notizbl. Bot. Gart. Berlin-Dahlem 9: 378. 1925. TYPE: BRAZIL. Bahia: Rio de Contas, Serra das Almas, carrasco, 1600 m, August 1913, P. von Lützelburg 242 (Holotype: M [scan seen]; Isotypes: B [destroyed] photos at F, GH and US, GH [scan seen]).

Synonym: Vernonia leucodendron (Matff.) MacLeish, Syst. Bot. 9: 134. 1984.

Distribution and habitat: Brazil (Bahia). Campo rupestre; 1000-1800 m.

Endemic to the Serra do Sincorá and Catolés area, Chapada Diamantina, Bahia. Easily 
recognized by its densely lanate robust stems and concolored leaves. Possible polyploids have been encountered showing a more robust habit and 10-15 florets per capitulum (instead of 5). Similar to L. santosii, but L. leucodendron is easily set apart by its concolored leaves (vs. discolorous), capitula arranged in dichasium of glomerules (vs. syncephalium), number of florets per capitulum (5 vs. 1-5), cylindrical cypselae with stramineous pappus (vs. prismatic cypselae with reddish pappus).

Representative specimens: BRAZIL. Bahia: Abaíra, Catolés, Campo do Bicota, 13²0'22” S, 4150’01" W, 1491 m, 19 September 2007, B. Loeuille et al. 347 (HUEFS, SPF); Rio de Contas, Mato Grosso, 13²7’S, 4150’W, 1500 m, 7 November 1993, W. Ganev 2449 (ALCB, HUEFS, SPF, US); ibid., Pico das Almas, vertente leste, subido do pico do campo norte do Queiroz, 1332' S, 41 ${ }^{\circ} 58^{\prime} \mathrm{W}, 1650 \mathrm{~m}, 10$ November 1998, R. M. Harley et al. 26351 (F, SPF, US).

4. Lychnophorella morii (H. Rob.) Loeuille, Semir \& Pirani, comb. nov.

Basionym: Lychnophora morii H. Rob., Phytologia 53: 378. 1983. TYPE: BRAZIL. Bahia: Serra dos Lençóis, Serra da Larguinha, ca. 2 km N.E. of Caeté-Açu (Capão Grande), 1000-1400 m, 41²9’ S, 12³6’ W, 25 May 1980, R. M. Harley 22554 (Holotype: UB, photos at C, F, MO, NY; Isotypes: E [not seen], K [scan seen], NY [scan seen], RB [not seen], UEC, US).

Distribution and habitat: Brazil (Bahia). Campo rupestre; 1000-1450 m.

Endemic of the Serra do Sincorá, Chapada Diamantina, Bahia state. The patent ovate leaves distally arcuate and the syncephalium surrounded by foliage leaves are distinctive of this species. Very similar to L. triflora, but the latter has narrowly lanceolate leaves usually ascending, while leaves of $L$. morii are wider ( $3 \mathrm{~mm}$ vs. $1-2 \mathrm{~mm}$ ) and patent. Furthermore, L. morii is restricted to the eastern and northern part of the Chapada Diamantina (Palmeiras, Mucugê, Lençóis) whereas L. triflora occurs on the southwestern part (Abaíra, Rio de Contas). Semir (1991) considered both species conspecific, but more studies are necessary to propose the synonymy. Also similar to L. regis, although the latter species' syncephalium is not surrouned by foliage leaves.

Representative specimens: BRAZIL. Bahia: Mucugê, Serra do Esbarrancado, Guiné, 1420 m, 29 June 2002, A. A. Conceição 1066 (SPF, UEC); Palmeiras, Morro do Pai Inácio, 12²8’ S, $41^{\circ} 27^{\prime}$ W, 9 July 1996, D. J. N. Hind et al. PCD 3519b (ALCB, HUEFS, SPF, US); ibidem, topo do Morro do Pai Inácio, 13³1'23” S, 4157’31” W, 24 August 2007, S. C. Ferreira \& A. L. Côrtes 329 (HUEFS).

5. Lychnophorella regis (H. Rob.) Loeuille, Semir \& Pirani, comb. nov.

Basionym: Lychnophora regis H. Rob., Phytologia 53: 375. 1983. TYPE: BRAZIL. Bahia: Mucugê, a $3 \mathrm{~km}$ ao Sul de Mucugê, na estrada que vai para Jussiape, 26 July 1979, $R$. M. King et al. 8151 (Holotype: CEPEC [scan seen], photos at C, F, MO, NY; Isotypes: 
F [not seen], MO [not seen], UC [scan seen], US).

Distribution and habitat: Brazil (Bahia). Campo rupestre; 1070-1960 m.

A species restricted to the Serra do Sincorá, Chapada Diamantina, Bahia. Easily recognized by its syncephalia at the apices of branches, not surrounded by foliage leaves. Similar to L. morii and L. triflora: see these species for a discussion of the differences.

Representative specimens: BRAZIL. Bahia: Abaíra, Catolés, Campo do Bicota, 13²0'22" S, 4150’01" W, 1491 m, 19 September 2007, B. Loeuille et al. 346 (HUEFS, SPF); Mucugê,

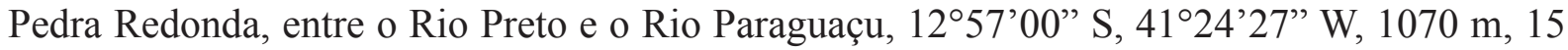
July 1996, D. J. N. Hind et al. PCD 3643 (ALCB, HUEFS, K, SPF); Piatã, Serra do Tromba,

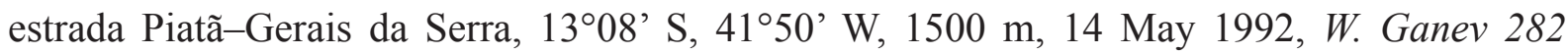
(HUEFS, SPF).

6. Lychnophorella santosii (H. Rob.) Loeuille, Semir \& Pirani, comb. nov.

Basionym: Lychnophora santosii H. Rob., Phytologia 45: 95. 1980. TYPE: BRAZIL. Bahia: Rio de Contas, Pico das Almas, a $18 \mathrm{~km}$ ao N. W. de Rio de Contas, 22 July 1979, R. M. King et al. 8114 (Holotype: RB [not seen] photos at C, F and MO; Isotypes: MO [not seen], US).

Distribution and habitat: Brazil (Bahia). Campo rupestre; 1680-2430 m.

Endemic of the highlands of the Serra do Sincorá and of the Catolés region, in Chapada Diamantina, Bahia. Easily recognized by its spathulate or obovate discolorous leaves. Resembling L. leucodendron: see that species for a discussion of the differences.

Representative specimens: BRAZIL. Bahia: Abaíra, Catolés, Pico do Barbado, 1800 m, 15 August 1998, A. M. Giulietti et al. 1445 (HRB, HUEFS); ibidem, Serra do Rei, subida do

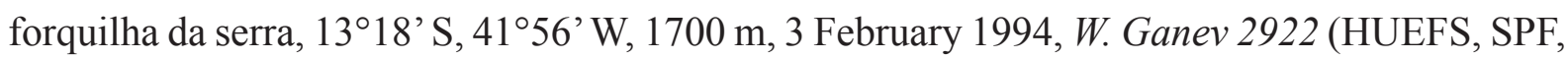
US); Rio de Contas, Pico das Almas, vertente leste, subida do pico do campo norte do Queiroz, $13^{\circ} 32^{\prime}$ S, $41^{\circ} 58^{\prime}$ W, 1500 m, 10 November 1988, R. M. Harley et al. 26329 (F, MBM, RB, SPF, UB, US).

7. Lychnophorella sericea (D. J. N. Hind) Loeuille, Semir \& Pirani, comb. nov.

Basionym: Lychnophora sericea D. J. N. Hind, Kew Bull. 55: 394. 2000. TYPE: BRAZIL.

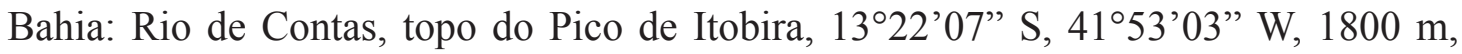
15 November 1996, R. M. Harley PCD 4308 (Holotype: ALCB [not seen]; Isotype: HUEFS, K [scan seen], SPF).

Distribution and habitat: Brazil (Bahia). Campo rupestre.

A rarely collected, endemic species. The persistent sericeous leaf indumentum on the adaxial surface is a remarkable feature. Similar to L. triflora, but adaxial surface of the leaves of that species are essentially glabrous.

Representative specimens: BRAZIL. Bahia: Abaíra, Serra ao Sul do riacho da Taquara, $13^{\circ} 15^{\prime}$ S, $41^{\circ} 55^{\prime}$ W, 1870 m, 10 January 1992, R. M. Harley et al. H 51282 (K, SPF). 
8. Lychnophorella triflora (Mattf.) Loeuille, Semir \& Pirani, comb. nov.

Basionym: Haplostephium triflorum Mattf., Notizbl. Bot. Gart. Berlin-Dahlem 8: 428. 1923

TYPE: BRAZIL. Bahia: carrasco gebist., Serra das Almas, 1913, P. von Lützelburg 179

(Holotype: M [not seen] photo at UEC; Isotypes: B [destroyed], photo at F, RB and US). Synonym: Lychnophora triflora (Mattf.) H. Rob., Phytologia 53: 371. 1983.

Distribution and habitat: Brazil (Bahia). Campo rupestre; 1200-2000 m.

Endemic of the Serra do Sincorá and Catolés region, in the Chapada Diamantina, Bahia. The combination of a syncephalium surrounded by foliage leaves, narrowly lanceolate ascending leaves, glabrous cypselae and extremely reduced outer pappus characterize L. triflora. It is very similar to L. regis, which has shorter leaves $(0.35-0.75$ vs. $0.6-1.2 \mathrm{~cm})$, longer capitula $(0.8$ -1.4 vs. $0.6-0.9 \mathrm{~cm}$ ) and does not have reduced leaves between capitula of the glomerule. Resembling $L$. morii and also similar to L. blanchetii and L. sericea: see these species for a discussion of the differences.

Representative specimens: BRAZIL. Bahia: Abaíra, Catolés, Serra do Barbado, 13¹7’41” S, 4154’31" W, 1700 m, 17 September 2007, B. Loeuille et al. 333 (HUEFS, SPF); Abaíra, Piatã, encosta Morro do Santana, fundo da igreja, 1270 m, 8 June 1992, W. Ganev 442 (HUEFS, NY, SPF, US); Rio de Contas, subida do morro ao lado da barragem no rio Brumado, 11 '34'27' S, 4150’44” W, 1157 m, 25 January 1998, L. P. Queiroz et al. 4938 (HUEFS, SPF).

XIII. Minasia H. Rob., Proc. Biol. Soc. Wash. 105: 648. 1992. TYPE: M. alpestris (Gardner) H. Rob.

Caulirosulas; stem unbranched, short, straight. Indumentum composed of T-shaped swollen trichomes with equal arms. Leaves in rosette, sessile or shortly petiolate, with a semiamplexicaul sheath, closely imbricated and appressed, tightly surrounding the stem, blade coriaceous to cartaceous, concolorous, margin usually entire, flat (not revolute). Inflorescence an axillary, pedunculate, solitary glomerule of capitula or a panicle of glomerules of capitula, rarely a panicle of capitula. Capitulum petiolate or sessile. Involucre campanulate; phyllaries 5-6(-8) series, strongly to weakly imbricate, persistent, pubescent, seldom glabrous; receptacle fimbrillate. Florets 20-50; corolla purple, tube longer than limb, rarely equal sized; corolla lobes pubescent; anthers calcarate and distinctly tailed; style lacking basal node. Cypsela cylindrical, pubescent, carpopodium prominent; pappus biseriate, setose, persistent, stramineous to reddish, outer series smaller than inner series, inner series straight, setae apices clavate. Chromosome number: $n=17$ (M. ramosa).

A genus of seven species endemic of the campos rupestres of the Espinhaço Range of mountains (Minas Gerais State). This is a monophyletic group having tailed anther base as a synapomorphy. The combination of the caulirosuletum habit, T-shaped swollen trichomes, a prominent carpopodium and biseriate setose pappus is diagnostic of the genus. An identification 
key is provided in Loeuille et al. (in prep; see Chapter 4).

1. Minasia alpestris (Gardner) H. Rob., Proc. Biol. Soc. Wash. 105: 650. 1992.

Basionym: Chresta alpestris Gardner, London J. Bot. 1: 239. 1842. TYPE: BRAZIL. Minas Gerais: 'in saxosis alpestribus in districtu Adamantum', July 1840, G. Gardner 4820 (Syntypes: BM [not seen], C [not seen], K [2 specimens] [scan seen])

Synonym: Vernonia alpestris (Gardner) Baker in Mart. \& Eichler, Fl. bras. 6(2): 55. 1873.

Distribution and habitat: Brazil (Minas Gerais). Campo rupestre; 950-1500 m.

Endemic of the Diamantina Plateau, Minas Gerais. Easily recognized by its oblanceolate leaves and laxly congested sessile capitula. It can be confused with $M$. scapigera, but the latter species have linear to lanceolate leaves and smaller capitula. The other species of the genus with oblanceolate leaves is $M$. pereirae, which otherwise is smaller in all its parts and whose cypsela has indumentum throughout the surface, whereas in M. alpestris the cypsela is distally glabrous.

Representive specimens: BRAZIL. Minas Gerais: Diamantina, estrada Conselheiro MataDiamantina, km 35, 18¹6’09” S, 4342’45” W, 1445 m, 20 October 2007, J. N. Nakajima et al. 4624 (HUFU, SPF); São Gonçalo do Rio Preto, P. E. do Rio Preto, da casa de hóspedes a cascata do Ribeirão das Éguas e então por fim ao camping, $18^{\circ} 08^{\prime} 43^{\prime}$ ' S, 4322'10” W, 8 April 2000, J. A. Lombardi et al. 3886 (BHCB, US); Serro, just west of Serro, on road from Conceição to Diamantina, 9 August 1960, B. Maguire et al. 49133 (NY, US).

2. Minasia cabralensis H. Rob., Phytologia 80: 350-351. 1996. TYPE: BRAZIL. Minas Gerais: Várzea da Palma, Serra do Cabral, Agro-industrial Serra do Cabral, 16 April 1996, G. Hatschbach et al. 64904 (Holotype: MBM; Isotype: US).

Distribution and habitat: Brazil (Minas Gerais). Campo rupestre; above $1000 \mathrm{~m}$.

Endemic of the Serra do Cabral, in the Espinhaço Range, Minas Gerais. Its pedunculate capitula and solitary capitula are distinctive. It can be confused with $M$. ramosa, but the latter has sessile to pedunculate capitula arranged in a panicle and usually longer leaves (up to $26 \mathrm{~cm}$ vs. up to $16 \mathrm{~cm})$. Resembling also M. splettiae, but this species has narrower leaves $(0.1-0.2 \mathrm{vs}$. $0.4-0.7 \mathrm{~cm})$ and fewer florets per capitulum (12-15 vs. 20-25).

Representative specimens: BRAZIL. Minas Gerais: Augusto de Lima, Serra do Cabral, ca.

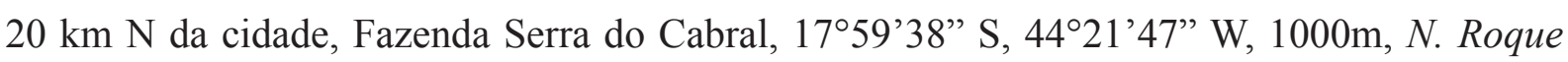
et al. CFCR 15307 (SPF); Joaquim Felício, Serra do Cabral, 1741'54” S, 44¹6’12” W, 27 April 1997, T. M. Lewinsohn et al. PIC 97010 (UEC); ibid., estrada Joaquim Felício-Várzea da Palma, 1741'52” S, 4416'05” W, 1134 m, 3 June 2008, B. Loeuille et al. 433 (HAW, K, RB, SPF). 
3. Minasia lewinsohnii J. Semir \& F. F. Jesus, Novon 14: 233. 2004. TYPE: BRAZIL. Minas Gerais: Diamantina, estrada Guinda-São João da Chapada, 7 September 1996, T. M. Lewinsohn et al. PIC 96696 (Holotype: UEC; Isotypes: K [not seen], MO [not seen], R [not seen], SPF, UEC, US [not found]).

Distribution and habitat: Brazil (Minas Gerais). Campo rupestre; above $1000 \mathrm{~m}$.

Known only from the Diamantina Plateau, Minas Gerais. Rarely collected species, comparable in general size of rosette and inflorescence to $M$. pereirae and $M$. splettiae, but the former has oblanceolate leaves (vs. ovate-elliptic) and the latter thinner and narrower leaves (0.1-0.2 vs. $0.2-0.8 \mathrm{~cm})$.

Representative specimens: BRAZIL. Minas Gerais: Diamantina, estrada para Conselheiro Mata, km 185, 18 July 1980, N. L. Menezes et al. CFCR 136 (SPF).

4. Minasia pereirae H. Rob., Proc. Biol. Soc. Wash. 105: 650. 1992. TYPE: BRAZIL. Minas Gerais: Rio das Pedras, 29 May 1955, E. Pereira 1626 (Holotype: RB; Isotype: NY, photo at US).

Distribution and habitat: Brazil (Minas Gerais). Campo rupestre; 1000-1200 m.

Endemic of the Diamantina Plateau. Diagnostic features are the short oblanceolate leaves and cypselae with indumentum over whole surface. Similar to M. lewinsohnii and M. splettiae in general size of habit, but the latter has linear to filiform leaves. For a discussion of the differences with $M$. alpestris, M. lewinsohnii and M. ramosa: see these species.

Representative specimens: BRAZIL. Minas Gerais: Diamantina, estrada DiamantinaCurralinho, a 3 km de Diamantina, 20 July 1980, N. L. Menezes et al. CFCR 191 (SPF); ibidem, estrada entre Diamantina e Gouveia, ca. 5 km de Diamantina, 8 July 2001, V. C. Souza et al. 25831 (BHCB, ESA, K, SPF, UEC); Gouveia, Barro Preto, torre TELEMIG, 20 March 1987, G. Hatschbach et al. 51160 (MBM, US).

5. Minasia ramosa Loeuille, Robinson \& Semir, Phytotaxa (in press, see Chapter 4). TYPE: BRAZIL. Minas Gerais: Joaquim Felício, Serra do Cabral, início da subida, 900 m, 14 April 1996, G. Hatschbach et al. 64718 (Holotype: ESA; Isotypes: CTES [not seen], MBM, US [2 specimens]).

Distribution and habitat: Brazil (Minas Gerais). Campo rupestre; 900-1050 m.

Endemic of the Serra do Cabral, in the Espinhaço Range, Minas Gerais. Easily recognized by the narrowly ensiform leaves up to $26 \mathrm{~cm}$, and sessile to pedunculate capitula arranged in a panicle. Similar to M. pereirae in its determinate inflorescence and totally setuliferous cypselae, but that species has oblanceolate leaves up to $8 \mathrm{~cm}$ long. Resembling also M. cabralensis: see that species for a discussion of the differences.

Representative specimens: BRAZIL. Minas Gerais: Joaquim Felício, Serra do Cabral, 17 April 1981, L. Rossi et al. CFCR 1064 (K, SPF); ibidem, estrada Joaquim Felício-Várzea da Palma, 17²2’27” S, 44¹1'37.1' W, 1026 m, 3 June 2008, B. Loeuille et al. 432 (HAW, K, MO, 
SPF, US); ibid., $8.4 \mathrm{~km}$ além da ponte sobre o Córrego da Onça, 1741'34" S, 44¹1'41.5" W, 986 m, 3 May 2009, R. Mello-Silva 3223 (SPF).

6. Minasia scapigera H. Rob., Proc. Biol. Soc. Wash. 105: 651. 1992. TYPE: BRAZIL. Minas Gerais: inter Villa da Campanha et St João d'El Rey, in pratis alpestribus, C. F. P. von Martius s.n. (546) (Holotype: M [not seen] photo at F, NY, US).

Synonyms: Vernonia scapigera Baker in Mart. \& Eichler, Fl. bras. 6(2): 55. 1873, nom. illeg. hom., non V. scapigera Less., Linnaea 4: 250-251. 1829.

Proteopsis scapigera Mart. ex Baker in Mart. \& Eichler, Fl. bras. 6(2): 55. 1873, nom. nud. pro syn.

Vernonia alpestris (Gardner) Baker var. angustifolia Glaz., Bull. Soc. Bot. (Mém. 3d) 56: 370. 1909, nom. nud.

Cacalia scapigera (Baker) Kuntze, Revis. Gen. P1. 2: 971. 1891.

Distribution and habitat: Brazil (Minas Gerais). Campo rupestre; 900-1300 m.

Known only from the Diamantina Plateau and Serra do Lenheiro (São João del Rey). A species distinct by its silverish linear to lanceolate leaves and sessile capitula densely congested in subspherical clusters. It can be confused with M. alpestris and M. cabralensis: see these species for a discussion of the differences.

Representative specimens: BRAZIL. Minas Gerais: Couto de Magalhães de Minas, Chapada do Couto, 17 July 1984, M. G. L. Wanderley et al. CFCR 4618 (F, K, SPF); Diamantina, km 685 da rodovia para Mendanha (BR 367), altos da trilha dos Escravos, 18¹3'04”S, 4335'36”W, 1300 m, 23 January 2007, B. Loeuille et al. 97 (K, MBM, NY, SPF, US); São João da Chapada, ca. $10 \mathrm{~km}$ N of São João da Chapada, road to Inhaí, 1050 m, H. S. Irwin et al. 28085 (NY, UB, US).

7. Minasia splettiae H. Rob., Phytologia 78: 397. 1995. TYPE: BRAZIL. Minas Gerais: estrada Diamantina-Conselheiro Mata, $20.3 \mathrm{~km}$ depois do asfalto, 23 September 1994, S. Splett 625 (Holotype: UB [not seen]; Isotypes: BONN [not seen], GH, SPF, US).

Distribution and habitat: Brazil (Minas Gerais). Campo rupestre.

Endemic of the Diamantina Plateau. Distinctive features are the thin linear to filiform leaves and 12-15-flowered capitula. Similar to M. cabralensis, M. lewinsohnii and M. pereirae: see these species for a discussion of the differences.

Representative specimens: BRAZIL. Minas Gerais: Diamantina, rodovia GuindaConselheiro Mata, próximo do km 21, 25 July 1998, G. Hatschbach et al. 68262 (BHCB, MBM, NY, US); ibid., margem da estrada Diamantina-Conselheiro Mata, 5 km de Diamantina, 30 August 1981, A. M. Giulietti et al. CFCR 1795 (SPF); Gouveia, 6 September 1971, G. Hatschbach 27313 (MBM). 
XIV. Paralychnophora MacLeish, Taxon 33: 106. 1984. TYPE: P. bicolor (DC.) MacLeish. Synonym: Sphaerophora Sch. Bip., Jahresber. Pollichia 20-21: 402. 1863, non Blume (1850) [Rubiaceae], nom. illeg. hom. TYPE: S. bicolor Sch. Bip. (= Paralychnophora bicolor (DC.) MacLeish).

Treelets to trees; stems moderately branched. Indumentum tomentose, velutinous to lanulose, composed of 3- to 5-armed swollen trichomes, sometimes not swollen, and unbranched trichomes. Leaves alternate, sessile to petiolate, with a semi-amplexicaul sheath, blade coriaceous, discolorous, margin entire, flat or revolute, venation brochidodromous. Inflorescence an axillar, pedunculate, solitary syncephalium (second-order). Capitulum sessile. Involucre cylindrical or campanulate, rarely ovoid; phyllaries (3-)4-5(-6) series, usually weakly imbricate, deciduous or seldom persistent, pubescent; receptacle fimbrillate, rarely naked. Florets 2-26; corolla purple to white, tube longer than limb; corolla lobes pubescent; anthers calcarate; style lacking basal node. Cypsela prismatic, glabrous or rarely pubescent ( $P$. atkinsiae), carpopodium prominent or inconspicuous; pappus biseriate or seldom triseriate ( $P$. atkinsiae), setose to subpaleaceous, stramineous, outer series smaller than inner series, persistent or rarely deciduous, inner series deciduous or infrequently persistent or caducous, straight or twisted. Chromosome number: $n=$ 18 (P. harleyi), 19 (P. bicolor, P. glaziouana and P. reflexoauriculata).

A genus of six species from Espinhaço Range of mountains in Minas Gerais and Bahia States, eastern Brazil. The genus is monophyletic and distantly related to Eremanthus and Lychnophora. It is characterized by the following combination of characters: semi-amplexicaul leaf sheath, 3- to 5-armed trichomes, axillary pedunculate second-order syncephalium, prismatic glabrous cypselae (except Paralychnophora atkinsiae) with a biseriate pappus ( $P$. atkinsiae rarely displays pappus with three series).

1. Paralychnophora atkinsiae D. J. N. Hind, Kew Bull. 55: 375. 2000. TYPE: BRAZIL. Bahia: Mucugê, estrada Mucugê-Andaraí, ca. 2 km de Mucugê, próximo ao córrego da Piabinha, 22 February 1994, P. T. Sano et al. CFCR 14403 (Holotype: SPF; Isotypes: K [scan seen], MO [scan seen], US).

Distribution and habitat: Brazil (Bahia). Campo rupestre; 900-1050 m.

Known only from the Mucugê area in the Serra do Sincorá, Bahia. Easily recognized by its narrow linear leaves with revolute margins, setuliferous cypselae and 2-3-seriate pappus.

Representative specimens: BRAZIL. Bahia: Mucugê, Centro do Projeto Sempre-Viva, trilha para Tiburtino, próximo aos rios Piabinha e Cumbuca, 1259’36” S, 41²0’29” W, 25 March

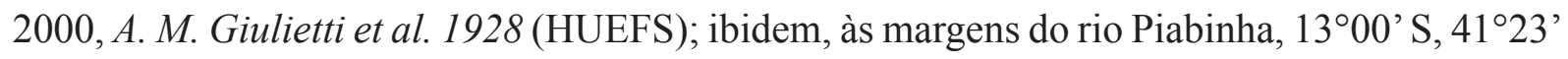
W, 16 February 2002, E. C. Oliveira 42 (CEN, HUEFS, SPF); ibidem, P. E. de Mucugê, trilha das Andorinhas, $11^{\circ} 34^{\prime} 20^{\prime}$ ' S, 41 ${ }^{\circ} 08^{\prime} 06^{\prime}$ 'W, 19 May 2007, S. C. Vieira et al. 267 (HUEFS). 
2. Paralychnophora bicolor (DC.) MacLeish, Taxon 33: 106. 1984.

Basionym: Albertinia bicolor DC., Prodr. 5: 81. 1836. TYPE: BRAZIL. Minas Gerais: habitat in altis, C. F. P. von Martius s.n. (530) (Holotype: M [scan seen]; Isotypes: M [not seen], P) Synonym: Lychnocephalus bicolor Mart. ex DC., Prodr. 5: 81. 1836, nom. illeg. pro syn. Vanillosmopsis bicolor (DC.) Sch. Bip., Jahresber. Pollichia 18-19: 168. 1861. Sphaerophora bicolor (DC.) Sch. Bip., Jahresber. Pollichia 20-21: 403. 1863.

Eremanthus bicolor (DC.) Baker in Mart., Fl. bras. 6(2): 165. 1873.

Eremanthus santosii H. Rob., Rhodora 98: 88. 1996 [1997]. TYPE: BRAZIL. Bahia: Santa Maria Eterna, 1 a 2 km de estrada de Canavieires [Canavieiras], 18 May 1970, T. S. dos Santos 820 (Holotype: CEPEC [scan seen]; Isotype: US).

Paralychnophora santosii (H. Rob.) D. J. N. Hind, Kew Bull. 55: 370. 2000.

Distribution and habitat: Brazil (Bahia). Campo rupestre, seldom in restinga coastal forest; 450-1800 m.

An uncommon species, with a disjunct distribution in the serras of the Chapada Diamantina and the lowland rainforests in Bahia. It is distinct in the oblanceolate leaves with cuneate base and often broadly recurved margins and capitula entirely connate. Similar to P. harleyi, but the latter has elliptic to obovate leaves and 5-12-flowered capitula (vs. 2-3). Resembling also to P. patriciana, which has 25-flowered capitula concrescent only at the base. Application of the name $P$. bicolor has been reviewed by Loeuille et al. (in prep.; see Chapter 4). As pointed out for Lychnophora uniflora, the type material of this species indicates Minas Gerais, whereas all further known collections come from Bahia State. It is probable that the information in the type label is mistaken.

Representative specimens: BRAZIL. Bahia: Abaíra, Catolés, Serra do Barbado, 13¹7’41'S, 4154'31”W, 1700 m, 17 September 2007, B. Loeuille et al. 330 (HUEFS, SPF); Arataca, R. P. P. N. Caminho das Pedras, Serra do Peito de Moça, entrada a $9.5 \mathrm{~km}$ do assentamento Santo Antônio, 15¹0'27” S, 39²0'22” W, 450-800 m, 22 November 2007, J. G. Jardim et al. 4687 (CEPEC, RB); Barra da Estiva, W of Barra da Estiva on the road to Jussiape, $3-13 \mathrm{~km}, 13^{\circ} 40^{\prime}$ S, 14 25' W, 1000-1300 m, 23 March 1980, R. M. Harley et al. 23809 (K, US).

3. Paralychnophora glaziouana Loeuille, Brittonia (in prep.; see Chapter 4). TYPE: BRAZIL. Minas Gerais: Diamantina, estrada para Conselheiro Mata, km 185, 26 July 1986, R. MelloSilva et al. CFCR 9962 (Holotype: SPF; Isotypes: BHCB, F [not seen], K [scan seen]). Synonyms: Eremanthus schwackei Glaz., Bull. Soc. Bot. (Mém. 3d) 56: 380. 1909, nom. nud. Paralychnophora schwackei (Glaz.) MacLeish, Taxon 33: 106. 1984, comb. illeg.

Distribution and habitat: Brazil (Minas Gerais). Campo rupestre; 750-1550 m.

Endemic to the Diamantina Plateau, in the Espinhaço Range. Distinctive features are the greyish indument (rarely light ochreous), flat leaf margins and 2-4-flowered capitula entirely connate. Similar to P. harleyi, but the latter has ochraceous indument (never greyish) and 5-12-flowered capitula. 
Representative specimens: BRAZIL. Minas Gerais: Diamantina, ca. $18 \mathrm{~km}$ E of Diamantina, 18¹1'02” S, 4332'12” W, 19 March 1970, H. S. Irwin et al. 27887 (NY, UB, US); GrãoMogol, Ribeirão, 23 April 1978, G. Hatschbach et al. 41421 (MBM, NY, US); Serro, distrito

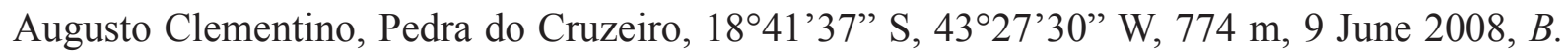
Loeuille et al. 451 (K, HAW, SPF).

4. Paralychnophora harleyi (H. Rob.) D. J. N. Hind, Kew Bull. 55: 370. 2000.

Basionym: Eremanthus harleyi H. Rob., Rhodora 98: 90. 1996 [1997]. TYPE: BRAZIL. Bahia: Rio de Contas, Pico das Almas, vertente leste, alto do vale acima da Faz. Silvina, 1550 m, 1331' S, 4158' W, 16 December 1988, R. M. Harley \& D. J. N. Hind H 27255 (Holotype: CEPEC [not seen]; Isotypes: AAU [not seen], K [scan seen], MO [not seen], SPF, U [not seen], US).

Distribution and habitat: Brazil (Bahia). Campo rupestre, rarely in cerrado; 400-1700 m.

A very common species fro the Catolés region and Serra do Sincorá in the Chapada Diamantina, Bahia. It is marked by an ochraceous indument and 5-12-flowered capitula. It can be confused with $P$. bicolor and P. glaziouana: see these species for a discussion of the differences.

Representative specimens: BRAZIL. Bahia: Abaíra, Belo Horizonte, acima do Jambeiro,

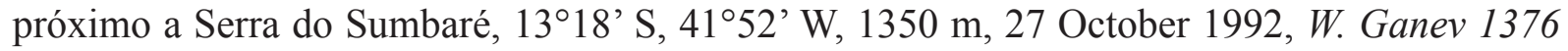
(HUEFS, SPF, UB, US); Lençóis, estrada de Lençóis BR 242, $5 \mathrm{~km}$ ao N de Lençóis, 19 December 1981, A. M. Carvalho et al. 1001 (CEPEC, RB, US); Piatã, Serra de Santana, sopé da Serra, 1309'23” S, 4146’29” W, 1275 m, 16 September 2007, B. Loeuille \& S. C. Ferreira 309 (HUEFS, SPF).

5. Paralychnophora reflexoauriculata (G. M. Barroso) MacLeish, Taxon 33: 106. 1984. Basionym: Eremanthus reflexoauriculatus G. M. Barroso, Rodriguésia 35-36: 6. 1960-61 [1962]. TYPE: BRAZIL. Pernambuco: Buíque, Chapada de São José, ca. 1000 m, 7 September 1960, A. Lima 60-3542 (Holotype: RB).

Distribution and habitat: Brazil (Bahia, Pernambuco, Sergipe). Campo rupestre of the Chapada Diamantina, Bahia, and rocky outcrops of the Serra do Catimbau (Pernambuco) and Serra da Itabaina (Sergipe); 300-1300 m.

Easily recognized by its sessile or subsessile leaves with auriculates bases and margins strongly revolute.

Representative specimens: BRAZIL. Bahia: Morro do Chapéu, Morrão, 4 February 2008, B. Loeuille et al. 396 (HAW, K, SPF); Pernambuco: Buíque, Serra do Catimbau, 24 December 2003, G. F. A. Melo de Pinna 24 (SPF); Sergipe: Itabaiana, E. E. Serra de Itabaiana, 19 September 1996, M. Landim et al. 1060 (ASE, SPF).

6. Paralychnophora patriciana D. J. N. Hind, Kew Bull. 55: 371. 2000. TYPE: BRAZIL. Bahia: Abaíra, Serra ao Sul do Riacho da Taquara, $13^{\circ} 15^{\prime}$ S, $41^{\circ} 55^{\prime}$ W, 27 January 1992, D. J. 
N. Hind \& R. F. Queiroz H 50967 (Holotype: SPF; Isotypes: K [scan seen], HUEFS, MO [not seen], TEX [not seen], US).

Distribution and habitat: Brazil (Bahia). Endemic to the Catolés region, Chapada Diamantina. Campo rupestre; $1700-2000 \mathrm{~m}$.

A rarely collected species characterized by the 25 -flowered capitula only concrescent at the base. Similar to P. bicolor: see that species for a discussion of the differences.

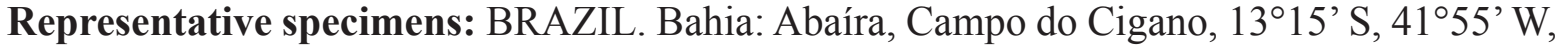
1800 m, 5 February 1992, B. Stannard et al. H51189 (CEPEC, HUEFS, K, SPF, US); ibidem,

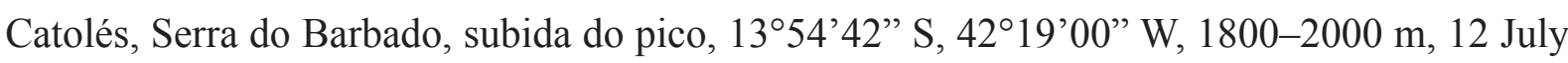
1993, W. Ganev 1828 (HUEFS, SPF, US); ibidem, 13¹7’41” S, 4154’31” W, 1700 m, 17 September 2007, B. Loeuille et al. 328 (HUEFS, SPF).

XV. Piptolepis Sch. Bip., Jahresber. Pollichia 20-21: 380. 1863, nom. cons., non Piptolepis Benth. Pl. Hartw. 29. 1840, nom. hom. illeg. TYPE: P. ericoides Sch. Bip.

Shrubs, seldom subshrubs or treelets; stems well branched. Indumentum tomentose to velutinous, composed of 3- to 5-armed swollen, sometimes not swollen, unbranched auriculate trichomes, seldom stellate swollen trichomes. Leaves alternate, sessile to petiolate, with a padlike or rarely semi-amplexicaul sheath, blade coriaceous, discolorous, seldom ericoid, margin entire, flat or revolute, venation brochidodromous or frequently hyphodromous. Inflorescence a terminal, sessile or rarely pedunculate, solitary capitulum or pseudoglomerule of capitula, rarely a syncephalium (second-order) ( $P$. pabstii). Capitulum sessile or seldom pedunculate. Involucre cylindrical or campanulate; phyllaries (3-)5-6 series, weakly imbricate, caducous, pubescent; receptacle areolate, rarely fimbrillate or naked. Florets (1-)9-29; corolla purple, tube longer than limb; corolla lobes pubescent or glabrous; anthers calcarate; style lacking basal node. Cypsela cylindrical, rarely prismatic or turbinate, glabrous or rarely pubescent $(P$. pabstii), carpopodium inconspicuous; pappus biseriate, deciduous or caducous, rarely persistent, whitish to stramineous, rarely reddish, setae bases enlarged, outer series smaller than inner series or subequal, setose to paleaceous, inner series straight or seldom twisted, subpaleaceous to paleaceous. Chromosome number: unknown.

A genus of eleven species, ten occurring in campos rupestres of the Espinhaço Range of mountains (Minas Gerais), one (P. pabstii) in the Serra dos Cristais (Goiás). The monophyly of Piptolepis is supported by molecular and morphological data (Loeuille et al. in prep.; see chapter 3 ) and the genus is characterized by the combination of pad-like leaf sheath (rarely a semi-amplexicaul leaf sheath), 3- to 5-armed swollen trichomes, weakly imbricate caducous phyllaries and outer pappus seta with an enlarged base. 
1. Piptolepis buxoides (Less.) Sch. Bip., Jahresber. Pollichia 20-21: 383. 1863.

Basionym: Vernonia buxoides Less., Linnaea 4: 247. 1829. TYPE: BRAZIL. 'E. Brasilia tropica misit', F. Sello(w) s.n. (Holotype: B [destroyed]).

Synonym: Vernonia pseudomyrtus A. St.-Hil., Voy. Distr. Diam. i. 94: 367. 1833. TYPE: BRAZIL. Minas Gerais: près Tapinhoancanga, A. de Saint Hilaire catologue B' 910574 (syntypes: B [destroyed] photo at F, K [scan seen], P [3 specimens] [scan seen]). Piptolepis pseudomyrtus (A. St.-Hil.) Sch. Bip. Jahresber. Pollichia 20-21: 384. 1863, non P. pseudomyrtus Baker in Mart. \& Eichler, Fl. bras. 6(2): 145. 1873, nom. illeg. hom.

Distribution and habitat: Brazil (Minas Gerais). Campo rupestre.

An infrequently collected species, characterized by ovate to oblanceolate leaves. It can be confused with P. schultziana, which has 17-29 florets per capitulum (vs 12-13). Also similar to $P$. campestris, but the velutinous to subsericeous, silverish canescent indument on the adaxial surface of leaves of the latter species easily separates it from $P$. buxoides. Also similar to $P$. ericoides: see that species for a discussion of the differences.

Representative specimens: BRAZIL. Minas Gerais: Alvorada de Minas, Itapanhoacanga, estrada Itapanhoacanga-cachoeira Campinas, ca. $3 \mathrm{~km}$ de Itapanhoacanga, 1847'51" S, 4326’35” W, 846 m, 14 November 2007, M. M. Saavedra et al. 529 (RB, SPF); Diamantina, April 1911, L. Damazio s.n. (RB)

2. Piptolepis campestris Semir \& Loeuille, Kew Bull. (in press; see Chapter 4). TYPE: BRAZIL. Minas Gerais: Diamantina, estrada para Conselheiro Mata, 11 April 1982, L. Rossi CFCR 3339 (Holotype: SPF; Isotype: UEC).

Distribution and habitat: Brazil (Minas Gerais). Campo rupestre.

Endemic to the Diamantina Plateau. Distinctive characteristics are the sessile to subsessile leaves up to $2 \mathrm{~cm}$ long, with a velutinous to subsericeous, silverish canescent indument on the adaxial surface. Similar to P. schultziana by the shape and size of leaves, but the latter species has adaxial leaf surface glabrescent, shiny and green. Also resembling to P. martiana, which has petiolate leaves up to $7.5 \mathrm{~cm}$ long.

Representative specimens: BRAZIL. Minas Gerais: Diamantina, margem da estrada Diamantina-Conselheiro Mata, $5 \mathrm{~km}$ de Diamantina, 30 August 1981, A. M. Giulietti et al. CFCR 1796 (K, SPF, UEC); ibidem, rodovia Guinda-Conselheiro Mata, 16 March 1987, G. Hatschbach et al. 50927 (MBM, US); ibidem, estrada Diamantina-Gouveia, 10 km de Gouveia, planalto de Guinda, 18 April 1987, D. Zappi et al. CFCR 10638 (K, HUFU, SPF).

3. Piptolepis ericoides Sch. Bip., Jahresber. Pollichia 20-21: 384. 1863. TYPE: BRAZIL. Minas Gerais: near Itambé, August 1840, G. Gardner 4750 (Lectotype: K [not seen], selected by Jeffrey and Hind (1994); Isolectotypes: GH, K [not seen], BM [not seen], US).

Synonym: Vernonia ericoides Less., Linnaea 6: 629. 1831, non V. ericoides (Lam.) Less. 
Linnaea 4: 247. 1829. TYPE: BRAZIL. No other data, F. Sello(w) 793 (Syntypes: B [destroyed] photos at F and US, F [fragment] [scan seen], K [not seen], P [not seen], photo at $\mathrm{F}$ and US).

Lychnophora diosmaefolia Pohl ex Baker in Mart. \& Eichler, Fl. bras. 6(2): 143. 1873, nom. nud. pro syn.

Distribution and habitat: Brazil (Minas Gerais). Campo rupestre; 850-1750 m.

A variable and widespread species of many serras of the Espinhaço Range. Easily recognized by its narrowed linear leaves and solitary capitula with 12-13 florets. It can be confused with $P$. buxoides, but that species has ovate to oblanceolate leaves.

Representative specimens: BRAZIL. Minas Gerais: Catas Altas, Serra do Caraça, Inficionado peak, 5 April 2007, A. M. Teles et al. 387 (BHCB); Grão-Mogol, rio Itacambiruçu, próximo a barra do Escurinho, 19 July 1998, G. Hatschbach et al. 68062 (ALCB, BHCB, ESA, MBM, UB, US); Santana do Riacho, Serra do Cipó, P. N. da Serra do Cipó, cânion das Bandeirinhas, beira do rio Cipó, 15 February 2002, B. Loeuille et al. 123 (SPF).

4. Piptolepis gardneri Baker in Mart. \& Eichler, Fl. bras. 6(2): 144. 1873. TYPE: BRAZIL. Minas Gerais: in Serra do Itambé, August1840, G. Gardner 4753 (Holotype: BM [scan seen]; Isotypes: $\mathrm{K}$ [2 specimens] [scan seen], $\mathrm{P}$ [not seen]).

Distribution and habitat: Brazil (Minas Gerais). Campo rupestre.

Known only from the type collection. Baker (1873) understood the following commentary of Gardner (1846: 210) under the description of Vernonia burchelliana as a description of a new species ('V. oleaster Gardner') based on the specimen Gardner 4753: 'Allied to $V$. oleaster, DC. (Gardn. n. 4753); but sufficiently distinguished by its much larger leaves, fewer flowers, and longer and more acuminated involucral bracts'. It seems clear to us that Gardner presented a comparison between the new species ( $V$. burchelliana) and Vernonia oleaster DC.; in brief, the name 'Vernonia oleaster Gardner' has not been validly published. Similar to P. monticola, but the leaves of $P$. gardneri are linear-elliptic to linear-oblong (vs. oblanceolate, linear-obovate to spatulate) and not glaucous (vs. glaucous).

5. Piptolepis glaziouana Beauverd, Bull. Soc. Bot. Genève, series II, 5: 239. 1913. TYPE: BRAZIL. Minas Gerais: entre Sopa et Diamantina, A. F. M. Glaziou 19550 (Holotype: G-BOIS [not seen]; Isotype: B [destroyed] photos at F and US, K [scan seen]).

Distribution and habitat: Brazil (Minas Gerais). Campo rupestre.

Endemic of the Diamantina Plateau. A rarely collected species. Distinctive features are the flat leaf margin, whitish florets, the cypsela with glabrous furrows, enlarged pappus setae base with a clavate apex. Resembling $P$. imbricata and $P$. leptospermoides very much, but these species have revolute leaf margins and lilac florets. More studies and collections are necessary to find out whether these three closely related species are conspecific or not.

Representative specimens: BRAZIL. Minas Gerais: Diamantina, Guinda, 7 September 1971, 
G. Hatschbach 27399 (MBM, US); ibidem, área da Copasa, reserva manancial Pau d'Fruta, 18¹5’30” S, 4340’26” W, 1336 m, 14 February 2007, A. K. A. Santos et al. 1070 (HUEFS).

6. Piptolepis imbricata (Gardner) Sch. Bip., Jahresber. Pollichia 20-21: 383. 1863.

Basionym: Vernonia imbricata Gardner, London J. Bot. 5: 209. 1846. TYPE: Brazil, Minas Gerais: bushy places on the Serro do Frio, near Milho Verde, August 1840, G. Gardner 4751 (Holotype: BM [scan seen]; Isotypes: B [destroyed] photo at F, K [2 specimens] [scan seen]).

Distribution and habitat: Brazil (Minas Gerais). Campo rupestre.

Endemic to the Diamantina Plateau. A rarely collected species. Distinctive features are the combination of cypselae with glabrous furrows and outer pappus smaller than inner series. It can be confused with $P$. leptospermoides, but the latter species has smaller leaves (5-6 vs. 6-8 $\mathrm{mm}$ long), which are conspicuoulsy ascending (vs. patent to ascending), and pilose cypsela furrows. Also similar to P. glaziouana: see that species for a discussion of the differences.

Representative specimens: BRAZIL. Minas Gerais: Diamantina, $15 \mathrm{~km}$ from Diamantina along road NE to Mendanha, 19 January 1981, R. M. King \& L. E. Bishop 8562 (UB, US); ibid., Mendanha km 585, 6 June 1985, J. Semir et al. 17543 (UEC); ibid., rodovia para Couto Magalhães, 17 September 1985, G. Hatschbach \& R. Kummrow 49776 (MBM, US).

7. Piptolepis leptospermoides (Mart. ex DC.) Sch. Bip., Jahresber. Pollichia 20-21: 382. 1863. Basionym: Vernonia leptospermoides Mart. ex DC., Prodr. 5: 17. 1836. TYPE: BRAZIL. Minas Gerais: in editis campis ad Tejuco, Serro Frio, 25 May 1818, C. F. P. von Martius 1310 (Holotype: M [not seen]; Isotype: P [not seen] photo of P: F and US).

Distribution and habitat: Brazil (Minas Gerais). Campo rupestre.

Endemic of the Diamantina Plateau. A species very distinct in the revolute leaf margins, cypsela with pilose furrows and outer pappus smaller than inner series. Resembling to P. glaziouana and P. imbricata: see these species for a discussion of the differences.

Representative specimens: BRAZIL. Minas Gerais: Diamantina, planalto, 6 October 1972, A. P. Duarte 14025 (RB, SPF); ibid., $10 \mathrm{~km} \mathrm{NE}$ of Diamantina, 4 October 1980, G. L. Smith et al. 1003 (GA, RB); ibid., campus JK da UFVJM, estrada de terra que desce atrás do Apiário da Universidade, em direção ao córrego Soberbo, 18¹1'54.2” S, 43³4'8.6” W, 1342 m, 30 October 2010, I. M. Franco et al. 609 (DIA, SPF).

8. Piptolepis monticola Loeuille, Kew Bull. (in press; see Chapter 4). TYPE: BRAZIL. Minas Gerais: Santo Antônio de Itambé, Pico do Itambé, B. Loeuille et al. 464 (Holotype: SPF; Isotypes: K, US).

Synonym: Piptolepis pseudomyrtus Baker in Mart. \& Eichler, Fl. bras. 6(2): 145. 1873, non P. pseudomyrtus (A. St.-Hil.) Sch. Bip. Jahresber. Pollichia 20-21: 384. 1863. TYPE: BRAZIL. Minas Gerais: habitat in Serra Itambé do Mato Dentro, C. F. P. von Martius 
s.n. (545) (Holotype: M [not seen] photos at F and US; Isotype: P [not seen]), nom. illeg. hom.

Distribution and habitat: Brazil (Minas Gerais). Campo rupestre; 1600-2015 m.

Endemic to the Pico do Itambé region. A poorly collected species, with subsessile to shortly petiolate leaves, pseudoglomerule with 3-4 capitula and 15-18 florets per capitulum. Similar to $P$. oleaster, but the leaves of $P$. monticola are pubescent to sericeous, glaucous and canescent (vs. velutinous and greenish). Also resembling P. gardneri: see that species for a discussion of the differences.

Representative specimens: BRAZIL. Minas Gerais: Santo Antônio de Itambé, Pico do Itambé, 5 May 1942, M. Magalhães 1575 (BHCB); ibid., 1700 m, 11 February 1972, W. R. Anderson et al. 35817 (NY, MO, RB, US); !); P. E. do Pico de Itambé, 10 May 2006, A. M. Teles et al. 244 (RB, SPF).

9. Piptolepis oleaster (Mart. ex DC.) Sch. Bip., Jahresber. Pollichia 20-21: 384. 1863.

Basionym: Vernonia oleaster Mart. ex DC., Prodr. 5: 17. 1836. TYPE: BRAZIL. Minas Gerais: in Serra da Piedade, May 1818, C. F. P. von Martius 1212 (543) (Holotype: M [scan seen] photo at $\mathrm{F}$; Isotype: $\mathrm{P}$ [not seen]).

Synonym: Albertinia oleaster Mart. ex DC., Prodr. 5: 17. 1836, nom. nud. pro syn.

Vernonia burchelliana Gardner, London J. Bot. 5: 209. 1846. TYPE: BRAZIL. Minas Gerais: Serro Frio, Diamond District, August 1840, G. Gardner 4754 (Holotype: BM [scan seen] photo at F and US; Isotypes: K [2 specimens] [scan seen], P [not seen]). Vernonia martiana Gardner, London J. Bot. 5: 210. 1846. TYPE: BRAZIL. Minas Gerais: rocky places near Cidade Diamantina, August 1840, G. Gardner 4754/2 (Holotype: BM [scan seen]; Isotypes: P [not seen], W [not seen] photo at F), syn. nov.

Piptolepis martiana (Gardner) Sch. Bip., Jahresber. Pollichia 20-21: 385. 1863, syn. nov.

Albertinia gonoclados Mart. ex Baker in Mart. \& Eichler, Fl. bras. 6(2): 144. 1873. nom. nud. pro syn.

Piptolepis schwackeana Glaz., Bull. Soc. Bot. (Mém. 3d) 56: 377. 1909, nom. nud.

Distribution and habitat: Brazil (Minas Gerais). Campo rupestre.

Restricted to the Diamantina region southwards to the Serra da Piedade near Ouro Preto. Rarely collected species. Easily recognized by its adaxial greenish oblanceolate, elliptic to lanceolate leaves and 15-25-flowered capitula. Similar to P. gardneri: see that species for a discussion of the differences. Synonymy is based on the study of recent collections of that species which shows a great variation in the leaf shape and number of florets per capitulum. Gardner probably collected materials of $V$. burchelliana and $V$. martiana at the same locality under the same number (4754) and only later set apart both sets, indicating the $V$. martiana's collection by 4754/2. Both collections appear under the number 4754 in Gardner (1846).

Representative specimens: BRAZIL. Minas Gerais: Diamantina, Mendanha, P. E. do Biribiri, 
caminho para a região dos Barris, 18 $14^{\prime} 17^{\prime}$ ' S, 4338'58' W, 718 m, 12 January 2011, I. M. Franco \& C. O. Andrino 644 (DIA). São Gonçalo do Rio Preto, P. E. do Rio Perto, entre Lapa do Tatu e córrego da Lapa, 1805’33.8”S, 43²0’30.3”W, 897 m, 9 February 2010, B. Loeuille et al. 517 (K, SPF, US); ibid., trilho da camping ao areal do córrego da Lapa, $18^{\circ} 05^{\prime} 28^{\prime \prime} \mathrm{S}$, 4320’30”W, 20 February 2002, J. A. Lombardi 4591 (BHCB, US).

10. Piptolepis pabstii (G. M. Barroso) Loeuille, Semir \& Pirani, comb. nov.

Basionym: Eremanthus pabstii G. M. Barroso, Sellowia 16: 173. 1964. TYPE: BRAZIL. Goiás: Cristalina, ca. 1250 m, 24 March 1963, E. P. Heringer 9229/1442 (Holotype: HB [not seen]; Isotypes: RB, UB [scan seen]).

Synonym: Vernonia pabstii (G. M. Barroso) MacLeish, Syst. Bot. 9: 135. 1984.

Distribution and habitat: Brazil (Goiás). Campo rupestre; 1000-1200 m.

A rarely collected species. Easily recognized by its subshrubby habit, syncephalium and one floret per capitulum.

Representative specimens: BRAZIL. Goiás: Água Fria de Goiás, GO 118, subida para a Torre, Repetidora de Roncador, 8 May 2000, G. Hatschbach et al. 70631 (BHCB, HUEFS, MBM, SPF, US); Cristalina, ca. $10 \mathrm{~km} \mathrm{~S}$ of Cristalina, $1200 \mathrm{~m}, 1$ March 1966, H. S. Irwin et al. 13224 (NY, UB, US); ibid., ca. 7 km by road NW of Cristalina on road to Brasília, $1100 \mathrm{~m}, 3$ April 1973, W. R. Anderson et al. 8080 (NY, UB, US).

11. Piptolepis schultziana Loeuille \& D. J. N. Hind, Kew Bull. (in press; see Chapter 4). TYPE: BRAZIL. Minas Gerais: Congonhas do Norte, Fazenda Imbaúbas, 1250 m, 1856’14.8” S, 4341'6.1” W, 20 January 2007, B. Loeuille et al. 76 (Holotype: SPF; Isotype: K).

Distribution and habitat: Brazil (Minas Gerais). Campo rupestre.

Known only from the northern and southwestern portions of the Serra do Cipó. Similar to $P$. campestris by the shape and size of leaves, but the adaxial surface of $P$. schultziana is glabrescent, shiny and green (vs. velutinous to subsericeous and silverish canescent). Also resembling $P$. buxoides, but the latter species has narrower leaves (3-4 mm vs. 4-7 mm) and fewer florets per capitulum (12-13 vs. 17-29).

Representative specimens: BRAZIL. Minas Gerais: Congonhas do Norte, estrada para Santana do Riacho, 1856' S, 4341' W, 1200 m, 3 March 1998, J. R. Pirani et al. 4179 (K, SPF); Santana do Pirapama, Distrito de São José da Cachoeira, Serra da Lapa, trilha do João Carrinho, 1902’52.8” S, 4344'19.3” W, 756-1080 m., 18 February 2007, V. C. Souza et al. 32693 (BHCB, ESA, K, SPF); Santana do Riacho, Lapinha, elevações imediatamente a nordeste de Lapinha, nas nascentes do córrego do Boqueirão, trilha para o alto do paredão, $19^{\circ} 06^{\prime} 21.2^{\prime \prime}$ S, 4340’32” W, 1315 m, 22 April 2006, B. Loeuille et al. 20 (K, SPF, US). 
XVI. Prestelia Sch. Bip., Festschr. Naturf. Ges. Emden 73 (1864) [probably1865]. TYPE: P. eriopus Sch. Bip.

Caulirosulas; stem unbranched, short and straight. Indumentum tomentose to lanate, composed of 3- to 5-armed trichomes, sometimes inverted Y-shaped and unbranched trichomes. Leaves in rosette, sessile, with a semi-amplexicaul sheath closely imbricated and appressed, tightly surrounding the stem, blade coriaceous, discolorous or concolorous, margin entire, revolute, venation a brochidodromous-acrodromous mixed pattern. Inflorescence an axillary, pedunculate, syncephalium (second-order). Capitulum sessile. Involucre campanulate; phyllaries 3-4 series, weakly imbricate, persistent, pubescent; receptacle areolate. Florets 5-10; corolla purple, tube longer than limb; corolla lobes glabrous; anthers calcarate; style lacking basal node. Cypsela turbinate, glabrous, carpopodium inconspicuous; pappus 2-3-seriate, persistent, setose, stramineous or reddish, setae bases enlarged, outer series smaller than inner series, inner series straight. Chromosome number: unknown.

A genus of two species from the southern portion of Espinhaço Range of mountains in Minas Gerais, Brazil. The following combination of characters is diagnostic: caulirosula habit, revolute leaves, peduculate syncephalium and persistent pappus.

1. Prestelia eriopus Sch. Bip., Festschr. Naturf. Ges. Emden 73 (1864) [probably1865]. TYPE: BRAZIL. Minas Gerais: in glaerosis Serra da Lapa, November 1824, L. Riedel 1127 (Holotype: LE [not seen]; Isotype: F [fragment] [not seen], P [not seen] photo at F, TEX and US). Synonym :Eremanthus eriopus (Sch. Bip.) Baker in Mart. \& Eichler, Fl. bras. 6(2): 169. 1873. Chresta eriopus (Sch. Bip.) H. Rob., Phytologia 45: 91. 1980.

Distribution and habitat: Brazil (Minas Gerais). Campo rupestre; 1000-1300 m.

Endemic of the Serra do Cipó up to the Diamantina Plateau. Distinctive features are the linear to narrowly lanceolate leaves with glabrous adaxial surface. Similar to P. purpurascens, but the latter species differs from $P$. eriopus in its lanceolate to oblong-spathulate leaves with densely lanate adaxial surface (becoming glabrescent with age), and higher number of florets per capitulum (8-10 vs. 5-7).

Representative specimens: BRAZIL. Minas Gerais: Congonhas do Norte, Serra do Cipó,

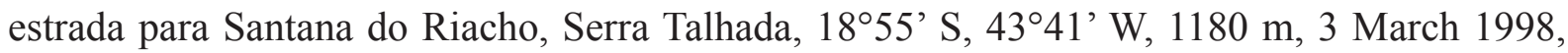
J. R. Pirani et al. 4168 (SPF); Diamantina, estrada Diamantina-Conselheiro Mata, 3-6 km da estrada Diamantina-Gouveia, 14 March 1999, V. C. Souza \& J. P. Souza 22212 (ESA, K, UEC); Santana do Riacho, Serra do Cipó, rodovia Lagoa Santa-Conceição do Mato Dentro MG 010, perto da sede do IBAMA, 14 February 2007, B. Loeuille et al. 113 (SPF).

2. Prestelia purpurascens (Glaz. ex Oliv.) Loeuille, Semir \& Pirani, comb. nov.

Basionym: Eremanthus purpurascens Glaz. ex Oliv., Hooker's Icon. 4(3): pl. 2282. 1894. TYPE: BRAZIL. Minas Gerais: Serra do Cipó près Congonha da Serra, 22 April 1893, 
A. F. M. Glaziou 19464 (Holotype: K [scan seen]; Isotypes: BR [not seen], C [not seen], $\mathrm{P}$ [3 specimens]).

Distribution and habitat: Brazil (Minas Gerais). Campo rupestre; 1000-1300 m.

Apparently endemic to the northern portion of the Serra do Cipó. A rarely collected species. Easily recognized by its lanceolate to oblong-spathulate leaves with densely lanate adaxial surface (becoming glabrescent with age). Resembling P. eriopus: see that species for a discussion of the differences.

Representative specimens: BRAZIL. Minas Gerais: Santana do Pirapama, Vale do Soberbo,

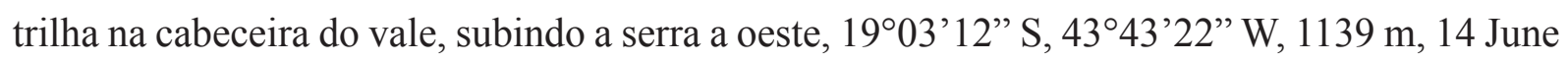
2009, L. Echternacht \& T. V. Barros 2049 (BHCB).

XVII. Proteopsis Mart. \& Zucc. ex Sch. Bip., Jahresber. Pollichia 20-21: 378. 1863. TYPE: P. argentea Mart. \& Zucc. ex Sch. Bip.

Caulirosulas; stem unbranched, short, straight. Indumentum sericeous, composed of unbranched trichomes. Leaves in rosette, sessile, with an amplexicaul sheath, closely imbricated and appressed, tightly surrounding the stem, blade coriaceous, concolorous, margins entire, flat (not revolute), actinodromous venation. Inflorescence an axillary, pedunculate, solitary glomerule of capitula with foliaceous subinvolucral bracts. Capitulum pedunculate. Involucre campanulate; phyllaries 5-6 series, strongly imbricate, persistent, glabrous, with spiny appendages; receptacle fimbrillate. Florets 80-110; corolla purple, tube longer than limb; corolla lobes glabrous; anthers calcarate; style lacking basal node. Cypsela turbinate, glabrous or pubescent, carpopodium prominent; pappus uniseriate, caducous, paleaceous, twisted, stramineous, setae bases enlarged. Chromosome number: unknown.

A monotypic genus from the campos rupestres of the Espinhaço Range of mountains in Minas Gerais State, Brazil. Proteopsis is easily set apart from the other caulirosulate genera by the phyllaries with spiny appendages and by the uniseriate pappus.

1. Proteopsis argentea Mart. \& Zucc. ex Sch. Bip., Jahresber. Pollichia 20-21: 378. 1863, non P. argentea Mart. \& Zucc. ex DC., Prodr. 5: 16. 1836, nom. nud. pro syn. TYPE: BRAZIL. Minas Gerais: Serra de Piedade, C. F. P. von Martius s.n. (Holotype: M [not seen]).

Synonym: Vernonia proteopsis DC., Prodr. 5: 16. 1836. TYPE: BRAZIL. Minas Gerais: Serra de Piedade, C. F. P. von Martius s.n. (Holotype: M [not seen]).

Distribution and habitat: Brazil (Minas Gerais). Campo rupestre; 900-1500 m.

Widespread in the Espinhaço Range, recorded in the Serra da Piedade, Serra do Cipó, Serra do Cabral and Grão-Mogol. A striking species, easily recognized by its silverish lanceolate leaves, phyllaries with spiny appendages, and capitulescence with a long and stout peduncle. Jesus et al. (2001) showed that the genetic diversity among individuals of each population of this species were similar or higher to the diversity found between populations of distant areas 
along the Espinhaço. Therefore they concluded that even tough there are local morphological variations it is not possible to recognize here more than a single species.

Representative specimens: BRAZIL. Minas Gerais: Grão-Mogol, estrada para Botumirim, Morro do Chapéu, entre Mombucas e Boa Vista do Bananal, 22 July 1985, G. Martinelli 11263 (BHCB, NY, RB); Joaquim Felício, Serra do Cabral, Fazenda Riacho de Barro, 10 June 2004, G. Hatschbach et al. 77713 (MBM, US); Santana do Riacho, Serra do Cipó, Lapinha, nas nascentes do córrego do Boqueirão, 1906’05” S, 4340’36” W, 1406 m, 22 April 2006, B. Loeuille et al. 24 (SPF).

XVIII. Vinicia Dematt., Bonplandia 16: 260. 2007. TYPE: V. tomentosa Dematt.

Subshrubs, stems branched. Indumentum tomentose, composed of 3- to 5-armed swollen and asymmetric T-shaped swollen trichomes. Leaves alternate, sessile, with a semi-amplexicaul sheath, blade membranaceous, discolorous, margin entire, flat (not revolute), eucamptodromous venation. Inflorescence a terminal, pedunculate, panicle of glomerules of capitula. Capitulum sessile. Involucre cylindrical; phyllaries 4-5 series, imbricate, persistent, pubescent; receptacle areolate. Florets 8-12; corolla purple, tube longer than limb; corolla lobes pubescent; anthers calcarate; style lacking basal node. Cypsela prismatic, pubescent, carpopodium inconspicuous; pappus biseriate, stramineous, outer series smaller than inner series, persistent, paleaceous, inner series caducous, setose, straight. Chromosome number: unknown.

A monotypic genus from the Serra do Cabral, in the central portion of the Espinhaço Range of mountains in Minas Gerais State, Brazil. Known from just one collection. Phylogenetic analyses indicate a close relationship with Minasia, both genera sharing T-shaped swollen trichomes.

1. Vinicia tomentosa Dematt., Bonplandia 16: 260. 2007. TYPE: BRAZIL. Minas Gerais: Joaquim Felício, Serra do Cabral, estrada Joaquim Felício-Várzea de Palma, ca. $10 \mathrm{~km}$ de

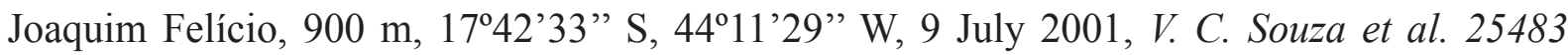
(Holotype: ESA; Isotypes: BHCB (not found), K [scan seen]).

Distribution and habitat: Brazil (Minas Gerais). Campo rupestre.

Endemic to the Serra do Cabral. Known only from the type collection. Easily recognized by its thin chartaceous leaves and panicles of glomerules.

\section{INCERTAE SEDIS}

More studies are necessary to accommodate the following species in the generic concepts proposed in the present synopsis or in new genera. Some of these species were included in phylogenetic analyses (Eremanthus crotonoides, Lychnophora damazioi and L. markgravii) (Loeuille et al. in prep.; see Chapter 3) but the results were poorly resolved as follows: (1) either a species emerged as an isolated lineage (E. crotonoides); or (2) its relationships to other 
genera were poorly supported (L. markgravii); or (3) a more complete taxonomic sampling is necessary (L. damazioi). In order to avoid unecessary new combinations and/or to create new monotypic genera, these species are kept unplaced in the subtribe and shall await for further evidence.

1. Eremanthus crotonoides (DC.) Sch. Bip., Jahresber. Pollichia 20-21: 396. 1863.

Basionym: Albertinia crotonoides DC., Prodr. 5: 81. 1836. TYPE: BRAZIL. Minas Gerais: montium sepibus, C. F. P. von Martius s.n. (Holotype: M [not seen]).

Synonyms: Albertinia verbascifolia Mart. ex DC., Prodr. 5: 81. 1836. TYPE: BRAZIL. Minas Gerais: ferruginosis Serra de Ant. Pereira, 1818, C. F. P. von Martius 915 (1297) (Holotype: M [scan seen]).

Vernonia crotonoides (DC.) Sch. Bip., Jahresber. Pollichia 18-19: 166. 1861.

Eremanthus verbascifolius (Mart. ex DC.) Sch. Bip., Jahresber. Pollichia 20-21: 397. 1863.

Cacalia crotonoides (DC.) Kunth, Revis. Gen. P1. 2: 969. 1891, 'crotonodes'.

Vernonia iodopappa Sch. Bip., Bot. Zeitung (Berlin) 3: 155. 1845, 'jodopappa', nom nud.

Albertinia bardanoides Mart. ex Baker in Mart. \& Eichler, Fl. bras. 6(2): 25. 1873, nom. nud. pro syn.

Distribution and habitat: Brazil (Bahia, Espírito Santo, Minas Gerais, Rio de Janeiro). Secondary woods, gallery forest margins, less frequently in campo rupestre and rarely in cerrado; 550-1800 m.

A widespread species in eastern Brazil, easily recognized by its paniculate inflorescences, 3-5-flowered capitula and reddish pappus. Distantly related from Eremanthus, its habit is similar to Gorceixia, and both taxa share stellate trichomes with long stalk. However, in the phylogenetic analyses, it emerged as a sister-group of a clade comprising nearly all Lychnophorinae except the basal lineages Albertinia, Blanchetia, Centratherum and Gorceixia. Also similar to some species of Piptocoma, a genus presently placed in the subtribe Piptocarphinae, but which phylogenetic position is unknown. It is noteworthy that furanoheliangolides (the synapomorphy of Lychnophorinae, Loeuille et al. in prep.; see Chapter 2) have been extracted from leaves of Piptocoma (Castro et al., 1989).

Representative specimens: BRAZIL. Bahia: Macarani, rodovia para Vila das Graças, 17.2 km E, ca. 4.4 km da Vila das Graças, 1546’19” S, 40²4'50” W, 560-600 m, 17 August 2001, A. M. Carvalho et al. 7009 (ALCB, NY). Espírito Santo: Santa Leopoldina, Luxemburgo, Pedra Preta, 15 March 2005, L. Kollmann et al. 7405 (MBM, MBML). Minas Gerais: Congonhas do Norte, Serra do Cipó, Serra Talhada, 9 km S de Congonhas do Norte na estrada para Conceição do Mato Dentro, $18^{\circ} 55^{\prime} 48^{\prime \prime}$ S, 4340’17” W, 1130 m, 20 January 2007, B. Loeuille et al. 73 (K, MBM, MO, NY, SPF, US). Rio de Janeiro: Rio das Ostras, entre Macaé e Rio das Ostras, 15 May 1993, J. R. Pirani \& R. Mello-Silva 2874 (NY, SPF, US). 


\section{'Lychnophora brunioides' group}

L. brunioides, $L$. harleyi and $L$. souzae have a similar obtriangulate leaf sheath that led us to think that these species are probably related. None of these species have been included in a phylogenetic analyses so far, and we shall expect that doing so would clarify the taxonomic position of these taxa. Further comments are given under each species.

2. Lychnophora brunioides Mart., Denkschr. Königl.-Baier. Bot. Ges. Regensburg 2: 149. 1822. TYPE: BRAZIL. Minas Gerais: in alpestribus summi Montis Itambé da Villa locis patentibus siccis, C. F. P. von Martius s.n. (Holotype: M [not seen] photo at F; Isotype: $\mathrm{P}$ [not seen]). Synonyms: Vernonia brunioides (Mart.) Less., Linnaea 4: 248. 1829.

Lychnophora brunioides var. alpicola Mart. ex DC., Prodromus 5: 80. 1836. TYPE: BRAZIL. Minas Gerais: in Serro Frio ad Tejuco, alt. 5000 ped., C. F. P. von Martius s.n. (Holotype: $\mathrm{M}$ [not seen] photo at $\mathrm{F}$ and US; Isotype: $\mathrm{P}$ [not seen]).

Distribution and habitat: Brazil (Minas Gerais). Campo rupestre.

Known only from the Pico do Itambé in Minas Gerais. The presence of an inconspicuous obtriangulate leaf sheath helps distinguish that species from Lychnophora pinaster (which has similar leaves but without leaf sheath). Coile and Jones (1981) excluded L. brunioides from Lychnophora and considered it a member of Piptolepis. However the latter genus is defined by its pad-like leaf sheath and caducous phyllaries, characters absent from L. brunioides. Also similar to Lychnophorella, but these species have also a pad-like leaf sheath base (vs. obtriangulate).

Representative specimens: BRAZIL. Minas Gerais: Santo Antônio do Itambé, alto do Pico do Itambé, 5 May 1942, M. Magalhães 1582 (BHCB, HB, RB); ibidem, 10 February 1972, W. R. Anderson et al. 35749 (RB, NY); ibidem, 18²3'53" S, 43²0’60” W, 2035 m, 28 January 2009, B. Loeuille et al. 467 (SPF, UEC).

3. Lychnophora harleyi H. Rob., Phytologia 53: 374. 1983. TYPE: BRAZIL. Bahia: Serra dos Lençóis about 7-10 km along the main Seabra-Itaberaba road, W of the Lençóis turning, by the rio Mucugézinho, ca. $800 \mathrm{~m}, 4^{\circ} 26^{\prime} \mathrm{S}, 12^{\circ} 28^{\prime} \mathrm{W}, 27$ May 1980, R. M. Harley et al. 22716 (Holotype: UB [not seen] photos at C, F, MO and NY; Isotypes: CEPEC [scan seen], K [scan seen] [2 specimens], RB [not seen], SPF, UEC, US [2 specimens]).

Distribution and habitat: Brazil (Bahia). Campo rupestre.

Known only from the type collection. Distinctive features are its oblong to obovate leaves and capitula in pseudoglomerules. Its leaf sheath is somewhat intermediate between the typical padlike of Lychnophorella and Piptolepis, and the one of L. brunioides and L. souzae. Its capitula are sometimes shortly pedunculate like the ones of $L$. souzae. 
4. Lychnophora souzae H. Rob., Phytologia 46: 104. 1980. TYPE: BRAZIL. Minas Gerais: Serra do Espinhaço, ca. $12 \mathrm{~km}$ NE of Diamantina, road to Diamantina, 27 January 1969, H. S. Irwin et al. 22690 (Holotype: UB [not seen] photo at C, F and NY; Isotypes: F [not seen], MO [not seen], NY [scan seen], RB [not seen], UEC, US).

Distribution and habitat: Brazil (Minas Gerais). Campo rupestre.

Known only from three collections. A very distinctive taxa, easily recognized by its spikelike inflorescences of reduced glomerules, with one or two florets, which has been considered as a case of syncephaly (Robinson, 1980b; Semir, 1991). However we disagree with such interpretation, due to the lack of a secondary receptacle. Unique is the posterior growth of the axis of the inflorescence which are primarily terminal. Sharing with L. brunioides a similar leaf sheath and with L. harleyi the presence of pedunculate capitula.

Representative specimens: BRAZIL. Minas Gerais: Diamantina, Biribiry, 24 March 1892, A. F. M. Glaziou 19491 (P); ibid., campus JK da UFVJM, final da estrada de terra que desce atrás do Apiário da Universidade, 18 11'40.8” S, 43³4’04.5” W, 1310 m, 25 February 2011, I. M. Franco \& M. M. T. Costa 710 (DIA, SPF).

5. Lychnophora damazioi Beauverd, Bull. Soc. Bot. Genève, series II, 5: 241. 1913. TYPE: BRAZIL. Minas Gerais: Serra do Cipó, in campis, June 1908, L. Damazio 2010 (Holotype: $\mathrm{G}$ [not seen] photo at F and US; Isotype: RB [not seen]).

Synonym: Lychnophoriopsis unicaulis Glaz., Bull. Soc. Bot. (Mém. 3d) 56: 379. 1909, nom. nud.

Vernonia damazioi (Beauverd) Leitão Filho \& Semir, Revista Brasil. Bot. 2: 113. 1979. Lychnophoriopsis damazioi (Beauverd) H. Rob., Proc. Biol. Soc. Wash. 105: 644. 1992.

Distribution and habitat: Brazil (Minas Gerais). Campo rupestre; 1000-1350 m.

Easily recognized by its treelet habit and short leaves with obtuse to rounded apices. Endemic from Serra do Cipó. Phylogenetic analyses indicate a close relationship with Prestelia and more distantly with Lychnocephalus, however L. damazioi differs sharply from these two genera by its lack of syncephalia and pedunculate capitula.

Representative specimens: BRAZIL. Minas Gerais: Congonhas do Norte, Serra do Cipó, Serra Talhada, 9 km S de Congonhas do Norte, na estrada para Conceição do Mato Dentro, 1856'15” S, 4341'06” W, 1250 m, 20 January 2007, B. Loeuille et al. 77 (K, SPF); Santana do Riacho, Serra do Cipó, about 14 km N of Chapéu do Sol, 1350 m, 7 October 1980, J. G. Stutts et al. 966 (GA, NY, US); ibid., 19¹7'15” S, 4335'20” W, 1100-1200 m, 11 July 1998, J. R. Stehmann \& E. Franceschinelli 2363 (BHCB, SPF, US).

6. Lychnophora albertinioides Gardner, London J. Bot. 5: 234. 1846. TYPE: BRAZIL. Minas Gerais: near Itambé, August 1840, G. Gardner 4827 (Syntypes: BM [not seen] [2 specimens] photos at F, GH, RB, E [not seen], F [not seen], G photo at F and US, GH, NY [scan seen], P [not seen], US). 
Distribution and habitat: Brazil (Minas Gerais). Probably campo rupestre.

Known only from three collections from the first half of the XIX ${ }^{\mathrm{e}}$ century. Distinctive features are the oblanceolate leaves and pseudoglomerules. Leaf shape and indument as well as the presence of a semi-amplexicaul leaf sheath seem to indicate a relationship with Piptolepis oleaster. A similar relationship has been suggested by Coile and Jones (1981) and Semir (1991). However, the inflorescence in axillary position and persistent phyllaries prevent us to include this taxon in Piptolepis.

Representative specimens: BRAZIL. Minas Gerais: Serra do Itambé, Serro Frio, C. F. P. von Martius s.n. (1243) (P); no other data, A. de Saint-Hilaire catalogue B'834-573 (P).

7. Lychnophora markgravii G. M. Barroso, Arch. Jar. Bot. Rio de Janeiro 14: 260. 1956. TYPE: Brazil, Minas Gerais: Serra de Grão Mogol, planalto, ca. 1000 m, 12 November 1938, Markgraf 3480 (Holotype: RB; isotype: RB).

Distribution and habitat: Brazil (Minas Gerais). Campo rupestre.

A striking species, easily recognised by its Rauh's model habit (Hallé et al., 1978) and axillary paniculate of glomerules. In the phylogenetic analyses L. markgravii emerged as the sistergroup of Paralychnophora, but there is no support for this relationship. This species shares with the latter the presence of semi-amplexicaul leaf sheath, 3- to 5-armed trichomes, axillary inflorescence and a biseriate pappus. However, L. markgravii does not show syncephalia and displays crenate leaves with T-shaped trichomes and a paleaceous pappus, characters not found in Paralychnophora. Habit and leaf characters are also similar with Heterocoma, but L. markgravii lacks phytomelanin in the cypselae which is the synapomorphy of that genus (unpublished data).

Representative specimens: BRAZIL. Minas Gerais: Botumirim, estrada para o rio do Peixe, entrada a $2.2 \mathrm{~km}$ de Botumirim, em frente a Fazenda Botafogo, 16 ${ }^{\circ} 52^{\prime} 42$ ' S, 42 52 ' $42^{\prime}$ ” W, 734 m, 18 November 2007, R. Mello-Silva et al. 3006 (RB, SPF); Grão-Mogol, Vale do córrego das Mortes, 16³4'49” S, 4254'04” W, 800 m, 6 June 2008, B. Loeuille et al. 440 (SPF); Joaquim Felício, Serra do Cabral, 950-1000 m, 15 May 2001, G. Hatschbach et al. 72048 (MBM, SPF, US). 


\section{EXCLUDED SPECIES}

1. Albertinia incanescens Mart. ex Colla, Herb. Pedem. iii. 290. 1834.

$=$ Unresolved (analysis of the holotype scan shows that this taxa does not belong to Lychnophorinae but more studies are necessary to identify it).

2. Centratherum angustifolium (Benth.) C.D.Adams, Journ. W. Afr. Sci. Assoc. 6: 149. 1961.

= Kinghamia angustifolia (Benth.) C. Jeffrey [subtribe Erlangeinae]

3. Centratherum burmanicum Gamble, Kew Bull. Misc. Inform. 1915: 90. 1915.

$=$ Unresolved.

4. Centratherum chinense Less., Linnaea 4: 320. 1829.

$=$ Blumea chinensis $(\mathrm{L}$.$) DC. [tribe Inuleae]$

5. Centratherum courtallense (Wight) Benth. \& Hook. f., Gen. Pl. (Bentham \& Hooker f.) 2: 225. 1873.

= Phyllocephalum scabridum (DC.) K. Kirkman [subtribe Erlangeinae]

6. Centratherum courtallense C. B. Clarke, Compos. Ind. 3. 1876.

= Unresolved.

7. Centratherum englerianum Muschl., Bot. Jahrb. Syst. 46: 57, f. 4. 1911.

$=$ Kinghamia engleriana (Muschl.) $\mathrm{C}$. Jeffrey [subtribe Erlangeinae]

8. Centratherum frutescens Benth. ex C. B. Clarke, Compos. Ind. 5. 1876.

$=$ Unresolved

9. Centratherum frutescens (Blume) Boerl., Handl. Fl. Ned. Ind. 2: 234. 1899.

= Phyllocephalum frutescens Blume [subtribe Erlangeinae]

10. Centratherum frutescens (Blume) Benth. \& Hook. f., Gen. Pl. (Bentham \& Hooker f.) 2: 225. 1873.

= Phyllocephalum frutescens Blume [subtribe Erlangeinae]

11. Centratherum frutescens var. javanicum (Miq.) J. Kost., Blumea 1: 379. 1935.

= Phyllocephalum frutescens Blume [subtribe Erlangeinae]

12. Centratherum frutescens var. papandaianense J. Kost., Blumea 1: 379. 1935.

= Phyllocephalum frutescens Blume [subtribe Erlangeinae]

13. Centratherum grande (DC.) Nob, Mém. Couronnées Autres Mém. Acad. Roy. Sci. Belgique 1895: 53. 1895.

= Gymnanthemum coloratum (Willd.) H. Rob. \& B. Kahn

14. Centratherum grande T. Durand \& Schinz, Etudes Fl. Congo, 169. (1896).

$=$ Unresolved

15. Centratherum hookeri C. B. Clarke, Compos. Ind. 3. 1876.

= Phyllocephalum scabridum (DC.) K. Kirkman [subtribe Erlangeinae]

16. Centratherum indicum (Less.) C. E. C. Fisch., Bull. Misc. Inform. Kew. 1940: 44. 1940.

= Phyllocephalum indicum (Less.) K. Kirkman [subtribe Erlangeinae]

17. Centratherum javanicum (Miq.) Boerl., Handl. Fl. Ned. Ind. 2: 234. 1891. 
= Phyllocephalum frutescens Blume [subtribe Erlangeinae]

18. Centratherum mayurii C. E. C. Fisch, Bull. Misc. Inform. Kew. 1940: 45.1940.

= Phyllocephalum indicum (Less.) K. Kirkman [subtribe Erlangeinae]

19. Centratherum metzianum Sch. Bip. ex Hook. f., Fl. Brit. India [J. D. Hooker] 3: 228. 1881.

= Phyllocephalum scabridum (DC.) K. Kirkman [subtribe Erlangeinae]

20. Centratherum molle Benth. \& Hook. f., Gen. Pl. (Bentham \& Hooker f.) 2: 225. 1873.

$=$ Phyllocephalum scabridum (DC.) K. Kirkman [subtribe Erlangeinae]

21. Centratherum phyllolaenum (DC.) Benth. ex Hook. f., Fl. Brit. India [J. D. Hooker] 3: 228. 1881.

$=$ Phyllocephalum scabridum (DC.) K. Kirkman [subtribe Erlangeinae]

22. Centratherum rangacharii Gamble, Kew Bull. Misc. Inform. 1920: 338. 1920.

= Phyllocephalum scabridum (DC.) K. Kirkman [subtribe Erlangeinae]

23. Centratherum reticulatum (Wight) Benth. \& Hook. f., Gen. Pl. (Bentham \& Hooker f.) 2: 228. 1873.

$=$ Phyllocephalum indicum (Less.) K. Kirkman [subtribe Erlangeinae]

24. Centratherum ritchiei Hook. f., Fl. Brit. India [J. D. Hooker] 3: 228. 1881.

= Phyllocephalum scabridum (DC.) K. Kirkman [subtribe Erlangeinae]

25. Centratherum scariosum C. B. Clarke, Compos. Ind. 4. 1876.

$=$ Unresolved.

26. Centratherum sengaltherianum Narayana, Curr. Sci. 50: 279. 1981

$=$ Phyllocephalum sengaltherianum (Narayana) Narayana

27. Centratherum tenue C. B. Clarke, Compos. Ind. 4. 1876.

$=$ Phyllocephalum scabridum (DC.) K. Kirkman [subtribe Erlangeinae]

28. Eremanthus angustifolius (Gardner) Baker in Mart. \& Eichler, Fl. bras. 6(2): 170. 1873.

$=$ Chresta angustifolia Gardner [subtribe Chrestinae]

29. Eremanthus curumbensis Philipson, Kew Bull. Misc. Inform. 7: 298. 1938.

= Chresta curumbensis (Philipson) H. Rob. [subtribe Chrestinae]

30. Eremanthus descampsii Klatt ex De Wild. \& T. Durand, Ann. Mus. Congo Belge, Bot; sér.

1, 1: 99, t. 50. 1899.

= Vernonia klattii MacLeish [unresolved]

31. Eremanthus exsuccus (DC.) Baker in Mart. \& Eichler, Fl. bras. 6(2): 166. 1873.

= Chresta exsucca DC. [subtribe Chrestinae]

32. Eremanthus harmsianus Taub., Bot. Jahrb. Syst. 21: 454. 1896.

$=$ Chresta speciosa Gardner [subtribe Chrestinae]

33. Eremanthus imbricatus G. M. Barroso, Rodriguésia 23-24: 6. 1962.

= Chresta exsucca DC. [subtribe Chrestinae]

34. Eremanthus jelskii Hieron., Bot. Jahrb. Syst. 36: 462. 1905.

= Cuatrecasanthus jelskii (Hieron.) H. Rob. [subtribe Piptocarphinae]

35. Eremanthus labordeii Glaz., Bull. Soc. Bot. (Mém. 3d) 56: 380 (1909), nom. nud. 
= Chresta exsucca DC. [subtribe Chrestinae]

36. Eremanthus martii (DC.) Baker in Mart. \& Eichler, Fl. bras. 6(2): 167. 1873.

$=$ Argyrovernonia martii (DC.) MacLeish [subtribe Chrestinae]

37. Eremanthus pinnatifidus Philipson, Kew Bull. Misc. Inform. 7: 299. 1938.

= Chresta pinnatifida (Philipson) H. Rob. [subtribe Chrestinae]

38. Eremanthus plantaginifolius (Less.) Baker in Mart. \& Eichler, Fl. bras. 6(2): 168. 1873.

$=$ Chresta plantaginifolia (Less.) Gardner [subtribe Chrestinae]

39. Eremanthus pycnocephalus (DC.) Baker in Mart. \& Eichler, Fl. bras. 6(2): 166. 1873.

= Chresta pycnocephala DC. [subtribe Chrestinae]

40. Eremanthus rivularis Taub., Bot. Jahrb. Syst. 21: 453. 1896.

$=$ Chresta angustifolia Gardner [subtribe Chrestinae]

41. Eremanthus scapigerus (Less.) Baker in Mart. \& Eichler, Fl. bras. 6(2): 168. 1873.

= Chresta scapigera (Less.) Gardner [subtribe Chrestinae]

42. Eremanthus speciosus (Gardner) Baker in Mart. \& Eichler, Fl. bras. 6(2): 169. 1873.

$=$ Chresta speciosa Gardner [subtribe Chrestinae]

43. Lychnophora itatiaiae Wawra, Itin. Princ. S. Coburgi 2: 17. 1888.

$=$ Chionolaena latifolia (Benth.) Baker [tribe Gnaphalieae]

44. Lychnophora van-isschoti Heckel, Rev. Cult. Colon. 11: 161. 1902, nom. nud.

= Chuquiraga jussieui J. F. Gmel. [tribe Barnadesieae]

45. Piptolepis Benth., Pl. Hartw. 29. 1840 nom. rej. (vs. Piptolepis Sch. Bip.)

$=$ Forestiera Poir. [Oleaceae]

46. Piptolepis foliosa (Gardner) Sch. Bip., Jahresber. Pollichia 20-21: 382. 1863.

= Lessingianthus linearifolius (Less.) H. Rob. [subtribe Lepidaploinae]

47. Piptolepis phillyreoides Benth., P1. Hartw. 29. 1840

$=$ Forestiera phillyreoides (Benth.) Torr. [Oleaceae]

48. Vanillosmopsis weberbaueri Hieron., Bot. Jahrb. Syst. 40: 352. 1908, non V. weberbaueri Hieron., Bot. Jahrb. Syst. 40: 354. 1908.

= Critoniopsis weberbaueri (Hieron.) H. Rob. [subtribe Piptocarphinae] 
Alencastro, F. M. M. R. DE. 1970. Contribuição ao estudo da nervação foliar das Compositae dos cerrados. II. Tribo Vernonieae. Rodriguesia 29: 13-45.

Baker, J. G. 1873. Compositae I. Vernoniaceae. Pages 5-180 in C. F. P. von Martius $\dagger$ And A. W. EICHLER, EDS, Flora brasiliensis, 6(2), Fried. Fleischer, Münich, Vienna, Leipzig.

—. 1882. On Gorceixia, a new genus of Vernoniaceae. J. Bot. 20: 225-227, tab. 232.

Barroso, G. M. 1969. Novitates Compositarum, II. Loefgrenia 36: 1-3, pl. 1-6.

Bean, A. R. 2004. A new combination in Centratherum Cass. (Asteraceae). Austrobaileya 6: 977-978.

Bean, A. R. 2009. The identity of Centaurea riparia DC. (Asteraceae). Austrobaileya 8: 97.

BELL, A. D. 2008. Plant form, an illustrated guide to flowering plant morphology. 2nd edition. Timber Press, Portland, OR.

Bentham, G. 1873. Compositae. Pages 163-533 in G. Bentham and J. D. Hooker, eds, Genera plantarum, Vol. 2, Part 1. Reeve \& Co., London and Williams and Norgate, London.

Bremer, K. 1994. Asteraceae. Cladistics \& classification. Timber Press, Portland, OR.

Candolle, A. P. DE. 1810. Observations sur les plantes composées, ou syngenèses. Second mémoire. Monographies de quelques genres de Cinarocéphales. Ann. Mus. Hist. Nat. 16: 181-208, pl. 6-15.

—. 1819. Théorie élémentaire de la botanique, second edition. Paris: Déterville.

—. 1836. Vernoniaceae. Pages 9-103 in A. P. De CAndolle, ed, Prodromus Systematis Naturalis Regni Vegetabilis, ... v. 5, Treutel et Würtz, Paris. Masson, Paris.

Cassini, H. 1817. Centratherum. Pages 383-384 in F. Cuvier, ED, Dictionnaire des Sciences Naturelles dans lequel on traite méthodiquement des différents êtres de la Nature, 2nd edition, 7, Levrault, Strasbourg. Le Normant, Paris.

Cassini, H. 1819. Suite du sixième mémoire sur la famille des Synanthérées, contenant les caractères des tribus. J. Phys. Chim. Hist. Nat. Arts 88: 189-204.

Cassini, H. 1828. Vernoniées. Pages 338-347 in F. Cuvier, ED, Dictionnaire des Sciences Naturelles dans lequel on traite méthodiquement des différents êtres de la Nature, 2nd edition, 57, Levrault, Strasbourg. Le Normant, Paris.

CAstro, V. 1989. Centratherin and related sesquiterpene lactones from Oliganthes discolor. Rev. Latinoamer. Quím. 20: 85-86.

Chen, S.-H., M.-J. Wu, And S.-M. Li. 1999. Centratherum punctatum Cass. ssp. fruticosum, a newly naturalized sunflower species in Taiwan. Taiwania 44: 299-305.

Colle, N. C., And S. B. Jones JR. 1981. Lychnophora (Compositae: Vernonieae), a genus endemic to the Brazilian Planalto. Brittonia 33: 528-542.

—

Cuatrecasas, J. 1934. Observaciones geobotánicas en Colombia. Trab. Mus. Nac. Ci. Nat., Ser. Bot. 27: 1-144. 
— , and H. Robinson. In press. Monography of the subtribe Espeletiinae. New York Botanical Garden, Smithsonian Institution, New York.

Dematteis, M. 1998. Chromosome studies of some Vernonia species (Asteraceae). Genet. Mol. Biol. 21: 381-385.

- 2007. Vinicia tomentosa, nuevo género y especie de Lychnophorinae (Vernonieae, Asteraceae) de Minas Gerais, Brasil. Bonplandia 16: 259-264.

Ellis, B., D. C. Dally, L. J. Hickey, K. K. Johnson, J. D. Mitchell, P. Wilf, and S. L. Wing. 2009. Manual of leaf architecture. Cornell University Press, Ithaca, NY.

EnDRESS, P. K. 2010. Disentangling confusions in inflorescence morphology: patterns and diversity of reproductive shoot ramification in angiosperms. J. Syst. Evol. 48: 225-239.

Evert, R. F. 2006. Esau's Plant anatomy: meristems, cells, and tissues of the plant body: their structure, function, and development. John Wiley \& Sons, Inc., Hoboken, New Jersey.

GARDNER, G. 1846. Contributions towards a Flora of Brazil, being the distinctive characters of some new species of Compositae, belonging to the tribe Vernoniaceae. London J. Bot. 5: 209-242.

Giulietti, A. M. and J. R. Pirani. 1988. Patterns of geographic distribution of some species from the Espinhaço Range, Minas Gerais and Bahia, Brazil. Pages 39-69 in: P. E. Vanzolini, And W. R. Heyer, eds, Proceedings of a workshop on Neotropical distribution patterns. Academia Brasileira de Ciências, Rio de Janeiro.

Giulietti, A. M., J. R. Pirani, and R. M. Harley. 1997. Espinhaço Range Region. Pages 397-404 in S. D. Davis, V. H. Heywood, O. Herrera-MacBride, J. Villa-Lobos, and A. C. Hamilton, eds, Centres of plant diversity, vol. 3 The Americas. WWF-IUCN, Washington,.

Givnish, T.J., R. W. McDiarmid, And W. R. Buck. 1986. Fire adaptation in Neblinaria celiae (Theaceae), a high-elevation rosette shrub endemic to a wet equatorial tepui. Oecologia 70 : $481-485$.

Glaziou, A. F. M. 1909. Plantae Brasiliae centralis a Glaziou lectae. Liste des plantes du Brésil central recueillies en 1861-1895. Bull. Soc. Bot. France 56, Mémoire 3e: 297-392.

Hallé, F., R. A. A. Oldeman, and P. B. Tomlinson. 1978. Tropical trees and forests: an architectural analysis. Springer-Verlag, Berlin, Heidelberg, New York.

Handro, W., J. F. B. M. CAmpos, And Z. M. Oliveira. 1970. Sobre a anatomia foliar de algumas Compostas dos campos rupestres. Ci. \& Cult. 22: 107-126.

HARRIS, E. M. 1995. Inflorescence and floral ontogeny in Asteraceae: a synthesis of historical and current concepts. Bot. Rev. 61: 93-278.

. 1999. Capitula in the Asteridae: a widespread and varied phenomenon. Bot. Rev. 65: $348-369$.

Hickey, L. J. 1979 [1980]. A revised classification of the architecture of dicotyledonous leaves. Pages 25-39 in C. R. Metcalfe and L. Chalk, eds, Anatomy od Dicotyledons, 2nd edition, Vol. 1. Clarendon Press, Oxford.

Hind, D. J. N. 1995. Compositae. Pages 175-278 in B. L. Stannard, ed, Flora of the Pico das 
Almas-Chapada Diamantina, Bahia, Brazil. Royal Botanic Gardens, Kew.

—. 2000a. Two new species of Paralychnophora (Compositae: Vernonieae) from Bahia. Kew Bull. 55: 367-379.

—. 2000b. A new species of Lychnophora (Compositae: Vernonieae: Lychnophorinae) from Bahia, Brazil. Kew Bull. 55: 393-397.

— 2003. Flora of Grão-Mogol, Minas Gerais: Compositae (Asteraceae). Bol. Bot. Univ. São Paulo 21: 179-234.

- 2009. Glossary in An annoted preliminary checklist of the Compositae of Bolivia.

Published on the internet http://www.kew.org/science/tropamerica/boliviacompositae/ index.html [accessed April 2011].

—, A. M. Giulietti, And R. M. Harley. 2006. Gorceixia decurrens (Compositae: Vernonieae): new for Bahia State, Brazil. Sitientibus Sér. Ci. Biol. 6: 129-132.

Hoffmann, O. 1890. Compositae, Tubuliflorae-Vernonieae. Pages. 120-131 in A. Engler And K. Prantl, eds, Die natürlichen Pflanzenfamilien, 4(5), Wilhelm Engelmann, Leipzig.

Jesus, F. F., V. N. Solferini, J. Semir, and P. I. Prado. 2001. Local genetic differentiation in Proteopsis argentea (Asteraceae), a perennial herb endemic in Brazil. Pl. Sys. Evol. 226: 59-68.

Keeley, S. C. and H. Robinson. 2009. Vernonieae. Pages 439-469 in V. A. Funk, A. Susanna, T. F. StUESSY AND R. J. BAYER, EDS, Systematics, evolution and biogeography of Compositae. IAPT, Wien.

Keles, L. C., N. I. de Melo, G. de Paula Aguiar, K. A. L. Wakabayashi, C. E. de Carvalho, W. R. Cunha, A. E. M. Crotti, J. L. Callegari Lopes, and N. P. Lopes. 2010. Lychnophorinae (Asteraceae): a survey of its chemical constituents and biological activities. Química Nova 33: $2245-2260$.

Kirkman, L. K. 1981. Taxonomic revision of Centratherum and Phyllocephalum (Compositae: Vernonieae). Rhodora 83: 1-24.

LESsING, C. F. 1829. De synanthereis herbarii regii berolinensis dissertatio prima. Vernonieae. Linnaea 4: 240-356.

—. 1831. De synthereis dissertatio quarta. Linnaea 6: 624-721.

- 1832. Synopsis generum Compositarum, earumque dispositionis novae tentamen monographus multarum capensium interjectis. Duncker \& Humblot, Berlin.

Luque, R., AND N. L. DE Menezes. 2003. Estructura primaria del tallo de Lychnophora Mart. (Vernonieae: Asteraceae). Plantula 3: 117-128.

Lützelburg, Ph. von. 1922. Estudo botânico do Nordeste. Insp. Obras contra as Secas, Vol. 3 (Publicação 57-série 1. A). Rio de Janeiro.

MacLeish, N. F. F. 1984a. Revision of Eremanthus Less. (Compositae: Vernonieae). PhD thesis, unpublished. University of Georgia.

—. 1984b. Eight new combinations in Vernonia (Compositae: Vernonieae). Syst. Bot. 9: 133136. 
- 1987. Revision of Eremanthus (Compositae: Vernonieae). Ann. Missouri Bot. Gard. 74: $265-290$.

— from Brazil. Syst. Bot. 9: 85-95.

Mansanares M. E., E. R. Forni-Martins, and J. Semir. 2001. IOBP Chromosome Data Lychnophora Mart. (Asteraceae). Newsl. IOPB, 33: 23-24.

$\longrightarrow$ - - AND —. 2002. Chromosome numbers in the genus Lychnophora Mart. (Lychnophorinae, Vernonieae, Asteraceae). Caryologia 55: 367-374.

— — - AND — 2007a. Cytotaxonomy of Lychnophora Mart. (Asteraceae: Vernonieae: Lychnophorinae) species. Caryologia 60: 21-28.

— - _ AND - 2007b. Cytotaxonomy of Lychnophoriopsis Sch.Bip. and Paralychnophora MacLeish species (Asteraceae: Vernonieae: Lychnophorinae). Bot. J. Linn. Soc. 154: 109114.

Martius, C. F. P. von. 1822. Novum plantarum genus Lychnophora. Denkschr. Königl.-Baier. Bot. Ges. Regensburg 2: 148-159, tab. 4-10.

1837. Herbarium Florae Brasiliensis. Flora 20: 1-128.

Mattfeld, J. 1923. (Compositae) in R. Pilger, ed., Plantas Lützelburgianae brasilienses I. Notizbl. Bot. Gart. Berlin-Dahlem 8: 428-451.

McNeill, J., F. R. Barrie, H. M. Burdet, V. Demoulin, D. L. Hawksworth, K. Marhold, D. H. Nicolson, J. Prado, P. C. Silva, J. E. Skog, J. H. Wiersema, and N. J. Turland (EDS.). 2006. International code of botanical nomenclature (Vienna Code): Adopted by the Seventeenth International Botanical Congress Vienna, Austria, July 2005. Regnum Vegetabile 146. Ruggell: Gantner.

Merrill, E. D. 1954. The botany of Cook's Voyages. Chron. Bot. 14: 161-384.

Nelson, G., AND P. Y. Ladiges. 2009. Biogeography and the molecular dating game: a futile revival of phenetics? Bull. Soc. géol. Fr. 180: 39-43.

Oliver, D. 1894. Sipolisia lanuginosa. P1. 2281 in J. D. Hooker, ED., Hooker's Icones Plantarum, ser. 4, 3 (v. 23), London.

PAYNe, W. W. 1978. A glossary of plant hair terminology. Brittonia 30: 239-255.

Peçanha, A. F., R. L. Esteves, and V. Gonçalves-Esteves. 2008. Palinotaxonomia de Albertinia brasiliensis Spreng, Eremanthus bicolor (DC.) Backer e Vanillosmopsis erythropappa (DC.) Sch. Bip. (Compositae-Vernonieae). Acta Bot. Bras. 22: 313-321.

Persoon, C. H. 1807. Synopsis plantarum: seu enchiridium botanicum complectens enumerationem systematicam specierum hucusque cognitarum... Vol. 2, Part 2. Parisiis Lutetiorum [Paris] (apud C. F. Cramerum.) et Tubingae (apud J. G. Cottam).

Philipson, W. R. 1938. Four new species of Vernonieae collected by Glaziou in Brazil. Bull. Misc. Inform. Kew 7: 298-300.

Picman, A. K. 1986. Biological activities of sesquiterpene lactones. Biochem. Syst. Ecol. 14: $255-281$. 
Ramella, L., P. Perret, M. Dematteis, S. E. Freire, and M. Soloaga. 2009. Tipificaciones y sinónimos nuevos en Senecioneae y Vernonieae (Compositae) de la flora del Paraguay. Candollea 64: 143-148.

Robinson, H. 1980a. Notes on the Lychnophorine genera Chresta and Eremanthus (Vernonieae: Asteraceae). Phytologia 45: 89-100.

- 1980b. New species of Vernonieae (Asteraceae). VI. Lychnophora souzae. Phytologia 46: 104-106.

- 1981. Episcothamnus and Bishopalea, two genera of Vernonieae (Asteraceae) from Brasil, and the resurrection of Sipolisia. Phytologia 48: 209-217.

—. 1990. Studies in the Lepidaploa complex (Vernonieae: Asteraceae) VII. The genus Lepidaploa. Proc. Biol. Soc. Washington 103: 464-498.

- 1992. Notes on Lychnophorinae from Minas Gerais, Brazil, a synopsis of Lychnophoriopsis Schultz-Bip., and the new genera Anteremanthus and Minasia (Vernonieae: Asteraceae). Proc. Biol. Soc. Washington 105: 640-652.

- 1997. The Paralychnophora group of Eremanthus (Vernonieae: Asteraceae). Rhodora 98: 85-93.

- 1999. Generic and subtribal classification of American Vernonieae. Smithsonian Contr. Bot. 89: 1-116.

— 2007 [2006]. Vernonieae. Pages 149-174 in J. Kadereit and C. JefFrey, vol. eds., Vol. 8: Asterales, K. Kubitzki, SERIES ED., The families and genera of vascular plants. Springer. Berlin, Heidelberg, New York.

—, F. Bohlmann, and R. M. King. 1980. Chemosystematic notes on the Asteraceae. III. Natural subdivisions of the Vernonieae. Phytologia 46: 421-436.

Roemer, J. J. 1796. Scriptores de plantis hispanicis, lusitanicis, brasiliensibus, adornavit et recudi curavit I.I. Römer M. D.... Norimbergae [Nürnberg], in Officina Raspeana.

Salles-de-Melo, M. R. C., R. M. de Lucena, J Semir, R de Carvalho, R. de C. Araújo Pereira, And A. M. Benko-Iseppon. 2010. Karyological features and cytotaxonomy of the tribe Vernonieae. Plant. Syst. Evol. 285: 189-199.

Schultz-Bipontinus, C. H. 1861. Cassiniaceae uniflorae, oder Verzeichniss der Cassiniaceen mit 1-blüthigen Köpfchen. Jahresber. Pollichia 18/19: 157-190.

—. 1863 [1864]. Lychnophora Martius! und einige benachbarte Gattungen. Jahresber. Pollichia 20/21: 321-439.

— 1864. Prestelia C. H. Schultz-Bipontinus. Hor. Vernoniacearum genus. Festschrift zum 50.-jährigen Jubiläum der Naturforschenden Gesellschaft zu Emden von 181473.

SEmir, J. 1991. Revisão taxonômica de Lychnophora Mart. (Vernonieae: Compositae). PhD thesis, unpublished. Universidade Estadual de Campinas, São Paulo.

Simon, M. F., R. Grether, L. P. Queiroz, C. Skema, R. T. Pennington, and C. E. Hughes. 2009. Recent assembly of the Cerrado, a neotropical plant diversity hotspot, by in situ evolution of adaptations to fire. Proc. Natl. Acad. Sci. 106: 20359-20364. 
Small, J. 1919. The origin and development of the Compositae. New Phytol. 18 (Reprint 11): $1-334+$ plates $1-6$.

Smith, A. P., And T. P. Young. 1987. Tropical Alpine plant ecology. Ann. Rev. Ecol. Syst. 18: $137-158$.

Sprengel, K. 1821. Neue entdeckungen im ganzen umfang der pflanzenkunde, Vol. 2. F. Fleischer, Leipzig

Sousa, O. V., M. C. Silvério, G. Del-Vechio-Vieira, F. C. Matheus, C. H. Yamamoto, and M. S. Alves. 2008. Antinociceptive and anti-inflammatory effects of the essential oil from Eremanthus erythropappus leaves. Journal of Pharmacy and Pharmacology 60: 771-777.

Starr, F., K. Starr, and L. L. Loope. 2010. New plant records from the Hawaiian archipelago. Bishop Mus. Occas. Pap. 107: 61-68.

Strother, J. L. 2006. Vernonieae. Pages 200-213 in Flora of North America Editorial CommiteE, ed, Flora of North America, Magnoliophyta: Asteridae (in part): Asteraceae, Vol 19, Part 1. Oxford University Press Inc., New York.

Theobald, W. L., J. L. Krahulik, and R. C. Rollins. 1979 [1980]. Trichome description and classification. Pages 40-53 in C. R. Metcalfe And L. Chalk, Eds, Anatomy of the dicotyledons, 2nd edition, Vol. 1. Clarendon Press, Oxford.

THIERs, B. (continuously updated). Index Herbariorum: a global directory of public herbaria and associated staff. New York Botanical Garden's Virtual Herbarium. http://sweetgum.nybg. org/ih [accessed April 2011].

Turner, B. L., J. Bacon, L. Urbatsch, and B. Simpson. 1979. Chromosome numbers in South American Compositae. Am. J. Bot. 66: 173-178.

Urban, I. 1906. Vitae itineraque collectorum botanicorum. Pages 1-154 in C. F. P. von Martius, Flora Brasiliensis Volume 1, Pars 1. R. Oldenbourg, Munich and Leipzig.

Vellozo, J. M. C. 1827 [1831]. Florae Fluminensis Icones Vol. 8. Ex off. lithogr. Senefelder. Parisiis [Paris].

Wagner, G. J., E. WAng, And R. W. ShePherd. 2004. New approaches for studying and exploiting an old protuberance, the plant trichome. Ann. Bot. 93: 3-11.

Watanabe, K., T. Yahara, G. Hashimoto, Y. Nagatani, A. Soejima, T. Kawahara, and M. NaKazawa. 2007. Chromosome numbers and karyotypes in Asteraceae. Ann. Missouri Bot. Gard. 94: 643-654.

Zaragüeta-Bagils, R., H. Lelièvre, and P. Tassy. 2004. Temporal paralogy, cladograms, and the quality of the fossil record. Geodiversitas 26: 381-389. 
TABLE 1. Taxonomic history of the subtribe Lychnophorinae (Asteraceae: Vernonieae). The X's inidicate genera included in the subtribe. Genus in boldface is described herein as new. ${ }^{1}$ No changes in the delimitation of the subtribe or generic concepts were proposed in the subsequent publications by Robinson (Robinson 2007; Keeley and Robinson, 2009). 


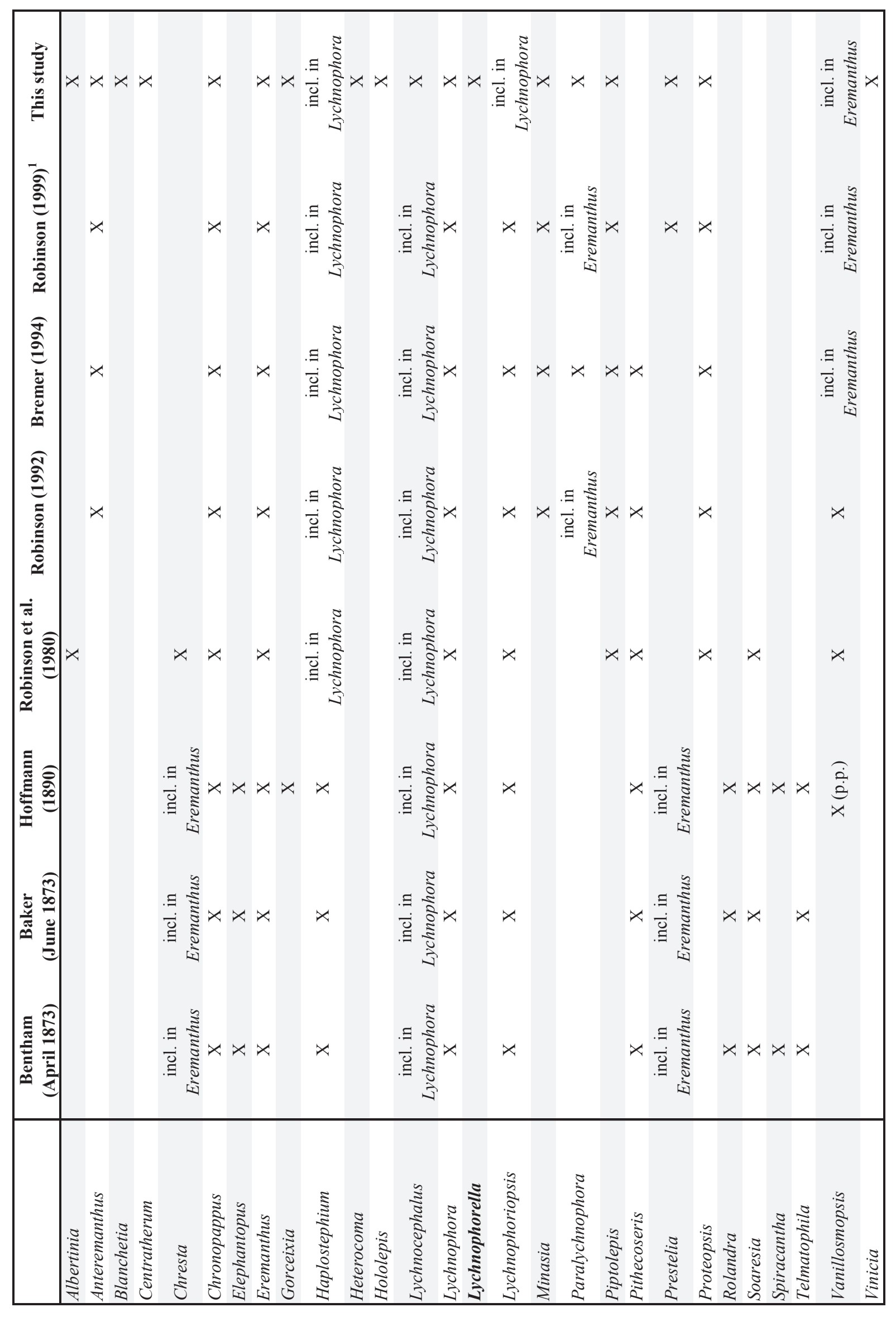




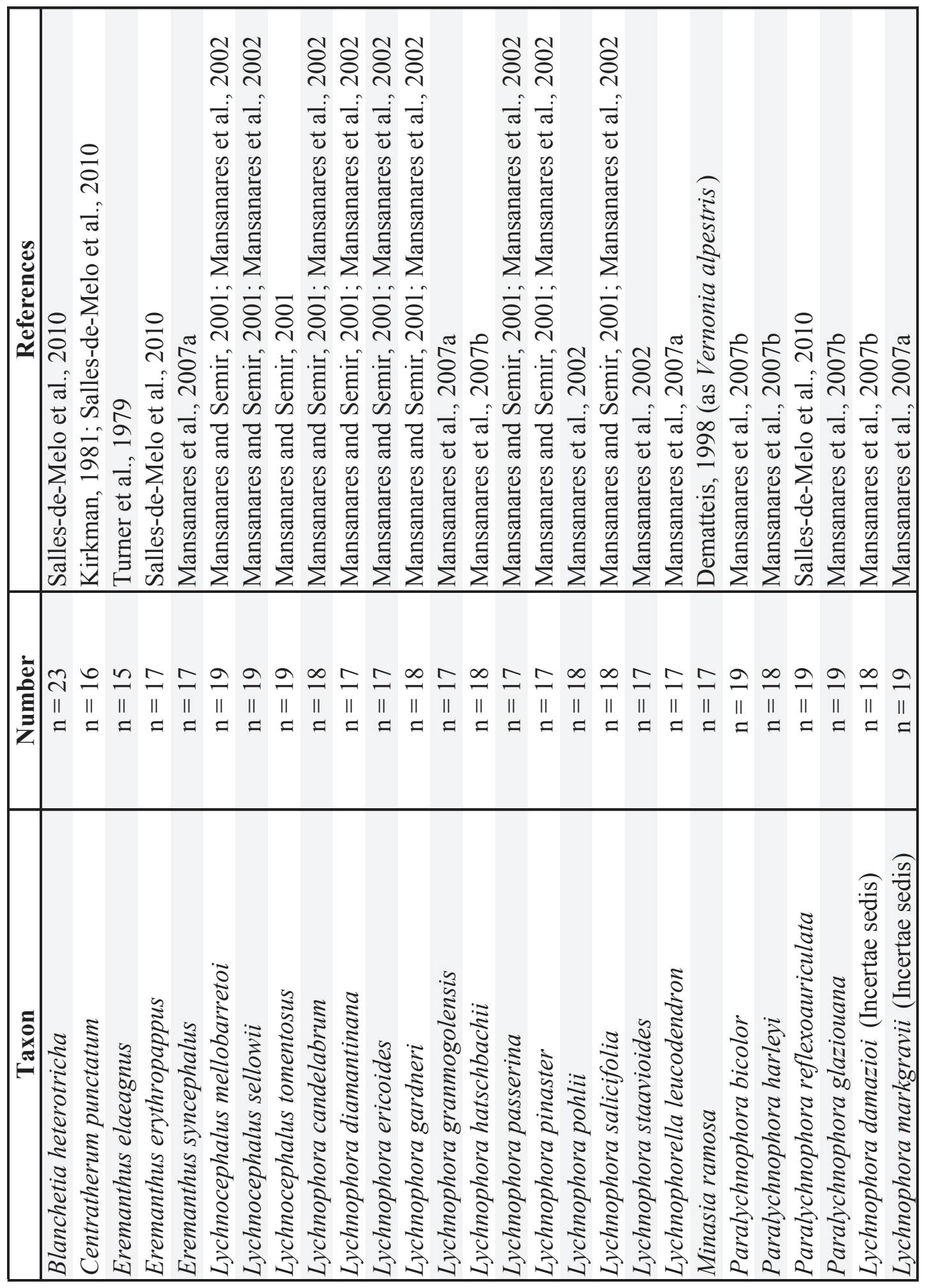

TABLE 2. Chromosome numbers in Lychnophorinae. 
FIgURE 1. Morphological diversity in Lychnophorinae. A, Albertinia brasiliensis Spreng.; B, Hololepis pedunculata (DC. ex Pers.) DC.; C, Lychnocephalus mellobarretoi (G.M. Barroso) Loeuille, Semir \& Pirani; D, Anteremanthus hatschbachii H. Rob.; E, Chronopappus bifrons (DC. ex Pers.) DC.; F, Heterocoma albida (DC. ex Pers.) DC.; G, Lychnophorella regis (H. Rob.) Loeuille, Semir \& Pirani; H, Lychnophora ericoides Mart.; I, Eremanthus elaeagnus (Mart. ex DC.) Sch. Bip. Photographs: A, A. Popovkin; B, C, D, E, H, I, B. Loeuille; F, C. Siniscalchi; G, S. C. Ferreira. 

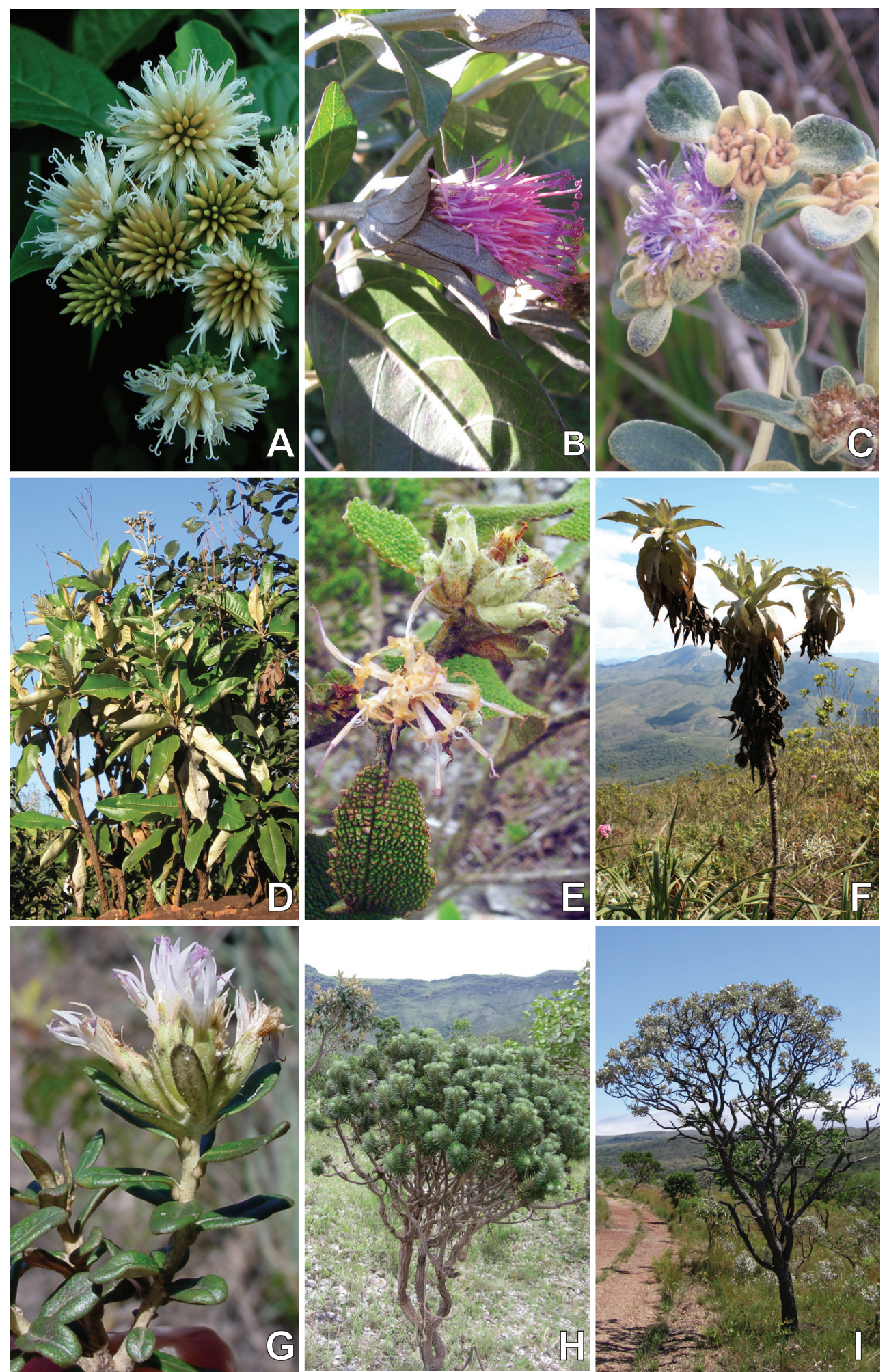


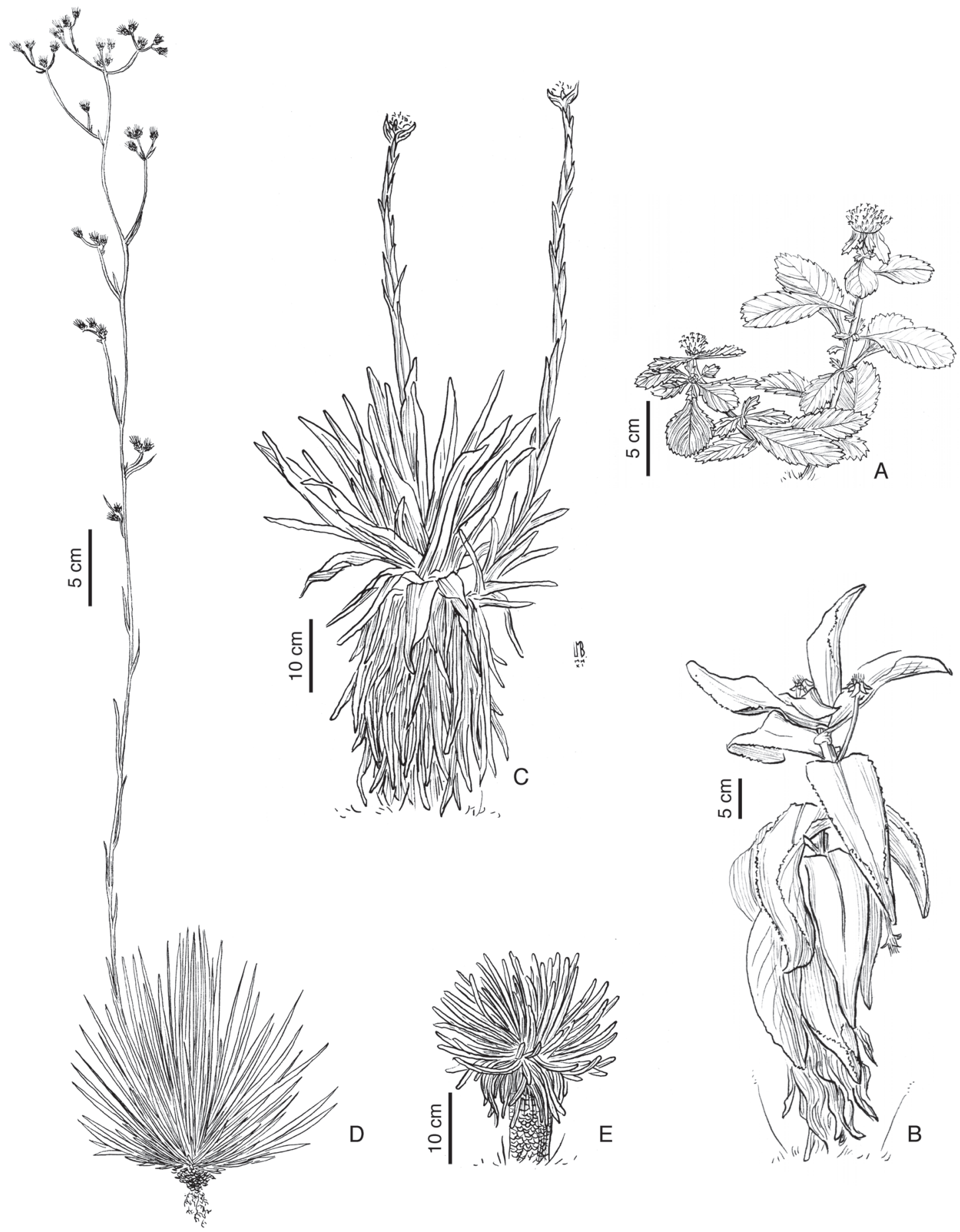

Figure 2. Diversity of life-forms in Lychnophorinae I. A, Herb, Centratherum punctatum Cass.; B, Heterocomoid habit (sensu Semir (1991)), Heterocoma robinsoniana Loeuille, J. N. Nakaj. \& Semir; C-E, Caulirosulas, C, Proteopsis argentea Mart. \& Zucc. ex Sch. Bip., D, Minasia ramosa Loeuille, Robinson \& Semir, E, Prestelia eriopus Sch. Bip. 

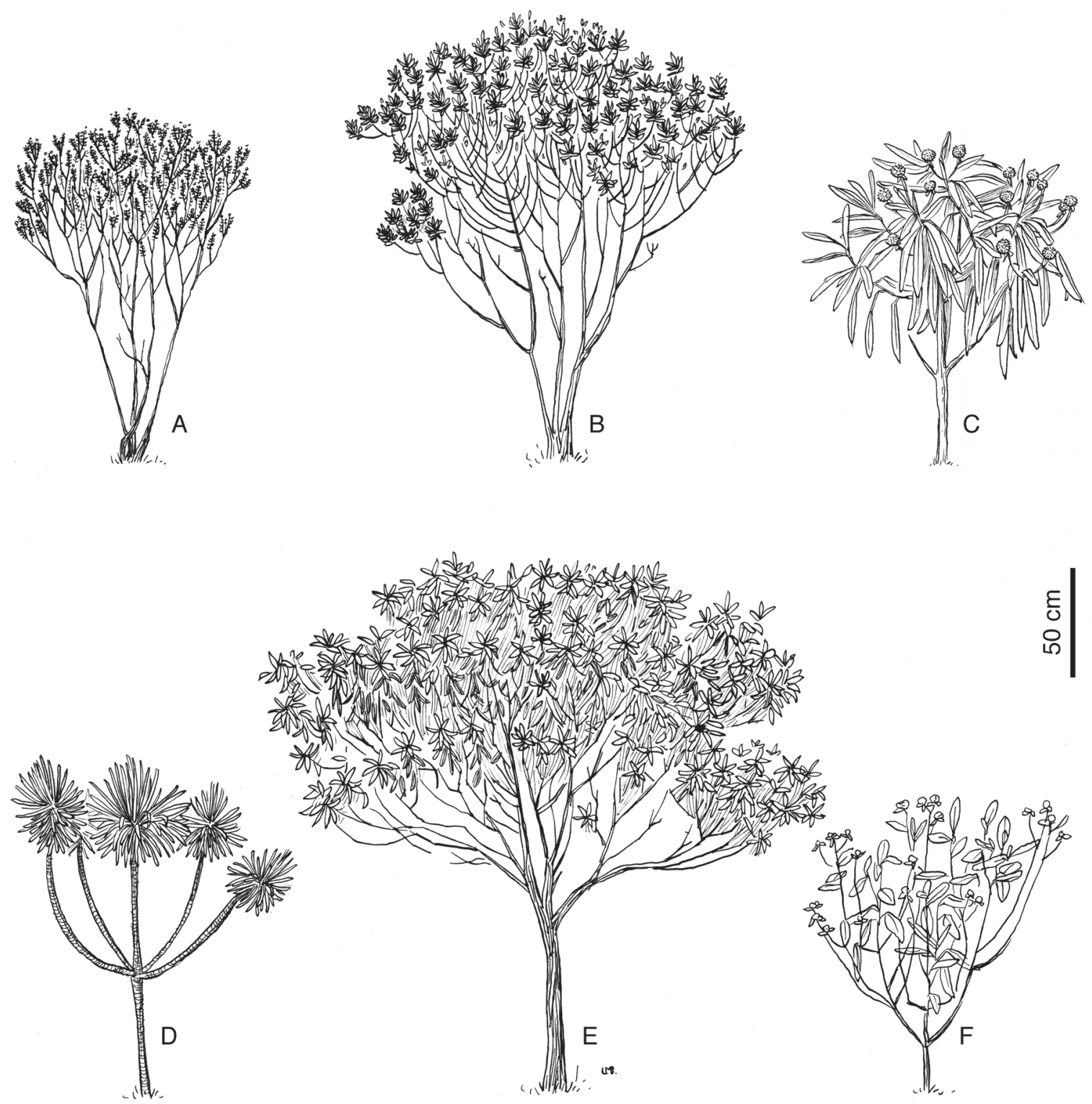

FiguRE 3. Diversity of life-forms in Lychnophorinae II. A-B, Shrubs, A, Lychnophorella triflora (Mattf.) Loeuille, Semir \& Pirani, B, Piptolepis monticola Loeuille; C-F, Treelets to trees, C, Paralychnophora bicolor (DC.) MacLeish, D, Lychnophora salicifolia Mart., E, Eremanthus erythropappus (DC.) MacLeish, F, Lychnocephalus mellobarretoi (G. M. Barroso) Loeuille, Semir \& Pirani. 

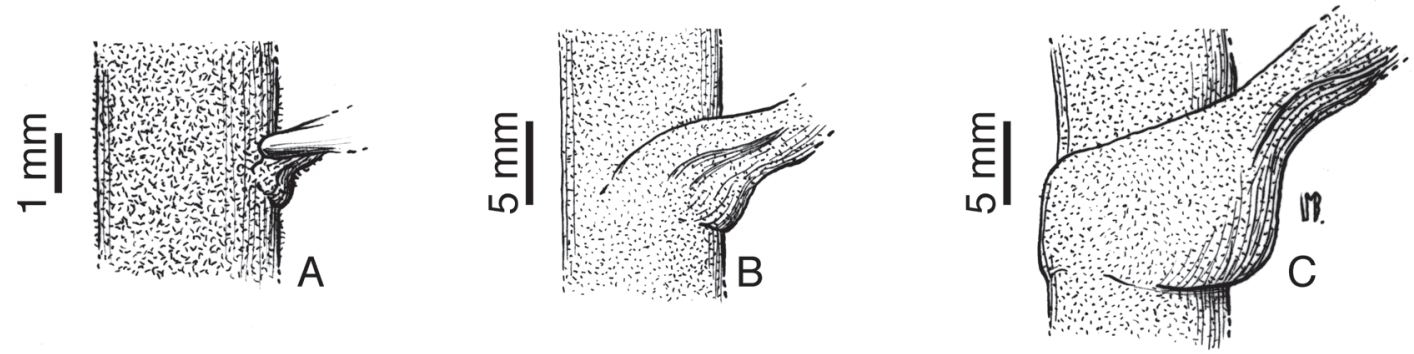

FIgURE 4. Types of leaf sheath in Lychnophorinae. A, pad-like, Lychnophorella regis (H. Rob.) Loeuille, Semir \& Pirani, B, semi-amplexicaul, Paralychnophora bicolor (DC.) MacLeish, C, amplexicaul, Proteopsis hermogenesii sp. ined.

FiguRE 5. Trichomes in Lychnophorinae. A-E, Unbranched, A, regular, Chronopappus bifrons (DC. ex Pers.) DC., B, auriculate, Piptolepis oleaster (Mart. ex DC.) Sch. Bip., C, geminate, Chronopappus bifrons (DC. ex Pers.) DC., D, side-armed, Lychnocephalus jolianus sp. ined., E, curly, Lychnophora markgravii G. M. Barroso; F-I, 2-armed, F, long arms T-shaped, Albertinia brasiliensis Spreng., G, asymmetric T-shaped, Lychnophora markgravii G. M. Barroso, H, swollen T-shaped, Minasia alpestris (Gardner) H. Rob., I, swollen with asymmetric T-shaped, Vinicia tomentosa Dematt., J, inverted Y-shaped, Lychnocephalus humillimus (Sch. Bip.) Loeuille, Semir \& Pirani; K-Q, 3- to 5-armed trichomes, K, regular, Heterocoma lanuginosa (Glaz. ex Oliv.) Loeuille, J. N. Nakaj. \& Semir, L, swollen, Eremanthus elaeagnus (Mart. ex. DC.) Sch. Bip., M, curly, Lychnophora pinaster Mart., N, porrect, Heterocoma gracilis Loeuille, J. N. Nakaj. \& Semir, O, geminate, Heterocoma lanuginosa (Glaz. ex Oliv.) Loeuille, J. N. Nakaj. \& Semir, P, long multicellular stalked, Gorceixia decurrens Baker, $\mathbf{Q}$, long multicellular stalked with side-arm, Gorceixia decurrens Baker; R-W, stellate, R, regular, Heterocoma ekmaniana (Philipson) Loeuille, J. N. Nakaj. \& Semir, S, swollen, Piptolepis oleaster (Mart. ex DC.) Sch. Bip., T, porrect, Heterocoma gracilis Loeuille, J. N. Nakaj. \& Semir, U, geminate, Heterocoma ekmaniana (Philipson) Loeuille, J. N. Nakaj. \& Semir, V, long stalked, Eremanthus crotonoides (DC.) Sch. Bip., W, with forked arms, Blanchetia heterotricha DC. 


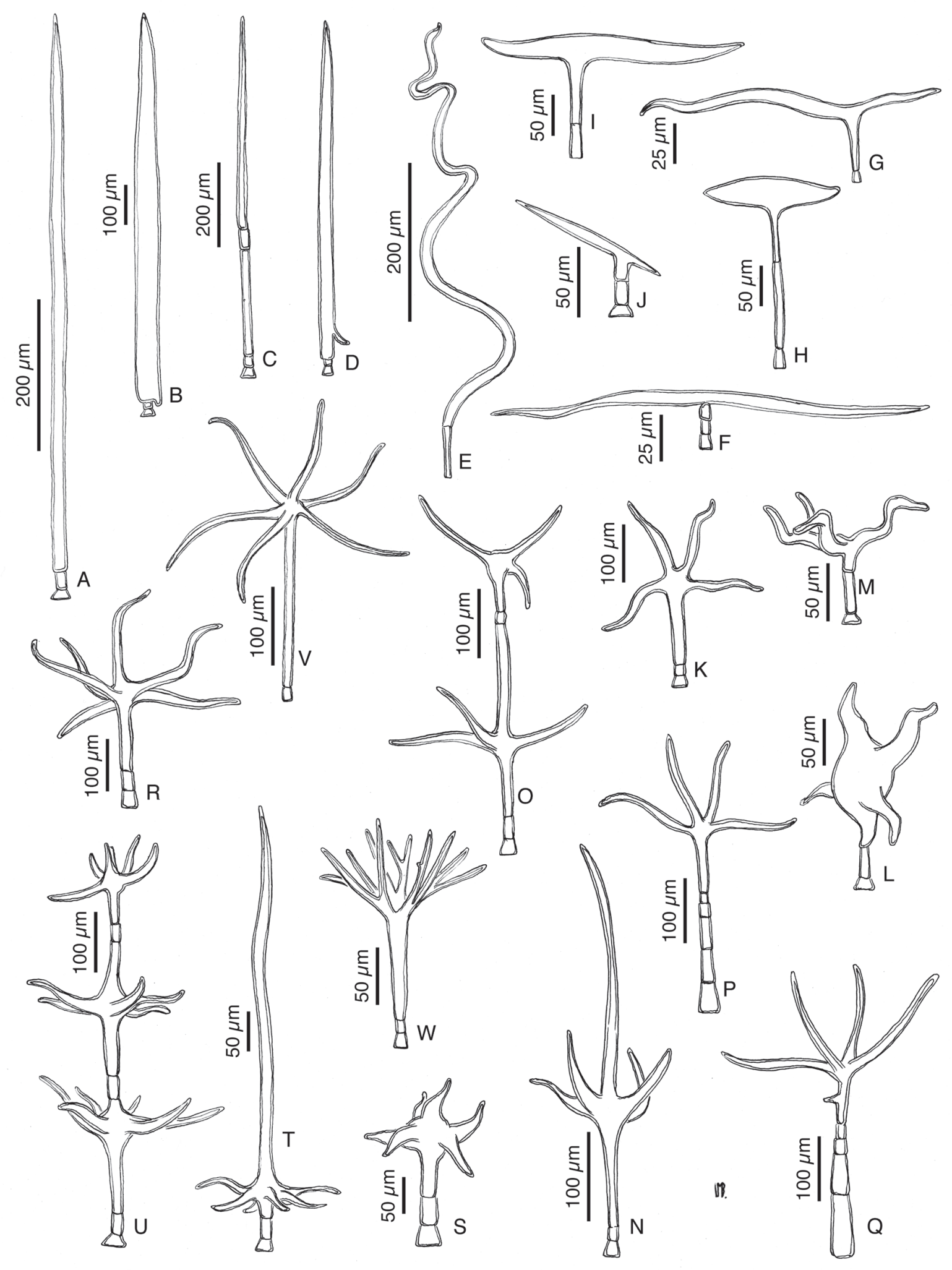




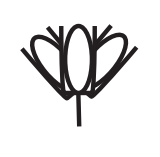

A

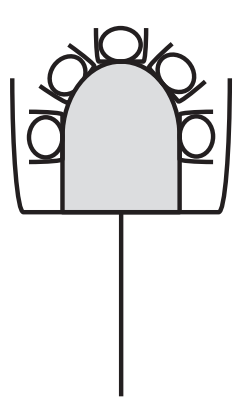

D

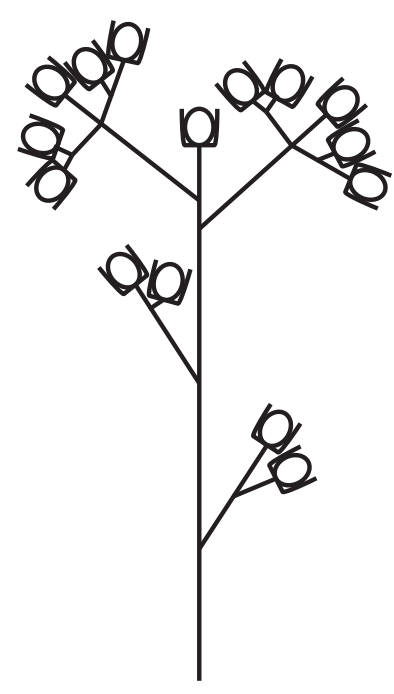

$\mathbf{F}$

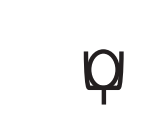

Capitulum

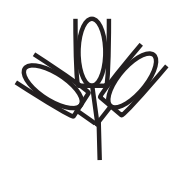

B

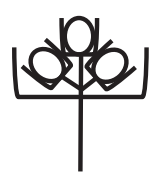

C

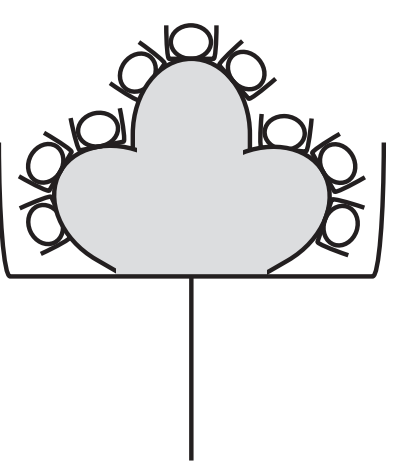

E

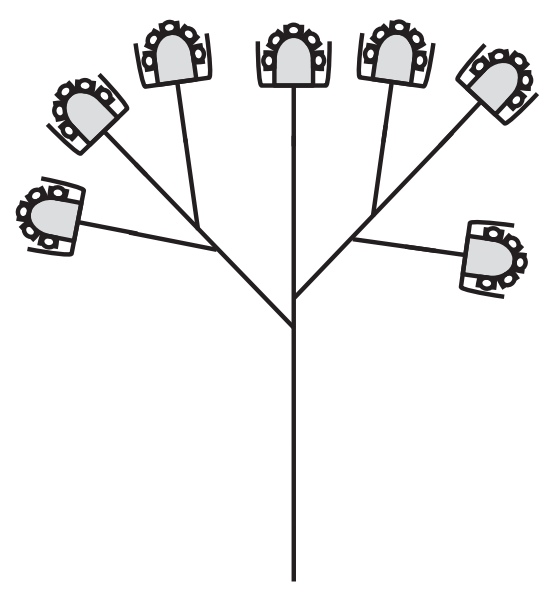

G

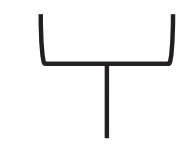

Secondary involucre

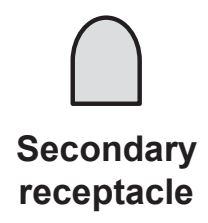

Figure 6. Capitulescences in Lychnophorinae. A, Glomerule; B, Pseudoglomerule; C, Pseudoglomerule with subinvolucral bracts; D, Syncephalium of second-order; E, Syncephalium of third-order; F, Panicle of capitula; G, Cyme of syncephalia (second-order). D, E, modified from Harris (1999). 

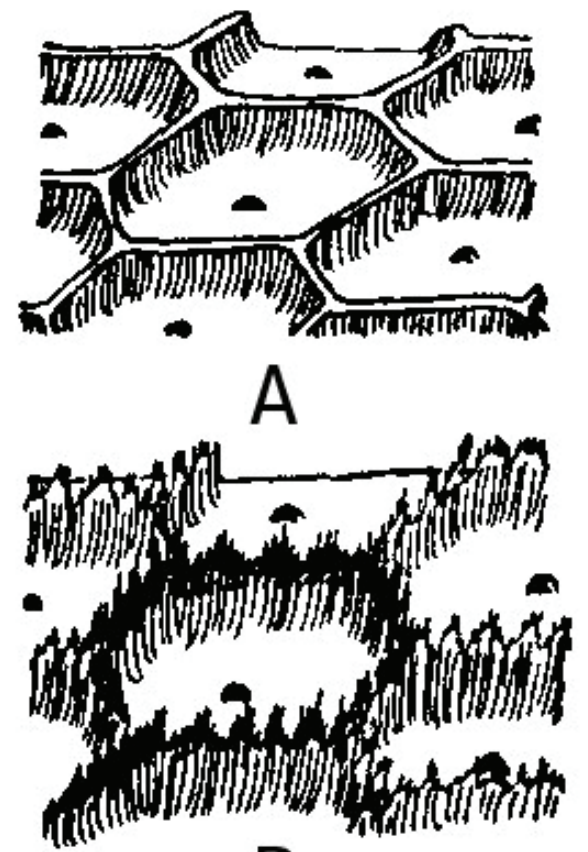

B

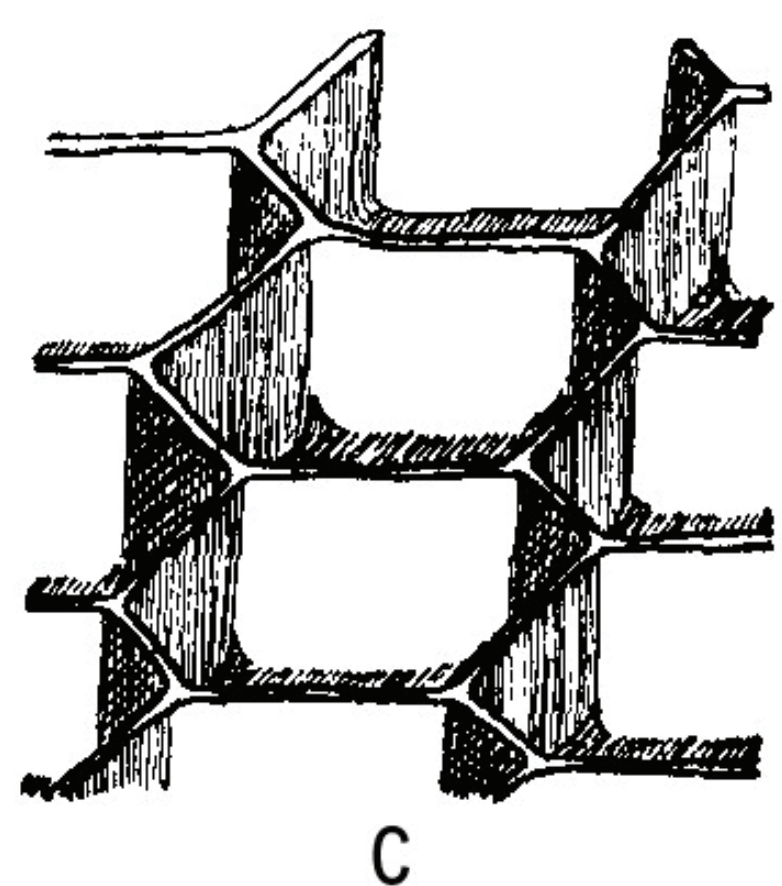

FIGURE 7. Receptacle surface in Lychnophorinae. A, Areolate; B, Fimbrillate; C, Alveolate. Modified from Small (1919). 

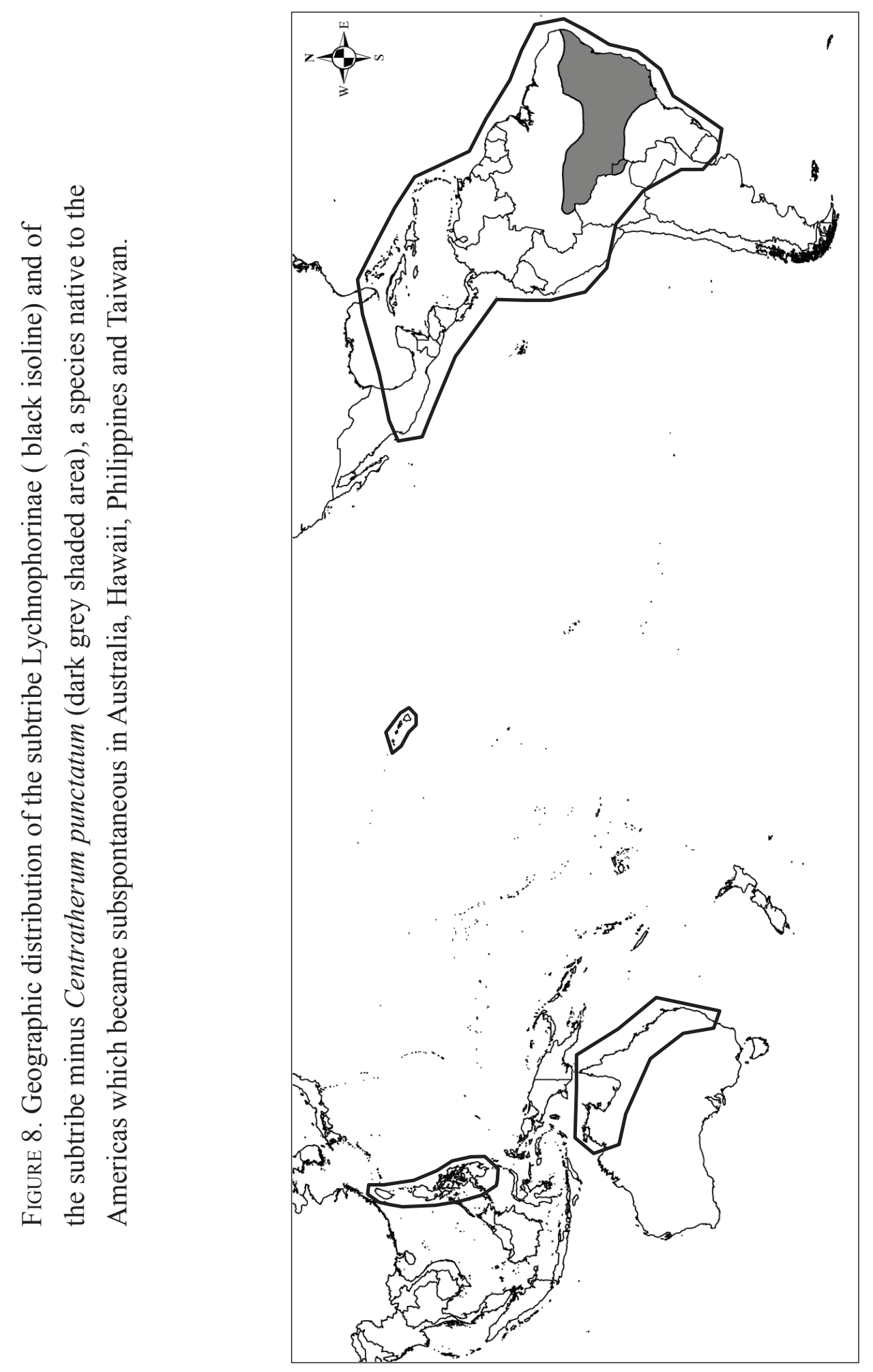


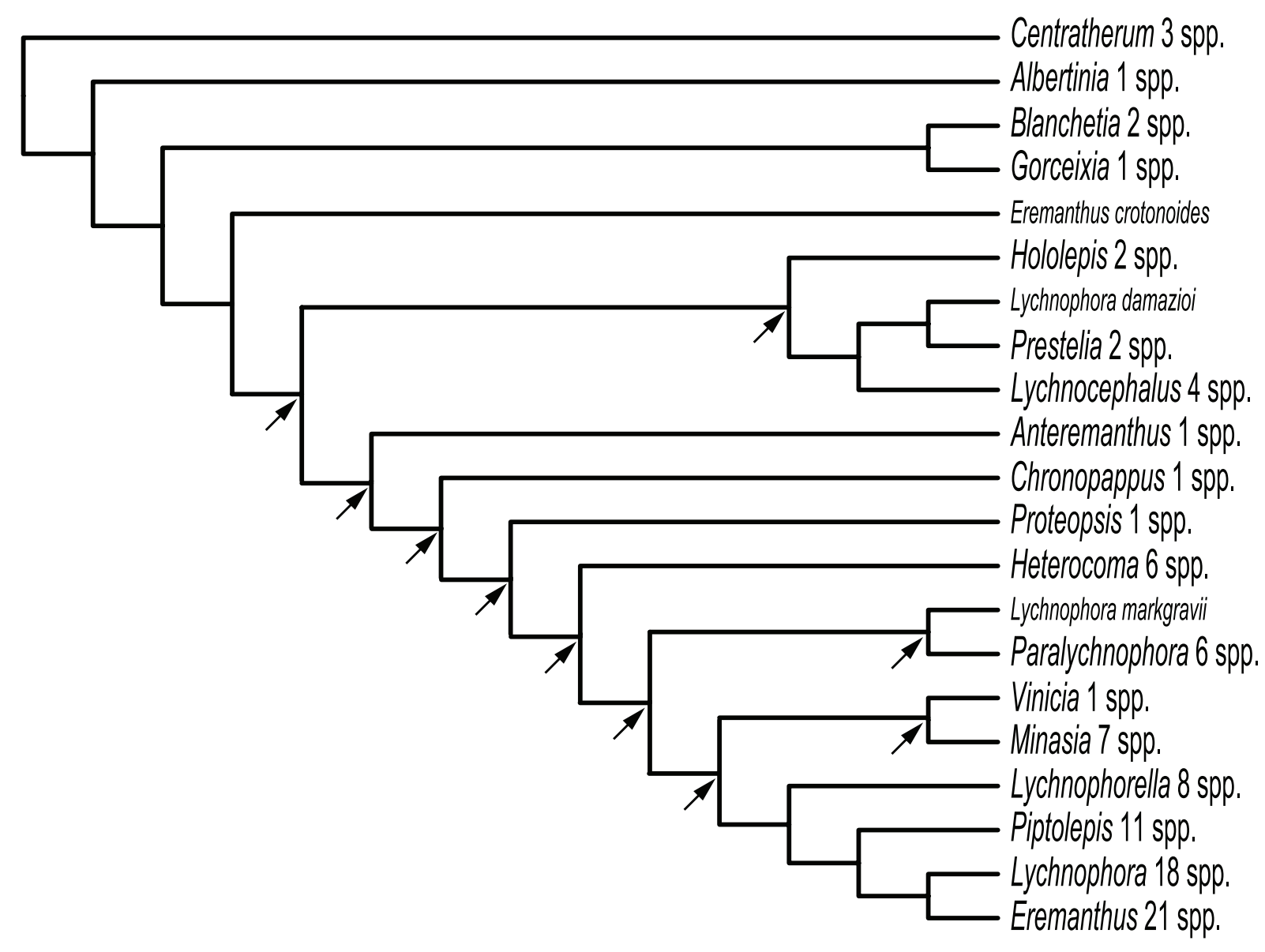

FIGURE 9. Hypothesized phylogenetic relationships within the Lychnophorinae based on molecular and morphological data. Arrow indicates nodes with support $<50 \%$ in the parsimony analyses. (Adapted from Loeuille et al. in press; see Chapters 2 and 3). 

CONCLUSIONS 

Our results of the phylogenetic analyses of American Vernonieae (Chapter 1) show the monophyly of the subtribes Chrestinae, Elephantopinae and Lychnophorinae, with minor adjustments. Only for the latter a phytochemical synapomorphy was found, while the two others are diagnosable by a simple combination of morphological characters (including microcharacters). The formation of a syncephalium is a multifactorial complex, and field studies are necessary to test the functional hypotheses we propose herein. An amplified concept of the subtribe Lychnophorinae is purposed with a new circumscription, encompassing the subtribes Centratherinae and Sipolisiinae, as well as three genera previously unplaced (Gorceixia) or placed in other subtribes: Albertinia (Vernoniinae) and Blanchetia (Piptocarphinae). This study also encourages further investigation in American Vernonieae. A more complete taxonomic sampling is needed to recognize monophyletic subtribes, especially regarding the Piptocarphinae and the Vernoniinae.

The study of the phylogeny of Lychnophorinae (Chapter 2) provided the foundation for a new generic classification in the subtribe based on monophyletic genera and presented as a synopsis in Chapter 5. Nonetheless, the relationships between these genera, a number of monotypic genera and some taxa previously placed in Eremanthus or Lychnophora remained unresolved due to a lack of resolution. The putative intergeneric hybrids and some other incrongruences found between nuclear and chloroplast phylogenies indicate that past hybridization probably occurred during the evolutionary history of the Lychnophorinae. Consequently, further studies are necessary to elucidate if the unresolved part of the Lychnophorinae phylogeny is linked or not with the inclusion of derived hybrids, i.e. whether some of the 'problematic' monotypic genera and taxa (e.g., Chronopappus, Lychnophora markgravii, Lychnophoriopsis damazioi etc.) have a hybrid origin. On the whole, we might not be able to depict the evolutionary history of the Lychnophorinae completely as a classic bifurcating tree.

The hierarchical representation of homology hypotheses has a deep impact on phylogenetic inference, as evidenced by the performed study comparing results under parsimony criteria with results from three-item analyses, using two morphological datasets: American Vernonieae taxa and Lychnophorinae (Chapter 3). Consequently, it has an impact also on natural classifications derived from it. The high level of homoplasy found in the two Vernonieae datasets here analyzed invites us to reflect on the reasons for such extensive convergence especially for characters of which its adaptative value is uncertain (e.g., style basal node and other microcharacters). It also appeals to the necessity of more morphological studies in order to formulate more robust homology hypotheses.

Field work and herbaria specimens analyses lead to the description of eight new species of Lychnophorinae (Eremanthus brevifolius, Heterocoma gracilis, H. robinsoniana, Minasia ramosa, Paralychnophora glaziouana, Piptolepis campestris, P. monticola and P. schultziana). 
This fact stresses the importance of field exploration in the present study and confirms the high diversity and endemism of these plants. The preparation of the synopsis of the Lychnophorinae also highlighted the need of revision for some genera (e.g., Piptolepis) or species complex (e.g., Lychnophora triflora group). It also showed that more morphological and molecular studies are necessary to draw solid conclusions on the taxonomic positions of the species that so far remained as incertae sedis: Eremanthus crotonoides, Lychnophora markgravii, Lychnophoriopsis damazioi and the Lychnophora brunioides group. 
